UNIVERSIDADE DE SÃO PAULO

Faculdade de Filosofia, Letras e Ciências Humanas

INTI ANNY QUEIROZ

\title{
A ARQUITETÔNICA DA ESFERA POLÍTICO-CULTURAL BRASILEIRA NOS ENUNCIADOS DO SISTEMA NACIONAL DE CULTURA
}

Versão corrigida

São Paulo

2019 


\author{
UNIVERSIDADE DE SÃO PAULO \\ Faculdade de Filosofia, Letras e Ciências Humanas \\ Departamento de Letras Clássicas e Vernáculas \\ Programa de Pós-Graduação em Filologia e Língua Portuguesa
}

INTI ANNY QUEIROZ

\title{
A ARQUITETÔNICA DA ESFERA POLÍTICO-CULTURAL BRASILEIRA NOS ENUNCIADOS DO SISTEMA NACIONAL DE CULTURA
}

Tese de doutoramento apresentada ao Departamento de Letras Clássicas e Vernáculas da Faculdade de Filosofia, Letras e Ciências Humanas da Universidade de São Paulo com vistas à obtenção do título de doutora em Letras.

Orientadora: Prof ${ }^{\mathrm{a}}$ Livre Docente Sheila Vieira de Camargo Grillo

\section{Versão corrigida}

São Paulo, julho de 2019 
Autorizo a reprodução e divulgação total ou parcial deste trabalho, por qualquer meio convencional ou eletrônico, para fins de estudo e pesquisa, desde que citada a fonte.

Catalogação na Publicação

Serviço de Biblioteca e Documentação

Faculdade de Filosofia, Letras e Ciências Humanas da Universidade de São Paulo

Q3a Queiroz, Inti Anny

brasileira nos enunciados do Sistema Nacional de

Cultura/ Inti Anny Queiroz; orientador Sheila

Vieira de Camargo Grillo. - São Paulo, 2019.

$415 \mathrm{f}$.

Tese (Doutorado)- Faculdade de Filosofia, Letras e Ciências Humanas da Universidade de São Paulo. Departamento de Letras Clássicas e Vernáculas. Área de concentraçăo: Filologia e Língua Portuguesa.

1. cultura. 2. filosofia da linguagem. 3 . Análise do discurso. 4. politicas públicas. 5. politica cultural. I. Grillo, Sheila Vieira de Camargo, orient. II. Título. 


\title{
ENTREGA DO EXEMPLAR CORRIGIDO DA DISSERTAÇÃO/TESE
}

\section{Termo de Ciência e Concordância do (a) orientador (a)}

\author{
Nome do (a) aluno (a): Inti Anny Queiroz
}

Data da defesa: 10/ 06 / 2019

Nome do Prof. (a) orientador (a): Sheila Vieira de Camargo Grillo

Nos termos da legislação vigente, declaro ESTAR CIENTE do conteúdo deste EXEMPLAR CORRIGIDO elaborado em atenção às sugestões dos membros da comissão Julgadora na sessão de defesa do trabalho, manifestando-me plenamente favorável ao seu encaminhamento e publicação no Portal Diqital de Teses da USP.

São Paulo, $23 / 07 / 2019$.

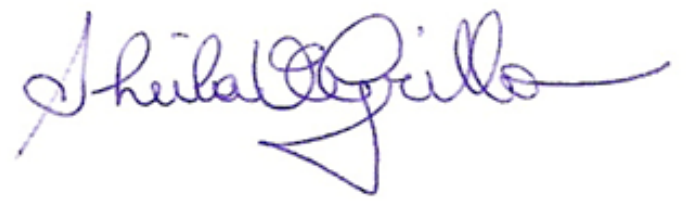


QUEIROZ, I. A.. A arquitetônica da esfera político-cultural brasileira nos enunciados do Sistema Nacional de Cultura. Tese apresentada à Faculdade de Filosofia, Letras e Ciências Humanas da Universidade de São Paulo para obtenção do título de Doutora em Letras.

O presente trabalho foi realizado com apoio da Coordenação de Aperfeiçoamento de Pessoal de Nível Superior - Brasil (CAPES). 


\section{AGRADECIMENTOS}

Agradeço primeiramente à minha orientadora, Professora Livre Docente Sheila Vieira de Camargo Grillo, que tanto me apoiou e ensinou, e nestes anos de convivência trouxe todo o suporte necessário para meu crescimento científico, intelectual e pessoal.

Ao Departamento de Letras Clássicas e Vernáculas, ao Programa de Filologia e Língua Portuguesa, à FFLCH e à USP, pela oportunidade de realização do doutorado.

À CAPES pela concessão da bolsa de pesquisa e apoio financeiro para o estudo.

Aos membros da banca avaliadora que desde a qualificação se empenharam para contribuir para que minha pesquisa evoluísse para seu melhor: Ilana Goldstein, Valmir de Souza, Urbano Cavalcante Filho e Luiz Rosalvo Costa.

À minha família, principalmente minha filha Anaís, minha avó Nilbem (in memoriam) e minha mãe Elizabeth, que sempre me apoiaram incondicionalmente em meus estudos.

Aos meus colegas de grupo de pesquisa pelo apoio: Ana Carolina, Arlete, Artur, Beatriz, Daniela, Flávia, Johnny, Kátia, Maria, Mayara, Sueli, Taciane, Urbano e Yuri.

Aos meus colegas pesquisadores e trabalhadores da cultura que me ajudaram nessa empreitada com reflexões e informações: Alessandro Azevedo, Alice Coutinho, Alvaro Santi, Américo Córdula, Ana Mesquita, Ana Paula do Val, André Cagni, Andrea Chiesorin, Aluisio

Marino, Alexandre Barbalho, Binho Perinotto, Breno Wilson, Cacá Machado, Carolina Ficheira, Claudineli Ramos, Daniela Ribas, Daniele Torres, Eduardo Sena, Guilherme Varella, Gustavo Guenzburger, Hanilton Medeiros, Helena Marona, Jesus dos Santos, Karina Poli, Lia Calabre, Luciana Lima, Luana Vilutis, Luane Ar, Marcos Costa, Martha Myrrah, Neri Silvestre, Pablo Paternostro, Ruberval Oliveira, Sergio Martins, Thais Rigolon, Theresia Rosados, Tony Gigliotti, Vanessa Cursi, Verônica Diaz, Yves Finzetto, e tantos outros.

$\mathrm{E}$ aos meus amigos de modo geral, que nesses anos de pesquisa não mediram esforços para ajudar no apoio emocional. Vocês sabem quem são. MUITO OBRIGADA! 


\section{RESUMO}

QUEIROZ, I. A. A arquitetônica da esfera político-cultural brasileira nos enunciados do Sistema Nacional de Cultura. Tese (Doutorado), Faculdade de Filosofia, Letras e Ciências Humanas, Universidade de São Paulo, 2019.

No início do século XXI, as políticas culturais mundiais começaram a tomar novos rumos após conferências promovidas em anos anteriores pela UNESCO, a fim de desenvolver um olhar mais diverso para a cultura. A partir de 2003, a gestão do ministro Gilberto Gil no Ministério da Cultura, acompanhando esta tendência mundial, mostrou que pretendia lançar, na esfera das políticas culturais, novas diretrizes para a gestão de cultura ao propor a criação de uma nova legislação capaz de oferecer alternativas às políticas públicas de cultura que deveriam privilegiar a diversidade cultural e a cultura produzida a partir de um olhar antropológico. Entre as medidas tomadas pela nova gestão, selecionamos como objeto desta pesquisa os processos de criação do Sistema Nacional de Cultura (SNC) a partir da Emenda Constitucional N. 71 de 2012 e os documentos anteriores e posteriores relacionados a ele. A questão principal desta pesquisa é: de que forma o Sistema Nacional de Cultura contribui para a constituição de uma nova arquitetônica da esfera político-cultural brasileira no início do século XXI? Os enunciados relativos ao Sistema Nacional de Cultura serão analisados a partir da abordagem teórica do chamado Círculo de Bakhtin. Nossa tese compreende que este novo "olhar" proposto para a cultura, com um enfoque antropológico, busca alterar a arquitetônica da esfera político-cultural brasileira no início do século XXI, por meio de uma nova legislação e de novos gêneros discursivos, como os Planos de Cultura, enunciados concretos que compõem a arquitetônica da proposta da Política Nacional de Cultura.

Palavras-chave: Esfera. Arquitetônica. Relações dialógicas. 


\begin{abstract}
QUEIROZ, I. A. The architectonic of the political cultural sphere in brazilian National System of Culture Statements. Tese (Doutorado), Faculdade de Filosofia, Letras e Ciências Humanas, Universidade de São Paulo, 2019.
\end{abstract}

At the beginning of the 21st century, world cultural policies began to take a new course after conferences promoted in previous years by UNESCO in order to develop a more diverse view of culture. From 2003, the administration of the Minister Gilberto Gil in the Ministry of Culture, following this world tendency, showed that he intended to launch, in the sphere of cultural policies, new guidelines for the management of culture by proposing a new legislation capable of offering alternatives to the public policies of culture that should privilege the cultural diversity and the culture produced from an anthropological perspective. Among the measures taken by the new management, we selected as object of this research the processes of creation of the National System of Culture (SNC) from Constitutional Amendment N. 71 of 2012 and the previous and subsequent documents related to it. The main question of this research is: in what way does the National System of Culture contribute to the constitution of a new architectonic of the Brazilian political-cultural sphere at the beginning of the 21st century? The statements related to the National Culture System will be analyzed from the theoretical approach of the so-called Bakhtin Circle. Our thesis understands that this new "look" proposed for culture, with an anthropological focus, seeks to change the architectonic of the Brazilian political-cultural sphere at the beginning of the 21st century, through new legislation and new discursive genres, such as Plans of Culture, concrete statements that compose the architectonic proposal of the National Culture Policy.

Keywords: Sphere. Architectonic. Dialogical relations. 


\section{RESUMÉN}

QUEIROZ, I. A. La arquitectónica de la esfera política y cultural brasileña em las declaraciones del Sistema Nacional de Cultura. Tese (Doutorado), Faculdade de Filosofia, Letras e Ciências Humanas, Universidade de São Paulo, 2019.

A principios del siglo XXI, las políticas culturales mundiales comenzaron a tomar nuevos rumbos tras conferencias promovidas en años anteriores por la UNESCO, a fin de desarrollar una mirada más diversa a la cultura. A partir de 2003, la gestión del ministro Gilberto Gil en el Ministerio de Cultura, acompañando esta tendencia mundial, mostró que pretendía lanzar, en la esfera de las políticas culturales, nuevas directrices para la gestión de la cultura al proponer la creación de una nueva legislación capaz de ofrecer alternativas a las políticas públicas de cultura que deberían privilegiar la diversidad cultural y la cultura producida a partir de una mirada antropológica. Entre las medidas tomadas por la nueva gestión, seleccionamos como objeto de esta investigación los procesos de creación del Sistema Nacional de Cultura (SNC) a partir de la Enmienda Constitucional № 71 de 2012 y los documentos anteriores y posteriores relacionados a él. La cuestión principal de esta investigación es: ¿de qué forma el Sistema Nacional de Cultura contribuye a la constitución de una nueva arquitectónica de la esfera político-cultural brasileña a principios del siglo XXI? Los enunciados relativos al Sistema Nacional de Cultura serán analizados a partir del abordaje teórico del llamado Círculo de Bakhtin. Nuestra tesis comprende que esta nueva "mirada" propuesto para la cultura, con un enfoque antropológico, busca alterar la arquitectónica de la esfera político-cultural brasileña a principios del siglo XXI, a través de una nueva legislación y de nuevos géneros discursivos, como los Planes de Cultura, enunciados concretos que componen la arquitectónica de la propuesta de la Política Nacional de Cultura.

Palabras-clave: Esfera. Relaciones dialógicas. Arquitectónica. 


\section{LISTAS DE ILUSTRAÇÕES E IMAGENS}

Figuras 1 e 2: Rede de interações previstas no SNC.................................................128

Figura 3: Site de consulta pública para revisão das metas do PNC 2015.....................139

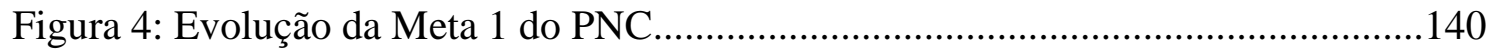

Figura 5: Mapa da evolução da Meta 1.......................................................................141

Figura 6: Situação da implantação do SNIIC na Meta 2 por região do país..................142

Figura 7: Dados SNIIC na meta 3 sobre a Cartografia da diversidade...........................142

Figura 8: Meta 46 Situação dos Planos setoriais e Colegiados CNPC...........................143

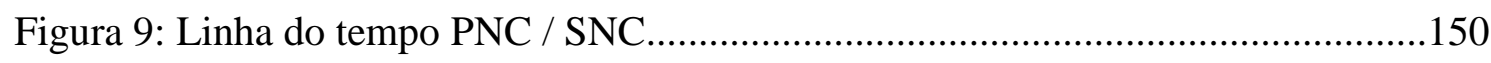

Figura 10: Demonstrativo orçamentário do FNC entre 2005 e 2016...........................153

Figura 11: Indicadores do orçamento federal da cultura entre 2010 e 2017 ...................154

Figura 12: Números sobre os seminários estaduais em 2008.....................................211

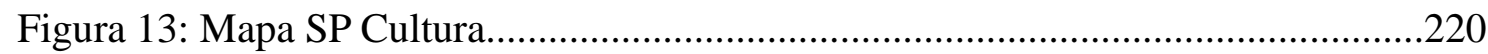

Figura 14: Site da III Conferência Nacional de Cultura..............................................230

Figura 15: Descritivo sobre a participação dos estados na III CNC.............................232

Figura 16: Resultados votação de itens prioritários da $3^{\text {a }} \mathrm{CNC}$, eixos 1 e 2 ..................235

Figura 17: Resultados da votação de itens prioritários da $3^{\text {a }} \mathrm{CNC}$, eixos 3 e 4 ...........235

Figura 18: Cronotopos dos planos de cultura na esfera político-cultural......................255

Figura 19: Dados Meta 3 Cartografia da diversidade das expressões culturais............261

Figura 20: Desenvolvimento da Meta 8 do PNC ao longo do tempo............................263

Figura 21: Inscritos na $3^{\mathrm{a}} \mathrm{CMC}-\mathrm{SP}$ por região da cidade........................................269

Figura 22: Distribuição de inscritos na $3^{\mathrm{a}} \mathrm{CMC}$ por subprefeitura de SP......................270

Figura 23: Meta 50 da Consulta Pública do Plano Municipal de Cultura de SP...........272

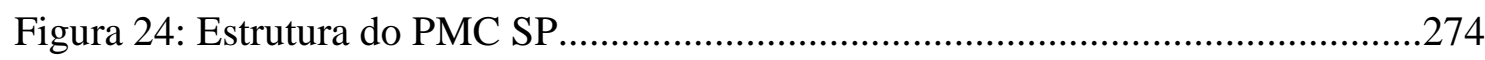

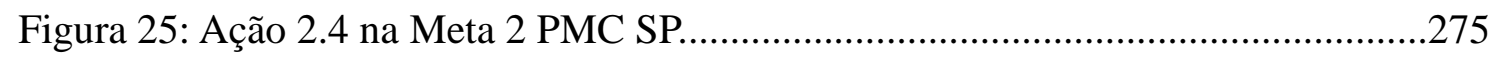

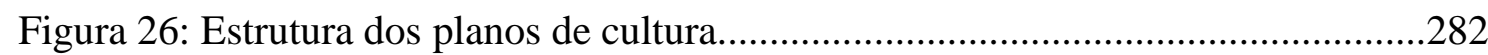

Figura 27: Meta 1 na publicação das metas do PNC.....................................................295

Figura 28: Como está sendo medida e situação da Meta 1........................................297

Figura 29: Diretrizes do Plano Estadual de Cultura de SP.............................................303

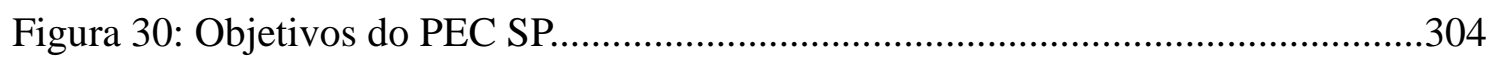

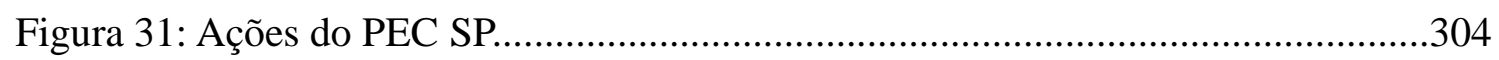

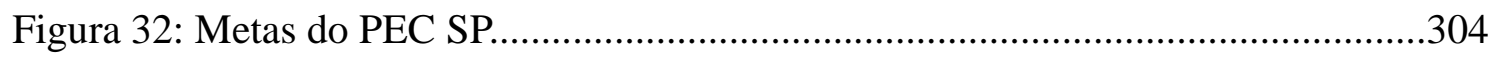

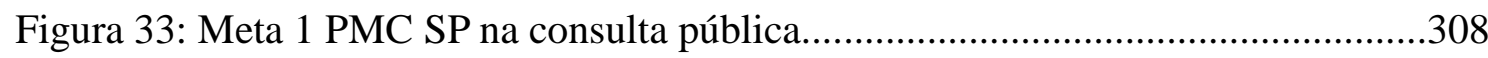


Figura 34: Meta 1 na versão final do PMC SP........................................................... 310

Figura 35: Meta 1 PMC SP no decreto publicado no Diário Oficial..............................311

Figura 36: Organização por eixos temáticos metas do PNC de 2017............................325

Figura 37: Distribuição de recursos por linguagem no Proac Editais............................343

Figura 38: Enunciados de referência na Meta 6 PMC SP..............................................351

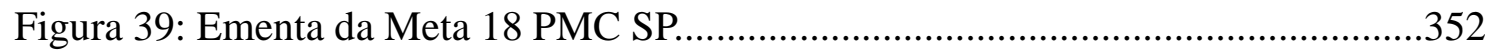

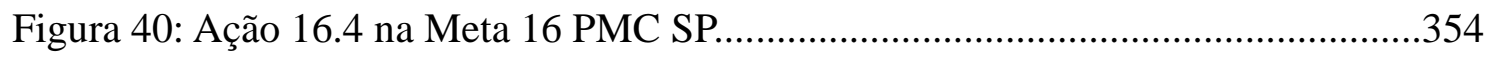

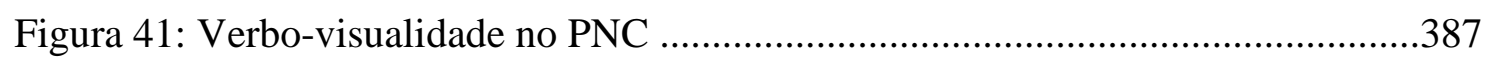

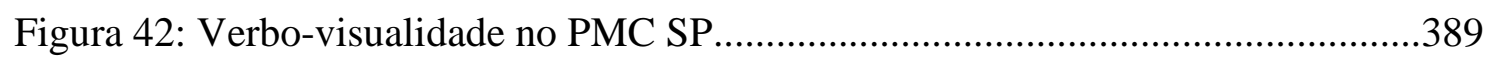

Figuras 43, 44, 45, 46: Fotos da publicação final PMC SP..........................................390

Figura 47: Verbo-visualidade no Eixo 2 do PMC-SP.....................................................391

Figura 48: Verbo-visualidade no Plano Estadual de Cultura de SP..............................392

\section{LISTA DE TABELAS}

Tabela 1: Distribuição de itens dos planos municipais analisados...............................298

Tabela 2: Desenvolvimento da diretriz 1 do PEC SP, objetivos, metas e ações.............307

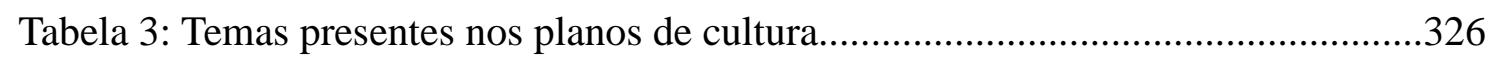

Tabela 4: Incidência de citações a grupos setoriais nos planos.....................................356

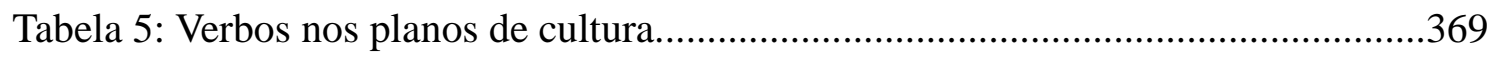




\section{LISTA DE SIGLAS E ABREVIATURAS}

ALESP - Assembleia Legislativa do Estado de São Paulo

ANCINE - Agência Nacional de Cinema

BID - Banco Interamericano de Desenvolvimento

CAPES - Coordenação de Aperfeiçoamento de Pessoal de Nível Superior

CEC - Conselho Estadual de Cultura

CEC - Comissão de Educação e Cultura (Câmara Federal)

$\mathrm{CF}$ - Constituição Federal

CFC - Conselho Federal de Cultura

CNC - Conferência Nacional de Cultura

CNIC - Comissão Nacional de Incentivo à Cultura

CNPC - Conselho Nacional de Políticas Culturais

CPF - Conselho, Plano e Fundo

DEM - Democratas (partido)

DLLLB - Diretoria do Livro, Leitura, Literatura e Bibliotecas

DOE - Diário Oficial do Estado

DOU - Diário Oficial da União

EC - Emenda Constitucional

EN - Ética à Nicômaco (Aristóteles)

ENECULT - Encontro de Estudos Multidisciplinares em Cultura

FCP - Fundação Cultural Palmares

FGV - Fundação Getúlio Vargas

FHC - Fernando Henrique Cardoso

FNC - Fundo Nacional de Cultura

FUNARTE - Fundação Nacional de Artes

FUNDARPE - Fundação do Patrimônio Histórico e Artístico de Pernambuco

IBGE - Instituto Brasileiro de Geografia e Estatística

ICMS - Imposto sobre Circulação de Mercadorias e Serviços

IPEA - Instituto de Pesquisa Econômica Aplicada

IPHAN - Instituto do Patrimônio Histórico e Artístico Nacional.

IPTU - Imposto sobre a Propriedade Predial e Territorial Urbana 
ISS - Imposto Sobre Serviços

LINC - Lei de Incentivo à Cultura

MCP - Movimento Cultural das Periferias

MEC - Ministério da Educação e Cultura

MES - Ministério da Educação e Saúde

MINC / MinC - Ministério da Cultura

MP - Medida Provisória

ONG - Organizações Não Governamentais

ONU - Organização das Nações Unidas

OPOYAZ - Sociedade para o Estudo da Língua Poética (rus)

PAC - Plano de Ação Cultural

PC do B - Partido Comunista do Brasil

PEC - Projeto de Emenda Constitucional

PIB - Produto Interno Bruto

PL - Projeto Lei

PLC - Projeto de Lei da Câmara

PMDB - Partido do Movimento Democrático Brasileiro

PNC - Plano Nacional de Cultura

PP - Partido Progressista

PPS - Partido Popular Socialista

PROAC - Programa de Ação Cultural

PROCULTURA - Programa Pró-cultura

PRONAC - Programa Nacional de Apoio à Cultura

PSB - Partido Socialista Brasileiro

PSDB - Partido da Social Democracia Brasileira

PSOL - Partido Socialismo e Liberdade

PT - Partido dos Trabalhadores

PV - Partido Verde

SAI - Secretaria da Articulação Institucional

SADI - Secretaria da Articulação e Desenvolvimento Institucional

SAv - Secretaria do Audiovisual

SCDC - Secretaria da Cidadania e da Diversidade Cultural

SEC - Secretaria de Estado da Cultura (SP) 
SFC - Sistema Federal de Cultura

SMC - Secretaria Municipal de Cultura

SNC - Sistema Nacional de Cultura

SNIIC - Sistema Nacional de Informações e Indicadores Culturais

SPHAN - Serviço do Patrimônio Histórico e Artístico Nacional

SUAS - Sistema Único de Assistência Social

VAI - Valorização de Iniciativas Culturais

UFBA - Universidade Federal da Bahia

UFSC - Universidade Federal de Santa Catarina

UNESCO - Organização das Nações Unidas para a Educação, Ciência e a Cultura 


\section{SUMÁRIO}

INTRODUÇÃO.

Parte1: FUNDAMENTOS TEÓRICOS METODOLÓGICOS: A ARQUITETÔNICA BAKHTINIANA NA CONSTRUÇÃO DE UMA METODOLOGIA DE ANÁLISE DA ESFERA POLÍTICO-CULTURAL BRASILEIRA

CAPÍTULO 1: O CONCEITO DE ARQUITETÔNICA..............................................8

1.1 - O conceito de arquitetônica na história da filosofia..................................................

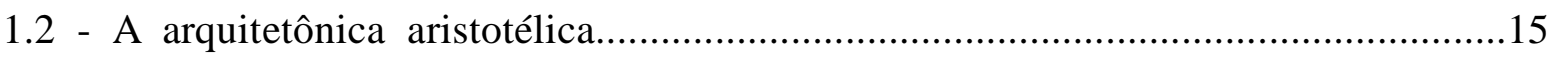

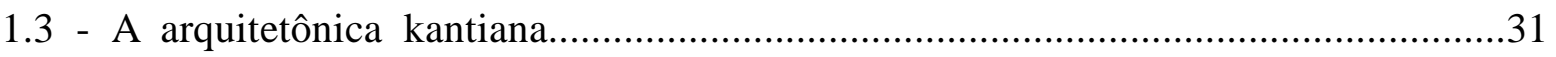

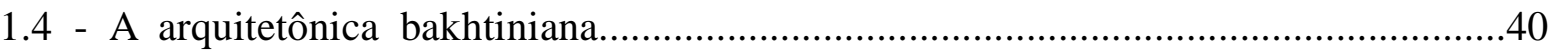

CAPÍTULO 2: PROJETANDO E CONSTRUINDO CAMINHOS PARA A ANÁLISE: METODOLOGIA, OBJETO DE PESQUISA E TESE ............................................70

2.1 - A arquitetônica, a esfera e o SNC: reflexões iniciais..............................................70

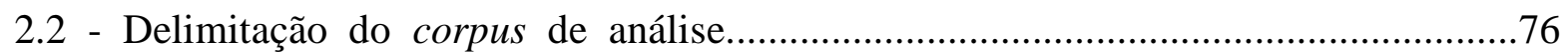

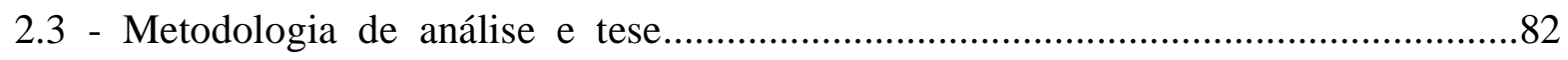

Parte 2: A ARQUITETÔNICA SÓCIO-POLÍTICA DA ESFERA POLÍTICOCULTURAL BRASILEIRA: HORIZONTE SOCIAL E INTERAÇÃO ENTRE SETORES DO PODER PÚBLICO E DA SOCIEDADE CIVIL

CAPÍTULO 3: A CONSTRUÇÃO DA ESFERA POLÍTICO-CULTURAL BRASILEIRA CONTEMPORÂNEA: HORIZONTE SOCIAL E ORGANIZAÇÃO DA

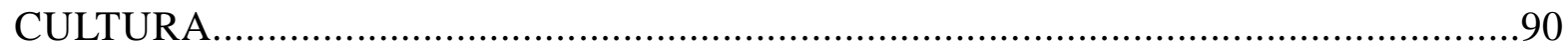

3.1 - Políticas culturais no século XX: uma breve introdução sobre o Brasil..................91

3.2 - A influência da UNESCO nas políticas culturais brasileiras.................................101

3.3 - A Política Nacional de Cultura no século XXI: o retrato de um país em mudança.

3.4 - A implantação dos Sistemas de Cultura em São Paulo: contexto estadual e municipal. 155

CAPÍTULO 4: A CONSTRUÇÃO DO SISTEMA NACIONAL DE CULTURA: AUTORIA,

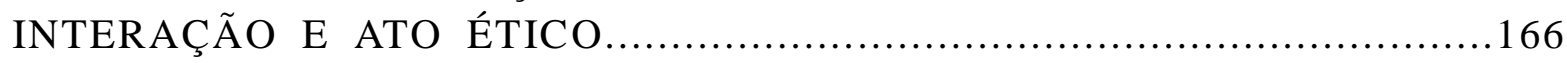

4.1 - O conceito de autoria nas teorias de Bakhtin...................................................166

4.2 - A autoria na esfera legislativa e no Sistema Nacional de Cultura.........................170

4.3 - Participação social e Estado: a construção interativa do Sistema.........................203

4.4 - Sistema Nacional de Cultura para quem?......................................................237 
Parte 3: A ARQUITETÔNICA DO GÊNERO DISCURSIVO PLANO DE CULTURA

CAPÍTULO 5: A RESPONSABILIDADE ÉTICA E O CRONOTOPO: ATOS NO TEMPOESPAÇO DO SISTEMA............................................................251

5.1 - O cronotopo bakhtinano na esfera político-cultural brasileira e a construção do gênero

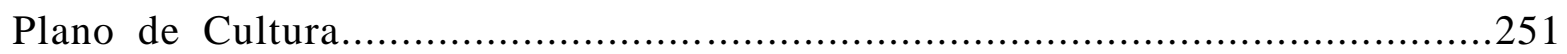

5.2 - O cronotopo e os desafios no Plano Nacional de Cultura....................................260

5.3 - Cronotopo e descentralização no Plano Municipal de Cultura da cidade de São

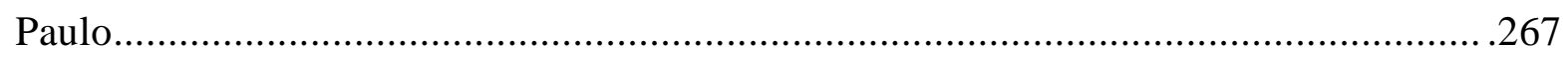

CAPÍTULO 6: AS ESPECIFICIDADES DO NOVO GÊNERO DISCURSIVO PLANO DE

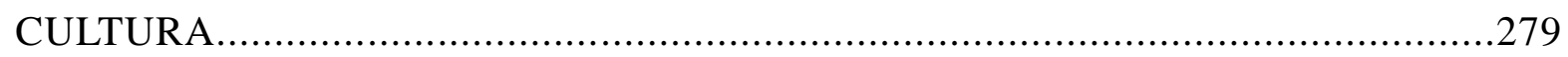

6.1 - A escrita do gênero plano de cultura..................................................................280

6.2 - A construção composicional dos Planos de Cultura..............................................290

6.2.1 - A construção composicional no Plano Nacional de Cultura............................ 294

6.2.2 - A construção composicional no Plano Estadual de Cultura de São Paulo....302

6.2.3 - A construção composicional no Plano Municipal de Cultura de São Paulo.......308

6.3 - O conteúdo temático dos Planos de Cultura.........................................................313

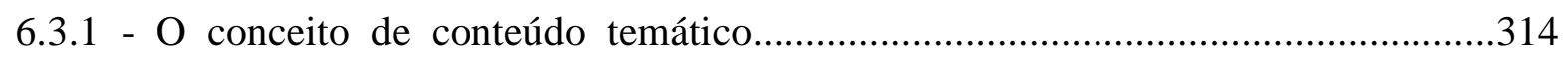

6.3.2 - O conteúdo temático no Plano Nacional de Cultura....................................... 319

6.3.3 - O conteúdo temático do Plano Estadual de Cultura de São Paulo......................340

6.3.4 - O conteúdo temático do Plano Municipal de Cultura de São Paulo....................348

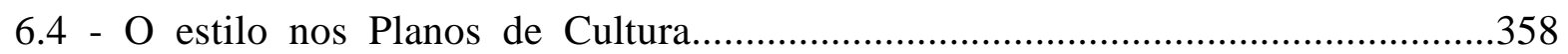

6.4.1 - O conceito de estilo no Círculo de Bakhtin..........................................................360

6.4.2 - A análise do estilo do gênero Plano de cultura...................................................365

6.4.2.1 - Análise do estilo na dimensão verbo-visual dos planos de cultura..................386

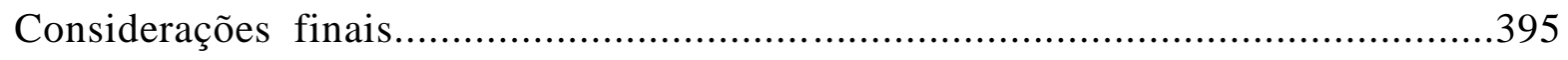

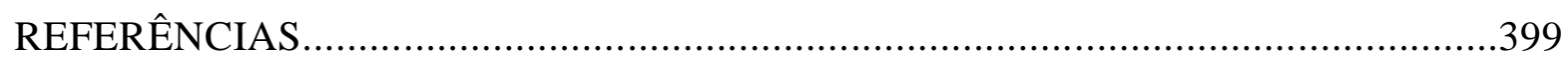




\section{INTRODUÇÃO}

O objetivo principal desta pesquisa é compreender como o Sistema Nacional de Cultura (SNC) contribui à constituição de uma nova arquitetônica da esfera político-cultural brasileira no início do século XXI. Para isso, analisaremos como os enunciados desse sistema se relacionam com as políticas públicas de cultura por meio de seu discurso e de sua importância nessa esfera, considerando que o SNC assim como evidenciado no artigo 216-A da Constituição Federal "Institui um processo de gestão e promoção conjunta de políticas públicas de cultura, democráticas e permanentes". O Sistema Nacional de Cultura foi instituído pelo MinC com a intenção de ser uma proposta descentralizadora da gestão pública de cultura que busca desconcentrar recursos e apoios, concentrados nos grandes centros como Rio e São Paulo, diversificar a ideia de cultura e fortalecer a construção democrática das políticas culturais nos quatro cantos do país. Para isso, o SNC apresenta um modelo baseado no federalismo e na participação social, como acontece no Sistema Único de Saúde (SUS) e no setor da educação, com distribuição de atribuições nos entes federados, e com uma estrutura pautada em Conselhos, Planos e Fundos.

Nesta pesquisa, buscaremos observar a arquitetônica da esfera político-cultural por meio da análise discursiva dos enunciados relativos ao SNC, bem como de seus processos de criação e escrita, da comparação com os discursos e documentos anteriores e posteriores a 2003. A questão principal da pesquisa é: de que forma o Sistema Nacional de Cultura contribui para a constituição de uma nova arquitetônica da esfera político-cultural brasileira no início do século XXI? Nossa tese é que o SNC busca viabilizar uma nova forma de organizar e articular as políticas culturais no país por meio de um olhar ampliado antropológico e com participação social, visando à diversidade, à ampliação do acesso e à descentralização da cultura. Contudo, por conta da complexidade da esfera e dos acontecimentos no horizonte social mais amplo, tem enfrentado desafios e dificuldades para ser consolidado no modelo proposto como política de Estado.

Propomos esta tese não apenas por sua importância em termos acadêmicos, já que é pioneira na observação do tema na área de letras. Acreditamos que poderemos contribuir à reflexão da esfera político-cultural e política do país, pois reporta um período de muitas instabilidades e mudanças, e o SNC, enquanto proposta de política pública estruturante, mostra-se como um desafio ainda maior. Esta pesquisa, e principalmente o detalhamento de alguns acontecimentos, só foi possível por conta de meu envolvimento direto com o setor da 
cultura desde os anos 1990: como artista da música, como ativista defensora dos artistas independentes e dos direitos culturais, e como professora de cursos de gestão cultural desde 2011. Isso permitiu estar presente ou muito próxima a muitos acontecimentos relatados na tese. Assim, a autora desta tese escreve não apenas enquanto uma acadêmica e observadora, mas também enquanto trabalhadora da cultura e ativista do setor. As quatro personas / vozes de uma mesma autora se mesclam ao longo das páginas e permite, em alguns momentos, propormos soluções para alguns problemas observados.

Esta tese também é uma continuação de reflexão sobre a esfera político-cultural iniciada em minha iniciação científica em 2010, aprofundada em meu mestrado (2011 - 2014) sobre o gênero projeto cultural e as leis de incentivo à cultura no Brasil e em São Paulo. Em alguns momentos desta pesquisa, retomaremos estes enunciados anteriores.

O enunciado que institui o Sistema Nacional de Cultura, aprovado e incluído na Constituição Federal apenas em 2012, relaciona-se diretamente com outros enunciados concretos criados a partir do ano 2000. Observaremos particularidades compartilhadas entre eles, o fato de terem sido gerados em momentos enunciativos diferentes, por autores diferentes e como atuam de forma concreta na esfera político-cultural.

As linhas mestras da política cultural brasileira no final do século XX, mais especificamente no período de redemocratização pós-ditadura militar na segunda metade dos anos 1980, parte da inexistência anterior de um Ministério da Cultura (MinC) no país. A primeira versão do MinC, que nasce em 15 de março de 1985 pelo decreto $n^{\circ} 91.144$ do presidente José Sarney, surge principalmente para a organização e a gestão de programas dentro das instituições públicas existentes como museus, bibliotecas e entidades reguladoras de interesse governamental. O advento da aprovação da Lei Sarney em 1986, a primeira lei de incentivo à cultura sancionada, desencadeou um novo modelo de gestão das verbas de cultura de caráter liberal. Com a proposta da Lei Sarney, o Estado passa a dividir com o mercado as decisões sobre quem poderia utilizar as verbas públicas para projetos culturais por meio de patrocínios de empresas que recebiam isenção fiscal.

Em 1991, a Lei Sarney foi substituída pela nova lei federal de incentivo à cultura, lei 8.313/91, conhecida como Lei Rouanet, também inspirada nos mesmos preceitos liberais da lei anterior que fornece benefícios a grandes empresas por meio da isenção fiscal. A partir de uma instrução normativa com outros critérios em junho de 1995, no início da gestão do Presidente Fernando Henrique Cardoso, a Lei Rouanet torna-se ainda menos democrática que a Lei Sarney, com regras que favorecem ainda mais o mercado em detrimento dos produtores 
culturais. Contudo, nesta gestão, os patrocínios via isenção fiscal passam a ser amplamente divulgados pelo governo federal, por meio do slogan federal "Cultura é um bom negócio" e a utilização deste tipo de mecanismo de dedução fiscal ${ }^{1}$ começa a ganhar força.

A efetiva alteração de paradigma desta arquitetônica começa a acontecer a partir da gestão seguinte, com o Presidente Luiz Inácio Lula da Silva a partir de 2003, e com a posse do artista Gilberto Gil no Ministério da Cultura (MinC), ccom a criação dos marcos legais que compõem o Sistema Nacional de Cultura. A resposta de nossa pergunta de tese deverá trazer particularidades contextuais e textuais para a compreensão desse novo sistema e seus componentes, refletindo assim a arquitetônica da esfera.

Nesta nova gestão em 2003, as políticas culturais brasileiras começam a tomar um novo rumo por meio da criação de novas leis, decretos e propostas de emendas constitucionais que privilegiavam, diferentemente das leis de incentivo à cultura, uma agenda estruturante para a cultura, inspirada nos processos e na arquitetura do SUS e do SUAS ${ }^{2}$. Esta proposta de um novo modelo de gestar a cultura aparece inicialmente nas reflexões das audiências públicas realizadas na Comissão de Educação e Cultura da Câmara Federal em 1999 e nos leva à criação da PEC do Plano Nacional de Cultura no ano 2000. Esta mudança de paradigma estruturante se apresenta de maneira integrada, descentralizada e compartilhada desde o início. Seja nas discussões com a sociedade civil na Comissão da Câmara, seja na relação entre os entes federados, o foco da proposta desse sistema estruturante se baseia na diversidade cultural, na ampliação do acesso à cultura e do fortalecimento das políticas públicas de cultura. Esse novo sistema, sua arquitetônica e como ele se reflete e refrata na esfera político-cultural no início do século XXI é o que pesquisaremos nesta tese: a construção do Sistema Nacional de Cultura (SNC).

Este modelo foi inspirado por diversos fatores e acontecimentos anteriores. Entretanto os relatórios e documentos desenvolvidos por comissões de cultura da UNESCO desde os anos 1980, com direcionamentos para as políticas culturais mundiais, deve ser tomado como um ponto chave para nossa reflexão.

O ministro Gilberto Gil, em seu discurso de posse no MinC, no ano de 2003, evidenciou a intenção e a vontade da gestão de ampliar o olhar sobre a cultura a partir do

\footnotetext{
${ }^{1}$ É importante salientar que diversos setores recebem incentivos fiscais do governo federal há muitos anos como: automobilístico, eletrodomésticos, indústria famacêutica etc. Contudo, o setor cultural figura como o que recebe o menor montante de recursos de isenção dentre uma lista de mais de 15 setores e é o único obrigado a divulgar em seus produtos este apoio do governo.

${ }^{2}$ Sistema Único de Assistência Social.
} 
enfoque antropológico e da diversidade cultural. Dentre as novas propostas da gestão estavam uma série de marcos legais que buscavam alterar o paradigma do olhar sobre a cultura e o modelo de gestão das políticas públicas de cultura. A gestão de Gil no MinC é o início dessa mudança de paradigma e sua figura enquanto cantor popular, negro e de reconhecida inteligência sociocultural é chave nessa construção.

O primeiro marco legal proposto e que deu o tom das diretrizes para a criação de todos os enunciados seguintes foi a PEC 306/2000 do Plano Nacional de Cultura (PNC), elaborada pelo deputado federal Gilmar Machado (PT - MG) e Marisa Serrano (PSDB - MS), e em seguida transformada na emenda constitucional N. 48 que gerou o parágrafo $3^{\circ}$, do Artigo 215 da Constituição Federal. Posteriormente, o PNC recebeu uma lei regulamentar por meio do projeto de lei 6.835/2006, aprovado como lei regulamentar 12.343/2010. A primeira proposta das diretrizes do PNC foi habilitada em 2007, criando então assim as bases concretas para construir o que o MinC passa a chamar de "Política Nacional de Cultura".

Entre os documentos criados em seguida, o mais importante deles e objeto central de nossa tese, foi a PEC do Sistema Nacional de Cultura (SNC). A PEC 416/2005, criada pelo deputado federal Paulo Pimenta (PT - RS), gerou o artigo 216-A por meio da emenda constitucional n. 71 de 29 de novembro de 2012. Entre 2005 e 2018, o SNC operou sua implantação a partir das normativas do Sistema Federal de Cultura e Conselho Nacional de Políticas Culturais estabelecidos pelo decreto presidencial 5.520/2005 e seus decretos complementares de 2009 e $2015^{3}$. A lei de regulamentação do SNC ainda não conseguiu ser aprovada ainda que desde 2016 vários PLs tenham sido inscritos na Câmara Federal com essa intenção. Trataremos disso no capítulo histórico da tese.

Para obtermos os resultados necessários à pesquisa, esta tese foi dividida em três partes complementares.

Na primeira parte, trataremos das bases teóricas e da metodologia proposta de modo a estruturar a análise do corpus. Desta maneira, almejamos contribuir teoricamente para os estudos das teorias bakhtinianas e dos estudos do discurso e filosofia da linguagem. $\mathrm{O}$ primeiro capítulo articula as bases teóricas para a investigação ao percorrer o espaço e as

\footnotetext{
${ }^{3}$ No primeiro semestre de 2019, o presidente Jair Bolsonaro inscreveu uma série de decretos a fim de derrubar os conselhos federais. Entre eles estariam os decretos do CNPC. No dia 27 de junho de 2019, o decreto presidencial 9891/19, cria novas regras para o CNPC em que são dissolvidos os colegiados setoriais (retirando todo o caráter de diversidade cultural construído ao longo dos anos), bem como a obrigatoriedade de realização de eleições diretas para membros da sociedade civil que, a partir de então, passam a ser escolhidos pelo Ministro da Cidadania e outros órgãos do executivo. Por conta do final desta pesquisa ter ocorrido em abril de 2019 e sua versão corrida em julho de 2019, optamos por não desenvolver uma análise mais profunda destes fatos recentes.
} 
intenções que o conceito de arquitetônica ocupa em diferentes sistemas filosóficos. Partiremos de um histórico do conceito na filosofia, trazendo diversos filósofos que trabalharam com a arquitetônica. Num segundo momento, observaremos o conceito principalmente em Aristóteles e Kant, para compreender melhor como isso foi estruturado ao longo da história, e, em seguida compreendê-lo de modo mais aprofundado nas obras do chamado Círculo de Bakhtin, ao qual nos filiamos como fundamentação teórica principal desta tese. Este primeiro capítulo busca contribuir para os estudos bakhtinianos, principalmente para os avanços do conceito de arquitetônica, inacabado pelos membros do Círculo, comprendendo as relações entre as obras, os conceitos-chave e os pensadores russos.

Além do conceito de arquitetônica no Círculo, nesta tese interessam também os conceitos de esfera, cultura, criação, signo ideológico, autoria, ato responsável, cronotopo, gênero discursivo, ética e estética, forma, conteúdo e material, que compõem a arquitetônica bakhtiniana e que poderão nos auxiliar na análise dialógica de nosso corpus. Buscaremos em outros filósofos abordados aqui, diálogos possíveis, consensos e dissensos teóricos, que marquem os limites entre as propostas filosóficas que permeiam a compreensão da arquitetônica. Visto que a presente tese não se trata de um estudo da área de filosofia e sim da área de linguagem, abordaremos apenas as obras filosóficas necessárias à compreensão da história do conceito de arquitetônica, a fim de melhor o descrevermos e sua pertinência à análise da esfera político-cultural brasileira.

No segundo capítulo, sobre a metodologia da tese, propomos uma abordagem que relaciona três métodos do Círculo: a análise da atividade estética como ação proposta por Bakhtin em Para uma filosofia do ato responsável, o método sociológico proposto por Volóchinov em Marxismo e filosofia da linguagem nos anos 1920 e a metalínguistica dos anos 1960 na obra Problemas da poética de Dostoiévski. Nesse capítulo, detalharemos nossa tese e o corpus necessário para responder nossa pergunta de pesquisa. A partir da proposta metodológica, apresentaremos outras duas partes com mais quatro capítulos que tratarão do contexto histórico, reflexão e análise do corpus.

Na segunda parte da tese, composta por dois capítulos, observamos o horizonte social e a esfera das políticas culturais no Brasil. No terceiro capítulo, traçaremos um panorama do contexto sócio-histórico em que se insere nossa reflexão. Partiremos de um recorte introdutório que inclui principalmente o desenvolvimento das políticas culturais brasileiras no século XX, desde a Era Vargas, passando por Mario de Andrade, seguindo até a gestão do Ministro Francisco Weffort no governo do presidente FHC no fim dos anos 1990 e de Luiza 
Erundina e Marilena Chauí na cidade de São Paulo. Num segundo momento, abriremos para o contexto internacional a fim de buscar as influências externas na esfera. A partir da construção contemporânea dos direitos civis na metade do século $\mathrm{XX}$, analisaremos documentos e processos da Organização das Nações Unidas (ONU) e da Organização das Nações Unidas para a Educação, Ciência e a Cultura (UNESCO), para compreender como estes influenciaram as políticas culturais brasileiras no século XXI. No terceiro tópico deste capítulo três, entraremos no recorte histórico principal desta pesquisa a partir da criação da PEC do PNC no ano 2000, da gestão do Ministro Gilberto Gil e do programa de cultura de Luiz Inácio Lula da Silva na eleição de 2002 A imaginação à serviço do Brasil e o reflexo deste nos anos seguintes da gestão petista até o período que sucede o impeachment da Presidenta Dilma Rousseff e seus desdobramentos seguintes. Terminaremos o capítulo tratando do contexto de implantação do Sistema nos níveis estadual e municipal de São Paulo, a fim de estabelecer os parâmetros necessários à observação do sistema nos entes federados.

No quarto capítulo, iniciaremos a análise dos documentos do corpus da tese de acordo com a proposta metodológica apresentada no capítulo segundo. Propomos uma análise sobre três temas pertinentes à nossa reflexão: a autoria nos enunciados do Sistema Nacional de Cultura, a participação social e suas relações com o Estado e a quem se destina o SNC.

$\mathrm{Na}$ terceira e última parte da tese, abordaremos a análise do sistema por meio da observação da arquitetônica do gênero discursivo Plano de Cultura pensado como o instrumento do fazer do SNC. Apresentamos no quinto capítulo o cronotopo e a responsabilidade ética no Sistema. No sexto capítulo, observaremos as especificidades deste gênero, compreendido como um importante enunciado da esfera político-cultural e que estrutura a arquitetônica do sistema. Para isso, faremos uma análise dos Planos de Cultura federal, estadual e municipal de São Paulo.

As respostas aos questionamentos iniciais poderão ser respondidos ao longo da pesquisa como uma construção arquitetônica, que se faz aos poucos, a cada nova informação, isto é, "tijolo a tijolo". Todavia como bem evidenciou Bakhtin, um enunciado é sempre uma resposta a outros e aguarda sempre novas respostas posteriores. Pensando nisso, ao longo das páginas a seguir, trazemos dezenas de perguntas aos leitores, buscando assim, permitir uma construção desta reflexão de forma dialógica e uma contribuição conjunta ao setor das políticas culturais e aos estudos do discurso. 


\section{Parte 1:}

FUNDAMENTOS TEÓRICOS METODOLÓGICOS: A ARQUITETÔNICA BAKHTINIANA NA CONSTRUÇÃO DE UMA METODOLOGIA DE ANÁLISE DA ESFERA POLÍTICO-CULTURAL BRASILEIRA 


\section{CAPÍTULO 1: O CONCEITO DE ARQUITETÔNICA}

O Dicionário de filosofia do filósofo espanhol Ferrater Mora (2000) traz em seus verbetes um longo descritivo do conceito de arquitetônica em que traça historicamente um percurso de suas significações. De acordo com Ferrater Mora, o conceito é de ordem filosófica e em boa parte dos casos está relacionado à sistematização de cada método filosófico em si e às reflexões da ética e da filosofia moral. A menção ou mesmo o uso significativo do conceito foi encontrado nos seguintes filósofos ao longo de sua pesquisa: Aristóteles, Tomás de Aquino, Leibniz, Lambert, Kant, Krug, Peirce, Wronski, Warrain, Bornstein. Além desses autores citados por Ferrater Mora, incluímos neste estudo outros pensadores que desenvolveram reflexões sobre o conceito: os filósofos Christian Wollf e Alexander Baumgarten; o escultor e filósofo da arte Adolf Hildebrand, o linguista e filósofo da linguagem Karl Vossler e os pensadores do Círculo de Bakhtin a quem nos filiamos enquanto linha teórica fundamental.

Neste capítulo, buscaremos traçar inicialmente um breve panorama do conceito encontrado nas obras dos respectivos filósofos ao longo da história. $\mathrm{Na}$ segunda parte, faremos uma leitura mais aprofundada do conceito de arquitetônica em Aristóteles, que, ao que se sabe, foi o primeiro a desenvolver o conceito em suas obras. Em seguida, partiremos para a compreensão do conceito em Immanuel Kant que, além de evidenciá-lo em sua teoria, é frequentemente citado por Bakhtin na obra Para uma filosofia do ato responsável. Finalmente, analisaremos a arquitetônica em obras dos autores do chamado Círculo de Bakhtin, buscando assim criar a base epistemológica para a tese e para a posterior análise do corpus.

\subsection{O conceito de arquitetônica na história da filosofia.}

O significado da palavra arquitetônica, encontrada em três dicionários ${ }^{4}$ de língua portuguesa, remete à arquitetura. De raiz etimológica grega arkhitektoniké significa "Reunião das normas técnicas próprias de construção; arte da construção; arquitetura.” (HOUAISS, 2010) Este significado, ainda que trate de uma esfera distinta de nossos interesses, nos remete a um traço semântico que não deve ser desconsiderado: as noções de arquitetura, construção e de estrutura arquitetônica, relacionadas a uma criação única, a uma sistematização, a uma

\footnotetext{
${ }^{4}$ Foram consultados além do Dicionário Houaiss (2009), os dicionários Mini-Aurélio (2001) e Dicionário completo da língua portuguesa (2000).
} 
organização estrutural, a um esquema construtivo. Acreditamos que essas são noções semânticas essenciais a um projeto arquitetônico e refletem de certa maneira (ainda que de modo formal) a compreensão da arquitetônica e ao que nos propomos nesta tese.

Teoricamente, a arquitetônica está relacionada a um tipo de sistematização que compreende os sistemas filosóficos e considera suas possibilidades de analogias para cada esfera ideológica, ou como o filósofo Gueroult nomeia no trecho abaixo, para cada "região".

De acordo com o que foi estabelecido precedentemente, todo sistema filosófico resultará na arquitetônica, já que é uma totalidade que coordena no interior de seu conceito, o conjunto de suas noções fundamentais, de seus problemas e de suas soluções. A diversidade e a heterogeneidade das regiões (conhecimento, ciência, arte, religião, direito, moral, etc.) que uma filosofia deve abarcar em seu problema total, não lhe permitem se desenvolver em apenas uma série. Ela deve enfeixar várias regiões da mesma forma que deve coordenar vários tipos de noções fundamentais. Tal enfeixamento, tal coordenação, só são possíveis se houver homogeneidade entre todos os elementos considerados. Mas, precisamente, as regiões e os problemas que lhe são inerentes são heterogêneos. Para estabelecer entre essas regiões o mínimo de homogeneidade exigida, a arquitetônica intervém com suas simetrias (correspondências, analogias) e suas extrapolações. (GUEROULT, 2007, p. 244)

Essa relação entre a arquitetônica e os sistemas filosóficos, evidenciada por Gueroult, será comum a boa parte dos filósofos em que o conceito aparece, ainda que com diferentes aplicações e em diferentes escolas filosóficas. Devemos atentar ao que Gueroult chama de regiões, que seria o equivalente próximo ao que se compreende por esfera/ campo na teoria bakhtiniana. Ao consideramos isso, é possível dizer que, para Gueroult, a arquitetônica estaria, de certo modo, ligada à organização das relações destas regiões ou esferas estruturalmente. Os trechos "ela deve enfeixar várias regiões" e "coordenar vários tipos de noções fundamentais" nos remetem à possibilidade de pensar a arquitetônica como um modo de criar mecanismos (filosóficos) em que as esferas se tocam, dialogam e são igualmente analisadas.

O primeiro filósofo descrito por Ferrater Mora em seu verbete sobre a arquitetônica é Aristóteles (Grécia, 385 A.C. - 322 A.C.). O grego emprega o conceito de maneiras distintas e em diversas partes de seu tratado Ética a Nicômaco ou Ética Nicomaqueica. Aristóteles foi discípulo da escola da ética racionalista de Sócrates e Platão e um dos maiores precursores do ensino filosófico pensado por Sócrates. Boa parte de suas obras foram publicadas postumamente a partir de manuscritos de seus discípulos. Ética a Nicômaco é considerada a fundadora da ética enquanto ciência prática, faz parte dos escritos esotéricos e busca "o estudo 
das vidas felizes de contemplação e de liderança política, das virtudes, da amizade e do prazer." (COOPER, 2010, p. 439). A arte, entendida pelos gregos como ciência e o princípio de bem relacionado ao conceito de arquitetônica, indica que esta tem um caráter de "saber organizador", interligado ao todo da reflexão aristotélica nesta obra, isto é, à ética. Desenvolveremos os apontamentos sobre o conceito em Aristóteles em um tópico exclusivo a seguir.

Tomás de Aquino (Itália, 1225 - 1274), posteriormente canonizado como Santo da Igreja Católica, foi um dos mais importantes filósofos da Baixa Idade Média, período que ainda conserva forte influência religiosa nos estudos de filosofia. Foi um dos principais nomes da tradição escolástica, influenciou os estudos sobre teologia ao longo da história. Conhecido estudioso de Aristóteles e da tradição grega clássica, em seus escritos, dedicou-se a comentar, entre outras obras, a Ética a Nicômaco. Sua visão dos escritos Aristotélicos, quase 1500 anos depois e sob forte influência cristã, demonstra um aprofundamento do conceito de arquitetônica na filosofia moral menos racionalista e mais mística de ordem cristã. De acordo com Mendoza (2010, p. 28), Aquino desenvolveu seus comentários a fim de analisar possíveis ambiguidades e erros do texto aristotélico. Nos comentários sobre o capítulo 1 do livro primeiro da Ética, onde o conceito de arquitetônica aparece pela primeira vez, Aquino trata dos fins e dos meios por meio de uma análise mais detalhada em que Aristóteles propõe uma ordenação das práticas em relação ao todo e dando maior importância às escolhas do homem.

Em todas as artes ou virtudes é verdade corrente que a finalidade da arquitetônica ou arte principal são francamente mais desejáveis que o propósito das artes e das virtudes dependentes da principal. A prova disso: os homens continuam a procurar o propósito das artes ou as virtudes inferiores em razão dos efeitos das principais (MENDOZA, 2010, p. 66 - tradução nossa). ${ }^{5}$

Aquino recuperou de Aristóteles a ideia de felicidade como fim último do ser, mas trouxe a influência cristã a esta noção ao nomear Deus e a religião cristã como a fonte dessa felicidade (COTRIM; FERNANDES; 2010, p. 299)

Outro importante filósofo que tratou do conceito de arquitetônica foi o alemão Gottfried Willhelm Leibniz (Leipzig, Alemanha, 1646 - 1716). Conhecido por sua filosofia científica, voltada principalmente à física e à matemática, utilizou o conceito de arquitetônica em suas obras Tentamen Anagogium (1695) e Monadologia (1714). Para ele, há dois reinos da

\footnotetext{
${ }^{5}$ Em todas las artes o virtudes es uma verdad corriente que los fines de las arquitetonicas o principales son francamente más deseables que los fines de lãs artes o virtudes, que dependen de las principales. Lo prueba de este modo: los hombres prosiguen o buscan los fines de las artes o virtudes inferiores em razón de los fines de las superiores.
} 
natureza corporal que se penetram sem confundir-se ou criar obstáculos um ao outro: o reino da potência, de acordo com o qual tudo pode ser explicado mecanicamente, mediante causas eficientes, tão prontamente quanto penetramos suficientemente em seu interior, e o reino da sabedoria, em que tudo pode ser "explicado arquitetonicamente, mediante causas finais, quando conhecemos suficientemente seus usos"

83. Entre outras diferenças que há entre as almas ordinárias e os Espíritos, algumas das quais já indiquei, há esta outra: que as Almas em geral são espelhos vivos ou imagens do universo das criaturas; porém, os Espíritos são, ainda, imagens da própria Divindade ou do próprio Autor da Natureza, capazes de conhecer o sistema do Universo e de imitar algo dele através de amostras arquitetônicas, sendo cada espírito como uma pequena divindade em seu domínio (T. § 147). (LEIBNIZ, 2007 [1714], p. 10)

A menção à arquitetônica nas teorias de Leibniz nos mostra que o conceito está relacionado a duas questões essenciais: primeiro, tudo pode ser explicado arquitetonicamente no reino da sabedoria e, segundo, é possível conhecer o sistema do universo ou imitá-lo por meio de amostras arquitetônicas.

O filósofo Alexander Gottlieb Baumgarten (Berlim, Alemanha - 1714 - 1762) tratou do conceito de arquitetônica em sua Metaphysica (1739) onde a designou como a estrutura do conhecimento metafísico. Publicou uma obra de metafísica em que define a arquitetônica como sinônimo de ontologia ou a ciência dos predicados gerais dos entes. Seus escritos também influenciaram as reflexões de Lambert sobre a arquitetônica.

Immanuel Kant (Konigsberg, Alemanha / Prússia, 1724 - 1804) utilizou o conceito de arquitetônica no penúltimo tópico do último capítulo de sua importante obra Crítica da razão pura (1781) para remeter à ideia de sistema filosófico teórico. Nas primeiras obras do Círculo de Bakhtin, é possível perceber o claro diálogo com a teoria kantiana não apenas como influência, mas principalmente como refutação teórica. Por essa razão, acreditamos ser pertinente ao nosso estudo desenvolver com maior detalhamento o conceito de arquitetônica na teoria kantiana em um tópico exclusivo a seguir.

Johann Heinrich Lambert (Alemanha, 1728 - 1777) foi filósofo, físico e matemático. Contemporâneo de Kant na Universidade de Konigsberg, realizou pesquisas sobre calor, luz e cores. (JAPIASSU, 1996, p. 152) Escreveu uma obra filosófica completa tratando da teoria do conhecimento chamado Novo Organon. Lambert "edificou uma arquitetônica" (FERRATER MORA, 2000, 195) ou como o próprio título do livro define uma

\footnotetext{
${ }^{6}$ LEIBNIZ, Tentamen anagogicum, Gerhardt, VII, 273, [1682].
} 
"teoria do simples e primeiro conhecimento filosófico e matemático". A obra original de 1771 sem tradução é intitulada Anlage zur Architektonik oder Theorie des einfachen und ersten in der philophischen und mathematischen Erkenntnis (Aplicação na arquitetônica ou teoria do simples e primeiro conhecimento filosófico e matemático - tradução nossa ${ }^{7}$ ) e foi uma continuação do Novo Organon com vistas a

(...) desenvolver a Doutrina da verdade (aletiologia), a Doutrina da realidade (ontologia) e a Doutrina do pensamento (metodologia). Em oposição à doutrina da escola de Leibniz-Wollf, Lambert considerava que o pensamento não se reduz a possibilidades e que, por conseguinte, uma ontologia deve apresentar um quadro que possa ser preenchido com a realidade de existências. (FERRATER MORA, 2000, p.196)

Para Lambert, os conceitos metafísicos devem estar relacionados aos conceitos lógicos e as verdades da razão nunca estão separadas das verdades de fato. Sua arquitetônica corresponde a um sistema ontológico, relacionado à realidade e, como este não pode estar nunca distante dos conceitos lógicos, o sistema é também lógico-ontológico, constituído por "todos os conceitos pensáveis suscetíveis de delimitar a totalidade das existências" (FERRATER MORA, 2000, p. 196).

Outro filósofo alemão que utilizou o conceito de arquitetônica foi Wilhelm Trautgott Krug (Wittemberg - Alemanha, 1770 - 1842) o qual foi grande divulgador das teorias kantianas na Alemanha. Sua teoria filosófica "fundamental" Fundamentalphilosophie era dividida

(...) numa doutrina filosófica elementar e numa doutrina metódica elementar, subdividindo esta última, por sua vez, em didática filosófica e arquitetônica filosófica. A missão da arquitetônica filosófica é o estudo das formas e métodos da própria filosofia, assim como o estudo das partes ou ramos em que a filosofia pode dividir. A arquitetônica filosófica considera a filosofia um todo sistemático ou científico que deve articular-se arquitetonicamente. (FERRATER MORA, 2000, p. 196)

Krug utilizou a ideia kantiana de arquitetônica para avançar com uma nova estruturação da filosofia enquanto arquitetônica sistemática, subdividindo a mesma em duas disciplinas distintas: doutrina dos conceitos de filosofia e doutrina das partes da filosofia. Esta divisão está em diálogo com as teorias kantianas de sistematização filosófica, porém Krug a nomeia de maneira diferente e mais didática, reconhecendo-as como doutrinas filosóficas distintas. Sua obra System der Theoretischen Philosophie (Sistema de Filosofia Teórica 1801) foi duramente criticada por Hegel no início do século XIX, o que provocou uma

\footnotetext{
${ }^{7}$ A tradução de todos os títulos das obras filosóficas presentes neste capítulo é livre e feita por nós com auxilio de dicionários e aplicativos de tradução.
} 
conhecida rivalidade entre os dois na academia alemã.

O conceito de arquitetônica foi utilizado também pelo filósofo messianista polonês Joseff Maria Hoené Wronski (Polônia, 1776 - 1853) para auxiliar em sua teoria da lei da criação em que trabalha com a arquitetônica do universo. A influência das teorias kantianas, ocorrida durante sua formação filosófica em universidades alemãs no final do século XVIII, pode ser percebida na obra publicada postumamente pelo filósofo francês Francis Warrain intitulada Architechtonique de l'univers (Arquitetônica do universo - 1936) e que comenta as teorias do filósofo polonês. O próprio Warrain, utilizando a teoria da lei de criação de Wronski, publica o livro L'armature metaphysique (A armadura metafísica - 1925) em que chama a arquitetônica de uma espécie de "armadura da metafísica" e como um de seus conceitos fundamentais.

Charles Sanders Pierce (EUA, 1839 - 1914) foi influenciado pelas teorias kantianas para compor parte de suas teorias filosófico-pragmáticas. O conceito de arquitetônica está presente no título do escrito A construção arquitetônica do pragmatismo (1893) publicado no Brasil como Obras incompletas. De acordo com Ferrater Mora, o filósofo americano Charles Pierce

(...) acolheu com entusiasmo o paralelo kantiano entre filosofia e arquitetura e ainda procurou apresentar alguns de seus pensamentos como um rascunho destinado a servir de esquema arquitetônico geral para todas as ciências, análogo em intenção ao que fora a filosofia de Aristóteles. (FERRATER MORA, 2000, p. 197)

A arquitetônica pierceana está relacionada com o método transcendental kantiano, em "seu pensamento contrastavam com as tendências naturalistas e empiristas" (idem, p. 197) Contudo, de acordo com Ferrater Mora, a relação da arquitetônica pierceana com a teoria kantiana "não vai além de uma concordância superficial" (ibidem, 197). Sua ideia de arquitetônica pensa um sistema filosófico, mas num sentido de não deixar que sua teoria tenha falhas estruturais, mantendo assim desimpedida sua investigação. Para Pierce, a arquitetônica atuava como uma base filosófica estrutural para sua teoria pragmática.

O filósofo da linguagem alemão Karl Vossler (Alemanha, 1872 - 1949) dedicou boa parte de sua obra a estudar as teorias positivistas do ideólogo italiano Benedetto Crocce. Ele acreditava que as teorias da linguagem escritas até aquele momento, principalmente de seus antecessores, entre eles o também alemão Wilhelm Von Humboldt ${ }^{8}$, influenciadas pelo

\footnotetext{
8 Ao que se sabe, Wilhelm Von Humboldt não utilizou o conceito de arquitetônica, mas foi influenciador das reflexões do Círculo e é largamente citado na obra de Valentin Volochinov Marxismo e filosofia da linguagem.
} 
idealismo kantiano e o espírito de ordem cultural de Hegel, não consideravam o elemento estético como parte relevante da linguagem. Na obra de 1905, Geist und kultur in der sprache (O espírito e a cultura na linguagem) refutou a tendência positivista da linguagem, ao propor que na pessoa concreta do falante, o ato estético e o espírito se manifestam juntos. No ensaio Os limites da sociologia linguística publicado em 1923, Vossler desenvolve o conceito de arquitetônica ao pensar a linguagem. Primeiro, ao tratar das diferenças estéticas da poesia e da prosa, fala das diferenças entre o homem poético, o homem lógico e o homem eloquente. Para ele, a eloquência poética traria uma musicalidade a esta linguagem que também apresenta um aspecto arquitetônico, imaginativo, que estaria, de certo modo, relacionado à estrutura gramatical da linguagem ou ao sistema da língua.

Pois também os idiomas, graças a sua ordenação de formas mais ou menos simétricas, graças a sua chamada gramática, tem em si certo elemento arquitetônico de que não podemos dar conta com uma explicação mecanicista nem mesmo por meio de referências exclusivas a necessidades intraidiomáticas, teleologicamente econômicas. Porque estas e dentro destas, o ornamental tem seus direitos. (...) Quanto mais alheio a seus fins atuais de compreensão seja uma forma idiomática, mais ainda entra no ornamental, exatamente igual nas formas arquitetônicas ${ }^{9}$. (VOSSLER, 1963, pp. 258 261 - tradução nossa)

No século XX, o conceito de arquitetônica foi utilizado pelo polonês Benedykt Bornstein (Varsóvia, Polônia, 1880 - 1948), que desenvolvia pesquisas sobre as teorias do método transcendental kantiano e também sobre as teorias de Henri Bergson desde seu doutoramento em 1913. Começou a tratar do conceito de arquitetônica na obra intitulada Architektonika zmyslowosci i rozsadku (Arquitetônica da sensualidade e da razão - 1927), mas foi em Architektonika swiat: Logika geometryczno-architektoniczna (Arquitetônica do universo: lógicas geométricas e arquitetônica - 1934) que a arquitetônica tomou forma para "basear a metafísica como ciência das estruturas universais do mundo numa lógica de caráter arquitetônico, não puramente formal, mas real-estrutural. Trata-se de uma lógica topológica, ou geométrico-arquitetônica". (FERRATER MORA, 2000, p. 197). Em Studia philosophica (1935) o filósofo diz que ao

(...) encontrar uma representação no espaço, a lógica põe em evidência o aspecto qualitativo deste e se transforma, sob a forma de uma lógica

\footnotetext{
9 “Pues también los idiomas, gracias a su ordenación de formas más o menos simétricas, gracias a su llamada gramática, tienen em si cierto elemento arquitectônico de que no podemos dar cuenta com uma explicación puramente mecanicista ni tampoco por médio de referencias exclusivas a necessidades intraidiomáticas, teleológicamente econômicas. Porque a La par, y halta dentro de ellas, ló ornamental tiene sus derechos. (...) Cuanto más ajena a sus fines actuales de compreensión sea uma forma iniomática, tanto más entra em lo ornamental, exactamente igual que em lãs formas arquitectonicas."
} 
geométrica, em protótipo da arquitetônica de todas as qualidades, que manifestam assim sua natureza puramente racional (BORNSTEIN, 1935, p. 446 apud FERRATER MORA, 2000, p.197).

Nos anos 1920 do século XX, os pensadores russos do chamado Círculo de Bakhtin começam a atualizar o conceito de arquitetônica. Mikhail M. Bakhtin (1895 - 1975) desenvolve o conceito principalmente em suas obras iniciais Para uma filosofia do ato responsável (1921) e O problema do conteúdo, do material e da forma na arte verbal (192324). Outro importante participante do Círculo, Pável Nikoláievitch Medviédev (1891 - 1938) trata do conceito na obra $O$ método formal nos estudos literários (1928), ao analisar as tarefas construtivas da arte em diálogo com o escultor e filósofo de arte alemão Adolf Hildebrand (Marburg - Alemanha, 1847 - 1921) que também utilizou o conceito na obra $O$ problema da forma na arte figurativa (Das Problem der Form in der bildenden Kunst - 1893).

Refletiremos sobre o conceito nas obras do Círculo, bem como do diálogo com outros pensadores, no último tópico deste capítulo.

Após esse breve relato sobre a arquitetônica na história da filosofia, propomos em nossa reflexão um maior aprofundamento do uso do conceito nas teorias de Aristóteles, Kant e no Círculo de Bakhtin. A observação mais atenta dessas três teorias poderá nos auxiliar nas respostas que buscamos acerca da arquitetônica bakhtiniana e da esfera político-cultural brasileira refletidas nos enunciados do Sistema Nacional de Cultura.

\subsection{A arquitetônica aristotélica}

Aristóteles foi, sem dúvida, um dos grandes influenciadores de todo o pensamento ocidental e, até os dias de hoje, sua forma de compreender o mundo ainda pode ser considerada como atual. Suas obras foram divididas em dois tipos de escritos: os exotéricos (destinados ao grande público) e os esotéricos ou acromáticos (destinados ao ensino, aos intelectuais e seus seguidores estudantes do Liceu). No livro sobre as Categorias organizado pelo filósofo português Antonio Monteiro (2002), a obra esotérica de Aristóteles aparece dividida da seguinte forma:

A) Diálogos ou obras do período da Academia: O Grilo, o Eudemo, o Protréptico ou Exortação à filosofia, Sobre as ideias, Sobre o bem, e Sobre a filosofia. B) Ciências teoréticas: 1. Lógica: Categorias, Acerca da interpretação, Primeiros analíticos, Segundos analíticos, Tópicos, Refutações sofísticas (O conjunto da obra lógica é conhecida pela designação de Organon). 2. Metafísica. 3. Filosofia da natureza: Física, Do céu, Sobre a alma, Da geração e da corrupção, os meteorológicos, A história dos animais, A geração dos animais, As partes dos animais, Sobre o movimento dos animais, e todo um conjunto de tratados breves de história natural. C) 
Ciências práticas: 4. Ética e política: Ética à Nicômaco, Magna moral, Ética a Eudemo, Política, A constituição de Atenas. D) Ciências da Criação: 5. Estudos sobre a arte: A retórica, A poética. (MONTEIRO, 2002, pp. 13 - 14)

Na observação das ciências estudadas por Aristóteles, destacamos a importância de sua proposta de divisão das ciências que nos séculos seguintes passaram a ser temas frequentes na historiografia da filosofia mundial. A divisão entre as ciências deve ser entendida como uma pista para nossa reflexão, ainda que nosso interesse esteja principalmente no conceito de arquitetônica em si, como veremos.

O desenvolvimento da arquitetônica aristotélica está presente na obra Ética à Nicômaco (EN), considerada a mais importante e madura dentre os três escritos sobre a Ética ${ }^{10}$ e como a reflexão inauguradora da mesma enquanto uma ciência. "A ética, como parte da filosofia é considerada por Aristóteles uma ciência prática, cujo resultado não é exterior ao agente, que na ordem prática, está situada na dependência da política”. (PELEGRIN, 2010, p. 28) De acordo com Cooper (2010), Aristóteles afirma no livro $X$, último da obra, que o propósito da Ética Nicomaqueia...

É vir a agir de certa maneira, ele está recordando-nos que o estudo ora a encerrar-se visa a nos tornar plenamente bons ao nos conferir o almejado entendimento prático da virtude. (...) nos tornemos pessoas dotadas de sabedoria prática ao fazer com que possuamos esse entendimento completo do bem humano e do lugar que a virtude nele ocupa. (COOPER, 2010, p. 444)

De acordo com Ferrater Mora, o conceito A $\rho \chi \imath \varepsilon \kappa \tau$ ovıкó $\varsigma$ (arquitekthon) ${ }^{11}$ pode ser

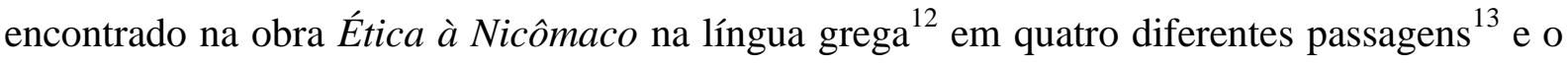
conceito pode ser considerado como fundamental, por ser evidenciado logo nas primeiras linhas e foi traduzido por diversas formas. No trecho abaixo, a arquitetônica aparece traduzido como as "artes principais" de que todas as outras artes ou ciências práticas teriam finalidade. Esta é definida por Aristóteles como a ciência política entendida de maneira ampla, e está

\footnotetext{
${ }^{10}$ A ética (ethiké) significa algo como a doutrina ou disciplina. Deriva de ethos, que significa o caráter habitual, dos costumes - o que faz da ética o equivalente etimológico do termo de origem latina moral (uma ciência dos costumes). (...) A virtude ética (arete) é um estado do sujeito, que é de certo modo a cristalização de bons hábitos, que se implantam tanto melhor no indivíduo quanto mais cedo ele os adquire na vida. (PELEGRIN, 2010, p. 28)

${ }^{11} \mathrm{O}$ conceito também foi encontrado na forma $\alpha \rho \chi \imath \varepsilon \varepsilon \kappa \tau \omega v$ (arquiteto dos fins) que traz o mesmo radical

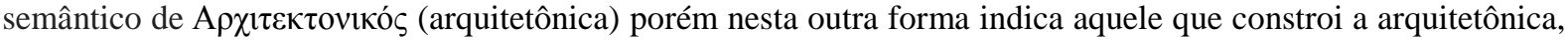
$o$ arquiteto dos fins.

${ }^{12}$ Para confirmação da presença do termo ou de similar etimológico consultamos uma edição bilíngue grego espanhol.

${ }^{13}$ Nas traduções consultadas, o conceito de arquitetônica aparece traduzido com diversas expressões. Trataremos disto com maior detalhamento a seguir.
} 
acima das ciências práticas.

Toda arte e toda indagação, assim como toda ação e todo propósito visam a algum bem; por isto foi dito acertadamente que o bem é aquilo a que todas as coisas visam. Mas nota-se uma certa diversidade entre as finalidades; algumas são atividades, outras são produtos distintos das atividades de que resultam; onde há finalidades distintas das ações, os produtos são por natureza melhores que as atividades. Mas como há muitas atividades, artes e ciências, suas finalidades também são muitas; a finalidade da medicina é a saúde, a da construção naval é a nau, a da estratégia é a vitória, a da economia é a riqueza. Onde porém, tais artes se subordinam a uma única aptidão - por exemplo, da mesma forma que a produção de rédeas e outras artes relativas a acessórios para a montaria se subordinam à estratégia, de maneira idêntica umas artes se subordinam sucessivamente a outras - as finalidades das artes principais devem ter precedência sobre todas as finalidades subordinadas; com efeito, é por causa daquelas que estas são perseguidas. (...) Se há, para as ações que praticamos, alguma finalidade que desejamos por si mesma, sendo tudo mais desejado por causa dela, e se não escolhermos tudo por causa de algo mais (...) evidentemente tal finalidade deve ser o bem e o melhor dos bens. Não terá então uma grande influência sobre a vida o conhecimento deste bem? (...) Aparentemente ele é o objeto da ciência mais imperativa e predominante sobre tudo. Parece que ela é a ciência política, pois esta determina quais são as demais ciências que devem ser estudadas em uma cidade e quais são os cidadãos que devem aprendê-las e até que ponto. (ARISTÓTELES, 1985, pp. 17-18, L 11094 a 1 - 30, grifos meus)

Aristóteles inicia a obra tratando da questão principal da Ética em que a finalidade de todas as ações "visam a algum bem" e como "há muitas atividades, artes e ciências, suas finalidades também são muitas", porém as finalidades das principais "devem ter precedência sobre as finalidades das outras". Tal finalidade suprema deve ser o bem e o "melhor dos bens" e este é o objeto da ciência (arquitetônica) soberana e predominante sobre tudo, relativa à ciência política. Esta determina quais seriam as demais ciências e suas finalidades e quais devem ser estudadas numa cidade para seu bem. A finalidade deste bem serve para um indivíduo e até mesmo para sua família, mas é ainda mais nobre e completa se servir especialmente à comunidade e à cidade. A finalidade suprema do bem é o bem viver que também pode ser traduzido como a felicidade (eudaimonia) e é o objeto da ciência (arquitetônica) que engloba todas as outras, a ciência suprema, definida desde Platão como a ciência política num sentido mais amplo. Para Aristóteles, o conjunto das ciências práticas que visam os costumes, a ética e a política, compõe a ciência política no sentido amplo e representa a "filosofia das coisas humanas". Aqui podemos perceber o finalismo aristotélico que permeia diversas de suas obras: tudo o que existe é explicável por aquilo em vista do que existe, para sua finalidade e a finalidade da arquitetônica é o melhor dos bens, o bem da cidade. 
A fim de melhor compreender porque a expressão relativa ao conceito de arquitetônica foi traduzida recentemente para as mais diversas línguas com expressões diferenciadas a nosso propósito, realizamos uma busca filológica detalhada em diversas traduções: em português, inglês, francês e espanhol e também na língua grega. Em boa parte destas, em notas e comentários iniciais, os tradutores ressaltam a dificuldade de se traduzir uma obra filosófica escrita há mais de 23 séculos, num contexto não apenas muito diferente, mas numa língua que em seu formato clássico, sofreu alterações muitas vezes desafiadoras até para os maiores especialistas.

Uma das principais dificuldades na tradução da Ética à Nicômaco é encontrar equivalentes satisfatórios para certos termos do original. Em alguns casos a palavra tradicionalmente usada em português como equivalente se desgastou com o passar do tempo e seu significado adquiriu tal ambiguidade que seu uso induziria o leitor ao equívoco. (KURY, 1985, p. 12)

Inicialmente buscamos a confirmação da presença do conceito de arquitetônica ou mesmo de expressões etimologicamente muito próximas a ele, no texto da Ética à Nicômaco em grego ${ }^{14}$. No contexto grego do século IV A.C. em que viveu Aristóteles e na língua grega clássica, a semântica da expressão era distinta da que temos hoje. Arquitetônica, como veremos a seguir, não estava em nenhum momento relacionada à arquitetura no sentido atual da palavra, ou a uma edificação construída e concreta. Naquele contexto, o que estivesse ligado à arquitetura e à construção, seria remetido à etimologia de "pedra" ( $\pi \dot{\varepsilon} \tau \rho \alpha)$. A

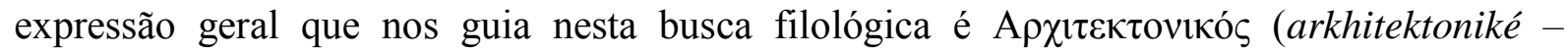
arquitetônica) ou $\alpha \rho \chi \imath \varepsilon \varepsilon ́ \kappa \tau \omega \nu$ (arkhitekthon - arquiteto) e traz em sua raiz etimológica o radical arché relativo a um poder superior, de comando ou autoridade ou como tratado desde os filósofos pré-socráticos, a um princípio que deveria estar presente em todos os momentos da existência de todas as coisas. A expressão também incluía a semântica de "ciência mestra" levando à ideia da faculdade do conhecimento organizador ou razão prática, e estaria relacionada inicialmente às teorias da tradição Platônica sobre a política.

Na observação da obra Ética à Nicômaco em versão bilíngue grego-espanhol, encontramos expressões relativas ao conceito de arquitetônica em quatro trechos e em diferentes formas de representação. O conceito aparece na obra em três importantes excertos. No livro 1, os capítulos 1 e 2 abordam respectivamente "todas as atividades humanas visam

\footnotetext{
${ }^{14}$ Por desconhecimento da língua grega, para compreender o uso do conceito de arquitetônica na obra em grego (utilizamos a edição bilíngue grego - espanhol) e a confirmação da presença do conceito na obra de Aristóteles, contamos com a ajuda da pesquisadora Helena Marona, mestre e doutoranda no PPG de Letras clássicas da FFLCH - USP e especialista na tradução do grego para o português da obra de Platão.
} 
a um bem" e "ciência do bem com vistas ao homem é a política". A expressão grega para arquitetônica com sentido de "arte principal ${ }^{15}$ " ou ciência prática soberana aparece nos trechos 1094 a 14 e 1094 a 25. É também relevante observar que o suposto título do capítulo segundo fala de uma ciência do bem, no caso a prática da ética tem como finalidade o homem e o bem viver e está contida nesta ciência ou arte suprema ou arquitetônica. Em ambas as passagens, e nas diversas traduções analisadas, o conceito, de formas distintas, busca mostrar que esta suposta ciência arquitetônica é:

a) Em português (brasileiro):

- "Artes principais (...) ciência mais imperativa e predominante sobre tudo". (ARISTÓTELES, 1985)

- "Artes fundamentais (...) arte mais prestigiosa e que mais verdadeiramente se pode chamar a arte mestra”. (ARISTÓTELES, 1991)

- "Artes principais (...) uma ciência que fosse preeminente, a ciência maior" (ARISTÓTELES, 2007, p. 37)

b) Em Espanhol:

- "Las (artes) principales (...) la ciencia más fundamental” (ARISTOTELES, 2002)

- " "Una ciência especial que los domina (...) La ciência soberana, de la ciência más fundamental de todas" (ARISTOTELES, 2007, p. 10)

c) Em inglês:

- "The master science (...) highest master science"16 (ARISTOTLE, 2005)

- "The ruling science (...) the most controlling science"17 (ARISTOTLE, 1985)

- "The master arts (...) The most authoritative of the sciences" 18 (ARISTOTLE, 1961)

- "Expertise (...) The most sovereign", i. e. the most architectonic". (ARISTOTLE, 2002)

d) Em francês:

- "La science special qui les domine (...) La science la plus fondamentale de toutes"20 (ARISTOTELES, 1992)

As diferenças entre as diversas traduções apontam para uma busca de compreensão de uma expressão que só foi de fato instituída como a conhecemos atualmente a partir de filósofos posteriores a Aristóteles. Entretanto, em todas as situações, a ideia de uma arte

\footnotetext{
${ }^{15}$ É relevante evidenciar que para os gregos antigos, arte e ciência são sinônimos. Arte no sentido atual do termo, para os gregos, a tekne, estava mais relacionada à prática do que à razão.

16 “A ciência mestra ( . .. ) a mais alta ciência mestra" (tradução nossa em todos os itens)

17 "A ciência dominante ( ... ) a ciência mais controladora"

18 "A arte mestra (...) a ciência com a maior autoridade"

19 " perícia (...) a mais soberana"

20 "A ciência que domina (...) a ciência mais fundamental de todas"
} 
principal ou arte mestra que rege todas as outras está presente. Apenas em duas traduções consultadas há a menção ao termo arquitetônica, no texto da Oxford University de 2002 e numa nota de roda pé da edição francesa de 1992.

A expressão arquitetônica é utilizada na leitura medieval cristã de Tomás de Aquino, em Comentário à Ética a Nicômaco de Aristóteles (2010) (da obra original em latim In decem libros Ethicorum expositio 1270 - 1272). Contudo a ética de Aquino pode ser entendida aqui não mais como vinculada à política, mas sim na relação ética espiritual com Deus, pois, para a tradição filosófica escolástica, só Deus é plenamente bom.

Posteriormente, dentre os filósofos modernos e contemporâneos, o conceito de arquitetônica foi amplamente utilizado como vimos no tópico anterior. Todavia, é relevante perceber que, em boa parte dos filósofos posteriores, o sentido da arquitetônica nos remete a algo sistemático, disciplinar e ao lado racional do homem, mesmo que de modos distintos. Entretanto, em Aristóteles, a ideia de uma arte ou ciência principal que contemplava de maneira superior todas as outras deve ser pensada não só por sua semântica complexa, mas principalmente por sua concreta significação no todo do pensamento aristotélico. $\mathrm{O}$ entendimento de que esta arte ou ciência prática principal, mais importante, mais soberana, equivaleria, para Aristóteles, à arte mestra e à ciência política de forma ampla é um reflexo da tradição filosófica clássica grega, da importância da polis neste contexto do século IV A.C. e ao desenvolvimento da política também como uma ciência prática para o bem da cidade.

A utilização do conceito em duas expressões diferentes no livro VI da Ética à Nicômaco, no final do capítulo 7 (1141 b 22) e no início do capítulo 8 (1141 b 25) chama ainda mais atenção à nossa reflexão, pois aqui Aristóteles retorna ao assunto e trata da arquitetônica como um "saber organizador", "faculdade dominante" ou "controladora" 21.

Nas diversas traduções que utilizamos, ou mesmo nos comentadores consultados, percebemos que o uso das expressões relativas às ciências ou sabedorias práticas e teóricas variam muito de acordo com a intenção da tradução ou mesmo de aplicação da exposição em teses diversas. Achamos pertinente utilizarmos também a reflexão sobre os termos em grego para melhor ilustrar as intenções do filósofo. A sabedoria teórica ou filosófica deve ser considerada por meio do termo sophia e a sabedoria prática ou discernimento (ou até mesmo escolha, decisão, prudência e honradez), pelo termo phronesis e que está relacionado com a noção de dilema. As duas expressões demonstram que Aristóteles buscava discutir a ética por

\footnotetext{
${ }^{21}$ Neste capítulo de Ética à Nicômaco, a expressão relativa à arquitetônica foi traduzida por estas formas diferentes nas três obras consultadas em língua portuguesa.
} 
meio dos usos teóricos e práticos da razão ou da sabedoria (considerada aqui de modo amplo e englobando as sabedorias teórica e prática). Os trechos do capítulo 7 do livro VII, que antecedem o uso do conceito de arquitetônica, mostram o que Aristóteles entendia por sabedoria e qual é sua relação com a ciência arquitetônica que era essencial para ambas.

A palavra sabedoria é usada nas artes para assinalar os mestres mais perfeitos em suas respectivas artes. (...) e neste sentido nada mais queremos dizer neste caso do que a excelência artística, mas pensamos que algumas pessoas são sábias em geral e não em alguma esfera em particular, nem sábias em algo mais (...) a sabedoria, portanto, é a mais perfeita das formas de conhecimento. Consequentemente, o sábio não deve apenas saber o que decorre dos primeiros princípios; ele deve também ter uma concepção verdadeira acerca dos próprios primeiros princípios. Logo, a sabedoria deve ser uma combinação da inteligência com o conhecimento - um conhecimento científico consumado das coisas mais sublimes. (ARISTÓTELES, 1985, p. 118)

$\mathrm{Na}$ continuação do capítulo, ele define distinções entre a sabedoria teórica ou filosófica (sophia), a ciência política (arquitetônica) e à prática da phronesis, o discernimento que implica um processo ou atividade de deliberação (boulesis) como um saber prático, e à ética. Conceitos estes que devem ser pensados tanto nas vidas particulares, quanto nas relações dos homens com a cidade e seu sistema legislativo. E é aqui que ele traz

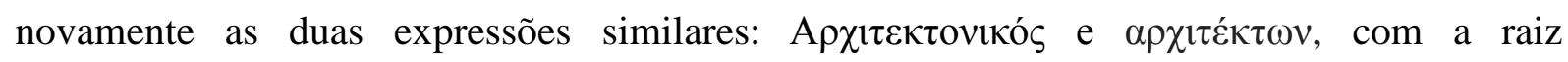
etimológica referente à arquitetônica e ao arquiteto da mesma, traduzidos com os respectivos sentidos de "faculdade dominante" e "mestres na arte" conforme os grifos.

Com efeito seria absurdo pensar que a ciência política ou o discernimento é o melhor conhecimento, já que o homem não é o que há de melhor no universo. (...) É obvio também que a sabedoria filosófica e a ciência política não podem ser a mesma coisa, pois se a disposição da alma relacionada com o interesse próprio de uma pessoa devesse ser chamada de sabedoria filosófica, não há uma sabedoria filosófica, haveria muitas sabedorias filosóficas (...) Das considerações precedentes resulta então a evidência de que a sabedoria filosófica é uma combinação do conhecimento científico com a inteligência, que permite perceber o que há de mais sublime na natureza. (...) O discernimento por outro lado relaciona-se com as ações humanas e coisas acerca das quais é possível deliberar, de fato, dizemos que deliberar bem é acima de tudo a função das pessoas de discernimento (...) As pessoas boas de um modo geral são as capazes de visar calculadamente ao que há de melhor para as criaturas humanas nas coisas passíveis de serem atingidas mediante a ação. (...) $\mathrm{O}$ discernimento se relaciona também com a ação, de tal modo que as pessoas devem possuir ambas as formas, ou melhor, mais conhecimento dos fatos particulares do que conhecimento dos universais. Mas também aqui deve haver alguma faculdade dominante. A ciência política e o discernimento correspondem à mesma qualidade da alma, sua essência porém não é a mesma. No caso da sabedoria relacionada com os assuntos da cidade, a forma de discernimento que desempenha papel dominante é a ciência legislativa, enquanto a que se relaciona com os casos 
particulares é conhecida pela denominação genérica de ciência política, esta é pertinente à deliberação e à ação, pois um decreto é algo a ser cumprido sob a forma de um ato individual. E por isto que se diz que somente os mestres nesta arte participam da política pois somente eles agem da mesma forma que um trabalhador manual. (ARISTÓTELES, 1985, pp. 119-120, grifos meus)

Percebemos aqui que Aristóteles busca mostrar que a sabedoria teórica ou filosófica está relacionada à sabedoria prática, porém as duas são distintas entre si e não têm a mesma essência. Esta sabedoria teórica conecta-se com as ciências da natureza e com entendimento do homem na relação com as questões fisiológicas de sua vida. Para Aristóteles, o estudo da física recobria o mais alto grau filosófico das ciências teóricas. Por outro lado, o discernimento ou saber prático trata dos costumes, da vida do homem em sociedade, de suas relações pessoais, sociais e políticas, das amizades, das leis, e consequentemente a todos esses fatores, de sua "bondade". No entanto, para ele, essa disposição de ser alguém bom, era uma disposição prática, mas não era apenas uma disposição social, era também uma possível disposição biológica, de linhagem e um tipo de saber teórico e era inicialmente individual. A ciência política enquanto ciência mestra deveria ser utilizada em nível individual, mas pensando no bem do coletivo.

$\mathrm{O}$ conceito $\alpha \rho \chi \imath \tau \varepsilon ́ \kappa \tau \omega v$ que remete à etimologia de uma expressão bem próxima à arquitetônica também foi encontrado no excerto do livro VII no início do capítulo 11, no trecho 1152 b 2 em que Aristóteles diz "Ao filósofo político também incumbe considerar a natureza do prazer e do sofrimento, pois ele é o arquiteto dos fins com vistas aos quais chamamos certas coisas de más e outras de boas estritamente.” (ARISTÓTELES, 1985, p. 146, grifos meus). Nesse livro da ética, ele discute as distinções entre as questões virtuosas e viciosas, as contingências e incontingências, os prazeres e desprazeres. No capítulo em específico, ele trata da dificuldade de compreensão da diferença entre a felicidade pelos prazeres ou desprazeres ou a felicidade plena conseguida apenas pela contemplação (theôria) por meio da sabedoria teórica que só o filósofo possui. A contemplação de ordem teórica é o trabalho que o filósofo, o arquiteto dos fins, tem como finalidade suprema e só esta leva à felicidade plena.

Para Aristóteles, a ciência política, em seu sentido amplo, era designada principalmente àqueles que tinham não apenas o saber prático, mas principalmente uma combinação deste com o saber teórico, a filosofia (sophia). Esse saber teórico ou intelectual não era designado a qualquer cidadão. Para chegar a este patamar superior era necessário um 
bom ethos obtido por meio do habitus desenvolvido ao longo da vida, uma boa linhagem biológica que daria uma predisposição física relacionada a uma inteligência no sentido fisiológico e o desejo de aprender os ensinamentos intelectuais teóricos. A combinação destes fatores possibilitam a arete, a virtude ética. Cabia então a estes filósofos a compreensão da natureza dos fatores que poderiam contribuir para a busca do bem maior, a felicidade (eudaimonia) e era plenamente conseguida pelos filósofos por meio da contemplação ou theôria. Este seria o critério prático principal da ação correta e da virtude moral ${ }^{22}$.

(...) a contemplação (theôria) é a eudaimonia (...) as ações corretas o são precisamente em razão de tornar possível ou promover de algum modo a theôria, e que os estados de caráter dignos de louvor como as virtudes ou excelências o são porque favorecem o estado e a atividade a ser valorados acima de tudo mais, o estado de sabedoria teórica (sophia) e a atividade da theôria. (ACKRILL, 2010, p. 103)

A busca de uma teoria que dialogasse com os preceitos políticos práticos da democracia ateniense constituem os três escritos sobre a ética do autor grego, sua obra política e também sua retórica, ainda que esta última faça parte das ciências criativas. $\mathrm{Na}$ Ética à Nicômaco, Aristóteles inaugura sua ética, mais tarde chamada pelos latinos de filosofia moral, pensando a relação do homem com sua comunidade e com a cidade, o bem viver na cidade, como deve se portar o cidadão virtuoso da cidade, sempre visando o fato de que, se os cidadãos vivem bem, a cidade é um lugar para todos. A ética é então parte importante desta ciência arquitetônica, a ciência política tida como a sabedoria mais soberana que tem por finalidade o bem do homem com vistas ao bem da cidade, à política e à visão grega de democracia.

No livro I da Ética a Nicômaco, a ética aparece como parte (ou introdução) desta "ciência arquitetônica" que é a política e que tem por fim o bem do homem; ela possui finalidade específica, largamente condicionada pelo bem da cidade. (...) (a ética) se desenvolve ao lado da economia doméstica e da política a qual comporta por sua vez dois aspectos: a prudência legislativa e a prudência política (no sentido restrito da ação política). Todas essas disciplinas se tornam elementos desta filosofia dos assuntos humanos que Aristóteles evoca no fim da Ética a Nicômaco. (VERGNIERES, 1998, pp.78)

A virtude ética ${ }^{23}$ estava relacionada com o ethos de cada cidadão, e foi largamente

\footnotetext{
${ }^{22}$ É importante ressaltar aqui que a sociedade ateniense era uma sociedade excludente, que entendia como cidadão apenas homens de meia idade, da aristocracia. Isto é, para os gregos, a virtude ética (arete) só era possível para estes homens "superiores".

${ }^{23}$ A virtude (arete) demonstra a excelência em alguma coisa. A virtude ética demonstra "um estado habitual que leva a escolher, que é um justo meio relativamente a nós, o qual é determinado por uma regra, tal como o determinaria o homem prudente"(ARISTÓTELES, EN, 1985, L II, 6, 1106 b 36)
} 
tratada nas três éticas, mas principalmente na Retórica. O estudo do ethos esteve presente em boa parte das obras do filósofo e deve ser entendido pela tríade retórica: ethos (a imagem de si no discurso / a demonstração da virtude), o pathos (as paixões / o outro / o auditório) e o logos (o discurso / o enunciado). O estudo Etológico ${ }^{24}$ dos costumes pode ser encontrado também nas obras das ciências da natureza, em que elabora um apanhado de comportamentos dos animais. Na Retórica, o estudo do ethos também foi desenvolvido, mas de uma forma distinta, através de uma tipologia de caracteres. Na Política foi desenvolvido ao demonstrar a realidade de povos e comunidades. Contudo, o ethos que nos interessa nesta tese articula-se com os estudos da ética e deve ser compreendido num termo plural ethe e está na relação dos costumes particulares do homem em diálogo com a comunidade.

Nos três livros de ética, a ethe $^{25}$ deve ser pensada na intenção de auxiliar o cidadão grego na "elaboração de uma ética coletiva adaptada ao povo particular" (VERGNIERES, 1998, p.9), visando à correção dos costumes de cada cidadão que vive em comunidade, isto é, a ethe está inserida nas reflexões sobre a criação das leis. Aristóteles acreditava que um cidadão livre que agia de maneira correta em seus assuntos particulares também o fazia para o bem da comunidade e consequentemente em sua relação com a polis de modo mais amplo.

A presença de um capítulo inicial que discorre sobre a finalidade da ciência arquitetônica, da mais importante e soberana, a ciência política, na mais importante obra sobre a ética, possibilita nossa reflexão sobre a relevância da filosofia política para o filósofo grego e para o contexto, bem como para toda a tradição grega, que tem início com as narrativas homéricas. Aristóteles destacou-se como filósofo por trazer a esta ciência também um caráter prático e de não mais servir apenas à aristocracia grega, mas também à cidade. $\mathrm{O}$ avanço democrático obtido ao longo das décadas que o precederam, bem como os debates com os escritos de Sócrates, Platão, ou mesmo com os sofistas Protágoras e Górgias, contribuíram para que a filosofia aristotélica chegasse a um patamar de sofisticação que a torna atual em alguns pontos até os dias de hoje.

A importância da cidade-estado em sua obra deve ser pensada como fator que explicaria o porquê de a ciência política ser entendida como a ciência principal, ou uma forma superior de sabedoria que engloba a sabedoria teórica e a sabedoria prática e que estaria acima de todas as outras ciências, pois estas deveriam operar de modo prático em favor da cidade e seus cidadãos visando o bem viver. "A cidade é definida como uma pátria em relação à qual

\footnotetext{
${ }^{24}$ Etológico aqui deve ser pensado no sentido de ethos dos animais.

${ }^{25}$ A palavra Ethe deve ser entendida não como um plural no sentido gramatical, mas como uma coletividade de ethos.
} 
cada um se situa numa relação de filiação e subordinação (...) que se exprime politicamente pela preeminência das leis". (VERGNIERES, 1998, p. 51)

Aristóteles acreditava que o homem era um animal político por natureza. Percebia que em suas relações mais particulares também agia de forma política. Para ele, a política é um conjunto de práticas para que os homens pudessem se dedicam a coexistir. Em sua obra Política (1998), Aristóteles desenvolveu um "Método Analítico" proposto para melhor descrever e analisar os regimes políticos existentes e dentro destes exemplificar o regime ateniense da democracia. O Método Analítico buscava "Dividir o composto até seus elementos não compostos (isto é, as partes ínfimas do todo).” (WOLFF, 2001, p. 48) Esse método visava pensar as relações que estruturam as partes num todo e a partir desse detalhamento compor um todo ideal.

Para Aristóteles, o cidadão deve tudo à cidade e nela se insere pela prática da democracia. É na política, praticada por meio da deliberação, que a democracia acontece. Esta ciência se bem aplicada na conexão entre o cidadão grego e a cidade leva ao bem maior desta vivência, à eudaimonia, à felicidade. A boa aplicação da ciência política depende ainda de outras disciplinas: a economia, em que se discutem as riquezas da cidade; as ciências da natureza, incluídas aí a medicina, as ciências que pensavam o céu e os animais; os estudos de lógica; e as ciências do homem, a ética, e sua busca particular do bem maior; a felicidade, mas também a política, pensada como prática, e a retórica, tida como uma técnica e não como uma ciência, mas que estaria à disposição da prática política como a arte da persuasão.

Nessa atuação prática com a cidade ateniense, o cidadão ${ }^{26}$ "tem o poder de mudar as leis se tiver apoio de concidadãos conscientes. Pode escolher entre persuadir e ser persuadido e a saber obedecer" (VERGNIERES, 1998, p. 51) Essa escolha pode ser definida aqui como a phronesis ou discernimento. A arte ou ciência política pensada em sua amplitude tinha então como finalidade o pleno exercício da democracia, sempre visando ao melhor para a cidade, ao bem viver, de maneira ética e em busca da felicidade.

A criação das leis era parte importante dessa boa relação com a cidade. A cidadania ateniense estava condicionada a esta participação, e para esta ser boa, dependia do discernimento ou do saber prático e da virtude ética, a arete.

\footnotetext{
${ }^{26}$ O cidadão grego participativo da democracia deve ser entendido aqui como homem adulto e de classe social não escrava, com boa linhagem familiar. Aristóteles, bem como seus predecessores, acreditavam que a possibilidade de um conhecimento intelectual estava diretamente relacionada com a linhagem biológica de cada pessoa. Mulheres, escravos, crianças, idosos, pessoas com qualquer tipo de deficiência ou mesmo que não tivessem a plena beleza com os padrões gregos, não eram considerados intelectualmente hábeis para bem deliberar na ágora democrática.
} 
É possível aferir que, para Aristóteles, a criação de leis está inserida nesta ciência arquitetônica, a ciência política, pois para criá-las e defendê-las de modo prático perante a massa de cidadãos gregos, era necessário ao legislador proponente de uma lei que possuísse conhecimento profundo desta ciência política arquitetônica, bem como discernimento e virtude, para que o ethos apresentado ao longo de sua deliberação, pudesse, através do logos, isto é, do discurso / enunciado de defesa desta lei, convencer o auditório (pathos) através da persuasão dos espíritos de que esta lei beneficiaria a polis.

A lei remete à faculdade humana de discurso, o logos e sua função é a declaração (digo que). A lei é o dito da cidade, a declaração comum que mantém juntos os cidadãos. Ela deve tornar-se a $\operatorname{doxa}^{27}$ de todos e para fazer isso era indispensável a educação do ethos.

A ideia de ciência política de forma ampla, porém, não nasceu em Aristóteles. A tradição filosófica grega já abordava o tema antes mesmo de Sócrates, com o filósofo Pitágoras no século VI A.C.. O grande mestre de Aristóteles, o filósofo Platão foi um dos que percebeu a relevância desta ciência política em sua conhecida obra República ${ }^{28}$, mas foi na obra $O$ Político que tratou do tema de modo mais teórico.

A ciência política que foi pensada por Platão como distinta da teoria política que deve ser compreendida como uma ciência intelectual (gnostike) e não uma simples prática política e se refere ao discernimento ou à prudência ${ }^{29}$ (phronesis), não tem finalidade crítica e sim diretiva com vistas a dar ordens "àqueles que agem, a fim de que suas ações se conformem à justa medida”. (VERGNIERES, 1998, p. 59) Para Platão, esta ciência política que Aristóteles pensava como arquitetônica, era uma ciência autodiretiva. Seu poder de decidir está inerente à razão de se autoregular, como caráter absoluto, o oposto do arbitrário e aqui se difere do que propôs Aristóteles alguns anos mais tarde. Para Platão, "toda aptidão ao poder reporta-se a um poder" (WOLFF, 2001, p.46) a ciência política, a "ciência que comanda", tinha um caráter de mando, diferentemente de Aristóteles que enxergava a arquitetônica como um processo de relação ética entre o particular e o coletivo. Na obra $O$ Político, Platão propõe que

\footnotetext{
27 A doxa representava o senso comum, o auditório universal, a opinião pública.

28 "Em a República, o filósofo não governa porque quer, mas porque deve fazê-lo. E ele deve fazê-lo, porque sua natureza filosófica, que ele precisa desenvolver, torna-o necessariamente portador dessa função. (...) Com isso Platão estabelece uma separação entre o exercício de poder e o desejo de exercê-lo. O melhor governante é precisamente aquele que, conhecendo o real, justamente por isso não tem vontade de governar, é aquele que não é movido pelas benesses que tanto atraem os homens à vida política, porque aprendem a desdenhar dos bens materiais e saberá como legislador impedir que a riqueza se insinue na cidade e comprometa sua unidade. (BOLZANI, 2006, p. XXXVII)

${ }^{29}$ Aqui podemos compreender a expressão grega Phronesis com diversas possibilidades de interpretação. Estamos considerando a partir da tradução utilizada por "discernimento", mas também é possível compreendê-la como: prudência, escolha ou mesmo como honradez. Ela é uma disposição prática que concerne ao que é bom ou ruim. O conceito teórico pode ser compreendido também como a excelência do intelecto prático.
} 
É claro que a ciência da legislação faz parte da ciência que comanda: a melhor coisa, mas não é que não temos nas leis ao invés um homem legislador dotado de bom julgamento (...) uma lei não pode nunca ordenar com exatidão para todos o melhor e o mais justo incluindo no instante o bem supremo. ${ }^{30}$ (PLATÃO, 2012, p. 299 , grifos e tradução nossa)

Para Platão, a razão tinha uma finalidade de justa medida e de algo bom visando à harmonia na cidade, isto é, sua finalidade principal estava na ciência política. A razão estava acima das leis e a ciência política também. Enquanto que, para Aristóteles, a ciência arquitetônica soberana está acima de todas as outras como arte principal que rege a finalidade das sabedorias práticas com vistas a um bem, e este bem depende de obras (ergon) das outras ciências.

Platão, no Político, afirma claramente a superioridade da ciência política não somente sobre a lei escrita, mas sobre o costume. A ciência, com efeito, é universal, isto é, ela é capaz de entrar no detalhe dos casos particulares; a lei é geral e só pode dar enunciados globais e aproximados; tende a instaurar a igualdade aritmética, nivelando as diferenças individuais, enquanto a ciência dá a cada um o que merece, segundo a igualdade geométrica. Enfim, a lei tem a rigidez e a cegueira do que está escrito; a ciência, quando está viva no espírito do político, deve pois sempre ter prioridade sobre a lei. (VERGNIERES, 1998, p. 62)

Na filosofia Platônica, esta razão estava condicionada à inteligência desta justa medida e à natureza mortal do homem, pois para ser um cidadão político e servir à cidade era preciso ter a virtude desta justa medida da razão. Caso contrário, se a justa medida não fizesse parte deste indivíduo, este homem recorreria ao vício e não poderia praticar a virtude na cidade, não poderia praticar a política. Aos homens viciosos, que não possuem a virtude era preferível que seguissem as leis, pois sua natureza humana não estava condicionada por esta justa medida da razão.

O pensamento ético de Aristóteles se constitui em relação ao de Platão, numa contestação de existência de um bem único, causa de todos os particulares. Contudo, Aristóteles concebe a existência de um bem acima de todos os outros na medida em que os outros a ele não são subordinados. Essa hierarquia dos bens corresponde à hierarquia das artes. Assim o bem do estrategista é subordinado ao bem do político, pois faz-se a guerra visando ao bem governo da cidade, ao passo que não se governa visando fazer a guerra, exceto numa cidade desencaminhada. Há portanto, um bem supremo, que se basta a si próprio e que é a felicidade. (...) Porém todo bem se define com relação a uma obra (ergon) o bem da medicina com relação à cura dos pacientes, a felicidade, bem supremo para os homens defini-se pois pela obra própria do homem, ou seja aquela que o caracteriza absolutamente. Esse é o

\footnotetext{
30 “ (...) è chiaro che la scienza della legislazione fa parte della scienza regia: La cosa migliore, però, non è Che abbiamo forza Le leggi bensi um uomo régio dotato di assennatezza. (...) uma legge non potrebe mais ordinare com esattezza per tutti la cosa migliore i piu giusta includendo nel contempo is bene piú alto."
} 
estado de homem virtuoso que só pode atingir o estado de plenitude representado pela felicidade, realizando sua natureza que é a de um animal político. (PELEGRIN, 2010, p.14)

Tanto para Platão ${ }^{31}$, quanto para Aristóteles, a natureza humana deveria ser condicionada pela educação e pelo habitus, como a educação intelectual para que o homem alcançasse a excelência para a ciência política. Assim, seria possível atingir a excelência da virtude expressa no ethos, aprender a deliberar utilizando a razão e o logos e obter a felicidade. Porém, para Platão, nem todos os homens conseguiriam alcançar essa arte suprema. A partir do excerto de Pelegrin, podemos aferir que em Aristóteles a finalidade da ciência política, isto é, da ciência suprema arquitetônica é a felicidade. Já a relação da virtude (arete), que pode ser demonstrada pelo ethos, estaria no ato (individual) ético e sua responsabilidade com a polis e o exercício da democracia, a política. E é por meio do habitus obtido ao longo da vida e da educação, que a habilidade de compreensão da ciência política se torna possível.

O ethos é um termo pelo qual os gregos exprimem o acordo bem sucedido entre uma natureza particular e uma norma social (quer assuma a forma do costume, quer da lei escrita). A articulação entre os dois elementos se opera graças a uma pedagogia normalizadora. (VERGNIERES, 1998, p. 71)

Aristóteles avançou na reflexão filosófica grega ao buscar na ação prática e seus estudos de biologia, pedagogia, retórica e ética, um ethos com fundamento na virtude do caráter. Para isso, relaciona a fundamentação da ética ao "princípio de responsabilidade humana a despeito dos múltiplos determinismos naturais, educativos e sociais" (VERGNIERES, 1998, p. 72). Para ele, era a partir do habitus, a prática de bons costumes desenvolvida desde a infância, que essas normas sociais responsáveis deveriam ser interiorizadas como normas racionais para a ação, para o ato ${ }^{32}$ com responsabilidade ética e com vistas ao bem viver em comunidade.

O hábito é o que permite, ao mesmo tempo, interiorizar uma norma inculcada do exterior pela sociedade, e descobrir normas racionais para a ação. Esta compreensão tornou-se possível porque a filosofia moral de Aristóteles integra a dimensão do tempo, da duração: seu horizonte é o da vida inteira, que se trata de bem viver. (VERGNIERES, 1998 , p. 72)

Em Platão, a razão dialoga com esta ciência política, a ciência arquitetônica de

\footnotetext{
${ }^{31}$ Porém, para Platão, a ciência política era inatingível ao homem, pois quase sempre, a usaria para vantagem própria. Ele compreende que este saber não estava associado ao bem supremo e que esta arte nem sempre buscaria como finalidade o bem viver na cidade.

$32 \mathrm{O}$ ato para Aristóteles é tratado em suas obras de três formas: energeia (atividade humana / processo de ação), entelekheia (potência ou finalidade natural interior ao sujeito) e acte (ação em si).
} 
Aristóteles, através do juízo da justa medida do bem viver. Em Aristóteles há "uma tendência para transitar do ato do raciocínio para um poder de propriedade da alma que raciocina"33. (CAYGIL, 2000, p. 270). Para Platão apenas aos seres superiores estava designada esta ciência política, já para Aristóteles era possível o aprendizado para recebê-la racionalmente e utilizá-la de modo prático. O filósofo brasileiro Marcos Zingano fala que Aristóteles

Em seus estudos de ética, ele procurou mostrar como, no domínio das ações e decisões, a razão tem seu lugar a fim de moderar e dirigir as emoções. Esta razão, porém, para ele, não é a razão demonstrativa, mas uma razão deliberativa. $\mathrm{O}$ ato de deliberar ou pesar razões rivais, cuja expressão política é a assembleia ateniense, foi visto por Aristóteles não como um substituto menos de uma saber ausente, mas como a legítima atividade racional de descoberta da verdade na ação. O prudente é aquele que sabe o que deve ser feito, o homem virtuoso propriamente dito, aquele que delibera bem. Saber no campo da ação equivale a saber deliberar. (...) Ética e Política são deliberativas. Deliberações são atividades racionais de descoberta da verdade no campo prático, tendo a estrutura típica de um ato de dar razões e justificar crenças, mas não se reduzem a demonstrações. (ZINGANO, 2002, p.104)

Aristóteles acreditava que a razão estava condicionada também ao saber prático e a fatores biológicos pertencentes ao homem. Como veremos no próximo tópico, o filósofo alemão Immanuel Kant acreditava que esta razão era anterior à experiência, à razão prática, isto é, a priori deste empírico e assim aproxima-se mais do pensamento platônico. Para Aristóteles, a ética, como ciência prática, estava subordinada à ciência política, pois o ser que age no mundo enquanto ato individual, só existe de fato na vida em sociedade e isso o torna um animal político por natureza.

O leitor não deve estranhar que Aristóteles diga política e não ética. Para o Estagirita, a ética tratou da ação e do bem no âmbito do indivíduo, é apenas uma ciência prática acessória e subordinada à política, a ciência prática maior; na medida em que o ser humano é um animal político, isto é, tem sua essência e se atualiza e realiza-se em ato (energeia) exclusiva e necessariamente na vida em sociedade no estado, o bem mais excelente, o nobre e o justo acabam por ser objetos da política e não da ética. Ontologicamente, o indivíduo isolado não é, não existe, embora exista biologicamente (somatica) e psicologicamente, determinando à necessidade da ética. (BINI, 2007, p. 38)

Neste tópico sobre Aristóteles pudemos perceber que a arquitetônica mostrou-se como um conceito relevante não apenas na obra sobre a ética, mas também na arte principal, ou seja, na ciência política vista de modo amplo, que comanda todas as ciências práticas de que o filósofo grego tratou em seus estudos esotéricos: a ética, a política, e as tecnes artísticas que

\footnotetext{
${ }^{33}$ Aqui, Caygill trata da influência de Platão em Aristóteles que assumiu uma postura mais realista e materialista do que seu antecessor em relação ao ato.
} 
incluem a retórica e a poética. É esta ciência arquitetônica, a arte mestra, que determina também as demais ciências e suas respectivas finalidades para o bem viver na cidade. Seu objetivo principal é a busca da felicidade na polis, a vida em coletividade. A arquitetônica nos remete ao conjunto das ciências práticas que compõem a filosofia das coisas humanas. Ao relacionar o saber prático e o saber teórico, bem como o particular ao coletivo, a arquitetônica aristotélica mostra o avanço de suas teorias em relação a Platão, que considerava a ciência política imanente à razão, diretiva e só possível em sua justa medida e a determinados seres superiores. Já Aristóteles acreditava que por meio do habitus seria possível educar o homem, enquanto animal político, para obter a virtude ética e a deliberação política, e assim atingir a ciência política mestra, a arquitetônica.

É relevante a nosso estudo perceber a importância da concepção de arquitetônica aristotélica em relação às práticas éticas e políticas e a criação das leis. Para o grego, o conhecimento supremo da ciência política, da arquitetônica, era essencial para o legislador propor boas leis e convencer seus concidadãos do benefício de cada lei à polis. Sem esta arte principal arquitetônica, o legislador não disporia da sabedoria que inclui as sabedorias teórica e prática para a criação das leis que regem a polis e devem sempre visar ao bem coletivo. É a arquitetônica que rege o discernimento político e o saber prático necessário para a legislação visa de um modo amplo, em relação à política da polis e ao pleno exercício da democracia. Se a democracia é o poder do povo e se este deve ser como diz Aristóteles, regido por sua finalidade, a finalidade da ciência política é o bem coletivo.

Em sua obra Política, Aristóteles a partir de uma estruturação (arquitetônica) discorre sobre a organização do Estado com vistas a compreender como ele estava estabelecido, mas principalmente para um fim que pudesse remeter a polis a um bem (democrático).

Como não podemos conhecer melhor as coisas compostas do que decompondo-as e analisando-as até seus mais simples elementos, comecemos por detalhar assim o Estado e por examinar a diferença das partes e procuramos saber se há uma ordem conveniente para tratar cada uma delas. (ARISTÓTELES, 1998, p. 2)

A compreensão dessa estrutura política em diálogo com a legislação fez com que Aristóteles deixasse um legado à reflexão política até os dias atuais e nos ensina como observá-la. As relações entre a ética dos cidadãos e o bem coletivo pontuadas pelo filósofo grego poderão nos auxiliar ao longo da tese quando pensarmos a criação dos enunciados relacionados ao Sistema Nacional de Cultura. 


\subsection{A arquitetônica kantiana}

O terceiro e penúltimo capítulo da obra Crítica da Razão Pura (KANT, 2012) do filósofo alemão Immanuel Kant é intitulado “A arquitetônica da razão pura” e iniciado com a seguinte definição "Por arquitetônica eu entendo a arte dos sistemas." (KANT, 2012, p. 600) A presença do conceito no título e na primeira oração do penúltimo capítulo da obra, que é considerada por especialistas como marco inicial de sua teoria, deve ser tomada como relevante a nossa reflexão. A arquitetônica deve ser pensada em Kant como parte da razão pura, isto é, das categorias que independem de experiência, sendo a priori ao empírico.

Neste capítulo estaria, de acordo com diversos filósofos, a proposta concreta de um novo método filosófico, que buscava separar a filosofia metafísica e a filosofia moral ${ }^{34}$ das ciências da natureza ou puras, no caso a matemática, a física e a psicologia médica e suas respectivas ramificações científicas.

Assim o sistema completo da metafísica se constitui de quatro partes principais: 1) da ontologia; 2) da fisiologia racional; 3) da cosmologia racional; 4) da teologia racional. A segunda parte, qual seja a doutrina natural da razão pura, contém duas divisões; a Phisica rationalis e a psychologia rationalis. (KANT, 2012, p. 608)

A arquitetônica para Kant é antes de tudo a arte de construção desse novo sistema filosófico que parte dos conhecimentos da razão pura. Todavia, deve ser considerada também um sistema organizador das categorias da razão humana. A arquitetônica seria um sistema organizador das categorias da razão pura independentes de experiência, a priori. A arquitetônica é a "doutrina do científico em nosso conhecimento geral", faz parte da doutrina do método (transcendental) e "contém o fim e a forma do todo que lhe é congruente". Assim a arquitetônica é a parte formal de uma ideia da razão pura que dá forma à razão prática.

Por arquitetônica eu entendo a arte dos sistemas. Uma vez que a unidade sistemática daquilo que o conhecimento comum transformou primeiramente em ciência, isto é, fazendo de um mero agregado daquele um sistema, a arquitetônica é a doutrina do científico em nosso conhecimento em geral e pertence necessariamente, portanto, à doutrina do método. (...) Por sistema, contudo eu entendo a unidade dos conhecimentos diversos sob uma ideia. Este é o conceito racional da forma de um todo, na medida em que por meio dele sejam determinados a priori tanto o âmbito do diverso como a posição das partes entre si. Assim, o conceito científico da razão contém o fim e a forma do todo que lhe é congruente. (...) A ideia necessita de um esquema

\footnotetext{
${ }^{34}$ A moral para Kant representa a esfera da liberdade interna ou adequada à lei da razão independente do direito dos outros. Já o direito ou as leis reais, que ele aborda em sua Metafísica dos Costumes, estão na esfera da liberdade externa ou adequada à lei racional, obrigados a isso também pela experiência dos outros.
} 
para sua realização de uma essencial diversidade e ordem das partes que tenha sido determinada a priori a partir do princípio do fim. $\mathrm{O}$ esquema que não é projetado segundo uma ideia, mas empiricamente, fornece uma unidade técnica, ao passo que aquele que só surge em decorrência de uma ideia (onde a razão fornece os fins a priori e não os espera empiricamente) funda uma unidade arquitetônica. Aquilo que denominamos ciência não pode surgir tecnicamente, devido à semelhança com o diverso ou ao uso contingente do conhecimento in concreto para todos os fortuitos fins externos, mas arquitetonicamente, devido à proximidade e à derivação de um único fim interno e supremo, que conformemente à ideia, isto é, a priori, o esboço (monogramma) e à divisão do todo em membros, bem como distingui-lo de todo o resto com segurança e segundo princípios. (KANT, 2012, pp. 600-601)

Kant propõe neste capítulo a criação de um sistema de filosofia como uma disciplina por meio de um novo método que depende apenas da ideia e que será organizado arquitetonicamente, compondo, assim, um sistema teórico e doutrinal. Das faculdades humanas parte o sistema das críticas da razão pura e prática. Enquanto isso, do sistema doutrinal surgem a natureza e os costumes ou liberdades. Ao mesmo tempo, ele procura respostas para uma série de perguntas feitas ao longo de toda Crítica da Razão Pura e com isso propõe construir esse novo método da doutrina transcendental.

Ninguém tenta produzir uma ciência sem ter uma ideia por fundamento. No seu desenvolvimento, contudo, raramente o esquema, ou mesmo a definição de ciência que ele oferece no princípio, correspondem à sua ideia; pois esta reside na razão. (...) Por isso é preciso determinar e definir as ciências, que são todas concebidas desde o ponto de vista de um certo interesse universal, não segundo a descrição que faz delas o seu criador, mas segundo a ideia que, a partir da unidade natural das partes que ele reuniu, pode ser encontrada na própria razão. (...) É uma pena que somente agora, depois de termos por tanto tempo reunido rapsodicamente, seguindo uma ideia em nós oculta, muitos conhecimentos a ela referidos que nos servem de material de construção e mesmo depois de termos por tanto tempo articulado tecnicamente esses conhecimentos, possamos enfim olhar para essa ideia sob uma clara luz e segundo os fins da razão projetar um todo arquitetonicamente. (KANT, 2012, p. 601)

Quando Kant escreveu a obra Crítica da Razão Pura estava ainda em diálogo com outros filósofos anteriores a ele, como fizera ao longo dos anos que precederam este renomado livro. No entanto, nesse período que antecede Crítica da Razão Pura, em seus Textos Pré-críticos (1983), ainda não havia de fato proposto um novo método filosófico. Os textos anteriores a 1781, data da publicação da primeira edição de Crítica da Razão Pura, buscavam responder às reflexões filosófico-metafísicas de Leibniz, Hume, Aristóteles, Hobbes, Rousseau, dentre outros. Entretanto, foi a partir de Crítica da Razão Pura, que Kant responde aos filósofos anteriores com uma nova proposta teórico-filosófica e assim buscou de 
fato distinguir-se dos racionalistas e dos dogmas empiristas. Esta resposta está condicionada, de modo geral, à chamada "Revolução Copernicana" de Kant, num debate direto com Leibniz e seus textos de cosmologia sobre os movimentos celestes e também com a tradição filosófica anterior a ele. A Revolução Copernicana de Kant visa demonstrar que não é o objeto que age sobre o homem, ao contrário disso, é o homem que comanda o objeto. Através dessa nova reflexão procura responder a uma série de perguntas que são basilares na construção de seu método audacioso em busca do conhecimento humano. "Só quero ter uma parte dos conhecimentos humanos, a saber, a ciência dos princípios supremos do conhecimento humano, o que é um projeto modesto.” (KANT, 2009, p. 57)

Kant é considerado o mais importante filósofo iluminista alemão e assim como diz Norberto Bobbio "o filósofo da autonomia moral, pois considera a liberdade moral de fato a obediência à lei fundamental da própria razão" (BOBBIO, 2000, p. 75). Assim como Rousseau e Hobbes, buscou na sociedade explicações para sua nova proposta de metafísica, a fim de compreender de modo inovador a razão humana. Ele discordava das teorias racionalistas e dogmáticas que o precederam, propondo, ao contrário dos racionalistas e dos empiristas, que o racionalismo e o empirismo eram processos distintos, mas deveriam em algum ponto conectar-se. Todavia, para ele, o teor da filosofia teórica era independente, era $a$ priori da experiência, do empirismo. A moral estava na razão pura. Kant tratou disso no início de sua obra Fundamentação da Metafísica dos costumes 35 “(...) elaborar uma filosofia teórica pura, completamente livre de tudo o que é empírico e que pertence à antropologia, porque a necessidade da existência de uma filosofia decorre de maneira evidente da ideia comum do dever e das leis morais ${ }^{36}$." (BOBBIO, 2000, p. 83)

A razão para Kant é uma estrutura vazia, uma forma pura sem conteúdos e é por isso que posteriormente sua ética foi chamada pelos estudiosos de ética formal. Uma vez que essa forma é inata, universal e igual para todos os seres humanos de todas as épocas, não pode ser adquirida pela experiência. Para ele, a estrutura da razão é como ele mesmo chama a priori ou formada por categorias ${ }^{37}$, vem antes da experiência prática, antes dos costumes, antes da

\footnotetext{
${ }^{35}$ A fundamentação da metafísica dos costumes de Kant equivale ao estudo dos princípios racionais a priori de nossa conduta (moral / ética) e busca satisfazer a exigência de expor os fundamentos da doutrina moral.

${ }^{36}$ A lei moral é aquela que não admite uma ação cumprida segundo interesse. Ela é a priori e depende de juízos da razão pura.

${ }^{37}$ As categorias kantinanas a priori, independentes da experiência, são: “1) quantidade (unidade, pluralidade, totalidade); 2) qualidade (realidade, negação, limitação); 3) relação (inerência e subsistência, substância e acidente, causalidade e dependência - causa e efeito, comunidade - permuta entre o agir e o sofrer); 4) modalidade (possibilidade, impossibilidade, existência, não-ser, necessidade, contingência)". (KANT, In: Glossário da Metafísica dos costumes, 2008, p. 27) Além disso, completam as categorias lógicas o tempo e o
} 
história, mas nos auxiliam no uso das experiências práticas, a posteriori. As categorias ou os princípios a priori são os "instrumentos racionais com os quais o sujeito do conhecimento organiza a realidade e a conhece" (CHAUÍ, 2006, p. 78). A matéria dessa razão, seus conteúdos, são adquiridos a posteriori, por meio da experiência empírica. Essa estrutura da razão é constituída por três estruturas a priori: forma da sensibilidade, forma do entendimento e forma da razão propriamente dita.

Em Crítica da Razão Pura, além dos conhecimentos do homem, Kant fala da razão pura teórica, a razão do conhecimento a priori e, da razão pura prática, observando a distinção da razão entre o agir e as causas desse agir que acontecerá a posteriori na experiência. $\mathrm{Na}$ razão pura prática estão as causalidades ou necessidades, ou mesmo as finalidades ou liberdades. Ao tratar da liberdade, Kant debate ainda que indiretamente com Rousseau e Hobbes e demonstra que, em sua primeira Crítica, um ponto importante a ser desenvolvido é a filosofia moral que está na razão. Deste mesmo modo, relaciona-se com a ética aristotélica e com os pensamentos platônicos como vimos no tópico anterior. Essa filosofia moral será amplamente abordada em sua segunda Crítica sobre a razão prática.

O encadeamento das obras kantianas é um quebra-cabeça filosófico, que parece fazer mais sentido de fato após a leitura de boa parte delas. As três críticas: Crítica da Razão Pura, Crítica da Razão Prática, Crítica do juízo “apresentam um verdadeiro sistema de permutações" (DELEUZE, 2000, p. 73) Esse sistema busca compreender como funciona a mente humana e suas relações sociais por meio de um sujeito transcendental que, para Kant, deve ser livre em suas escolhas racionais de fundo moral. Todavia, essas escolhas ou juízos são parte da razão humana e disso resulta sua compreensão da distinção do estado de natureza e cultura, que passa a ser formulada como parte da doutrina transcendental do método a partir da segunda parte de Crítica da Razão Pura.

Para Kant, as ideias máximas da moral são juízos a priori, parte da razão humana independente de experiência e que a posteriori nos guiam em nosso agir, em nossas experiências práticas, em nossos costumes. A arquitetônica tem como base esse sistema-ideia formal que estrutura a razão humana e o método por meio de categorias a priori, da razão julgadora. É possível dizer que a arquitetônica é parte de um projeto de filosofia moral kantiana que regula o viver cultural dos seres humanos, seu conhecimento e postula as questões morais mais básicas na razão.

Para o entendimento da arquitetônica kantiana, é necessária a compreensão do todo da

espaço. 
obra, incluindo não apenas as três críticas, mas também as obras: Fundamentação da Metafísica dos Costumes e a Metafísica dos Costumes.

O entrelaçamento de conceitos previstos em seu sistema é a cada obra detalhado, cuidadosamente explicado e inserido em seu sistema filosófico. Kant parece, em alguns momentos de seus livros, querer conversar diretamente com o leitor e mostrar essa sistematização em seus mais ricos detalhes. Mostra seu ponto de vista em passagens escritas em primeira pessoa do singular, afirma com precisão os detalhes desse sistema quando lhe convém e compartilha suas dúvidas sempre que necessário com perguntas que auxiliam no desenvolvimento do método como um todo.

A arquitetônica deve ser pensada em Kant como a "arte dos sistemas", ou como Lalande propõe "a teoria do que existe de científico no nosso conhecimento em geral" (LALANDE, 1999, p.88). Contudo, esse saber científico presume um saber supremo organizador relacionado à razão a priori. Kant utiliza esse saber científico para falar da faculdade de desejar da razão e sua relação com a liberdade que nos torna naturalmente seres “civilizados" (ou não) e passíveis de conviver na sociedade. Essa vontade, que é inicialmente interna

(...) pode até ser livre, mas isto só pode estar ligado à causa inteligível de nosso querer. Pois, no que diz respeito aos fenômenos de externalização das mesmas e as ações, nós só podemos, de acordo com uma máxima fundamental inquebrantável sem a qual não poderíamos exercitar a razão no uso empírico. (KANT, 2012, p. 581)

Para Kant, ainda que na experiência empírica, na externalização da vontade, agimos fora das categorias da razão pura de fundo moral, a razão continua atuando como fator $a$ priori para nos auxiliar no entendimento do agir a posteriori, nas experiências empíricas da vida na ordem dos costumes. A vontade, para Kant, está refletida na prática, mas ela parte inicialmente da razão pura e de suas regras inquebráveis.

Dentro de sua teoria, Kant formulou uma série de juízos e imperativos morais relativos à razão, os chamados imperativos categóricos. O imperativo categórico máximo "Seja bom!" fornece o tom para a filosofia moral kantiana. Está relacionado ao bem supremo que é fundamento determinante à finalidade da razão pura e à categoria a priori de causalidade. Por meio deste imperativo categórico, o sujeito será guiado racionalmente, e com isso terá liberdade de agir como ser moral. O ser deve ser bom e isto guiará suas ações em suas práticas sociais empíricas.

A arquitetônica do sistema filosófico kantiano pode ser entendida tanto como a arte de 
construir e estruturar racionalmente um sistema filosófico científico quanto à ideia do todo da razão humana pura, que compreende este sistema científico geral (e neste caso também, como em Aristóteles, uma ciência suprema ou faculdade dominante) com a compreensão de que

(...) a razão humana é por sua natureza arquitetônica, isto é, considera todos os conhecimentos como pertencentes a um sistema possível e por isso permite também somente aqueles princípios que pelo menos não tornem um conhecimento projetado incapaz de coexistir, em qualquer sistema, com outros em conjunto" (KANT, 2012, p. 397)

Para Caygill "Kant combina a definição de Baumgartem ${ }^{38}$ de arquitetônica de sua Metaphysica (1739), onde ela designa a estrutura do conhecimento metafísico, com a abordagem mais metodológica de Lambert em seu Arkitectonik que ele vê como arte de estabelecimento de uma estrutura." (CAYGILL, 2000, p. 39) O sistema kantiano é uma unidade aparentemente organizada com finalidade de relação às partes da ciência que neste também se relacionam entre si. "No começo da Crítica da Razão Pura, Kant já definira a razão humana como arquitetônica por natureza e a vira como todo o conhecimento" (idem, p.39), como parte de um possível sistema moral. Para ele, "o filósofo não é um artista da razão, mas o legislador da razão humana". (KANT, 2012, p. 604)

Essa arquitetônica filosófica (pensada de modo amplo) ou a lei da razão humana teria dois objetivos principais de composição a posteriori, no empírico, a natureza e a liberdade, e assim, relaciona-se num segundo momento com a filosofia da moral humana ou dos costumes que "trata de tudo o que é filosofia da moral daquilo que deve ser", ou seja, o que será $a$ posteriori no mundo da experiência ou da filosofia empírica.

Agora, a lei da razão humana (filosofia) tem dois objetos, natureza e liberdade, e, portanto, inclui tanto a lei da natureza como a lei moral, por princípio em dois sistemas filosóficos separados, mas ultimamente em apenas um. A filosofia da natureza refere-se a tudo o que é; a filosofia da moral refere-se apenas o que deve ser. Cada filosofia então, ou é o conhecimento derivado de uma razão pura, ou é um conhecimento racional derivado de princípios empíricos. O primeiro é chamado de filosofia pura, a segunda filosofia empírica. ${ }^{39}$ (KANT, 2004, p. 1179, tradução nossa)

O conceito de arquitetônica em Kant deve ser pensado também em relação à

\footnotetext{
${ }^{38}$ Baumgartem publicou uma obra de metafísica em que define a arquitetônica como sinônimo de ontologia ou a ciência dos predicados gerais dos entes. Seus escritos influenciaram as reflexões de Lambert sobre a arquitetônica.

${ }_{39}$ Ora, La legislazione della ragion umana (La filosofia) ha due oggetti, La natura e La liberta, e dunque contiene tanto La legge di natura quanto La legge morale, da princípio in due sistemi filosofici separati, ma ultimamente in uno solo. La filosofia della natura riguarda tutto cio Che è; La filosofia dei costumi riguarda soltanto cio Che deve essere. Ogni filosofia poi, o è uma conoscenza derivante dalla ragion pura, o è uma conoscenza razionale derivante da principi empirici. La prima si chiama filosofia pura, La seconda filosofia empírica.
} 
construção da ética como uma disciplina da filosofia moral que acompanhou a historiografia das reflexões filosóficas ao longo da história. Do mesmo modo estão os questionamentos da sociedade como um todo em relação ao que seria ética e moral e ao agir em relação ao outro no mundo social.

Para Kant, a arquitetônica, que é base estrutural-formal de seu sistema de razão pura, traz consigo como parte do todo, a ideia moral máxima a priori e esta, como independente de experiência, é imanente à razão humana. Entretanto, ainda que esta ideia seja parte da razão pura, é na razão prática que está de fato em conexão com a ética, como a realização de uma moral na vida prática ou metafísica dos costumes em sociedade. Esta estrutura arquitetônica compõe de forma lógica a base do conhecimento em Kant. Esta forma lógica a priori deve se sistematizar para receber assim o conteúdo a posteriori a partir das experiências da vida.

A relação entre as três Críticas kantianas não acontecem apenas em termos teóricos. Como dissemos anteriormente, elas devem ser compreendidas como um sistema arquitetônico ainda mais amplo, que visa à construção de uma filosofia crítica. $\mathrm{O}$ diálogo com a ética aristotélica também é um fator perceptível em diversas partes da teoria kantiana e deve ser tomada como fator essencial em nosso estudo. Na Crítica da Razão Prática, Kant

(...) além de apresentar o princípio da moralidade, tem que dar conta de sua relação com a "Crítica da Razão Pura” e também apontar a possibilidade de realização da moralidade. A questão surge com toda força no conceito de soberano bem, ou seja, na relação da virtude com a felicidade. (TERRA, 1998, p. 296)

Kant discorda da ética aristotélica pois acredita na imanência da razão em contraste com a razão obtida por meio de um ethos construído pelo habitus, de modo técnico e prático ao longo dos anos, mas que também dependia de uma propensão fisiológica de boa linhagem familiar. O filósofo alemão acredita que todo homem, independente de sua origem e de seus atos, tem a possibilidade de escolha e de juízo para alcançar o bem, pois o bem está inerente a ele em seus juízos a priori. A opção pela virtude na teoria kantiana é parte da razão pura prática, que é julgadora e conta com juízos e imperativos categóricos a priori para orientá-la no agir.

As categorias e o sistema estrutural-formal de Kant demonstram que, para ele, a forma não está unida ao conteúdo. Para ele, o conteúdo está relacionado ao material empírico e aos resultados provenientes dos atos, das práticas resultantes dos juízos, das escolhas na razão prática.

Ao dividir os objetos da filosofia doutrinal em natureza e liberdade, Kant conecta-se 
com a divisão científica da filosofia clássica em lógica, física e ética com que inicia o prefácio da Fundamentação da Metafísica dos Costumes. Todavia, nesta obra faz uma reflexão de suas proposições ao utilizar e refutar preceitos da filosofia clássica dizendo que

(...) nada há a corrigir nela, a não ser, talvez, acrescentar o princípio da mesma para, desta maneira, de uma parte, nos assegurar de sua completude, de outra parte, determinar corretamente as subdivisões necessárias. Todo conhecimento racional é ou material, e considera um objeto qualquer, ou formal e ocupa-se meramente da forma do entendimento ou da razão ela própria e das regras universais do pensamento em geral, sem distinção dos objetos. A filosofia formal chama-se lógica; a material, porém, que tem a ver com objetos determinados e com as leis a que estão submetidos é por sua vez, dúplice. Pois essas leis ou são leis da natureza ou são leis da liberdade. A ciência da primeira se chama Física, a da outra é a Ética; àquela também se dá o nome Doutrina da Natureza; a esta, Doutrina dos Costumes. (KANT, 2009, pp. $62-63$ )

Esta divisão entre as leis da natureza e leis da liberdade (ou dos costumes) corresponde posteriormente aos usos especulativo e prático da razão pura, em que o especulativo apresenta o conhecimento a priori teórico de todas as coisas e seria o que ele chama de conhecimento arquitetônico e o segundo as categorias a priori que são necessárias para nossas ações práticas na vida cultural a posteriori, nos costumes.

As obras de Kant, de acordo com o filósofo brasileiro Ricardo Terra "não são escritas organizadamente, são montadas e sofrem com este processo" (TERRA, 1995, p. 14). Esta quase dependência de relação teórica entre suas obras cria a ideia de sistema filosófico complexo, mas dificulta ao leitor o entendimento da teoria como um todo. A presença de uma nova definição de filosofia na introdução da Crítica do Juízo pode ser vista como uma complementação teórica de Kant, que mais de quinze anos depois de Crítica da Razão Pura, repensa o sistema filosófico que a partir da Crítica do Juízo

(...) é dividido em dois domínios, o formal e o material, como o primeiro (lógico) incluindo a forma de pensamento num sistema de regras e o segundo oferecendo a possibilidade de conhecimento racional, conceitual, de objetos pensáveis. Este último, ou sistema real da filosofia, está dividido de acordo com objetos teóricos e práticos, interessando-se a filosofia teórica por proposições sobre a possibilidade de coisas e suas determinações e a filosofia prática por proposições que dão à liberdade suas leis. (CAYGILL, 2000, p. 151)

A unidade sistemática que estrutura a arquitetônica para Kant é o que eleva o conhecimento à categoria de ciência ou transforma um simples agregado de conhecimento em sistema científico de ordem racional. Esta arte arquitetônica consiste em unificar partes de conhecimentos em ideias que são realizadas no sistema por meio do que Kant chama de 
"esquemas" que combinam as pluralidades de ordenação das partes do mesmo no todo. Os esquemas que surgem empiricamente produzem unidades técnicas, já os resultantes da própria ideia, da razão pura, geram unidades arquitetônicas. Esse sistema está interessado em "proposições sobre possibilidades de coisas" (idem, p. 151). A arquitetônica parte da razão científica do sujeito, já o esquema kantiano busca sistematizar a partir de tudo o que o sujeito pode fazer.

O esquematismo kantiano é o modo de realizar a ideia de uma unidade arquitetônica da razão e é definido como "uma pluralidade e uma ordenação das partes que sejam essenciais e determinadas a priori segundo o princípio definido pelo seu fim” (KANT, 2012, p.600) Este esquema demonstra uma ordenação organizativa e participa material e formalmente da construção do todo. $\mathrm{O}$ esquema arquitetônico "fornece sumário antecipatório ou monograma de todo sistema" (idem, p.600 ) uma referência que esclarece a anterior descrição de Kant do esquema como um monograma, através do qual as próprias "imagens tornam-se possíveis" (KANT, 2012, p.600). A ideia de sumário ou esquema, ainda que nos pareça uma ideia concreta, pode auxiliar a compreendermos a função da arquitetônica kantiana enquanto organizadora de uma tese de modo apenas racional, sem o desenvolvimento dos conteúdos, por exemplo. É uma "arte oculta nas profundezas da alma" e é como que um "monograma da imaginação pura a priori". Se pensada numa analogia contemporânea, a arquitetônica seria o nosso hardware mental.

Ao compreender a arquitetônica como a "arte dos sistemas" da razão pura, isto é, da esquematização das ideias puras a priori da razão, pensada aqui como entendimento e conhecimento científico puramente racional, Kant demonstra que, para ele, ao contrário de Aristóteles, a arquitetônica é parte da estrutura formal desse conhecimento e da filosofia moral. A matéria resultante desse pensamento está condicionada ao que vem a posteriori, às experiências, à vida e à aplicação dessa moral nos costumes. Sua proposta de distanciamento com o pensamento racionalista fica evidenciada quando pensamos na relação de suas teorias com Aristóteles, que compreendia a arquitetônica como uma faculdade suprema, como uma ciência principal que era também adquirida ao longo do tempo a partir de práticas.

A possibilidade mesma de uma arquitetônica da razão pura não é apenas uma imagem reguladora ou metafórica que caracteriza e compreende o sistema das faculdades de conhecimentos, mas antes um conceito que modela profundamente a razão e a sua construção na história da filosofia. Mesmo que a história filosófica seja para Kant negativa e inteiramente conflituosa do ponto de vista conceitual, ou mesmo que ele, antes da Crítica, não tenha conquistado um destino tão duradouro, a razão não deixa de cumprir o seu 
propósito mais esperado, isto é, de que ela é na sua natureza arquitetonicamente histórica nos seus processos de coletagem e reciclagem. (...) Ao considerar então esses elementos, exposições ou imagens conceituais que configuram e caracterizam o capítulo da arquitetônica, veremos que não é por acaso ou inteiramente inconsequente o fato de Kant terminar a primeira Crítica com a proposta ou investigação de uma "história da razão pura", ou seja, de uma concepção que, segundo o filósofo, ainda deve ser preenchida, pelo menos futuramente, no "sistema" como conhecimento especulativo ou racional. Essa possibilidade, entretanto, mostrará inclusive que a necessidade mesma de uma razão arquitetônica é essencialmente válida, não só para determinar sistematicamente as faculdades de conhecimento, mas principalmente todo o conhecimento que a razão busca e constrói como fins determinados. (ARAUJO, 2011, pp. 93-94)

Não era nossa intenção neste breve capítulo esboçar uma análise profunda das complexas teorias filosóficas kantianas, mas observar o papel e o lugar do conceito de arquitetônica em relação ao todo de sua teoria e pontos em diálogo. Foi possível comprovar, assim como inicialmente previsto, que a arquitetônica é, de fato, um conceito de relevância em sua teoria, ao ser parte estrutural de seu entendimento da natureza da razão humana e fator essencial na busca de um novo método filosófico.

A reflexão acerca do conceito de arquitetônica na história da filosofia, no pensamento grego clássico, mas também no iluminismo alemão, trouxe algumas pistas que poderão nos auxiliar na compreensão do conceito no Círculo de Bakhtin. A partir do próximo tópico, desenvolveremos a análise do conceito na teoria bakhtiniana e assim buscaremos encontrar caminhos para a análise do corpus desta pesquisa.

\subsection{A arquitetônica bakhtiniana}

A arquitetônica bakhtiniana é o conceito teórico principal que rege nossa reflexão nesta pesquisa e começou a ser desenvolvido nos escritos do Círculo de Bakhtin a partir dos anos 1920. Buscaremos neste tópico uma ampla abordagem dialógica do conceito na teoria do Círculo, traçando a relação com outros conceitos-chave e com as teorias anteriores. Como a própria teoria propõe, os conceitos teóricos estão em diálogo e assim compõem a arquitetônica bakhtiniana.

Propomos como método a análise do conceito de arquitetônica, bem como dos conceitos a ele correspondentes por meio de uma observação historiográfico-teórica, em que boa parte das obras do Círculo serão examinadas na ordem temporal de escrita. Não vamos nos deter inicialmente em questões históricas do chamado Círculo de Bakhtin, porém essa 
história será introduzida quando necessário, mediante a exposição das reflexões.

Mikhail Mikháilovitch Bakhtin (Orel, Russia, 1895 - Moscou 1975) publicou o pequeno texto Arte e responsabilidade, na Revista $O$ dia da arte, na cidade de Nevel em setembro de 1919. Note-se que este texto foi publicado menos de dois anos após a Revolução Russa de outubro de 1917 que teve como seu centro de atividade principal a cidade de Petrogrado $^{40}$ onde Bakhtin vivia no período.

A atividade revolucionária vivenciada e as mudanças históricas radicais que aconteciam ao seu redor causaram relativa influência em suas reflexões e em sua teoria. Isso fica ainda mais evidenciado posteriormente, quando a ideia de ato responsável assimila a ideia de ativismo, compreendida como atributo de um ser ativo e responsável por seus atos no mundo. A Revolução Russa estava à sua volta e Bakhtin era um jovem de 22 anos no momento da revolução. De algum modo, os fatos ocorridos causaram considerável impacto em suas reflexões e continuaram exercendo ao longo dos anos em suas obras.

Os filósofos estadunidenses Michael Holquist e Katerina Clark desenvolveram na biografia de Bakhtin seu posicionamento enquanto filósofo e sobre o entendimento da arquitetônica não apenas como um conceito teórico, mas também como a sistematização de toda a teoria bakhtiniana. Porém, ao contrário de seus antecessores que compreendiam a arquitetônica como um sistema formalmente ordenador da razão, para ele a arquitetônica parte de um pressuposto de construção cultural que é baseado na relação entre forças centrífugas e centrípetas de criação.

É impossível aos participantes das lutas entre as forças centrípetas e centrífugas permanecerem neutros. Alguns pensadores como Aristóteles, Descartes e Hegel favoreceram o caráter ordenador das forças centrípetas ${ }^{41}$, em oposição àqueles filósofos, de Heráclito a Emmanuel Levinas, que têm preferido os poderes inerentes às forças centrífugas. Bakhtin pertence à segunda tradição, de modo que, ao chamar seu empreendimento de "arquitetônica", tira este termo técnico não apenas da filosofia, onde significa a ciência de sistematizar conhecimento, mas também da edificação, onde tem a ver com mensurações efetivas, proporções de pedras e madeira reais e a infinita variedade que estas podem assumir em construções específicas. (CLARK; HOLQUIST, 2008, p.55)

\footnotetext{
40 A partir de 1924, após a morte de Lenin, a cidade passou a se chamar Leningrado. Em 1991, após a Perestróika, a cidade volta a ter seu nome original São Petesburgo.

41 As forças centrífugas e centrípetas são conceitos tomados dos estudos da física e que Bakhtin utiliza para pensar as forças de expressão e opressão no discurso. A unificação e a centralização das ideologias verbais são as forças centrípetas da vida social, linguística e ideológica. Por outro lado as forças centrífugas são inerentes ao ser que busca, em seu eterno existir evento, criar novos discursos em enunciados nas diversas esferas ideológicas.
} 
Com a revolução russa, Bakhtin, assim como diversos pensadores russos do período, parte para a vida em cidades menores, onde a atividade revolucionária não estava tão turbulenta, entre as cidades de Vítebsk, Leningrado e Niével, e outras cidades russas. Assim, os diversos integrantes de seu grupo de intelectuais retomam os encontros para discussão das teorias. O grupo composto por Matvei Kagan, Mikhail Bakhtin e Valentin Volóchinov, entre outros nomes, iniciam o que seria o embrião do que chamariam posteriormente de Círculo de Bakhtin.

No pequeno texto Arte e responsabilidade, Bakhtin inicia a reflexão sobre o que viria a ser o conceito ao pensar na arquitetônica como algo que relaciona no ser a ética (vida) e a estética (arte/ criação) o tornando responsável. “Arte e vida não são a mesma coisa, mas devem tornar-se algo singular em mim, na unidade da minha responsabilidade" (BAKHTIN, 2010b, p. XXXIV). Nesse texto, o conceito de arquitetônica ainda não aparece, porém seu fio condutor é largamente abordado em sua obra seguinte, Para uma filosofia do ato responsável escrita entre os anos 1920-21.

Especialistas na teoria bakhtiniana afirmam que Arte e responsabilidade abre o projeto de um livro de uma filosofia moral nunca concluído e publicado, que incluiria este e outros dois textos do período: Para uma filosofia do ato responsável e $O$ autor e a personagem na atividade estética. Bakhtin abre Arte e responsabilidade escrevendo sobre o que seria a arquitetônica mesmo sem usar a expressão.

Chama-se mecânico ao todo se alguns de seus elementos estão unidos apenas no espaço e no tempo por uma relação externa e não os penetra a unidade interna do sentido. As partes desse todo, ainda que estejam lado a lado e se toquem, em si mesmas são estranhas umas às outras. Os três campos da cultura humana - a ciência, a arte e a vida - só adquirem unidade no indivíduo que os incorpora à sua própria unidade. (...) O que garante o nexo interno entre os elementos do indivíduo? Só a unidade da responsabilidade. Pelo que vivenciei e compreendi na arte, devo responder com minha vida para que todo o vivenciado e compreendido nela não permaneçam inativos. (...) Arte e vida não são a mesma coisa, mas devem tornar-se algo singular em mim, na unidade da minha responsabilidade. (BAKHTIN, 2010b, pp. XXXIII - XXXIV)

Aqui Bakhtin está em debate de discordância com Kant que, como vimos no tópico anterior, propõe uma divisão do mundo teórico, da vida e da arte nos respectivos fundamentos de suas críticas da razão pura, da razão prática e do juízo (estético).

Para Kant não há uma fusão concreta nos elementos. É relevante perceber que no trecho acima Bakhtin opera com duas importantes categorias da lógica kantiana: o tempo e o espaço. No entanto, ele evidencia que essas categorias na forma kantiana são categorias 
mecânicas quando estão unidas numa relação externa. Em Kant são apenas categorias de ordem formal, sistemática e lógica. Assim, estas não penetram a "unidade interna do sentido" que se dá no ser situado historicamente. Para Bakhtin, esta "penetração" acontece de forma prática, no ato responsável do ser.

O teórico russo retoma as categorias kantianas e as une com a unidade interna do sentido que está contida no ser, através de seu lugar único no mundo, um lugar que é espacial e exotópico, temporal e histórico, e pleno de valores axiológicos da relação deste ser com o mundo. O sentido de um ato só ocorre na relação responsável do ser com o mundo a seu redor.

No último período de Arte e responsabilidade, Bakhtin evidencia a arte como algo concreto e esteticamente realizado pelo homem e a vida como algo dado e de ordem ética. Ambas "devem tornar-se algo singular em mim", isto é, transformadas num movimento de processo interior para algo novo. Estas se encontram naquilo que é "singular em mim", por meio do meu ser, "na unidade da minha responsabilidade". O mundo da vida e o mundo da cultura equivalem aos mundos dados e ao transformado. Somente eu, do lugar que ocupo, respondo por meus atos e sou responsável por eles e assim construo novas possibilidades para a vida como ser cultural. Esse processo de "dever tornar-se", de transformação de algo que já existe em algo novo, pressupõe o que Bakhtin trabalhará detalhadamente em sua obra seguinte Para uma filosofia do ato responsável ${ }^{42}$. Bakhtin neste texto aborda o "ato de pensamento, de sentimento, de desejo" e diz que "tudo é um ato meu, também o pensamento e o sentimento" (PONZIO, 2010d, p. 9)

Este texto, que na tradução brasileira traz partes não presentes em outras traduções, apresenta uma proposta de construção de uma filosofia moral, e se conecta com a proposta de Prima Philophia ${ }^{43}$ de Aristóteles ${ }^{44}$, mas principalmente com a proposta de filosofia moral doutrinal (ou filosofia da vida) de Kant também chamada de Lebensphilosophie da qual tratamos no tópico anterior ao falar da arquitetônica kantiana. Para Bakhtin, assim como para

\footnotetext{
${ }^{42}$ K Filósofii Postúpka é o título dado por Serguei Botcharóv a este texto do início dos anos 1920, desprovido de título e das primeiras oito páginas (das complexas cinquenta e duas), conforme a numeração do autor, quando o publicou em 1986. (PONZIO, 2010d, p. 9)

43 A Prima Philosofia de Aristóteles foi posteriormente chamada de Metafísica pelo pensador Andrônico de Rodes no século I a.c. que nomeou de metafísica a série de livros que vinham após as obras de física ,isto é, as que estavam além da física e que tratavam das coisas do ser em si. A metafísica, ou ontologia como ficou conhecida principalmente a partir do século XVI, ocupa-se do ser como ser, algo que é superior, supremo, na ordem do que é e do conhecimento.

${ }^{44}$ É relevante relembrar aqui que Aristóteles fundou a disciplina da ética como uma ciência prática concreta no mundo. Ele criou a posteriormente chamada "Ética materialista" e estavam previstas nessa ética as relações entre as categorias do ser e do que se relaciona a ele: as normas e os bens, a ética individual e social, a classificação das virtudes, e a relação entre o saber teórico e o saber prático.
} 
os outros filósofos, a filosofia da vida só pode ser uma filosofia moral, ou uma ética. Contudo, como veremos, cada um deles pensou a ética de modo diferente, ainda que com diversos pontos em comum.

Desde o começo de Para uma filosofia do ato responsável até seu final, o debate teórico com Kant é nomeado, ou mesmo feito de modo velado a partir de expressões que nos remetem ao pensamento do filósofo alemão. E é a partir disso, assim como em Arte e responsabilidade, que a filosofia moral bakhtiniana vai se construindo dialeticamente num processo arquitetônico.

Os três momentos essenciais da arquitetônica de Bakhtin aparecem a todo instante, os valores, o tempo e o espaço, mas é o produto da atividade estética e seu sentido no mundo da vida que motivam o texto desde o início.

Também a atividade estética não consegue ligar-se a esta característica do existir (ser) que consiste na sua contingência e no seu caráter de evento aberto; e o produto da atividade estética, no sentido que lhe é próprio, não é o existir em seu efetivo devir, e, no que concerne à sua existência, ele se integra no existir mediante o ato histórico de uma ativa percepção estética. (...) Somente na sua totalidade tal ato é verdadeiramente real, participa do existir-evento (...) é incorporado na unidade singular do existir que vai se realizando. (BAKHTIN, 2010d, pp. $41-42$ )

Bakhtin continua o texto tratando de um ponto essencial no entendimento do conceito quando fala das diferenças dos mundos da vida e da cultura. Para ele, o mundo da cultura é "o mundo no qual se objetiva o ato da atividade de cada um" (BAKHTIN, 2010d, p.43), o mundo de nossas atividades individuais, singulares. Já o mundo da vida é aquele em que "tal ato realmente, irrepetivelmente, ocorre". (idem, p.43)

No ato-evento do existir o ser "reivindica a completa e definitiva autodeterminação na unidade de um determinado domínio do sentido - da ciência, da arte, da história" (idem, pp.42-43). O ser experimenta "o ato da atividade de cada um" mas vive nesse processo a experiência como um "jano bifronte"; de um lado, é determinado pela esfera, ou como ele chama aqui, "domínio de sentido", e, por outro, se autodetermina a partir da singularidade irrepetível da vida e de seu momento único na história.

$\mathrm{O}$ ato deve encontrar um único plano unitário para refletir-se em ambas as direções, no seu sentido e em seu existir; deve encontrar a unidade de uma responsabilidade bidirecional, seja em seu conteúdo (responsabilidade especial), seja em relação ao seu existir (responsabilidade moral) de modo que a responsabilidade especial deve ser um momento incorporado de uma única e unitária responsabilidade moral. Somente assim se pode superar a perniciosa separação e a mútua impenetrabilidade entre cultura e vida. (BAKHTIN, 2010d, pp. 43 - 44) 
Bakhtin traz aqui um ponto de grande relevância à nossa pesquisa ao nomear o "domínio do sentido" e que mais tarde, em outros textos, seria nomeado com diversas expressões: campo, esfera (da cultura, da atividade humana, ideológicas), áreas, sistemas ideológicos constituídos e equivale à ideia de superestrutura nas teorias marxistas com que o Círculo passa a relacionar-se mais fortemente a partir de 1925. Essa conexão do ser-evento com a esfera, enquanto ser autodeterminado em seus atos, pode ser pensada como um fator que nos auxiliará nos próximos capítulos ao pensarmos o estado atual da esfera das políticas culturais no Brasi, nosso objeto de reflexão. Assim como evidenciou Aristóteles, a ética parte do individual para a prática no coletivo. Para Bakhtin, esta relação bifronte acontece em relação à esfera e o ser, o individual encontra as leis das esferas e a elas responde responsavelmente em seu devir, em seu tornar-se (do mundo da vida - dado - ao mundo da cultura - criado).

A escrita de Bakhtin em Para uma filosofia do ato responsável é circular. Em diversos momentos, ele repete algumas considerações que permeiam boa parte da obra. Primeiro da relação dos momentos da arquitetônica: sentido, tempo, espaço, em relação articulada com os valores do ser único em seu ato, na autodeterminação da esfera e nas relações com o outro. Sua exposição busca, em boa parte das vezes, refutar as teorias de Kant que é nomeado abertamente ou mesmo retomado pela expressão "pensamento teórico". Um dos pontos centrais dessa refutação é a questão do dever do ser em seu ato responsável. O dever é visto por Bakhtin como um dos aspectos que nos levam à arquitetônica.

Não existe um dever estético, científico e ao lado deles, um dever ético: há apenas o que é estética, teórica e socialmente válido e ao qual se pode agregar um dever a respeito do qual todas estas validades são de caráter técnico, instrumentais. Tais posições adquirem sua validade no interior de uma unidade estética, científica sociológica; enquanto adquirem o dever na unidade de minha vida singular e responsável. (...) O dever é uma categoria original do agir ato (postuplénie - postúpok) e tudo é um ato meu, inclusive o pensamento e o sentimento, é uma certa atitude (ustanovka) da consciência, cuja estrutura nos propomos a desvendar fenomenologicamente. (...) (BAKHTIN, 2010d, p. $47-48$ )

Para Bakhtin, a compreensão desta arquitetônica deve ser sociológica e fenomenológica. Ele coloca novamente o ser humano em relação constante com o mundo concreto que o cerca e não mais como Kant pensara em sua Revolução Copernicana em que o indivíduo apenas é um ser racional que comanda o objeto a posteriori. Bakhtin descreve a visão de Kant sobre isso em Para uma filosofia do ato responsável.

Mas o mundo como objeto de conhecimento teórico procura fazer passar como o mundo como tal, isto é, não só como unidade abstrata, mas também 
como concretamente único em sua possível totalidade; o conhecimento teórico visa assim construir uma filosofia primeira (Prima philosofia) na forma de gnosiologia teórica. (BAKHTIN, 2010d, p.50)

Para ele, o grande problema na teoria da razão de Kant está justamente em considerar que o momento de conteúdo-sentido é apenas uma unidade teórica como juízo de validade universal, isto é, um juízo puramente teórico que não leva em conta os aspectos históricos e individuais do ser (autor, tempo, circunstância e unidade moral de sua vida, seus valores). Ele evidencia a todo momento que é no ato responsável do ser-existir no mundo que os elementos teóricos e os elementos da vida se unem em uma relação de vida e cultura. Para Bakhtin, o ato não é mera circunstância proveniente de um juízo racional imanente como para Kant, e sim uma escolha concreta no mundo, de um ser único, historicamente situado, dotado de emoção e vontade, com valores axiológicos obtidos ao longo da vida e que tem neste ato total responsabilidade com o outro. Para ele, a experiência influencia o ato responsável do ser que é participativo, assim como seu pensamento.

$\mathrm{O}$ ato real de cognição - não do interior de seu produto teórico abstrato (isto é, desde o interior de um juízo universalmente válido) mas como ato responsável - incorpora cada significado extratemporal no existir-evento singular. Todavia, a contraposição habitual entre a verdade eterna (istina) e a nossa temporalidade imperfeita possui um sentido não teórico; tal asserção inclui em si um certo sabor axiológico e assume um caráter emotivovolitivo: eis aqui a verdade eterna (e isso é bom) e eis aqui a nossa imperfeita vida temporal, transitória, efêmera (e isso é mau). Mas temos aqui o caso de um pensamento participativo, sustentado em um tom penitente que busca superar o próprio caráter dado, em favor do que se coloca como algo que está para ser alcançado; mas tal pensamento participativo se desenvolve propriamente dentro da arquitetônica do existir do evento do qual estamos falando. (BAKHTIN, 2010d, pp. 55 - 56)

Ao contrário de Kant, que coloca inicialmente a moral na base da razão pura, Bakhtin põe a moral na razão prática em direção ao mundo da vida, na realidade, na experiência, pois ela está no ato, seja no ato-pensamento, seja no ato-estético concreto.

É necessário reconduzir a teoria em direção não a construções teóricas e à vida pensada por meio destas, mas ao existir no evento moral, em seu cumprir-se real - à razão prática - o que, responsavelmente, faz quem quer que conheça, aceitando a responsabilidade de cada uma dos atos de sua cognição em sua integralidade, isto é, na medida em que o ato cognitivo como meu ato faça parte, com todo o seu conteúdo, da unidade da minha responsabilidade, na qual e pela qual eu realmente vivo e realizo atos. (BAKHTIN, 2010d, p. 58)

No diálogo com outros filósofos, o pensador russo busca reconhecer algumas contribuições dos neokantianos em relação ao pragmatismo e ao positivismo, contudo é ao 
materialismo histórico ${ }^{45}$ que Bakhtin dá créditos ao dizer que estes foram os únicos que compreenderam o ato participativo ainda que com "pecado metodológico" que não diz quais são suas reais tarefas. Para ele, o materialismo histórico

(...) que com todos os seus limites e suas lacunas, atrai uma consciência participante pelo fato que procura construir o seu mundo de tal modo que um ato, determinado concretamente, histórico e real encontre lugar nele; por isso uma consciência que tem um propósito e age se descobre em tal mundo. (BAKHTIN, 2010d, p. 68)

Ao tratar dos problemas dos sistemas éticos que até então se apresentaram na história da filosofia, Bakhtin retoma o debate com Aristóteles quando fala que a ética materialista busca fundar normas morais conteudísticas e de validades universais nem sempre aplicáveis a todos. Já em relação à ética formal kantiana, o russo critica a universalidade do dever dos imperativos categóricos. Ao tratar da ética, apresenta mais aspectos de sua filosofia moral que nega o formalismo e traz um ser ativo, criativo e responsável concretamente.

No ato, a vontade é ativa de modo efetivo e criativo, mas não fornece de modo algum uma norma, uma fórmula universal. A lei é obra de um ato especial - um ato-pensamento, mas mesmo o ato-pensamento não é ativo no aspecto conteudísticamente válido de uma fórmula. O ato-pensamento é produtivamente ativo somente no ato da incorporação da verdade válida em si no ser histórico (aspecto realmente constitutivo do conhecer do aprender): o ato é ativo no produto real único que ele criou (em uma ação real efetuada, em uma palavra dita, em um pensamento pensado, onde além disso, a validade abstraída de si da lei jurídica real não é mais que um momento). A respeito da lei considerada em sua validade de sentido, a atividade do ato se manifesta somente em um reconhecimento realmente efetuado, em um juízo efetivamente expresso. (BAKHTIN, 2010d, p. 78)

A partir desse momento, Bakhtin parte para a definição de ato responsável de fato e da apresentação dos pontos de seu método filosófico. Para ele, o ato entendido como produto e processo (érgon e enérgeia) deve ser considerado não só por seu conteúdo, "Mas na sua própria realização - de modo algum conhece, de modo algum possui o existir unitário singular da vida; orienta-se por ele e considera sua completude - seja no seu aspecto conteudístico, seja na sua real facticidade singular do interior.” (BAKHTIN, 2010d, p.79) E continua

O ato é o resultado final, uma consumada conclusão definitiva; concentra, correlaciona e resolve um contexto único e singular e já final o sentido e o fato, o universal e o individual, o real e o ideal, porque tudo entra na

\footnotetext{
${ }^{45}$ É possível dizer que com este trecho que Bakhtin, demonstrava alguma simpatia pelas teorias do materialismo histórico elaboradas pelo marxismo russo do período. Porém, ao contrário de seus parceiros Volóchinov e Medviédev não há evidências concretas em toda sua obra de uma filiação concreta às ideias marxistas. De acordo com Emerson (2003, p. 96) Bakhtin era "um anti-revolucionário". Já para Clark e Holquist (2008, p. 64) “A revolução, não obstante, exerceu grande impacto sobre o desenvolvimento intelectual de Bakhtin”.
} 
composição de sua motivação responsável, o ato constitui o desabrochar da mera possibilidade na singularidade da escolha uma vez por todas. (BAKHTIN, 2010d, p. 80)

Ainda que Bakhtin busque nesta obra a construção de uma filosofia moral, o aspecto da linguagem já intrigava o pensador que entendia a importância do produto estético da comunicação humana como a relação do ser com o mundo. Ele diz que a linguagem deve ser "muito mais adaptada para exprimir exatamente esta verdade do que revelar o aspecto lógico abstrato na sua pureza." (idem, p.83) Pela linguagem não falamos apenas palavras, falamos verdades (ou mentiras).

A definição de ato ético responsável, assim como a teoria bakhtiniana da moral, vai se construindo aos poucos, e com afirmações cada vez mais fortes e concretas. Para Bakhtin, a vida não tem álibi. "O ato responsável é precisamente o ato baseado no reconhecimento desta obrigatória singularidade. É essa afirmação do meu não álibi no existir que constitui a base da existência" (BAKHTIN, 2010d, p. 99) Ele compreende que o ser em sua posição ativaresponsiva é responsável por seus atos na vida.

Pouco antes do que ele chama de "Primeira parte" da obra, Bakhtin apresenta a estrutura de sua metodologia de análise. Isso nos faz crer que, de fato, este texto é parte do projeto de uma grande obra de filosofia moral que buscava descrever a "arquitetônica do mundo real", que por conta das dificuldades pessoais em relação ao também difícil contexto russo, acabou não se concretizando.

O mundo no qual o ato se orienta fundado na sua participação singular no existir: este é o objeto da filosofia moral. (...) ele tem a ver somente com uma pessoa única e com um objeto único (...) que lhe são dados em tons emotivos-volitivos individuais. (...) Mas estes mundos concreto-individuais, irrepetíveis de consciências que realmente agem (tem alguns componentes em comum: não nos conceitos de leis gerais, mas no sentido de momentos comuns das suas arquitetônicas concretas). É esta arquitetônica do mundo real do ato que a filosofia moral deve descrever, não como um esquema abstrato, mas como o plano concreto do mundo do ato unitário singular, os momentos concretos fundamentais de sua construção e da sua disposição recíproca. Estes momentos fundamentais são: eu-para-mim, o outro-paramim, e eu-para-o-outro; todos os valores da vida real e da cultura se dispõem ao redor destes pontos arquitetônicos fundamentais do mundo real do ato: valores científicos, estéticos, políticos (incluindo também os éticos e sociais) e finalmente religiosos. (BAKHTIN, 2010d, p. 114)

Aqui Bakhtin não apenas fundamenta o objeto de sua filosofia moral que é "O mundo no qual o ato se orienta fundado na sua participação singular no existir", porém também refuta Kant mais uma vez quando coloca a arquitetônica como um elemento estrutural concreto de seu sistema filosófico de uma maneira completamente diversa do 
filósofo alemão, que percebe a arquitetônica apenas na razão pura. Para o russo, a arquitetônica do mundo real é o objeto de descrição da filosofia moral. Para Bakhtin é "esta arquitetônica do mundo real do ato que a filosofia moral deve descrever" e assim relaciona este mundo como aquele "no qual o ato se orienta fundado na sua participação singular no existir". A arquitetônica acontece no ato, este ato relaciona valores de seres concretos: eupara-mim, o outro-para-mim, e eu-para-o-outro e acontece de maneira singular no tempo e no espaço, historicamente situados.

Ele continua a reflexão descrevendo sobre o que vai tratar nesta "Primeira parte" e nomeia os quatro passos metodológicos de sua análise sobre a filosofia moral do ato ético.

A primeira parte do nosso estudo será dedicada precisamente à análise dos momentos fundamentais da arquitetônica do mundo real, não enquanto pensado mas enquanto vivido. A parte seguinte será dedicada à atividade estética como ação, não a partir do interior do seu produto mas do ponto de vista do autor enquanto participante responsável, e à ética da criação artística. A terceira parte será dedicada à ética da política, e a última à ética da religião. (BAKHTIN, 2010d, p. 115)

Sua metodologia de análise trazia uma ordem organizacional que levava em conta: vida, arte, autoria, ética, política e religião. Para ele, primeiro deve ser feita uma análise da arquitetônica do contexto social mais amplo e da vida vivida; em seguida, uma análise estética, ética e exotópica da obra ou enunciado, levando em conta o ato e a autoria, bem como a relação ética-responsável deste autor-criador com o mundo; posteriormente, uma análise ética da política e, quando for o caso, uma análise de fatores místicos ou religiosos. $\mathrm{Na}$ obra Para uma filosofia do ato responsável, ele realiza essa análise no poema lírico Separação (Razluka) de Púshkin, porém, antes disso, diferencia a análise por meio não de um ato estético, mas sim na vida.

Para nossa pesquisa, é relevante atentarmos ao método de análise proposto por Bakhtin neste ponto de Para uma filosofia do ato responsável. A compreensão da arquitetônica do contexto social e da realidade, a autoria responsável dos enunciados do corpus e os fatores éticos da política serão fatores que poderão nos auxiliar na busca pelas respostas desta pesquisa. Compreender "como um todo arquitetônico é disposto em torno de mim como único centro de realização do meu ato"

Para minha consciência ativa e participante esse mundo, como um todo arquitetônico é disposto em torno de mim como único centro de realização do meu ato; (...) me realizo em minha ação visão, ação pensamento, açãofazer prático. Em correlação com o meu lugar particular que é o lugar do qual parte a minha atividade no mundo, todas as relações espaciaistemporais pensáveis adquirem um centro de valores em volta do qual 
compõem um determinado conjunto arquitetônico concreto estável e a unidade possível se torna singularidade real. (...) Este centro não é imanente (...) No interior do sistema, cada componente desta unidade é logicamente necessário mas o sistema em si no seu todo é apenas algo relativamente possível; é somente em correlação comigo, comigo enquanto penso ativamente, somente em correlação com o ato do meu pensamento responsável que tal sistema se incorpora na real arquitetônica do mundo vivido, como seu momento, se enraíza na sua real singularidade, significativa como valor. (BAKHTIN, 2010d, pp. 118-120)

A citação acima descreve qual é o teor do conceito bakhtiniano de arquitetônica que começa a ser desenhado em Para uma filosofia do ato responsável. O ser ativo e participante entende que é parte do diálogo com outros seres e de forma ativa e criativa participa do mundo da vida e da cultura. Aqui também refuta a ideia de Kant, de que a arquitetônica está na razão pura, quando diz que "este centro não é imanente" e que o sistema em si só é possível em correlação com o ser no mundo da vida. Enquanto para Kant a arquitetônica está na razão pura e é a arte dos sistemas na ideia formal, para Bakhtin a arquitetônica só existe na relação com o ser no mundo da vida e em suas ações concretas na existência, pois é este que dá sentido à arquitetônica do mundo vivido. Este ser faz acontecer o ato utilizando seus valores e sua responsabilidade como ser único e historicamente situado. Para Bakhtin a arquitetônica está na razão prática.

Em sua obra seguinte, o ensaio $O$ problema do conteúdo, do material e da forma na criação literária, escrito entre os anos de 1923-24, publicado no Brasil no livro Questões de literatura e estética (2010), Bakhtin continua a reflexão ao trazer o conceito de forma arquitetônica.

Para ele, as formas arquitetônicas podem estar situadas na arte nos "valores morais e físicos do homem estético", na natureza "no seu ambiente", na vida no "acontecimento no seu aspecto da vida particular, social, histórica e etc". As formas arquitetônicas são "aquisições, realizações", são "formas de existência estética na singularidade" (BAKHTIN, 2010, p.25). São as formas do conteúdo, determinam as formas composicionais e criam "o objeto estético, que é o conteúdo da atividade estética, dotado de uma singularidade e de uma estrutura (...) a forma arquitetônica define o gênero" (SOBRAL, 2010, pp. 112-113)

As formas arquitetônicas são as formas dos valores morais e físicos do homem estético, as formas da natureza enquanto seu ambiente, as formas do acontecimento no seu aspecto da vida particular, social, histórica, etc.; todas elas são aquisições, realizações, não servem a nada, mas se auto-satisfazem tranquilamente, são as formas de existência estética na sua singularidade. (BAKHTIN, 2010, p.25) 
Nesta obra Bakhtin desenvolve uma crítica à pretensão de alguns Círculos russos, em especial ao que ele chama de "Método formal ou Morfológico" referente ao grupo da OPOYAZ $^{46}$ e do Círculo Linguístico de Moscou ${ }^{47}$. Para ele, o método formal mostrava-se "metodicamente impreciso" (BAKHTIN, 2010, p.15) em relação à "estética sistemáticofilosófica geral" ao apresentar uma crítica estética não científica. A "primazia do material (...) isola as artes umas das outras" (idem, p.17). A base crítica do método é puramente o material e vem da proximidade com o positivismo empírico.

Bakhtin evidencia que o método formal russo difere-se da estética formal de Kant e Herbart e da estética de conteúdo de Schelling e Hegel, pois "a obra de arte é condicionada pelo material dado" (BAKHTIN, 2010, p. 19) e não levam em conta a "atividade artística valorizante do criador". (idem, p.20) A partir disso, Bakhtin desenvolve então, por meio de um tom crítico sagaz e com refinamento de detalhes, uma crítica ao método formal russo, para assim, propor uma metodologia de análise estética com base em uma proposta de filosofia da linguagem que compreende a ética em diálogo com a estética e que foi iniciada em Arte e Responsabilidade.

Os conceitos de ato, autoria, arquitetônica e domínio cultural estão presentes em $O$ problema do material, do conteúdo e da forma na criação literária. Ao trazer esses conceitos para a reflexão, Bakhtin continua a construção de sua teoria que agora traz uma orientação não mais de uma filosofia moral, mas uma proposta dialógico-filosófico-estética.

Ao contrário dos formalistas que colocavam o foco no material, para ele "deve-se distinguir rigorosamente (...) o conteúdo, momento indispensável no objeto artístico" (BAKHTIN, 2010, p. 21) Este conteúdo é em sua base ético. O domínio ético é essencial nessa relação e equivale ao pessoal, ao político e ao social. O objeto artístico pode ser pensado a partir do

(...) objeto estético em sua singularidade e estrutura puramente artística, por meio do método teleológico ${ }^{48}$. Compreender teleologicamente a estrutura da obra e como o objeto estético se realiza. Assim compreende-se como ocorre

\footnotetext{
${ }^{46}$ No ano de 1916 em São Petersburgo foi formada a "Sociedade para o Estudo da Linguagem Poética". OPOYAZ é a sigla do grupo em Russo. "Aquela era uma coalizão de dois grupos distintos: os estudantes profissionais da língua da escola de Baudoin de Courtnay, tais como Lev Iakubiski e E. Polianov e teóricos da literatura como Vitor Chklóvski, Boris Eikhenbaum e S. Bernstein.”(TEZZA, 2003, p. 87)

${ }^{47}$ O Círculo linguístico de Moscou foi inicialmente liderado por Roman Jakobson e tinha como principal intenção inicial os estudos da dialetologia e do folclore por meio da linguística de inspiração saussureana.

${ }^{48}$ É relevante ressaltar o que é o teleológico na história da filosofia. O termo começou a ser usado na Grécia por Anaxágoras. Depois foi amplamente utilizado por Sócrates, Platão e Aristóteles. Sua significação principal é a finalidade e as causas das coisas. Os filósofos escolásticos medievais utilizaram o termo para provar a existência de Deus. O mesmo foi retomado na filosofia moderna em Kant para o mesmo fim quando desenvolve o juízo teleológico de que se não podemos provar a inexistência de Deus pode ser que ele exista.
} 
a criação da forma composicional derivada da forma arquitetônica. (...) As formas arquitetônicas principais são comuns a todas as artes e a todo o domínio da estética, elas constituem a unidade deste domínio. (BAKHTIN, 2010, pp. 25 - 26)

Assim como em Para uma filosofia do ato responsável, Bakhtin traz novamente a reflexão sobre a singularidade do criador e o conceito de domínio que posteriormente em outras obras do Círculo seria chamado de esfera, campo, sistemas ideológicos constituídos, etc. No capítulo $O$ problema do conteúdo, ele propõe o que seria o desenvolvimento efetivo de sua teoria da cultura. Para Bakhtin, a cultura está nas fronteiras dos domínios ou esferas.

O problema deste ou daquele domínio da cultura no seu conjunto conhecimento, ética, arte - pode ser compreendido como o problema dos limites desse domínio. Este ou aquele ponto de vista criador, possível ou realizado de fato, só se torna necessário e indispensável de modo convincente quando relacionado com outros pontos de vista criadores: só quando nas suas fronteiras nasce a necessidade absoluta desse ponto de vista, em sua singularidade criativa, é que ele encontra seu fundamento e sua justificação sólida. (BAKHTIN, 2010, p. 29)

Aqui Bakhtin traz novamente o conceito de domínio, no caso da cultura, que pode ser relacionado ao que Volóchinov tratará poucos anos depois no segundo capítulo da obra Marxismo e filosofia da linguagem. As fronteiras dos domínios culturais ressaltam os diferentes pontos de vista na singularidade criativa. Os domínios culturais aqui mencionados (conhecimento, ética $\mathrm{e}$ arte) coincidem com o trinômio inicial do texto Arte $e$ responsabilidade (ciência, vida e arte) e com o que foi postulado em O Problema do conteúdo, do material e da forma sobre cognição, ética e estética. Essa singularidade está presente no todo arquitetônico e aparece principalmente por meio dos valores axiológicos que perpassam a unidade cultural e criam os pontos de vista por meio dos seres. O pesquisador brasileiro Carlos Faraco evidencia a importância da questão axiológica ${ }^{49}$ que perpassa os domínios da cultura humana.

Outro dado fundamental para as concepções de Bakhtin é que cada um desses grandes domínios da cultura humana está perpassado de uma atmosfera axiológica: cada um deles tem como princípio estruturante (como seu fiat $^{50}$ ) atitudes/ posições axiológicas, ou seja, se constitui como um universo dinâmico de valorações. Daí nossa insistência em afirmar sempre que, para Bakhtin, a axiologia (e não propriamente a ontologia) é a Prima Philosofia. (FARACO, 2009, p. 100)

\footnotetext{
${ }^{49}$ A axiologia foi inicialmente pensada na história da filosofia por Lapie (1902), Urban (1906) e Hartmann (1908) e pode ser também entendida e filósofos posteriores assim como em Bakhtin como um conceito que explicita os valores éticos e estéticos do ser. (ABBAGNANO, 2015)

${ }^{50}$ Fiat entendido como fazer.
} 
Os valores axiológicos sempre devem ser considerados em relação ao contexto e aos domínios da cultura e são um ponto chave na construção arquitetônica e do sentido. Como evidenciou Faraco, estes domínios ou esferas são perpassados por axiologias e valores que as constituem ainda que de maneira dinâmica, não fixa.

No capítulo sobre $O$ problema do material, Bakhtin se aprofunda nas reflexões sobre a criação estética e traz novamente o conceito de arquitetônica quando diz que "é importante compreender justamente a originalidade do objeto estético, como tal, e a originalidade da ligação puramente estética dos seus elementos, ou seja, de sua arquitetônica" (BAKHTIN, 2010, p. 54) Contudo, esta ligação puramente estética não deve ser entendida como uma relação formal como vimos na discussão em Para uma filosofia do ato responsável. Neste ensaio, Bakhtin continua a entender a obra como um centro organizador de diversos fatores, os momentos arquitetônicos (eu-para-mim, outro-para-mim, eu-para-outro). Estes são plenos de vida e determinados pelo sujeito do ato ético, o autor-criador da obra em relação aos outros do mundo e do discurso que responderão futuramente ao que está sendo proposto nos momentos da arquitetônica. Os elementos do objeto estético são carregados de valores axiológicos.

Na parte final do ensaio, Bakhtin trata da forma e diz que esta é plena de conteúdo. Assim o autor é um experimentador da forma e do material e, com sua vida, plena de existir e valores axiológicos, a preenche de conteúdo, criando assim uma nova unidade cultural.

$\mathrm{Na}$ forma eu encontro a mim mesmo, minha atividade produtiva de formalização axiológica, eu sinto vivamente meu movimento criador do objeto, sendo que não na primeira criação, não só na execução pessoal, mas também na contemplação da obra de arte: eu devo experimentar-me, numa certa medida, como criador da forma, para realizar inteiramente uma forma artisticamente significante enquanto tal. (BAKHTIN, 2010, p. 58)

No conjunto das obras do Círculo, O problema do material do conteúdo e da forma na criação literária pode ser considerada a primeira proposta de reflexão de estética da criação verbal, ainda que em diversos momentos do texto outras linguagens artísticas sejam citadas como a música, o teatro e as artes visuais. Todavia, o ensaio pode ser compreendido como uma evolução das duas obras anteriores em que Bakhtin estava mais preocupado com questões de filosofia moral no ato e na vida, ainda que, no final, ele traga uma análise a partir de um poema lírico de Pushkin e compreenda que o ato ético acontece de modo ainda mais concreto na produção estética. Em O problema do material do conteúdo e da forma na criação literária, Bakhtin começa a mostrar sua relação cada vez maior com os estudos das linguagens da cultura, de sua análise do homem-sujeito e suas relações no mundo ético e 
estético, por suas relações com a linguagem e o mundo social.

Para compreender as considerações sobre arquitetônica deste período, devemos levar em conta reflexões contidas na obra seguinte $O$ autor e a personagem na atividade estética escrita entre os anos de 1924 e 1927, em que Bakhtin desenvolveu mais profundamente conceitos já elencados nos textos anteriores, com a compreensão da autoria na obra literária e as relações com o herói desta obra.

Bakhtin abre o ensaio com o conceito que nos interessa e num diálogo com os textos anteriores o relaciona com a questão da autoria. Aqui fica ainda mais clara a diferença entre a criação literária e o ato no mundo vivido. A relação entre o autor e a personagem de sua obra literária auxiliou Bakhtin a repensar sua teoria arquitetônica. A partir de Autor e a personagem na atividade estética, a arquitetônica deve ser também pensada na obra literária como "fundamento geral e de princípio quanto nas peculiaridades individuais" do autor. Essa relação inspira a construção do todo da personagem.

A relação arquitetonicamente estável e dinamicamente viva do autor com a personagem deve ser compreendida tanto em fundamento geral e de princípio quanto nas peculiaridades individuais de que ela se reveste nesse ou naquele autor, nessa ou naquela obra. (...) É especificamente estética essa resposta ao todo da pessoa-personagem, e essa resposta reúne todas as definições e avaliações ético-cognitivas e lhes dá acabamento em um todo concreto-conceitual singular e único e também semântico. Essa resposta total à personagem tem um caráter criador produtivo e de princípio. De modo geral toda relação de princípio é de natureza produtiva e criadora. O que na vida na cognição e no ato chamamos de objeto definido só adquire determinidade na nossa relação com ele: é nossa relação que define o objeto e sua estrutura e não o contrário (...) a resposta total, que cria o todo do objeto, realiza-se de forma ativa, mas não é vivida como algo determinado, sua determinidade reside justamente no produto que ela cria, isto é, no objeto enformado; o autor reflete a posição volitivo-emocional da personagem e não a sua própria posição em face à personagem (BAKHTIN, 2010b, p. 3-5)

No trecho, além da redefinição de arquitetônica para pensar a obra literária, é possível também perceber novamente o debate com Kant. Ao dizer que é nossa relação com o objeto que o define, Bakhtin mostra a influência do filósofo alemão. Contudo é preciso perceber que esta relação sujeito-objeto, para Bakhtin está presente na produção estética (que é também ética) da obra literária e relaciona o autor-criador à personagem no objeto estético, mas não de forma mecânica. Para Bakhtin a relação do sujeito que comanda o objeto acontece arquitetonicamente na obra literária e incorpora os valores axiológicos e o tom emotivovolitivo do autor.

É nesta obra também que Bakhtin traz a definição de um conceito muito importante 
para o todo de sua obra, o autor. Ainda que a autoria já tenha sido largamente desenvolvida no texto $O$ problema do material do conteúdo e da forma na criação literária e em relação com a obra estética, aqui a definição é ainda mais nítida e relaciona a arquitetônica ao autor quando este é definido como o "agente da unidade tensamente ativa do todo acabado". Como foi dito há pouco, o autor rege o objeto estético e é ele que dá o acabamento a este objeto. Este acabamento não é apenas de ordem formal, mas principalmente de conteúdo. O autor é o agente da arquitetônica da obra.

Autor: é o agente da unidade tensamente ativa do todo acabado, do todo da personagem e do todo da obra, é este transgrediente a cada elemento particular desta. Na medida em que nos compenetramos da personagem, esse todo que a conclui não pode ser dado de dentro dela em termos de princípio e ela não pode viver dele nem por ele guiar-se em seus vivenciamentos e ações, esse todo lhe chega de cima para baixo - como um dom - de outra consciência ativa: da consciência criadora do autor. (BAKHTIN, 2010b, p. 10)

Como propomos uma abordagem bakhtiniana nesta pesquisa, não apenas na visão teórica em que nos apoiamos, mas também no método, é importante salientar aqui o contexto sócio-histórico mais amplo em que Bakhtin e seus parceiros de reflexão encontram-se neste momento da história. Após a morte de Vladimir Lenin em 1924, a União Soviética passou a ser liderada por um grupo de sete líderes do Partido Comunista e a situação de fome e dificuldades gerais voltaram a se agravar, principalmente com o avanço da liderança de Stalin perante o grupo. No período entre 1924 e 1929, o grupo de pensadores amigos de Bakhtin volta a se reunir com maior assiduidade, porém, de volta para onde tudo começou: a cidade de Petrogrado, que a partir de 1924 passa a ser chamada de Leningrado.

Neste período foram escritas importantes obras do grupo, mais tarde chamado Círculo de Bakhtin. As ditas obras disputadas do Círculo são relativas a este período em que se encontravam com mais frequência principalmente em Leningrado.

Não é nossa intenção nesta tese desenvolver uma reflexão acerca da autoria das obras do Círculo no período. Achamos prudente, porém, evidenciar a autoria trazida nas primeiras edições das obras russas e as que já estão traduzidas para a língua portuguesa. Deste período do Círculo nos interessam neste momento do estudo as seguintes obras:

a) O método formal nos estudos literários: Introdução crítica a uma poética sociológica, obra de 1928, com a autoria de Pavel N. Medviédev ${ }^{51}$.

\footnotetext{
${ }^{51}$ Pável Nikoláievitch Medviédev nasceu em 1891 e foi executado em 1938 pela polícia de Stalin como traidor da revolução. Durante sua vida teve efetiva participação política e acadêmica. Em 1933, foi professor titular do
} 
b) Marxismo e filosofia da linguagem: Problemas fundamentais do Método Sociológico na Ciência da linguagem, com sua primeira edição publicada em $1929^{52}$ com a autoria inicialmente atribuída a Mikhail Bakhtin, mas atualmente legada a Valentin N. Volóchinov ${ }^{53}$.

c) Problemas da poética de Dostoiévski publicado originalmente em 1929 com o título Problemas da obra de Dostoiévski e republicado com a inclusão de trechos que geraram um novo capítulo e sob o título atual em 1963. A versão atual também apresenta a autoria de Mikhail Bakhtin, que contou com a ajuda de um grupo de jovens estudiosos do Instituto Górki para sua publicação. Há evidências de que a obra começou a ser escrita em 1922 em paralelo ao projeto do livro de filosofia moral. No texto original de 1929, ainda não estava presente a proposta de organização de uma nova disciplina, a metalinguística.

As três obras, apesar de trazerem temas diferentes, possuem uma base conceitual em comum, isto é, abordam de modo muito similar conceitos teóricos novos, que após este período tornar-se-iam centrais na obra de Bakhtin e fundamentam as bases do Método Sociológico e da Metalinguística.

O método sociológico foi amplamente desenvolvido por Volóchinov na obra Marxismo e Filosofia da Linguagem mas foi abordado inicialmente por Bakhtin em O problema do conteúdo, do material e da forma na criação literária ao tratar do problema do conteúdo.

O método sociológico não só transcreve o acontecimento ético no seu aspecto social, já vivido e avaliado empaticamente na contemplação estética, mas também sai dos limites do objeto e introduz o acontecimento em ligações sociais e históricas mais amplas. (BAKHTIN, 2010, p. 43)

Neste trecho, Bakhtin parece já desenhar o método que Volóchinov desenvolveu em Marxismo e Filosofia da linguagem de forma mais ampla. O método sociológico do Círculo presente em Marxismo e Filosofia da linguagem (MFL) propõe uma síntese das teorias de pensadores anteriores ao Círculo como evidencia Grillo (2017) no prefácio da tradução da obra. "Em MFL opera-se uma síntese dialética entre a filosofia neokantiana da linguagem de caráter idealista e a sociologia marxista, entre o subjetivismo individualista e objetivismo abstrato, entre o psíquico e o ideológico" (GRILLO, 2017, pp. 52-53)

Na obra $O$ Método formal nos estudos literários, Medviédev aproxima-se com o texto

\footnotetext{
Instituto Histórico-filológico de Leningrado. Foi responsável pelo departamento de cultura e prefeito de Vítebsk pouco antes da revolução de 1918.

${ }^{52}$ V. N. Volóchinov. Markssizm i filossófiia iazyká. Osnóvnye probliémy sotsiologuítcheskogo miétoda v naúke o iazyké. Leningrad: Priboi, 1929

${ }^{53}$ Valentin Nikolaevitch Volóchinov nasceu em São Petesburgo em 1895 e faleceu em Leningrado em 1936 de tuberculose. Foi professor no Instituto Pedagógico Hertzen e pesquisador no Instituto Estatal para a Cultura da Fala e no Instituto para a História Comparativa das Literaturas e Línguas do Ocidente e Oriente (ILIaZV).
} 
O problema do material do conteúdo e da forma na criação literária de Bakhtin quando propõe uma análise crítica ao método formal russo. A proximidade de data de escrita das duas obras evidencia a autoria diferenciada de $\operatorname{ambos}^{54}$. A reflexão de Medviédev propõe logo na primeira página uma análise literária fundada na "ciência das ideologias". Para ele essa ciência tem seus fundamentos

(...) profunda e solidamente alicerçados no marxismo, que formulou uma definição geral das superestruturas ideológicas, de suas funções na unidade da vida social, de suas relações com a base econômica e, em parte, também na relação interna entre elas. No entanto, até hoje, o estudo detalhado das particularidades específicas, da peculiaridade qualitativa de cada campo da criação ideológica - ciência, arte, moral, religião - encontra-se ainda em estado embrionário. (MEDVIÉDEV, 2012, p.43)

É nítido que Medviédev buscava se aliar às teorias marxistas que serviram de base para a revolução russa e que no momento de escrita desta obra tentava se estabilizar na difícil conjuntura após a morte de Lenin. Entretanto, alia-se à reflexão feita por Volóchinov no segundo capítulo de Marxismo e Filosofia da linguagem quando trata da questão das esferas como superestruturas ideológicas e da importância da observação destas para a ciência das ideologias e assim ser pensada em diálogo com a proposta do método sociológico.

Ao evidenciar que a obra buscaria uma análise de viés literário por meio da perspectiva de uma ciência das ideologias e como o título mesmo diz, numa refutação ao método formal dos formalistas da OPOYAZ, Medviédev invoca a teoria marxista sobre a base e superestrutura para pensar a criação estética e a reflexão acerca dos campos da criação ideológica.

Entre a teoria geral das superestruturas em suas relações com base e o estudo concreto e cada fenômeno ideológico específico existe uma espécie de ruptura, um campo nebuloso e instável que cada pesquisador atravessa por sua própria conta e risco: porém, muitas vezes ele simplesmente passa por esse campo, fechando os olhos para toda dificuldade e obscuridade. Como consequência, ou a especificidade do fenômeno estudado é afetada, como no caso da obra de arte, ou, então, sua análise "imanente" que leva em conta essa especificidade sem, no entanto, ter nada em comum com a sociologia, é ajustada artificialmente à base econômica. $\mathrm{O}$ que falta é justamente um estudo sociológico elaborado sobre as particularidades específicas do material, das formas e dos propósitos de cada campo da criação ideológica. Com efeito, cada um desses campos, tem sua linguagem com suas formas e métodos suas leis específicas de refração ideológica da existência comum. Nivelar todas essas diferenças, desprezar a diversidade fundamental, é o que há de menos peculiar no marxismo. (MEDVIÉDEV, 2012, p. 43-44)

\footnotetext{
${ }^{54}$ Para saber mais sobre a disputa das autorias dos textos recomendamos a leitura do prefácio do livro de Medviédev, O método formal nos estudos literários, escrito pela pesquisadora Sheila Grillo.
} 
Medviédev ressalta a importância de um estudo sociológico elaborado da obra relacionada com os "propósitos do campo da criação ideológica". Ele compreende que "cada um desses campos, tem sua linguagem com suas formas e métodos suas leis específicas de refração ideológica da existência comum" (Idem, p. 44). Os campos refletem ideologicamente seus modos de produção no mundo da vida.

Ao falar de um estudo sociológico necessário para pensar nos campos de criação ideológica, ele remete seu diálogo diretamente às reflexões que Bakhtin fizera antes em $O$ problema do material do conteúdo e da forma na criação literária e a Volóchinov em seu texto Marxismo e Filosofia da linguagem sobre o método sociológico. No período, um dos maiores, se não o maior interesse do grupo, era construir um método sociológico, oposto ao método formal, que pudesse corporificar uma análise das criações ideológicas e principalmente da linguagem verbal literária, inspirado no materialismo histórico. Para Medviédev, este método era uma ciência de base marxista e deveria compreender o objeto de análise em relação direta com os propósitos do campo, das superestruturas ideológicas, à base econômica e aos processos históricos e sociais.

Medviédev discute ao longo de sua obra de maneira direta sua crítica aos formalistas e assim compõe sua proposição de método sociológico especificamente para a análise literária. Sua proposta de criação de uma obra traz elementos anteriormente destacados por Bakhtin nos textos de modo geral em relação à análise estética do objeto artístico. Ao falar do todo construído numa obra literária, que a organiza no tempo e no espaço em relação ao sentido, mais especificamente na poesia, nos remete diretamente à arquitetônica. $\mathrm{O}$ tempo, o espaço e o sentido organizam o todo do material.

O seu objetivo é criar a impressão da unidade do material e da organização do corpo sonoro da totalidade. Essa totalidade é organizada no tempo real e no espaço real principalmente se for um gênero poético que exija apresentação em voz alta. O sentido com sua organização predomina sobre essa totalidade material, constrói-se, desenvolve-se em uma ligação ininterrupta com ela. Por isso é impossível compreender um sem o outro. Apenas na unidade da construção, o som como seu elemento torna-se um som poético, o sentido torna-se um sentido poético e sua relação torna-se não ocasional, mas construtiva. Na própria língua, tomada independentemente da organização, não há nada disso. (MEDVIEEDEV, 2012, p. 161).

A arquitetônica de Medviédev pode ser pensada como a unidade de organização e construção do sentido no discurso que integra uma unidade cultural em seu material, forma e conteúdo por meio da ética e da estética. Esta arquitetônica é organizada pelo espaço, tempo e sentido, num evento único e histórico. O todo (arquitetônico) está contido na unidade 
resultante do sentido, isto é, a arquitetônica não é só forma, é também conteúdo. É relevante percebermos aqui a clara distinção com a arquitetônica kantiana, que entende o sistema como uma estrutura meramente formal de ordem teórico-científica. Para Medviédev, a arquitetônica está ainda mais próxima do conteúdo, pois busca o sentido que organiza o material, no tempo e espaço reais, num dado momento socio-histórico. A relação com o todo está diretamente relacionada com o acabamento da obra, que se vincula ao excedente de visão extralocalizado e à visão de mundo do autor em diálogo com os discursos sociais e do outro, como elemento constitutivo da interação e da atividade criativa do autor.

No capítulo relativo às Tarefas construtivas da arte, Medviédev nomeia o conceito de arquitetônica ao trazer o diálogo com o filósofo da arte e escultor alemão Adolf Hildebrand. Para isso, cita um trecho de sua obra $O$ problema da forma na arte figurativa (1914).

$\mathrm{Na}$ atividade artística do passado, observamos que a construção arquitetônica de uma obra de arte sempre esteve em primeiro plano, enquanto seu aspecto imitativo desenvolvia-se bem lentamente. Isso reside na própria natureza do assunto, porquanto o sentimento artístico geral, a necessidade instintiva de criar, a partir dos fragmentos daquilo que foi por nós vivido, algo que concebemos como inteiro, cria e dispõe as relações diretamente de si, como no caso da música; já a observação artística da natureza traz somente pouco a pouco seu material cada vez mais rico. É característico de nossa época, a época científica, que a atividade artística prática não saia do limite da imitação. O sentimento arquitetônico ou está inteiramente ausente, ou se satisfaz pela ordem puramente exterior, mais ou menos harmoniosa. Minha aspiração nesse livro é converter em centro de atenção essa construção arquitetônica da obra artística e desenvolver os problemas que a forma apresenta desse ponto de vista, como uma demanda necessária, fundamentada nas nossas relações factuais com a natureza. (HILDEBRAND apud MEDVIÉDEV, 2012, p. 92)

Hildebrand desenvolve sua proposta de trazer novamente à pauta a construção arquitetônica ao debate da criação artística. Como escultor, ele parece compreender concretamente a importância da arquitetônica para a unidade de sentido na criação artística. Ainda que não traga as categorias de tempo e espaço, ou mesmo as relações de valores (axiológicos) tão presentes no conceito pensado pelo Círculo, chama atenção a percepção de que a arquitetônica é o fator criativo, que torna uma obra singular e inovadora, mas como "unidade construtiva da obra". Para ele a arquitetônica se apresenta no aspecto formal da obra mas em relação ao conteúdo. Medviédev em diálogo com o escultor alemão diz que

Aquilo que Hildebrand chama arquitetônico é na verdade, a unidade construtiva da obra. O próprio termo arquitetônico não foi mantido em virtude de se ligar ao nosso assunto por meio de associações estranhas. Como se expressa essa abordagem construtiva arquitetônica de uma obra de 
arte figurativa? Uma obra é um corpo espacial fechado. Ela é parte de um espaço real e está organizada como uma unidade justamente dentro dele. Como ponto de partida, deve-se tomar essa organização real da obra como uma totalidade autossignificante e construtiva. $\mathrm{O}$ gênero, o modo e as funções do conteúdo objetivo introduzido na construção de uma obra são determinados por esse lugar real, depois pela organização de suas partes e por aquelas funções que assume cada uma das partes e todo o corpo organizado no espaço real. Independente do significado imitativo, representativo ou outro, que possa receber um ou outro elemento da totalidade espacial, é necessário, antes de mais nada, definir o lugar no conjunto real e organizado de uma obra, isto é, o lugar de seu significado construtivo nos limites do espaço real. (MEDVIÉDEV, 2012, p. 92 - 93)

O debate entre Medviédev e Hildebrand evidencia que ambos buscavam compreender esta arquitetônica e o pensador russo explicita o que ele compreende por arquitetônica na obra de arte que auxilia no acabamento que o autor dá a ela por meio do sentido, isto é, pelo conteúdo. Para Medviédev, a obra de arte, ao contrário de outros tipos de enunciado, recebe acabamento estético por seu autor, que está extralocalizado a ela. A unidade do material e a organização da totalidade no tempo e espaço reais, no contexto e no campo ideológico são fatores essenciais, demonstrando novamente a influência do materialismo histórico que permeia a ciência da ideologia. Não apenas os campos (ou esferas) determinam a organização do sentido, mas também a função social do que é criado e sua localização no tempo-espaço. O objeto estético tem um lugar (tempo e espaço), uma organização arquitetônica e tem função real no mundo real, mesmo que seja uma obra literária. Quando ele menciona "o lugar de seu significado construtivo nos limites do espaço real" evidencia o caráter historicamente situado do autor criador, como um organizador que constitui a obra.

O mesmo teor de base materialista histórica é sentido já nas primeiras páginas da obra Marxismo e filosofia da Linguagem: Problemas fundamentais do método sociológico na ciência da linguagem que por muitos anos foi citado como escrita por Bakhtin, mas atualmente acredita-se a partir de sua edição original ter sido escrita por Valentin Volóchinov. Este não nomeia o conceito de arquitetônica em nenhuma página de seu livro, mas desenvolve reflexões que podem nos remeter diretamente a ele. Ao tratar dos campos da criatividade ideológica, que muito nos importa nesta pesquisa e a relação destes com os signos ideológicos, fala que:

Cada campo possui sua função específica na unidade da vida social. Entretanto, o caráter sígnico é um traço comum a todos os fenômenos ideológicos. Qualquer signo ideológico é não apenas um reflexo, uma sombra da realidade. Qualquer fenômeno ideológico signico é dado em 
algum material: no som, na massa física, na cor, no movimento do corpo e assim por diante. (...) O signo é um fenômeno do mundo externo. (VOLÓCHINOV, 2017, p. 94)

Como já evidenciado, os teóricos do Círculo operam o conceito de esfera ou campo ou mesmo domínio da cultura, sem explicitar uma expressão única ou mesmo uma definição única. Em boa parte das obras, fazem uma reflexão filosófica sobre o assunto. Por vezes costumam chamar as esferas ideológicas de "campos da atividade humana" ou "sistemas ideológicos constituídos", ou mesmo, como no trecho acima, "campo de criatividade ideológica". Na obra Marxismo e Filosofia da linguagem, o tema é tratado com expressões diversas.

No segundo capítulo de Marxismo e Filosofia da linguagem, Volóchinov, ao tratar da filosofia da linguagem, trava um debate com a teoria kantiana ao falar das categorias mecânicas (as mesmas mencionadas por Bakhtin no início de Arte e responsabilidade). Com isso, demonstra que a síntese realizada pelo Círculo neste momento de seu desenvolvimento teórico apresenta em sua construção arquitetônica geral uma refutação às teses kantianas e suas categorias da causalidade mecânica, bem como ao aspecto formal do método formal russo e reforça o apoio nas ciências das ideologias marxistas ao pensar as esferas em relação direta com a teoria marxista sobre a base e as superestruturas ideológicas.

O domínio de aplicação das categorias da causalidade mecânica é extremamente restrito e nas próprias ciências da natureza torna-se cada vez mais limitado à medida que os seus princípios fundamentais são dialeticamente ampliados e aprofundados. A aplicação dessa categoria inerte é inadmissível no que diz respeito às questões básicas do materialismo histórico e de toda a ciência das ideologias. O estabelecimento da ligação entre a base e um fenômeno isolado, que foi retirado do contexto ideológico integral e unificado, não possui nenhum valor cognitivo. Primeiro, a importância de uma mudança ideológica deve ser definida no contexto da ideologia correspondente, considerando que qualquer área ideológica é uma totalidade que reage com toda a sua composição à alteração da base. Por isso a explicação deve preservar toda a diferença qualitativa dos campos em interação e observar todas as etapas que acompanham essa mudança. Apenas nessa condição o resultado da análise não será uma correspondência externa de dois fenômenos ocasionais e que se encontram em diferentes planos, mas um processo de formação dialética de uma sociedade real, que tem início na base e termina nas superestruturas. (VOLÓCHINOV, 2017, pp. 103 - 104, grifos do autor)

Aqui Volóchinov ressalta a importância da base econômica para o desenvolvimento das superestruturas ideológicas, ou como ele também nomeia neste trecho, os campos. As mudanças (sociais, discursivas, funcionais, concretas) em cada campo ideológico são diretamente proporcionais às mudanças na base, isto é, na economia de uma dada sociedade. 
A ciência das ideologias, no âmbito de propor um método sociológico, deve perceber estas relações entre base (econômica) e as ideologias (esferas). Ao trazer a expressão "categorias da causalidade mecânica" ele nos remete ao aspecto formal que o Círculo buscava refutar e também à questão da arquitetônica que para ele deve estar diretamente relacionada ao contexto. É possível dizer, ainda que o conceito não seja desenvolvido na obra, que Volóchinov compreendia que a arquitetônica estava relacionada com os domínios ideológicos. Para ele, qualquer fenômeno de criação deve ser compreendido na interação e na relação entre os campos, em diálogo com o contexto sócio-histórico que o permeia e ao campo ideológico a que pertence. Não é possível compreender o todo de qualquer fenômeno social (e comunicacional) e sua arquitetônica, sem compreender suas relações externas com o horizonte social mais amplo e com o campo ideológico.

Completamos a reflexão sobre as obras do Círculo do período dos anos 1920 com a análise da obra de Bakhtin sobre Dostoiévski. A terceira obra do período foi publicada em 1929 com o título Problemas da Obra de Dostoiévski e em sua edição atual (publicada na União Soviética em 1963) recebe o nome de Problemas da Poética de Dostoiévski. O período da primeira publicação do livro ocorreu num momento muito difícil para Bakhtin. Os expurgos Stalinistas a partir de 1928 e a perseguição política a diversos intelectuais obrigaram que o grupo se dissolvesse. Bakhtin foi preso em janeiro de 1929 e alguns dias depois seu livro foi publicado. Em junho do mesmo ano, uma perinefrite complicou a doença já existente em suas pernas e por isso, em julho, foi transferido para um hospital. Após muitos interrogatórios, Bakhtin foi sentenciado a um exílio no Cazaquistão na cidade de Kustanai. (CLARK; HOLQUIST, 2008, p. 167 - 168)

Em Problemas da Poética de Dostoiévski, Bakhtin continua sua reflexão feita em Problemas da Obra de Dostoiévski e inclui mais alguns trechos e um novo capítulo inteiro que o faz mergulhar ainda mais obra do escritor russo. É nesse novo capítulo inserido da publicação de 1963, mas ainda em diálogo com os livros de Volóchinov e Medviédev dos anos 1920, que Bakhtin cria novas nuances em seu próprio método e as bases para a disciplina que ele chama de Metalinguística.

Não há informações do período em que a primeira versão do livro foi escrita efetivamente, mas tudo indica que foi em período similar a Marxismo e Filosofia da linguagem. Todavia, há evidências que este começou a ser escrito no final de $1921^{55}$. Bakhtin

\footnotetext{
${ }^{55}$ A pesquisadora Caryl Emerson no prefácio da edição americana da obra cita uma carta enviada por Bakhtin a Matvei Kagan em janeiro de 1922 em que contava sobre o início da escrita de um livro sobre a obra de
} 
já havia citado o método sociológico antes de todos os outros participantes do Círculo em $O$ problema do material do conteúdo e da forma na criação literária. Na edição dos anos 1960, feita em parceria com um grupo de jovens estudantes do Instituto Górki, lançava no conjunto da teoria a importância das relações dialógicas do discurso que "são objetos de estudo da metalinguística" (BAKHTIN, 2010c, p. 209) e que pelo trecho abaixo nos remete à arquitetônica ao operar com as relações e as categorias lógicas do discurso. Para que a arquitetônica aconteça numa singular produção de sentido é necessário um "momento dialógico".

As relações dialógicas são irredutíveis às relações lógicas ou às concretosemânticas, que por si mesmas carecem de momento dialógico. Devem personificar-se na linguagem, tornar-se enunciados, converter-se em posições de diferentes sujeitos expressas na linguagem para que entre eles possam surgir relações dialógicas. A vida é boa. A vida não é boa. Estamos diante de dois juízos revestidos de determinada forma lógica e um conteúdo concreto-semântico (juízos filosóficos acerca do valor da vida) definido. Entre esses juízos há certa relação lógica: um é a negação do outro. Mas entre eles não há nem pode haver quaisquer relações dialógicas, eles não discutem absolutamente nada entre si (embora possam propiciar matéria concreta e fundamento lógico para a discussão). Esses dois juízos devem materializar-se para que possa surgir relação dialógica entre eles ou tratamento dialógico deles. Assim, esses dois juízos, como uma tese e uma antítese, podem unir-se num enunciado de um sujeito, que expresse a posição dialética deste em relação a um dado problema. Nesse caso não surgem relações dialógicas. Mas se esses dois juízos forem divididos entre dois diferentes enunciados de dois sujeitos diferentes, então surgirão entre eles relações dialógicas. (...) Para se tornarem dialógicas, as relações lógicas e concreto-semânticas devem, como já dissemos, materializar-se, ou seja, devem passar a outro campo da existência, devem tornar-se discurso, ou seja, enunciado, e ganhar autor, criador de dado enunciado cuja posição ele expressa. (BAKHTIN, 2010c, pp. 209 - 210)

Para Bakhtin as relações dialógicas "penetram toda a linguagem humana" (BAKHTIN, 2010c, p. 47), se inserem no discurso. São evidenciadas no relativo contraponto lógico dos sentidos "um é a negação do outro"(Idem, p. 209). Remetem a valores em embate, não apenas em discursos em diálogo, mas a discursos anteriores, posteriores, visões de mundo de ordem histórica, mas personificada nos seres em interação através de discursos. Os discursos das diversas personagens de Dostoiévski foram um laboratório para esta reflexão. Os diferentes tipos de discursos, mesmo os monológicos, serviram de ponto de partida para a percepção de que havia um diálogo que acontecia muito além do perceptível. As relações dialógicas estão nas entrelinhas do texto, estão no discurso e ganham vida na interação. 
"Somente quando contrai relações dialógicas essenciais com as ideias dos outros é que a ideia começa a ter vida" (BAKHTIN, 2010c, p. 96) É na materialização das relações lógicas e concreto-semânticas do discurso que a arquitetônica se revela, na construção do todo do enunciado prenhe de sentido.

Na edição dos anos 1960 de Problemas da Poética de Dostoiévski, Bakhtin também aborda o fenômeno da carnavalização da linguagem que dá o tom em sua obra escrita nos anos 1940 sobre François Rabelais. Bakhtin reserva boa parte do quarto capítulo de Problemas da Poética de Dostoiévski para discutir gêneros clássicos e contemporâneos que apresentaram a cosmovisão carnavalesca.

Já tivemos oportunidade de falar das particularidades da estrutura da imagem carnavalesca. Esta tende a abranger e a reunir os dois polos do processo de formação ou os dois membros da antítese: nascimento-morte, mocidadevelhice, alto-baixo, face-traseiro, elogio-impropério, afirmação-negação, trágico-cômico, etc. e o polo superior da imagem biunívoca reflete-se no plano inferior segundo o princípio das figuras das cartas do baralho. Isso pode ser expresso assim: os contrários se encontram, olham-se mutuamente, refletem-se um no outro, conhecem e compreendem um ao outro. (BAKHTIN, 2010c, p. 204)

Ao demonstrar os variados "dois membros da antítese", Bakhtin busca preparar seu leitor para a reflexão sobre as relações dialógicas. A antítese tratada aí é não apenas uma referência à dialética discursiva, mas principalmente ao começo da compreensão de que discursos em interação sempre trazem diferentes: tons, signos, referentes e são construídos por meio dessas nuances. A diferença produz sentido e faz com que os sentidos sejam organizados também por diferenças. Entretanto, não deve ser pensada como a teoria do valor de Saussure ${ }^{56}$, em Bakhtin as diferenças são evocadas no discurso, recebem sentido não no sistema linguístico, mas na organização da comunicação no mundo real, tem historia, tempo, espaço e principalmente autoria e essa organização é arquitetônica. Assim, é possível dizer que a arquitetônica, como uma sistematização organizadora de sentidos, também leva em conta essas antíteses em seus momentos arquitetônicos, nas relações lógicas e dialógicas que permitem a criação de um enunciado. No todo arquitetônico de um enunciado, não há apenas o discurso e as intenções de sentido de um determinado autor historicamente situado, há também outros discursos contrastantes de tempos anteriores, auxiliando na construção de um novo enunciado projetado para um novo diálogo no futuro. Nas relações dialógicas, a tensão dialógica se faz presente assim como nas relações da vida cotidiana. Elas refletem e refratam

\footnotetext{
${ }^{56}$ Para Saussure, basicamente, um signo é o que outro não é. O valor saussureano está no contraste entre os signos linguísticos numa abordagem sincrônica.
} 
discursos da vida e tomam forma nas esferas da atividade humana. As relações de interação previstas nos momentos arquitetônicos pensadas por Bakhtin nessa obra (eu-para-mim, outropara-mim, eu-para-outro) fazem ecoar vozes temporais e atemporais, no pequeno e no grande tempo, e são personificadas em um dado enunciado concreto que tem função específica no mundo social e é corporificado num domínio cultural.

Em seu livro Cultura popular da idade média e no renascimento: o contexto de François Rabelais (2008), busca completar o que hoje podemos chamar uma proposta de filosofia da cultura iniciada em Para uma filosofia do ato responsável e continuada em $O$ problema do material do conteúdo e da forma na criação literária.

Na obra $O$ problema do material do conteúdo e da forma na criação literária, Bakhtin compreende que "Cada fenômeno de cultura é concreto e sistemático, ou seja, ocupa uma posição substancial em relação à realidade preexistente de outras atitudes culturais e por isso mesmo participa da unidade cultural prescrita" (BAKHTIN, 2010, p.31) A unidade cultural tem uma arquitetônica e esta se apresenta em sua relação com o mundo da vida e da cultura. O conceito de cultura foi amplamente tratado em Queiroz (2014), porém nesta tese terá uma função norteadora para pensarmos fatores referentes à nossa análise do corpus bem como nossa hipótese. Devemos compreender a cultura como parte constitutiva da arquitetônica, pois a organização de sentidos nas unidades culturais relaciona-se com cada domínio cultural num determinado espaço e tempo. A cultura está nas fronteiras, na relação com outras culturas, com outras formas de produção do mundo, como bem pontuou Bakhtin em $O$ problema do material do conteúdo e da forma na criação literária. No entanto, para que exista esta cultura é preciso pensar que ela só existe no conjunto de unidades culturais de uma determinada comunidade semiótica e no conjunto de enunciados produzidos em uma dada esfera cultural. A unidade cultural pressupõe em seu todo construído como que mônadas ${ }^{57}$ que refletem e refratam uma dada cultura. Bakhtin compreendia que estas são produzidas e organizadas no momento de criação, no ato do autor em seu tom emotivovolitivo como pontuado na obra $O$ Autor e a personagem na atividade estética. Para Bakhtin, a cultura é compreendida de forma ampliada, estando nas fronteiras entre as esferas da cultura. A cultura permeia tudo, reflete e refrata tudo, é ativada por forças centrífugas e centrípetas, mas é no ser e pelo ser que a cultura é transformada arquitetonicamente em enunciado concreto e ganha vida no mundo. Este é o mundo da cultura e sua relação com o

\footnotetext{
${ }^{57}$ Bakhtin utiliza o termo em O problema do material do conteúdo e da forma na criação literária para tratar das unidades de cultura.
} 
mundo da vida.

Na obra Cultura popular da idade média e no renascimento: O Contexto de François Rabelais (2008), Bakhtin não se preocupa em trazer uma definição do conceito de cultura como fez em O problema do material do conteúdo e da forma na criação literária porém desenvolve uma longa reflexão acerca do tema. Fala sobre a cultura popular em contraste com a cultura oficial, do dialogismo e da construção de uma determinada cultura num determinado tempo histórico, por meio da reflexão sobre a cosmovisão carnavalesca do escritor francês medieval François Rabelais. Interessa a nossa pesquisa perceber a relação antagônica entre a cultura popular e a cultura oficial (reforçada nos períodos carnavalescos), ou como a cultura popular em alguns momentos da história da cultura busca mostrar o "mundo às avessas". Esse antagonismo carnavalesco é criativo e arquitetônico. Bakhtin aponta que a visão carnavalesca na literatura medieval proporcionava a

(...) abolição provisória das diferenças e barreiras hierárquicas entre pessoas e a eliminação de certas regras e tabus vigentes na vida cotidiana criavam um tipo especial de comunicação ao mesmo tempo ideal e real entre as pessoas, impossível de estabelecer na vida ordinária. Era um contato familiar e sem restrições, entre indivíduos que nenhuma distância separa mais. Como resultado, a nova forma de comunicação produziu novas formas linguísticas: gêneros inéditos, mudanças de sentido ou eliminação de certas formas desusadas, etc. (BAKHTIN, 2008, p. 14)

É importante notar que na carnavalização não apenas o mundo acontece às avessas e as hierarquias sociais não são as mesmas, mas também novas produções de sentido são permitidas e novos gêneros surgem por conta da ordem fora do padrão hegemônico. A cultura oficial que Bakhtin trata em Cultura popular da idade média e no renascimento: O Contexto de François Rabelais era específica do período medieval, porém pode ser entendida no grande tempo da história, como a cultura hegemônica das manifestações institucionais, não apenas do Estado, mas também da elite intelectual de um determinado tempo e espaço, em boa parte dos casos uma cultura de base erudita, esteticamente complexa. Para a elite, apenas no período das festas carnavalescas é permitido o riso, o cômico, o grotesco. Fora desse período carnavalesco, este tipo de estética é legada apenas ao que se chama de cultura popular. Esse (pré)conceito parece ainda existir na contemporaneidade.

O riso e a visão carnavalesca do mundo, que estão na base do grotesco, destroem a seriedade unilateral e as pretensões de significação incondicional e intemporal e liberam a consciência, o pensamento e a imaginação humana, que ficam assim disponíveis para o desenvolvimento de novas possibilidades. Daí que uma certa "carnavalização" da consciência precede e prepara sempre as grandes transformações, mesmo no domínio científico. 
(BAKHTIN, 2008, p. 43)

Se de fato a carnavalização prepara para grandes transformações de valores ao mostrar uma possibilidade de um mundo às avessas, seria essa carnavalização uma possibilidade de maior liberdade criativa que teria influência na arquitetônica das unidades de cultura? A carnavalização atua assim como uma possibilidade transformadora do mundo da cultura, que faz avançar mais rapidamente, nas tensões sociais (éticas e estéticas). Ela é uma importante força centrifuga social.

Devemos retomar aqui o que Bakhtin compreende por arquitetônica: um centro organizador do sentido, que utiliza categorias de espaço, tempo e valores do ser historicamente situado e em interação com outros seres em ato. A carnavalização pode ser entendida como um fator que amplia a liberdade estética (com responsabilidade ética) desse ser criador para a composição de um novo objeto estético, pois este não está mais totalmente determinado por valores da cultura hegemônica vigente num certo tempo histórico e assim novas possibilidades de arquitetônica podem surgir.

Para finalizar este tópico sobre a arquitetônica bakhtiniana, achamos relevante trazer o texto Os gêneros do discurso (2003) escrito no início dos anos 1950. Neste ensaio, Bakhtin desenvolve profundamente sua teoria do enunciado concreto ao compreender a relação entre a oração e o enunciado, das pequenas produções de sentido num texto e seu todo. Nesta obra de sua fase mais madura, em nenhum momento ele menciona o conceito de arquitetônica, porém é possível escutar os ecos do conceito em todo o texto e particularmente nos momentos conclusivos. Como vimos anteriormente é a arquitetônica que determina o gênero em diálogo com a esfera. A arquitetônica organiza assim o sentido de modo sistemático, envolvendo forma, conteúdo, valores, tempo, espaço, autorias e formas concretas das diversas possibilidades de comunicação.

Falamos apenas através de determinados gêneros do discurso, isto é, todos os nossos enunciados possuem formas relativamente estáveis e típicas de construção do todo. Dispomos de um rico repertório de gêneros de discurso orais (e escritos) Em termos práticos, nós os empregamos de forma segura e habilidosa, mas em termos teóricos podemos desconhecer inteiramente a sua existência. (BAKHTIN, 2010b, p.282)

Nosso questionamento fica ainda mais evidente quando no ensaio $O$ problema do texto na linguística, na filologia e em outras ciências humanas, escrito e publicado entre os anos de 1959 e 1961, Bakhtin coloca que "Os gêneros do discurso são modelos tipológicos de construção da totalidade discursiva". (BAKHTIN, 2010b, p. 334) ou mesmo quando ele fala 
que o enunciado é "um conjunto de sentidos" (idem, p. 329). Esta reflexão nos permite dizer que cada gênero apresenta uma arquitetônica própria, pois suas especificidades constroem o sentido do todo do enunciado. O conceito de arquitetônica não é restrito a ele, mas deve ser pensado no conjunto do entendimento de outros conceitos e ideias do Círculo e compõe por meio desta reflexão as relações dialógicas e sua importância no mundo da cultura, para a constituição do mesmo. Os conceitos de esfera, signo ideológico, autoria, ato responsável, responsabilidade, gêneros do discurso, são parte da construção da arquitetônica das ideias do Círculo e auxiliam no entendimento da própria arquitetônica. Ao longo desta tese trabalharemos com esses conceitos e outros conceitos-chave conexos na análise de nosso corpus. Deste modo, será possível observarmos como de fato operam na construção da arquitetônica e nas práticas sociais da esfera político-cultural brasileira.

$$
* * *
$$

Como vimos ao longo deste primeiro capítulo, o conceito de arquitetônica foi utilizado por diversos filósofos ao longo da história. Originalmente desenvolvido por Aristóteles na obra Ética à Nicômaco, referindo-se à ciência política como um saber supremo, condicionava outras ciências práticas a esta, dentre elas a ética e a política como prática social. O pensador grego relacionava dentro de sua ética materialista, uma série de outros conceitos pertinentes à arquitetônica.

Em Kant, a arquitetônica foi pensada como um dos fatores principais para a criação de uma concepção de filosofia teórica de ordem puramente racional. Significava a "arte dos sistemas" da razão pura, estava diretamente condicionada à estrutura formal do conhecimento a priori e não demandava a experiência para que pudesse criar esquemas de pensamento da razão pura.

Em nossa pesquisa, trabalhamos com as teorias do Círculo de Bakhtin, que compreende a arquitetônica de duas formas, e com claras influências de Aristóteles e Kant, ao mesmo tempo que refutava e ressignificava as teses destes filósofos. De Aristóteles veio não apenas o conceito em si, mas principalmente a compreensão de que a arquitetônica compreende o todo dos nossos atos sociais, que são responsáveis para com a polis ou a coletividade de seres. Para Aristóteles o ato como produto do homem estava diretamente condicionado ao bem da polis e por isso é um ato que pressupõe a ética. $\mathrm{O}$ mesmo acontece em Bakhtin, porém aqui o ser em seu ato responsável responde ao outro nos momentos arquitetônicos (eu-para-mim, eu-para-o-outro, outro-para-mim). Também de Aristóteles vem a ideia da arquitetônica como um saber maior organizador que relaciona o conhecimento 
teórico com a prática social.

A influência de Kant nos remete à ideia de arquitetônica como uma sistematização e acontece em forma de refutação em boa parte das relações teóricas entre eles, como vimos no início deste tópico. Contudo, as categorias lógicas de tempo e espaço como condicionantes de organização do sentido e da base da arquitetônica em Bakhtin tornam-se ponto chave para compreender o conteúdo e não mais a forma como foi visto em Kant. Dele também vem a essência da arquitetônica como sistema estruturante do pensamento, porém para Bakhtin esse pensamento é transformado em ato, e concretizado em forma de um enunciado concreto. Enquanto para Kant ele estava apenas na ideia abstrata teórica, na razão pura, para Bakhtin está no ato no mundo vivido, na razão prática.

A arquitetônica bakhtiniana ${ }^{58}$ pode ser entendida de dois modos. Por um lado, a arquitetônica é um conceito sistematizador superior que engloba todas as categorias filosóficas bakhtinianas de compreensão de mundo, a composição da malha conceitual da teoria. Por outro, ela compreende o todo englobante de um enunciado concreto que é realizado num ato responsável, enquanto potência no ser único e num momento histórico único e sempre em relação de interação com o outro, com o contexto e com a esfera ideológica. Nos dois casos, a arquitetônica deve ser pensada em relação ao todo da cultura, com parâmetros éticos e estéticos e que se realizam nas práticas sociais interativas/ discursivas. A arquitetônica organiza o sentido e a composição do enunciado, seja ele um objeto de arte ou qualquer outro gênero discursivo da comunicação humana e assim neles se refletem e refratam o mundo e suas esferas ideológicas.

Buscaremos nas páginas a seguir encontrar essa arquitetônica nos documentos de nosso corpus sobre o SNC, bem como nas ações dos agentes envolvidos nos processos históricos ao longo dessa construção. Desta maneira vamos construir nosso percurso para responder os questionamentos dessa tese.

\footnotetext{
${ }^{58}$ Aqui devemos entender Bakhtin como uma síntese das teorias do Círculo sobre a arquitetônica.
} 


\section{CAPÍTULO 2: PROJETANDO E CONSTRUINDO CAMINHOS PARA A ANÁLISE: METODOLOGIA, OBJETO DE PESQUISA E TESE}

Neste segundo capítulo, vamos traçar os percursos de construção da pesquisa. Em primeiro lugar, trataremos do assunto central da tese, o Sistema Nacional de Cultura e sua relação com a arquitetônica e a esfera. Na sequência, falaremos do corpus selecionado para nosso estudo com a intenção de demonstrar e justificar a escolha de cada um dos enunciados na construção da arquitetônica que buscamos mostrar. E finalmente abordaremos a metodologia utilizada para a análise dos enunciados, inspirada nas teorias do chamado Círculo de Bakhtin e nossa tese.

\section{1 - A arquitetônica, a esfera e o SNC: reflexões iniciais}

As diversas mudanças no comando do Ministério da Cultura nestes últimos anos e a complexidade de implantação do Sistema Nacional de Cultura (SNC) como um todo vêm gerando dificuldades em estabelecer o que foi proposto para a gestão das políticas culturais no início do século XXI, bem como os ideais de ampliação do olhar de cultura proposto pela Unesco para as políticas culturais mundiais nos anos 1990. As maiores dificuldades são o sucesso do modelo federalista num país de geografia continental e a efetiva implantação dos Planos e Sistemas de Cultura territoriais, nas pontas (cidades e estados).

O esquema base do Sistema de Cultura, pensado de modo descentralizado em plano federal e também nos entes federados, tem uma estrutura chamada CPF que se refere como sigla ao trinômio estruturante: Conselho, Plano e Fundo (de cultura). Para que o Sistema seja completamente implantado é necessário que milhares de sistemas, conselhos, planos e fundos de cultura sejam construídos em cidades e estados.

Desde o ano de 2010 até 2020, período de vigência do primeiro decênio do Plano Nacional de Cultura (PNC), foi inicialmente prevista a escrita de pelo menos dois mil planos de cultura em todo país pelas comissões e conselhos estaduais e municipais de cultura, bem como a escrita e aprovação de outras milhares de leis de Planos e Sistemas de Cultura desenvolvidos por parlamentares, conselhos e comissões locais. A Meta número 1 do Plano Nacional de Cultura prevê que até 2020 ao menos 3339 cidades tenham aderido ao SNC. Entretanto, com as diversas rupturas e instabilidades políticas dos últimos anos, chegamos ao início do ano de 2019 com um número muito menor de adesões e de sistemas territoriais implantados do que o ideal e com um órgão federal de cultura diminuído a uma secretaria 
subalterna do novo Ministério da Cidadania.

Ainda que os prognósticos futuros não sejam positivos, a implantação do SNC continua em vigência por sua presença como parte da Constituição Federal. Em parte dos estados e municípios, os processos de implantação continuam caminhando em diferentes estágios e velocidades. Nos processos de implantação de sistemas, cada etapa pede aos cidadãos, agentes culturais e secretarias de cultura paciência para a construção dos conselhos, e posteriormente dos planos de cultura. E nem sempre essa ordem de sistematização é seguida, pois em boa parte dos casos há desconhecimento dos métodos e ou as etapas são realizadas de acordo com as "oportunidades" políticas de cada ente federado.

Os planos de cultura devem apresentar propostas de políticas culturais com vigência decenal prevendo não apenas as ações a serem desenvolvidas ao longo do tempo, mas também estarem em diálogo com os orçamentos locais e planos plurianuais, contando com o apoio do poder executivo vigente durante cada período. Este talvez seja o maior desafio da proposta.

A criação dos enunciados dos Planos de Cultura nos entes federados tem se mostrado um entrave na implantação do sistema, principalmente em razão de sua produção textual complexa, da necessidade de pesquisas de diagnóstico e de demandas dos produtores de cultura. Outro ponto que se mostrou como um desafio é a necessidade da participação social de artistas e produtores culturais locais - membros da sociedade civil - na escrita dos planos. Não deve haver pressa na construção de um bom plano de cultura, porém há um prazo para construí-lo para que se mantenha atual. Dentre os planos previstos no sistema estão também os Planos Setoriais ${ }^{59}$. Estes deverão ser construídos em conjunto com os planos territoriais.

Além das recentes rupturas políticas, os atrasos e entraves também têm acontecido por motivos de ordem regional, de desinformação ou mesmo de disputas político-ideológicas. Nem sempre parlamentares locais conhecem o sistema ou mesmo comungam dos mesmos ideais da proposta em democratizar a construção das políticas de acesso à cultura, como tem ocorrido nos processos do Sistema Estadual Paulista, por exemplo ${ }^{60}$.

De acordo com os manuais de orientação do MinC, os Planos de Cultura nos estados e municípios, bem como as minutas de projetos de lei de sistemas, conselhos e fundos, deverão ser escritos por "diversas mãos": por integrantes do setor cultural, por gestores de secretarias, por comissões especiais, por conselheiros locais e populares da sociedade civil interessados em participar da construção desses sistemas territoriais. Estes deverão integrar diversas

\footnotetext{
59 Aliado aos Planos Estatuais e Municipais, representados pela alcunha de Planos territoriais, também deverão ser escritos os Planos Setoriais que trarão especificidades de áreas culturais e artísticas de cada região.

${ }^{60}$ Trataremos da implantação do Sistema paulista no próximo capítulo.
} 
conferências, reuniões e etapas de desenvolvimento até chegar num enunciado que deverá estabelecer como serão as leis que instituirão cada sistema, com seus planos, conselhos e fundos de cultura. Em alguns casos, os textos dos planos de cultura passarão por etapas de consulta pública presencial e via internet. Essa ação possibilitará novas interações, com leituras e sugestões de novas metas e ações aos enunciados propostos. Estes processos requerem tempo, espaço, disposição, oportunidades, recursos e principalmente vontade e mobilização.

A escrita dos planos e suas respectivas leis deverão apresentar forma e conteúdos relativamente similares ao plano federal, porém com conteúdos baseados em demandas locais e pensando como essas políticas culturais devem ser aplicadas concretamente em cada uma das cidades. Além das leis reguladoras dos CPF (Conselhos, Planos e Fundos), que apresentam formato relativamente estável enquanto enunciado da esfera legislativa, há também um tipo de enunciado específico que buscaremos chamar a partir desta tese de gênero discursivo plano de cultura, por conta do crescimento em sua produtividade neste período e por sua diferenciada construção composicional. Trataremos do gênero discursivo plano de cultura e de suas especificidades na parte final desta tese.

Para afirmar que o Plano de cultura é um gênero discursivo da esfera político-cultural brasileira partimos da constatação de que os enunciados dos planos de cultura apresentam, conforme o manual oferecido pelo MinC para a escrita dos enunciados, forma composicional relativamente pré-estabelecida pelos manuais do SNC, ao preverem itens desses enunciados: princípios, diretrizes, estratégias, objetivos, metas e ações. Em termos de conteúdos, é orientado pelo MinC que o Sistema deve prover a descentralização e a diversidade cultural. Sua produtividade enquanto gênero discursivo deve ser levada em conta, pois a vigência de cada plano é decenal. Mais de 377 planos foram escritos e aprovados ${ }^{61}$ até 2015 e outros deverão ser escritos e aprovados ao longo do decênio até o final de 2020. A intenção é que até 2020 mais 3300 municípios tenham iniciado o processo de adesão ao SNC. Além disso, cada um dos planos deverá passar por revisões a cada cinco anos e serem reescritos no final de cada decênio a partir de novos diagnósticos, demandas territoriais e setoriais e encontros entre

\footnotetext{
${ }^{61}$ O número de 377 planos de cultura escritos e instituídos localmente é uma estimativa oficial do Ministério da Cultura feita com base em dados do IBGE de 2015. A pesquisa de 2015 no site do PNC aponta que: $30 \%$ (8) dos estados e 7\% (369) dos municípios possuem planos de cultura regulamentados; 100\% (27) dos estados e 39\% (2.155) dos municípios possuem conselhos de cultura; e 96\% (26) dos estados e 19\% (1.064) dos municípios possuem fundos exclusivos de cultura. No período final de escrita desta tese em 2018, não conseguimos informações oficiais sobre o status atual da quantidade de planos de cultura regulamentados. Entretanto podemos afirmar que em três anos este número deve ser maior pois no final do ano de 2017, o MinC informou que 2.542 municípios já haviam assinado o Acordo de Cooperação Federativa.
} 
gestores e sociedade civil. Estes processos de escrita, revisão e reescrita a cada cinco e dez anos, com uma construção composicional e conteúdos relativamente pré-estabelecidos, podem fornecer ao plano de cultura o caráter de gênero discursivo.

Os sistemas de cultura dos entes federados apresentam um modelo de lei, e os autores responsáveis deverão ser, na maior parte dos casos, deputados estaduais e vereadores que inscreverão as leis destes sistemas em seus respectivos órgãos legislativos. Em alguns casos, o texto base do objeto da lei de sistema de cultura poderá partir de iniciativa popular ou mesmo do órgão de cultura local. Ainda que aparentemente o formato destes enunciados seja similar a qualquer lei, com capítulos, artigos e parágrafos, para a escrita dos sistemas nos entes federados, o MinC estabeleceu um texto modelo com características específicas que poderá ser utilizado e adaptado à realidade de cada local.

Ainda que o MinC sugira modelos de lei para o Sistema de Cultura, é necessário destacar as dificuldades das diversas etapas do processo de implantação. Uma delas é a criação de ferramentas de pesquisa de mapeamento, diagnóstico e demanda de acordo com características regionais, com vistas a orientar para a criação dos planos, fundos e conselhos de cultura.

Além da escrita de cada um dos enunciados, a escrita de planos e sistemas dos entes federados deverá convergir com a proposta do todo, isto é, com a arquitetônica do Sistema Nacional de Cultura que busca um olhar ampliado com viés antropológico, diversificado e descentralizador de política cultural e que priorize o direito à cultura para todos. Os enunciados produzidos em cada cidade e estado, tanto de planos quanto de sistemas, deverão estar em relação dialógica de concordância ideológica com sistemas e planos de cultura estaduais, com o Plano Nacional de Cultura, bem como com a aplicação concreta de suas metas e ações previstas, e principalmente com o Sistema Nacional de Cultura.

O sucesso desta nova Política Nacional de Cultura dependerá de diversos fatores: do diálogo entre os enunciados produzidos, da satisfatória realização de ações propostas em cada enunciado nos prazos previstos, do cumprimento de metas, da responsabilidade dos envolvidos, do diálogo entre as diversas esferas ideológicas relacionadas no processo e seus respectivos modos de produção e funcionamento. Todos os elementos da arquitetônica do sistema deverão estar em sintonia para que o SNC possa apresentar resultados satisfatórios na prática em trazerem mudanças efetivas na esfera político-cultural. A necessidade do diálogo satisfatório de todas as partes envolvidas demonstra a dificuldade do sucesso da proposta já em seu início. Na esfera política, o consenso é sempre um desafio. Principalmente em 
períodos de disputa mais acirrada.

Nossa pesquisa busca observar prioritariamente como tem acontecido a construção do SNC na esfera político-cultural, a partir do que está previsto nos enunciados relativos ao processo em nível federal e como este foi sendo desenvolvido pelos agentes responsáveis por ele.

O Sistema ainda não reflete e refrata o todo da esfera político-cultural brasileira, que apresenta muitas diferenças e instabilidades de gestão, assim como muitas carências de informação em diversos territórios do país. Entretanto, os processos de implantação do SNC, com seu caráter descentralizador, buscam avançar no mapa e atingir territórios que nunca tiveram planejamentos para suas políticas culturais locais. Assim, é nítido que o SNC ainda é um sistema piloto, em implantação, e que aos poucos avança pelo território nacional. Se o SNC sobreviver às rupturas político-ideológicas futuras, poderá começar a ser efetivado com maior sucesso após seu primeiro decênio, quando um maior número de municípios estiverem organizados e com seus sistemas implantados.

Por conta da complexidade observada na escrita dos Planos de cultura, tomamos a arquitetônica como um dos pontos centrais de nossa reflexão, já que os enunciados criados nos entes federados, por seu caráter federalista e de democracia participativa, agem como força centrífuga do sistema e da nova proposta de política cultural em nível federal ao terem garantido a autonomia local e a descentralização do poder de decisão, com a inserção das vozes sociais. A arquitetônica do SNC se institui principalmente de baixo para cima construindo a base do sistema a partir dos municípios e dos agentes locais. Isso fica evidenciado na ordem da realização das conferências que se iniciam pelos munícípios. Ainda que a temática das discussões seja pautada pelo Ministério da Cultura, são as conferências municipais que apresentam as vozes e as vontades dos agentes da esfera, nem sempre em consenso. A arquitetônica do SNC é uma construção que mescla as vozes do poder público e da sociedade civil produtora de cultura, nem sempre de forma equilibrada.

Nossa pesquisa parte da constatação da necessidade de análise dos enunciados criados a partir do ano 2000, para compreender essa arquitetônica. O SNC e marcos legais relacionados, bem como os enunciados auxiliares e os entes federados, conforme veremos a seguir ao tratar do corpus poderão trazer pistas sobre nossa pergunta de tese. Esta análise visa não apenas responder nossa pergunta de pesquisa, mas também trazer alternativas por meio de análises discursivas, com o propósito de contribuir dialogicamente nos processos de implantação deste novo modelo de política cultural. Uma abordagem científica do assunto 
poderá auxiliar na construção de novas metodologias de produção, análise e entendimento de enunciados da esfera político-cultural, principalmente no que tange aos planos de cultura. Esta tese poderá ser utilizada por estudiosos de áreas diversas, auxiliando a compor a organização discursiva desta esfera ideológica tão peculiar como a político-cultural.

Entendemos que o SNC busca recriar a arquitetônica da esfera político-cultural brasileira, visando a uma nova forma de distribuição de verbas e a descentralização do poder de decisão das políticas, fortalecendo assim as políticas públicas de cultura de caráter mais diverso. Se atentarmos à fase anterior onde apenas as leis de incentivo à cultura atuavam efetivamente como o principal mecanismo de financiamento cultural no país, com concentração de recursos no Rio e São Paulo e o poder de decisão da distribuição das verbas relegado ao mercado e aos patrocinadores, podemos perceber que, a partir da proposta de implantação do SNC, a esfera político-cultural passa a buscar um novo modelo de estruturação. O Sistema é proposto com a intenção de reverter ideologicamente a distribuição de recursos e poderes de decisão e os modos de produção na esfera.

No entanto, é importante ressaltar que não basta termos um sistema implantado em todo país, se continuarmos tendo a maior parte das verbas de cultura sendo distribuídas via Lei Rouanet que até o momento detém o controle fiscal das verbas de cultura, pois regulamenta o Fundo Nacional de Cultura (FNC). A lógica da esfera só terá uma alteração definitiva em seu paradigma, com uma nova regulamentação do Fundo Nacional de Cultura, como por exemplo foi previsto na proposta de projeto de lei Procultura ${ }^{62}$. O FNC é a fonte financeira que deverá alimentar o sistema. Nos últimos anos, as fontes de recursos do Fundo foram insuficientes para que tivesse sido alcançado o volume necessário ao sistema. A escassez de recursos principalmente após 2010 colaborou para que a implantação do sistema não avançasse conforme planejado. Sem um fundo fortalecido, o sistema em sua forma geral ainda é uma estrutura de planejamento sem possibilidade de distribuição de recursos federais aos entes federados. Sem o fortalecimento do FNC, os entes federados receberão poucas verbas do governo federal, e terão que criar mecanismos locais para gerarem fontes para seus próprios fundos, dificultando o processo sistemático e a prática efetiva. Contudo, ainda que o

\footnotetext{
${ }^{62}$ O PL 6722/2010 do Procultura tramita no Congresso Nacional desde 2010 como texto substitutivo ao PL 1139/2008 escrito pelo deputado federal Pedro Eugênio. Foi aprovado na Câmara Federal em 2014 e entrou em discussão no Senado Federal como PLC 93/2014 e com relatoria do senador maranhense Roberto Rocha (PSB MA). Em dezembro de 2018, a matéria foi arquivada sem aprovação por conta do final da legislatura. Em março de 2019, o senador petista Humberto Costa pediu o desarquivamento do PL para a retomada da tramitação a partir da Comissão de Cultura do Senado. A proposta prevê, entre outros mecanismos, o repasse de recursos via fundos territoriais, a equiparação de recursos entre o montante destinado aos patrocínios via mecenato e as verbas destinadas aos sistemas de cultura.
} 
FNC não tenha força para distribuir verbas de forma democrática, a ideia do sistema já terá mexido fortemente no modo dos agentes culturais pensarem as políticas culturais a partir dos processos de participação social e de cidadania.

Essa estrutura pensada em compartilhamento de verbas e um novo modelo de gestão pública aparece inicialmente nos enunciados do $\mathrm{PNC}$, depois nos enunciados do SNC, entre outros documentos relacionados como manuais criando assim uma nova proposta de arquitetônica para a esfera. Estes enunciados projetam essa nova arquitetônica que a Política Nacional de Cultura com olhar ampliado de cultura visa estabelecer para a esfera políticocultural brasileira. Contudo, a dependência do Sistema ao FNC, isto é, ao montante de verbas que o alimentarão, é ainda uma barreira prática, que pode comprometer sua implantação e sua existência concreta enquanto sistema federativo de cultura.

\section{2 - Delimitação do corpus de análise}

Nosso corpus principal será composto de enunciados concretos diretamente relacionados com a estrutura do Sistema Nacional de Cultura, conforme indicado nos documentos oficiais, e com nossa pergunta de tese: de que forma o Sistema Nacional de Cultura contribui para a constituição de uma nova arquitetônica da esfera político-cultural brasileira no início do século XXI?

Analisaremos como isso está refletido e refratado nos enunciados do Sistema. A fim de complementar a reflexão e a análise, sugerimos também um corpus auxiliar com documentos relevantes à construção do Sistema e que poderá fornecer informações contextuais, numéricas, comparativas e ideológicas em momentos essenciais desta tese.

$\mathrm{Na}$ delimitação de nosso corpus, buscamos principalmente aqueles enunciados que poderão evidenciar a nova arquitetônica da esfera político-cultural proposta pelo sistema e são eles:

a) Corpus principal:

- Emendas Constitucionais e Propostas de Emendas Constitucionais: EC 48/2005 (art. 215) e EC 71/2012 (art. 216 A da Constituição Federal), relativos às PECs 306/2000 e 416/2005 (34/2012) que tratam do PNC e do SNC respectivamente, bem como suas tramitações legislativas e justificativas parlamentares; 
- Decreto presidencial que cria o Sistema Federal de Cultura e organiza o Conselho Nacional de Política Cultural (Decreto 5.520/2005) e seus complementares de 2009 e 2015 (decretos e tramitação);

- Lei regulamentar do Plano Nacional de Cultura (lei federal 12.243/2010) e anexos. (Lei e tramitação enquanto PL) e Metas do PNC;

- Planos de Cultura do estado ${ }^{63}$ e da cidade de São Paulo e sua respectiva legislação.

b) Corpus auxiliar:

- Programa de cultura da "Coligação Lula Presidente" para a eleição de 2002 intitulado: A Imaginação a serviço do Brasil;

- Discurso de Posse do Ministro Gilberto Gil no MinC (janeiro / 2003);

- Cartilha Como fazer um Plano de Cultura (novembro/ 2013);

- Guia de orientação para os estados (novembro/ 2011) e Guia para orientação dos municípios (dezembro / 2012);

- Manual Estruturação, Institucionalização e Implementação do SNC (Dezembro 2011);

- Documentos da I, II e III Conferência Nacional de Cultura (textos base, caderno de propostas e resultados) (2005, 2010 e 2013);

- Publicações Plano Nacional de Cultura - Diretrizes Gerais (edições 2007 e 2008);

- Publicação Porque aprovar o Plano Nacional de Cultura (Abril / 2009);

- Planos de Cultura de diversos estados e municípios disponíveis no site do SNC.

- Materiais do MinC / UFBA para a formação de gestores orientando a escrita de Planos de Cultura.

Estão previstos no corpus principal os enunciados oficiais relacionados diretamente com o objeto de tese, o Sistema Nacional de Cultura, enunciados de ordem legislativa e estruturante do sistema e suas respectivas tramitações no Congresso. Entram no corpus auxiliar os demais enunciados que podem apoiar a análise com vistas a responder de maneira mais satisfatória nossa pergunta de tese. Elencamos principalmente aqueles que trazem orientações e informações históricas e ideológicas essenciais para a construção da arquitetônica ao evidenciarem as autorias, as interações, as axiologias e os processos de construção do Sistema.

\footnotetext{
${ }^{63}$ Até o final da escrita desta tese o Plano Estadual de Cultura de São Paulo ainda não havia sido aprovado e o Plano Municipal de Cultura estava aprovado desde dezembro de 2016 como decreto municipal.
} 
Para a escolha dos enunciados do nosso corpus principal utilizamos os seguintes critérios:

a) Ser um dos marcos legais reguladores do Sistema;

b) Ser estruturante na implantação do Sistema;

c) Estar previsto na descrição das partes do Sistema.

Para a escolha dos enunciados do nosso corpus auxiliar utilizamos os seguintes critérios:

a) Estar previsto na descrição das partes do Sistema;

b) Ter relevante relação histórica com a construção do SNC e da esfera no período;

c) Influenciar na implantação do SNC e PNC enquanto manual, mecanismo de adesão, orientação para sua aprovação e construção ou trazer elementos sobre a interatividade e a participação social;

d) No que tange à escolha de enunciados do sistema nos entes federados: a escolha do estado / município a analisar ocorreu pela localidade desta pesquisa (enunciados do estado e município de São Paulo), porém observaremos também outros planos de cultura de diferentes estados e municípios do país a fim de obtermos melhores resultados;

e) Documentos que evidenciem que o Sistema é um todo dividido em partes estruturantes, composto principalmente pelo formato CPF (Conselhos, Planos e Fundos) mas que devem dialogar arquitetonicamente.

Dos documentos do corpus principal evidenciamos inicialmente as emendas constitucionais relativas aos artigos 215 (EC 48/2005) e 216 A (EC 71/2012) da Constituição Federal, aprovados por meio das PECs 306/2000 e 416/2005 que tratam do SNC e do PNC e suas respectivas tramitações no Congresso Nacional. Esses documentos são partes legais e estruturantes do sistema, portanto atuam como balizadores da arquitetônica. Principalmente as emendas constitucionais, em suas poucas linhas, descrevem com forte viés político-ideológico no que deve consistir essa nova proposta para a esfera nas partes do Sistema e o conteúdo do Plano Nacional de Cultura. Como parte do texto da Constituição Federal, as emendas do PNC e do SNC são a parte mais importante da arquitetônica do Sistema e norteadoras da esfera no período de vigência destes documentos.

Nos documentos do corpus principal, achamos relevante incluir o decreto 5.520/2005, bem como suas atualizações de 2009 e 2015, que têm como objeto a instituição do Sistema Federal de Cultura (SFC) e a reorganização do Conselho Nacional de Política Cultural (CNPC). Este decreto serviu como marco pré-regulatório do Sistema, pois, para sua efetiva 
regulamentação, seria necessário aguardar a aprovação da PEC do SNC, que foi viabilizada pela ementa constitucional N. 71 apenas em 2012 e sua lei de regulamentação. O decreto normatizou, desde 2005, duas necessidades emergenciais para a implantação do Sistema: reformular o Conselho Federal de Cultura ${ }^{64}$ e iniciar os processos de implantação de sistemas territoriais e setoriais. Este decreto aborda principalmente questões de ordem formal e operacional, e como deve ser desenvolvida a participação social na construção do sistema. Questões relacionadas à forma arquitetônica do Sistema também estão previstas, ao descrever como deverá ser regida, pelo menos até que seja aprovada uma nova lei de regulação do SNC, a forma do conteúdo relacionada à construção do Sistema.

A lei do Plano Nacional de Cultura (lei 12.243/2010) regulamenta a emenda constitucional do PNC e traz detalhes sobre sua implantação e poder como marco regulatório. Seus anexos e diretrizes posteriores (principalmente as metas 1, 2 e 46 do PNC de 2010 que tratam do SNC) delineiam quais rumos e ações o Sistema deve cumprir em seu primeiro decênio. Assim, a lei não trata apenas do Plano, mas também do Sistema. As metas constantes no anexo desta lei foram revisadas e resumidas em 53 metas para o decênio até 2020 e tratam do conteúdo prático da estrutura do Sistema. Nas metas estão estabelecidos os planos para o desenvolvimento da proposta do Sistema para determinado período.

Os Sistemas Estadual e Municipal de Cultura do estado e município de São Paulo e seus Planos de Cultura, ambos em processo de implantação e aprovação nos respectivos legislativos, foram escolhidos por conta da localidade desta pesquisa. A análise destes processos e documentos poderá auxiliar na compreensão da implantação do Sistema nos entes federados, não apenas na observação de seus enunciados como parte do Sistema, mas também dos desafios, dos processos de escrita, consulta pública, ementas, debates legislativos e embates político-ideológicos regionais.

Os Sistemas e Planos territoriais, entendidos como partes estruturantes do Sistema, podem demonstrar a responsividade entre os entes federados e a descentralização e o diálogo previsto no Sistema de forma ainda mais concreta, a saber: as metas estabelecidas no Plano Nacional de Cultura apresentam caráter mais amplo e norteador aos territórios e setoriais; já as metas estabelecidas nos estados e municípios apresentam propostas de ações mais concretas nas pontas dos sistemas e dialogam diretamente com as metas do plano federal. As metas do PNC dependem dos resultados das metas dos estados e municípios para serem

\footnotetext{
${ }^{64}$ Como veremos detalhadamente no próximo capítulo, o Conselho Federal de Cultura foi uma criação do período da ditadura. Sua reformulação como CNPC neste decreto reverte a atuação do conselho para um caráter mais participativo e democrático.
} 
efetivamente cumpridas em termos concretos, tanto quantitativos, quanto qualitativos.

Nos documentos do corpus auxiliar desta pesquisa, buscamos observar aqueles que poderiam auxiliar na construção político-ideológica e histórica do Sistema.

O programa de cultura de Luiz Inácio Lula da Silva para a eleição 2002 A imaginação à serviço do Brasil e o discurso de posse do Ministro Gilberto Gil em 2003 foram escolhidos como itens deste corpus auxiliar, pois atuaram como balizadores em termos políticos, ideológicos e históricos da proposta do Sistema. Passados mais de quinze anos de suas escritas muitas coisas aconteceram, não apenas na conjuntura, mas também em termos de aplicação de políticas culturais. Todavia, a análise destes dois documentos servirá como lastro de pensamento político-ideológico do momento inicial de construção desta nova proposta arquitetônica, auxiliando na compreensão de seus centros de valores com vistas à nova proposta de esfera político-cultural. Esses documentos, enquanto enunciados da esfera executiva, apresentam visões de mundo de importantes agentes do processo e de atuação política no comando do Sistema. Representam as vozes do Estado, e do poder executivo, tanto da ordem do pensamento, quanto do fazer e da agenda política em proposição. O programa da eleição de Luiz Inácio Lula da Silva em 2002 foi o primeiro documento a apresentar oficialmente o que deveria ser o Sistema Nacional de Cultura ${ }^{65}$.

O manual Estruturação, Institucionalização e Implementação do SNC lançado no final de 2011 busca orientar a implantação do Sistema visando à compreensão do todo em âmbito federal. Suas premissas articulam o SNC enquanto um todo estruturante e prevê como serão articuladas suas partes, como estas devem dialogar, como acontecerá a participação social e como devem ser os processos de implantação em cada ente federado e em cada setorial.

As publicações Guia de orientação para os estados e Guia de orientação para os municípios serão fundamentais em nossa análise linguístico-discursiva, pois, além de estabelecerem regras de implantação do sistema e construção de enunciados nos entes da federação, também sugerem o modelo do projeto de lei do Sistema para estados e municípios. De acordo com os guias, esse modelo deve servir de modelo textual e auxiliar parlamentares e órgãos de cultura para a escrita das leis de implantação dos Sistemas Estaduais e municipais.

Outro enunciado relevante nesta análise é a cartilha Como fazer um plano de cultura que visa auxiliar gestores e participantes dos conselhos e comissões de cultura de todo país,

\footnotetext{
65 A menção ao Sistema não estava indicada na ementa parlamentar que deu origem ao Plano Nacional de Cultura e que data enquanto PEC do ano 2000. Por isso consideramos que foi no programa de Lula para a eleição de 2002 que o SNC foi formalmente e oficialmente detalhado pela primeira vez ainda que, como veremos adiante, o SNC ainda fosse chamado neste documento de SNPC (Sistema Nacional de Políticas Culturais).
} 
bem como a todos que participam das consultas públicas, a escrever seus planos de cultura estaduais e municipais. Numa observação inicial, percebemos que o documento pouco trata das especificidades destes enunciados em termos de produção textual. O foco da publicação é na função social do Sistema e dos planos na gestão pública de cultura. Uma atenta análise desta cartilha poderá evidenciar os pontos positivos e negativos no auxílio da criação dos planos enquanto enunciados concretos, bem como a responsividade ética para o desenvolvimento do SNC como um todo.

Os documentos referentes à I, II e III Conferência Nacional de Cultura (CNC), tanto cadernos de propostas como textos base, quanto o enunciado que remete aos resultados das plenárias públicas, serão fatores relevantes para a observação da participação social em nível nacional. Devem ser entendidos não apenas como o ponto de vista da sociedade civil em diálogo com o Estado, mas como processo de interação da esfera e construção da arquitetônica. A I conferência traz um primeiro aceno do Ministério ao que se pretendia enquanto o local da participação social na construção do SNC. Todavia, é nos resultados da terceira conferência que poderemos escutar melhor as vozes da sociedade civil e a responsividade ao que se estava propondo. Ainda que as duas conferências anteriores tenham importância na construção inicial do Sistema, foi na terceira Conferência que o SNC surge como ponto principal da discussão e nas respostas dos participantes da sociedade civil. Na III CNC, o sistema é ainda mais transversal a todos os demais temas abordados. Foi a partir da II Conferência que o processo de implantação do SNC foi de fato ativado na esfera, pois amplificou a informação sobre o Sistema e gerou a aceleração da adesão de um grande número de municípios nos anos de 2012 e 2013. No momento da terceira conferência, o sistema já era conhecido de boa parte dos participantes e estava inserido como prioridade nos debates da esfera pública da cultura.

As duas publicações Plano Nacional de Cultura - Diretrizes Gerais (edição 1 em 2007 e edição 2 em 2008) demonstram quais eram a diretrizes para a construção do PNC, bem como de seu projeto de lei regulamentar que já estava inscrito no Congresso desde 2005. Logo após a publicação da primeira edição, o MinC promoveu debates nos 27 estados brasileiros que resultaram em centenas de novas sugestões às diretrizes e a inclusão de 80 novos itens na publicação de 2008 .

A publicação Porque aprovar o Plano Nacional de Cultura de abril de 2009 foi desenvolvida para acelerar o processo de aprovação da lei regulamentar do PNC no Congresso Nacional. Os pontos mais interessantes da publicação são a construção do histórico 
do PNC e SNC até aquele momento e os resultados dos 27 seminários para discussão do PNC que ocorreram em todos estados brasileiros em 2008.

Outros importantes materiais para nossa observação são os produzidos pela Universidade Federal da Bahia (UFBA) em conjunto com o MinC a fim de orientar gestores de cultura para a criação de planos de cultura e a implantação de sistemas municipais. Os materiais disponibilizados tanto impressos quanto as plataformas via internet, tanto moodle quanto no youtube ou mesmo cartilhas digitais, podem nos auxiliar a compreender a construção territorial da arquitetônica e o próprio gênero plano de cultura.

Para finalizar nossa análise, utilizaremos os planos de cultura territoriais de pelo menos quatro estados e 35 municípios. Estes enunciados nos auxiliarão nas reflexões do último capítulo da tese acerca das especificidades do gênero discursivo plano de cultura.

Os dados coletados durante a pesquisa poderão servir como base para nossa reflexão a respeito da relação sociodialógica desses enunciados com a esfera político-cultural, compondo assim a nova arquitetônica proposta pelo sistema. Deverão apresentar além da reflexão discursiva entre autores e enunciados, reflexões sobre o papel do SNC enquanto instrumento descentralizador e facilitador de distribuição de verbas públicas para a cultura produzida no país visando a ampliação do acesso ou mesmo seus problemas para atingir esses pressupostos. Por este motivo, além dos enunciados de nosso corpus, buscaremos também outros dados sobre o financiamento da cultura, como orçamentos anuais, Planos plurianuais (PPAs), dados do IBGE etc.

Analisaremos o corpus principal e o corpus auxiliar desta tese observando-os como enunciados concretos produzidos em situações sócio-históricas determinadas, com autorias diversas e condicionados pela esfera político-cultural.

\section{3 - Metodologia de análise e tese}

Para atingir os resultados buscados nesta tese iniciamos nossa proposta metodológica com a pergunta de tese: de que forma o Sistema Nacional de Cultura contribui para a constituição de uma nova arquitetônica da esfera político-cultural brasileira no início do século XXI?

Como vimos, o SNC busca viabilizar uma nova forma de organizar e articular as políticas culturais no país por meio de um olhar de cultura ampliado, e que os enunciados que instituem este sistema estão relacionados com outros enunciados concretos criados no mesmo período do início do século XXI. 
Nossa hipótese compreende que o olhar antropológico para a cultura é o ponto central para o início da alteração na arquitetônica da esfera político-cultural brasileira por meio dos enunciados que compõem o Sistema Nacional de Cultura. Este olhar para a cultura deve ser compreendido através de um enfoque ampliado, em toda sua diversidade e situada na centralidade dos setores da gestão pública. Da mesma maneira nos remete a um novo modelo proposto de financiamento à cultura, em que os recursos devem ser distribuídos de maneira descentralizada. Essa proposta de mudança incide não apenas na superestrutura mas deverá afetar também a infraestrutura e justamente por isso o desafio é ainda maior.

Gilberto Gil não participou diretamente da idealização do SNC, mas é em sua gestão no MinC que esse Sistema começa a ser articulado de modo prático, em forma de ato responsável, evidenciando o conteúdo dos enunciados concretos em questão no mundo da vida. Para o Ministro Gilberto Gil, assim como para o SNC, a diversidade e centralidade da cultura deveriam ser as forças motrizes para a mudança de paradigma e isso está evidenciado em seu discurso de posse no MinC. Todavia, Gil não foi o único personagem desta construção. Buscaremos ao longo da pesquisa encontrar outros autores criadores desta arquitetônica e também compreender as forças centrifugas e centrípetas que incidiram nos processos ao longo dos anos.

A reflexão teórica realizada no primeiro capítulo desta tese sobre a arquitetônica nos mostrou que, no desenvolvimento desse conceito, tanto nos textos bakhtinianos, quanto do Círculo, encontramos três propostas de análise inter-relacionadas: a arquitetônica do mundo real do ato ético, o método sociológico dos anos 1920 e a metalinguística formulada nos anos 1960.

Nosso percurso de análise tem sua origem na reflexão filosófica a respeito da arquitetônica do mundo real do ato ético que orienta a seguinte ordem metodologicamente fundamentada para o estudo dos enunciados do Sistema Nacional de Cultura:

a) Descrição e análise do horizonte social que contribui à construção das políticas culturais brasileiras contemporâneas;

b) Identificação dos autores e agentes enquanto participantes responsáveis da criação dos enunciados do Sistema, e como reveladores dos procedimentos éticos e políticos adotados, e sua interação na implantação do sistema no tempo-espaço;

c) Análise da materialidade linguístico-discursiva dos enunciados do corpus, tomados como enunciados produzidos em situações sócio-históricas determinadas e condicionados pela esfera político-cultural; 
d) Reflexão acerca da arquitetônica da esfera político-cultural no todo dos enunciados do SNC e do gênero plano de cultura.

A tese foi dividida em três partes distintas e em seis capítulos que se completam arquitetonicamente. A resposta à nossa pergunta de pesquisa surgirá aos poucos, ao longo das reflexões, num processo construtivo, organizando sentidos, refletindo e refratando assim a arquitetônica da esfera político-cultural por meio dos enunciados e dos processos analisados.

O primeiro passo metodológico compreende, como Bakhtin evidenciou em Para uma filosofia do ato responsável, a "análise dos momentos fundamentais da arquitetônica do mundo real” (Bajtin, 1997[1920-24], p. 61, tradução nossa), ou seja, a recuperação dos processos de construção da esfera político-cultural a partir dos atos concretos de formulação dos marcos legais ao longo da história e das posições políticas dos autores envolvidos. Desenvolveremos esse passo a partir do capítulo terceiro, relativo ao horizonte social, quando nos aprofundaremos na conjuntura dos anos 2000 a 2017, descrevendo momentos que colaboraram para a produção de cada um dos enunciados envolvidos na arquitetônica da esfera no período e compondo uma base para a compreensão da arquitetura do sistema. Primeiramente abordaremos questões pertinentes à nossa reflexão presentes no contexto da esfera no século XX no Brasil, e, em seguida, partiremos para a observação das políticas internacionais de cultura, principalmente da UNESCO e sua influência no Brasil no período atual. Seguimos então para a análise da esfera político-cultural no Brasil no contexto sóciohistórico do início do século XXI e com a posse do Ministro Gilberto Gil no MinC. Para isso, descreveremos e analisaremos as políticas culturais implantadas no período até o ano de 2018 (ano em que se completam oito anos da vigência do PNC e seis anos do SNC). No último tópico do capítulo, realizaremos uma exposição da implantação dos sistemas de cultura no estado e no município de São Paulo.

O segundo passo metodológico da análise, baseado na proposta de Bakhtin presente em Para uma filosofia do ato responsável, tratará da "análise da atividade estética como ação" (Bajtin, 1997[1920-24], p. 61) não a partir do interior do seu produto, mas do ponto de vista do autor enquanto participante responsável e da ética da criação responsável. Buscaremos traçar os autores dos enunciados, suas relações discursivas, políticas, éticas, estéticas, em cada um dos eventos, em cada um dos atos de cada um dos enunciados do corpus principal.

Este segundo passo metodológico será dividido em quatro tópicos que comporão o capítulo 4 desta tese. Iniciaremos a reflexão com um tópico sobre o conceito de autoria 
pensado pelos pensadores russo do Círculo. Em seguida, falaremos sobre "A autoria no Sistema Nacional de Cultura" a fim de observarmos quem foram os participantes diretos da criação dos enunciados legislativos do sistema, não apenas autores individuais, mas também grupos constituídos, valores axiológicos compartilhados ou não, relações e momentos emotivo-volitivos e as diversas exotopias. Esta segunda etapa metodológica, que analisa a "atividade estética como ação", nos traz de volta às reflexões do conjunto de textos iniciais de Bakhtin nos anos 1920, em que autoria, ato responsável, valores éticos e as relações entre o eu e o outro, são constitutivos da construção da arquitetônica na filosofia da cultura e da linguagem. Esta relação entre autores está na base da construção do Sistema, seja de autores criadores, nos momentos originais de cada ato, de cada enunciado, seja em relação aos interlocutores nos processos, seja os leitores e futuros autores de enunciados do sistema, que deverão se orientar pelos enunciados originais nos tempos seguintes. Os enunciados relacionados ao SNC, cada qual em seu tempo-espaço, criam um cronotopo específico, principalmente nos enunciados dos planos de cultura. Mais do que os sistemas de cultura, são os planos que agem como enunciado concreto com força centrífuga social dessa arquitetônica ao dizerem o que deve ser feito, a partir das demandas da população às instâncias do poder público. Aqui observaremos não apenas os enunciados em si, mas também os processos de criação e escrita, inseridos nas reflexões e tramitações dos marcos legais no Congresso Nacional.

Continuando as reflexões do segundo passo metodológico, teremos um tópico chamado "Participação social e Estado: a construção interativa do Sistema" para a reflexão acerca das interações realizadas para a produção dos enunciados e sobre as tensões ocorridas nesses momentos fundamentais da arquitetônica. A participação social prevista na estrutura do sistema para auxiliar na criação dos enunciados (seminários, consultas públicas dos marcos legais, conferências de cultura, interações on-line pelos sites dos órgãos oficiais de cultura, audiências públicas etc) é sem dúvida um fator que deverá ser levado em conta, pois, além de ser previsto como ferramenta descentralizadora de construção do sistema, é o instrumento dialógico que o fundamenta e o legitima no âmbito social de forma ética. A participação social é interativa e é a principal força centrífuga desta nova arquitetônica.

As relações entre Estado e sociedade civil estão em cheque nos sistemas e planos de cultura, pois estes atuam como instrumentos oficiais que rompem com a hegemonia estatal da democracia representativa e propõem um novo modo de deliberação na esfera a partir de conselhos e consultas públicas, instituindo assim uma possibilidade de democracia 
participativa $^{66}$ e direta ${ }^{67}$. Os planos de cultura produzidos por diversas mãos da sociedade civil podem ajudar a elevar a cultura popular ao patamar de cultura oficial, legitimada pelo Estado, ao trazerem a força da dimensão simbólica do ponto de vista da população para enunciados instituídos nas esferas estatal e legislativa. Ainda que a cultura hegemônica seja uma construção muito mais complexa e não dependa essencialmente de documentos oficiais para estar estabelecida numa determinada sociedade, essa possibilidade de oficialização da cultura pelo olhar mais popular poderá gerar uma futura alteração de paradigma no âmbito sociocultural. Neste ponto da reflexão será essencial perguntarmos: Quem são os setores, produtores e grupos de cultura participantes dos processos sociais interativos e elencados nos documentos relativos ao sistema e como estes dialogam no sistema? Quais são os poderes e os valores axiológicos em disputa? Quais foram os processos de participação social que auxiliaram na construção do Sistema e qual o peso real destes ao longo de sua implantação?

As tensões entre o que está previsto nos planos escritos por pessoas do setor cultural e o que de fato é realizado em forma de ato concreto no mundo da vida pelos agentes do poder executivo demonstram uma importante parte dessa arquitetônica, pois revelam as tensões entre autores e leitores, população e gestores, sociedade civil e Estado.

Os sistemas e planos de cultura devem dialogar com as realidades dos envolvidos (a quem se governa ou a quem se destina o sistema) para que sejam de fato valorados por esses atos. Para isso propomos a seguinte questão: Quem são os grupos a que se destina o SNC e o PNC?

Para finalizar o segundo passo metodológico, o quinto capítulo da tese será dedicado à “ética da política" (BAKHTIN, 2010d, p. 115), pois será necessário levar em conta a arquitetônica também como originalmente pensada por Aristóteles, percebendo as relações entre ética e política, em que o bem da comunidade deve estar acima das necessidades particulares dos envolvidos nos processos. O capítulo intitulado "A responsabilidade ética e o cronotopo: atos no tempo-espaço do Sistema" buscará apresentar a análise filosófica da ética na política cultural proposta pelo Sistema analisando os atos éticos nos processos políticos, pensados no espaço e no tempo.

Neste momento da tese, será essencial compreender os centros de valores em disputa

\footnotetext{
66 Na democracia participativa, ao contrário da democracia representativa, o poder de criação de leis e marcos regulatórios é dividido com os conselhos populares, eleitos e compostos por membros da sociedade civil, na maioria das vezes em regime voluntário.

${ }^{67} \mathrm{Na}$ democracia direta, a sociedade civil tem o poder de participar diretamente das tomadas de decisões do Estado. O poder de deliberação é ainda maior do que no modelo participativo.
} 
nos enunciados, a responsabilidade ética dos autores e dos atos, em acontecimentos históricos situados, e a projeção destes no tempo-espaço. Os Planos de Cultura criam uma lista de ações a serem executadas num período de dez anos, porém é preciso observar que os autores destes enunciados geralmente não serão os autores das ações futuras previstas nos textos. A responsabilidade das ações futuras é na maioria das vezes do outro (quase sempre desconhecido) em um tempo e espaço futuro determinado, porém desconhecido.

O cronotopo bakhtiniano poderá ser um fator essencial em nossa reflexão já que estamos lidando com enunciados que projetam atos a partir de outros atos para o tempo futuro numa dada conjuntura em que cada qual tem autores e leitores com diferentes exotopias. Bakhtin traz a reflexão sobre a importância de compreendermos que os autores não têm a noção de realidade acabada, pois são parte de um acontecimento e com isso lhes é impossível dar um acabamento no presente. A exotopia é o lugar de onde observo, atuo e de onde dou meu acabamento, e deve levar em conta o tempo e espaço. Se, por um lado, quem escreve os Planos de Cultura não sabe quem os executará ao longo do decênio, por outro, para os futuros leitores e agentes que desenvolverão as ações previstas num determinado Plano de Cultura nem sempre houve a chance de terem sido parte da criação deste Plano. Esses agentes dos Planos no futuro não terão a mesma visão exotópica deste enunciado que tiveram aqueles que estavam presentes em sua escrita num ponto anterior do tempo-espaço. A realidade representada num tempo futuro é ainda mais abstrata, já que o tempo futuro ainda não chegou e tudo o que for dito acerca do futuro é mera suposição. As ações e os cronotopos previstos nos Planos estão sujeitos a toda e qualquer mudança de planos, pois dependem de outras pessoas e das conjunturas.

Nossa metodologia prevê o desenvolvimento de um terceiro passo metodológico que decorrerá da análise da arquitetônica do gênero plano de cultura e da materialidade linguístico-discursiva destes enunciados. Este terceiro passo será desenvolvido a partir do quinto capítulo, mas principalmente ao longo do sexto capítulo da tese sobre o gênero plano de cultura. Neste último capítulo será desenvolvida uma análise da materialidade linguística dos planos federal, estadual e municipal, que trarão as pistas concretas para respondermos finalmente nossa pergunta de tese sobre a nova arquitetônica da esfera proposta no Sistema. Observaremos as especificidades do gênero Plano de Cultura, por meio da análise dos enunciados para assim comprovarmos sua importância como objeto do fazer do sistema e como novo gênero da esfera político-cultural.

Os conceitos presentes no segundo capítulo da obra Marxismo e Filosofia da 
linguagem (2017), relativos ao método sociológico proposto por Volóchinov e as reflexões de Queiroz (2014), serão utilizados para auxiliar na compreensão do funcionamento da esfera político-cultural no século XXI e sua relação com os enunciados. A metalinguística bakhtiniana, bem como as teorias relativas aos gêneros discursivos, serão essenciais para analisarmos a materialidade linguística e as especificidades do gênero plano de cultura no último capítulo da tese.

De Aristóteles trazemos para nossa análise a compreensão do que é ético na política, compreendendo o entendimento de que o bem comum, de todos, é sempre o mais ético e isso deve ser pensando principalmente na criação das leis. De Bakhtin trazemos o ser responsável e responsivo, que age no mundo sem álibi. E de Kant a ideia de que é no mundo dos costumes, da vida, que compreendemos a justiça e a ética operando efetivamente.

A partir da próxima parte da pesquisa, iniciaremos a análise do corpus e dos elementos que, ao longo dos últimos dezenove anos, auxiliaram na construção da nova arquitetônica da esfera político-cultural brasileira. Utilizaremos as reflexões teóricas e metodológicas feitas até aqui para buscar compreender esta complexa política estruturante para a cultura proposta no início do Século XXI. 
Parte 2:

A ARQUITETÔNICA SÓCIO-POLIITICA DA ESFERA POLÍTICO-CULTURAL BRASILEIRA: HORIZONTE SOCIAL E INTERAÇÃO ENTRE SETORES DO PODER PÚBLICO E DA SOCIEDADE CIVIL 


\section{CAPÍTULO 3: A CONSTRUÇÃO DA ESFERA POLÍTICO-CULTURAL BRASILEIRA CONTEMPORÂNEA: HORIZONTE SOCIAL E ORGANIZAÇÃO DA CULTURA}

A compreensão dos princípios norteadores das políticas culturais contemporâneas no Brasil não deve ser considerada por uma construção exclusiva de um grupo de pessoas ou mesmo das intenções de Gilberto Gil e sua equipe no Ministério da Cultura (MinC) no início do século XXI. Ao contrário disso, além dos princípios propostos a partir dos anos 2000, é preciso observar que essas políticas originam-se de uma construção histórica acumulada, que relaciona e nos remete a ideias oriundas de fontes distintas, e também do diálogo entre esferas, tipos de cultura política, legislações anteriores e principalmente da construção da identidade brasileira e sua relação com a cultura e o Estado. Essa construção refletida e refratada na esfera político-cultural brasileira ao longo do tempo teve um novo significado e uma proposta de mudança de paradigma desde a gestão do ministro Gilberto Gil no MinC e responde ao que foi construído (ou não) nos períodos anteriores.

O recorte histórico principal desta pesquisa, desenvolvido principalmente neste capítulo terceiro, partirá de dois tópicos introdutórios sobre os processos da esfera no século XX e que darão base para compor o panorama detalhado do período recente.

Iniciaremos a reflexão com a gestão de cultura na cidade de São Paulo, de Mario de Andrade nos anos 1930 a Marilena Chauí nos anos 1990, buscando observar as influências que estas experiências proporcionaram para as políticas culturais brasileiras do século XXI.

Achamos igualmente pertinente retomar esse percurso histórico a partir das experiências da ONU, UNESCO, dentre outras instituições em nível mundial e observar como estas ditaram os rumos das políticas culturais mundiais e consequentemente do Brasil.

O terceiro tópico do capítulo tratará sobre o ponto central desta tese, a construção do Sistema Nacional de Cultura e a nova proposta de política cultural. O recorte histórico desta etapa se inicia com a instituição da PEC do Plano Nacional de Cultura no Congresso Nacional no ano 2000, nos levará até o ano de 2017, logo após o impedimento da presidenta Dilma Rousseff em maio de 2016, gerando a instabilidade do sistema. Entretanto, a título de documentação histórica, trataremos também de alguns desdobramentos posteriores a esse período, chegando ao início de 2019, com a eleição do Presidente Jair Bolsonaro e o fechamento do Ministério da Cultura.

Finalizaremos o capítulo três com a abordagem da implantação dos sistemas de cultura 
no estado e na cidade de São Paulo para assim perceber como ocorre o desenvolvimento dos sistemas territoriais e observarmos os resultados do SNC de forma mais ampla.

Nosso estudo será desenvolvido por meio da recuperação da história contemporânea da esfera contemplando elementos interessantes à nossa reflexão, pois estes permeiam todos os discursos e fatos que podem colaborar para compreendermos a construção da arquitetônica da esfera político-cultural ao longo do tempo até os dias atuais ${ }^{68}$.

\section{1 - Políticas culturais no século XX: uma breve introdução sobre o Brasil}

Em Queiroz (2014) tratamos da história das políticas culturais no Brasil a partir da chegada da Família Real portuguesa e a impressão do primeiro livro em terras brasileiras no ano de 1811. É também relevante ressaltar a criação do Museu Nacional no ano de 1818 por D. João VI e da Academia Imperial de Belas-Artes, chamada a partir de 1831 de Escola Nacional de Belas Artes pelo principe D. Pedro II. Entretanto, nesta pesquisa, partiremos do recorte histórico da Era Vargas e os programas implementados pelo Ministério da Educação e Saúde (MES) nos anos 1930. Dos programas criados pelo Ministro Gustavo de Capanema e sua equipe, podemos ressaltar a criação do Serviço do Patrimônio Histórico e Artístico Nacional (SPHAN) como um relevante marco nas políticas públicas de cultura, ainda que com caráter patrimonial e institucional. Do mesmo período é importante relatar a criação do primeiro Conselho Nacional de Educação, a realização da primeira Conferência Nacional de Educação, instituída, juntamente com a Conferência de Saúde, pela Lei 378/1937 e principalmente a criação, do primeiro Conselho Nacional de Cultura (CNC) pelo Decreto lei 526 de 1938.

Mesmo que as propostas de Vargas e sua equipe para as políticas culturais em âmbito federal tivessem iniciado um processo de construção de políticas públicas no setor, o advento da gestão de Mário de Andrade como diretor geral do Departamento de Cultura de São Paulo pode ser considerado um dos principais marcos para o início da compreensão da construção dessas políticas no século XX e os reflexos destas atualmente.

Em 1935, a Prefeitura de São Paulo criou, pela primeira vez na história brasileira, um órgão de gestão pública da cultura, no sentido moderno de pensar o papel do Estado neste setor. Coube a Mário de Andrade assumir a função do que seria hoje o "Secretário de Cultura de São Paulo". A política cultural que coordenou teve alcance nacional e tornou-se referência de

\footnotetext{
${ }^{68}$ Um detalhamento mais apurado das políticas culturais brasileiras ao longo do século XX pode ser visto em Queiroz (2014).
} 
serviço público de qualidade. Basta citar duas iniciativas: a criação da primeira rede de bibliotecas públicas do país, que incluía bibliotecas móveis instaladas em micro-ônibus, para ampliar o acesso da população à leitura, e o financiamento de expedições etnográficas aos "sertões" do Brasil, que documentaram as várias expressões das culturas populares e indígenas. (MEIRA; GAZINELLI, 2006, p. 12)

A visão de Mário de Andrade sobre a importância da cultura na construção da identidade nacional, obtida principalmente nas viagens e anotações sobre as expressões das culturas tradicionais e originárias brasileiras, representou uma ruptura com a ideia de pensar a cultura apenas sob influência europeia. A pesquisa viabilizada pela gestão trouxe um caráter especial à cultura popular, que a partir de então mostrou sua importância na construção da identidade nacional, não sendo vista como algo "menor".

Mario de Andrade, quando diretor desse departamento, recebeu muitos ataques e sofreu incompreensões, mas conseguiu estabelecer o mínimo necessário em relação a uma formulação de política pública para a cultura, dando um grande salto qualitativo e colocando a preocupação da Gestão pública municipal em relação às questões culturais na cidade. Mario buscou colocar um outro olhar sobre a cultura popular e suas tradições dando um novo status às manifestações folclóricas antes vistas só por uma via 'exótica' ou como uma cultura 'menor'. (SOUZA, 1997, p. 26)

Mario e sua equipe puderam mapear o início do que seria mais tarde considerado o começo da organização da cultura no país. O projeto visava um salto maior do que um departamento municipal deveria realizar, já que o grupo que circulava por todo o país e apoiava o então governador Armando de Salles Oliveira, buscava a aplicação posterior dessas políticas numa possível gestão em nível federal.

Mario de Andrade participou ativamente de um projeto público da elite paulista, de cunho social-democrata, que via no acesso à cultura um meio eficaz de suplantar o atraso intelectual. O grupo de Paulo Duarte, Sergio Milliet, Rubens Borba de Moraes, do qual Mario de Andrade também fazia parte, reunido em torno do governador Armando de Salles Oliveira visava criar instituições que uma vez este eleito presidente, seriam implantadas no país. São Paulo tornou-se um laboratório de políticas públicas de promoção de bem-estar social pela via da cultura, sem populismo. (CALIL, 2015, p.14)

Os programas construídos por Mario de Andrade e sua equipe orientavam-se pela lógica do acesso à cultura não como processo civilizatório característico do século XIX e sim como meio para um processo construtivo com vistas a "suplantar o atraso intelectual" brasileiro, como acelerador para melhoria da qualidade de vida a partir da fruição da cultura. Instituído a partir do ato N. 861 de maio de 1935, o Departamento de Cultura e Recreação da 
Municipalidade de São Paulo foi o primeiro órgão especificamente voltado para a cultura do país e aconteceu numa cidade em pleno desenvolvimento.

Quatro divisões compunham o Departamento: Expansão Cultural, Educação e Recreio, Documentação Histórica e Social, e Bibliotecas, chefiadas respectivamente por Mario de Andrade (acumulando o posto ao de diretor), Nicanor Miranda, Sérgio Milliet e Eurico de Góes. Este, aposentado no ano seguinte à fundação, foi substituído por Rubens Borba de Moraes. Em julho de 1936 surgiu uma quinta divisão: Turismo e Divertimentos Públicos, sob a responsabilidade de Nino Gallo. (PENTEADO, 2015, p. 19)

Numa São Paulo dos anos 1930, que crescia vertiginosamente graças às indústrias e a exportação do café, a construção de políticas públicas de cultura, com requinte e detalhamento pouco vistos em outros países até então, mostram o quanto Mário e seu grupo estavam na vanguarda ao pensar a cultura como direito do cidadão. O objetivo do Departamento era "estimular e desenvolver todas as iniciativas destinadas a favorecer o movimento educacional, artístico e cultural" ${ }^{\prime 69}$.

A gestão de Mario de Andrade é considerada até hoje como um marco institucional que compreendia que as políticas culturais não precisavam estar inseridas em órgãos destinados a outros setores como a educação, esportes e lazer, mas sim relacionadas a estas áreas. O Departamento de Cultura, ao propor a cultura como um fator importante para a cidadania, demonstra que este foi um dos pontos iniciais de influência para a construção dos preceitos da esfera no início do século seguinte. A ideia de cultura como direito dos cidadãos pode ser percebida ao longo de diversos documentos do período.

Nos anos 1950, mais especificamente nos anos da gestão do então presidente Juscelino Kubstichek, temos a criação do Ministério da Educação e Cultura (MEC) e do Instituto Superior de Estudos Brasileiros.

Nesta mesma década, a esfera das políticas de cultura recebeu um importante reforço com a criação de dois órgãos públicos: o Ministério da Educação e Cultura (MEC) no Brasil e a criação do Ministério de Assuntos Culturais na França ambos em 1953. A criação desses órgãos previa a organização de uma política pública de cultura em nível nacional e como tendência dos governos vigentes do período, esta organização deveria, tanto no Brasil como na França, priorizar o incentivo a uma cultura de identidade nacional e a democratização da cultura. O MEC cria em 1955 o Instituto Superior de Estudos Brasileiros (ISEB) encabeçado por intelectuais ligados ao governo e às esferas acadêmicas. Os ideais do Instituto marcavam fortemente as reflexões sobre cultura e Estado sob o viés desenvolvimentista do governo do então presidente Juscelino Kubistchek. O ISEB priorizava os estudos

69 Revista do Arquivo Municipal. São Paulo: DAH/DCM/ Prefeitura do Município de São Paulo, v.12, 1935, p. 229 . 
fundados na filosofia com vistas à uma internacionalização e ao desenvolvimento da economia brasileira. (QUEIROZ, 2014, p. 22)

Outro período relevante a nossa pesquisa e que devemos ressaltar nesta breve introdução é o da ditadura militar, que foi transformador para as políticas culturais ainda que com vistas a normatizar e centralizar o poder decisório de forma autoritária. Logo após o golpe de 1964, o Ministério da Educação e Cultura (MEC), criado em 1953 por Juscelino Kubitschek, foi dividido pelos militares por razões estratégicas. Com isso, a cultura perdeu o estatuto ministerial, passando a ser gerida pelo Departamento de Assuntos Culturais, com submissão direta ao presidente militar, e, durante os primeiros anos do regime, serviu principalmente para a gestão da censura artística.

No entanto, os militares sabiam da importância da cultura enquanto campo de disputa ideológica e, no ano de 1966, criam o Conselho Federal de Cultura (CFC) ${ }^{70}$ também gerido diretamente pela presidência e não pelo Departamento de Assuntos Culturais.

Por recomendação da presidência da república, foi formada uma comissão para elaborar estudos visando a reformulação da política cultural do país. Foi sugerida a criação de um Conselho Federal de Cultura (CFC) nos moldes do Conselho Federal de Educação. Para os elaboradores da proposta, o Conselho Nacional de Cultura não tinha efetiva atuação nacional, limitava-se a ações pontuais, de pouca abrangência. Em 24 de novembro de 1966, por meio do decreto-lei N. 74, foi criado o Conselho Federal de Cultura constituído por 24 membros diretamente nomeados pelo presidente da república. (CALABRE, 2009, p.68)

A criação do CFC buscava formular as políticas culturais num período de crescimento da repressão política e da censura para a classe artística e cultural. As instituições vinculadas agiam como "órgãos centralizadores e de normatização em suas respectivas áreas". (CALABRE, 2009, p. 69)

Em fevereiro de 1968, aconteceu a Primeira Reunião Nacional dos Conselhos de Cultura "visando à articulação, à coordenação e à execução do Plano Nacional de Cultura. (...) a reunião significava o primeiro passo para a construção do Sistema Nacional de Cultura" (idem, p. 70) A coincidência de nomes com os enunciados centrais de nossa pesquisa não é mero acaso. No período da ditadura, foram propostos diversos Planos Nacionais em diversos setores públicos. Contudo, ao contrário dos marcos legais e dos programais atuais, que buscam a descentralização num sistema de modelo federativo, estes do período da ditadura militar, ainda que com estrutura semelhante (com conselho, fundo e plano) serviam apenas à

\footnotetext{
70 De acordo com Calabre (2009) o decreto de criação do CFC não fazia menção alguma ao Conselho Nacional
} de Cultura criado em 1938 no MES de Gustavo de Capanema. 
centralização das decisões de cada setor em torno da presidência militar. O Plano Nacional de Cultura do período era considerado pelo CFC como

(...) a única forma de garantir os recursos financeiros necessários para a implementação das políticas setoriais de longo prazo. O projeto era criar um fundo similar ao existente na área da educação. (...) Mesmo sem conseguir assegurar dotações orçamentárias fixas para financiar os planos de longo prazo, o conselho executou uma parte significativa dos objetivos traçados, sempre custeados por dotações extras. (CALABRE, 2009, p. 72)

Já no ano de 1973, a pedido do então Ministro da Educação Jarbas Passarinho, o Conselho começou o processo da construção da Política Nacional de Cultura. O Plano desenvolvido pelo CFC nos anos anteriores foi considerado inviável pela presidência, principalmente por questões orçamentárias. Neste mesmo ano, o CFC entregou o documento "Diretrizes para uma Política Nacional de Cultura", e, em agosto, foi lançado o Plano de Ação Cultural, em substituição ao Plano Nacional de Cultura.

Em lugar de planos, deveriam ser preparadas diretrizes para as políticas públicas de cultura que, após serem submetidas à apreciação do presidente da República, deveriam ser desdobradas pelo Departamento de Assuntos Culturais em planos, programas, projetos e políticas. (CALABRE, 2009, p. 76)

O período do regime militar configurava uma estrutura política centralizadora, em que a União decidia tudo em relação a estados e cidades. As primeiras tentativas de criar enunciados reguladores do setor, como a primeira versão do Plano Nacional de Cultura em 1969 e o estabelecido Plano de Ação Cultural (PAC) em 1975, indicam que, desde esse período, já se pensava a estruturação do setor cultural de forma abrangente enquanto política de Estado, viabilizada e centralizada pelo poder federal. O documento de 1975, no entanto, trazia inovações, reivindicadas pelos trabalhadores do setor e que nos influenciam até os dias de hoje, como a criação da Fundação Nacional das Artes, a FUNARTE, proposta a partir do texto do PAC.

Órgãos foram criados a partir de algumas demandas específicas de setores artísticos, como é o caso da Fundação Nacional de Arte - FUNARTE; outros a partir da aglutinação de institutos já existentes, como a Empresa Brasileira de Filmes - Embrafilme; outros, ainda, tiveram seu raio de ação ampliado, como o Serviço Nacional de Teatro. Foram criados conselhos para tratar dos aspectos legais dos setores ligados à indústria cultural, como o Conselho Nacional do Direito Autoral - CNDA - e o Conselho Nacional de Cinema CONCINE. Tinha-se ali, na verdade, a estrutura que veio redundar na criação do Ministério da Cultura em 1985. (BOTELHO, 2006, p. 46) 
Em 1976, o Conselho Federal de Cultura realizou em Salvador o Encontro Nacional de Cultura, cujo tema geral foi "Sistema Nacional de Cultura". Tal sistema foi abordado em sessões com temas distintos: Sistema Nacional de Arquivos, Integração Regional e Regionalização Cultural, Sistema Nacional de Bibliotecas, Sistema Museológico Brasileiro e Proposições para a Política de Integração Nacional de Cultura. (MEIRA; GAZZINELLI, 2006, p.14)

Com o início do processo de redemocratização, principalmente a partir de 1979 na gestão do Presidente João Figueiredo e sua consolidação a partir do movimento das Diretas Já desde 1984, novas propostas de gestão do setor cultural foram tomando força, como a embrionária Lei Sarney que tramitava no Congresso enquanto projeto de lei desde 1972.

Podemos considerar o período que vai da Era Vargas até 1985, como a primeira etapa das políticas culturais brasileiras que, de acordo com o pesquisador de políticas culturais Albino Rubim, configura um período das "três tristes tradições das políticas culturais nacionais no Brasil (...) sinteticamente retidas pelas noções: ausências, autoritarismos e instabilidades" (RUBIM, 2010, p.11)

Até a redemocratização na metade anos 1980, as políticas públicas de cultura no Brasil buscavam principalmente a organização e gestão de instituições públicas como museus, bibliotecas e entidades reguladoras de interesse governamental. A cultura era pautada apenas pelo olhar institucional do Estado, de cima para baixo e como uma prestadora de serviços. Mesmo em experiências de vanguarda como a de Mario de Andrade, era o Estado que ditava o que deveria ser feito em termos de projetos e processos socioculturais. Ainda não havia a oportunidade de a população produtora de cultura participar das produções e muito menos opinar sobre quais políticas culturais seriam mais interessantes ao país.

A Constituição Cidadã de 1988 oficializou o retorno do país e de suas políticas públicas para a ideia de federalismo que a constituição de 1967, elaborada durante a ditadura militar, havia enterrado. O país, entendido enquanto federação desde sua constituição de 1891 e reiterado nas constituições seguintes, sofreu um forte abalo com a centralização do regime ditatorial dos anos 1960, principalmente a partir de 1967. Durante os chamados "anos de chumbo", aos entes federados não cabia mais nenhuma autonomia administrativa ou competência decisória estatal. Os estados estavam sujeitos às vontades da União com forte viés autoritário. Até os governadores estaduais eram designados pelo presidente militar. A Constituição Federal de 1988 tinha a missão de se "retratar diante dos abusos ocorridos durante o regime militar (...) restabelecer o regime federalista e adotar medidas destinadas a 
resguardá-lo e ampliá-lo dentre elas o estabelecimento do município enquanto ente federado." (CUNHA FILHO; RIBEIRO, 2013, p. 32)

A situação no final dos anos 1980 era de uma reviravolta na condução das políticas públicas, agora descentralizadas e que estariam refletidas em toda forma de ação política. $\mathrm{O}$ federalismo previsto na nova constituição trazia não apenas uma autonomia aos entes federados, mas direitos e deveres, e uma possibilidade voluntária de participar, ou não, de programas sociais implementados pela União.

Desde o início dos anos 80, um conjunto de reformas político-institucionais redundaram na recuperação das bases federativas do Estado brasileiro. A retomada das eleições diretas para todos os níveis de governo a partir de 1982, a descentralização fiscal da constituição de 1988, a definição dos municípios como entes federativos autônomos nesta mesma carta implicaram que, nos anos 90, as relações entre os níveis de governo passassem a ser relações próprias de um Estado Federativo. (...) Em um Estado Federativo, os governos subnacionais têm a prerrogativa de não aderir a programas federais que pretendem delegar-lhes competências. (ARRETCHE, 2000, p. 16-17)

Apesar da proposta constitucional de programas federalistas estatais, as políticas culturais penderam para um modelo liberal de influência estadunidense, que privilegiava o privado ante ao público e não utilizava o mesmo modelo federalista das políticas de assistência social e de saúde iniciadas no mesmo período. O advento da Lei Sarney, a primeira lei de incentivo à cultura aprovada no ano de 1986, desencadeou um novo processo de gestão das políticas culturais, em que o Estado dividia com as empresas parte das decisões sobre quem poderia utilizar as verbas para projetos culturais por meio de patrocínios via isenção fiscal.

Pouco antes da aprovação definitiva da Lei Sarney, tivemos a criação do primeiro Ministério da Cultura de nossa história em março de 1985, pelo decreto presidencial $\mathrm{n}^{\circ}$ 91.144/85. Para a pasta foi nomeado como ministro o economista Celso Furtado que foi coautor da lei de incentivo e assim justificou a existência da pasta exclusiva. A Lei Sarney e a criação do Ministério da Cultura marcam o início do segundo período das políticas culturais brasileiras, o período dos incentivos fiscais e da cultura num modelo liberal como pauta governamental federal.

No início dos anos 1990, a Lei Sarney foi engavetada e a primeira versão do MinC foi extinta pelo Presidente Fernando Collor de Melo logo no início de sua gestão, alegando corte de despesas e indícios de corrupção. Em seu lugar foi criada uma secretaria capitaneada pelo então deputado Sergio Paulo Rouanet. 
No ano seguinte, com a proximidade do processo de seu impedimento iminente, Collor, tentando driblar o momento difícil, buscou apoio junto à classe artística ao trazer de volta o mecenato cultural numa nova lei de isenção fiscal. O processo de criação e aprovação da nova lei ocorreu em poucas semanas. Seu Secretário de Cultura, Sergio Paulo Rouanet, inspirado na lei anterior e na Lei Mendonça (lei municipal de São Paulo criada e aprovada no ano de 1990), criou a nova lei federal de cultura, lei 8.313/91, conhecida como Lei Rouanet.

Outro importante processo que está relacionado com nossa reflexão aconteceu na gestão de Luiza Erundina na prefeitura de SP no início dos anos 1990. A gestão se inspirou nos preceitos do que se passou a chamar de "Cidadania cultural" onde o mote central era ampliar o olhar sobre o que é cultura e priorizar o direito à cultura. De acordo com o pesquisador e gestor Hamilton Faria, o direito à cultura no projeto de Erundina e de sua Secretária Municipal de Cultura, Marilena Chauí, deve ser entendido como:

O direito de produzir cultura, apropriando-se dos meios culturais já existentes ou inventando outros significados; o direito de usufruir dos bens da cultura ao possibilitar à população o acesso a esses mesmos bens; o direito à informação em geral e sobre os serviços culturais da cidade; o direito a usufruir os espaços para debater, refletir e criticar; o direito à experimentação e à invenção do novo nas artes e nas humanidades e finalmente um direito propositalmente sempre esquecido, e absolutamente inédito: o direito de participar das decisões quanto ao fazer cultural. (FARIA, 1997, p.12)

Durante a gestão da prefeita Luiza Erundina, tivemos uma série de novos projetos desenvolvidos por sua secretária de cultura, Marilena Chauí, que demonstraram essa nova proposta com o olhar mais popular e com maior participação dos agentes culturais na organização, entre eles: "Grafite e a pichação em São Paulo" (1989); "Cidade, cidadão, cidadania" (1990), "Rede imaginária: Televisão e democracia” (1990), "Ciclo Mario Pedrosa de Arte e Política" (1991) e "São Paulo dos 1000 povos: diga não ao preconceito, diga sim à solidariedade" (1992). Além disso, foram criadas no último ano de gestão quatorze Casas de Cultura nas periferias da cidade e que existem até hoje. Estas casas priorizavam a construção coletiva da cultura com olhar ampliado com as comunidades dos entornos. “(...) as Casas de Cultura envolveram milhares de moradores na discussão de temas de interesse da comunidade e do país através de fóruns locais e ações intersecretariais" (FARIA, 1997, p. 15)

A gestão Chauí adquiriu 300 mil livros novos e dobrou o acervo de todas as bibliotecas municipais da cidade. Foi também nessa gestão que as primeiras experiências de orçamento participativo começaram a ser aplicadas em São Paulo. "No ano de 1992 mais de 
mil pessoas, principalmente dos bairros reuniram-se na secretaria para aprovar o novo orçamento e propor prioridades na política cultural, dando ênfase mais às ações culturais que à construção de novos equipamentos" (idem, p.17)

(...) a gestão de Marilena Chauí rompeu com muitos conceitos estabelecidos, abriu caminhos para a implementação de projetos culturais democráticos, criou experiências, multiplicou-se por governos e sociedades e trouxe, através de uma reflexão inovadora, elementos fundamentais para construir novos paradigmas para a relação Estado e sociedade no campo da cultura. (FARIA, 1997, p. 20)

No livro que escreveu sobre sua experiência como secretária de cultura, Chauí volta seu olhar para uma ampliação do conceito de cultura que foi a base de sua gestão e com isso aproxima-se do conceito antropológico de cultura da Unesco e de Gilberto Gil, como veremos adiante.

Uma definição alargada da cultura, que não a identificasse com as belas artes, mas que a apanhasse seu miolo antropológico de elaboração coletiva e diferenciada de símbolos, valores, ideias, objetos práticas e comportamentos pelos quais uma sociedade, internamente dividida e sob hegemonia de uma classe social, define para si mesma as relações com o espaço, o tempo, a natureza e os humanos; uma definição política da cultura pelo prisma democrático, e, portanto, como direito de todos os cidadãos, sem privilégios e sem exclusões; uma definição conceitual da cultura como trabalho da criação: trabalho da sensibilidade, da imaginação, e da inteligência na criação das obras de arte, trabalho da reflexão da memória e da crítica, na criação de obras de pensamento. Trabalho no sentido dialético da negação das condições e dos significados imediatos da experiência por meio de práticas e descobertas de novas significações e abertura do tempo para o novo, cuja primeira expressão é a obra de arte ou a obra de pensamento enraizadas na mudança do que está dado e cristalizado. (CHAUÍ, 2006, p. 72)

Ao compararmos as experiências contemporâneas da Lei Sarney e da gestão Chauí em São Paulo, ambas posteriores ao período militar, observamos que enquanto em âmbito federal as políticas culturais seguiram um modelo liberal que priorizava a indústria cultural e o mercado, na cidade de São Paulo propuseram um modelo que projetava um tipo de democracia participativa e a cidadania cultural.

Os anos 1990 também viram a primeira recriação do Ministério da Cultura pelo então Presidente Itamar Franco no ano de 1992 e seu Ministro Antonio Houaiss. Ainda que tenhamos disponíveis poucos estudos e dados sobre o período, sabe-se que o volume de projetos aprovados e captados na Rouanet nos primeiros anos era ínfimo e que foi apenas a partir de 1995 que este passou a dar o tom para a esfera. (QUEIROZ, 2014, p. 27) 
A partir da segunda metade dos anos 1990, a Lei Rouanet foi amplamente incentivada pelo Estado, principalmente na gestão do Presidente Fernando Henrique Cardoso por meio de sua regulamentação com novos critérios ainda mais liberais. Na instrução normativa N. 1 de junho de 1995, ficou estabelecido que as políticas de incentivo à cultura em plano federal passassem a ser geridas pelo ideal do slogan "Cultura é um bom negócio". O crescimento do número de projetos aprovados no período não indicava, no entanto, o crescimento de projetos com captação de recursos. Isto é, boa parte dos projetos aprovados não conseguia recursos no mercado de patrocínios e os poucos que captavam eram sempre dos mesmos proponentes. ${ }^{71}$

Após uma série de instruções normativas, decretos e leis complementares, a lei Rouanet foi dividida em três tópicos principais: o mecenato, o Ficart ${ }^{72}$ e o Fundo Nacional de Cultura. O mecenato tornou-se o principal mecanismo da lei graças ao interesse de produtores e das empresas patrocinadoras em seu uso e foi crescendo ao longo dos anos chegando a seu auge por volta de $2005^{73}$.

Na gestão seguinte, com a posse do artista Gilberto Gil no Ministério da Cultura, as políticas culturais brasileiras tomaram um novo rumo por meio da criação de novos marcos legais que buscavam privilegiar, ao contrário das leis de incentivo à cultura do período anterior, a diversidade cultural e a ampliação do acesso à cultura. Mesmo que este período tivesse convivido com a ainda fortalecida Lei Rouanet, que desde 1991 utiliza a maior parte dos recursos da cultura por meio das isenções fiscais de empresas, a ideia de uma alteração de paradigma na gestão da cultura, nos permite dizer que um terceiro período das políticas culturais começaria com a gestão de Gilberto Gil como Ministro da Cultura de Lula: o período da democratização cultural, visando a ampliação do acesso à cultura, da democracia cultural e da diversidade cultural.

No final do século XX, as políticas culturais passam a ter maior importância na esfera cultural e artística brasileira como vimos anteriormente. A implantação de uma pasta ministerial única para a cultura em 1985, o crescimento do número de projetos culturais

\footnotetext{
${ }^{71}$ Tanto a lei Rouanet quanto a lei Sarney operam pela lógica do mecenato. Ainda que a verba seja pública, a escolha de quais projetos devem receber recursos é feita por empresas estatais e privadas.

${ }^{72} \mathrm{O}$ FICART destina-se à captação de recursos no mercado financeiro mediante oferecimento de quotas de fundos em condomínio administrados por instituições financeiras fiscalizadas pela Comissão de Valores Mobiliários (CVM). Os valores das quotas do FICART não podem ser deduzidos do Imposto de Renda, pois remuneram os investidores com juros e dividendos. Contudo o FICART não teve sua efetiva implantação enquanto mecanismo de cultura ao longo dos anos. Novos estudos sobre o uso do Ficart estavam sendo desenvolvidos no MinC em 2015, na segunda gestão de Juca Ferreira.

${ }^{73} \mathrm{O}$ crescimento da divulgação da lei e o bom momento econômico do país contribuíram para que a Lei Rouanet tivesse seus melhores resultados no início da gestão de Gilberto Gil, porém ainda como reflexo dos investimentos da gestão anterior na ideia de cultura como um bom negócio. Ver mais sobre em Queiroz (2014).
} 
financiados pela Lei Rouanet, o aumento nos investimentos no cinema nacional, trouxeram maior importância ao setor cultural que até então era desinteressante aos governos do passado em que a cultura era vista apenas por modelos mais institucionais e apenas tratavam de temas restritos ao patrimônio, ao folclore, aos museus ou dentro dos temas da educação.

$\mathrm{Na}$ virada para o século XXI, o modelo de financiamento das leis de incentivo à cultura passa a ser questionado pelo setor cultural, pois na maioria dos casos as verbas dos patrocínios ficavam restritos aos projetos culturais de grandes produtoras que eram letradas nas burocracias necessárias e tinham contatos no mercado do marketing cultural (QUEIROZ, 2014, p. 29) A nova gestão de Gil, pautada na ampliação do acesso à cultura e na diversidade, é também inspirada no slogan federal do período "Brasil um país de todos" e no programa de governo da eleição de 2002 de Lula A imaginação a serviço do Brasil. A mudança de paradigma que trata a cultura não apenas como arte ou patrimônio, mas algo bem mais amplo, passa a ser percebida na implantação desse novo modelo de política cultural. "O panorama começa a mudar a partir de Gilberto Gil no Ministério da Cultura. A construção da Conferência Nacional de Cultura; do Plano Nacional de Cultura e do Sistema Nacional de Cultura são marcos emblemáticos do processo de mudança”. (ALCANTARA, 2013, p. 3) Retornaremos a este tema ainda neste capítulo.

As diretrizes que nortearam os primeiros anos da gestão Gil foram claramente inspirados por relatórios desenvolvidos pelas comissões de cultura da UNESCO no final do século XX. Esses documentos não apenas influenciaram, mas também ditaram, às diversas nações participantes da organização, quais deveriam ser os novos direcionamentos desenvolvidos nas políticas culturais mundiais com vistas à sustentabilidade e principalmente à diversidade e ao acesso à cultura. Trataremos mais detalhadamente das relações entre os documentos da UNESCO e sua influência nas políticas culturais brasileiras no tópico a seguir.

\section{2 - A influência da UNESCO nas políticas culturais brasileiras}

Logo após o fim da segunda guerra mundial e por conta da necessidade de novas perspectivas de mundo, principalmente na Europa devastada, um grupo de pensadores e gestores mundiais criam a Organização das Nações Unidas $(\mathrm{ONU})^{74}$. No ano de 1945 , foi

\footnotetext{
${ }^{74}$ A primeira tentativa de criar uma entidade mundial com fins parecidos ocorreu no período entre guerras. A Liga das Nações foi instituída em 1919 pelo Tratado de Versalhes, mas dissolvida em 1946. Ainda que tivesse um intuito de reunião mundial, a Liga buscava uma articulação mais militar e de sanções econômicas do que a ONU.
} 
publicada a Carta das Nações Unidas escrita e referenciada por 50 países num encontro na cidade de São Francisco, Califórnia (EUA). Nesse documento histórico, contemporâneo ao fim da segunda guerra, a importância da cultura já aparece como um dos fatores essenciais para a manutenção da paz mundial. O respeito à cultura do outro era um dos princípios almejados na carta. A cultura é citada nos artigos 1, 13, 55, 57, e 73 da carta. A partir daquele documento a cultura começa a ser considerada como um direito humano básico.

\begin{abstract}
Art $^{\circ}$. 55 Com o fim de criar condições de estabilidade e bem-estar, necessárias às relações pacíficas e amistosas entre as Nações, baseadas no respeito do princípio da igualdade de direitos e da autodeterminação dos povos, as Nações Unidas promoverão: a. A elevação dos níveis de vida, o pleno emprego e condições de progresso e desenvolvimento econômico e social; b. A solução dos problemas internacionais econômicos, sociais, de saúde e conexos, bem como a cooperação internacional, de caráter cultural e educacional; c. O respeito universal e efetivo dos direitos do homem e das liberdades fundamentais para todos, sem distinção de raça, sexo, língua ou religião. (ONU, 1945)
\end{abstract}

No mesmo ano, em Londres, é criada como um dos braços da ONU, a Organização das Nações Unidas para a Educação, a Ciência e a Cultura, conhecida pela sigla UNESCO, definitivamente oficializada enquanto organização por meio da publicação de sua constituição. O texto traz um detalhamento dos princípios e das ações contempladas pela instituição que serviria de força motor de cooperação mundial para os temas de educação, ciência e cultura. Não por acaso, a constituição da UNESCO cita a Carta das Nações Unidas enquanto princípio norteador da Organização.

O propósito da Organização é contribuir para a paz e para a segurança, promovendo colaboração entre as nações através da educação, da ciência e da cultura, para fortalecer o respeito universal pela justiça, pelo estado de direito, e pelos direitos humanos e liberdades fundamentais, que são afirmados para os povos do mundo pela Carta das Nações Unidas, sem distinção de raça, sexo, idioma ou religião. 2. Para realizar este propósito, a Organização deverá: (a) Colaborar no trabalho de fazer avançar o conhecimento e o entendimento mútuos entre os povos, através de todos os meios de comunicação de massa, e com esse objetivo recomendar aqueles acordos internacionais que possam ser necessários para promover o livre fluxo de ideias, através da palavra e da imagem; (b) Oferecer impulso renovado à educação popular e disseminação da cultura: (...) (c) Manter, expandir e difundir o conhecimento: Garantindo a conservação e a proteção do legado mundial de livros, obras de arte e monumentos de história e de ciência, recomendando as convenções internacionais necessárias às nações envolvidas; Estimulando a cooperação entre as nações em todos os ramos de atividade intelectual, incluindo o intercâmbio internacional de pessoas ativas nos campos da educação, da ciência e da cultura, além do intercâmbio de publicações, objetos de interesse artístico e científico. (UNESCO, 2002 [1945]) 
Logo depois, no ano de 1948, durante a Assembleia Geral das Nações Unidas, a Declaração Universal sobre os Direitos Humanos é proclamada pela resolução 217 A (III) instituindo outra série de princípios às duas organizações e aos países participantes. $\mathrm{O}$ documento é um marco histórico na luta pelos diretos civis dos cidadãos de todo o mundo e até hoje baliza a criação e o pensamento da legislação de diversos países, como por exemplo, nossa Constituição Cidadã de 1988. O texto, assim como seus documentos antecessores, criado por diversos gestores de diferentes países, compreende a importância da cultura enquanto direito básico e a exalta para a boa convivência mundial.

Artigo 22. Todo ser humano, como membro da sociedade, tem direito à segurança social e à realização, pelo esforço nacional, pela cooperação internacional e de acordo com a organização e recursos de cada Estado, dos direitos econômicos, sociais e culturais indispensáveis à sua dignidade e ao livre desenvolvimento da sua personalidade. (...)

Artigo 27. 1. Todo ser humano tem o direito de participar livremente da vida cultural da comunidade, de fruir das artes e de participar do processo científico e de seus benefícios. (ONU, 1948)

No artigo 27 mais especificamente podemos ver indícios do que mais tarde seria tratado como o direito à cultura, ou mesmo o direito ao acesso à cultura. Ao propor que "Todo ser humano tem o direito de participar livremente da vida cultural da comunidade", a declaração mostra que a cultura é um direito básico de todo e qualquer cidadão, de qualquer país que se importe com os direitos dos que lá vivem. A “fruição das artes" nos remete diretamente ao acesso à cultura. "Fruir das artes" é não apenas um direito constituído, mas uma possibilidade de garantia de acesso a essa fruição na comunidade e nas cidades.

Vinte anos mais tarde, nos anos 1960, é celebrado o Pacto Internacional dos Direitos Econômicos, Sociais e Culturais ${ }^{75}$, adotado pela Resolução n.2.200-A (XXI) da Assembleia Geral das Nações Unidas, em 16 de dezembro de 1966 e ratificada pelo Brasil apenas em 24 de janeiro de $1992^{76}$. Dentre os trechos mais relevantes do Pacto podemos destacar o artigo 1 que preza pela autodeterminação de ordem política, econômica, social e cultural. Se pensarmos a cultura num sentido mais amplo, é possível compreendermos que neste período da história contemporânea, com os avanços da globalização, garantir a autodeterminação de povos do mundo era essencial, pois poderia prevenir a colonização econômica e cultural de

\footnotetext{
${ }^{75}$ Disponível em: < http://www.planalto.gov.br/ccivil 03/decreto/1990-1994/d0591.htm > acesso em 20 de abril de 2016.

${ }^{76}$ Aqui é relevante ressaltar o atraso do reconhecimento do documento pelo Brasil em quase 30 anos por conta do regime militar e a demora na reorganização democrática no país.
} 
tais povos. "Artigo $1^{\circ} \S 1$. Todos os povos têm o direito à autodeterminação. Em virtude desse direito, determinam livremente seu estatuto político e asseguram livremente seu desenvolvimento econômico, social e cultural”. (ONU, 1966)

Outro importante marco foi a Conferência Geral da Organização das Nações Unidas para a Educação, Ciência e Cultura que aconteceu em Paris de 17 de Outubro a 21 de Novembro de 1972. Nesta conferência foi instituída a Convenção para a Proteção do Patrimônio Mundial, Cultural e Natural. A importância desse documento deve-se principalmente por conceituar e especificar o que entendiam por patrimônio e o que deveria ser protegido. A ideia de patrimônio cultural presente no documento destaca a importância das edificações históricas para a humanidade e também todo tipo de elementos que remetessem a qualquer período da história desde artefatos arqueológicos até edificações mais recentes de relevante interesse artístico.

Para fins da presente Convenção serão considerados como patrimônio cultural: Os monumentos. - Obras arquitectônicas, de escultura ou de pintura monumentais, elementos de estruturas de caráter arqueológico, inscrições, grutas e grupos de elementos com valor universal excepcional do ponto de vista da história, da arte ou da ciência; Os conjuntos. - Grupos de construções isoladas ou reunidos que, em virtude da sua arquitetura, unidade ou integração na paisagem têm valor universal excepcional do ponto de vista da história, da arte ou da ciência; Os locais de interesse. - Obras do homem, ou obras conjugadas do homem e da natureza, e as zonas, incluindo os locais de interesse arqueológico, com um valor universal excepcional do ponto de vista histórico, estético, etnológico ou antropológico. (UNESCO, 1972) ${ }^{77}$

No ano de 1982 aconteceu na cidade do México a Conferência Mondiacult que buscou refletir acerca do que era entendido por cultura nas décadas anteriores. De acordo com informações na página da UNESCO, a discussão acerca do conceito de cultura foi o mote central dessa conferência que gerou o importante documento Declaração do México. Este documento foi o primeiro a trazer para o âmbito da legislação mundial os conceitos de diversidade cultural e identidade para as reflexões mundiais sobre cultura. Também é neste documento que surge pela primeira vez em termos oficiais a ideia que a cultura é o que nos torna humanos e vai muito além da arte e do patrimônio.

(...) a conferência concorda em que, no seu sentido mais amplo, a cultura pode ser considerada atualmente como o conjunto dos traços distintivos espirituais, materiais, intelectuais e afetivos que caracterizam uma sociedade e um grupo social. Ela engloba, além das artes e das letras, os modos de vida, os direitos fundamentais do ser humano, os sistemas de valores, as tradições e as crenças. Concorda também que a cultura dá ao homem a capacidade de refletir sobre si mesmo. É ela que faz de nós seres

\footnotetext{
${ }^{77}$ Disponível em: $<$ http://whc.UNESCO.org/archive/convention-pt.pdf $>$ acesso em 15 de junho de 2016.
} 
especificamente humanos, racionais, críticos, e eticamente comprometidos. Através dela discernimos os valores e efetuamos opções. Através dela o homem se expressa, toma consciência de si mesmo, se reconhece como um projeto inacabado, põe em questão as suas próprias realizações, procura incansavelmente novas significações e cria obras que o transcendem. (...) Cada cultura representa um conjunto de valores único e insubstituível já que as tradições e as formas de expressão de cada povo constituem sua maneira mais acabada de estar presente no mundo. A afirmação da identidade cultural contribui, portanto, para a liberação dos povos; ao contrário, qualquer forma de dominação nega ou deteriora essa identidade. (...) A identidade cultural de um povo se renova e enriquece em contato com as tradições e valores dos demais. A cultura é um diálogo, intercâmbio de idéias e experiências, apreciação de outros valores e tradições; no isolamento, esgota-se e morre. O universal não pode ser postulado em abstrato por nenhuma cultura em particular, surge da experiência de todos os povos do mundo, cada um dos quais afirma a sua identidade. Identidade cultural e diversidade cultural são indissociáveis (UNESCO, 1982)

O entendimento de que não existe uma hierarquia e nem mesmo culturas superiores a outras existe desde as reflexões de antropólogos como Frans Boas e foi um dos pontos centrais da reflexão no evento mexicano, que foi retificado posteriormente na publicação Nuestra diversidad creativa de 1996.

Esta publicação demonstra já em seus tópicos no sumário que essa visão contemporânea de mundo, orientada por diversos antropólogos desde o final do século XIX, estava finalmente se estabelecendo naquele momento no âmbito das reflexões ditas "oficiais". As discussões compreendiam a diversidade cultural como algo muito mais ampliado do que apenas relacionado à ideia tradicional de cultura e que essa diversidade poderia contribuir também para o desenvolvimento social e econômico.

As propostas do tratado giram em torno dos seguintes temas que também nomeiam os capítulos: uma nova ética global; compromisso com o pluralismo; criatividade e empoderamento; desafios de um mundo mais midiático; mulheres, gênero e cultura; as crianças e a juventude; o patrimônio cultural a serviço do desenvolvimento; cultura e meio ambiente; repensar as políticas culturais.

Logo nas primeiras linhas da introdução depreendemos a semelhança com a ideia de cultura e as reflexões que nortearam as políticas culturais brasileiras na gestão de Gilberto Gil.

Quando não há distinção entre "cultura" e no sentido humanista do termo 'cultura' em seu sentido antropológico, ou seja, o conjunto de características distintivas que caracterizam o modo de vida de uma sociedade de um povo ou uma sociedade, surge uma grande confusão tanto no discurso acadêmico como no político. No ponto de vista antropológico, a expressão "relação entre cultura e economia" não tem sentido, uma vez que a economia é parte da cultura de um povo. Com efeito, a ambiguidade de tal expressão é o 
principal obstáculo ideológico à Comissão: a cultura é um aspecto ou uma ferramenta de desenvolvimento, entendida no sentido do progresso material; ou o objetivo da finalidade do desenvolvimento, entendido em sentido de realização da vida humana em suas diversas formas e em sua totalidade? ${ }^{78}$ (UNESCO, 1996, p. 13)

O questionamento sobre o conceito antropológico de cultura num documento da Unesco, sobre se este deve ser entendido no sentido material, por meio de sua base econômica, ou pensado apenas como a compreensão dos modos de vida do ser humano, nos remete não apenas ao discurso de Gil, mas também às reflexões dos pensadores do Círculo de Bakhtin acerca da cultura e das esferas ideológicas. Estariam as esferas ideológicas constituídas condicionadas à infraestutura econômica? Seria a economia parte da cultura ou a cultura uma ferramenta de desenvolvimento econômico?

A compreensão do conceito de diversidade cultural como fator central para a discussão do conceito de cultura a partir dos anos 1980 começou a ser levantada principalmente por antropólogos de origem iberoamericana como o argentino Nestor Garcia Canclini que, nos anos 1990, estabeleceu sua pesquisa no México por conta da centralidade do país nas reflexões sobre o tema junto às organizações internacionais. Mais do que falar sobre o que é cultura ou a arte, a diversidade toma conta das reflexões e traz um novo tom às propostas tratadas em nível mundial.

Outra importante reunião dos anos 1980 ocorreu em Washington D.C. intitulada $A$ Global Assessment of the 1989 Recommendation on the Safeguarding of Traditional Culture and Folklore: Local Empowerment and International Cooperation (Avaliação global de 1989 Recomendação sobre a Salvaguarda da Cultura Tradicional e Folclore: Empoderamento Local e Cooperação Internacional). Essa reunião determinou, entre outros apontamentos, que deveriam ser realizados oito seminários regionais entre os anos de 1995 e 1999. Na Europa o encontro ocorreu na cidade de Nice em junho de 1995; na América Latina, na Cidade do México em 1997; na Ásia, em Tóquio no ano de 1998; novamente na Europa, na Finlândia em

\footnotetext{
78 "Cuando no se distingue entre "cultura" y em el sentido humanista del término y "cultura" em su acepción antropológica es decir, el conjunto de rasgos distintivos que caracterizam el modo de vida de un pueblo o de uma sociedad, se origina gran confusión tanto em el discurso acadêmico como em el político. Desde el punto de vista antropológico, la expressión "relación entre cultura y economia", carece de sentido, puesto que la economia forma parte de la cultura de um pueblo. En efecto el ambiguidad de uma expressión semejante constituye el principal escollo ideologico para la Comissión: es la cultura um aspecto o um instrumento del desarrollo, entendido em el sentido de progreso material; o el objetivo de la finalidad del desarrollo, entendido em el sentido de realización de la vida humana bajo sus multiples formas y em su totalidad?” (UNESCO, 1996, p. 13)
} 
1998; na Ásia Central, no Usbequistão em 1998; na África, em 1999, na cidade de Accra, numa ilha do oceano Pacífico e em Beirute considerando assim o Oriente Médio. As reuniões ocorridas em diferentes regiões fortaleceram a atuação das organizações internacionais localmente, mas também visavam à discussão dos temas locais e da diversidade, ao compreender que cada região do mundo, cada país tem demandas e problemas diferentes a lidar. Os resultados de cada reunião foram tranformados em relatórios e publicações que definiam localmente as especificidades culturais e as demandas de cada ponto do planeta.

Neste mesmo período, a UNESCO criou uma comissão específica para o desenvolvimento da cultura, visando compreender as mudanças da produção cultural no fim do século XX e como estas estariam diretamente relacionadas com o desenvolvimento de certas regiões do mundo. O relatório gerado pela comissão foi o pilar para as discussões na Conferência Mundial de Políticas Culturais realizada em 1998 em Estocolmo. Em pleno avanço das políticas liberais e da globalização, o documento permitiu à Comissão uma maior observação da influência das indústrias culturais nos países subdesenvolvidos, a chamada mundialização da cultura (ORTIZ, 2007).

Em 1992, juntamente com as Nações Unidas, a UNESCO criou a "Comissão Mundial de Cultura e Desenvolvimento". No relatório final de trabalho, a Comissão propôs, a partir do diagnóstico elaborado, uma série de formulações que procuravam dar conta das transformações pelas quais a cultura passou ao longo do século, em especial o papel central ocupado pelas indústrias culturais e pela mídia, papel intimamente relacionado com o seu atual momento de globalização ou mundialização. $O$ relatório foi fundamental para que, em 1998, a entidade organizasse, em Estocolmo, a "Conferência Mundial de Políticas Culturais". (BARBALHO, 2008, p. 20)

Em 2001, a UNESCO publica a Declaração Universal sobre a Diversidade Cultural, mesmo ano em que também foi proclamado numa Assembleia da ONU o dia 21 de maio como o dia da diversidade cultural. Esse documento é sem dúvida um marco importante em nossa reflexão, pois traz à tona e em destaque a legitimação da diversidade como ponto central na questão da cultura contemporânea. O documento apresenta em seus doze artigos e também em seu plano para aplicação uma série de pontos em comum com os enunciados principais em nosso corpus de pesquisa, o Sistema Nacional de Cultura e o Plano Nacional de Cultura. Chama atenção, logo no início da declaração, a relação entre o tipo de discurso do documento e o futuro discurso do Ministro da Cultura Gilberto Gil que estava prestes a cuidar da pasta e também a ideia do mundo da cultura proposto por Bakhtin.

Artigo 1 - A diversidade cultural, patrimônio comum da humanidade A cultura adquire formas diversas através do tempo e do espaço. Essa 
diversidade se manifesta na originalidade e na pluralidade de identidades que caracterizam os grupos e as sociedades que compõem a humanidade. Fonte de intercâmbios, de inovação e de criatividade, a diversidade cultural é, para o gênero humano, tão necessária como a diversidade biológica para a natureza. Nesse sentido, constitui o patrimônio comum da humanidade e deve ser reconhecida e consolidada em beneficio das gerações presentes e futuras.(...)

Artigo 4 - Os direitos humanos, garantias da diversidade cultural A defesa da diversidade cultural é um imperativo ético, inseparável do respeito à dignidade humana. Ela implica o compromisso de respeitar os direitos humanos e as liberdades fundamentais, em particular os direitos das pessoas que pertencem a minorias e os dos povos autóctones. Ninguém pode invocar a diversidade cultural para violar os direitos humanos garantidos pelo direito internacional, nem para limitar seu alcance. (UNESCO, 2001, p.3)

No artigo 1 da declaração, achamos pertinente evidenciar o seguinte trecho: a "cultura adquire formas diversas através do tempo e do espaço". Esta afirmação nos remete à arquitetônica bakhtiniana formulada em Para uma filosofia do ato responsável, que evidencia a relação da criação simbólica, às categorias de tempo e espaço não como formas mecânicas $a$ priori como defendeu Kant, mas como processos diferenciados ao longo da história e realizados por um autor em ato.

Já no artigo 4 da Declaração, a cultura é vista como direito e garantia de diversidade que deve ser tida como imperativo ético, não pode ser contestada, pois incide diretamente na dignidade humana. Aqui novamente remetemos o discurso não apenas à defesa da cultura nos discursos futuros de Gil e dos documentos do MinC, mas também à ideia de responsabilidade e ética, conforme vimos no primeiro capítulo desta tese. Garantir a diversidade cultural é um imperativo ético na medida em que proporciona a possibilidade do diálogo e o respeito a todas as comunidades culturais e sua produção simbólica.

No ano de 2002, foi desenvolvida na cidade de Porto Alegre durante o Fórum Mundial Social, mais especificamente no IV Fórum de Autoridades Locais pela Inclusão Social de Porto Alegre, a Agenda 21 da Cultura $^{79}$. Inspirado na Agenda 21 do Meio Ambiente escrita em 1992 no México, o documento sobre a cultura foi discutido por diversas frentes em todo mundo durante dois anos e finalmente aprovado numa conferência ocorrida em Barcelona, em 2004. Protocolada inicialmente pela UNESCO, suas proposições foram geridas a partir de outubro do mesmo ano pela organização United Cities and Local Governments (UCLG), que seria equivalente a uma organização das Nações Unidas para as cidades. A organização informa em seu site que compreende a cultura como um dos quatro pilares da sustentabilidade, ao lado do econômico, do social e do ambiental.

\footnotetext{
${ }^{79}$ Informações disponíveis no site: < http://www.agenda21culture.net/ > acesso em 21 de agosto de 2016.
} 
No texto da Agenda 21 da Cultura encontramos diversos trechos que nos remetem às políticas culturais desenvolvidas no país na gestão Gil, como, por exemplo, o item 11 que trata mais especificamente dos princípios da agenda e fala como as políticas culturais do século XXI deveriam ser desenvolvidas. O excerto destaca a necessidade de equilíbrio entre o público e o privado, e que a base da liberdade cultural é a autonomia dos cidadãos na produção de cultura.

11. As políticas culturais devem encontrar um ponto de equilíbrio entre interesse público e privado, vocação pública e institucionalização da cultura. Uma excessiva institucionalização, ou a excessiva prevalência do mercado como único distribuidor de recursos culturais, comporta riscos e levanta obstáculos ao desenvolvimento dinâmico dos sistemas culturais. A iniciativa autônoma dos cidadãos, individualmente ou reunidos em entidades e movimentos sociais, é a base da liberdade cultural. (UCLG, 2004, p. 3)

Na parte do texto que trata dos compromissos, verificamos outro item que interessa à nossa busca. O item 17 aborda a diversidade cultural e o compromisso com o fomento à amplitude de oferta e a garantia de presença de todas as culturas inclusive nas mídias. É possível dizer que o trecho nos remete aos preceitos básicos do programa Cultura Viva ${ }^{80}$, que prioriza a diversidade, as culturas dos povos originários e as identidades das minorias.

17. Estabelecer políticas que fomentem a diversidade cultural, a fim de garantir a amplitude da oferta e a presença de todas as culturas, especialmente das minoritárias ou desprotegidas, nos meios de comunicação e de difusão, incentivando as co-produções e os intercâmbios, e evitando posições hegemônicas. (Idem, p. 4)

Ao longo do documento, diversos itens nos remetem aos preceitos de políticas culturais implementados no Brasil no início do século XXI, mas é relevante destacar o item 47 que aborda a centralidade da cultura no desenvolvimento de políticas públicas. "47. Assegurar a centralidade da cultura no conjunto das políticas locais, impulsionando a redação de agendas 21 da cultura em cada cidade do território, em coordenação íntima com os processos de participação cidadã e planificação estratégica." (UCLG, 2004, p. 6, grifos nossos) A centralidade da cultura ou a transversalidade da cultura é um dos eixos centrais das diretrizes do Plano Nacional de Cultura. O trecho também menciona a necessidade de escrita de agendas regionais para a cultura. No caso do Brasil, não foram escritas Agendas 21 regionais, porém é possível pensarmos nos Planos Estaduais e Municipais de Cultura como os documentos que realizariam esta função social em cada território. O excerto também fala da

\footnotetext{
${ }^{80}$ O programa Cultura Viva foi instituído logo no início da gestão Gil e trouxe um novo modelo de distribuição de recursos para a cultura a partir dos preceitos de sustentabilidade para projetos socioculturais por meio da obrigatoriedade da compra de um "kit multimídia" para Pontos de Cultura.
} 
participação cidadã e do planejamento estratégico, que igualmente são estruturantes no SNC. Isso fica ainda mais evidente no item seguinte, que diz: “48. Realizar propostas de acordo sobre os mecanismos de gestão da cultura com os outros níveis institucionais, respeitando o princípio de subsidiaridade ${ }^{81}$." (UCLG, 2004, p. 6) O princípio da subsidiaridade remete às recomendações que as conferências municipais fazem às conferências estaduais de cultura, e estas às conferencias federais, à participação social prevista na escrita de planos de cultura e à importância da sociedade civil no desenvolvimento das políticas de cultura.

Outro item fundamental no texto é o de número 49, que aborda a importância de realizar, até o ano de 2006, uma "proposta de sistema de indicadores culturais que dê conta do desenvolvimento desta Agenda 21 da Cultura a partir de métodos gerais que possa facilitar a monitoração e a comparabilidade.”(idem, p.6) Aqui somos imediatamente levados ao Sistema Nacional de Indicadores e Informações Culturais (SNIIC) criado pelo MinC no final do ano de 2011 e que desde 2015 conta com nova plataforma regulada pelos preceitos da Conta Satélite da Cultura ${ }^{82}$ do IBGE e que desde 2014 é plataforma base para contabilizar os avanços do Plano Nacional de Cultura.

\section{A Convenção sobre a Proteção e Promoção da Diversidade das Expressões Culturais} foi proclamada na $33^{\text {a }}$ reunião da Conferência Geral da UNESCO celebrada em Paris em outubro de 2005. O documento

(...) visa principalmente orientar e legitimar os países na elaboração e implementação de políticas culturais próprias, necessárias à proteção e promoção da diversidade cultural. Em 18 de março de 2007, após mais de 50 países a ratificarem, sendo o Brasil o $40^{\circ}$ da lista, a Convenção entrou em vigor (KAUARK, 2010, p. 1)

De acordo com Kauark, este documento teve participação fundamental do grupo brasileiro em sua idealização e desenvolvimento.

Segundo os relatos dos gestores do Ministério da Cultura, o posicionamento do Brasil em favor da Convenção exerceu forte influência nos demais países em desenvolvimento, a exemplo das nações africanas e latinas. Esse peso político do país na arena internacional estava respaldado por um trabalho anterior de análise, feito pelo GT e pelos gestores de ambos os ministérios, bem como pela participação efetiva durante as reuniões e inclusive no Comitê de Redação instaurado. Essa posição do Brasil frente aos demais

\footnotetext{
81 Subsiariedade é o princípio que determina que os assuntos devem ser tratados sempre que possível, pela autoridade mais baixa. Parte do pressuposto de que os instrumentos estatais para a satisfação dos interesses da sociedade devem estar o mais próximo possível do indivíduo, ou seja, de quem legitima o poder público estatal reporta-se aos princípios do federalismo, à limitação dos poderes do estado e ao fortalecimento das liberdades individuais. (OBSERVATÓRIO ITAÚ CULTURAL, 2007, p. 59)

${ }^{82}$ A Conta Satélite da Cultura foi estabelecida pelo IBGE por meio de normas internacionais de informação que buscaram padronizar índices e indicadores, principalmente da América Latina.
} 
países e também em articulação com o grupo de países formado pela União Europeia e Canadá, auxiliou no desequilíbrio da disputa com os EUA durante essas reuniões. (KAUARK, 2010, p. 5. )

Ao entrevistar diplomatas do Itamaraty em sua pesquisa, bem como o próprio Ministro Gilberto Gil e o Presidente da FUNARTE no período, Sergio Mamberti, Kauark diz que todos concordaram com as premissas levadas à convenção em Paris, essenciais para a tônica do enunciado. Desta vez era o Brasil influenciando as ideias sobre as políticas culturais mundiais a partir de nossa própria experiência. De acordo com Finzeto (2017):

Dessa forma, a negociação da Convenção da Diversidade passa a ser tema prioritário ao MinC à medida que havia a possibilidade de se obter um instrumental multilateral que garantiria a legalidade da atuação estatal na adoção de medidas de proteção de suas culturas. O processo de negociação na Convenção não foi simples devido à tentativa norte-americana de estabelecer bens e serviços culturais no âmbito dos acordos da Organização Mundial do Comércio. (FINZETO, 2017, p.93)

A influência dos discursos contidos nos documentos da UNESCO e de comissões mundiais organizadas por ela e por entidades afins poderá ser percebida em nosso próximo tópico e nos próximos capítulos desta tese, quando esmiuçarmos os enunciados relacionados à Política Nacional de Cultura proposta a partir dos anos 2000.

\section{3 - A Política Nacional de Cultura no século XXI: o retrato de um país em mudança}

A história das políticas culturais brasileiras no início do século XXI coincide com os planejamentos das políticas para uma possível gestão de Luiz Inácio Lula da Silva que almejava a presidência desde os anos 1990. A construção de um programa de governo com perspectiva social, que levasse em conta as necessidades da população trabalhadora, era a premissa central dos discursos contidos nas propostas do Partido dos Trabalhadores (PT) desde seu surgimento no fim dos anos 1970.

Em 1982, ano em que os entes federados puderam ter eleições diretas após 18 anos de absoluta ruptura no regime democrático, foram eleitos deputados e governadores nos estados da União. O PT elegeu oito deputados federais, dentre eles seis do estado de São Paulo. Em âmbito estadual, o Partido elegeu treze deputados estaduais, sendo nove deles apenas para a Alesp. Essas experiências legislativas foram o início da construção do PT e foram sendo refletidas e construídas ao longo dos anos em diversos congressos do partido. No ano de 1988, o PT elegeu prefeitos em três importantes capitais: Vitória, Porto Alegre e São Paulo. Nesse momento, os processos de discussão do orçamento participativo ganham fôlego e 
passam a ser parte do método a ser seguido nos anos seguintes.

No livro Governo e cidadania: Balanços e reflexões sobre o modo petista de governar, publicado em 1999 com vistas a orientar a militância para refletir sobre a construção do programa do partido para a eleição presidencial seguinte, é possível ver importantes nomes discutindo sobre o que fazer e o que deveria ser proposto. Chama atenção o texto escrito por Cristovam Buarque, que faz uma proposição de quatro passos na construção do programa e trata do que deveriam ser as premissas básicas para processo:

1. Completar a democracia brasileira (...) porque em vez de democracia mergulhamos em um sistema novo chamado liberalismo global, que não é o mesmo que democracia. 2. (...) abolir a pobreza no Brasil (...) esse apartheid social, diminuir a desigualdade é um processo posterior (...) a abolição da pobreza não é um problema econômico, é um problema ético e social. 3. Melhorar a qualidade de vida a partir de uma reorganização social. (...) 4. Ser o partido da ecologia. (BUARQUE, 2002, p.47)

Dentre as ações preparatórias para um futuro governo Lula estavam, entre outras ações, a atividade da base parlamentar. Um projeto popular por meio da criação de leis que possibilitassem a implantação de um novo paradigma voltado aos interesses dos trabalhadores já vinha sendo construído desde os anos 1980. Todavia, foi no final dos anos 1990, que os marcos legais que visavam servir de base programática à ascensão de Lula ao mais alto posto executivo do país começaram a ser propostos no Congresso Nacional.

As novas propostas para as políticas públicas de cultura para o século XXI nasceram de uma série de encontros ocorridos principalmente no ano de 1999 com a presença de intelectuais e agentes culturais. A gênese do projeto que estava nascendo viria das experiências de cidadania cultural de cidades como Recife, Porto Alegre e principalmente São Paulo na gestão de Luiza Erundina e Marilena Chaú́, em que o mote central seria a interferência da população na gestão cultural. As discussões que pautaram esses encontros permeavam algumas ideias centrais:

a) Descentralização / desconcentração - Inversão de prioridades. Não mais fazer política cultural só nos grandes centros e nos centros dos grandes centros;

b) Qual é o papel dos agentes e produtores de cultura no processo de construção dessas políticas? Esta nova política não seria apenas para os artistas e produtores, mas feitas com eles.

Esses debates logo reverberaram na Câmara Federal, principalmente na Comissão de Educação e Cultura. No ano 2000, nesta mesma comissão, surgiu a discussão sobre o Plano Nacional de Cultura enquanto parte de um projeto maior composto por diversos marcos legais 
posteriores, nos mais diversos setores, e que buscava a democratização do acesso à cultura e à criação de políticas culturais e sociais com vistas a um projeto político de longo prazo. A nova legislação proposta pelos parlamentares do partido a partir deste período visava uma mudança estrutural e ideológica nas práticas das políticas de Estado.

No âmbito da cultura, o primeiro marco legal e que deu o tom das diretrizes para a criação de todos os enunciados seguintes foi o do Plano Nacional de Cultura (PNC) gerado através da PEC $306 / 2000^{83}$. A proposta elaborada pelo Deputado Federal Gilmar Machado (PT - MG) assinada em parceria com a deputada Marisa Serrano (PSDB/MS) ${ }^{84}$, ao ser aprovada, se transformou na emenda constitucional N. 48/2005. Em seguida, a emenda foi inserida como parágrafo $3^{\circ}$ no Artigo 215 da Constituição Federal. Sua regulamentação foi desenvolvida a seguir por meio do projeto de lei $6.835 / 2006^{85}$ e aprovado cinco anos depois como lei federal $12.343 / 2010^{86}$. A primeira versão oficial finalizada das diretrizes do PNC foi habilitada em 2007 criando assim as bases para o que o MinC passa a chamar de Política Nacional de Cultura. Com aprovação da PEC do PNC em 2005, é efetivado oficialmente o início de um processo de projeção de políticas culturais em longo prazo e que, de acordo com seus princípios, poderia acabar com o longo período de "instabilidades" destacado por Albino Rubim.

A aprovação pelo Congresso Nacional e subsequente elaboração do PNC, em parceria com a Câmara dos deputados, emerge como outro fator favorável à superação da tradição de instabilidade, pois o Plano tem duração prevista de 10 anos. Ele está ancorado no Ministério, no Congresso Nacional e na sociedade civil, dada sua construção como política pública. A aprovação do projeto de lei 6.835/2006, em 16 de março de 2010 é alvissareira no sentido de dotar a cultura de um planejamento e de metas mais permanentes. (RUBIM, 2010, p.17)

No ano de 2001, Marco Aurélio Garcia, da Fundação Perseu Abramo, junto a outros intelectuais e artistas militantes petistas, convocou uma reunião para a construção de uma proposta do partido para a cultura e que no ano seguinte se transformou no documento $A$ 83 Informações oficiais sobre a PEC 306/2000. Disponível em: < http://www.camara.gov.br/proposicoesWeb/fichadetramitacao?idProposicao=14692 > acesso em 08 de março de 2014.

${ }^{84}$ Ainda que a deputada tucana também assine a PEC de acordo com alguns documentos extraoficiais, como o Programa de Lula e alguns livros sobre o tema, tanto no site do Congresso, quanto nos documentos oficiais do MinC não há a confirmação de sua efetiva participação enquanto autora participante da matéria.

85 Informações oficiais sobre o projeto lei 6385/2006. Disponível em: < http://www.camara.gov.br/proposicoesWeb/fichadetramitacao?idProposicao=319143 > acesso em 08 de março de 2014.

86 Informações oficiais sobre a Lei 12343 que institui o PNC. Disponível em: < http://www2.camara.leg.br/legin/fed/lei/2010/lei-12343-2-dezembro-2010-609611-norma-pl.html > acesso em 08 de março de 14. 
imaginação a serviço do Brasil, base para o programa de Lula na eleição de 2002.

No programa geral de Lula é possível observar diversas propostas de implantação de políticas sociais nos mais variados setores. As propostas das áreas de educação, saúde, transporte, trabalho já desenhavam a arquitetura do que poderiam ser os anos seguintes. Um dos documentos mais pertinentes à nossa observação é a publicação $A$ imaginação a serviço do Brasil, o programa de Lula para a cultura naquele pleito. O texto busca apresentar a importância da cultura para o desenvolvimento social e econômico do país. O enunciado demonstra a influência da UNESCO quando trata a cultura como um dos direitos básicos do cidadão. Também é possível destacar a transversalidade da cultura quando menciona que esta deveria ser conjugada com os demais setores.

Está expresso nesse texto o compromisso com Políticas Públicas de Cultura entendidas como um direito básico do cidadão. Como um direito republicano tão importante como o direito ao voto, à moradia digna, à saúde, à educação, à aposentadoria. A transmissão dos seus valores ensinados e aprendidos ao longo da história. Portanto, o que propomos aqui é a recuperação do papel da esfera pública de suas tarefas indutoras e reguladoras da produção e difusão cultural, a formação do gosto e a qualificação dos nossos artistas em todas as linguagens. Conjugar as Políticas Públicas de Cultura com as demais políticas de governo e redefini-las, em sintonia com o novo Projeto Nacional, de forma que venham a cumprir o papel de recuperar a auto-estima do nosso povo, contribuir para a inclusão social, romper com o apartheid cultural vigente e afirmar a nossa imagem diante das demais culturas do mundo é a tarefa que a sociedade brasileira exige do novo governo. Nós mergulhamos no mosaico cultural do Brasil para recolher as experiências concretas que realizamos hoje, nos Estados e municípios que governamos, para, a partir delas e da elaboração dos estudiosos, gestores e artistas oferecer ao país um Programa que expresse o que desejamos: "A imaginação a serviço do Brasil”. (PARTIDO DOS TRABALHADORES, 2002, p. 1)

O documento traz como premissa principal uma citação ao item 35 do programa geral do partido que trata das políticas públicas de cultura para "realizar um amplo processo de inclusão cultural, garantindo, de forma progressiva, o acesso de toda a cidadania à produção e fruição cultural, bem como a livre circulação de ideias e de formas de expressão artística" (Idem, p.8) O programa geral de Lula em 2002 apresenta como eixos estruturantes programáticos: o social, o democrático e o nacional. A agenda proposta para a cultura elenca itens que servirão de base para a política a ser implementada e prevê: cultura como política de Estado, economia da cultura, gestão democrática, direito à memória, cultura e comunicação, transversalidades das políticas públicas de cultura. Os itens são desenvolvidos a partir dos três eixos estruturantes do programa geral.

O primeiro capítulo do programa intitulado Cultura como direito social básico 
demonstra o tom de todo o documento, o entendimento de que cultura é uma premissa básica à cidadania e deveria ser levada em conta junto aos demais setoriais sociais públicos como educação e saúde. O primeiro apontamento concreto de propostas do documento, não por acaso, faz menção ao nosso objeto de pesquisa, o SNC, que naquele momento ainda não tinha um nome definitivo.

Qualquer política de cultura a ser adotada pelo país deve garantir a abertura dos canais institucionais e financeiros, por meio da constituição do Sistema Nacional de Política Cultural, a amplos setores tradicionalmente atendidos pelas políticas de recorte social ou assistencialistas. (PARTIDO DOS TRABALHADORES, 2002, p.13).

Logo em seguida, o enunciado parte a uma extensa crítica ao MinC do período FHC e ao modelo de financiamento à cultura vigente até então e especialmente à Lei Rouanet. "(...) o MinC defende com clareza a quem pretende beneficiar com sua política: aqueles capazes de realizarem estratégias de comunicação competentes para atraírem a atenção das empresas e garantirem o retorno de marketing esperado." (PARTIDO DOS TRABALHADORES, 2002, p. 14) Citam também Enrique Iglesias, presidente do Banco Interamericano de Desenvolvimento (BID), em pronunciamento na Assembleia-Geral da UNESCO em 1997, para justificar a cultura como fator de desenvolvimento social e econômico. É interessante observar aqui que, apesar do viés social da proposta, a ideia de cultura como desenvolvimento econômico permeia boa parte do documento.

Finalmente, no desenvolvimento dos itens que servirão de base para a agenda de cultura, mais especificamente no que tange à "Gestão democrática", o enunciado apresenta como prioridade a implantação do PNC e do SNC.

3.1 Implantar o Plano Nacional de Cultura: o Governo Democrático Popular se empenhará. pela aprovação no Congresso Nacional, do Projeto de Emenda Constitucional (PEC 306-A, de 2000), de autoria dos deputados Gilmar Machado (PT/ MG) e Marisa Serrano (PSDB/MS), que acrescenta ao artigo 215 da Constituição Federal, o parágrafo $3^{\circ}$, instituindo o Plano Nacional de Cultura de duração plurianual, visando ao desenvolvimento cultural do País e à integração das ações do poder público que conduzem à: I. defesa e valorização do patrimônio cultural brasileiro; II. produção e difusão de bens culturais; III. formação de pessoal qualificado para a gestão da cultura em suas múltiplas dimensões; IV. democratização do acesso aos bens de cultura; V. valorização da diversidade Étnica e regional; 3.2. implantar o Sistema Nacional de Política Cultural. Com base nas prescrições constitucionais, o Ministério da Cultura deve implantar o Sistema Nacional de Política Cultural, através do qual o poder público garantirá a efetivação de políticas públicas de cultura de forma integrada e democrática, em todo o país, incluindo aí, especialmente, a rede escolar. O SNPC é a condição necessária para a efetiva descentralização da política nacional de cultura, pois os diversos projetos e/ou equipamentos públicos culturais, das três 
esferas de governo, assim como as instituições privadas e do terceiro setor, somente acessariam os recursos do FNC no caso de estarem legalmente integradas ao Sistema. Com essa proposta, o controle social do funcionamento e aplicação dos recursos advindos do FNC, via SNPC, deverá ser feito, de forma democrática e participativa, pelos conselhos de cultura respectivos. Em caso da não existência desses, sua criação ser obrigatória para a inclusão do município ou estado no Sistema. (PARTIDO DOS TRABALHADORES, 2002, p. 13)

O trecho que fala sobre o futuro SNC (aqui ainda chamado de Sistema Nacional de Política Cultural - SNPC) revela que, desde 2002 pelo menos, o projeto de estruturação do sistema (com conselhos e fundos) já estava definido. Ainda que a PEC do SNC só tenha sido inscrita no Congresso ano de 2005, a arquitetônica inicial do SNC já estava oficialmente desenhada no programa de cultura de Lula em 2002.

O programa geral de Lula é assinado e coordenado por Antonio Palocci e o documento referente à cultura é assinado por diversos intelectuais e artistas e foi coordenado por: Antonio Grassi, Hamilton Pereira da Silva, Marco Aurélio de Almeida Garcia, João Roberto Peixe, Márcio Meira, Margarete Moraes, Sérgio Mamberti. As participações de Grassi, Meira, Mamberti e Peixe, como pensadores da cultura e futuramente personagens chave do MinC na construção do Sistema, foram fundamentais na formulação dessas políticas.

Com a posse de Lula em 2003, os processos previstos em seus programas finalmente poderiam começar a tornar-se realidades concretas. O tom das propostas imediatamente estariam refletidos nos gestores escolhidos para compor os principais cargos do executivo. A escolha do cantor Gilberto Gil foi sem dúvida estratégica para o novo projeto. Não apenas por sua relação com a cultura popular brasileira, mas também por ser negro e respeitado como um grande artista no Brasil e no exterior, fator que ajudaria na divulgação das propostas e por ser um articulador cultural de reconhecida inteligência que estava além do visível. Gil era a pessoa perfeita para romper os paradigmas simbólicos das políticas culturais para uma proposta mais popular, ainda que ele não estivesse presente na idealização do programa. $\mathrm{Na}$ época, Gilberto Gil era integrante do Partido Verde (PV) e foi chamado também por fazer parte da coligação da chapa.

Já como ministro, Gil, em seu discurso de posse no MinC no ano de 2003, evidenciou a intenção e a vontade da gestão de ampliar o olhar sobre a cultura a partir do enfoque antropológico e da diversidade cultural. O conteúdo chave de sua proposta nos remete aos discursos da Unesco a partir dos anos 1980 e ao olhar de cidadania cultural de Chauí. Gil trouxe este novo olhar que levava em conta não apenas a cultura vista como arte ou como 
instituição, que dava o tom para as gestões anteriores, mas a cultura como parte de um todo, em sua forma mais ampla e diversa, em diálogo com os mais diversos setores do desenvolvimento social e econômico. Em tom quase metafórico, Gil enunciava esta nova forma de pensar a cultura e seus fazeres.

(...) E o que entendo por cultura vai muito além do âmbito restrito e restritivo das concepções acadêmicas, ou dos ritos e da liturgia de uma suposta "classe artística e intelectual". (...) Cultura como tudo aquilo que, no uso de qualquer coisa, se manifesta para além do mero valor de uso. Cultura como aquilo que, em cada objeto que produzimos, transcende o meramente técnico. Cultura como usina de símbolos de um povo. Cultura como conjunto de signos de cada comunidade e de toda a nação. Cultura como o sentido de nossos atos, a soma de nossos gestos, o senso de nossos jeitos. Desta perspectiva, as ações do Ministério da Cultura deverão ser entendidas como exercícios de antropologia aplicada. (...) Não cabe ao Estado fazer cultura, mas, sim, criar condições de acesso universal aos bens simbólicos. Não cabe ao Estado fazer cultura, mas, sim, proporcionar condições necessárias para a criação e a produção de bens culturais, sejam eles artefatos ou mentefatos. Não cabe ao Estado fazer cultura, mas, sim, promover o desenvolvimento cultural geral da sociedade. Porque o acesso à cultura é um direito básico de cidadania (...) (GIL, 2003)

Gil diz em seu primeiro discurso como Ministro da Cultura na Comissão de Educação e Cultura da Câmara dos Deputados:

(...) fiz uma série de consultas a pessoas que conhecem profundamente cada setor da cultura. Procurei ainda me aproximar dos militantes do PT que elaboraram o programa de cultura da campanha eleitoral, um documento excelente chamado "A imaginação a serviço do Brasil". O presidente Lula me deixou à vontade para escolher a equipe e formular o plano de ação. Houve pressões, claro, mas não do presidente ou das forças políticas que o apoiaram. Elas vieram do movimento social organizado do setor e dos lobbies que atuam na cultura, preocupados com as possíveis mudanças. Resisti às pressões e exerci radicalmente a autonomia concedida pelo presidente. Escolhi os dirigentes do MinC de acordo com a minha convicção e a minha sensibilidade, prezando, como disse, a capacidade e a pluralidade. Montei um time que, sob todos os aspectos, merece o adjetivo "heterogêneo" (GIL, 2005).

Os preceitos de uma nova maneira de fazer política cultural começaram a ser divulgados efetivamente aos agentes da esfera a partir da campanha pela aprovação da PEC $150^{87}$, inscrita no congresso em 2003 e que propunha uma ampliação do orçamento mínimo das pastas de cultura.

\footnotetext{
87 A PEC 150/2003 propunha uma ampliação do piso dos orçamentos de cultura nos três âmbitos públicos. Previa um mínimo de $2 \%$ para o orçamento federal, de 1,5\% para os estados e $1 \%$ para os municípios. Por conta da resistência do próprio ministério da fazenda petista à proposta, alegando falta de verbas, em 2014 a deputada Jandira Feghali (PC do B - RJ) apresentou uma nova proposta, a PEC 421, que previa o aumento escalonado dos
} 
Outro marco histórico do período inicial foi o programa Cultura Viva, lançado em 2004, criado pelo historiador e gestor Célio Turino. O Cultura Viva possibilitou a implantação e o apoio a mais de dois mil Pontos de Cultura já na primeira fase da gestão e buscava incentivar a produção de cultura autossustentável, construída de baixo para cima. Os Pontos de Cultura foram a primeira ação efetiva de democracia cultural ${ }^{88}$ desta nova gestão pois, ao obrigar a compra de um kit multimídia, permitia aos grupos beneficiados, gerarem renda e se autogerirem. Entretanto, ainda como programa de governo, não viabilizava uma nova forma estruturante de fazer política cultural, mas mostrava que era possível distribuir as verbas de cultura de uma maneira diferente do que previa a Lei Rouanet, isto é, fora da lógica do mercado e visando a sustentabilidade.

Entre os diversos documentos criados em seguida, o mais importante deles e objeto central de nossa tese é a PEC do Sistema Nacional de Cultura (SNC). Inscrita pelo Deputado Federal Paulo Pimenta (PT- RS) por meio das Propostas de Emendas Constitucionais, PEC 416/2005 ${ }^{89}$ (Câmara), mas aprovado como PEC 34/2012 ${ }^{90}$ no Senado Federal gerou o artigo 216-A da CF por meio da emenda constitucional n. $71^{91}$ de 29 de novembro de 2012.

O SNC na Constituição Federal "fundamenta-se na Política Nacional de Cultura e nas diretrizes estabelecidas no Plano Nacional de Cultura”. O Sistema estava previsto na estrutura do PNC e soma-se a este para a construção dessa nova arquitetura de política cultural, principalmente com a aprovação do Decreto Presidencial 5.520/2005 que institui o

orçamentos. A PEC foi aprovada na CCJC, mas por conta da crise política atualmente encontra-se parada entre comissões da Câmara dos deputados.

${ }^{88}$ (...) democratização da cultura é, na essência, um processo de popularização das chamadas artes eruditas (artes plásticas, ópera música erudita, etc) Na base desses programas de popularização está a ideia de que diferentes segmentos de uma população gostariam de ter acesso a esses modos culturais - ou poderiam ser persuadidos a expor-se a eles - caso se recorresse aos instrumentos adequados de educação, sensibilização e facilitação dessas práticas. (...) A essa concepção opõe-se a da democracia cultural, fundada no argumento de que programas de popularização como os defendidos pela tese da democratização cultural não vão nem longe, nem fundo o suficiente e se baseiam em concepções discutíveis do que é bom ou mau em cultura, do que é ou não um valor cultural, do que deve e pode ou não deve ser consumido. Para os defensores da democracia cultural, a questão principal não reside na ampliação da população consumidora, mas na discussão sobre quem controla os mecanismos de produção cultural e na possibilitação do acesso à produção da cultura em si mesma. Políticas de democracia cultural se apoiariam não na noção de serviços culturais a serem prestados á população mas no projeto de ampliação do capital cultural de uma coletividade no sentido mais amplo dessa expressão. (COELHO, 2012, pp. $162-163$ )

89 Informações oficiais sobre a PEC 416/2005. Disponível em: < http://www.camara.gov.br/proposicoesWeb/fichadetramitacao?idProposicao=290677 > acesso em 08 de março de 2014.

${ }^{90}$ PEC 34/2012 (PEC do SNC no Senado Federal) Disponível em: < http://www25.senado.leg.br/web/atividade/materias/-/materia/106347?o=c > acesso em 08 de dezembro de 2014. ${ }_{91}$ Projeto de emenda constitucional 71/2012 que institui o artigo 216-A na constituição. Disponível em: < http://legis.senado.leg.br/legislacao/ListaTextoIntegral.action?id=246188\&norma=265892 > Acesso em $12 \mathrm{de}$ dezembro de 2014. 
Sistema Federal de Cultura ${ }^{92}$ e reorganiza Conselho Nacional de Políticas Culturais.

Art. 216-A - O Sistema Nacional de Cultura, organizado em regime de colaboração, de forma descentralizada e participativa, institui um processo de gestão e promoção conjunta de políticas públicas de cultura, democráticas e permanentes, pactuadas entre os entes da Federação e a sociedade, tendo por objetivo promover o desenvolvimento humano, social e econômico com pleno exercício dos direitos culturais. $\S 1^{\circ} \mathrm{O}$ Sistema Nacional de Cultura fundamenta-se na política nacional de cultura e nas suas diretrizes, estabelecidas no Plano Nacional de Cultura e rege-se pelos seguintes princípios: I - diversidade das expressões culturais; II - universalização do acesso aos bens e serviços culturais; III - fomento à produção, difusão e circulação de conhecimento e bens culturais; IV - cooperação entre os entes federados, os agentes públicos e privados atuantes na área cultural; V integração e interação na execução das políticas, programas, projetos e ações desenvolvidas; VI - complementaridade nos papéis dos agentes culturais; VII - transversalidade das políticas culturais; VIII - autonomia dos entes federados e das instituições da sociedade civil; IX - transparência e compartilhamento das informações; X - democratização dos processos decisórios com participação e controle social; XI - descentralização articulada e pactuada da gestão, dos recursos e das ações; XII - ampliação progressiva dos recursos contidos nos orçamentos públicos para a cultura. $\S$ $2^{\circ}$ Constitui a estrutura do Sistema Nacional de Cultura, nas respectivas esferas da Federação: I - órgãos gestores da cultura; II - conselhos de política cultural; III - conferências de cultura; IV - comissões intergestores; V planos de cultura; VI - sistemas de financiamento à cultura; VII - sistemas de informações e indicadores culturais; VIII - programas de formação na área da cultura; e IX - sistemas setoriais de cultura. $\S 3^{\circ}$ Lei federal disporá sobre a regulamentação do Sistema Nacional de Cultura, bem como de sua articulação com os demais sistemas nacionais ou políticas setoriais de governo. $\S 4^{\circ}$ Os Estados, o Distrito Federal e os Municípios organizarão seus respectivos sistemas de cultura em leis próprias." Art. $2^{\circ}$ Esta Emenda Constitucional entra em vigor na data de sua publicação " (EC n.71, 2012, art. 216-A)

Com a aprovação da PEC do Plano Nacional de Cultura em 2005 são iniciadas as ações para implantá-lo. Além da PEC do SNC, inscrita naquele mesmo ano no Congresso, Gil e equipe passam para uma nova etapa, a composição das diretrizes que comporiam as metas deste Plano agora previsto na Constituição Federal.

A criação do Protocolo de Intenções visando ao desenvolvimento de condições institucionais para a implantação do Sistema Nacional de Cultura é uma das primeiras ações realizadas pelo MinC para a implantação do SNC. Graças ao protocolo, entre março de 2005 a junho de 2006, mais de 1.700 municípios já haviam aderido ao sistema. O protocolo ressaltava

\footnotetext{
${ }^{92}$ O Sistema Federal de Cultura difere-se do Sistema Nacional de Cultura na nomenclatura e na estrutura. Enquanto o SNC compreende o todo do sistema, incluindo os sistemas estaduais, municipais e setoriais, o SFC compreende as tarefas, a interlocução com outros organismos estatais, atribuições do sistema em âmbito federal e como este deve se articular com os demais entes federados. De certo modo, é possível dizer, que o SFC é uma pré-regulamentação do SNC que permite seu funcionamento na prática.
} 
entre seus objetivos os seguintes pontos: a formulação e implantação do Plano Nacional de Cultura; a criação, instalação, implementação e/ou fortalecimento dos Conselhos de Política Cultural de forma integrada; a realização de conferências de cultura; o fortalecimento de sistemas de financiamento específicos para cultura, e a integração e otimização dos recursos financeiros; a implantação de sistemas setoriais das diversas áreas da cultura - bibliotecas, museus, centros culturais, artes em geral, patrimônio cultural, entre outras - com participação e controle social; a implantação e disponibilização democrática do Sistema Nacional de Informações Culturais, constituído de bancos de dados sobre bens, serviços, programas e instituições de natureza cultural; a criação, implantação ou manutenção de órgão específico de gestão da política cultural no âmbito de cada Município signatário. (MEIRA; GAZZINELLI, 2006, p. 19) Porém, o protocolo permitia que os entes federados ficassem ligados ao sistema por apenas dois anos. Caso este ente não completasse a implantação de seu sistema em dois anos, a adesão estaria automaticamente desfeita. Por este motivo, em 2009, o MinC criou o Acordo de Cooperação Federativa que substituiu o Protocolo na adesão ao SNC. O Acordo, entre outros novos critérios, permitiu que esse período de "pré-implatação" dos sistemas territoriais não mais tivesse um limite temporal estabelecido.

A aprovação do Decreto Presidencial 5.520/2005 em 24 de agosto de 2005, que institui o Sistema Federal de Cultura (SFC) e regulamenta a composição do Conselho Nacional de Políticas Culturais (CNPC), é o início da organização do que viria a ser o SNC nos anos seguintes. O objetivo principal do SFC, além de gerir a parte federal do sistema é integrar todas as outras partes do MinC e suas entidades relacionadas na gestão dessa nova política.

Resumindo, o Sistema Federal de Cultura objetiva a integração de programas e ações culturais promovidos por diferentes áreas da administração direta e indireta federal, além daquelas sob a coordenação do Ministério da Cultura e entidades a ele vinculadas - a Biblioteca Nacional, a Funarte, o Iphan, a Fundação Palmares, a Casa de Rui Barbosa e a Agência Nacional de Cinema (Ancine). A idéia geral é otimizar investimentos, promover a informação cultural integrada, realizar padrões de gestão e planejamento de políticas e ações culturais à altura do que a área e o país merecem e promover a avaliação permanente das diretrizes, metas e objetivos acordados para o desenvolvimento contínuo do setor. Para tal, parte-se do princípio de que a sociedade é o principal árbitro da gestão - fazendo-se representar em conselhos gerais ou setoriais e nas conferências de cultura. A sociedade, nesta visão, é entendida enquanto setorizada em diferentes áreas do fazer cultural e enquanto comunidade ampla, de usuários, cidadãos, etc. (MEIRA; GAZZINELLI, 2006, p. 18)

Com a expectativa da aprovação da PEC do SNC, mas com a PEC do PNC aprovada era necessário iniciar o processo com as ferramentas legais disponíveis. O decreto em seu artigo 
primeiro institui o SFC como uma ferramenta de integração entre os órgãos competentes do governo federal com vistas a articular ações previstas no PNC. Entendido como uma prévia do SNC regulamentado, o decreto do SFC delegava ao MinC diversas competências interessantes aos avanços do plano, como por exemplo: "exercer a coordenação geral do sistema", "coordenar e convocar a Conferência Nacional de Cultura", "incentivar, integrar e coordenar a formação de redes e sistemas setoriais", "estimular a implantação dos Sistemas Estaduais e Municipais". O decreto de 2005 foi uma pré-regulamentação do SNC, porém com poder para acelerar o processo como um sistema integrado ao PNC que já estava aprovado e em fase de regulamentação. O SFC era necessário inclusive para ativar a formulação da lei de regulamentação do PNC (e de suas metas), pois colocava em prática pontos essenciais do sistema, o Conselho (CNPC), as Conferências (CNC) e principalmente a implantação dos sistemas territoriais e setoriais. Entretanto, o mecanismo legal "decreto" deve ser compreendido como frágil na jurisprudência. Pode ser "derrubado" a partir de outro decreto presidencial que promova a extinção do mesmo, ou do SFC e do CNPC. A aprovação da lei de regulamentação do SNC poderia trazer maior garantia para a aplicação do SNC e do CNPC nesse processo, por ser um mecanismo legal mais resistente às vontades políticas antagônicas, pois depende também dos outros poderes, judiciário e legislativo.

Em 2006, o MinC contabilizava mais de 1200 municípios com acordo firmado no SNC, pois um dos critérios para a participação na I CNC era a adesão ao sistema. A Secretaria de Articulação Institucional (SAI) que cuidava do SNC e era capitaneada desde o final de 2003 por Marcio Meira começa a se preocupar neste momento com três pontos essenciais: a arquitetura, o ordenamento jurídico e a formação do sistema. E disso resulta o decreto de 2005. Era necessário iniciar os processos de implantação pelo país e o SNC ainda dependia da aprovação de sua PEC e posteriormente de sua regulamentação.

No segundo semestre de 2006, o MinC realizou a primeira formação sobre o SNC com módulos de 30 oficinas realizadas em parceria com o "Sistema CNI/SESI/SENAI, com o objetivo de aproximar a produção cultural dos municípios envolvidos dos Arranjos Produtivos Locais (APLs) ${ }^{93}$ ". (CALABRE, 2006, p.09) De acordo com o documento organizado pela

\footnotetext{
${ }^{93}$ APLs (Arranjos Produtivos Locais) é um conjunto de fatores econômicos, políticos e sociais, localizados em um mesmo território, desenvolvendo atividades econômicas correlatas e que apresentam vínculos de produção, interação, cooperação e aprendizagem. Os arranjos geralmente incluem empresas - produtoras de bens e serviços finais, fornecedoras de equipamentos e outros insumos, prestadoras de serviços, comercializadoras, clientes, etc., cooperativas, associações e representações - e demais organizações voltadas à formação e treinamento de recursos humanos, informação, pesquisa, desenvolvimento e engenharia, promoção e financiamento.
} 
pesquisadora Lia Calabre, os resultados esperados a partir dessas oficinas eram:

Avançar na constituição dos sistemas públicos municipais e estaduais, e na elaboração do Sistema Nacional de Cultura; Fortalecer e estimular a criação de instituições públicas de cultura; Fortalecer as entidades e movimentos da sociedade civil; Gerar ou fortalecer mecanismos de apoio a empreendimentos culturais; Desenvolver e promover o intercâmbio entre produção cultural e APLs; Ampliar a integração dos programas que o MinC desenvolve de forma descentralizada; Ampliar o conhecimento sobre o $\mathrm{SMinC}^{94}$ em médios municípios; Auxiliar na relação entre poder público e sociedade civil local; Auxiliar no relacionamento da produção cultural com o setor produtivo local; e Qualificar o relacionamento dos setores público e privado da cultura com representantes do Poder Legislativo. (CALABRE, 2006, p. 10)

A publicação em livro da primeira versão das diretrizes que estruturariam o PNC no ano de 2007 chamou a atenção do setor cultural para essa nova etapa de democratização de informações sobre as políticas culturais e da ampliação do acesso à produção de cultura. Entretanto, foi por meio de sua segunda edição em 2008, que recebeu centenas de interações da sociedade civil em seminários realizados em todos os estados, que de fato o PNC passa a tomar forma substancial de sua arquitetônica.

No ano de 2008, Gilberto Gil deixa o Ministério para retornar a sua carreira como cantor. Em seu lugar, toma posse seu Secretário Executivo Juca Ferreira. Restando apenas dois anos de governo Lula, a equipe de Juca empenha-se em continuar as políticas e os programas criados durante a gestão de Gil. Porém, os trâmites de implantação do SNC ainda dependiam da aprovação da lei regulamentar do PNC e da PEC do SNC. Com isso, é possível dizer que nesses dois anos da gestão Juca, a implantação do sistema não foi prioridade, ainda que tenham realizado a importante II Conferência Nacional de Cultura em 2010.

O segundo livro sobre as diretrizes do PNC de 2008 foi publicado já com a assinatura de Juca Ferreira, e evidenciava as três dimensões que o Plano (e consequentemente o Sistema) estava propondo: dimensão simbólica, dimensão cidadã, dimensão econômica. O documento ressalta a importância da diversidade cultural e cita como fonte justificativa e de inspiração, a UNESCO, a Declaração Universal sobre a Diversidade Cultural, a Conferência Mundial sobre Políticas Culturais, a Agenda 21 da Cultura, e a Convenção para a proteção e Promoção da Diversidade das Expressões Culturais.

O Plano Nacional de Cultura está sendo elaborado, portanto, em um contexto político em que ganham força várias iniciativas voltadas ao fortalecimento de relações internacionais mais solidárias, com as quais o Brasil deve dialogar e contribuir. Pois estas articulações são imprescindíveis para lidar com uma

\footnotetext{
${ }^{94}$ Sistema MinC.
} 
conjuntura de tensão entre o local e o global, que expressa problemas e oportunidades inéditos. (MINISTÉRIO DA CULTURA, 2008, P. 15)

A publicação do PNC de 2008 sofreu diversas alterações se comparada à primeira edição de 2007. Traz um planejamento minucioso de toda a arquitetura de sua implantação e uma exposição de todas as ações que possibilitavam sua construção até aquele momento, divididos em anos e relações entre legislações criadas no Brasil e globalmente. O documento apresenta uma linha do tempo de todas as ações relacionadas realizadas até então e que comporiam a construção inicial do Plano / Sistema e inclui também os marcos legais para a cultura da Unesco e órgãos internacionais. O documento descreve em uma linha do tempo as ações realizadas relevantes à construção do sistema:

a) Seminário Cultura para Todos (2003) - Discussões para formulação e implementação da nova Política Nacional de Cultura;

b) Agenda 21 da Cultura (2004);

c) Câmaras Setoriais (2004) - estabelecem instâncias de diálogo entre Estados e representantes dos segmentos artísticos, voltadas à elaboração de políticas setoriais e transversais da Cultura;

d) Emenda constitucional N. 48 do PNC (2005) é aprovada em julho;

e) Proposta de Emenda Constitucional 416 do SNC (2005) é apresentada ao Congresso Nacional;

f) Decreto 5.520 de 24 de agosto (2005) institui o Sistema Federal de Cultura, com de finalidade integração de instituições e programas relacionados à cultura. É o primeiro passo para o SNC, pois também reformula o Conselho Nacional de Políticas Culturais;

g) $1^{\mathrm{a}}$ Conferência Nacional de Cultura (2005);

h) Convenção para a Proteção e a Promoção da Diversidade das Expressões Culturais (2005);

i) Projeto de Lei 6835 (2006) que propõe a instituição e a regulamentação do PNC;

j) Elaboração das diretrizes gerais do PNC (2006/ 2007);

k) Sistema de Informações e Indicadores Culturais (SNIIC) que tem seu primeiro levantamento estatístico gerando o primeiro diagnóstico oficial para a definição das metas do PNC. (2007);

1) Subcomissão Permanente de Cultura (2007) é criada no congresso para abrigar as audiências públicas para debates das propostas dos marcos legais propostos;

m) Suplemento Cultura (2007) - O IBGE publica as informações básicas sobre os 
municípios, a MUNIC. Os resultados da pesquisa sobre os municípios incidem diretamente nas formulações do PNC;

n) Instituto de Pesquisa Econômica Aplicada - IPEA (2007) - publica dois estudos sobre economia da cultura em parceria com o MinC;

o) Seminários Estaduais do Plano Nacional de Cultura (2008) com participação de gestores do MinC, parlamentares e sociedade civil ${ }^{95}$.

Dentre as ações realizadas entre os anos 2000 e 2008, sem dúvida, uma das mais relevantes foi a I Conferência Nacional de Cultura (CNC) em dezembro de 2005. Foram realizados mais de 400 encontros municipais entre setembro e dezembro de 2005, com a participação de mais de 40 mil pessoas, gestores de 1158 municípios, 19 estados e 438 conferências territoriais anteriores. As resoluções da $1^{\text {a }} \mathrm{CNC}$ compõem as diretrizes do projeto de lei do PNC apresentado em 2006 e aprovado como lei regulamentar em 2010. O envolvimento de milhares de pessoas no processo comprova que as metas propostas no PNC de fato foram construídas com ampla participação social.

A Conferência Nacional de Cultura (CNC) é a instância de consulta pública periódica do Conselho Nacional de Políticas Cultural que objetiva colher subsídios para a construção do Plano Nacional de Cultura e do Sistema Nacional de Cultura. A Conferência Nacional é a culminância de processos de encontros municipais, estaduais e macrorregionais. (SOTO; CANEDO; OLIVEIRA; SALGADO, 2010, P. 34)

Além disso, o documento de 2008 traz os valores e conceitos que estruturam o PNC em suas "Estratégias e diretrizes gerais". É inegável o diálogo com os preceitos da Agenda 21 da Cultura e são essenciais para nossa reflexão de tese, pois determinam qual é a visão de política cultural que se buscava:

a) Fortalecer a ação do estado no planejamento e na execução das políticas culturais;

b) Incentivar, proteger e valorizar a diversidade artística e cultural brasileira;

c) Universalizar o acesso dos brasileiros à fruição e à produção cultural;

d) Ampliar a participação da cultura no desenvolvimento socioeconômico sustentável;

e) Consolidar os sistemas de participação social na gestão das políticas culturais.

Nos anos de 2009 e 2010, o MinC elaborou junto à Universidade Federal da Bahia (UFBA) o Programa de Formação de Gestores e Conselheiros Culturais que serviu como curso piloto posteriormente aplicado em estados e municípios em parceria com a Universidade Federal de Santa Catarina (UFSC) e posteriormente com outras universidades.

\footnotetext{
${ }^{95}$ Informações presentes na publicação sobre o Plano Nacional de Cultura de 2008.
} 
A Coordenação-Geral de Instrumentos de Gestão do Sistema Nacional de Cultura - CGSNC é responsável pelos Programas Nacionais de Apoio ao Fortalecimento Institucional de Órgãos Gestores da Cultura e de Formação de Gestores Culturais e desenvolve os seguintes projetos: Formação de Gestores e Conselheiros Culturais; Apoio à Elaboração de Planos Estaduais e Municipais de Cultura; Oficinas Temáticas. (OLIVIERI, 2018, p. 170)

Também neste mesmo período e em parceria com a UFBA, elaborou um mapeamento $^{96}$ das instituições públicas e privadas que promoviam formação na área de produção e gestão cultural. A compreensão de que era essencial preparar e formar gestores para este novo modelo de política foi surgindo ao longo dos processos de implantação do sistema pelo país. Por meio dessas primeiras experiências foram moldando o que seria esse primeiro curso e com o mapeamento foram compreendendo quais eram as regiões que mais careciam dessas formações.

A expectativa pela aprovação do projeto de lei de regulamentação do PNC que aconteceria em 2010 ainda não resolvia as principais questões do sistema. Além da PEC do Sistema tramitar vagarosamente pelo Congresso Nacional, o Fundo Nacional de Cultura ainda estava regulamentado via Lei Rouanet. A dependência do legislativo para a aprovação da PEC do SNC, bem como a dependência de uma nova regulação do Fundo Nacional de Cultura (FNC) atrapalhou o planejamento inicial da urgência de uma Política Nacional de Cultura renovada. O FNC, enquanto mecanismo previsto inicialmente na Lei 8.313, a Rouanet, conserva a premissa de que este mecanismo depende e responde à lei do mecenato.

O uso do FNC até hoje ainda decorre da lógica prevista no Programa Nacional de Apoio à Cultura (Pronac), de que as verbas remanescentes de projetos ou de contrapartidas alimentem o Fundo ou que este dependa da dotação orçamentária prevista na Lei Orçamentária Anual federal. Enquanto este mecanismo não tiver uma nova regulamentação aprovada, a distribuição de verbas para a cultura ainda estaria relegada aos preceitos da Lei Rouanet ou as vontade políticas na distribuição de recursos do orçamento anual. Desse modo, ainda não consegue fornecer as verbas necessárias à plena execução do SNC e do PNC em todo país.

O primeiro passo para que o FNC seja regulado para a distribuição de verbas via SNC foi instituído a partir de 2010 com a criação do Projeto de Lei Procultura que visa estabelecer o novo Programa Nacional de Fomento e Incentivo à Cultura. Inicialmente pensado como

\footnotetext{
${ }^{96}$ Disponível em: < http://www.organizacaocultural.ufba.br/index.php?/apresentacao $>$ acesso em $12 \mathrm{de}$ novembro de 2017.
} 
uma proposta que apenas tornaria a distribuição geográfica dos recursos da lei Rouanet mais justa, recebeu ao longo da tramitação um texto substitutivo escrito pelo deputado federal petista Pedro Eugênio, mas assinado pelo poder executivo que, entre diversas novas premissas, prevê uma nova regulamentação dos repasses do FNC voltado ao SNC. Com a aprovação da Procultura, pelo menos $30 \%$ das verbas de impostos recolhidos via incentivo fiscal poderiam abastecer diretamente o SNC e o PNC via transferência fundo a fundo para estados, municípios e Distrito Federal. Além de alterar significativamente o mecanismo do mecenato, prevendo critérios diferenciados para estipular a isenção fiscal para projetos mais ou menos comerciais, com diferentes faixas de desconto no imposto de renda, o PL também prevê a criação dos fundos setoriais e designava como a distribuição dos recursos devia ocorrer. Todavia, o PL encontrou muita resistência de parlamentares favoráveis à manutenção da Lei Rouanet. A partir de 2014, esteve em apreciação no Senado Federal como PLC 94/2014 em relatoria com senador Roberto Machado (PSB-MA). No final do ano de 2018, o PL foi arquivado por conta do final da legislatura dos senadores. Em março de 2019, o PL foi desarquivado pelo senador petista Humberto Costa e retomou sua tramitação a partir da Comissão de Cultura do Senado. Ainda aguarda apreciação em outras comissões.

João Roberto Peixe, ex-Secretário de Articulação Institucional do MinC no início do primeiro governo Dilma, faz uma crítica à manutenção do modelo de financiamento ligado à Lei Rouanet e defende que haja uma equiparação de fundos em que o FNC receba o mesmo montante destinado ao patrocínio de projetos via mecenato.

Na realidade, a política de financiamentos público da cultura no Brasil nos governos Lula e Dilma não mudou e continua sendo determinada pela lei 8.313/91, a chamada Lei Rouanet, com o mecanismo da renúncia fiscal, com todas as suas distorções, permanecendo e se fortalecendo cada vez mais como a principal forma de financiamento público na área cultural. (...) É impossível implementar uma nova política cultural no Brasil mantendo praticamente intocável a velha política de financiamento público via renúncia fiscal, onde $\mathrm{o}$ setor privado $\mathrm{e}$ as regiões mais fortes economicamente continuem privilegiadas, concentrando os recursos, em detrimento das políticas públicas e das regiões mais pobres economicamente, embora detentoras do maior patrimônio cultural do país: a sua diversidade. Não é por acaso que as regiões que apresentam maior nível de adesão ao SNC são exatamente as mais excluídas pela atual Lei Rouanet: as regiões Norte e Nordeste. Para alterar esse quadro é imprescindível assegurar que o Projeto de Lei do Procultura estabeleça que os recursos destinados ao FNC na Lei Orçamentária Anual (LOA) não poderão ser inferiores aos destinados ao mecanismo da renúncia fiscal. Além de recursos do orçamento, o FNC deve contar, também, com outras fontes de financiamento. Em especial, deve utilizar o dispositivo previsto na lei 12.351, de 22 de dezembro de 2010 e buscar assegurar para o FNC o mínimo de $10 \%$ dos recursos do Fundo Social do Pré-Sal (meta 50 do Plano Nacional de Cultura). (PEIXE, 2016, 
pp. $241-242)$

É importante ressaltar que, ainda que o PL do Procultura não tenha sido aprovado, a menção ao Sistema Nacional de Cultura em diversas partes do texto do PL é um fator que não pode ser descartado. O SNC nomeia um dos capítulos do enunciado, que também trata da criação de fundos setoriais, de uma nova regulamentação do FNC e da equiparação dos Fundos, que visavam alimentar os sistemas nos entes federados. A regulamentação destes mecanismos é essecial ao sistema, principalmente por alterar a lógica financeira do Fundo Nacional de Cultura. A não aprovação deste PL atrasou o desenvolvimento do sistema. Para retomar este importante processo da engrenagem enquanto esse PL tramita no Congresso Nacional, será necessário buscar outras fontes de recursos para o mesmo, como por exemplo, o fundo do pré-sal.

Outro ponto essencial e que impedia os avanços do sistema, ainda que este já estivesse em plena implantação, eram as verbas escassas destinadas à cultura e a baixa execução do que estava previsto no orçamento federal. Em 2010, o governo federal destinou a maior porcentagem ao FNC em sua Lei Orçamentária Anual (LOA), uma previsão de 840 milhões. Contudo, neste mesmo ano a execução do FNC não chegou nem a 437 milhões. Nas últimas décadas do século XX, o montante destinado à função cultura ${ }^{97}$ em âmbito federal nunca ultrapassou o patamar dos 1,5\% na LOA, e, em sua execução, em raros momentos ultrapassou $0,30 \%$ liquidados do orçamento geral. Isto é, ainda que tenhamos conseguido chegar à marca histórica de quase $1,5 \%$ de orçamento na função cultura, o empenho e a execução dessas verbas sempre apresentou menos de $1 / 3$ do que lhe era destinado por lei. A decisão do montante empenhado para cada pasta ministerial é sempre do alto escalão do governo. Porém a decisão do montante direcionado ao FNC é do Ministro da Cultura. Entretanto neste mesmo ano, o montante reservado para a Rouanet via isenção fiscal foi de 1,457 bilhões de reais, quase o dobro do FNC. Mesmo num ano com um orçamento geral positivo como 2010, não foi do interesse da Presidência da República e das pastas ministeriais da Fazenda e Planejamento investir efetivamente no FNC e nesse novo projeto para a cultura. De acordo com Carlos Paiva Neto, que é pesquisador do tema e foi Secretário de Fomento e Incentivo à Cultura entre 2015 e 2016:

Os dados mostram que o Fundo Nacional de Cultura, no governo FHC (1995-2002) teve seus recursos dobrados (de R\$ 50 para $\mathrm{R} \$ 105$ milhões, sendo que em 2001 chegou a 172 milhões), e no governo Lula (2003 - 2010)

\footnotetext{
${ }^{97}$ A função cultura compreende todos os recursos previstos para as ações culturais num orçamento público e não apenas recursos do MinC, mas também de outros órgãos do executivo e do legislativo.
} 
multiplicado por seis (de R \$ 101 milhões para R \$ 622 milhões) tendo caído drasticamente desde então, encerrando o ano de 2016 com R\$ 68 milhões. (PAIVA NETO, 2017, p.33)

O PL 6.835/2006 de regulamentação do Plano Nacional de Cultura aprovado em 2010 como lei federal 12.343/2010 e composto por um anexo com 275 ações foi considerado inatingível no primeiro processo decenal.

Figuras 1 e 2: Rede de interações previstas no SNC
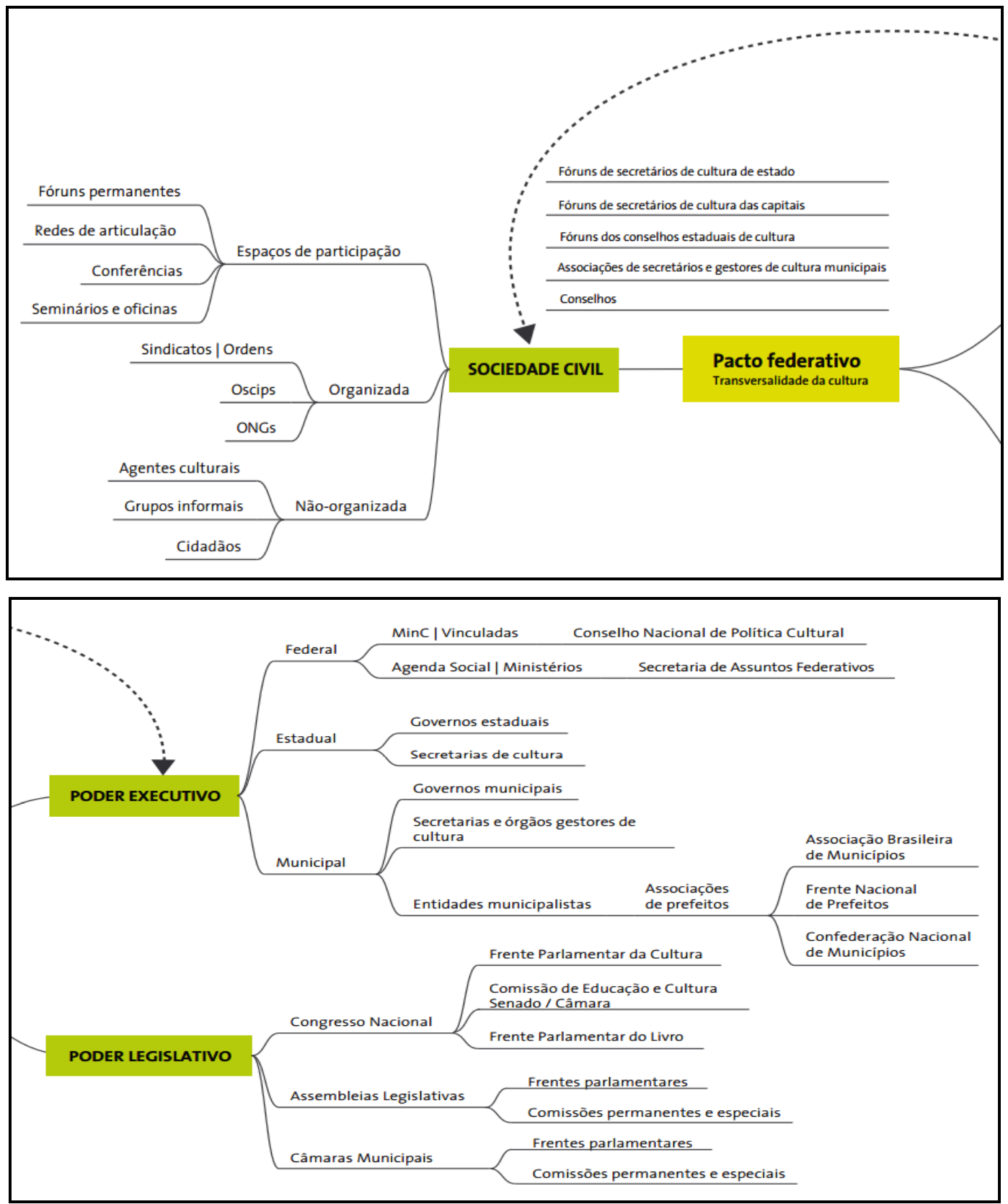

Fonte: Publicação Porque aprovar o Plano Nacional de Cultura (2009) ${ }^{98}$

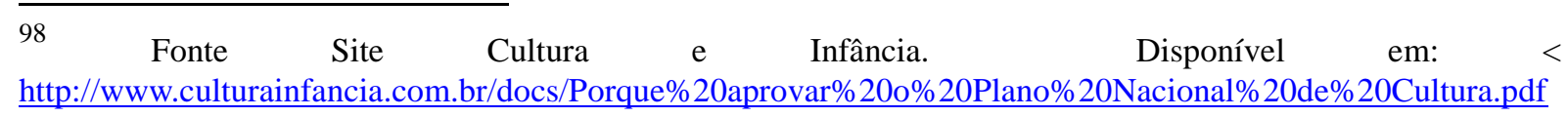
$>$ Acesso em 16 de agosto de 2016. 
Para auxiliar na aprovação do PL no ano de 2009 o MinC publicou o documento intitulado Porque aprovar o Plano Nacional de Cultura. A publicação traz um descritivo detalhado do que estavam construindo que visava auxiliar o leitor na compreensão da complexa estrutura proposta para o Pacto Federativo. Na imagem acima, que está dividida ao meio por conta de seu tamanho, é possível observar o desenho de todas as partes envolvidas no pacto previsto no sistema. Ainda que o processo tivesse passado por diversas etapas e discussões após a aprovação da lei 12.343/2010, uma reformulação foi necessária para assim chegar às 53 metas do Plano que deram início ao processo efetivamente. Uma consulta pública realizada entre 21 de setembro e 20 de outubro de 2011 definiu as 53 metas do PNC que foram publicadas no DOU por meio da portaria 123, de 13 de dezembro de 2011, sendo 22 das metas diretamente relacionadas ao SNC.

(...) submeteu a consulta 48 metas, preestabelecidas com base nas 275 ações e diretrizes que compõem o anexo do PNC. (...) De acordo com o MinC durante este período, foram feitas 8.679 visitas ao site por 6.723 pessoas, foram gerados 488 comentários e mais de 600 contribuições sobre as metas. Além da discussão em cima das metas preestabelecidas outras 62 novas metas foram sugeridas. Ao final do processo foram escolhidas 53 metas. (VARELLA, 2014, p.153)

No ano de 2010, foi realizada a II Conferência Nacional de Cultural capitaneada pela nova Secretária de Articulação Institucional (SAI) Silvana Meireles. Esta segunda Conferência teve relevante papel na construção do SNC, pois divulgou ainda mais o processo que estava acontecendo e quase dobrou o número de entes federados ao sistema. Trataremos de mais detalhes sobre a II CNC no próximo capítulo desta tese.

Durante a gestão das duas ministras da primeira gestão do Governo Dilma Rousseff (2011 - 2014), Ana de Hollanda e Marta Suplicy, a implantação das novas políticas para a cultura sofreu um atraso considerável, ainda que tivéssemos alguns avanços. Já no início da gestão foram anunciados cortes no orçamento da cultura, principalmente em programas que tinham sido utilizados como referência na campanha eleitoral de 2010, como o Cultura Viva. Estes cortes causaram uma grande mobilização dos agentes culturais em todo país que passaram o ano todo criticando as ações de Ana de Hollanda e do MinC, pedindo a saída da nova ministra de Dilma e o retorno das verbas ao programa.

A Ministra Ana de Hollanda (janeiro 2011 - setembro 2012) não teve como prioridade investir nos avanços da nova política cultural que vinha acontecendo. Ao contrário disso, em seu período no Ministério realizou cortes no programa Cultura Viva, e em seu lugar priorizou 
os debates sobre a Economia Criativa num viés industrial, demonstrando que estava trazendo uma nova agenda para a cultura. Ana criou a Secretaria de Economia Criativa e fechou a Secretaria de Diversidade Cultural criada por Gil e que cuidava dos Pontos de Cultura desde 2004. Contudo, durante a curta gestão de Ana (um ano e meio), algumas secretarias do MinC caminhavam com certa autonomia. Com isso foi possível continuar a implantação do SNC de algum modo, mesmo sem seu empenho enquanto ministra, pois os processos continuavam ocorrendo na Secretaria de Articulação Institucional, agora no comando de João Roberto Peixe, que era um militante pela construção do Sistema desde que compunha o CNPC. O empenho de Peixe nos anos da gestão Ana deve ser entendido como muito relevante para o andamento de diversas ações do SNC no período.

Em 2011, no governo Dilma, e com Ana de Hollanda como Ministra da Cultura, a SAI passa por uma reformulação na qual, significativamente, a implantação do SNC passa a ser seu foco principal. É também sintomático que Roberto Peixe, que estava à frente do SNC como Coordenador Geral de Relações Federativas e Sociedade da SAI, assuma a Secretaria. Este momento configura-se, portanto, como um marco no sentido do Sistema voltar a ocupar uma centralidade entre os projetos do Ministério, lugar que já tinha ocupado no primeiro governo Lula, durante a passagem de Meira e sua equipe. (BARBALHO, 2014, p. 10)

No ano de 2011, o MinC assinou um Termo de Cooperação Técnica com duas universidades federais para assessorar na implantação dos sistemas nos estados e municípios. Na primeira etapa do projeto estava previsto que a Universidade Federal da Bahia (UFBA) ${ }^{99}$ daria assessoria aos municípios e a Universidade Federal de Santa Catarina (UFSC) ${ }^{100}$ aos estados.

Nesta fase, a UFBA (mais especificamente professores dos cursos de Comunicação, Produção Cultural e de Administração) forneceria a metodologia para orientar os gestores municipais e conselheiros na correta implantação dos sistemas. O método inicial previa uma orientação por duas plataformas via internet e Ensino à distância via Moodle e também utilizava apostilas complementares e vídeos no youtube. A capacitação de gestores públicos de cidades e estados era um desafio na articulação entre o MinC, as universidades e as secretarias, pois a proposta ainda estava sendo pensada e desenhada e o sistema ainda era apenas um piloto.

\footnotetext{
99 Plataforma Moodle para assessoria dos Municípios. Disponível em: < http://www.moodle.ufba.br/course/category.php?id=728 > acesso em 01 de junho de 2016.

${ }_{100}$ Plataforma Moodle para assessoria as estados. Disponível em: < https://grupos.moodle.ufsc.br/course/view.php?id=183 > acesso em 01 de junho de 2016.
} 
A pesquisadora e gestora, Telma Luzia Pegorelli Olivieri (2018), que foi Coordenadora Geral de Instrumentos de gestão do SNC e responsável pelo Programa Nacional de Formação de Gestores e Conselheiros descreve que, além dos cursos desenvolvidos pela UFBA e UFSC, outros cursos foram reconhecidos e assessorados pelo MinC com vistas a formar gestores em diversos pontos do país tanto no formato EAD quanto presenciais.

a) Programa de Formação em Gestão Cultural (UFBA / extensão) 2010 / 11;

b) Curso para Formação de Gestores Culturais dos Estados do Nordeste $1^{\text {a }}$ edição (UFRPE / Latu sensu) 2012;

c) Curso de Extensão em Administração Pública de Cultura (UFRS / Extensão) 2013;

d) Curso de Extensão e Aperfeiçoamento em Gestão Cultural (UFPA / Extensão) 2013 / 14 ;

e) Programa de Apoio ao Desenvolvimento Cultural dos Municípios do estado do Rio de Janeiro PADEC (UERJ / Extensão) 2013 / 14;

f) Curso de Gestão Cultural - Formação de gestores Culturais do estado da Paraíba (UFCG / Extensão) 2013 / 14;

g) Metodologia para a Formação de Gestores Culturais dos estados e Municípios do Centro-oeste (UNB / Extensão) 2014;

h) Curso para Formação de Gestores Culturais dos Estados do Nordeste $2^{a}$ edição (UFBA / latu sensu) 2014;

i) Curso de Capacitação ao Sistema Municipal de Cultura (Consórcio Culturando / Extensão) 2014;

j) Curso de Extensão em Gestão Cultural - Municípios do Estado de Roraima (UFRR / Extensão) 2015.

Esses cursos promoveram o diálogo com os gestores e foram relevantes para compreender melhor como o sistema se estruturava nos mais diferentes tipos de cidades e estados e qual seriam as dificuldades para conseguir capacitar um número muito maior de gestores em milhares de cidades do país. Diferentes estados e municípios e seus respectivos gestores têm tempos diferentes de aprendizado, processos internos de burocracia e diferentes interesses efetivos nas políticas de cultura e no SNC. Estas diferenças geraram relativas distinções de processos na lógica de implantação em cada um dos territórios.

Os cursos de capacitação de gestores para a implantação dos sistemas foram pensados a partir dessas diferenças. Nas modalidades EAD, foram criadas plataformas simples, 
didáticas e com recursos verbo-visuais para auxiliar todos os públicos com diferentes formações e níveis de escolaridade. As plataformas incluíam os conteúdos das aulas, textos com reflexões e detalhes sobre as burocracias, um fórum de discussão para os gestores trocarem experiências e atividades escritas para incentivar a composição do que seriam as futuras minutas dos enunciados dos sistemas de cultura em cada território participante da formação.

Inicialmente, a UFBA assessorou gestores de vinte cidades, sendo doze capitais e oito municípios de grande porte que já estavam com seus acordos de cooperação assinados. De cada município foram selecionadas duas pessoas totalizando quarenta participantes. Até o fim de 2013, período de finalização desta primeira etapa, foram contabilizados treze municípios com minutas redigidas e prontas para inscrição como projetos de lei. A prioridade naquele momento era disseminar conhecimento e compreender se a metodologia adotada seria eficaz para assessorar as mais de duas mil cidades que estavam previstas para os próximos anos a escreverem seus enunciados.

A segunda etapa do projeto ocorreu entre 2014 e 2015 e contou com uma ampliação considerável ao assessorar 439 municípios, dentre eles 80 municípios da Bahia. No final de 2015, 32\% destes municípios apresentaram a implantação do sistema em fase avançada com minutas escritas e planos em vias de aprovação.

O Projeto de Apoio à Elaboração dos Planos Estaduais de Cultura (PAEPEC) foi desenvolvido por meio de um acordo da Faculdade de Administração da UFSC com o MinC para o auxílio da implantação dos Sistemas e Planos nos estados. Nas duas primeiras etapas participaram do projeto 16 estados da União e o Distrito Federal. ${ }^{101} \mathrm{O}$ projeto buscou implantar uma metodologia que envolvesse os gestores estaduais nas fases necessárias para a construção dos Planos estaduais: (1) instâncias de governança, (2) Processo de sensibilização e mobilização, (3) Diagnóstico, (4) Prognóstico e (5) Monitoramento e Avaliação.

A terceira etapa do projeto iniciada em 2016 sofreu considerável atraso no início de sua implantação por conta da crise política causada pelo impeachment de Dilma. Esta terceira etapa previa o treinamento de multiplicadores em outras universidades federais do país como já havia ocorrido, por exemplo, no estado de Roraima. No ano de 2017, o projeto avançou mais uma vez com a produção dos materiais em conjunto com pesquisadores da UFBA: Planos Municipais de Cultura: guia de elaboração e as apostilas divididas em 5 módulos

${ }^{101}$ Estados participantes da etapa: Acre, Amapá, Bahia, Ceará, Goiás, Mato Grosso, Mato Grosso do Sul, Paraíba, Rio de Janeiro, Rio Grande do Norte, Rio Grande do Sul, Rondônia, Roraima, Santa Catarina, Sergipe, Tocantins. 
disponíveis no site do SNC.

A aprovação da emenda constitucional N. 71 que instituiu o Sistema Nacional de Cultura no final do ano de 2012 oficializou os Acordos de Cooperação Federativa entre o MinC, estados e municípios que já estavam sendo realizados desde 2009 a fim de adiantar a implantação do sistema. O SNC descentraliza a implementação das políticas culturais previstas no Plano Nacional de Cultura ao estabelecer mecanismos de gestão compartilhada entre os entes federados e a sociedade civil, divide responsabilidades, proporciona maior participação social, porém ao mesmo tempo depende não apenas das ações do MinC para o sucesso da proposta, pois dá autonomia aos entes federados para articularem seus fundos, planos e conselhos.

Esse diálogo entre os agentes e ações dos entes federados é uma das principais partes da arquitetura do sistema como um todo e uma das peças-chave ao sucesso da proposta, bem como de seu viés de participação social e descentralização, ao dividir responsabilidades. Se por um lado a autonomia aos entes federados possibilita que estados e municípios não dependam exclusivamente do âmbito federal para executarem seus planos de cultura, por outro, ainda dependem da estrutura do sistema para manter a coerência da política proposta.

Pela arquitetura proposta, o sistema será criado não apenas em nível nacional, mas serão instituídos também o Sistema Estadual de Cultura e o Sistema Municipal de Cultura. E em todos os níveis federativos, os elementos constitutivos serão: órgãos gestores de cultura; conselho de política cultural; sistema de financiamento à cultura; comissões intergestoras; programa de formação na área de cultura; sistema de informações e indicadores culturais; sistemas setoriais de cultura; e conferência de cultura. (VARELLA, 2014, p. 160)

A estrutura básica do SNC dividida no que chamam de CPF (Conselho, Plano e Fundo) e nos sistemas territoriais e setoriais amplia a visão do financiamento à cultura até então dominado pela lógica mercantil do mecenato via Lei Rouanet. O SNC deve ser pensado não apenas como um sistema federal, mas um sistema que busca recuperar o federalismo em seu formato mais democrático em termos geográficos e linguagens artísticas culturais, e que visa distribuir verbas diretamente aos entes federados e aos setoriais ${ }^{102}$. Entretanto, apesar da autonomia e da proposta de descentralização, a maior parte dos entes federados depende do MinC para compreender o funcionamento da implantação do sistema e principalmente das verbas. Os primeiros anos da implantação do SNC foram de muito aprendizado e busca de

\footnotetext{
102 São setoriais no CNPC / MinC (em sua última composição 2016): Audiovisual, arquivos, arquitetura e urbanismo, artesanato, arte digital, artes visuais, cultura afro brasileira, cultura indígena, cultura popular, circo, dança, design, literatura, moda, música, patrimônio imaterial, patrimônio material e teatro.
} 
compreensão do que era essa nova política que deveria ser feita de baixo para cima, principalmente no que tange à escrita ideal dos enunciados que impulsionam suas ações concretas, isto é, os planos de cultura. Estes enunciados devem ter sua escrita dividida e definida não apenas como planos territoriais, mas também como planos setoriais ${ }^{103}$ e deverão ser norteados pelas demandas e diagnósticos de cada território. Todos estes enunciados comporão uma grande arquitetônica, numa nova forma de distribuir verbas para a cultura, com ideais de ampliação do acesso com ampla participação popular em sua construção. Trataremos dos planos de cultura ao longo dos próximos capítulos de análise.

Logo em seguida, ainda em 2012, a proposta para o projeto de lei complementar de regulamentação do SNC foi enviado pelo MinC para a Casa Civil para que a presidência desse seu aval para a inscrição no Congresso. Entretanto este projeto não avançou no alto escalão do executivo na primeira gestão Dilma. O projeto de regulamentação só foi efetivamente enviado para a Câmara em fevereiro de 2016 e tramitou em comissões do Congresso Nacional como PL 4271/16 ${ }^{104}$ até 31 de janeiro de 2019, quando foi arquivado por meio do regimento geral da Câmara. Todavia, em fevereiro de 2018, o Deputado Chico D’Angelo (PT-RJ) propôs um novo projeto de lei para a regulamentação do SNC. O PL 9474/2018 ${ }^{105}$, assim como o PL anterior, propõe diretrizes para a estruturação e desenvolvimento do CPF do sistema, com capítulos designados para cada uma de suas partes.

Deste modo, o SNC permanece até hoje sem regulamentação, operando por meio dos decretos do Sistema Federal de Cultura. João Roberto Peixe, ex-secretário de Articulação institucional do MinC na gestão Dilma, escreveu um artigo no ano de 2015 relatando toda a história do Sistema e apresenta informações sobre a proposta de regulamentação enviada à Casa Civil, sobre a época em que estava no posto.

Com a promulgação da Emenda Constitucional 71/2012 que instituiu o Sistema Nacional de Cultura conquistamos uma grande vitória. No entanto, não se seguiu como era esperado, a aprovação da lei de sua regulamentação. Alinhado com o Art.216-A da Constituição federal, foi elaborado conjuntamente pelo MinC, estados, Distrito Federal, municípios e sociedade civil, o projeto de lei complementar (PLP) de regulamentação do SNC. Essa proposta de lei foi aprovada pelo Conselho Nacional de Política Cultural (CNPC) e debatida em todos os estados brasileiros. É com base nesse documento que estados e municípios, orientados pelo MinC, estão

\footnotetext{
103 Aliado aos Planos Estatuais e Municipais, representados pela alcunha de Planos territoriais, também deverão ser escritos os Planos Setoriais que trarão especificidades de áreas culturais e artísticas de cada região.

${ }^{104}$ Disponível em: < http://www.camara.gov.br/proposicoesWeb/fichadetramitacao?idProposicao=2076622 > acesso em 15 de março de 2019.

${ }^{105}$ Disponível em: < https://www.camara.leg.br/proposicoesWeb/fichadetramitacao?idProposicao=2167682 > acesso em 15 de março de 2019.
} 
constituindo os seus sistemas de cultura. Enviado pelo MinC em 2012, esse projeto se encontra há mais de três anos travado na Casa Civil da Presidência da República. Quando já deveríamos estar com essa lei em vigência e o SNC operando a pleno vapor, o projeto de lei sequer foi enviado pelo Executivo para apreciação pelo Congresso Nacional. O projeto de lei proposto é composto por três grandes títulos. O primeiro - Da política Nacional de Cultura - define as atribuições do estado no campo cultural, os direitos culturais e o conceito de cultura; o segundo - Do Sistema Nacional de Cultura - apresenta e detalha o modelo de gestão a ser compartilhado entre os entes da federação e a sociedade civil, seus princípios, objetivos, estrutura organizacional e componentes, com suas atribuições e inter-relações e o terceiro - Do financiamento - trata dos recursos, do processo de planejamento e da gestão orçamentária e financeira do sistema. (PEIXE, 2016, p. 238)

O PL 4721/16, inscrito na Câmara pelo deputado federal João Derly (REDE - RS) foi dividido em 23 artigos, e quatro capítulos. Apresenta logo em seu início as diretrizes, objetivos e a estrutura do SNC. Uma das partes mais interessantes da proposta trata da formação de gestores no artigo 17:

Art. 17. Os programas de formação de pessoal na área da cultura são estratégicos para a implementação e gestão do Sistema Nacional de Cultura. $\S 1^{\circ}$ O Ministério da Cultura deverá elaborar o Programa Nacional de Formação de Pessoal na Área da Cultura com vistas ao estímulo e ao fomento à qualificação nas áreas consideradas vitais para o funcionamento do Sistema. § $2^{\circ}$ Estados, Distrito Federal e municípios deverão elaborar seus programas de formação de pessoal na área da cultura em consonância com o Programa Nacional. ${ }^{106}$

A proposta de regulamentação feita pelo deputado gaúcho da REDE foi arquivada no início de 2019, por conta do final da gestão e também de haver outro PL em trâmite, e com o mesmo fim, desde 2018.

O projeto de lei 9.747/2018, proposto pelo Deputado Federal Chico D’Angelo para a regulamentação do SNC, apresenta uma proposta mais abrangente para a cultura e uma estrutura mais complexa com 30 artigos divididos em cinco capítulos. Demonstra foco no desenvolvimento das partes do Sistema, que aparece em um de seus capítulos, e traz relevantes artigos que remetem ao financiamento, ao Fundo Nacional de Cultura e ao que ele chama de "Plano Anual de Metas e Investimentos Culturais.

Art. 19. São objetivos do financiamento público da cultura: I - assegurar a desconcentração do financiamento e do fomento à cultura; II - garantir a oferta de serviços culturais em todos os locais e a todos os grupos e

\footnotetext{
${ }^{106}$ Disponível em: < http://www.camara.gov.br/proposicoesWeb/fichadetramitacao?idProposicao=2076622 > acesso em 17 de novembro de 2017.
} 
comunidades do País; III - priorizar projetos que estejam em consonância com as diretrizes da política cultural, com os objetivos do Sistema Nacional de Cultura e com as metas do Plano Nacional de Cultura; IV - promover e facilitar o intercâmbio cultural, especialmente por meio da criação de regimes aduaneiros especiais para a entrada de bens culturais no País, na forma do regulamento; $\mathrm{V}$ - estimular o investimento privado como fonte de financiamento; VI - fomentar e apoiar programas especiais de financiamento para empresas culturais, conforme a regulamentação; VII - estabelecer convênios internacionais de cooperação financeira para projetos culturais específicos com governos estrangeiros e instituições multinacionais e regionais, públicas e privadas; VIII - garantir a implantação das metas do Plano Nacional de Cultura e dos respectivos planos setoriais; IX - garantir as ações aprovadas nas Conferencias Nacionais de Cultura e nas conferencias setoriais.

Art. 20. O Ministério da Cultura publicara até 31 de dezembro de cada ano, Plano Anual de Metas e Investimentos Culturais, com as 15 percentagens de todos os instrumentos de financiamento e fomento, divididos por áreas e setores e programas e projetos culturais, a ser aplicados no exercício seguinte, em conformidade com as metas estabelecidas no Plano Nacional de Cultura e nos Planos Nacionais Setoriais de Cultura.

Art. 21. Ao final de cada exercício o Ministério da Cultura publicará a percentagem de execução do Plano Anual de Metas e Investimentos Culturais, referentes ao exercício anterior.

Já no início do ano de 2019, como regulamentação ao $§ 3^{\circ}$ do art. 216-A o deputado governista Luiz Lima (PSL - RJ) inscreve o PL 1801/2019 ${ }^{107}$ e como apensado a este, o deputado Chico D’Angelo inscreve uma nova proposta, o PL 1971/2019 ${ }^{108}$. Ambos tramitam simultâneamente na Câmara Federal. Uma das diferenças observadas entre estes dois últimos PLs de regulamentação é que o criado pelo deputado governista menciona a recém criada Secretaria Especial da Cultura vinculada ao Ministério da Cidadania, enquanto o do deputado do PDT, fala ainda da vinculação do SNC ao Ministério da Cultura, neste momento inexistente. No fechamento desta tese, os três últimos PLs citados tramitavam juntos na Comissão de Cultura. Pelo teor das tramitações no site da Câmara, nos permitimos afirmar que, o SNC será alvo de uma longa disputa política entre governistas e oposição nos próximos tempos.

Continuando nosso percurso histórico, voltamos à Ministra Marta Suplicy (setembro 2012 - novembro 2014), que substituiu Ana de Hollanda no MinC do primeiro governo Dilma. Marta teve como prioridade de gestão a implantação do Vale Cultura, mecanismo que prioriza a dedução físcal de $1 \%$ do valor devido ao imposto de renda a empresas que

\footnotetext{
${ }^{107}$ Disponível em: < https://www.camara.leg.br/proposicoesWeb/fichadetramitacao?idProposicao=2195663 > acesso em 06 de julho de 2019.

${ }^{108}$ Disponível em: < https://www.camara.leg.br/proposicoesWeb/fichadetramitacao?idProposicao=2196492 > acesso em 06 de julho de 2019.
} 
oferecerem a seus funcionários um benefício mensal no valor de 50 reais para gastos com cultura. Durante o período em que foi ministra, realizou diversas viagens pelo país a fim de divulgar o mecanismo. Em raros momentos da gestão pudemos ver a Ministra falando sobre o SNC ou sobre o PNC. Todavia, a ministra manteve a autonomia da Secretaria de Articulação Institucional que continuou organizando o SNC.

O principal legado de Marta para o SNC ocorreu antes mesmo de se tornar ministra e deve-se à grande influência que a mesma tem no Congresso Nacional por sua trajetória parlamentar. Talvez não por acaso, era dela desde julho daquele ano a relatoria no Senado da PEC 34/2012, relativa à matéria originária da PEC 416/2005 do SNC na Câmara Federal. Sua força política como parlamentar acelerou a tramitação no Senado e possibilitou a aprovação da PEC do SNC em novembro 2012. Sua influência possibilitou ainda que, durante seu mandato como ministra, diversas leis de cultura fossem aprovadas com maior facilidade, como por exemplo, a Lei Cultura Viva em 2014.

Foi também durante a gestão de Marta que foi criado o site exclusivo do Plano Nacional de Cultura, juntamente com a reformulação do site do MinC. Este site foi desenvolvido para a divulgação do PNC e de suas 53 metas. Recebeu quatro atualizações efetivas da situação das metas: uma em novembro de 2014, outra em junho de 2015 e uma parcial em dezembro de 2015, e outro em dezembro de $2017 .{ }^{109}$

Em junho de 2013, João Roberto Peixe sai da Secretaria de Articulação Institucional e em seu lugar assume Bernardo Mata Machado. É nesse contexto que inicia o processo de construção do planejamento de como seriam feitos os repasses do SNC para estados e municípios.

Com o sistema ainda sem regulamentação aprovada e sem a possibilidade concreta das transferências fundo a fundo por conta da dependência do FNC aos preceitos da Rouanet, a demora para a distribuição das verbas aumentava ainda mais e a impaciência dos estados e municípios também. A solução foi a destinação de verbas via editais. O primeiro edital ${ }^{110}$ do SNC para a distribuição de verbas foi publicado apenas em março de 2014, contemplando pequenos montantes a estados com o sistema já implantado e com leis aprovadas. Neste ano, o FNC recebeu uma dotação total via Lei Orçamentária Anual de apenas 133 milhões, que além de alimentar o sistema, também deveria bancar a Funarte e seus editais e os demais editais do

\footnotetext{
109 Em 2017, durante a gestão de Michel Temer, o Site de consulta às metas do Plano Nacional de Cultura recebeu uma nova interface. Disponível em: < http://pnc.culturadigital.br/ > acesso em 27 de dezembro de 2018. ${ }_{110}$ Disponível em: < http://www.cultura.gov.br/inscricoes-abertas/-/asset_publisher/kQxYTMokF1Jk/content/saiminc-lanca-edital-de-fortalecimento-do-snc/10883 > acesso em 10 de novembro de 2017.
} 
MinC. O edital oferecia um valor total de 30 milhões de reais a serem disputados pelos seis estados que já estavam com seus sistemas implantados e dividia os apoios aos estados em três eixos:

a) EIXO 01 - Promoção da Diversidade Cultural Brasileira. Apoio a projetos de desenvolvimento sustentável de comunidades tradicionais e grupos de culturas populares. (Meta 6 do PNC) (verba total 2,5 milhões);

b) EIXO 02 - Fomento à Produção e Circulação de Bens Culturais. Apoio à produção e circulação de bens culturais. (Metas 22 e 24 do PNC) Financiamento de projetos de montagem e de circulação de espetáculos, mostras e eventos. (verba total 12,5 milhões);

c) EIXO 03 - Implantação, Instalação e Modernização de Espaços e Equipamentos Culturais. (verba total 15 milhões)

A divisão do edital em eixos e temas específicos demonstrava que o MinC não pretendia, pelo menos por enquanto, repassar uma verba a um estado para que este aplicasse territorialmente com autonomia local e de acordo com as prioridades elencadas em seus Planos Estaduais de Cultura. Os apoios visavam alimentar especificamente metas e temas previamente estabelecidos pelo MinC, como a cultura popular, a montagem e circulação de espetáculos e o apoio a equipamentos. Ao determinar o tipo de apoio a temas específicos, o MinC direciona as verbas para fins do seu interesse, rompendo com a autonomia e a descentralização das políticas culturais dos estados que nem sempre têm esse mesmo tipo de interesse ou esses temas como prioritários. Este direcionamento a temas de interesse federal não respeita um dos pontos chave da arquitetônica proposta pelo sistema, a descentralização da política cultural e a construção de baixo para cima. Nestes termos é possível considerar o formato do edital como centralizador na decisão da destinação dos recursos pelo MinC. Esse mesmo modelo de edital com temas e eixos específicos também foi realizado para municípios e repetido no ano seguinte comprovando assim que o próprio MinC continuava mantendo a lógica da política centralizadora de cima para baixo e ao contrário do que prega a agenda 21 da cultura, no princípio de subsidiariedade.

A segunda gestão de Dilma na presidência começou em janeiro de 2015 após uma eleição muito disputada e difícil. O apoio do setor cultural durante a campanha caminhava ao lado da promessa do retorno de Juca Ferreira ao MinC. O sociólogo baiano estava naquele momento no meio de uma gestão como Secretário de Cultura Municipal de São Paulo na gestão do prefeito Fernando Haddad, em que, entre outras medidas, estava iniciando a 
implantação do Sistema Municipal de Cultura. Com o retorno de Juca ao MinC em janeiro de 2015, um novo formato de Ministério é proposto. A Secretaria de Articulação Institucional (SAI) agora liderada por Vinicius Wu cuidaria principalmente dos processos de implantação do SNC, visando a estruturação do PNC junto à Secretaria de Políticas Culturais (SPC) liderada por Guilherme Varella. A nova estrutura possibilitou que em 2015 fosse iniciado um novo período para o SNC, com a revisão do Plano federal que completava cinco anos.

A revisão das 53 metas do PNC foi realizada por consulta pública num site específico em que as pessoas da sociedade civil poderiam dizer se estavam ou não de acordo com cada uma das metas e também enviar sugestões para alterações nos textos.

Figura 3: Site de consulta pública para revisão das metas do PNC 2015

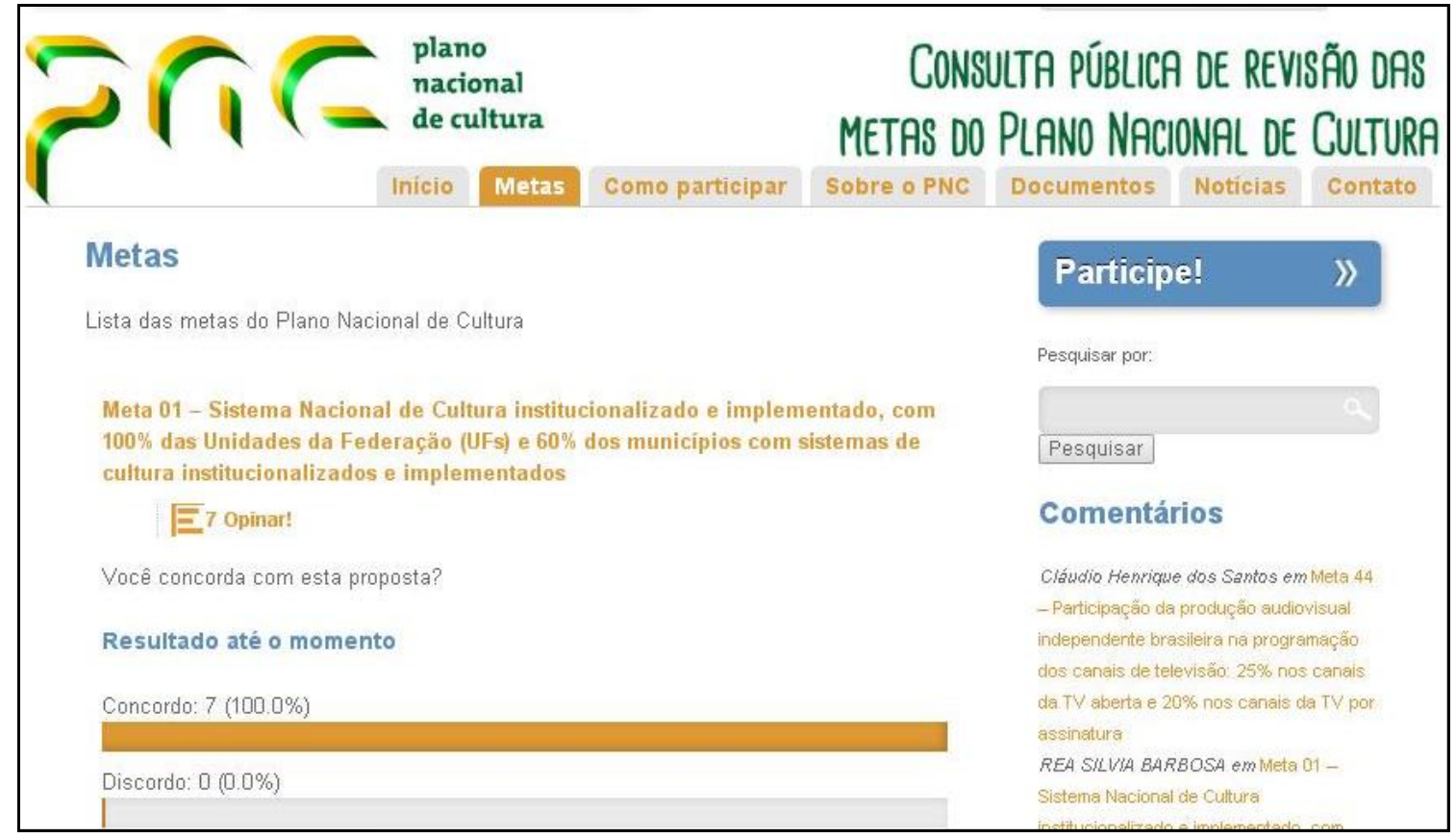

Fonte: site $\mathrm{PNC}^{111}$.

Em agosto de 2015, o MinC lançou quatro editais do SNC para municípios propostos pela SAI em parceria com: Secretarias do Audiovisual (SAv), Secretaria da Cidadania e da Diversidade Cultural (SCDC), Fundação Cultural Palmares (FCP) e Diretoria do Livro, Leitura, Literatura e Bibliotecas (DLLLB). O edital realizado em parceria com a SCDC previa a implantação de redes de Pontos de Cultura nas cidades num valor total de $\mathrm{R} \$ 3,8$ milhões. Para a participação nos editais era necessário que os municípios já estivessem com a implantação de seus sistemas municipais em estágio avançado. O critério mínimo exigido é que estivessem com seus projetos de leis de sistema, conselho, plano e fundo encaminhados para aprovação em suas câmaras municipais.

\footnotetext{
${ }^{111}$ Disponível em: < http://pnc.culturadigital.br/> acesso em 16 de julho de 2016
} 
O detalhamento das metas do PNC no site que tem base na plataforma digital do MinC mostra o andamento da construção do Sistema ao longo do tempo. A meta 1 dialoga diretamente com a construção da forma da arquitetônica do Sistema, ao prever os sistemas dos entes federados como base de sua composição.

Meta 1: Sistema Nacional de Cultura institucionalizado e implementado, com 100\% das Unidades da Federação (UFs) e 60\% dos municípios com sistemas de cultura institucionalizados e implementados. Ter sistemas de cultura em todos os estados e em 3.339 cidades do Brasil (60\%), para tornar efetivo o Sistema Nacional de Cultura. (Site PNC, 2016)

O gráfico abaixo, atualizado pela última vez em dezembro de 2017, apresenta a evolução da meta 1 do PNC. É possível ver que, no primeiro ano de plano, dezessete estados da federação já haviam aderido ao SNC, mas apenas três deles conseguiram finalizar seus processos de implantação do Sistema completo com suas leis de Sistema, Plano, Fundo e Conselho aprovadas. A situação mostra que, mesmo com as articulações, cursos e encontros realizados, os processos continuaram lentos. Apesar de termos 100\% dos estados com acordos de cooperação assinados, apenas oito estados estavam com seus sistemas implantados até julho de 2016, menos de $30 \%$ após seis anos de implantação.

Figura 4: Evolução da Meta 1 do PNC

\begin{tabular}{|c|c|c|c|c|c|c|c|c|c|}
\hline Indicador & 2010 & 2011 & 2012 & 2013 & 2014 & 2015 & 2016 & 2017 & $\begin{array}{l}\text { Ponto } \\
\text { da } \\
\text { meta } \\
2020\end{array}$ \\
\hline $\begin{array}{l}\text { Quantidade de UF com Acordo de Cooperação } \\
\text { Federativa para desenvolvimento do Sistema } \\
\text { Nacional de Cultura publicado }\end{array}$ & $\begin{array}{l}3,7 \% \\
(1)\end{array}$ & $\begin{array}{c}63,0 \% \\
(17)\end{array}$ & $\begin{array}{c}85,2 \% \\
(23)\end{array}$ & $\begin{array}{c}96,3 \% \\
(26)\end{array}$ & $\begin{array}{c}96,3 \% \\
(26)\end{array}$ & $\begin{array}{c}96,3 \% \\
(26)\end{array}$ & $\begin{array}{c}96,3 \% \\
(26)\end{array}$ & $\begin{array}{l}96,3 \%^{1} \\
(26)\end{array}$ & $\begin{array}{l}100 \% \\
(27)\end{array}$ \\
\hline $\begin{array}{l}\text { Quantidade de UF com Sistemas Estaduais ou } \\
\text { Distrital de Cultura instituídos por leis próprias }\end{array}$ & & $\begin{array}{c}11,1 \% \\
(3)\end{array}$ & $\begin{array}{c}14,8 \% \\
(4)\end{array}$ & $\begin{array}{l}18,5 \% \\
(5)\end{array}$ & $\begin{array}{l}22,2 \% \\
(6)\end{array}$ & $\begin{array}{c}25,9 \% \\
(7)\end{array}$ & $\begin{array}{l}29,6 \% \\
(8)\end{array}$ & $\begin{array}{c}33,3 \% \\
(9)\end{array}$ & $\begin{array}{c}100 \% \\
(27)\end{array}$ \\
\hline $\begin{array}{l}\text { Quantos municípios com Acordo de Cooperação } \\
\text { Federativa para desenvolvimento do Sistema } \\
\text { Nacional de Cultura publicado }\end{array}$ & & & $\begin{array}{l}1 \% \\
(33)\end{array}$ & $\begin{array}{c}37,6 \% \\
(1.256)\end{array}$ & $\begin{array}{l}57,5 \% \\
(1.920)\end{array}$ & $\begin{array}{c}65,0 \% \\
(2.171)\end{array}$ & $\begin{array}{c}66,8 \% \\
(2.233)\end{array}$ & $\begin{array}{l}76,1 \% \\
(2.542)\end{array}$ & $\begin{array}{c}60 \% \\
(3.342)\end{array}$ \\
\hline $\begin{array}{l}\text { Quantidade de municípios com seus sistemas de } \\
\text { cultura instituídos por leis próprias. }\end{array}$ & & & & & $\begin{array}{l}1,1 \% \\
(38)\end{array}$ & $\begin{array}{l}3,6 \% \\
(120)\end{array}$ & $\begin{array}{l}6,9 \% \\
(230)\end{array}$ & $\begin{array}{c}8 \%^{2} \\
(269)\end{array}$ & $\begin{array}{c}60 \% \\
(3.342)\end{array}$ \\
\hline
\end{tabular}

Fonte: site PNC. ${ }^{112}$

A situação da meta no que tange aos sistemas municipais demonstra maior lentidão nos processos. Na atualização de 2016, apesar de termos um surpreendente número de 2.233 municípios com adesão ao Sistema, apenas 6,9\% deles (230 municípios) estavam com sistemas municipais completamente implantados. Boa parte das adesões municipais ocorreu em 2013. Em novembro de 2014, 1.920 municípios já tinham aderido ao SNC, porém poucos conseguiram chegar ao fim do processo em dois anos. Os avanços entre 2016 e o ano de 2017 mostram que o processo do SNC diminuiu consideravelmente seu ritmo de implantação com apenas 309 novos

\footnotetext{
${ }^{112}$ Disponível em: < http://pnc.culturadigital.br/> acesso em 21 de dezembro de 2018
} 
municípios assinando acordos nesse meio tempo, e 39 com leis de sistemas instituídos, atingindo no final deste ano o patamar de apenas 8\% A diminuição na divulgação do sistema pelo governo federal, a lentidão para a realização dos diagnósticos regionais, a complexa construção de enunciados de sistema, plano, fundo e conselho, a dificuldade para a mobilização da sociedade civil, a resistência de prefeituras e secretarias ao processo político e a falta de verbas para as etapas iniciais como as conferências municipais e as consultas públicas podem justificar a dificuldade da meta 1 avançar e do sistema conseguir a capilaridade necessária para sua implantação bem como desenvolver todas as 53 metas previstas no Plano até 2020.

Figura 5: Mapa da evolução da Meta 1

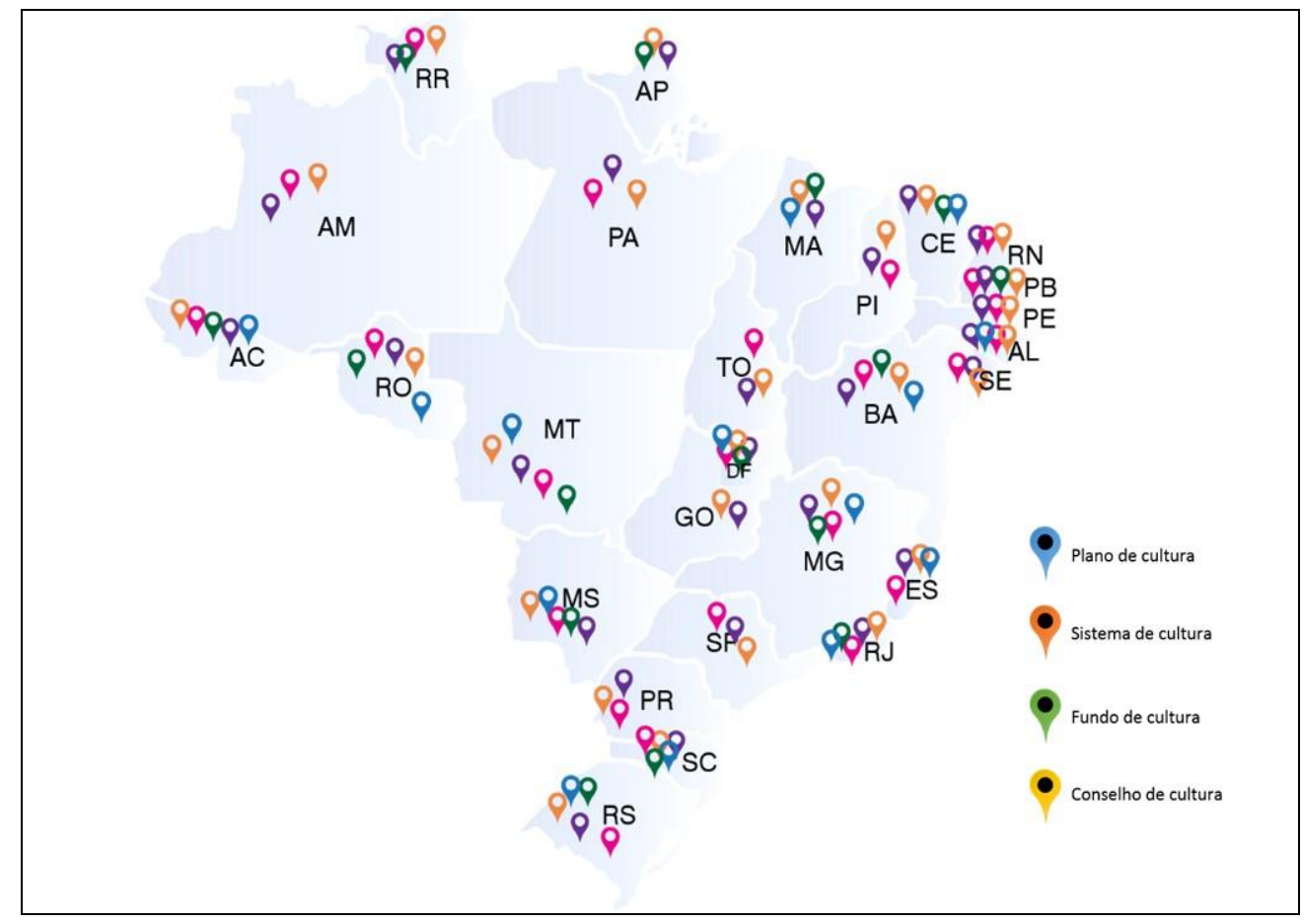

Situação do CPF implantado nos estados (em 31/12/2017). Fonte: site PNC ${ }^{113}$. $^{114}$

Como a maioria das metas do PNC depende dos resultados nas pontas do sistema, o atraso na aprovação de leis municipais e estaduais prejudica a fluidez da implantação do SNC como um todo. O mapa acima indica a situação dos estados em dezembro de 2017. É possível perceber que os estados com sistemas já aprovados (em laranja) estão espalhados pelas cinco regiões, com destaque para a região nordeste que apresenta um número maior de sistemas completos com conselho, plano e fundo.

\footnotetext{
${ }_{113}^{113}$ Disponível em: < http://pnc.culturadigital.br/> acesso em 16 de julho de 2016.

114 Importante salientar que neste mapa não há indicação de quais estados já tem conselhos de cultura (pin amarelo).
} 
A Meta 2 do PNC também se refere diretamente à estrutura do SNC e aos conteúdos e resultados ao tratar do Sistema Nacional de Informações e Indicadores Culturais (SNIIC).

Meta 2: $100 \%$ das Unidades da Federação (UFs) e 60\% dos municípios com dados atualizados no Sistema Nacional de Informações e Indicadores Culturais (SNIIC). Obter e divulgar informações atualizadas sobre a área cultural de todos os estados e de 3.339 cidades do Brasil (60\%).

O SNIIC pode ser relacionado com um dos itens da Agenda 21 da Cultura ao tratar da necessidade do mapeamento e diagnóstico territoriais. A primeira tentativa da implantação de cadastro voluntário do SNIIC apresentou pouca adesão do setor cultural. Após uma parceria com o Instituto Tim, que formulou uma plataforma aberta e que poderia ser utilizada também para os mapeamentos de estados e municípios, o SNIIC foi reformulado e pensado de forma a obter informações de outros mapas de informação que estivessem em diálogo.

A meta 2 informa em sua atualização de dezembro de 2015 que 25 estados e 468 municípios já estavam enviando suas informações diretamente para a nova plataforma do SNIIC. Em 2017, contabilizam 493 municípios: 17 da região Norte, 178 do Nordeste, 46 do Centro-Oeste, 119 do Sudeste e 133 da região Sul.

Figura 6: Situação da implantação do SNIIC na Meta 2 por região do país

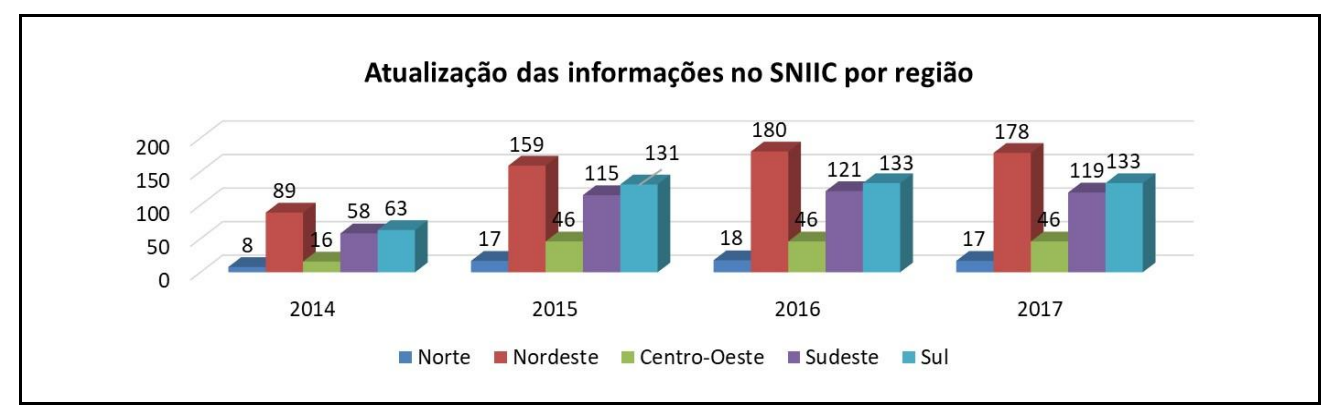

Fonte Site PNC ${ }^{115}$

A meta 3 que trata da cartografia da diversidade conta com informações do SNIIC.

Figura 7: Dados SNIIC na meta 3 sobre a Cartografia da diversidade

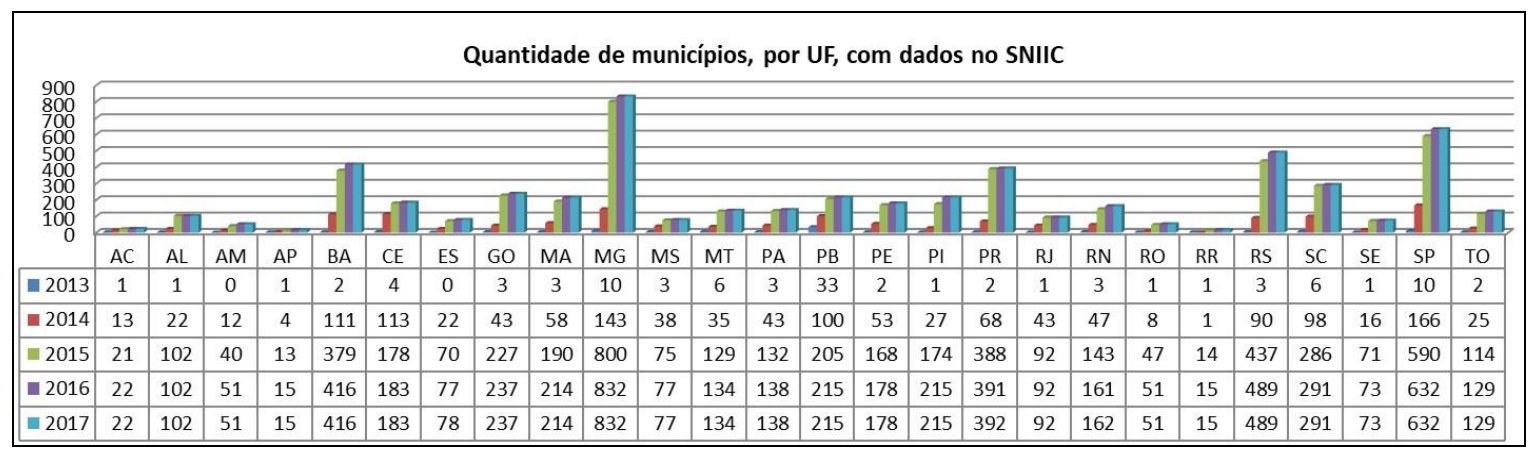

Fonte: site $\mathrm{PNC}^{116}$.

\footnotetext{
${ }^{115}$ Disponível em: < http://pnc.culturadigital.br $>$ acesso em 29/12/2018
} 
Os avanços da meta 3 devem demonstrar efetivamente, na esfera, o quanto o sistema refletiu e refratou a esfera. Porém é possível perceber que entre 2016 e 2017, os dados são iguais o que pode apontar a parada da plataforma.

A Meta 46 também faz parte da construção direta do SNC ao tratar do Conselho Nacional de Política Cultural (CNPC) e dos planos setoriais.

Meta 46: 100\% dos setores representados no Conselho Nacional de Política Cultural (CNPC) com colegiados instalados e planos setoriais elaborados e implementados. Instalar colegiados e elaborar planos de cultura para todos os setores representados no Conselho Nacional de Política Cultural.

Dos dezesseis setores elencados na composição do CNPC, no final de 2015, todos já estavam com seus colegiados instalados e dez deles já tinham seus Planos Setoriais elaborados e aguardando aprovação. No final do ano de 2017, o número de planos setoriais elaborados subiu para onze.

Figura 8: Meta 46 Situação dos Planos setoriais e Colegiados CNPC.

\begin{tabular}{|c|c|c|c|c|}
\hline Setores culturais com representação no CNPC & $\begin{array}{c}\text { com plano setorial } \\
\text { elaborado }\end{array}$ & Ano de aprovação & Vigência & Possui metas? \\
\hline \multicolumn{5}{|l|}{ Arquitetura e urbanismo } \\
\hline Arquivos & $\mathrm{x}$ & 2016 & 2026 & Sim \\
\hline \multicolumn{5}{|l|}{ Arte digital } \\
\hline Artes visuais & $\mathrm{x}$ & 2010 & & Não \\
\hline Artesanato & $x$ & 2016 & 2025 & Sim \\
\hline Circo & $\mathrm{x}$ & 2010 & & Não $(*)$ \\
\hline Culturas indígenas & $(* * * *)$ & 2010 & 2020 & Não \\
\hline Culturas populares & $(* * * *)$ & 2010 & 2020 & Não \\
\hline Dança & $\mathrm{x}$ & 2010 & & Sim \\
\hline Design & $x$ & 2016 & 2026 & Sim \\
\hline Expressões artísticas culturais afro-brasileiras*** & $\mathrm{x}$ & 2016 & 2026 & Sim \\
\hline Livro, leitura e literatura & $\mathrm{x}$ & 2011 & & Não $(* *)$ \\
\hline Moda & $\mathrm{x}$ & 2016 & & Sim \\
\hline Museu & $\mathrm{x}$ & 2010 & 2020 & Sim \\
\hline Música & $(* * * *)$ & 2010 & & Não \\
\hline \multicolumn{5}{|l|}{ Patrimônio imaterial } \\
\hline \multicolumn{5}{|l|}{ Patrimônio material } \\
\hline Teatro & $\mathrm{x}$ & 2010 & & Não \\
\hline \multicolumn{5}{|l|}{ Arquitetura e urbanismo } \\
\hline Total & 15 & & & 8 \\
\hline
\end{tabular}

Fonte: Situação em dezembro de 2017 no site PNC. ${ }^{117118}$

O processo de instalação dos novos colegiados do CNPC foi desenvolvido a partir de uma votação realizada pela internet e presencialmente para eleger os participantes do Conselho e os membros colegiados dos setores. No site criado, era possível articular a votação a partir de cada estado da União. Assim, cada estado pôde eleger seus representantes, titulares e suplentes para cada setor. Foram mais de 70 mil inscritos para participar da votação dos 27 estados brasileiros. Com isso, as discussões sobre os Planos setoriais puderam começar a ser reorganizadas e repensadas já com os novos membros do Conselho e colegiados eleitos

116 Disponível em: < http://pnc.cultura.gov.br/category/metas/3/ acesso em 29 de dezembro de 2018.

${ }^{117}$ Fonte: site PNC. Disponível em: < http://pnc.culturadigital.br/> acesso em 29 de dezembro 2018.

${ }^{118} \mathrm{Na}$ tabela acima há a repetição do setor de arquitetura e urbanismo. 
para o período de dois anos.

Em junho de 2015, durante três dias, o MinC realizou em Brasília o Seminário Internacional de Sistemas de Cultura: Política e Gestão Cultural descentralizada e Participativa. O evento contou com a presença de gestores de todos os estados brasileiros e de quatro países: Colômbia, Espanha, França e Uruguai. O evento foi transmitido pela internet e contou com palestras de todos os principais envolvidos com a implantação do Sistema no MinC, nas universidades parceiras, e dos estados e munícipios com implantação do Sistema em estágio avançado.

Em agosto, o MinC já contabilizava 2670 municípios com adesão ao sistema. Porém muitos destes estados ainda estavam muito distantes do ideal em relação a seus municípios. A média geral de municípios com adesão naquele momento era de 47,9\%. Enquanto isso, importantes estados como São Paulo, Paraná, Minas Gerais e Goiás, não chegavam nem a 40\% de seus municípios no sistema. Em 2014, a adesão de cidades ao sistema começou a diminuir, caindo de $10 \%$ ao ano para menos de 1,5\%. A falta de perspectivas das transferências fundo a fundo, os trâmites eleitorais e suas questões político-partidárias e a dificuldade de criar leis locais tornou os avanços do sistema mais lento.

Em abril de 2016, o governo federal sofre um abalo institucional com a aprovação da abertura do processo de impeachment da presidenta Dilma Rousseff com indicação de possibilidade de Crime de Responsabilidade Fiscal por conta de "pedaladas fiscais" ocorridas em 2014 e 2015. O encaminhamento do processo foi aprovado pelo Congresso no dia 17 de abril de 2016 e a admissibilidade de processo pelo Senado Federal na semana seguinte. Com isso, a presidenta foi afastada do cargo inicialmente por 180 dias, deixando em seu lugar seu vice Michel Temer que assumiu o posto no dia 12 de maio de 2016.

O afastamento de Dilma, considerado por boa parte da população, por juristas renomados e por diversos intelectuais não apenas no Brasil como um golpe jurídico-institucional, já que não foram provados indícios de crime efetivo, trouxe a oportunidade ao novo gestor interino de mudar completamente a configuração ministerial e propor um novo projeto de governo. No dia 12 de maio de 2016, mesmo dia de sua posse enquanto presidente interino, Temer lançou a Medida Provisória MP 726/2016 que extinguiu o Ministério da Cultura e o vinculou novamente ao MEC como uma secretaria anexa. Esta MP também determinou o formato do MEC como Ministério da Educação e Cultura e sendo gerido a partir disso pelo deputado federal Mendonça Filho, então líder do Partido Democratas na Câmara.

De imediato, o setor cultural reagiu negativamente ao fechamento do MinC assim como à 
sua nova configuração como uma secretaria menor no escopo da pasta da educação. Diversas manifestações foram realizadas em todo país e no dia 15 de maio de 2016 começaram as ocupações artísticas nos prédios das entidades vinculadas ao MinC em todo país por artistas, agentes culturais ou mesmo por pessoas da sociedade civil que apoiavam o movimento. Primeiramente foi ocupado o prédio do IPHAN em Curitiba e nos dois dias seguintes os prédios da FUNARTE em Belo Horizonte, Rio de Janeiro e São Paulo. Em menos de uma semana todos os 27 estados do país contavam com ocupações artísticas de prédios vinculados ao MinC.

A divulgação das ocupações pela grande mídia foi possibilitada pela adesão imediata de grandes artistas ao movimento, que estiveram presentes principalmente na ocupação da Funarte Rio de Janeiro no Palácio de Capanema. Shows com Caetano Veloso, Lenine, Erasmo Carlos, entre outros artistas de renome, levaram ao prédio e a seus arredores milhares de pessoas apoiando o movimento. O apoio irrestrito de diversos atores famosos da Rede Globo como Marieta Severo, Camila Pitanga, entre outros, também fortaleceu a divulgação do movimento ao conseguir forte veiculação em seus jornais. O movimento intitulado como \#OcupaMinC ganhou força com diversos debates, encontros, vídeos, entrevistas, matérias e ações do setor cultural de todo o Brasil, divulgadas pelas redes sociais e com grande adesão da sociedade civil.

No dia 26 de maio de 2016, por conta da pressão do setor cultural, Temer recuou em sua decisão e recriou o Ministério da Cultura através da Medida Provisória 728/2016. Contudo, o texto definia como estrutura central do Ministério um novo formato. A MP previa que a Secretaria Executiva seria mantida, uma secretaria especial para o IPHAN seria criada e a Comissão Nacional de Incentivo à Cultura, que cuida dos projetos da Rouanet, estaria garantida. Para a liderança da gestão foi chamado o carioca e diplomata Marcelo Calero filiado ao PSDB, então Secretário de Cultura do Município do Rio de Janeiro, que assumiu como Ministro Interino da Cultura no dia 21 de maio.

No dia 27 de julho, foram exonerados 81 funcionários do Ministério, dentre eles mais da metade do setor de Cultura Digital que trabalhavam diretamente com o SNIIC e técnicos da Secretaria de Fomento e Incentivo à Cultura (SEFIC). No início de agosto de 2016, o ministro interino deu uma entrevista no Jornal O Globo acusando a equipe anterior de gastos abusivos e que haviam deixado um "rombo" de mais de 1 bilhão de reais. O ex- secretário executivo do MinC, João Brant, respondeu a Calero num texto publicado no site Brasil 247 dizendo que:

O orçamento discricionário da pasta para este ano é de 604 milhões. Sem dúvida um valor aquém do necessário, fruto de uma situação de crise fiscal e de cortes realizados pelo Congresso Nacional. Mas justamente por reconhecimento dessa situação e pelo empenho da equipe do ministério, no primeiro 
contingenciamento do ano a Cultura foi a que teve o menor contingenciamento na Esplanada. O segundo contingenciamento reduziu o orçamento para 430 milhões, mas esta era uma situação claramente provisória, enquanto se aguardava a aprovação da nova meta fiscal. A mudança na meta aconteceu quando Temer já estava na presidência interina. Com o déficit ampliado em mais de 70 bilhões pelo novo governo, tendo alcançado $170 \mathrm{bi}$, seria natural que se retornassem os 604 milhões para o MinC. (BRANT, 2016) $)^{119}$

Em 18 de agosto de 2016 foi publicado no Diário Oficial da União um novo Decreto presidencial (8.837/2016) alterando a estrutura regimental do Ministério da Cultura. O decreto, além de alterar a estrutura, também mudou o nome de diversos setores e secretarias. A Secretaria de Articulação Institucional (SAI) responsável pela implantação do SNC passou a se chamar Secretaria de Articulação e Desenvolvimento Institucional (SADI) e foi dividida em dois departamentos: 1. Departamento de Desenvolvimento Institucional; e 2. Departamento de Promoção Internacional. A criação de um departamento exclusivo para a promoção internacional evidencia o caráter da nova gestão feita por um diplomata, o interesse com os assuntos das Relações Exteriores.

No dia 31 de agosto de 2016, o Senado federal decidiu pela aprovação do impedimento da Presidenta Dilma Rousseff. Com isso, Michel Temer assumiu a presidência e Marcelo Calero o Ministério da Cultura. No dia 4 de setembro foi publicado na página do Facebook do MinC um texto intitulado "Cultura faz um balanço dos 100 dias de gestão" em que tratam de um aporte financeiro no programa Cultura Viva, da valorização dos servidores, da reestruturação, da recriação da Secretaria de Economia Criativa, da atualização da Lei Rouanet, entre outros temas. Sobre a SADI publicam o seguinte texto:

A Sadi coordenará diversos projetos inovadores. Entre eles, o lançamento do projeto Observa Sistema Nacional de Cultura (SNC), que pretende criar um ambiente virtual para promover o desenvolvimento estruturado das ações voltadas para a qualificação da gestão cultural de estados e municípios brasileiros. O programa será desenvolvido em parceria com a Escola de Administração da Universidade Federal da Bahia (UFBA). Além disso, em parceria com a Universidade Federal do Rio Grande do Sul (UFRGS), a SADI deu início ao processo de avaliação do Programa Nacional de Formação de Gestores e Conselheiros Culturais pelo Centro de Estudos Internacionais sobre Governo (CEGOV), da UFRGS. Desde 2009, esse programa realizou 13 projetos em todas as regiões do Brasil, por meio de parcerias que possibilitaram a qualificação de mais de 4300 gestores em mais de 1000 municípios. ${ }^{120}$

\footnotetext{
${ }^{119}$ Texto disponível em: < http://www.brasil247.com/pt/colunistas/geral/247885/MinC-sem-cultura.htm > acesso em 20 de setembro de 2016.

${ }^{120}$ Trecho do texto "Cultura faz balanço dos 100 dias de gestão" publicado na página do Facebook do MinC em 4 de setembro de 2016. Disponível em: < https://www.facebook.com/notes/minist\%C3\%A9rio-da-cultura/culturafaz-balan\%C3\%A7o-dos-100-dias-de-gest\%C3\%A3o/909059585865973> acesso em 15 de setembro de 2016.
} 
As novidades apresentadas foram o projeto Observa Sistema Nacional de Cultura (SNC) e a avaliação do Programa Nacional de Formação de Gestores e Conselheiros Culturais. Todavia é preciso ressaltar que o programa de auxílio a formação de gestores para a implantação do SNC já estava acontecendo desde 2011 e neste momento o Observa SNC configura o desenvolvimento de sua terceira etapa.

Em novembro de 2016, outra crise desestabiliza o MinC com a repercussão de uma gravação que o Ministro Marcelo Calero fez de uma conversa com o então Ministro da Secretaria de Governo de Temer, Geddel Vieira Lima, que o havia pressionado para liberar uma obra em um edifício na cidade de Salvador embargada pelo IPHAN. Nos dias seguintes, com o aumento da repercussão do caso, que gerou a demissão do Ministro Geddel e uma grande crise política no governo Temer, Calero pede exoneração do cargo no MinC. Em seu lugar toma posse o deputado pernambucano Roberto Freire (PPS - SP).

A maior parte do setor cultural não celebrou a nomeação de Freire, que assim como Calero não atuava efetivamente na cultura. Logo após sua nomeação, ainda no conturbado mês de novembro, Freire participou do programa Roda Viva na TV Cultura para falar de suas pretensões no MinC. As falas de Freire sobre os programas já existentes no MinC demonstraram que ele não estava disposto a continuar com alguns avanços essenciais nas políticas culturais da forma que estavam sendo feitas. Em sua rápida gestão, a única ação que merece destaque foi a publicação de uma nova Instrução Normativa que tornaria a Lei Rouanet ainda mais excludente e complexa.

No mês de maio de 2017, após outra crise institucional no governo Temer, Roberto Freire pede demissão do MinC. A instabilidade foi gerada após as denuncias sobre Michel Temer feitas pelo presidente da empresa JBS, Joesley Batista, que apresentou gravações e provas de que estaria recebendo propina da gestão. No lugar de Freire assume inteirinamente seu secretário executivo João Batista Andrade, que trazia um extenso histórico de gestão na cultura. Entretanto a permanência de João Batista no cargo foi apenas até o mês de junho de 2017, quando este veio a público falar sobre as condições precárias em que o Ministério de encontrava, sem verbas e sem apoio algum do alto escalão do executivo. Neste momento foi também noticiado que o FNC estaria com seus recursos zerados e que diversos programas estariam completamente parados.

No lugar do interino João Batista foi nomeado Sergio Sá Leitão que acumulava em seu histórico, entre outros cargos, o de Chefe de Gabinete de Gilberto Gil no MinC entre os anos 
de 2003 e 2006. O nome não foi celebrado por boa parte do setor cultural, principalmente porque a indicação ter sido feita pela base MDBista de Temer.

No mês de agosto de 2017 é divulgado um novo modelo de site para o Plano Nacional de Cultura, totalmente remodelado e agora com atualizações periódicas. A atualização e a observação das metas do Plano Nacional de Cultura aparentemente estavam sendo retomadas. No mês de outubro é divulgado um site que reúne dados da cultura (dados.cultura.gov.br) alimentado por instituições do MinC. Além disso, neste mesmo período, o site do MinC traz como manchete que novos municípios estariam fazendo adesão ao SNC. Após a crise política causada pelo Impeachment, a gestão dá os primeiros indícios de que estavam retomando finalmente a construção do sistema, ainda que em ritmo lento.

Entretanto estes avanços foram novamente parados no ano de 2018. A aproximação da eleição e o interesse do Ministro da Cultura Sergio Sá Leitão em fazer uma nova reestruturação na Lei Rouanet impediram mais uma vez que o Sistema Nacional de Cultura continuasse sua implantação efetiva no mesmo ritmo. A quarta Conferência Nacional de Cultura, que deveria ter acontecido em 2017, não aconteceu. No início de dezembro de 2018, o MinC lançou uma consulta pública para a reestruturação no CNPC.

O novo presidente eleito em outubro de 2018, Jair Bolsonaro, toma posse em janeiro de 2019 e faz uma radical reforma ministerial. Mais uma vez o Ministério da Cultura é fechado e transformado numa sub-Secretaria Especial da Cultura dentro do novo Ministério da Cidadania, que também engloba o esporte e o desenvolvimento social. O novo ministério está sob a tutela do Ministro Osmar Terra e a Secretaria Especial da Cultura e delegada ao gaúcho José Henrique Medeiros Pires.

Uma reestruturação de todos os ministérios e secretarias foi proposta a partir do decreto federal 9.764 de 2 de janeiro de $2019^{121}$, em que o SNC, bem como suas partes, ficam definitivamente dentro da Secretaria da Diversidade Cultural, extinguindo assim a SADI. De acordo com as primeiras declarações de Bolsonaro e de Henrique Pires, a prioridade da nova gestão será uma nova reformulação da Lei Rouanet, com justificativa da necessidade do apoio prioritário a projetos fora do eixo Rio-SP. ${ }^{122}$

\footnotetext{
${ }^{121}$ Disponível em: http://www.planalto.gov.br/ccivil_03/ato2019-2022/2019/decreto/D9674.htm. > acesso em 12 de fevereiro de 2019.

122 Até o fechamento desta tese em março de 2019, os sites do SNC e do PNC ainda estavam no ar. Entretanto estes processos ainda não haviam sido trabalhados pela nova equipe.
} 
Entretanto é importante evidenciar que neste momento de uma nova ruptura, a cultura torna-se uma pasta subalterna no poder executivo, sem autonomia e com orçamento do FNC ainda mais reduzido do que no ano anterior, o que denota o não interesse, pelo menos inicial, em continuar a construção do sistema.

No dia 11 de abril de 2019, Bolsonaro institui um novo decreto federal ${ }^{123}$ que exitngue e atribui novas diretrizes para as composições de Conselhos e Colegiados setoriais. A medida afetou duramente o Conselho Nacional de Política Cultural e seus colegiados setoriais, bem como gerou um efeito "cascata" em Conselhos e colegiados nos entes federados, como por exemplo no estado de SP, como veremos a seguir.

No início de Junho de 2019, o site do Ministério da Cidadania divulga a adesão de quatro novas cidades ao SNC. Seu site é reformulado, os manuais de adesão reorganizados na plataforma e um novo modelo da SNIIC suge com o nome de SIM Cultura. Porém, em 27 de junho de 2019, por meio do Decreto 9891/2019, mais uma vez o CNPC sofre mais um ataque. O novo governo apresenta uma proposta que desconsidera a existência dos colegiados setoriais, retira a menção à realização de uma eleição direta para o Conselho, que a partir disso passa a ser escolhido pelo Ministro da Cidadania e por outros ministros e secretários e principalmente reduz considervalmente a diversidade cultural do documento, reduzindo a apenas 5 setores, como no decreto de 2005. O que irá acontecer efetivamente com o SNC em termos federais e a proposta de mudança de paradigma da esfera dentro dessa gestão que se inicia em 2019, só o futuro dirá.

$$
* * *
$$

Nos processos ocorridos ao longo do tempo, diversos agentes, inclusive desconhecidos por nós, atuaram para organizar a arquitetônica do SNC. Técnicos, assistentes, secretários, monitores, advogados, pesquisadores, entre outros tantos tipos e funções, também podem ser considerados agentes da construção do Sistema.

Em nosso percurso histórico foi possível observar que o sistema, bem como a arquitetônica da esfera político-cultural, foi sendo construído aos poucos e de forma dialógica, com interação entre o poder público e a sociedade civil. Sua arquitetônica também recebeu influências de processos de políticas culturais anteriores, inclusive internacionais como os encontros da Unesco, por exemplo. Os protagonistas desta história são os autores diretos e os centros de valor dessa arquitetônica, mas os anônimos da sociedade civil intercederam em

\footnotetext{
${ }^{123}$ Decreto presidencial disponível em: < http://www.in.gov.br/materia/lasset publisher/Kujrw0TZC2Mb/content/id/71137350?fbclid=IwAR0EoYEUBfMCdLeEoZLrR7e fyRb7RUQ 312NKQkXoHjgYILRTTbWDqEWl4g > acesso em 12 de abril de 2019.
} 
diversos momentos e foram cada vez mais participativos por meio dos processos de interação oferecidos pelo MinC como as Conferências de Cultura que ocorreram cada vez mais em municípios e também nos estados e no âmbito federal. Na linha do tempo do PNC é possível perceber quais foram os eventos essenciais de sua origem e construção arquitetônica, conforme a imagem a seguir:

Figura 9: Linha do tempo PNC / SNC.

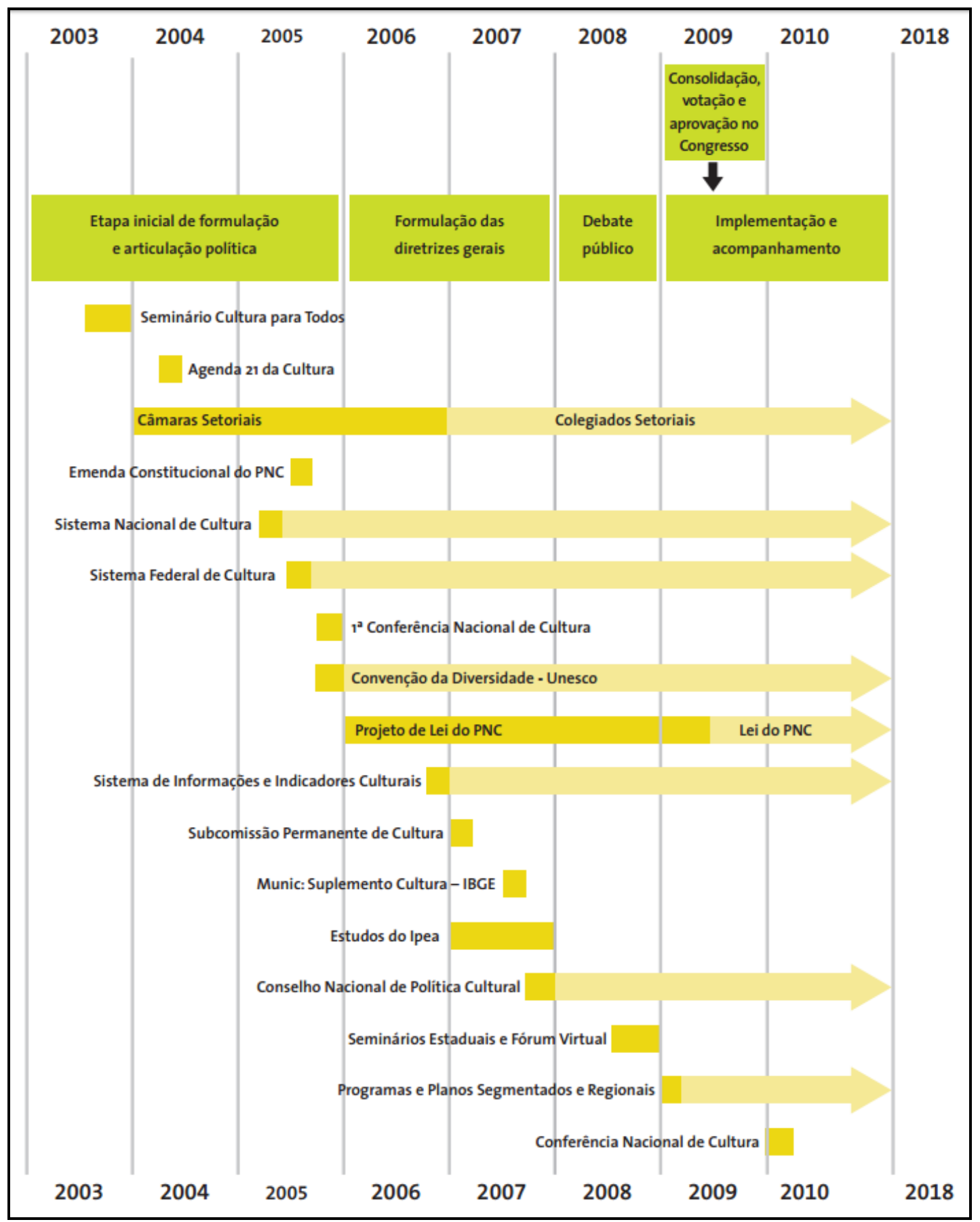

Fonte: Publicação Porque aprovar o $P N C^{124}$.

${ }^{124}$ Disponível em: < http://www.culturainfancia.com.br/docs/Porque\%20aprovar\%200\%20Plano\%20Nacional\%20de\%20Cultura.pdf $>$ 
A partir da imagem acima e dos acontecimentos detalhados em nossa análise foi possível perceber que a construção da arquitetônica do SNC no tempo-espaço esteve dividida em sete etapas principais:

a) Entre 2000 e 2002: Etapa de idealização. PEC 3006/2000 Deputado Gilmar Machado e programa de Lula para a eleição presidencial com diversos autores;

b) Entre 2003 a 2005 - Etapa de formulação, articulação política e início da implantação. Posse de Gil no MinC. Institucionalização da SAI (Marcio Meira) e Etapa de articulação no MinC e formulação. Acontecimentos influenciadores: Seminário CULTURA PARA TODOS (2003), AGENDA 21 da Cultura (2004), Convenção da Diversidade (UNESCO), Câmaras Setoriais, $1^{\text {a }}$ Conferência Nacional de Cultura (2005). Aprovação da PEC 306/2000 (EC 48/2005) do PNC e inscrição da PEC 416/2005 relativa ao SNC no Congresso. Decreto 5520/2005 (SFC e CNPC);

c) Entre 2006 e 2007 - Etapa de diagnóstico e formulação das diretrizes gerais do PNC. Estudos IPEA, audiências na Comissão de Educação e Cultura do Congresso, resultados MUNIC/IBGE - Suplemento Cultura da pesquisa, Caderno de Diretrizes Gerais do PNC (1 ${ }^{\mathrm{a}}$ ed.), instalação do Conselho Nacional de Política Cultural;

d) Entre 2008 e 2010 - Etapa de debate público, consolidação e votação no congresso da lei do PNC. Posse ministro Juca Ferreira. Estabelecimento do CNPC, revisão Final do PNC, Seminários Estaduais e Fórum virtual, votação nas Comissões da Câmara, votação final no Congresso e aprovação da lei 12343 (PNC). Início da elaboração de Planos Nacionais Setoriais (teatro, circo, dança, música, artes visuais, livro e leitura, museus, culturas populares, culturas indígenas). Secretaria de Articulação Institucional com Marcos Acco e Silvana Meireles. Realização da $2^{\mathrm{a}} \mathrm{CNC}$;

e) Entre 2011 e 2014 - Etapa de Implantação PNC (início do período decenal) e ampliação dos acordos do SNC nos entes federados. Posse Ministra Ana de Hollanda. Aprovação PEC 416/2005 (EC 71/2012 e EC 34/2012) que trata do SNC. Posse Marta Suplicy em 2012. Secretaria de Articulação Institucional com Bernardo Mata-Machado e João Roberto Peixe. Realização da $3^{\mathrm{a}} \mathrm{CNC}$;

f) Entre 2015 e até maio de 2016. Etapa de revisão do PNC. Posse Ministro Juca Ferreira. Reorganização do SNC na Secretaria de Articulação Institucional com Vinicius Wu e Guilherme Varella na Secretaria de Políticas Culturais. Realização da eleição de novos 
membros colegiados e titulares do CNPC; Inscrição da primeira versão do projeto de lei de regulamentação do SNC no Congresso Nacional.

g) A partir de maio de 2016 até o início de 2019 - Etapa de instabilidade e atraso na implantação. Impeachment de Dilma Rousseff. Fechamento e reabertura MinC. Ocupação de 27 espaços do MinC pela sociedade civil contra o fechamento e do desmonte das políticas culturais. Posse de Michel Temer e Marcelo Calero no MinC. Mudança de nome da SAI para SADI (Secretaria de Articulação e Desenvolvimento Institucional). Posse de Roberto Freire no MinC. Entrada e saída de Roberto Freire no MinC. Entrada de Sergio Sá Leitão no MinC. Inscrição da segunda versão do projeto de lei de regulamentação do SNC no Congresso Nacional. Fim do governo Temer e eleição de Jair Bolsonaro e novo fechamento do MinC.

Por meio da observação da construção histórica do Sistema e dos personagens principais que atuaram na criação e composição desta arquitetura ao longo do tempo, foi possível verificar que o SNC, assim como o PNC, foram criados, construídos e pensados por diversas pessoas e grupos e não seria justo atribuirmos sua criação a uma só pessoa ou grupo. Entretanto ainda mais importante é perceber que algumas intenções são perceptíveis na análise dos números e atos relacionados a eles. Isto é, a manutenção dos modos de produção e da infraestrutura pode revelar que apesar da intenção de mudança da esfera, a base econômica mostra que isso não aconteceu efetivamente.

A presença do Sistema Nacional de Política Cultural no programa de Lula para as eleições de 2002, ainda que seja a primeira evidência oficial da ideia do Sistema, não comprova que ali seria seu nascimento enquanto proposta. Conforme vimos, a ideia de Sistema já estava inserida nas reuniões de intelectuais e agentes culturais em 1999 e posteriormente nas discussões realizadas na Comissão de Cultura e Educação da Câmara no ano de 2000 e era inspirada nas construções do Sistema Nacional de Educação e no Sistema Único de Saúde (SUS). É possível dizer, a partir da análise da linha do tempo que, até o ano de 2010, o processo ainda estava em criação e início de construção. Foi a partir de 2010, com a aprovação da lei do PNC, o início do decênio do PNC, a observação de suas metas e principalmente com a realização da II Conferência Nacional de Cultura, que o Sistema passa efetivamente do papel para a implantação concreta nas políticas públicas da esfera. Coincidentemente ou não, o ano de 2010 foi marcado pela transição política com a eleição presidencial. No lugar de Lula entra sua candidata Dilma Rousseff e, com isso, também uma nova proposta de governo de um modo geral, ainda que com a continuidade do mesmo partido no poder. A crescente crise econômica internacional logo se refletiu não apenas na economia 
brasileira mas principalmente nas verbas públicas da cultura federal. Após um período de crescimento no orçamento de cultura durante os dois governos Lula, já no primeiro ano da gestão Dilma, o setor sofreu uma relativa diminuição de investimento federal.

Figura 10: Demonstrativo orçamentário do FNC entre 2005 e 2016.

\begin{tabular}{|c|c|c|c|c|c|c|}
\hline \multicolumn{7}{|c|}{$\begin{array}{l}\text { MINISTÉRIO DA CULTURA - MINC } \\
\text { SECRETARIA EXECUTIVA - SE } \\
\text { SUBSECRETARIA DE PLANEJAMENTO, ORÇAMENTO E ADMINISTRAÇÃO - SPOA } \\
\text { COORDENAÇÃO GERAL DE ORÇAMENTO, FINANÇAS E CONTABILIDADE - CGOF }\end{array}$} \\
\hline \multicolumn{7}{|c|}{$\begin{array}{l}\text { Ministério da Cultura - Fundo Nacional da Cultura - FNC } \\
\text { Demonstrativo Orçamentário FNC - } 2005 \text { a } 2016 \text { - RP } 2 \text { (Despesas Discricionárias) - Exceto FSA }\end{array}$} \\
\hline Exercício & PLOA & Emendas & LOA & Lei + Creditos & Empenhado & Liquidado \\
\hline 2005 & 88.947 .357 & 101.627 .200 & 190.574 .557 & 190.574 .557 & 132.456 .544 & 132.456 .544 \\
\hline 2006 & 114.687 .887 & 67.894 .308 & 182.582 .195 & 182.612 .195 & 138.091 .942 & 138.091 .942 \\
\hline 2007 & 118.283 .003 & 1.870 .000 & 120.153 .003 & 252.877 .157 & 119.076 .074 & 119.076 .074 \\
\hline 2008 & 292.790 .463 & -32.740 .078 & 260.050 .385 & 397.411 .893 & 240.952 .476 & 240.952 .476 \\
\hline 2009 & 295.470 .020 & 140.515 .000 & 435.985 .020 & 430.594 .697 & 343.174 .482 & 343.174 .482 \\
\hline 2010 & 139.019 .792 & 701.425 .174 & 840.444 .966 & 826.172 .628 & 412.387 .767 & 412.387 .767 \\
\hline 2011 & 204.070 .000 & 88.505 .610 & 292.575 .610 & 292.537 .149 & 265.551 .259 & 265.551 .259 \\
\hline 2012 & 249.900 .000 & 105.720 .000 & 355.620 .000 & 396.542 .754 & 190.262 .425 & 190.262 .425 \\
\hline 2013 & 260.203 .000 & 84.768 .918 & 344.971 .918 & 367.383 .503 & 160.137 .617 & 160.137 .617 \\
\hline 2014 & 166.750 .302 & 133.200 .000 & 299.950 .302 & 299.950 .302 & 133.557 .902 & 133.557 .902 \\
\hline 2015 & 163.750 .302 & 94.792 .000 & 258.542 .302 & 258.542 .302 & 74.957 .079 & 74.957 .079 \\
\hline 2016 & 100.000 .000 & -28.420 .611 & 71.579 .389 & 71.579 .389 & - & - \\
\hline TOTAL & 2.193 .872 .126 & 1.459 .157 .521 & 3.653.029.647 & 3.966.778.526 & 2.210 .605 .568 & 2.210 .605 .568 \\
\hline
\end{tabular}

Fonte: Ascom/ Minc. ${ }^{125}$

De certo modo, é importante compreender que a gestão de Dilma Rousseff, ainda que do mesmo partido que o anterior, se apresenta como um novo agente e com uma nova agenda e prioridades, e também como uma nova autoria na condução da arquitetônica do sistema como um todo. $\mathrm{O}$ montante de verbas destinado à pasta da cultura pode indicar as intenções ideológicas e as escolhas do governo federal em cada um dos períodos e por isso pode ser considerado um dos fatores de autoria dentro da arquitetônica, já que o financiamento é parte essencial da proposta do Sistema. Enquanto na gestão de Lula é possível ver um relativo crescimento de verbas (ainda que pequeno), na gestão Dilma, a partir de 2011, os valores decresceram a cada ano. Não pretendemos fazer uma análise aprofundada de dados da economia da cultura neste momento da tese, porém é relevante perceber na tabela acima que o ano de 2010, último ano da gestão Lula mostra o auge do fortalecimento das verbas do FNC, principalmente no que tange ao orçamento executado pelo MinC (orçamento liquidado / executado) estimado em 412 milhões de reais. Após 2010, o montante destinado ao FNC ${ }^{125}$ Nos anos seguintes a 2016 , os recursos do FNC foram cada vez mais escassos e a informação sobre a
aplicação dos recursos cada vez menos transparente. 
inicia um processo de decréscimo que atinge seu pior resultado em $2016^{126}$.

A queda no investimento do FNC a partir de 2011 deve-se não apenas ao início do agravamento da crise econômica, mas também pode ser considerado pelas prioridades do novo governo federal se levarmos em conta que o orçamento geral da pasta cultura no período, incluindo as verbas de Rouanet e administração direta raramente ultrapassavam o patamar de $0,03 \%$ do PIB nacional. Na tabela abaixo é possível perceber que ainda que o montante tenha um relativo crescimento de 2011 a 2015, a porcentagem em relação ao todo foi decrescendo em proporção ao orçamento federal como um todo ou se manteve igual num patamar aquém do desejado.

Figura 11: Indicadores do orçamento federal da cultura entre 2010 e 2017

\begin{tabular}{|c|c|c|c|c|c|c|c|c|c|}
\hline Indicador & $\begin{array}{l}2010 \\
\text { (R\$) }\end{array}$ & $\begin{array}{c}2011 \\
\text { (R\$) }\end{array}$ & $\begin{array}{c}2012 \\
\text { (R\$) }\end{array}$ & $\begin{array}{l}2013 \\
\text { (R\$) }\end{array}$ & $\begin{array}{c}2014 \\
\text { (R\$) }\end{array}$ & $\begin{array}{l}2015 \\
\text { (R\$) }\end{array}$ & $\begin{array}{l}2016 \\
\text { (R\$) }\end{array}$ & $\begin{array}{l}2017 \\
\text { Alcançado } \\
\text { (R\$̣) }\end{array}$ & $\begin{array}{l}\text { Ponto } \\
\text { da } \\
\text { meta } \\
2020\end{array}$ \\
\hline $\begin{array}{l}\text { Despesas públicas } \\
\text { federais para } \\
\text { cultura - } \\
\text { Orçamento MINC }\end{array}$ & 1.092 .536 .726 & 982.413 .458 & 1.278 .630 .684 & 1.498.710.290 & 1.530 .734 .514 & 1.763 .570 .613 & $666.785 .691,41$ & $759.898 .878,00$ & \\
\hline $\begin{array}{l}\text { Despesas públicas } \\
\text { federais para } \\
\text { cultura - Aporte } \\
\text { Outros Órgãos** }\end{array}$ & 140.308 .017 & 135.085 .335 & 148.022 .990 & 48.699 .053 & 58.775 .287 & 63.489 .656 & $7.634 .408,95$ & $3.680 .243,00$ & \\
\hline $\begin{array}{l}\text { TOTAL Recursos } \\
\text { públicos federais } \\
\text { para cultura }\end{array}$ & 1.232 .844 .743 & 1.117.498.793 & 1.426 .653 .674 & 1.547 .409 .343 & 1.589 .509 .801 & 1.827 .060 .269 & $674.420 .100,36$ & $763.579 .121,00$ & \\
\hline PIB (milhões) & 3.885 .847 & 4.373 .658 & 4.805 .913 & 5.316 .455 & 5.687 .309 & 5.904 .331 & $6.266 .894,74$ & $6.559 .940,00$ & \\
\hline $\begin{array}{l}\% \text { de recursos } \\
\text { públicos federais } \\
\text { para cultura/PIB }\end{array}$ & $0,032 \%$ & $0,026 \%$ & $0,030 \%$ & $0,029 \%$ & $0,028 \%$ & $0,030 \%$ & $0,011 \%$ & $0,012 \%$ & $\begin{array}{c}0,043 \\
\%\end{array}$ \\
\hline
\end{tabular}

Fonte: site do PNC. Dados presentes na meta $51^{127}$.

$\mathrm{Na}$ relação com o avanço do sistema, e na aplicação ao FNC também houve decréscimo. Após 2015 a queda é ainda mais brusca e deve-se à ruptura institucional que afeta diretamente o sistema. A compreensão dos dados orçamentários de cada ano do processo trazem a informação sobre as prioridades da agenda política de cada momento. Contudo também demonstra que em nenhum momento estes recursos tiveram uma ampliação considerável. O Sistema deve ser entendido não apenas como um novo modelo estruturante de política cultural, mas também como uma nova forma de distribuir recursos para a cultura, com menor concentração e maior democratização. Porém, até o momento isso ainda não aconteceu efetivamente.

\footnotetext{
${ }^{126}$ Os dados referentes aos anos de 2016 e 2017 indicam a continuidade na queda de valores, porém, devido à ruptura no governo, não encontramos dados consistentes para evidenciar esta informação.

${ }^{127}$ Fonte: Site do Plano Nacional de Cultura. Disponível em: < http://pnc.culturadigital.br/metas/aumento-de-37acima-do-pib-dos-recursos-51-publicos-federais-para-a-cultura/ $>$ acesso em 10/03/2018.
} 


\section{4 - A implantação dos Sistemas de Cultura em São Paulo: contexto estadual e municipal.}

A implantação do SNC nos estados e municípios é parte integrante da lógica do processo de implantação do sistema em termos federativos. Com vistas à análise do corpus que será desenvolvida nos próximos capítulos, e por uma questão de localização desta pesquisa, aqui nos deteremos na observação histórica da implantação dos Sistemas de Cultura do estado e do município de São Paulo.

Desde o início, os processos de construção do Sistema Estadual de Cultura em São Paulo encontraram um cenário não muito propício para sua implantação por conta da falta de interesse da gestão estadual nessa nova Política Nacional de Cultura. Há pouca ou quase nenhuma informação disponível sobre as conferências estaduais de cultura do estado, justamente por conta da falta de interesse do estado na realização desses encontros.

No período do chamado do MinC para a realização das primeiras conferências municipais e estaduais em 2005, visando á $1^{\text {a }}$ CNC, o estado de São Paulo não realizou sua primeira conferência estadual (ainda que diversos municípios tenham realizado as suas). Em novembro de 2009, a Secretaria de Estado da Cultura de São Paulo, capitaneada no período pelo secretário João Sayad, promoveu no Memorial da América Latina a $1^{\text {a }}$ Conferência Estadual de Arte e Cultura ${ }^{128}$ para discutir asssuntos de interesse da gestão no dia 25 . E no dia 26 de novembro, ocorreu o que seria nossa primeira Conferência Estadual de Cultura ligada ao SNC, onde foram escolhidos os delegados para a $2^{\mathrm{a}} \mathrm{CNC}$ que aconteceria no ano seguinte em Brasília.

São Paulo foi um dos estados que mais tarde fez sua adesão ao SNC, de acordo com informações no site do Plano Estadual. O primeiro estado a concluir o processo de implantação do Sistema Estadual de Cultura foi o Ceará no ano de 2009.

O Estado de São Paulo aderiu ao Sistema Nacional de Cultura por meio do Acordo de Cooperação Federativa firmado, em 6/9/2013, entre a União e o Governo do Estado de São Paulo, nos termos da Portaria 156 do Ministério da Cultura, de 6/12/2012. Pelo Acordo, a Secretaria de Cultura fica incumbida de instituir o Sistema Estadual de Cultura, formada por nove componentes, seis obrigatórios e três optativos. ${ }^{129}$

Logo após a adesão ao SNC, a Secretaria de Estado da Cultura de São Paulo (SEC)

\footnotetext{
${ }^{128}$ Disponível em: < http://www.saopaulo.sp.gov.br/spnoticias/ultimas-noticias/governo-abre-inscricoes-paraconferencia-de-arte-e-cultura/ > acesso em 07 de julho de 2019.

129 Informações disponíveis no site que abrigou a consulta pública do Plano Estadual de Cultura. Disponível em: < http://www.planoestadualdecultura.sp.gov.br/?page $\mathrm{id}=7$ > acesso em 2 de junho de 2016.
} 
publicou uma resolução que criou o primeiro grupo interno para a articulação da implantação do Sistema. A resolução SC 109, de 20 de dezembro de 2013 criou o Grupo de Trabalho Interno para a Discussão da Elaboração do Plano Estadual de Cultura do Estado de São Paulo. De acordo com a resolução, ao grupo composto, caberia articular todas as ações iniciais de implantação do sistema paulista.

A $3{ }^{\mathrm{a}}$ Conferência Estadual de Cultura (CEC) (que na verdade seria a segunda) ocorrida em setembro de 2013 no Memorial da América Latina teve a participação de mais de 800 agentes do setor cultural. As propostas aprovadas na CEC paulista traz em seu texto um tom que não representava as vontades do governo estadual, mas do setor cultural local. Isso fica evidenciado no item 3 do Eixo 1 que exige como premissa "Que o Estado aplique 3\% de seu orçamento anual na Secretaria de Cultura". Em 2013, o orçamento estadual investido na pasta da cultura não chegava aos $0,5 \%$ do PIB paulista, e nos anos que seguiram, o governo estadual declarou cortes de mais de $30 \%$ de orçamento na pasta da cultura por dois anos seguidos, chegando em 2016 com um orçamento de menos de $0,2 \%$.

A primeira tentativa de inscrição do projeto de lei do Sistema Estadual Paulista, nomeado como "Código Estadual de Cultura", apresentou um erro do parlamentar responsável pela inscrição da primeira proposta da lei. O Deputado Estadual Edmir Chedid (DEM - SP) inscreveu o PL relativo ao Sistema na Assembleia Legislativa do Estado de São Paulo (ALESP) em outubro de 2014 com um texto copiado da lei similar escrita no estado da Bahia. O texto inscrito no sistema legislativo estadual apresentava diversas incidências da palavra "Bahia" em trechos em que deveria constar a palavra "São Paulo". O erro foi noticiado na grande mídia local pela jornalista Monica Bergamo e o PL com os erros ficou disponível no site da Assembleia Legislativa por algumas semanas. A primeira tentativa de projeto de lei do sistema paulista foi arquivada atrasando ainda mais o processo.

Por outro lado e por iniciativa do setor cultural, um grupo de especialistas, artistas e produtores culturais assumiu a escrita das minutas para a implantação do Sistema. A publicação da Resolução SC nº 85, de 19 de agosto de 2014, revogava alguns itens da resolução 109 e visava designar membros para comporem a Comissão de Sistematização de Informações, Elaboração e Redação do Plano Estadual de Cultura do Estado de São Paulo.

A Comissão de Sistematização realizou diversas reuniões e escreveu novas propostas para o projeto de lei do Sistema, em conjunto com os textos de implantação do Plano e do Fundo de Cultura paulista. Em março de 2015, a comissão apresentou a primeira proposta de minutas ao Secretario de Estado da Cultura Marcelo Mattos Araújo numa reunião no prédio 
da secretaria para encaminhamento ao legislativo e executivo estadual. Todavia, para garantir a legitimidade da ação, a Comissão convocou uma audiência pública na Assembleia Legislativa de São Paulo, para a entrega oficial das minutas. A audiência foi organizada pela classe artística paulista e por alguns parlamentares simpáticos à causa da cultura em 29 de abril de 2015 e contou com a presença de mais de 300 pessoas. Neste evento, também foi criada a Frente Pró-Sistema Estadual de Cultura, composta por diversas entidades artísticas e culturais do estado para ampliar o debate. A Frente se propôs a liderar a luta para a implantação do Sistema Paulista em conjunto à Comissão de Sistematização, bem como a luta pela aprovação das leis do sistema com conteúdo apoiado pelos agentes da esfera em São Paulo. Composta por relevantes nomes do setor cultural, a Frente também tinha como representantes na Alesp os deputados estaduais: João Paulo Rillo (naquele momento ainda no PT), Carlos Gianazzi (PSol) e Leci Brandão (PC do B) que compunham a Frente Parlamentar de Cultura do Estado de São Paulo.

Durante um ano as minutas escritas pela Comissão de Sistematização, composta por pessoas do setor cultural, contendo os projetos de lei do Sistema, Plano, Fundo e Conselho estadual estiveram em análise pelo setor jurídico da Secretaria de Estado da Cultura. Entre $1^{\circ}$ de agosto e 15 de setembro de 2015, a minuta escrita pela Comissão com as metas do Plano Estadual $^{130}$ ficou em consulta pública via internet e permitiu a todos os interessados sugerirem alterações no enunciado com vistas a melhorar trechos e inserir novas metas coerentes com as demandas do setor.

Contudo, paralelo a isso e à revelia dos processos de implantação liderados pelo setor cultural paulista, o Deputado Edmir Chedid retomou o processo por meio da proposta de projeto de lei do Código Estadual de Cultura com minutas diferentes das propostas pela Comissão de Sistematização. No dia 19 de novembro de 2015, ele esteve em reunião com o Secretário de Cultura Marcelo Araújo, conforme noticiado no site da Alesp e entregou uma nova proposta de seu PL do Código. ${ }^{131}$

Neste momento, a implantação do sistema paulista inicia um processo de mão dupla. Se por um lado, o processo de implantação do Sistema estadual corria conforme os manuais de implantação do MinC determinavam, por outro, o processo foi "atropelado" a partir de um acordo entre os governistas estaduais. No dia 13 de abril de 2016, numa atitude fora do contexto, é inscrito na Assembleia Legislativa do Estado de São Paulo, o projeto de lei N.

130 A consulta pública do Plano Estadual de Cultura de São Paulo está disponível em: < http://www.planoestadualdecultura.sp.gov.br/?page id=464 > acesso em 3 de junho de 2016.

131 Informação disponível em: < http://www.al.sp.gov.br/noticia/?id=368691 > acesso em 2 de junho de 2016. 
$305^{132}$, do Código Estadual de Cultura com autoria de Edmir Chedid e com pouca relação com as minutas propostas pela Comissão da cultura. O texto, ao contrário do que sugere o modelo de projeto de lei de sistema de cultura, se apresenta como um compêndio de leis já existentes como o Proac, ou mesmo a definição de datas festivas da cultura popular paulista. O Código inscrito pelo deputado do partido Democratas ignorou totalmente o teor dos enunciados produzidos pela comissão de agentes culturais e não inclui em seu objeto instituir o Sistema Estadual de Cultura, muito menos um Plano Estadual de Cultura. O PL se inscreve à frente do processo de implantação do Sistema Paulista de Cultura ignorando as propostas escritas por pessoas do setor cultural desde 2014 com ampla participação popular. O mesmo deputado estadual, que em 2014 havia inscrito a primeira tentativa de Sistema estadual, foi um pivô de um esforço do governo do estado de São Paulo de desenvolver o processo de implantação do sistema de forma incoerente aos preceitos do SNC, sem participação popular em sua idealização e com uma estrutura diferente da sugerida pelo MinC.

Numa tentativa de barrar o texto de Edmir Chedid, o deputado estadual João Paulo Rillo, com ajuda de agentes culturais do estado, inscreveu no dia 21 de abril de 2016 dezesseis emendas de alteração do texto do PL do Código. As emendas foram escritas a partir das minutas desenvolvidas anteriormente pela Comissão do setor cultural e em diálogo com o enunciado do PL de Edmir Chedid. As emendas previam alterações para tornar o conteúdo do texto inscrito mais próximo às premissas das minutas escritas para o sistema estadual de cultura, legitimadas nas audiências e em consulta públicas.

No dia 25 de abril de 2016, o PL de Chedid entrou para análise nas comissões da Alesp: CCJR - Comissão de Constituição, Justiça e Redação. CEC - Comissão de Educação e Cultura. CFOP - Comissão de Finanças Orçamento e Planejamento. Os últimos andamentos substanciais do PL no site da Alesp informa que:

a) Em 3 de agosto de 2016, o Deputado Marcos Zerbini (PSDB), relator da Comissão de Constituição, Justiça e Redação, deu seu parecer favorável à matéria;

b) Em 13 de junho de 2018, o Deputado Luiz Turco (PT), pela Comissão de Educação e Cultura, com voto favorável ao projeto, porém contrário à emenda $\mathrm{n}^{\circ} 14$ e favorável às demais emendas apresentadas. Este foi contestado pelo deputado Gilmaci Santos (PRB) que pediu vistas ao projeto no dia 27 de novembro.

De outro lado, corria o processo das minutas feitas pela Comissão. Em agosto de 2016,

132 PL 305/2016 disponível em: < http://www.al.sp.gov.br/propositura/?id=1310397 > acesso em 2 de junho de 2016. 
depois de passar por várias instâncias, o então Secretário Adjunto José Roberto Sadek finalmente encaminhou para o governador parecer pedindo a aprovação do plano escrito pela comissão de sistematização. Em setembro de 2016, a Procuradoria Geral do Estado (PGE) contestou alguns pontos. A Casa Civil devolveu o documento à SEC para correção de alguns apontamentos. No mês de novembro de 2016, a SEC encaminha um novo documento à PGE, com o PL corrigido e responde as contestações. Em dezembro de 2016, o Secretário Marcelo Araújo pede exoneração do cargo e Sadek assume a cadeira interinamente, até que em março de 2017, José Luiz Penna, presidente do Partido Verde, assume a Secretaria Estadual de Cultura. Atualmente o Plano Estadual de Cultura encontra-se parado na PGE.

A fim de acelerar o processo, em dezembro de 2017, a Secretaria Estadual de Cultura de São Paulo preparou um decreto de instituição do Conselho Estadual de Política Cultural que seguiu para a sanção do Governador. Com a saída de Geraldo Alckmin para concorrer à eleição presidencial e a posse de seu vice-governador Márcio França, a assinatura do decreto coube a França, que não apenas assinou o contrato, mas autorizou a realização da eleição do Conselho e que de fato foi publicado em edital no Diário Oficial do estado logo após as eleições gerais de 2018. O edital de eleição do Conselho previa eleger 12 colegiados de 17 setores (6 titulares e 6 suplentes). Iniciamente o processo eleitoral estava com data marcada para acontecer no início de dezembro de 2018. Entretanto, a SEC desistiu de realiza-lo neste período e deixou para ser realizado em 2019, pela gestão seguinte, alegando falta de tempo e recursos para ampliar os locais de votação presencial.

Com a posse do novo governador João Dória em janeiro de 2019, a SEC passa a se chamar Secretaria de Cultura e Economia Criativa e este nomeia para o cargo de secretário Sérgio Sá Leitão, que entre 2017 e 2018 estava como Ministro da Cultura de Temer.

No mês de fevereiro de 2019, o Secretário Sérgio Sá Leitão decide parar o processo de eleição do Conselho por vias democráticas e em reuniões com a militância do setor cultural propõe que o Conselho Estadual de Políticas Culturais seja escolhido por ele junto a entidades representativas da cultura. No dia 15 de abril de 2019, numa atitude arbitrária e contrária ao que vinha sido dialogado entre representantes do setor e o secretário, o governador João Doria veicula em suas redes sociais um vídeo divulgando seu "novo" Conselho Estadual de Cultura composto por notáveis escolhidos por ele e em maioria representantes de camadas mais elitizadas e conservadoras das artes.

A história da implantação do sistema municipal começa com a realização da $1^{\mathrm{a}}$ 
Conferência Municipal de Cultura no ano de 2004, na gestão da prefeita Marta Suplicy com o tema "A cultura em São Paulo: diversidade e direitos culturais". As discussões realizadas estiveram em torno de seis eixos: 1. Gestão cultural; 2. Memória e patrimônio cultural; 3. Cultura como atividade econômica; 4. Globalização e metrópole; 5. Interfaces da cultura com a educação; 6. Cidadão e cultura. A conferência foi precedida de onze pré-conferências nas macrozonas da cidade, com mais de 3600 participantes. Destas resultaram 658 propostas da sociedade civil e a indicação de 85 representantes para a conferência principal. Ao todo foram aprovadas 131 propostas e encaminhadas para a Conferência Estadual de Cultura.

A $2^{\text {a }}$ Conferência Municipal de Cultura ocorreu em 2009 durante a gestão do prefeito Gilberto Kassab e foi organizada por uma comissão de funcionários da Secretaria Municipal de Cultura. Não teve a realização de pré-conferências territoriais e contou com a presença de apenas 292 participantes. Não encontramos em nossa pesquisa maiores informações sobre essa segunda conferência.

A adesão do município ao SNC a partir do Acordo de Cooperação Federativa aconteceu no dia 26 de julho de 2013 já na gestão do prefeito Fernando Haddad e seu secretário Juca ferreira e deu início à $3^{\mathrm{a}}$ Conferência Municipal de Cultura $(\mathrm{CMC})$ ocorrida entre os dias 27 de julho e 4 de agosto. Nos dias 27 e 28 de julho foram realizadas as préconferências territoriais em cinco macrorregiões da cidade. Nos dias 2 a 4 de agosto foi realizada a terceira conferência no Memorial da América Latina com a presença de 784 participantes e aprovou 60 propostas. A oportunidade de aderir ao SNC após duas conferências anteriores e realizar concomitantemente a conferência durante o primeiro ano da gestão de Haddad possibilitou que o processo tivesse desde o início uma organização que seguisse os trâmites sugeridos pelos manuais do SNC.

Aliado a isso, em 2013, a Secretaria Municipal de Cultura de São Paulo foi pioneira na implantação de uma plataforma digital colaborativa para mapeamento da cultura em todo país. A parceria com o Instituto Tim possibilitou o desenvolvimento de um software livre para auxiliar nos processos de diagnósticos com ampla participação social. A plataforma SP Cultura ${ }^{133}$ passou a receber inscrições de agentes culturais, equipamentos públicos, eventos e projetos a fim de acelerar com ajuda da sociedade civil a contabilização dos avanços culturais na cidade de SP. Em 2014, a plataforma começou a ser usada pela SMC para a inscrição de seus editais e concursos do setor. Com isso, o processo recebeu um volume ainda maior de inscrições dos mais diversos tipos.

\footnotetext{
${ }^{133}$ Disponível em: < http://spcultura.prefeitura.sp.gov.br/ > acesso em 15 de agosto de 2016.
} 
A publicação Participação e cidadania cultural: A experiência da III Conferência Municipal de Cultura foi lançada no evento "Seminário Participa Cultura: Construindo o Sistema Municipal de Cultura" ocorrido em abril de 2014 no auditório da Biblioteca Mario de Andrade e contou com a presença maciça de pessoas do setor cultural. O livro distribuído gratuitamente oferecia uma prévia do diagnóstico com as demandas municipais para a cultura e trouxe o detalhamento das propostas temáticas aprovadas na $3^{\mathrm{a}}$ Conferência e que deveriam servir de base para a construção do Plano Municipal.

A efetiva implantação do Sistema Municipal de Cultura começou em julho de 2015 com a realização de um edital de contratação de uma Fundação para a organização das etapas seguintes. A escolhida foi a Fundação São Paulo, filiada à Pontifícia Universidade Católica. O processo contou com uma equipe de 18 pessoas e designou duas consultoras para desenvolver o diagnóstico sobre o município durante três meses a partir dos resultados iniciais vistos na terceira conferência.

A etapa seguinte, da formulação das diretrizes, ações, metas para a consulta pública, foi realizada entre os meses de setembro e dezembro de 2015 a partir de encontros entre gestores em reuniões territoriais e setoriais. Em outubro, ocorreram oficinas temáticas internas com gestores da secretaria e membros da fundação que organizou a etapa. Nesses encontros foi formulado o primeiro esboço do texto com as 50 metas do Plano Municipal de Cultura (PMC) da cidade de São Paulo visando a etapa seguinte da consulta pública. As metas foram elencadas a partir das sugestões da $3^{\mathrm{a}} \mathrm{CMC}$.

A consulta pública do PMC foi realizada entre 25 de fevereiro a 25 de março de 2016 em site específico ${ }^{134}$ e também em reuniões presenciais que reuniram mais de 2600 participantes entre os dias 25 de fevereiro a 10 de março de 2016 em diferentes pontos da cidade e em reuniões temáticas setoriais abertas à sociedade civil.

Os projetos de lei que compõem a base do sistema foram inscritos em 2015 como PL 01-00248/2015 (lei do Conselho Municipal de Cultura) e PL 16.278/2015 (lei do Fundo Municipal de Cultura) com vistas a acelerar o processo. A lei do Fundo foi aprovada ainda em 2015 e a lei do Conselho ainda está em fase de aprovação na Câmara Municipal.

O texto do Plano Municipal de Cultura com as metas definitivas organizadas após a consulta pública esteve entre junho e novembro parado na Secretaria de Governo da prefeitura. Em dezembro de 2016, o Sistema e o Plano Municipal de Cultura de São Paulo

\footnotetext{
${ }^{134}$ Disponível em: < http://www.planomunicipaldecultura.prefeitura.sp.gov.br/> acesso em 10 de setembro de 2016.
} 
foram aprovados por meio do decreto municipal 57.484/2016.

Em janeiro de 2017, a nova gestão municipal do prefeito João Dória toma posse e a SMC passa a ser capitaneada pelo Secretário André Sturm, que apresenta um discurso para a cultura diferente do anterior. $\mathrm{O}$ apagamento de mais de cinco quilômetros de murais de grafite na Avenida 23 de maio e o anúncio da privatização de centros culturais e bibliotecas demonstraram que esta nova gestão não estava de acordo com os planejamentos previstos nos conteúdos do Plano Municipal de Cultura da cidade recém aprovado. Para comprovar isso, no início de fevereiro anunciam o congelamento de mais de $47 \%$ da verba para a cultura aprovada na Lei Orçamentária Anual, inviabilizando boa parte dos programas já existentes e elencados no Plano de cultura da cidade. Em resposta a isso, os trabalhadores da cultura da cidade se mobilizam e criam a Frente Única da Cultura SP, e no dia 27 de março de 2017 realizam uma manifestação intitulada "Descongela a cultura já" com mais de sete mil pessoas presentes e noticiada em toda a grande mídia do país. O movimento tinha como premissas iniciais o descongelamento das verbas da cultura da cidade e a imediata implantação do Plano Municipal de Cultura (PMC SP).

Em março de 2017, a prefeitura apresenta seu programa de metas que ignora totalmente o PMC SP. As duas únicas metas para a cultura presentes no programa, que é base para o Plano Plurianual de Dória, versam sobre a ampliação em $15 \%$ da quantidade de público em equipamentos culturais e bibliotecas.

No início de junho de 2017, após um grave incidente de ameaça de agressão a um agente cultural de Ermelino Matarazzo por parte do secretário Sturm, dezenas de integrantes de diversos movimentos culturais ocupam a Secretaria Municipal de Cultura exigindo a saída imediata do Secretário. A partir desse momento, o diálogo entre a SMC e o setor passa a ser ainda mais difícil. Confrontos diários em artigos escritos nos jornais Folha de São Paulo e O Estado de São Paulo, com textos de ambas as partes, deixam ainda mais claro que o diálogo era impossível e que a nova gestão não estava interessada nem no Plano Municipal de Cultura nem em permitir a participação social dos agentes culturais na construção das políticas da cidade. Ao contrário disso, propunha uma política de privatizações de todos os equipamentos públicos de cultura da cidade sem nenhum tipo de consulta popular.

No dia 16 de novembro de 2017, o Ministério Público da cidade de São Paulo abre um inquérito para averiguar irregularidades na implantação do Plano Municipal de Cultura pela prefeitura de Dória. A denúncia inclui o não cumprimento da meta 1 do PMC que prevê a execução $2 \%$ de orçamento para cultura (nesse momento executada em menos de $0,5 \%$ ) e a 
não execução de programas previstos no PMC e em lei, como o Fomento ao Teatro e o Fomento à cultura da periferia.

O orçamento da cultura da cidade fechou o ano de 2017 com mais de $45 \%$ de sua verba prevista ainda congelada (e não executada). O orçamento para o ano de 2018, enviado pela SMC para o projeto de lei da Lei Orçamentária Anual (LOA), apresentou uma redução de 15\% relativa ao ano anterior. Após a realização das audiências do orçamento na Câmara de $\mathrm{SP}$, os movimentos de cultura da cidade conseguiram ampliar a margem do projeto de orçamento original, mas ainda permanecendo em pelo menos $7 \%$ menor do que o aprovado em 2017 com 0,84\% relativo ao orçamento geral da cidade. O foco das reivindicações dos movimentos da cultura não era apenas pela ampliação do orçamento, era principalmente pela implantação do Plano Municipal de Cultura.

O Plano Plurianual (PPA) de Dória, aprovado na Câmara no dia 13 de dezembro de 2017 e que valerá até o ano de 2021, não apresentou nenhum item relativo à implantação do Plano Municipal de Cultura. Também é possível perceber no PPA, que a projeção orçamentária para a Secretaria Municipal de Cultura até 2021 sofrerá redução significativa, mantendo-se nos quatro anos no patamar máximo de 0,8\%. Este dado contraria a Meta 1 do Plano Municipal de Cultura de São Paulo, que projeta que a cidade chegue aos $2 \%$ de verba para a cultura até $2021^{135}$. Ao contrário disso, a projeção do PPA prevê uma redução da verba.

Em abril de 2018, João Dória sai da prefeitura para concorrer à eleição para o cargo de governador do estado de São Paulo e em seu lugar fica seu vice-prefeito Bruno Covas que mantém a mesma política de cortes no orçamento para o setor cultural. Isso foi evidenciado com a proposta de Lei Orçamentária Anual municipal para o ano de 2019, que trouxe uma diminuição de mais de $18 \%$ nos recursos da cultura quando comparado ao ano anterior.

Em janeiro de 2019, o prefeito Covas exonerou André Sturm da Secretaria Municipal de Cultura e em seu lugar nomeia o empresário Alexandre Yousseff, que em suas declarações iniciais na imprensa não mencionou o Plano Municipal de Cultura, nem mesmo a maioria dos programas municipais existentes há muitos anos e estabelecidos em leis.

\footnotetext{
${ }^{135}$ Projeções do PPA 2018 - 2021 para o orçamento da SMC: 2018 - R\$ 488.156.209 (0,85\% do total do orçamento); 2019 - $\mathrm{R} \$ 469.174 .440$ (0,81\%) redução de 19 milhões; 2020 - $\mathrm{R} \$ 518.572 .879$ (0,82\%); 2021 $\mathrm{R}$ \$ $526.387 .588(0,81 \%)$ ampliação de apenas 8 milhões. Informações disponíveis em < http://www.camara.sp.gov.br/blog/ppa-plano-de-habitacao-e-47-projetos-de-vereadores-sao-votados/ > acesso em 15 de dezembro de 2017.
} 
Em 12 de março de 2019, o Movimento Cultural das Periferias (MCP) realizou uma grande audiência cidadã da cultura no teatro Cia Pessoal do Faroeste no bairro da luz, com a presença do secretário e sua equipe e de mais de 300 pessoas da sociedade civil. Nesta audiência, integrantes do MCP apresentaram uma série de dados e reivindicações, entre elas a imediata implantação do Plano Municipal de Cultura de São Paulo e a criação de uma Comissão de Política Cultural da Periferia, para trabalhar em conjunto com a SMC e com o legislativo a fim de retomar os processos do Sistema Municipal de Cultura.

A primeira ação concreta para isso foi a criação de uma subcomissão de estudos do Plano Municipal de Cultura no mês de maio de 2019 na Câmara Municipal da cidade, submetida à Comissão de Finanças e Orçamento. A subcomissão visa a análise e atualização do PMC, bem como a inserção de itens orçamentários na Lei Orçamentária Anual da cidade para 2020 com vistas a regionalizar os recursos para que estes cheguem de fato às periferias da cidade.

$* * *$

Neste capítulo sobre o horizonte social foi possível verificarmos que de fato a história das políticas culturais no Brasil e no contexto mundial devem ser levadas em conta ao pensarmos a arquitetônica da esfera.

Da primeira fase das políticas culturais trazemos o caráter autoritário e com viés de Estado forte e com foco numa identidade construída de cima para baixo. Primeiro da Era Vargas, mais especificamente da gestão de Mario de Andrade do Departamento de Cultura de São Paulo, trazemos a primeira tentativa de fazer uma política cultural com sotaque brasileiro, com viés nacionalista, mas também vanguardista para época e que pensava que era possível a inclusão pela cultura. Depois, na fase da ditadura militar, entre 1964 e 1985, devemos prestar atenção às nomenclaturas das políticas para cultura adotadas na época e sua similaridade com as que estudamos no período contemporâneo. A importância de um Conselho Federal de Cultura para a construção de um Plano Nacional de Cultura estava sendo pensado no início da repressão ditatorial no ano de 1967, porém com um caráter autoritário e de concentração de poder.

A reabertura política em 1985 alterou consideravelmente o viés das políticas culturais da primeira fase e nos permite dizer que iniciou assim a segunda fase das políticas culturais no país, caracterizada pelos incentivos fiscais, em que o mercado divide com o estado as decisões sobre como as verbas de cultura são distribuídas. Essa segunda fase orienta-se pelo fortalecimento do mecenato, isto é, os patrocínios e os editais, concretizados principalmente 
na Lei Rouanet, e seus preceitos vigoram até os dias atuais. Entretanto foi no final dos anos 1980 que em São Paulo a gestão de Erundina / Chauí na SMC SP propõe como premissa básica a cidadania cultural e a participação popular nas decisões das políticas culturais e da distribuição dos recursos.

A influência da UNESCO nas políticas culturais brasileiras, principalmente após a reabertura democrática, deve ser levada em conta em nossa reflexão. Os conceitos de diversidade cultural e a ideia de ampliação de acesso à cultura foram cada vez mais influenciando diversos países do mundo a repensarem suas formas de desenvolver a gestão da cultura. No Brasil, essa influência veio principalmente a partir da gestão de Gilberto Gil em 2003 no MinC. O questionamento sobre qual conceito de cultura deveria ser defendido e a defesa de uma cultura no viés antropológico demonstram que Gil estava também influenciado pelas diretrizes da UNESCO.

As propostas de mudança de paradigma da nova gestão do MinC que, a partir de 2003, contava com um ministro conhecido mundialmente, estavam expressas nos diversos marcos legais propostos a partir do ano 2000. Essa “malha” de leis, PECs, decretos etc. buscava compor uma nova arquitetônica para a esfera por meio de novos conceitos e centros de valor ideológicos, principalmente as ideias de diversidade cultural, ampliação do acesso e participação social. A mudança de paradigma estava posta em processo, mas o processo de ruptura com o impeachment de Dilma em 2016 e a eleição de Bolsonaro em 2019, destabilizou essa construção e deixou dúvidas sobre sua efetiva continuidade. Um processo semelhante de ruptura aconteceu na cidade de São Paulo com a eleição do prefeito João Doria e a parada na implantação do Plano Municipal de Cultura. A eleição de João Doria em 2019 para o governo do estado de São Paulo também gera dúvidas sobre a possibilidade da continuidade dos processos, principalmente após a derrubada da eleição direta para a composição do Conselho Estadual de Cultural em 2019. 


\section{CAPÍTULO 4: A CONSTRUÇÃO DO SISTEMA NACIONAL DE CULTURA: AUTORIA, INTERAÇÃO E ATO ÉTICO}

Como vimos no capítulo anterior, o Sistema Nacional de Cultura chega ao final de 2018 com diversos processos de instabilidade após um intervalo/ruptura no Governo federal gerado pelo processo de impedimento da Presidenta Dilma Rousseff e a troca de ministros na pasta da cultura. A ruptura resultou no fechamento e a recriação do MinC a partir das Medidas Provisórias (MP) 726/2016 e 728/2016 e em quatro mudanças de Ministro e de partido em sua condução em apenas doze meses de sua condução, e novamente num novo fechamento do MinC em janeiro de 2019.

Ainda que em nível federal o Sistema tenha sofrido um lapso temporal em razão da instabilidade no Poder Executivo, e que também atingiu o andamento do Plano Nacional de Cultura com o atraso de ações previstas, não podemos esquecer que, devido à sua estrutura descentralizadora, o sistema continua avançando nos estados e municípios ainda que de maneira mais lenta. No entanto, mesmo com a continuação dos processos nos entes federados, a grande maioria destes ainda não haviam concluído as etapas básicas previstas para a implantação do Sistema até o final de 2017.

Desenvolvemos esta segunda etapa de análise por meio da observação dos documentos do corpus, principal e auxiliar, e de seus processos de composição, mas principalmente examinando os agentes envolvidos. Iniciaremos o capítulo com a abordagem do conceito de autoria em Bakhtin para melhor compreender a importância dos envolvidos nos processos da arquitetônica do Sistema. Num segundo momento, analisaremos a autoria nos marcos regulatórios relativos ao SNC e ao PNC, levando em conta que foram escritos em processos da esfera legislativa com seus modos de produção específicos para cada tipo de documento legal, mas que tiveram interferências de outras esferas, como a político-cultural. Adiante, trataremos da participação social na construção do SNC e a quem se destina o Sistema.

\section{1 - O conceito de autoria nas teorias de Bakhtin}

O conceito de autoria nas obras de Mikhail Bakhtin foi sendo desenvolvido ao longo de décadas e pode ser pensado como uma chave para a arquitetônica de sua teoria. Nas primeiras obras do pensador russo, Arte e responsabilidade e Para uma filosofia do ato responsável, a autoria ainda não estava no foco, porém é possível dizer que, ao pensar a 
responsabilidade do ato ético do ser, Bakhtin já projetava o que viria a ser esse autor que é responsável por seus atos criativos no mundo da vida e da arte.

Na obra $O$ problema do conteúdo, do material e da forma na criação literária da metade dos anos 1920, Bakhtin passa a tratar do autor-criador de uma obra em diálogo aberto com os formalistas russos. Para ele, o autor-criador é um momento constitutivo da forma artística, pois é a "ponte" para o diálogo axiológico com o conteúdo, ao assumir um posicionamento valorativo em relação ao material e à forma. Nesta obra, Bakhtin também aborda outras esferas, como a científica e a política, e trata da autoria nestas outras esferas observando a ética e as relações axiológicas com o conteúdo. Isto é, a relação axiológica ativa pressupõe que o autor-criador se expressa pela forma, mas é por seu conteúdo e sua relação com outros discursos, que apresenta seus valores, sua ética e sua responsabilidade.

O autor-criador é um momento constitutivo da forma artística. Eu devo experimentar a forma como minha relação axiológica ativa com o conteúdo, para prová-la esteticamente: é na forma e pela forma que eu canto, narro, represento, por meio da forma eu expresso meu amor, minha certeza, minha adesão. (BAKHTIN, 2010, p. 58).

Ainda nos anos 1920, em seu ensaio O autor e a personagem, Bakhtin (2010b, p. 10) diz que o "Autor: é o agente da unidade tensamente ativa do todo acabado, do todo da personagem, do todo da obra, e este é transgrediente a cada elemento particular desta.”. Neste ensaio, Bakhtin trabalha com a diferenciação entre o autor-pessoa e autor-criador. O autorpessoa se confunde com a pessoa em si e suas experiências na vida e, para Bakhtin, é um tanto "ingênuo". O autor-criador de um determinado enunciado literário tem a possibilidade de uma visão exterior da obra e com isso pode fornecer a esta um acabamento. Ainda que nesta reflexão ele trabalhe o conceito de autoria principalmente em enunciados artísticos, o conceito de excedente de visão evidencia que, no caso de enunciados não artísticos, o acabamento só será possível por meio do olhar do outro.

Esse excedente da minha visão, do meu conhecimento, da minha posse excedente sempre presente em face de qualquer outro indivíduo - é condicionado pela singularidade e pela insubstitutibilidade do meu lugar no mundo: porque nesse momento e nesse lugar, em que sou o único a estar situado em dado conjunto de circunstâncias, todos os outros estão fora de mim. (BAKHTIN, 2010b, p. 21).

No texto dos anos 1930, O discurso no romance, Bakhtin faz a relação do conceito de autoria com o de heterodiscurso, carregado de vozes sociais. Aqui o autor-criador é aquele que dá sua voz social ao todo artístico ainda que saiba que este discurso esteja impregnado de vozes de outros anteriores a ele. 
Conceber seu objeto pelo discurso é um ato complexo: por um lado, todo objeto precondicionado e contestado é elucidado, por outro, é obscurecido pela opinião social heterodiscursiva, pelo discurso do outro sobre ele, e nesse complexo jogo de claro-escuro entra o discurso que dele se impregna, que nele lapida seus próprios contornos semânticos e estilísticos. (BAKHTIN, 2015, p. 49).

O heterodiscurso introduzido no romance é aí submetido a uma elaboração literária. As vozes históricas e sociais que povoam a língua fornecem-lhe percepções concretas, organizam-se no romance em um harmonioso sistema estilístico que traduz a posição socioideológica diferenciada do autor e de seu grupo no heterodiscurso da época. (Idem, p. 78).

A assinatura do autor-criador de um enunciado carrega uma carga de responsabilidade para o futuro deste, seja em seus resultados imediatos ou num futuro mais distante, pois as respostas a ele virão de algum modo. Ao assinar um enunciado, o autor assume sua responsabilidade na autoria e perante o mundo, pois como Bakhtin mesmo diz, a vida, a existência, não tem álibi.

No texto dos anos 1954-56, Os gêneros do discurso, Bakhtin relaciona a autoria aos limites do enunciado e a sua conclusibilidade, bem como amplia a sua reflexão para esferas não literárias, como a científica:

O objeto é objetivamente inexaurível, mas ao se tornar tema do enunciado (por exemplo, de um trabalho científico) ele ganha uma relativa conclusibilidade em determinadas condições, em certa situação do problema, em um dado material, em determinados objetivos colocados pelo autor, isto é, já no âmbito de uma ideia definida do autor. (BAKHTIN, 2010b, p. 281).

Bakhtin correlaciona os gêneros discursivos com as diferentes posições sociais de cada tipo de autor. Em cada esfera e em cada gênero, temos tipos diferentes de autoria que dialogam com as especificidades do enunciado.

A questão do falante (do homem, do sujeito do discurso, do autor do enunciado, etc.). A linguística conhece apenas o sistema da língua e o texto. Por outro lado, todo enunciado, até uma saudação padronizada, possui uma determinada forma de autor (e de destinatário). (BAKHTIN, 2010b, p. 382).

A forma de autoria depende do gênero do enunciado. Por sua vez, o gênero é determinado pelo objeto, pelo fim e pela situação do enunciado. As formas de autoria e o lugar (posição) ocupado na hierarquia pelo falante (líder, czar, juiz, guerreiro, sacerdote, mestre, homem privado, pai, filho, marido, esposa, irmão, etc.). A posição hierárquica correlativa do destinatário do enunciado (súdito, réu, aluno, filho, etc.). Quem fala e a quem se fala. Tudo isso determina o gênero, o tom, e o estilo do enunciado: a palavra do líder, a palavra do juiz, a palavra do mestre, a palavra do pai, etc. É isso o que determina a forma da autoria. A mesma pessoa real pode manifestar-se em diversas formas autorais. (Idem, p. 389-390). 
Nas reflexões de Bakhtin, encontramos diferentes formulações sobre a autoria: a de autor-criador como aquele que cria esteticamente com base em suas posições valorativas e assim confere acabamento da obra estética, principalmente no âmbito da esfera literária, mas também de um autor que participa ativamente de um ato nas demais esferas da vida, que, ao criar um determinado enunciado, realiza um ato ético responsável.

Em síntese, embora um enunciado possua um autor, a sua voz não é a única; é possível "escutar outras vozes" sociais em diálogo polêmico com o projeto de dizer e as possíveis ressonâncias no público presumido que receberá este enunciado. Essa "bagagem" de outras vozes impregnadas nos enunciados evidencia o que Bakhtin, na Obra Problemas da Poética de Dostoievski chama de "relações dialógicas" que:

(...) devem personificar-se na linguagem, tornar-se enunciados, converter-se em posições de diferentes sujeitos expressas na linguagem para que entre eles surjam relações dialógicas. (...) devem tornar-se discurso, ou seja, enunciado, e ganhar autor, criador de dado enunciado cuja posição ele expressa. (...) são possíveis não apenas entre enunciações integrais (relativamente), mas o enfoque dialógico é possível a qualquer parte significante do enunciado, inclusive uma palavra isolada. (BAKHTIN, 2010c, pp. 209 -210).

O conceito de autor está na centralidade da definição dos limites do enunciado e do seu conteúdo. É o autor-criador quem dá o primeiro acabamento ao enunciado, no caso de um enunciado artístico, por meio de sua forma arquitetônica, de seu tom emotivo-volitivo, de sua criação numa totalidade organizada pela expressão. Essa forma arquitetônica traz a singularidade do enunciado e mostra não apenas sua forma, mas principalmente o conteúdo valorado deste enunciado, os valores axiológicos de seu autor-criador. É relevante observarmos a atividade totalizante do autor que, numa dada esfera de produção, num momento único da história, em uma situação de comunicação, num horizonte social específico, dá acabamento ao objeto de dizer em relação ao outros participantes dos processos criativos. No caso de um enunciado não artístico, esse acabamento é possível a partir da relação com o outro ou com outros enunciados e discursos. Este autor se relaciona com outros enunciados anteriores e com outras vozes, que acabam por impregnar quase involuntariamente o enunciado que está sendo criado.

O enunciado vivo, que surgiu de modo consciente num determinado momento histórico em um meio social determinado, não pode deixar de tocar as milhares de linhas dialógicas vivas envoltas pela consciência socioideológica no entorno de um dado objeto da enunciação, não pode deixar de ser participante ativo do diálogo social. É disto que ele surge, desse diálogo, como sua continuidade, como uma réplica e não como se ele se relacionasse à parte. (BAKHTIN, 2015, p. 49). 
Como vimos, as diferentes esferas compreendem diferentes processos autorais. No caso da esfera legislativa, a autoria está diretamente relacionada com outros discursos sociais existentes, com o ato ético responsável de seus autores diretos (e indiretos) e da sua relação com os outros agentes participantes dos processos, como veremos a seguir.

\section{2- A autoria na esfera legislativa e no Sistema Nacional de Cultura}

A autoria de enunciados produzidos na esfera legislativa pode ser pensada não apenas por meio do teor do texto originalmente inscrito nos parlamentos, mas também pelas interferências ocorridas na proposta originalmente inscrita no início do processo, já que este, até chegar a sua aprovação e redação final, passa por uma série de alterações e interações. Essas interferências podem ocorrer por meio das diversas ferramentas disponíveis aos parlamentares e seus assessores, para conduzir os processos de inscrição e aprovação dos marcos legais, mas também por discursos provenientes de outros agentes externos à esfera que se envolvem durante o processo, seja qual for sua natureza.

Nesta pesquisa, escolhemos para nosso corpus principal três tipos de marcos legais: duas emendas constitucionais, uma lei regulamentar e um decreto presidencial. Escolhemos para esta análise da autoria estes enunciados da esfera legislativa que poderão garantir a efetividade destas políticas, mas principalmente por serem os documentos que regem todo o SNC. As Emendas Constitucionais (EC) são instrumentos legais para realizar adições e mudanças em artigos da Constituição Federal (CF) vigente e são instituídas por meio de Propostas de Emendas Constitucionais (PEC). Apenas não podem ser alteradas e nem abolidas por ECs as chamadas Clausulas Pétreas ${ }^{136}$. Nas demais partes da CF, as emendas constitucionais podem alterar pequenos trechos ou mesmo inserir novos artigos e parágrafos em capítulos já existentes. A partir deste momento da tese passaremos a analisar discursivamente os enunciados do corpus e por isso achamos pertinente iniciar pelos autores dos enunciados do corpus principal.

A criação de um marco legal, seja uma Proposta de Emenda Constitucional ou mesmo uma lei, precede de um momento de criação. A este momento está intrínseca a presença de

\footnotetext{
${ }^{136}$ As Clausulas Pétreas de uma constituição não podem ser alteradas por nenhum tipo de mecanismo e devem ser interpretadas estritamente por seu teor. No caso da CF de 1988, o artigo $60 \S 4^{\circ}$ determina quais são os limites para sua alteração: $\S 4^{\circ}$ - Não será objeto de deliberação a proposta de emenda tendente a abolir: I - a forma federativa de Estado; II - o voto direto, secreto, universal e periódico; III - a separação dos Poderes; IV os direitos e garantias individuais.
} 
pelo menos um autor que, por meio de um ato no mundo, criará uma nova unidade de cultura na esfera legislativa. Contudo, ao contrário da criação de uma obra de arte na esfera artística, que recebe acabamento único de seu autor, na criação dos marcos legais na esfera legislativa, é possível dizer que, em sua composição, estão, além da voz de seu autor original, as vozes de outros agentes do processo legislativo e vozes anteriores a este processo. Um enunciado responde a outros anteriores a ele.

Podemos considerar que, num processo legislativo básico, teremos sujeitos em interação e a possibilidade das seguintes vozes: a voz do(s) autor(es) da lei, as vozes dos respectivos assessores parlamentares que auxiliam na pesquisa dos temas e na escrita dos enunciados legislativos, as vozes das deliberações de seus relatores (às vezes, expressas em emendas e textos substitutivos), dos convidados de audiências nas diversas comissões em que foram analisadas ou mesmo as vozes dos vetos posteriores ou a não sanção da lei pelo Presidente da República, o chefe do poder executivo e vozes de processos anteriores a sua criação. Para Bakhtin, essas vozes expressas no discurso equivalem à materialização das ideias, das consciências em diálogo na construção de sentido.

A ideia não vive na consciência individual isolada de um homem: mantendose apenas nessa consciência, ela degenera e morre. Somente quando contrai relações dialógicas essenciais com as ideias dos outros é que a ideia começa a ter vida, isto é, a formar-se, desenvolver-se, a encontrar e renovar sua expressão verbal, a gerar novas ideias. O pensamento humano só se torna pensamento autêntico, isto é, ideia, sob as condições de um contato vivo com o pensamento dos outros, materializando na voz dos outros, ou seja, na consciência dos outros expressa na palavra. É no ponto desse contato entre vozes-consciências que nasce e vive a ideia. (BAKHTIN, 2010c, p.98)

Há casos em que os projetos de leis são discutidos e votados não por seu teor completo, mas por artigos. Nesses processos, as vozes da plenária poderão aprovar ou não determinados trechos destes marcos legais por meio de disputas políticas e interesses (ou não) nos temas propostos. Em alguns casos, novas leis e PECs poderão alterar o texto do que foi determinado em um dado enunciado do passado, de acordo com diferentes conjunturas, interesses e desacordos políticos.

Uma lei, ainda que tenha um autor inicial proponente, é um tipo de enunciado que, em boa parte dos casos, pode revelar diversas vozes e poderá ser alterada ao longo do trâmite e do tempo, por meio de demandas sociais ou apenas da necessidade de sua atualização. Por isso, podemos afirmar que os marcos legais são enunciados com alto teor dialógico.

Ainda é preciso levar em conta que, na esfera legislativa, por seu caráter político, a 
divisão partidária influencia diretamente nos trâmites e interações relativos às leis. As relações entre os grupos políticos, ou como são chamadas, as bancadas parlamentares, são fatores que devem ser levados em conta ao observarmos a trajetória de uma determinada lei. Conseguir apoio nos mais diversos grupos políticos é de extrema importância para que uma lei consiga ser aprovada com mais facilidade, e principalmente, para chegar ao final do processo com uma redação final que mantenha as intenções político-ideológicas de seu autor inicial.

Assim como vimos ao tratar da Ética de Aristóteles, as leis estão diretamente relacionadas à ciência política, pois para criá-las e defendê-las perante a massa de cidadãos, era necessário ao legislador proponente de uma lei que fosse dotado do conhecimento deste saber arquitetônico profundamente. Este deve ser dotado de discernimento e de virtude para que o ethos apresentado ao longo de sua deliberação legislativa, possa, através do logos, isto é, do discurso / enunciado de defesa desta lei, convencer o auditório (pathos) através da persuasão dos espíritos de que esta lei beneficiará a comunidade. A criação das leis está diretamente relacionada com ética individual e o ethos de seu autor, que deve deliberar bem, convencer os outros parlamentares da plenária de que esta lei é de fato um benefício à população. Cabe àqueles que participarão do processo legislativo o discernimento para que esta seja aprovada ou não de acordo com o melhor para o bem do país.

O processo de uma lei requer a ética e a política. Contudo, ao tomarmos como nossa fundamentação teórica os preceitos da teoria bakhtiniana, vemos que o ato ético necessita de uma análise ainda mais profunda do que a da ética material de Aristóteles ou da ética formal de Kant. O ato ético bakhtiniano pressupõe um "dever ser" com vistas ao outro e em relação com todos os pontos da arquitetônica. Devo pensar sobre qual é de fato o modo correto de agir, para mim e para o outro, de modo prático e em relação ao contexto. Ao criar uma lei, não são as necessidades e vontades individuais do sujeito parlamentar que devem imperar e sim o que na prática beneficiará a coletividade de pessoas que o elegeu. Os eleitores representam diretamente "o outro" de um parlamentar autor de uma determinada proposta na esfera legislativa.

Ao ato ético é inerente a um dever ser, intuitivo e internamente imperativo: uma espécie de saber, em qualquer circunstância, qual é a opção correta para atuar. Atuar "eticamente" é atuar "para outro". Esse dever ser não pode, de modo algum, decorrer da ética formal, que pretende postular valores gerais e abstratos, e nem da ética material, cujos princípios podem fundamentar-se a partir de disciplinas particulares correspondentes, nenhuma das quais é capaz de justificá-lo teoricamente. (BUBNOVA, 2013, p. 11)

Estes agentes (autores da lei, assessores, relatores, demais parlamentares, ministros e 
presidente da república) devem atuar conjuntamente para compor a escrita de marcos legais, em diferentes etapas do processo, que devem estar de acordo com os preceitos éticos e políticos de um determinado país, e, no caso do Brasil atual, de acordo com a Constituição Federal vigente de 1988.

Nos dias atuais, contamos com ferramentas mais democráticas como as consultas públicas feitas via internet nos sites do Congresso Nacional, em que a sociedade civil pode opinar se é a favor ou contra determinada proposta legislativa ou mesmo sugerir alterações em trechos de alguns marcos legais, como ocorreu em diversos processos legislativos da cultura. Ainda que essas consultas públicas não tenham uma influência direta nos resultados das proposições, por estarem previstas como um dos mecanismos de participação social na Constituição Federal, agem como pressão política externa aos parlamentares.

É possível aferir que os marcos legais, por conta de seu caráter ético e político, trazem em seu conteúdo forte teor ideológico, com forças em disputa. Para Volóchinov:

Qualquer produto ideológico é não apenas uma parte da realidade natural e social - seja ele um corpo físico, um instrumento de produção ou um produto de consumo - mas também, ao contrário desses fenômenos, reflete e refrata outra realidade que se encontra fora de seus limites. Tudo que é ideológico possui uma significação: ele representa e substitui algo encontrado fora dele, ou seja, ele é um signo. Onde não há signo também não há ideologia. (VOLÓCHINOV, 2017, P. 91)

O forte teor ideológico se evidencia ao pensarmos que, nestes enunciados, pontos de vista sobre determinado tema social poderão atingir milhares de pessoas. Para Costa (2017):

(...) o dialogismo se refere ao caráter compartilhado, isto é, relacional dos sentidos produzidos seja no enunciado, seja na palavra. Daí a natureza simultaneamente social e ideológica do dialogismo. Posto que a ideologia se constitui em significados e sentidos construídos na relação (e , portanto, no diálogo) entre o eu e o outro, o dialogismo representa, então, a condição e o meio para sua realização. Logo, o dialogismo é o modo pelo qual se produz o ideológico. Dialógico e ideológico têm, nessa perspectiva, uma relação de indissociabilidade, sendo o signo, então, ideológico justamente porque dialógico. Desse ponto de vista, a palavra, signo ideológico por excelência, é o elo dialógico pelo qual se ligam, simultâneamente, o subjetivo, o intersubjetivo e o social. (COSTA, 2017, p. 138)

O teor ideológico presente nas deliberações em plenária e no conteúdo dos enunciados produzidos na esfera demonstra as diferentes avaliações sociais e a ética dos envolvidos nas interações, as diferenças de interesses políticos e econômicos, mesmo que estes nem sempre prezem pela ética coletiva. Os valores inseridos nestes enunciados determinarão também a forma do conteúdo relacionado à arquitetônica de um enunciado. 
Suponhamos o seguinte caso. Dois grupos sociais inimigos dispõem de um mesmo material linguístico, isto é, de um léxico absolutamente idêntico, e das mesmas possibilidades morfológicas e sintáticas, e assim por diante. Nessas condições, se as diferenças de nossos dois grupos sociais estiverem condicionadas pelas premissas socioeconômicas fundamentais de sua existência, as mesmas palavras terão entonações profundamente diferentes; nas mesmas construções gramaticais gerais, elas serão inseridas em combinações semânticas e estilísticas profundamente diferentes. As mesmas palavras irão ocupar um lugar hierárquico diferente na totalidade do enunciado, como ato social concreto. Uma combinação de palavras em um enunciado concreto ou em uma apresentação literária é sempre determinada pelos seus coeficientes de avaliação e pelas condições sociais de realização desse enunciado. (MEDVIEDEV, 2012, p. 187)

No que tange à forma, os diversos tipos de marcos legais têm uma construção composicional normatizada pelos preceitos da esfera legislativa que determina como cada um desses gêneros discursivos devem ser compostos. Esses gêneros legislativos são relativamente estáveis e apresentam alta produtividade na esfera, principalmente as PECs, leis e decretos. Ainda que a forma seja relativamente estável, seus conteúdos podem apresentar visões de mundo completamente diferentes a depender de quem os escreve e de sua base ideológica, intensificando muitas vezes a disputa na esfera.

Nos conteúdos, percebemos as intenções éticas dos interlocutores e autores. "o conteúdo, em sua base, é ético" (BAKHTIN, 2010c, p. 21). Cada partido ou grupo político tem declaradamente tipos diferentes de visões de mundo, tem distintas avaliações sociais ou ênfases valorativas.

Qualquer palavra, realmente dita, não possui apenas um tema e uma significação no sentido objetivo, conteudístico dessas palavras, mas também uma avaliação, pois todos os conteúdos objetivos existem na fala viva, são ditos ou escritos em relação a uma certa ênfase valorativa. Sem uma ênfase valorativa não há palavra. (VOLÓCHINOV, 2017, p.233).

Cada parlamentar está relativamente sincronizado ideologicamente com a proposta de seu grupo político ou partido, e suas propostas legislativas podem ser observadas também ao se considerar o grupo político-ideológico a que pertencem e os valores axiológicos defendidos em conjunto. Entretanto, na disputa política ocorrida entre os diferentes grupos nas plenárias, com posições ideológicas e avaliações sociais distintas, esses signos ideológicos aparecem ainda mais. A esfera legislativa se constrói a partir dessa disputa política acirrada, que evidencia a arena e "O signo transforma-se no palco da luta de classes." (VOLÓCHINOV, 2017, p. 113)

Toda enunciação verbalizada do homem é uma pequena construção 
ideológica. A motivação do meu ato é, em pequena escala, uma criação jurídica e moral; uma exclamação de alegria ou tristeza é uma obra lírica primitiva; as considerações espontâneas sobre as causas e efeitos de fenômenos são embriões de conhecimentos científicos, filosóficos etc. Os sistemas ideológicos estáveis e enformados das ciências, das artes, do direito etc. cresceram e se cristalizaram a partir do elemento ideológico instável, que através das ondas vastas dos discursos interior e exterior banham cada ato nosso e cada recepção nossa. Evidentemente, a ideologia enformada exerce, por sua vez, uma poderosa influência reflexa em todas as nossas reações verbalizadas. (BAKHTIN, 2009, p. 88)

Contudo, ainda que este receba influências de seu grupo e da esfera, o ponto de vista e os valores axiológicos do autor indivíduo também estarão refletidos no enunciado que está sendo criado. O autor é constitutivo da obra, e seu discurso se constroi em diálogo com outros discursos. Seus valores estão presentes em seu conteúdo, nas formas escolhidas e em diálogo com outros discursos. Bakhtin (2010) em O problema do conteúdo do material e da forma na atividade estética diz que

(...) nenhum ato cultural criador tem relação com uma matéria indiferente a valores, totalmente casual e desordenada (...) ele se relaciona com algo já apreciado e de certa forma ordenado, perante o qual agora ele deve ocupar com conhecimento de causa, sua posição axiológica. (BAKHTIN, 2010, pp. 29-30)

O autor ou os autores não estão indiferentes ao que está sendo criado. Estes têm intenção, vontade e apreço ideológico por aquilo que estão compondo, um enunciado pleno de valores axiológicos e avaliações sociais. O autor é responsável por aquilo que está criando em seu ato criativo. De acordo com Bakhtin, a relação do autor com a realidade pré-existente no ato ético é diferente da relação puramente estética. No ato ético, esta relação "é habitualmente expressa como a relação do dever para com a realidade” (BAKHTIN, 2010, p. 32)

$\mathrm{O}$ entendimento de que a esfera legislativa brasileira tem sua estrutura e seu modus operandi específicos, bem como uma hierarquia interior e uma relação com os três poderes da República, orienta nossa análise. A autoria na esfera legislativa, principalmente em tramitações com maior disputa política, pode se revelar como um "quebra-cabeças" com diversas vozes que trazem valores axiológicos e interesses políticos distintos e que, algumas vezes, são impossíveis de conhecer. A esfera legislativa, por conta de seu caráter institucional e político-partidário, e por ser permeada por interesses dos mais diversos grupos sociais, faz ecoar vozes diversas em disputa num só processo de criação de um enunciado. Entretanto por ser uma esfera com gêneros discursivos altamente normativos, a percepção de vozes 
individuais é quase sempre mais difícil de ser percebida.

Nesta reflexão inicial sobre autoria, podemos aferir que o processo de construção arquitetônica de um enunciado na esfera legislativa demonstra o diálogo de diversas consciências, com fortes posições avaliativas, em que os fatores ideológico e ético são uma mistura de valores individuais, de grupos políticos e da sociedade civil. No Brasil, a esfera legislativa faz parte de um governo democrático dividido em três poderes autônomos e assim assume como característica enunciados compostos por sujeitos em interação.

A intersubjetividade não implica dois sujeitos isolados em processo de comunicação, mas a base para a concepção da pessoa enquanto uma completa estrutura dialógica. Uma única consciência, para Bakhtin, é impossível: uma contradição em termos. Ao mesmo tempo, a alteridade absoluta do outro implica uma profunda personalização das posições dos sujeitos em interação. (BUBNOVA, 2013, p. 10)

Como em outras esferas ideológicas, devemos considerar a relação dos autores com os outros interlocutores, a situação de comunicação, o gênero e suas especificidades, a relação com outras esferas de produção e circulação de determinado enunciado, e os outros diferentes enunciados produzidos em diálogo durante o processo. Todos esses fatores incidem na autoria e na criação do enunciado. "A forma de autoria depende do gênero do enunciado. Por sua vez, o gênero é determinado pelo objeto, pelo fim e pela situação do enunciado. As formas de autoria e o lugar (posição) ocupado na hierarquia pelo falante". (BAKHTIN, 2010b, pp. 389390)

Vimos no capítulo anterior, que tratou do contexto sócio-histórico, que o primeiro marco legal que inicia os processos de alteração no paradigma na esfera político-cultural foi a PEC 306/2000 do PNC que busca inserir o parágrafo $3^{\circ}$ ao artigo 215 da Constituição Federal. A apresentação da proposta ocorreu no dia 29 de novembro de 2000 pelo Deputado Federal Gilmar Machado (PT - MG). Em uma entrevista fornecida à pesquisadora Paula Felix dos Reis (2011), no ano de 2007, Machado conta que a ideia de elaborar uma política específica para a cultura surgiu a partir das discussões desenvolvidas durante a $1^{\mathrm{a}}$ Conferência Nacional de Educação, Cultura e Desporto realizada pela Comissão de Educação e Cultura da Câmara Federal entre os dias 22 e 24 de novembro de 2000 em Brasília.

Nós fizemos um grande seminário, eu era presidente da comissão de Educação e Cultura da Câmara. Como fruto do anseio de muitos artistas, muitos intelectuais, das pessoas que vieram participar da conferência, surgiu a necessidade de termos um Plano que organizasse o processo da cultura no Brasil, já que outras áreas já possuem. Por exemplo, o Sistema Único de Saúde já existe há muitos anos, fruto da mobilização desde a constituinte; a 
educação tem a Lei de Diretrizes e Bases, tem um Sistema Nacional, tem um Plano Nacional, obrigatoriamente de dez em dez anos tem que ser feitas, metas cumpridas, de dez em dez anos você tem que ter um Plano. Então nós resolvemos que isso faltava na Constituição brasileira, eu entrei com uma emenda fruto dessa conferência, da mobilização dessas pessoas, e fui o primeiro signatário. (REIS, 2011, p. 162)

Nos trechos "Como fruto do anseio de muitos artistas, muitos intelectuais, das pessoas que vieram participar da conferência, surgiu a necessidade de termos um Plano que organizasse o processo da cultura no Brasil, já que outras áreas já possuem" e "eu entrei com uma emenda fruto dessa conferência, da mobilização dessas pessoas" é possível perceber que o Plano não foi uma ideia exclusiva de Gilmar Machado. Aqui ele demonstra que a criação da PEC vem de um processo de discussões anteriores ao ano 2000 e que se fortificaram na conferência realizada na comissão da Câmara Legislativa. Gilmar evidencia que ele estava em diálogo com outros parlamentares e também com estes intelectuais e artistas. O processo de criação da PEC foi construído dialogicamente, a partir dos debates da conferência, com diversas pessoas em diferentes etapas da interação e recebeu influência de discussões anteriores como vimos no capítulo terceiro. Ainda que ele diga que foi o primeiro signatário, ele divide a responsabilidade da ideia com outros agentes do processo.

Durante os dois primeiros anos, o processo esteve restrito apenas à Câmara dos Deputados, onde ocorreram diversas sessões para seu debate. Nesse ínterim, o então Ministro da Cultura de FHC, Francisco Weffort, foi convocado para emitir um parecer sobre a PEC ocorrida durante uma audiência pública da Comissão de Educação e Cultura em março de 2002. O parecer escrito pela relatora, a Deputada Federal Lídia Quinan (PMDB - GO), relata que:

Na Audiência Pública, realizada no dia 20 de março deste ano, compareceram os seguintes convidados: Dr. Francisco Corrêa Weffort, Ministro de Estado da Cultura, Dr. Ottaviano Carlos De Fiori, Secretário do Livro e Leitura, Dr. Octávio Elísio Alves de Brito, Secretário do Patrimônio, Museus e Artes Plásticas, Dr. Humberto Braga, Secretário da Música e Artes Cênicas e Dr. José Álvaro Moisés, Secretário do Audiovisual. Todos os convidados foram unânimes ao manifestar sua plena concordância com a PEC. O próprio Ministro da Cultura, Francisco Weffort, disse, enfaticamente, que: "...a minha convicção de que o Brasil está maduro para ter um Plano Nacional de Cultura verdadeiramente, porque nós já chegamos a certas convicções sobre os grandes objetivos da cultura que são de alcance nacional e que vão além de quaisquer diferenças de natureza política, partidária, ideológica, regional ou o que seja." Ressaltou, também, que, a exemplo da educação, a cultura constitui, hoje, uma política de estado e não apenas de governo: "Quer dizer, mude como for a política governamental ou o governo, seja qual for o resultado desta ou daquela eleição, como é próprio do procedimento democrático, o Estado Brasileiro terá que seguir 
determinadas metas na área da cultura, assim como na área da educação." O Ministro enfatizou ainda quatro aspectos que julga fundamentais na definição constitucional de um Plano Nacional de Cultura. São eles: a valorização de nossa identidade nacional em meio ao processo de globalização, a difusão cultural, para que os próprios brasileiros conheçam e valorizem a diversidade de nosso País, a preservação do patrimônio histórico e a defesa e promoção do idioma nacional. ${ }^{137}$

Quinan evidenciou em seu relatório que era importante aprovar a proposta, pois esta visava "apenas trazer benefícios à cultura e nunca diminuí-los". Relatou que a matéria já contava com a assinatura de apoio de 177 parlamentares da Câmara e que acreditava ser importante sua aprovação por sua semelhança ao Plano Nacional de Educação que consta no artigo 214 da CF.

Aqui fica claro que, independente de filiação partidária, ou mesmo de grupo político, tanto a deputada peemedebista Lídia Quinan, quanto o Ministro tucano, Weffort, concordavam sobre a importância e os benefícios da proposta para a cultura. Entretanto, é preciso ressaltar que o então ministro, assim como evidenciado no relatório descrito pela deputada, tratou dos aspectos que julgava fundamentais num Plano de Cultura:

(...) a valorização de nossa identidade nacional em meio ao processo de globalização, a difusão cultural, para que os próprios brasileiros conheçam e valorizem a diversidade de nosso País, a preservação do patrimônio histórico e a defesa e promoção do idioma nacional ${ }^{138}$.

O excerto do relatório aponta que a visão de cultura e os valores ideológicos de Weffort em relação ao que estava em questão remetem a alguns itens já mencionados anteriormente no artigo 215 precedentes à nova PEC, que tratam do patrimônio histórico e da difusão cultural ${ }^{139}$.

A PEC 306/2000 relativa ao PNC foi aprovada e transformada em Emenda constitucional 48 no dia 10 de agosto de 2005. Seu teor inseriu no artigo 215 (já existente e que trata da garantia do pleno exercício dos direitos culturais) o terceiro parágrafo que diz o seguinte:

\footnotetext{
${ }^{137}$ Disponível em: <

http://www.camara.gov.br/proposicoesWeb/prop_mostrarintegra;jsessionid=4F46049AD6ADC1B91EA176531F 1DDA72.proposicoesWeb2?codteor $=24900 \&$ filename $=$ Tramitacao-PEC $+306 / 2000>$ acesso 23 setembro 2016. ${ }^{138} \mathrm{Idem}$.

${ }^{139}$ No ano 2000, ainda na gestão FHC-Weffort, foi implantado o programa de Salvaguarda do patrimônio imaterial a partir do decreto 3.551/2000. O programa viabiliza projetos de identificação, reconhecimento, salvaguarda e promoção da dimensão imaterial do Patrimônio Cultural Brasileiro, com respeito e proteção dos direitos difusos ou coletivos relativos à preservação e ao uso desse bem. É um programa de apoio e fomento que busca estabelecer parcerias com instituições dos governos federal, estaduais e municipais, universidades, organizações não governamentais, agências de desenvolvimento e organizações privadas ligadas à cultura e à pesquisa.
} 
$\S 3^{\circ}$ A lei estabelecerá o Plano Nacional de Cultura, de duração plurianual, visando ao desenvolvimento cultural do País e à integração das ações do poder público que conduzem à: I - defesa e valorização do patrimônio cultural brasileiro; II - produção, promoção e difusão de bens culturais; III formação de pessoal qualificado para a gestão da cultura em suas múltiplas dimensões; IV - democratização do acesso aos bens de cultura; V valorização da diversidade étnica e regional.

Apesar de sua escrita resumida e até certo ponto de caráter abrangente, o trecho acima traz ênfases valorativas que podem demonstrar que o autor da PEC, quando da sua criação, considerou não apenas a complexidade da esfera da cultura como um todo, mas pensou também na complexidade da gestão da cultura, entendida a partir deste momento pelo olhar da política cultural de fato. Essa afirmação fica mais evidente nos trechos em que se ocupa da formação para gestão da cultura e da democratização do acesso. A partir daquele momento não apenas a produção da cultura e o patrimônio estavam em pauta, mas um caráter mais político-social, visando à democratização do acesso e à diversidade. Essa visão da cultura também sugere o interesse do autor em possibilitar que a esfera político-cultural, por meio daquela proposta, pudesse ser repensada como processo de gestão pública e para isso acontecer seria necessário levar em conta a formação de gestores especializados nas práticas de um setor complexo e diferente como a cultura.

Outro processo que ocorreu nesse período, e de que já tratamos no capítulo anterior, foi a eleição presidencial de 2002 com a nova gestão do Partido dos Trabalhadores. Como vimos, a eleição de Lula trouxe em seu programa de governo para a área de cultura propostas estruturantes, como o Plano Nacional de Cultura e o Sistema Nacional de Políticas Culturais, que a partir de 2005 foi chamado de Sistema Nacional de Cultura. Aqui é importante observarmos dois tipos de mobilizações: primeiro a criação do programa de cultura de Lula para a eleição de 2002 e, num momento seguinte, a composição do novo Ministério da Cultura em sua gestão depois de eleito.

O programa de cultura de Lula intitulado A imaginação a serviço do Brasil foi desenvolvido e assinado por intelectuais e fazedores de cultura dos mais diversos tipos que já acompanhavam o PT há alguns anos. O criador da PEC do PNC, o deputado Gilmar Machado, não está dentre os autores mencionados no enunciado, e não há evidências concretas dentre os citados, de um autor único para a ideia da criação deste sistema. Os nomes citados no documento são:

Colaboraram com este texto: Antonio Grassi, Hamilton Pereira da Silva, Marco Aurélio de Almeida Garcia, João Roberto Peixe, Márcio Meira, Margarete Moraes, Sérgio Mamberti, (coordenadores) Alexandre Rands, 
Alfredo Bosi, Aloysio Guapindaia, Álvaro Banducci, Ângelo Osvaldo, Antonio Albino Rubim, Arnaldo Godoy, Bernardo da Matta Machado, Beto Almeida, Carlos Porto, Celina Albano, Celso Schröder, Claudia Brito, Dalva Sampaio dos Santos, Daniel Hertz, Déa Fenelon, Edson Silva, Emiliano José, Eugênio Bucci, Fernando Mineiro, Fernando Ferro, Flávio Arend, Fred Zero 4, João Motta, José do Nascimento Junior, Juarez Dayrel, Juarez Guimarães, Lúcia Hussak, Luiz Marques, Marcelo Mário Melo, Marcelo Menna Barreto, Márcio Porto Carrero, Marcos Gomes, Mariana Sampaio, Marinor Brito, Marta Porto, Michele Arroyo, Mila Frati, Nelson Brito, Nilson Rodrigues, Paulo Simões, Paulo Vieira, Paulo Zílio, Ricardo Lima, Sandro di Lima, Télia Negrão, Vera Millet, Vítor Ortiz, Walmir Bispo Santos, Walnice Nogueira Galvão. (PARTIDO DOS TRABALHADORES, 2002, p. 22)

Ainda que não seja evidente a autoria do SNC no enunciado do programa em questão, os apontamentos em diversos artigos sobre os processos de montagem da equipe do novo MinC de Gilberto Gil nos ajudam a refletir sobre alguns personagens-chave que poderiam ter participado mais fortemente da criação do Sistema e desses processos estruturantes.

$\mathrm{Na}$ distribuição inicial (2003) de cargos do Ministério, o resultado foi a divisão política especialmente em três grupos: membros do PT, dentre os quais podemos citar Marcio Meira (assumiu a Secretaria do Patrimônio, Museus e Artes Plásticas, e posteriormente a Secretaria de Articulação Institucional), José Nascimento Júnior (Diretoria de Museus e Centros Culturais - IPHAN), Antonio Grassi (Funarte) e Sergio Mamberti (Secretaria de Música e Artes Cênicas, depois à frente da secretaria de Identidade e da Diversidade Cultural); membros do Partido Verde, a exemplo de Juca Ferreira (Secretaria Executiva do MinC, e depois Ministro da Cultura) e Sergio Xavier (Chefe de gabinete do ministro e posteriormente responsável pela Secretaria de Fomento e Incentivo à Cultura); e antigos conhecidos e aliados de Gilberto Gil, tais quais Marcelo Carvalho Ferraz (CoordenaçãoGeral do programa Monumenta), Waly Salomão (Secretaria do Livro e da leitura), Antonio Risério e Roberto Pinho (assessores especiais de Gil). Dentre os sete coordenadores do documento de campanha do PT (Antonio Grassi, Hanilton Pereira da Silva, Marco Aurélio de Almeida Garcia, João Roberto Peixe, Márcio Meira, Margarete Moraes, Sérgio Mamberti) apenas três vieram a fazer parte da equipe do MinC (Antonio Grassi, Márcio Meira, Sérgio Mamberti) sendo que apenas Marcio Meira ficou sendo o responsável pela condução do SNC. (REIS, 2011, p. 156)

Reis (2011) evidencia a responsabilidade do antropólogo Márcio Meira à frente da construção do Sistema. Isso se comprova em sua atuação perante a construção do SNC anos mais tarde, como personagem fundamental para o início de sua implantação com o Decreto de 2005 do Sistema Federal de Cultura e do CNPC que possibilitou o Acordo de Cooperação com estados e municípios e a construção da I Conferência Nacional de Cultura. Meira esteve à frente da Secretaria de Articulação Institucional (SAI) e do SNC desde o início do segundo semestre de 2003 até janeiro de 2007, quando foi demitido por Gil (ação duramente criticada 
pelo PT numa nota publicada na internet $)^{140}$. Numa entrevista concedida à pesquisadora Paula Felix dos Reis (2008) e publicada em sua dissertação de mestrado, Meira declarou logo após sua saída do MinC sobre os bastidores desses dois processos e qual era a intenção em relação ao SNC.

Então eu entrei na discussão no ano de 2001, 2002 exatamente para coordenar o programa de cultura do Presidente Lula de 2002. Eu coordenei junto com o Hamilton Pereira que atualmente é secretário do Ministério do Meio Ambiente e nós construímos aquele programa, não fomos só nós, nós coordenamos aquele processo que culminou naquele programa (...) eu acho que é um marco na história da política cultural porque ele é o resultado de todo o acúmulo histórico, aí a gente poderia dizer desde Mario de Andrade, que recuperou uma série de pressupostos. (...) eu fui chamado para ser o coordenador da transição do Ministério da Cultura. Depois fui chamado pelo Ministro Gilberto Gil para ser Secretário de Articulação Institucional (...) e lá nessa secretaria eu era responsável pela implantação no país do Sistema Nacional de Cultura e também da articulação do MinC com outros ministérios, outras instituições, o diálogo com a sociedade civil, a coordenação da Conferência Nacional de Cultura. Aquele livro $1^{a}$ CNC - Conferência Nacional de Cultura Estado e Sociedade Construindo Políticas Públicas de Cultura é toda uma síntese de todo trabalho que a gente fez naqueles 4 anos lá. (...) Qual é a ideia, o princípio central, que estava por todo aquele trabalho que fizemos: é o princípio constitucional. (...) Então partindo desse pressuposto constitucional que nós começamos a fazer nosso trabalho, ou seja, o Brasil tem um Sistema Nacional de Cultura que envolve município, estados, DF, a União Federal e a sociedade civil e também o setor privado, as empresas etc, ou a gente vai ter que ficar naquela situação em que cada um faz o que quer, não tem uma política articulada, com foco, com prioridades (...) A posição oficial do Ministério da Cultura, que é a posição do ministro, sempre foi uma posição de afirmação, de apoio à concepção do Sistema. Agora, até que ponto isso conseguiu se consolidar plenamente dentro desse conjunto de atores, isso a gente pode dizer tranquilamente que isso não se consolidou até o momento, na minha visão, plenamente. Porque se trata de uma construção, um sistema não se faz por decreto, é um processo de construção. Se ele não é visto dessa forma é melhor não fazer. (REIS, 2008, p. 121 - 122)

Chama atenção na declaração o foco no princípio constitucional. A presença da cultura no artigo $5^{\circ}$ da constituição, como direito civil constituído numa Cláusula Pétrea, a existência de outros artigos relativos à cultura e o federalismo, naquele momento, significavam uma boa maneira de reestruturar a forma e o conteúdo de fazer as políticas culturais no país. Meira, ao declarar que de fato fez parte da autoria do SNC no programa de Lula (ainda que assumindo a construção coletiva) e ser responsável por sua construção concreta no MinC à frente da SAI, torna-se um dos principais autores da construção do SNC quando diz:

\footnotetext{
${ }^{140}$ Nota disponível no Jornal Hora do Povo. Disponível em: < http://www.horadopovo.com.br/2007/janeiro/1001-07/pag3h.htm >. Acesso em 24 de setembro de 2016.
} 
(...) lá nessa secretaria eu era responsável pela implantação no país do Sistema Nacional de Cultura e também da articulação do MinC com outros ministérios, outras instituições, o diálogo com a sociedade civil, a coordenação da Conferência Nacional de Cultura. (idem)

Ao assumir publicamente a responsabilidade pela implantação do Sistema e do Conselho e da organização do diálogo de toda a estrutura e programas do MinC com todos os outros agentes da esfera pública e após declarar que fez parte da idealização do mesmo desde os primórdios das discussões antes do ano 2000, toma para si de forma ética a responsabilidade pelo ato. Meira compreende que o Sistema, como ele mesmo declara, não existe apenas como uma abstração num enunciado de um marco legal. Isso se evidencia quando diz que "um sistema não se faz por decreto". O Sistema é uma construção a partir de uma ação concreta no mundo e tem como pressuposto básico o dever de torná-lo realidade. Contudo, ao afirmar que, naquele momento, o Sistema ainda não estava consolidado, reconhece de forma responsável que o processo construtivo ainda estava aquém do que haviam imaginado desde o início.

Neste trecho, está nítido que a relação de Meira com os processos foi de tamanha importância que, não apenas seu cargo, mas as funções que estavam delegadas a ele, o tornavam um dos principais responsáveis pela efetiva implantação do sistema e consequentemente pela reestruturação da gestão de cultura na esfera político-cultural em nível federal no período entre 2003 e 2007. Contudo, seu posicionamento é ético ao dizer sobre outros personagens que tiveram parte nessa história.

Podemos aferir que a responsabilidade ética da construção do sistema é compreendida por Meira como um ato ético construído em interação com seus pares, seus outros, e que o Sistema era fruto de um acúmulo histórico de ações, reflexões, valores e construções coletivas. Aqui percebemos que a arquitetônica do Sistema desde o início era pensada como fruto de uma construção compartilhada, com muitas vozes e muitos autores. Todavia, é possível afirmar que Meira foi um dos principais autores responsáveis, pois reconhece seu ato na esfera político-cultural para com o Sistema quando chama pra si a responsabilidade desse ato ainda que no momento da entrevista não mais faça parte da gestão da SAI.

O ato responsável é bidirecional e deve incorporar ao conteúdo uma responsabilidade moral singular e assim superar a separação entre cultura e vida (...) estes dois momentos portanto, seja o do sentido, seja o históricoindividual (factual) são dois momentos unitários e inseparáveis na valoração deste pensamento como meu ato responsável. (BAKHTIN, 2010d, p. 44) 
Os autores sujeitos participantes na gestão inserem seus valores axiológicos como sujeitos no mundo na construção da arquitetônica do Sistema. E com isso também inserem valores na arquitetônica da esfera que reflete e refrata a construção desse novo modelo de política cultural. Tanto no teor dos enunciados, quanto na construção do Sistema e da esfera, os sujeitos envolvidos são participantes responsáveis ativos, pois colocam um pouco de si na criação e construção disso. Os valores ideológicos de Marcio Meira sujeito e os valores ideológicos do grupo e dos demais envolvidos (inclusive os agentes na esfera legislativa) devem estar em consonância, pois qualquer discordância em relação ao teor do que estava sendo construído poderia configurar em atrasos ou mesmo rupturas no que estava sendo proposto. Desde o início, a intenção dos envolvidos era de que aquela proposta se tornasse real no mundo. Assim é possível dizer que tinham uma responsabilidade ética para que aquilo de fato acontecesse. $\mathrm{O}$ foco da proposta era sua realização plena no futuro e que deveria resultar numa alteração de paradigma na esfera.

É possível uma dupla combinação do mundo com o homem: de dentro deste, como seu horizonte, e de fora, como seu ambiente. De dentro de mim, no contexto dos valores e sentidos de minha vida, o objeto a mim se contrapõe como objeto do propósito dessa mesma vida (ético, cognitivo e prático): aqui ele é um elemento do acontecimento único, singular e aberto da existência, do qual participo com interesse forçado em seu desfecho. De dentro de minha participação real na existência, o mundo é um horizonte da minha consciência atuante, operante. Só (permanecendo dentro de mim mesmo) nas categorias cognitivas, éticas e prático-técnicas (de bem, verdade e clareza de fins práticos) consigo orientar-me nesse mundo como acontecimento, por-lhe ordem na composição material, condicionando-me desse modo a imagem de cada objeto para mim, sua tonalidade volitivo-emocional, seu valor, seu significado. De dentro de minha consciência participante da existência, o mundo é o objeto do ato, do ato-pensamento, do ato-sentimento, do atopalavra, do ato-ação; seu centro de gravidade situa-se no futuro, no desejado, no devido e não no dado autossuficiente do objeto, em sua presença, em seu presente, em sua integridade, em sua já exequibilidade. (BAKHTIN, 2010b, pp. 88 - 89)

Ao longo da entrevista, Meira cita diversos nomes como o do Deputado Gilmar Machado e sua relação direta com o PNC, ou mesmo a importância de Gilberto Gil nesta construção. Chama atenção também o tom emotivo-volitivo que Meira expressa em diversos momentos da entrevista quando fala sobre o histórico do Sistema. Em uma entrevista gravada, ainda que esta tenha um tom formal, o sujeito entrevistado narra os acontecimentos do passado sem a possibilidade de editar qualquer trecho ou tipo de entonação. Ainda que este corrija dados informados durante o processo, a entrevista possibilita que o entrevistado fale com detalhes muito subjetivos e apresente seu ponto de vista sobre determinado assunto, 
revelando ênfases valorativas.

$\mathrm{Na}$ entrevista, Meira dá sua avaliação social sobre o processo em que esteve inserido intensamente por mais de três anos e demonstra o tom emotivo-volitivo de quem fez parte disso. Ainda que muitas pessoas participassem dos processos, ele enquanto secretário responsável pela construção inicial do Sistema traz um olhar único, intransferível. Ele é o autor que enforma a ideia e a preenche de conteúdos. Bakhtin evidencia essa relação do autor com a obra, dos participantes do acontecimento e o fator emotivo-volitivo

A diretriz volitivo emocional de cada participante é profundamente individual e há luta entre eles: estou diante de um acontecimento único porém complexo, em que cada participante ocupa sua posição única na totalidade do acontecimento, e essa totalidade não pode ser compreendida mediante o vivenciamento empático com os participantes mas pressupõe um ponto de distância em relação a cada um e a todos juntos. Em casos desse tipo recorre-se ao auxílio do autor ao vivenciar empaticamente com ele dominamos o todo da obra. (BAKHTIN, 2010b, p. 60)

Como podemos ver acima, para Bakhtin, a diretriz emotivo volitiva de um determinado enunciado é "profundamente individual" isto é, as vontades e emoções em cada ato são fatores essenciais do sujeito criador e podem mudar de acordo com o envolvimento de cada um deles em relação ao objeto. Ao tratar do SNC apresentando um tom emotivo-volitivo em sua fala, Meira demonstra que tinha uma relação muito próxima e de responsabilidade ética com o Sistema e com sua construção. O olhar extra-localizado de Meira, enquanto o responsável pelo Sistema, é único. Ele foi o "primeiro pai que criou a criança". Sem seu esforço inicial, que deve ser entendido como ato responsável, o sistema talvez não tivesse saído do papel. Entretanto, Meira não trabalhou sozinho. Foi necessário saber gerir uma equipe compromissada e que tivesse o mesmo apreço e consenso ideológico pela proposta para que sua gestão e construção fossem possíveis.

A relação de Meira com o Sistema nos faz refletir acerca de sua posição enquanto ser responsável pela construção dessa arquitetônica. O significado do SNC para ele era único e era recheado de sua construção valorativa. Meira é um importante centro de valor do SNC e foi corresponsável por essa arquitetônica “(...) que se compõe de objetos reais em interrelação real, que dispõem ao redor de um centro concreto de valores (...)Todo o tópos de valores, toda a arquitetônica da visão seriam diferentes se não fosse ele o centro de valores". (BAKHTIN, 2010, pp. 124 - 125)

No final do trecho, Meira evidencia seu olhar agora extra-localizado, quando fala que ele é feito por meio de uma construção até aquele momento não plenamente consolidada "a 
gente pode dizer tranquilamente que isso não se consolidou até o momento, na minha visão, plenamente".

A construção do Sistema no período em que Meira esteve à frente da SAI deve-se principalmente pela criação do Decreto 5.520/2005 que instituiu o Sistema Federal de Cultura e a recomposição do Conselho Nacional de Políticas Culturais. O Decreto foi criado por Meira e pelo grupo liderado por ele. Na entrevista, ele assume que participou ativamente de sua criação e implantação ainda que este tenha sido um Decreto Presidencial assinado por Lula.

Um decreto presidencial, criado e inscrito pelo poder executivo, não carece de uma tramitação no Congresso Nacional, já que não se refere à inovação no ordenamento jurídico. Não é uma lei nova, é uma atribuição do poder executivo quando este precisa "preparar" uma lei para ser executada. A maioria das leis necessita de regulamentação para que sua execução seja viabilizada, assim o presidente pode expedir regulamentos com o fim único de dar cumprimento ao que determina a lei. Esta competência está expressa no artigo 84 parágrafos IV e VI da CF.

Art. 84. Compete privativamente ao Presidente da República: I - nomear e exonerar os Ministros de Estado; II - exercer, com o auxílio dos Ministros de Estado, a direção superior da administração federal; Constituição ; IV sancionar, promulgar e fazer publicar as leis, bem como expedir decretos e regulamentos para sua fiel execução. V - vetar projetos de lei, total ou parcialmente; VI - dispor, mediante decreto, sobre: a) organização e funcionamento da administração federal, quando não implicar aumento de despesa nem criação ou extinção de órgãos públicos; ${ }^{141}$

A criação da pré-regulamentação do SNC pelo decreto 5.520/2005 foi uma estratégia do poder executivo para que este pudesse iniciar sua implantação o quanto antes. A demora de cinco anos na aprovação da lei regulamentar do PNC evidencia isso. A maior agilidade na disponibilidade de um decreto em relação à aprovação de uma lei regulamentar ou a uma PEC foi um meio de permitir que, a partir de 2005, estados e municípios iniciassem os processos do Sistema.

É importante ressaltar que o decreto supracitado foi complementado por outros dois decretos presidenciais posteriores: 6.973/2009 e 8.611/2015. O decreto 6.973/2009 foi aprovado em outubro de 2009 e também conta com a assinatura de Lula, mas foi oriundo de uma demanda do MinC. No ano de 2009, Meira já não estava mais à frente da SAI. Em seu

\footnotetext{
${ }^{141}$ Constituição Federal disponível em:< http://www.planalto.gov.br/ccivil_03/constituicao/constituicaocompilado.htm> acesso em 25 de setembro de 2016.
} 
lugar, neste período de gestão da Ministra Ana de Hollanda, estava como responsável pela SAI a secretária Silvana Meireles, que permaneceu no cargo até o fim de 2010. Já o decreto 8.611/2015 foi criado e instituído quando da segunda gestão de Juca Ferreira no MinC e no comando da SAI estava Vinicius Wu.

Os decretos complementares incluíram diversos itens relevantes para a implantação do Sistema que já estava acontecendo desde 2005. Os itens inseridos visavam atualizar o decreto de 2005 suprindo lacunas percebidas durante os anos de construção do Sistema de forma concreta. Chama a atenção nos dois decretos, mas principalmente no decreto complementar de 2015, no artigo 12, a inserção de novas linguagens no escopo dos colegiados setoriais do CNPC como: artesanato, moda, cultura Hip Hop, design, arquitetura e urbanismo, expressões artísticas culturais afro-brasileiras, patrimônio material, capoeira, cultura alimentar, culturas quilombolas e cultura dos povos e comunidades tradicionais de matriz africana. No decreto original, as linguagens previstas para o CNPC configuravam uma visão mais tradicional de cultura com a inserção apenas das artes, do patrimônio, museus e arquivos e da cultura indígena. Ao inserirem no decreto mais áreas culturais, os autores demonstram que durante esses anos puderam compreender melhor a ideia de cultura ampliada e da diversidade que Gilberto Gil havia proposto inicialmente. Ao mesmo tempo, estes foram incluídos a partir de demandas dos próprios representados por cada uma dessas áreas, como veremos no tópico a seguir sobre a participação social.

O parágrafo proposto pela PEC do PNC em 2000 nos remete a outro documento que posteriormente deveria fazer parte da construção dessa sistematização quando diz "A lei estabelecerá o Plano Nacional de Cultura, de duração plurianual". Aqui temos uma projeção do que seria feito logo depois, a partir do projeto de lei 6.835/2006, aprovado como lei regulamentar 12.343 em dezembro de 2010, também de autoria do Deputado Gilmar Machado, em parceria com os deputados Paulo Rubem Santiago (PT - PE) e Iara Bernardi $(\mathrm{PT}-\mathrm{SP})$.

A publicação das diretrizes do PNC em 2007 e sua republicação em 2008, como vimos no capítulo anterior, gerou uma série de discussões e encontros em todo país a fim de chegarem a um documento definitivo. Ainda que o texto inicial da lei regulamentar do PNC tenha sido escrito pelo deputado Gilmar Machado, com importantes contribuições de Paulo Rubem Santiago e Iara Bernardi, sua construção ao longo dos cinco anos de aprovação passou por consulta pública realizada nos seminários estaduais e com participação de mais de cinco mil pessoas. Isso nos faz pensar num processo com direta influência da sociedade civil com a 
participação de centenas de co-autores e evidencia o caráter dialógico dos enunciados analisados.

Todavia, devemos considerar o processo parlamentar da lei 12.343/2010 até sua aprovação, pois esta garantiu a aplicação do teor previsto na EC 48/2005 do PNC. De acordo com o pesquisador e ex-Secretário de Políticas Culturais do MinC, Guilherme Varella, "a Lei 12.343/10 consolida princípios e objetivos, define prioridades, estipula metas e delimita temporalmente, num espaço de dez anos, as ações que devem ser tomadas pelo poder público para a consecução de políticas públicas na área de cultura”. (VARELLA, 2014, p.96)

Para que possamos retomar a reflexão acerca da arquitetônica da esfera politicocultural no período, devemos destacar os valores e conceitos elencados na publicação das diretrizes do PNC publicada em 2008 e sua relação com a lei do PNC:

1) Cultura, um conceito abrangente: expressão simbólica, direito de cidadania e vetor de desenvolvimento; (...) 2) A cultura brasileira é dinâmica: expressa relações entre o passado, presente e futuro de nossa sociedade; (...) 3) As relações com o meio ambiente fazem parte dos repertórios e das escolhas culturais; (...) 4) A sociedade brasileira gera e dinamiza sua cultura, a despeito da omissão e interferência autoritária do Estado e da lógica específica do mercado; (...) 5) O Estado deve atuar como indutor, fomentador e regulador das atividades, serviços e bens culturais; (...) 6) Ao Ministério da Cultura cabe formular, promover e executar políticas, programas e ações na área da cultura; (...) 7) O Plano Nacional da Cultura está ancorado na corresponsabilidade das diferentes instâncias do poder público e da sociedade civil. (MINISTÉRIO DA CULTURA, 2008, pp. 3132 - grifos meus)

Ao compararmos o trecho acima com a redação final da lei 12.343/2010, encontramos indícios de que, em seu processo de criação e tramitação no congresso, os autores se pautaram pelos mesmos pressupostos elencados nas diretrizes estabelecidas pelos documentos do MinC de 2007 e 2008. Foi o segundo documento das diretrizes publicado em 2008 que trouxe as vozes da sociedade civil a partir das discussões nos seminários estaduais. O diálogo acontece em todo o texto da lei e em seus anexos. Isso demonstra que a lei e as publicações das diretrizes foram processos que caminharam juntos.

Ao observarmos o processo de tramitação do projeto da lei pelo site da Câmara Federal desde o início é possível perceber que o texto inicial proposto pelos três autores originais não apresentou o formato de enunciado de lei conforme aprovada, mas sim uma proposta do que seria o plano, com justificativas, detalhes do que se estava propondo e até a metodologia da implantação e das conferências. O texto com 21 páginas escrito em formato dissertativo apresenta como introdução uma justificativa ao que se estava propondo. 
A história demonstra que tem havido um processo de exclusão da maioria de nossa população. Nossas crianças e nossos jovens, embora herdeiros de um grande patrimônio cultural e criativos o suficiente para enriquecê-lo e legar às gerações que virão, não conseguem ver seu próprio rosto na grande produção cultural dominante. A política cultural tem sido privilégio de poucos que dividem entre si os recursos, sejam públicos ou privados, destinados à criação e produção cultural. A I Conferência Nacional de Cultura, organizada desde a base, nos municípios, estados e regiões, congregando os diferentes atores, públicos e privados discutiram profundamente questões centrais como gestão pública e cultura, cultura e direito à cidadania, economia da cultura, patrimônio cultural, comunicação e cultura, a democratização e descentralização dos meios de comunicação, o Sistema Nacional de Cultura, entre outros pontos e deliberou pelas diretrizes que devem nortear a política cultural brasileira, constituindo-se no Plano Nacional de Cultura com suas metas bem definidas. Desta forma, apresento aos nossos pares esta proposta do Plano Nacional de Cultura, em anexo, resultado de um amplo debate em todo o País. Tenho a certeza que receberá a acolhida dos nobres deputados. ${ }^{142}$

Nas primeiras linhas da justificativa, os autores revelam qual é sua avaliação social sobre a esfera. Falam do tema "exclusão" como princípio justificador, e com forte tom de denúncia social nos trechos: "tem havido um processo de exclusão da maioria de nossa população", "não conseguem ver seu próprio rosto na grande produção cultural dominante", "A política cultural tem sido privilégio de poucos que dividem entre si os recursos, sejam públicos ou privados". Aqui percebemos a tensão entre os conceitos de exclusão /inclusão e privilegiados/ desprivilegiados. Os autores trazem neste trecho uma justificativa ética essencial para nossa reflexão, pois apontam que o PNC (e o Sistema) poderia ser uma possibilidade de "direito à cidadania", de "democratização" e de inclusão, assim como os signos ideológicos que destacamos ao falar das diretrizes.

É relevante salientar que nesse momento que os autores falavam sobre democratização do acesso, e ainda não sobre democracia cultural. A diferença entre os dois termos foi tomando forma ao longo dos anos com as discussões sobre o que era de fato a ampliação do acesso. À medida que a reflexão sobre a democratização da cultura foi evoluindo, apontava cada vez mais para a ampliação do acesso aos serviços oferecidos pelo estado para as artes. Era necessário partir para algo ainda mais democrático, onde a ampliação do acesso também pudesse considerar os recursos para a produção artística e cultural deveriam estar ao alcance de todos de forma igualitária. Cada vez mais essa passou a ser a tônica das discussões, ainda que com alguma confusão entre os termos.

\footnotetext{
${ }^{142}$ Texto disponível em: < http://imagem.camara.gov.br/Imagem/d/pdf/DCD19ABR2006.pdf\#page=160 > acesso em 22 de setembro de 2016.
} 
Em janeiro de 2007, o PL do PNC foi arquivado numa ação de reorganização interna da Câmara, juntamente com centenas de outros decretos, leis e PECs. Em fevereiro, Gilmar Machado pediu seu desarquivamento. Com isso o PL reinicia sua tramitação novamente e em abril começa seu processo de discussão na Comissão de Educação e Cultura (CEC). Até dezembro, fica em relatoria com o deputado Frank Aguiar (PMDB - SP) que devolveu o projeto à comissão em dezembro sem analisá-lo. Após dois anos de inatividade na pauta, em abril de 2009, a deputada Fátima Bezerra (PT - RN) é designada pela comissão como nova relatora do PL. No mês de setembro, Fátima apresenta um parecer com uma extensa reflexão sobre o PNC e junto a ele, um texto substitutivo, agora em formato de projeto de lei. Neste momento é criado o enunciado no formato do gênero projeto de lei regulamentar da Câmara Federal, por meio das reflexões existentes no extenso texto inicial dos deputados autores originais somados aos acúmulos gerados pela I Conferência Nacional de Cultura e dos seminários estaduais de 2008.

Nas justificativas ao substitutivo do PL, é apresentado com profundidade o tema da gestão da cultura. Ao longo do enunciado, são citados e comentados trechos de diversos documentos relacionados como os resultados da I CNC, os documentos mexicanos da UNESCO (Mondiacult e Nuestra Diversidad Creativa), a Agenda 21 da Cultura, a Convenção para a Proteção e a Promoção da Diversidade das Expressões Culturais etc. Além disso, também faz referências a reflexões de pensadores brasileiros da cultura como Lia Calabre e Sergio Mamberti, a fim de complementar sua argumentação. O documento assinado por Fatima Bezerra apresenta, além das reflexões e do texto da lei, também os anexos contendo as diretrizes, estratégias e ações do PNC. Isso leva a crer que os textos, tanto da lei quando dos anexos, foram escritos em parceria com membros do MinC, por meio das discussões, reuniões e encontros realizados com a sociedade civil. Essa parceria é evidenciada pelo teor da publicação Porque aprovar o Plano Nacional de Cultura de abril de 2009, mesmo período em que se inicia o processo de relatoria de Fátima na CEC. A publicação foi desenvolvida pelo MinC com intenção de auxiliar a compreensão da estrutura e do funcionamento do plano e do sistema como um todo, endereçado tanto para a sociedade civil, quanto para os demais deputados da Câmara.

Depois do substitutivo proposto pela relatora Fátima Bezerra, a matéria recebeu sete emendas parlamentares ao texto propostas pelo deputado Emiliano José (PT - BA) quando estava em análise na Comissão de Constituição e Justiça em dezembro de 2009. As emendas propunham pequenas alterações em diversos trechos do PL. As emendas propostas por 
Emiliano José resultaram em algumas alterações consideráveis no texto, como, por exemplo, no Art. $3^{\circ}$ Parágrafo $4^{\circ}$ que trata das atribuições do poder público.

\section{Versão Deputada Fatima Bezerra.}

$\S 4^{\circ}$ Poderão colaborar com o Plano Nacional de Cultura, em caráter voluntário, outros entes, públicos e privados, tais como empresas, organizações corporativas e sindicais, organizações da sociedade civil, fundações, pessoas físicas e jurídicas que se mobilizem para a garantia dos princípios, objetivos, diretrizes e metas do PNC, estabelecendo termos de adesão específicos.

Versão Deputado Emiliano José.

$\S 4^{\circ}$ O Poder Executivo federal, observados os limites orçamentários e operacionais, poderá oferecer assistência técnica e financeira aos entes da federação que aderirem ao plano, nos termos de regulamento.

E no Art. $11^{\circ}$ que trata das disposições finais em seu Parágrafo único:

Versão Deputada Fatima Bezerra.

Parágrafo único. A primeira revisão do plano será realizada após quatro anos da promulgação desta Lei e contará com a participação de especialistas, instituições culturais e órgãos do poder público, com o apoio da sociedade civil, do Conselho Nacional de Política Cultural e de outros órgãos colegiados de caráter consultivo, na forma do regulamento.

Versão Deputado Emiliano José.

Parágrafo único. A primeira revisão do plano será realizada após quatro anos da promulgação desta Lei, assegurada a participação do Conselho Nacional de Política Cultural - CNPC e de ampla representação do poder público e da sociedade civil, na forma do regulamento. ${ }^{143}$

O documento contendo as emendas propostas pelo deputado Emiliano, além de alterar seis trechos da lei, sugeriu também um novo artigo ao enunciado que dá a competência aos entes federados de realizarem suas próprias conferências territoriais e setoriais:

Art. 14. A Conferência Nacional de Cultura e as conferências setoriais serão realizadas pelo Poder Executivo federal, enquanto os entes que aderirem ao PNC ficarão responsáveis pela realização de conferências no âmbito de suas competências para o debate de estratégias e o estabelecimento da cooperação entre os agentes públicos e a sociedade civil para a implementação deste Plano Nacional de Cultura - PNC.

Podemos aferir que a redação final do texto da lei $12.343 / 2010$ foi um processo de escrita e criação na esfera legislativa composto por diversas mãos, com influência das discussões incentivadas pelo MinC e ocorridas na sociedade civil. Todavia, é relevante

\footnotetext{
${ }^{143}$ Disponível em: < http://www.camara.gov.br/proposicoesWeb/prop mostrarintegra?codteor=752712\&filename=Tramitacao-

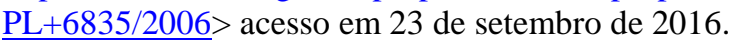


evidenciar que todos os cinco deputados que efetivamente participaram do processo de escrita eram do mesmo partido. O enunciado final da lei foi construído num processo dialógico, com diferentes momentos de escrita e com sujeitos de esferas distintas em interação (deputados federais do PT, membros do MinC e sociedade civil).

Ainda que tivesse sofrido um atraso considerável em seu processo entre 2007 e 2009, em nenhum momento o PL teve dificuldades para ser aprovado ou enfrentou problemas concretos de disputa política por trechos de seu conteúdo. O único embate político ocorrido no processo foi o requerimento 404/10 apresentado em 15 de abril de 2010 pelo deputado Milton Vieira (DEM - SP), alegando que a matéria deveria ser levada a ampla discussão na plenária da Câmara, pois era de interesse de "diversos segmentos da sociedade civil". $\mathrm{O}$ ato indica a tentativa do deputado de um partido da oposição em atrasar ainda mais um processo que já durava cinco anos. O recurso também tratava, entre diversos pontos elencados, das diversas mudanças na proposta desde sua tramitação em que esta passou de um gênero dissertativo ao formato de uma lei.

(...) demais disso, não só os fundamentos como toda a organização normativa e textual, metodologia, diretrizes e propostas por eixo temático, que acompanham o Projeto original, foram inteira e substancialmente modificados e ampliados no Substitutivo adotado pela Comissão de Educação e Cultura. ${ }^{144}$

A tentativa de "manobra" parlamentar é evidenciada quando o deputado do partido Democratas não leva em conta em seu requerimento que o teor do conteúdo da proposta não foi alterado, apenas sua forma. Por conta da tentativa de obstrução do deputado da oposição, o deputado Gilmar Machado apresentou outro requerimento pedindo à casa a retirada do requerimento de Milton Vieira por meio do enunciado de "retirada de proposições de iniciativa coletiva N. 6692/2010”, que foi deferido pelo presidente da Câmara em 22 de abril. Com isso, o PL do PNC prosseguiu para sua redação final e aprovação por consenso parlamentar conforme substitutivos e emendas no dia 25 de novembro de 2010. No dia 02 de dezembro, o texto foi publicado no Diário Oficial da União (DOU) com a sanção presidencial de Lula. Trataremos de outros detalhes da Lei do PNC e seus anexos ao longo da tese.

Ainda mais importante para nossa reflexão é perceber os agentes participantes dos processos de criação e aprovação do nosso principal enunciado da pesquisa, o SNC. A PEC 416/2005 do SNC foi inscrita na Câmara Federal pelo Deputado Paulo Pimenta (PT - RS) em

\footnotetext{
${ }^{144}$ Requerimento disponível em: < http://www.camara.gov.br/proposicoesWeb/prop mostrarintegra?codteor=752712\&filename=Tramitacao-

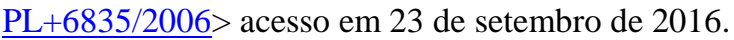


junho de 2005 e visava inserir um novo artigo à $\mathrm{CF}$, o artigo $216 \mathrm{~A}^{145}$. A estratégia de criar não apenas um novo parágrafo à $\mathrm{CF}$, mas um novo artigo, com teor distinto do artigo 216 que trata principalmente do patrimônio, demonstra que a PEC do SNC buscava de fato ser mais um dos artigos da cultura e não apenas um adendo à Constituição.

Como vimos anteriormente, em fevereiro de 2007, a mesa diretora da Câmara propôs o arquivamento da PEC juntamente com centenas de outras PECs e projetos de leis, assim como aconteceu com o PL regulamentar do PNC. Em junho do mesmo ano, Paulo Pimenta expediu um requerimento para o desarquivamento da PEC que continuou assim sua tramitação. Em agosto de 2008, a PEC foi aprovada na Comissão de Constituição, Justiça e de Cidadania com relatoria da Deputada Sandra Rosado (PSB - RN) que emitiu parecer pela admissibilidade da matéria ainda que contasse com os votos contrários dos deputados: Nelson Trad (PMDB - MT), Antonio Carlos Biscaia (PT - PR), Fernando Coruja (PPS - SC), Gerson Peres (PP - PA), Ayrton Xerez (PSDB - RJ) e Edson Aparecido (PSDB - SP). O único comentário com demonstração de ponto de vista de Sandra no parecer diz que a matéria "merece ser admitida ao debate parlamentar"146.

No site da Câmara Federal é possível observarmos duas versões diferentes da PEC 416. A primeira de junho de 2005, com o enunciado original de autoria do Deputado Paulo Pimenta, trazia uma introdução menor sobre seu objeto e apenas cinco itens relativos ao Sistema.

\footnotetext{
${ }^{145}$ O teor do Artigo 216 já existente na Constituição Federal diz o seguinte: Art. 216. Constituem patrimônio cultural brasileiro os bens de natureza material e imaterial, tomados individualmente ou em conjunto, portadores de referência à identidade, à ação, à memória dos diferentes grupos formadores da sociedade brasileira, nos quais se incluem: I - as formas de expressão; II - os modos de criar, fazer e viver; II - os modos de criar, fazer e viver; III - as criações científicas, artísticas e tecnológicas; IV - as obras, objetos, documentos, edificações e demais espaços destinados às manifestações artístico-culturais; V - os conjuntos urbanos e sítios de valor histórico, paisagístico, artístico, arqueológico, paleontológico, ecológico e científico. $\S 1^{\circ} \mathrm{O}$ Poder Público, com a colaboração da comunidade, promoverá e protegerá o patrimônio cultural brasileiro, por meio de inventários, registros, vigilância, tombamento e desapropriação, e de outras formas de acautelamento e preservação. $\S 1^{\circ} \mathrm{O}$ Poder Público, com a colaboração da comunidade, promoverá e protegerá o patrimônio cultural brasileiro, por meio de inventários, registros, vigilância, tombamento e desapropriação, e de outras formas de acautelamento e preservação. $\S 2^{\circ}$ Cabem à administração pública, na forma da lei, a gestão da documentação governamental e as providências para franquear sua consulta a quantos dela necessitem. $\S 3^{\circ} \mathrm{A}$ lei estabelecerá incentivos para a produção e o conhecimento de bens e valores culturais. $\S 4^{\circ}$ Os danos e ameaças ao patrimônio cultural serão punidos, na forma da lei. $\S 5^{\circ}$ Ficam tombados todos os documentos e os sítios detentores de reminiscências históricas dos antigos quilombos. $\S 6^{\circ}$ É facultado aos Estados e ao Distrito Federal vincular a fundo estadual de fomento à cultura até cinco décimos por cento de sua receita tributária líquida, para o financiamento de programas e projetos culturais, vedada a aplicação desses recursos no pagamento de: I - despesas com pessoal e encargos sociais; II - serviço da dívida; III - qualquer outra despesa corrente não vinculada diretamente aos investimentos ou ações apoiados. (Incluído pela Emenda Constitucional nº 42, de 19.12.2003)

${ }^{146}$ Parecer disponível em: < http://www.camara.gov.br/proposicoesWeb/prop mostrarintegra?codteor $=347500 \&$ filename $=\mathrm{PRL}+1+\mathrm{CCJC}+\% 3$ D\%3E+PEC+416/2005 > acesso em 26 de setembro de 2016.
} 
Art. o 216-A. O Sistema Nacional de Cultura, organizado em regime de colaboração, de forma horizontal, aberta, descentralizada e participativa, compreende: I - o Ministério da Cultura; II - o Conselho Nacional da Cultura; III - os sistemas de cultura dos Estados, do Distrito Federal e dos Municípios, organizados de forma autônoma e em regime de colaboração, nos termos da lei; IV - as instituições públicas e privadas que planejam, promovem, fomentam, estimulam, financiam, desenvolvem e executam atividades culturais no território nacional, conforme a lei; V - os subsistemas complementares ao Sistema Nacional de Cultura como o Sistema de Museus, Sistema de Bibliotecas, Sistema de Arquivos, Sistema de Informações Culturais, Sistema de Fomento e Incentivo à Cultura, regulamentados em lei específica. Parágrafo único. O Sistema Nacional de Cultura estará articulado como os demais sistemas nacionais ou políticas setoriais, em especial, da Educação, da Ciência e Tecnologia, do Turismo, do Esporte, da Saúde, da Comunicação, dos Direitos Humanos e do Meio Ambiente, conforme legislação específica sobre a matéria. ${ }^{147}$

A segunda versão com o texto substitutivo proposto em abril de 2010 , pelo então relator deputado Paulo Rubem Santiago (PT - PE), já demonstra a evolução da reflexão acerca do enunciado original. O deputado pernambucano buscou desenvolver o texto original de Paulo Pimenta para algo que trouxesse maior articulação com as discussões que estavam ocorrendo fora da esfera legislativa. Bem mais complexo que o enunciado anterior, este substitutivo traz quatro parágrafos diferentes distribuídos em 21 itens que tratam respectivamente de seus princípios e diretrizes, da sua estrutura, da futura lei de regulamentação e dos sistemas nos entes federados. É relevante lembrar que Paulo Rubem Santiago também esteve envolvido no processo de escrita, relatoria e aprovação da lei regulamentar do PNC que começou quase que simultaneamente em 2005. O texto substitutivo foi aprovado como redação final da PEC em 29 de novembro de 2012 após aprovação como EC 71 no Senado Federal e transformado no artigo 216-A.

Art. 216-A. O Sistema Nacional de Cultura, organizado em regime de colaboração, de forma descentralizada e participativa, institui um processo de gestão e promoção conjunta de políticas públicas de cultura, democráticas e permanentes, pactuadas entre os entes da federação e a sociedade, tendo por objetivo promover o desenvolvimento - humano, social e econômico com pleno exercício dos direitos culturais. $\S 1^{\circ}$ - O Sistema Nacional de Cultura fundamenta-se na política nacional de cultura e nas suas diretrizes, estabelecidas no Plano Nacional de Cultura, e rege-se pelos seguintes princípios: I - diversidade das expressões culturais; II - universalização do acesso aos bens e serviços culturais; III - fomento à produção, difusão e circulação de conhecimento e bens culturais; IV - cooperação entre os entes

\footnotetext{
${ }^{147}$ Proposição original PEC 416/2005 Deputado Paulo Pimenta disponível em: < http://www.camara.gov.br/proposicoesWeb/prop mostrarintegra;jsessionid=6A37C208F0BA5D3D5EB3F21A48 1BE551.proposicoesWeb1?codteor $=316130 \&$ filename=Tramitacao-PEC+416/2005 $>$ acesso em 26 de setembro de 2016.
} 
federados, os agentes públicos e privados atuantes na área cultural; V integração e interação na execução das políticas, programas, projetos e ações desenvolvidas; VI - complementaridade nos papéis dos agentes culturais; VII - transversalidade das políticas culturais; VIII - autonomia dos entes federados e das instituições da sociedade civil; IX - transparência e compartilhamento das informações; X - democratização dos processos decisórios com participação e controle social; XI - descentralização articulada e pactuada da gestão, dos recursos e das ações. XII- ampliação progressiva dos recursos contidos nos orçamentos públicos para a cultura. $\S$ $2^{\circ}$ Constitui a estrutura do Sistema Nacional de Cultura, nas respectivas esferas da federação: I- órgãos gestores da cultura; II- conselhos de política cultural; III- conferências de cultura; IV- sistemas de financiamento à cultura; V- planos de cultura; VI- comissões intergestores; VII- sistemas de informações e indicadores culturais; VIII- programas de formação na área da cultura; e IX- sistemas setoriais de cultura. $\S 3^{\circ}$ - Lei federal disporá sobre a regulamentação do Sistema Nacional de Cultura, bem como de sua articulação com os demais sistemas nacionais ou políticas setoriais de governo. $\S 4^{\circ}$ - Os Estados, o Distrito Federal e os Municípios organizarão seus respectivos sistemas de cultura em leis próprias. ${ }^{148}$

É possível ressaltar que a designação de Paulo Rubem em fevereiro de 2010 para a relatoria foi feita a partir da instituição de uma comissão especial para a discussão da PEC requerida pelo Deputado Odair Cunha (PT - MG). Essa comissão especial possibilitou a realização de audiências públicas para a discussão da matéria com participação de agentes de outras esferas, tanto do MinC quanto da sociedade civil. Participaram como convidados debatedores da primeira audiência do dia 24 de fevereiro de 2010: o então Ministro Juca Ferreira, Anita Pires como Presidente do Fórum Nacional dos Secretários e Dirigentes Estaduais de Cultura, Jandira Feghali como Presidente do Fórum Nacional dos Secretários de Cultura das Capitais e João Roberto Costa do Nascimento como Coordenador Geral de Relações Federativas e Sociedade do Ministério da Cultura.

A participação do então Ministro da Cultura Juca Ferreira nesta audiência pública realizada em fevereiro de 2010 deve ser considerada, pois demonstra uma relação entre os poderes executivo e legislativo. É essencial à aprovação de um marco legal que esteja diretamente vinculado ao executivo em sua posterior execução a participação e o apoio de seu gestor de mais alto grau hierárquico. Ainda que a comissão especial de discussão da PEC tenha sido solicitada pelo deputado Odair Cunha, o interesse do executivo na aceleração da aprovação está intrinsicamente demonstrada nessa participação. Entretanto, a

\footnotetext{
${ }^{148}$ Proposta de texto substitutivo escrito pelo deputado Paulo Santiago para a PEC 416/2005 em abril de 2010. Disponível em: <

http://www.camara.gov.br/proposicoesWeb/prop mostrarintegra?codteor=754357\&filename=SBT+1+PEC41605 +\%3D\%3E+PEC+416/2005 > acesso em 26 de setembro de 2016.
} 
responsabilidade de Juca Ferreira neste momento para com a PEC deve ser observada além do marco legal e dos interesses em sua aprovação. O ano de 2010 pode ser entendido como o ano de eleição presidencial. Reforçar a presença no legislativo, bem como acelerar o processo de aprovação da PEC era um compromisso relevante para o processo como um todo. $\mathrm{O}$ resultado da eleição foi favorável ao processo por conta da manutenção do mesmo partido no poder. A eleição de Dilma Rousseff garantiu que o interesse do MinC na PEC continuasse na gestão seguinte, mesmo com a entrada da Ministra Ana de Hollanda no lugar de Juca.

Após a apreciação e aprovação das comissões internas, a proposta foi incluída na ordem do dia de dez sessões da plenária da Câmara dos deputados, com discussão de votação em primeiro turno no dia 30 de maio de 2012. Nesta sessão, o Deputado Federal Mendonça Filho (DEM - PE) tentou uma obstrução por requerimento solicitando "a retirada de pauta desta matéria, o adiamento da discussão por dez sessões, que a discussão fosse feita por grupo de artigos, o adiamento da votação por cinco sessões, e que a votação fosse feita artigo por artigo" ${ }^{149}$. Porém, após a deliberação de alguns deputados presentes defendendo que a PEC estivesse na pauta de votação, e negociações internas entre os parlamentares, o deputado pernambucano retirou o requerimento e a sessão procedeu para a votação.

A PEC foi aprovada pelos deputados em primeiro turno por 361 votos a favor e um voto contrário do então Deputado Jair Bolsonaro (PP - RJ). No dia 26 de junho, a PEC foi discutida em sua décima sessão e aprovada em segundo turno por 326 votos a favor e um contra, do mesmo deputado do Partido Progressistas ${ }^{150}$.

Em 28 de junho, a PEC foi enviada ao Senado para sua discussão final onde foi inscrita como PEC 34/2012. Em agosto de 2012, a PEC foi submetida à Comissão de Constituição Justiça e Cidadania do Senado Federal, na responsabilidade de relatoria da então senadora Marta Suplicy (neste momento ainda no PT - SP) que emitiu parecer favorável à proposta. No dia 12 de setembro de 2012, a PEC foi levada a discussão e votação e aprovada em primeiro turno por unanimidade pelos 56 senadores presentes e o mesmo ocorrendo em

\footnotetext{
${ }^{149}$ Informação obtida no histórico da tramitação da PEC 416/2005. Disponível em: < http://www.camara.gov.br/proposicoesWeb/fichadetramitacao?idProposicao=290677> acesso em 26 de setembro de 2016.

${ }^{150}$ Devemos salientar que a oposição à aprovação da matéria pelo deputado Bolsonaro foi observada em outros processos legislativos de cultura e educação. O deputado foi opositor a todas as matérias destes setores que ousavam apresentar qualquer visão ideológica de cunho mais progressista e de modernização de políticas sociais durante aquele mandato. O voto contrário único de Bolsonaro demonstra claramente sua avaliação social contrária ao conteúdo da proposta que visa alterar substancialmente a gestão cultural para algo mais democrático e diverso, justamente o oposto da visão autoritária e ultraconservadora do político em questão que atualmente está no PSL e foi eleito presidente da república no mandato iniciado em 2019 e, portanto, o novo responsável por ditar as políticas culturais do país.
} 
segundo turno na mesma data com 54 senadores. A sessão final de aprovação ocorreu na Câmara Federal em 29 de novembro de 2012 com a promulgação da Emenda Constitucional N. 71 e contou com os discursos do Presidente da Câmara dos Deputados, Deputado Federal Marco Maia (PT - RS), o Deputado Federal Paulo Pimenta, a já Ministra da Cultura Marta Suplicy $^{151}$, e o Presidente do Senado Federal e do Congresso Nacional, Senador José Sarney $(\mathrm{PMDB}-\mathrm{AP})$.

Ao atentarmos à autoria da PEC relativa ao SNC devemos reconstruir seu processo de criação, que, como vimos, foi fruto do trabalho de muitas ações de diferentes autores e agentes. No texto de justificativa da PEC 416/2005 relativa ao SNC seu autor inicial, o deputado Paulo Pimenta escreveu:

Um sistema universalizador de gestão da cultura deve acolher, como elementos-chave, a criação dos conselhos de cultura, dos fundos de cultura e das formas de participação democrática e descentralizada dos produtores culturais e das comunidades em geral, além da atuação autônoma e articulada das três esferas de governo. Com isso, estabelecem-se as bases para implantar os componentes das políticas culturais: formação, criação, produção, distribuição, consumo, conservação e fomento. A partir desses elementos centrais, é possível pensar as políticas culturais como estratégias voltadas para o desenvolvimento cultural e econômico do País, para a garantia do direito de acesso aos bens culturais como prerrogativa essencial da população na construção da cidadania e para a defesa da diversidade cultural e das identidades culturais locais frente à globalização. Esta iniciativa vem complementar outras ações em tramitação nesta Casa com o objetivo de consolidar uma política cultural para o País. Uma delas é a Proposta de Emenda à Constituição $n^{\circ} 306$, de 2000, do Deputado Gilmar Machado e outros, que institui o Plano Nacional de Cultura, aprovada pelo Congresso em 2005. Outra iniciativa no mesmo sentido é a Proposta de Emenda à Constituição no 150, de 2003, do Deputado Paulo Rocha e outros, que institui a vinculação de receita para a cultura, colocando em debate a questão do papel do Estado como fomentador das atividades culturais e da previsão orçamentária para a efetivação das políticas públicas de cultura. ${ }^{152}$

A citação à PEC 306/2000 feita na justificativa do deputado que consta em anexo ao enunciado da PEC 416/2005 e à PEC 150/2003 ${ }^{153}$ nos leva a crer que o deputado Paulo Pimenta estava buscando não apenas demonstrar a relação dos enunciados dentro da arquitetura do sistema, mas principalmente propor a aprovação destas outras duas propostas.

\footnotetext{
${ }^{151}$ Marta assumiu o posto de ministra da cultura alguns dias após a votação da PEC do SNC no senado.

152 Justificativa à inscrição da Proposta de Emenda Parlamentar do SNC 416/2005. Disponível em: < http://www.camara.gov.br/proposicoesWeb/prop_mostrarintegra;jsessionid=566A7270FAB7601DDE007C61F4 608F0C.proposicoesWeb2? codteor $=316130 \&$ filename $=$ Tramitacao-PEC $+416 / 2005>$ acesso em 26 de setembro de 2016.

${ }^{153}$ A PEC 150/2003 versa sobre a ampliação dos orçamentos de cultura nos três âmbitos de governo. Atualmente tramita com uma proposta substitutiva como PEC 421/2014 e aguarda apreciação.
} 
A visão do processo de Paulo Pimenta apontava para a construção do Sistema como um todo, para sua arquitetônica. Assim também foi a visão do deputado Paulo Rubem em seu texto substitutivo. Ambos estavam em diálogo constante com membros do MinC nos períodos, pois os discursos que traziam em seus relatórios, pareceres e justificativas eram semelhantes aos enunciados produzidos pelo MinC. Neste trecho da justificativa, Paulo Pimenta demonstra qual é sua visão de política cultural quando diz que

\begin{abstract}
A partir desses elementos centrais, é possível pensar as políticas culturais como estratégias voltadas para o desenvolvimento cultural e econômico do País, para a garantia do direito de acesso aos bens culturais como prerrogativa essencial da população na construção da cidadania e para a defesa da diversidade cultural e das identidades culturais locais frente à globalização. (PIMENTA, 2005, p. 3)
\end{abstract}

Para ele, as políticas culturais deveriam ser "estratégias" de "desenvolvimento cultural e econômico", mas também a garantia do direito à cultura como essencial à cidadania e a defesa da diversidade. Mais uma vez vemos aqui os mesmos centros de valores apontados anos antes na PEC do PNC de Gilmar Machado, pois trata da gestão da cultura para o acesso e para a diversidade. Contudo, nesse novo momento, a ideia de política cultural como estratégia voltada para o desenvolvimento principalmente econômico parece estar se fortalecendo. O SNC deve ser pensado não apenas como um novo modelo de gestão pública da cultura, mas principalmente como um novo modelo de distribuição das verbas públicas da cultura. Ao tratar da proposta com menção ao desenvolvimento econômico, Pimenta parece compreender bem o todo da proposta de gestão e sinaliza sua responsabilidade perante a esfera econômica brasileira de forma mais geral. A PEC do SNC, enquanto processo que relaciona as esferas político-cultural e legislativa, está diretamente relacionada à infraestrutura econômica e isso transparece inclusive em seu conteúdo. É possível dizer que Paulo Pimenta, ao evidenciar o caráter também econômico da proposta do SNC, busca chamar a atenção para um setor que nas últimas décadas tem gerado milhares de empregos e renda a trabalhadores brasileiros, mas também que o investimento em cultura possibilitaria ampliar o desenvolvimento econômico do país por meio de um de seus setores mais produtivos, a cultura. Entretanto, é necessário salientar mais uma vez, que a produção cultural brasileira contemporânea ainda é normatizada pelo poder público federal principalmente através dos preceitos da Lei Rouanet, que regulamenta o funcionamento do Fundo Nacional de Cultura. A proposta de distribuição de verbas da cultura a partir do SNC busca converter o funcionamento do financiamento à cultura para um modelo descentralizador, inclusivo e em 
favor da diversidade cultural e da ampliação do acesso. A Lei Rouanet, como vimos anteriormente, privilegia que as decisões sejam tomadas pelo mercado de empresas patrocinadoras. Enquanto o SNC age como força centrífuga ao propor um novo modelo democrático de construção de políticas culturais e distribuição mais justa de verbas da cultura por meio de um novo modelo de FNC, a Rouanet, e seus defensores, agem como força centrípeta ao tentarem manter o sistema de financiamento como está, privilegiando uma minoria de produtores culturais e concentrando os recursos no eixo Rio-SP. Aqui fica ainda mais claro o que Volóchinov evidencia em Marxismo e Filosofia da Linguagem quando fala da força da base econômica em relação às superestruturas.

O estabelecimento da ligação entre a base e um fenômeno isolado, que foi retirado do contexto ideológico integral e unificado, não possui nenhum valor cognitivo. Primeiro, a importância de uma mudança ideológica deve ser definida no contexto da ideologia correspondente, considerando que qualquer área ideológica é uma totalidade que reage com toda a sua composição à alteração da base. Por isso a explicação deve preservar toda a diferença qualitativa dos campos em interação e observar todas as etapas que acompanham essa mudança. Apenas nessa condição o resultado da análise não será uma correspondência externa de dois fenômenos ocasionais e que se encontram em diferentes planos, mas um processo de formação dialética de uma sociedade real, que tem início na base e termina nas superestruturas. (VOLÓCHINOV, 2017, p. 104 - grifos do autor)

Nesta reflexão, Volóchinov evidencia que por meio da concreta mudança na base econômica poderá haver uma alteração nas superestruturas, isto é, nas esferas ideológicas, mas há uma relação dialética, em que a superestrutura pode afetar esta infraestrutura e gerar o início dessa mudança. "qualquer área ideológica é uma totalidade que reage com toda a sua composição à alteração da base". A tentativa de alteração do modelo de gestão pública (na superestrutura da esfera político-cultural) é um dos meios para a alteração no modelo de financiamento à cultura (na base econômica). Entretanto, a resistência de parlamentares apoiadores da Lei Rouanet e do modelo liberal de financiamento à cultura na aprovação da Procultura demonstra que a arquitetônica da esfera só pode ser alterada de fato com a alteração do modelo de financiamento na gestão político-cultural. Volóchinov ressalta que a mudança social pode ser sentida a partir da palavra e do conjunto de signos nos enunciados de uma determinada superestrutura. É na constituição de uma esfera ideológica, e por seus enunciados, que ocorrem os primeiros sinais de mudança que posteriormente poderão afetar algum tipo de mudança social.

O problema da correlação entre a base e as superestruturas - que é extremamente complexo e demanda uma enorme quantidade de material prévio para sua elaboração produtiva - pode ser, em grande parte, 
compreendido justamente no material da palavra. Pois, no plano que nos interessa, a essência desse problema se reduz a como a existência real (a base) determina o signo e como o signo reflete e refrata a existência em formação. As particularidades da palavra enquanto signo ideológico, que analisamos no capítulo anterior, fazem dela o material mais conveniente para a orientação principal de todo o problema. Nessa relação é importante não tanto a natureza sígnica da palavra, mas a sua onipresença social. Pois a palavra participa literalmente de toda interação e de todo contato entre as pessoas: da colaboração no trabalho, da comunicação ideológica, dos contatos eventuais cotidianos, das relações políticas etc. Na palavra se realizam os inúmeros fios ideológicos que penetram todas as áreas da comunicação social. É bastante óbvio que a palavra será o indicador mais sensível das mudanças sociais, sendo que isso ocorre lá onde essas mudanças ainda estão se formando, onde elas ainda não se constituíram em sistemas ideológicos organizados. A palavra é o meio em que ocorrem as lentas acumulações quantitativas daquelas mudanças que ainda não tiverem tempo de alcançar uma nova qualidade ideológica, nem de gerar uma nova forma ideológica acabada. A palavra é capaz de fixar todas as fases transitórias das mudanças sociais, por mais delicadas e passageiras que elas sejam. (VOLÓCHINOV, 2017, p. 106 - grifos do autor)

A proposta de alteração no mecanismo de financiamento da cultura presente no SNC, e explícita no texto de justificativa da PEC escrita por Paulo Pimenta, revela a responsabilidade do autor em apresentar uma nova forma de desenvolvimento econômico mais justo em termos de distribuição, mas que ainda assim seria benéfico à economia do país. A argumentação busca apresentar um novo modelo de economia da cultura por meio de uma proposta que se relaciona com o caráter federalista da Constituição Federal. Contudo, o autor é consciente de que a alteração do modelo de financiamento seria um desafio no processo político, por interferir nos preceitos da infraestrutura e, talvez, por este motivo ressalta o viés econômico implícito na arquitetônica do sistema que está sendo proposto. Isso está ainda mais claro quando o autor coloca em seu texto a importância da aprovação da Proposta de Emenda à Constituição $n^{\circ}$ 150, de 2003 que amplia o orçamento da cultura ao patamar base de $2 \%$ no plano federal. Como vimos no capítulo anterior não houve uma ação efetiva do alto escalão do executivo de ampliar concretamente o orçamento da cultura ao longo do processo. A ampliação no orçamento do FNC foi um reflexo que acompanhou o crescimento econômico do país no período ate 2010 e não um ato de ampliação além das porcentagens usuais. Ainda que o deputado chame atenção para a PEC 150 e sua projeção de ampliação do piso para $2 \%$ de orçamento para a cultura, o mesmo não ocorreu pelos responsáveis por esta decisão. Cabe aos Ministérios da Fazenda e Planejamento, bem como ao presidente, autorizar qualquer tipo de ampliação real de orçamento em uma determinada rubrica orçamentária e em sua execução, ainda que o MinC solicite essa ampliação já na aprovação da Lei Orçamentária 
Anual. A ampliação no orçamento em termos de execução efetiva foi relativamente baixa, não alcançando nem 1/5 do patamar ideal de $2 \%$. Voltaremos a essa reflexão ao longo da tese.

Ao proporem a PEC do SNC, buscam consolidar a construção do Sistema. Porém, para seu pleno estabelecimento ainda faltava sua regulamentação (que até o fechamento desta tese ainda tramitava como um PL) e um novo modelo do Fundo Nacional de Cultura e seus repasses aos fundos territoriais.

Nos enunciados produzidos numa esfera de caráter normativo como a legislativa, os rastros da autoria são quase que imperceptíveis ao longo dos textos em termos de estilo autoral, estes devem ser considerados principalmente a partir de seus conteúdos e do forte teor axiológico das proposições. $\mathrm{O}$ estilo do gênero deve ser levado em conta pois são gêneros relativamente consolidados na esfera. Isso é ainda mais evidenciado quando pensamos no papel dos assessores parlamentares ao longo dos processos. É essencial levar em conta que em boa parte dos casos, os textos presentes nos enunciados legislativos são criados e escritos por estes assessores quase sempre desconhecidos pela sociedade civil. Cada deputado federal pode contratar oficialmente entre 5 e 25 secretários parlamentares para serviços de secretaria, assistência e assessoramento direto. Há casos de parlamentares com quase 100 assessores, ainda que isto não esteja previsto em lei. Os assessores especializados na escrita de marcos legais atuarão em diversas etapas dos processos de escrita e aprovação de uma determinada matéria. Ainda que estes assessores não assinem oficialmente a autoria dos enunciados, é possível dizer que são agentes de suma importância na construção dos mesmos. Assim, os assessores tornam-se co-autores de diversos marcos legais mesmo que permaneçam nos bastidores da esfera. Partindo desse pressuposto é possível aferir que dentre as vozes presentes nestes enunciados, devemos levar em conta os valores axiológicos destes agentes co-autores, que ao escreverem boa parte dos textos e desenvolverem pesquisas para a construção das matérias, mesclam nas entrelinhas suas visões de mundo e avaliações sociais. Deste modo, há uma corresponsabilidade ética de parlamentares e assessores no ato criativo responsável da escrita de uma lei mesmo sendo incógnitos na assinatura dos enunciados.

$$
* * *
$$

Por meio da observação do histórico e dos enunciados propostos, e dos autores e agentes envolvidos em seus processos de criação, começamos a observar mais concretamente um esboço da arquitetônica do SNC. Pudemos verificar que este estava propondo um novo modelo de gestão e compreensão de cultura para a esfera político-cultural em termos de sua construção ao compreender a política cultural como possibilidade de inclusão por meio da 
ampliação do acesso e da diversidade. Contudo, percebemos nos processos da PEC do SNC, na comparação entre os textos de Paulo Pimenta e Paulo Rubem Santiago, que o segundo soube desenvolver melhor e com maior diálogo com a esfera político-cultural as proposições contidas na emenda. Ao inserir mais itens em estreita relação com os manuais e diretrizes que estavam sendo desenvolvidos no período, e com os resultados dos processos de participação social, Paulo Rubem, em seu ato responsável de escrita do texto substitutivo, evidenciou o caráter descentralizador do sistema.

Os processos históricos também compõem uma parte constitutiva dessa arquitetônica. Ao observarmos a construção do PNC/ SNC, podemos perceber que, no início dos anos 2000, Gilmar Machado, que iniciou os processos com a PEC do PNC, não poderia imaginar a complexidade e a grande quantidade de ações posteriores que levariam à concretização do que ele idealizou para seu plano de cultura. Ainda mais difícil seria aos outros agentes iniciais do processo, intelectuais e artistas, perceberem a complexidade estrutural do Sistema, tanto em termos legislativos, quanto em termos de gestão pública. Os desafios que seriam estabelecidos ao longo do tempo como atrasos e obstáculos políticos e econômicos também não foram considerados no início da construção das propostas. As dificuldades tornaram-se mais latentes ao longo da construção do sistema e ficaram ainda mais claras a partir de 2010 com a proposição do projeto de lei da Procultura e a tentativa efetiva de alteração no modelo de financiamento. Como diria Bakhtin, na construção da arquitetônica, devemos levar em conta todos os pontos relacionados, os valores, os agentes e suas relações e também sua construção no tempo-espaço. "A valoração do sentido sobre o plano abstrato pode ser encarnada somente em uma situação concreta unitária, na qual se dá também uma entonação real, uma situação no seu todo, que se define em relação a um centro concreto de valores." (BAKHTIN, 2010d, p. 127)

A aprovação do decreto 5.520 de 2005, capitaneado por Marcio Meira na SAI, foi central no início da construção e implantação do SNC. Foi com ele que muitos estados e municípios puderam iniciar seus processos territoriais de Sistema e muitas outras ações ganharam força como: o PL que gerou a lei regulamentar do PNC (12.343/2010), a $1^{\text {a }}$ CNC e as propostas brasileiras feitas à Convenção da Diversidade da Unesco em 2005. Foi também a partir desse período que as instituições federais buscaram se organizar para quantificar os indicadores culturais necessários para avaliação dos diagnósticos e resultados do Sistema. No ano de 2006 foi criado o SNIIC e iniciados os planejamentos para o desenvolvimento das pesquisas do IPEA e do IBGE. 
Ainda que o formato de Sistema e de Plano não fossem uma novidade para o país (já que o primeiro PNC surgiu inicialmente no período da ditadura militar) é preciso considerar que a ideia de uma nova forma de fazer política cultural, de uma forma mais ampla e compreendendo a cultura em toda sua diversidade foi tomando corpo a partir das reflexões e encontros promovidos por Gilmar Machado. Essa construção prosseguiu nos discursos de Gil e ações de Marcio Meira, que compreendiam que o Sistema que estava sendo construído coletivamente poderia tornar possível a ideia de uma cultura acessível e transversal, que colocasse em diálogo diversos setores e abrangesse as mais diferentes linguagens culturais e os mais diversos públicos. Contudo, os períodos seguintes não foram apenas de construção do processo. Muitos obstáculos fizeram com que o sistema tivesse uma série de atrasos em sua constituição, como a questão legislativa, a implantação nos territórios, a falta de investimentos concretos como abordados neste tópico e principalmente a crise política.

Entretanto, um fator estava cada vez mais inserido e fortalecido nos processos da arquitetônica do SNC: a participação social. Essa amplitude e esse diálogo cada vez mais ampliado, porém, só seria possível mediante a abertura do diálogo com a sociedade civil fazedora de cultura, presente nos encontros, conferências e consultas públicas realizados a partir de 2003, como veremos no tópico a seguir.

Após essa análise sobre a autoria no SNC, podemos aferir que dentre as vozes presentes nos enunciados analisados, devemos levar em conta os valores axiológicos destes agentes que se materializam nas entrelinhas desses enunciados. Os assessores especializados na escrita de marcos legais atuaram em diversas etapas dos processos de escrita e aprovação de uma determinada matéria. Ainda que esses assessores não assinem oficialmente a autoria dos enunciados e sejam anônimos nas informações publicadas, são agentes relevantes em sua criação e construção dos mesmos, tornando-se, assim, coautores anônimos de diversos marcos legais.

Os deputados, por assinarem a autoria e a relatoria destes marcos legais, assumem a responsabilidade ética pelo teor desses enunciados em relação ao mundo. Como evidenciou Bakhtin, a assinatura é a prova de que a vida não tem álibi e num enunciado reforça a responsabilidade pelo dito. Deste modo, há uma corresponsabilidade ética de parlamentares, assessores e sociedade civil no ato criativo responsável da escrita de uma lei ainda que alguns desses agentes permaneçam incógnitos e não participem da assinatura dos enunciados. No entanto, como vimos, a autoria se difere de assinatura nesses processos da esfera: há os 
processos em que autores assinam os marcos legais (seja como autor ou relator), e há os coautores que contribuem anonimamente, por exemplo, os assessores legislativos, cuja função é participar da escrita e revisão dos enunciados, ou mesmo agentes da sociedade civil presentes nas audiências.

Ao proporem os marcos legais analisados, os autores estavam em relação com outros marcos legais e discursos sociais e assim foram aos poucos construindo a arquitetônica desse novo sistema de gestão pública da cultura. Pudemos verificar que o SNC e seus autores estavam propondo uma forma de gestão e compreensão de cultura para a esfera políticocultural em termos de sua construção, na qual estavam presentes valores como possibilidade de democratização e de inclusão por meio da ampliação do acesso e da diversidade. Ao observarmos a construção histórica do Sistema e os personagens principais que atuaram na criação e composição desta arquitetura ao longo do tempo, foi possível verificar que o SNC e o PNC foram criados, construídos e pensados por diversos sujeitos autores. Entretanto, apesar da diversidade de autorias, constatamos um consenso político-ideológico de vozes nos enunciados, pois todos os autores principais envolvidos na construção dos textos eram do Partido dos Trabalhadores e os criaram de acordo com as propostas de gestão das políticas culturais do governo naquele período.

\section{3 - Participação social e Estado: a construção interativa do Sistema}

A participação social foi, desde o final dos anos 1980, uma das ferramentas previstas na CF de 1988 mais utilizadas por movimentos sociais e também pelos governos do PT em suas gestões municipais. Sobre isso, Silva (2008) diz que:

É no regime de democracia representativa que se desenvolvem a cidadania e as questões de representatividade, que tendem a fortalecer-se no regime de democracia participativa. A Constituição combina representação e participação direta, tendendo, pois, para a democracia participativa. É o que, desde o parágrafo único do artigo $1^{\circ}$ está configurado, quando, aí, se diz que todo o poder emana do povo, que o exerce por meio de representantes eleitos (democracia representativa), ou diretamente (democracia participativa). Consagram-se nesse dispositivo, os princípios fundamentais da ordem democrática adotada. Outros preceitos, como os referentes aos sistemas eleitoral e partidário, oferecem os desdobramentos para seu funcionamento. (SILVA, 2008, p. 16)

Tanto mecanismos da democracia representativa quanto de participativa estão presentes na Constituição Federal de 1988. A democracia participativa está representada por meio dos mecanismos de participação social como: plebicitos, consultas públicas e audiências 
públicas, entre outros. Estes mecanismos foram utilizados por movimentos sociais e em diversas gestões municipais petistas inicialmente nas discussões do orçamento participativo $^{154}$. Contudo, devemos ressaltar que a participação social no país cresceu efetivamente por meio da prática e da instituição dos conselhos populares no início do século XXI, nos mais diversos setores.

A existência de conselhos no Brasil data dos anos 1930, mas foi apenas nos anos 1970 durante a ditadura que esses conselhos começaram a existir de maneira mais numerosa ainda que, na maior parte dos casos, fossem meramente decorativos, por conta do autoritarismo do regime vigente, e compostos por notáveis.

A pesquisadora Luciana Tabagiba (2010) chama atenção para os "Conselhos Comunitários" criados no governo de Reynaldo de Barros em São Paulo em 1979 que buscavam criar canais de comunicação entre o povo e o governo, garantir legitimidade ao governo local e transformar a ação tecnocrata da municipalidade em uma ação participada (Decreto 16.10000/1979). Entretanto, Gohn (2003) diz que esses conselhos eram utilizados como forma de cooptação das lideranças e manipulação das demandas populares. (GONH, 2003, p. 73)

Após a reabertura democrática aconteceram diversas mobilizações e ações para a instalação de conselhos no país, com caráter mais democrático e com maior atividade. Com a Constituição de 1988, o formato de conselho ganha novas possibilidades pois "redefine a posição e função dos conselhos a partir de uma nova arquitetura jurídica-política que lhes conferia maior legitimidade, força e permanência”(TABAGIBA, 2010, p. 30) Em 2001, mais de $90 \%$ dos municípios brasileiros já registravam a presença de conselhos nas mais diversas áreas. Em 2007, já contávamos com mais de 40 conselhos instituídos em âmbito federal, sendo que onze deles foram criados a partir de ações do governo Lula. (TABAGIBA, 2010, p. 31) Para Tabagiba, o que pode tornar esses novos conselhos mais participativos e "potencialmente democratizantes" se comparados aos anteriores a 1988 são os princípios aos quais se assentam. Ela enumera esses princípios (idem, pp. 32 - 33):

a) Composição Plural e paritária: Com pluralidade e relativa quantidade de membros, distribuídos entre membros dos governos e sociedade civil, bem como maneiras mais democráticas para a escolha dos mesmos.

b) A natureza pública dos acordos: "Os conselhos deveriam ter no processo dialógico

\footnotetext{
${ }^{154}$ As primeiras experiências de orçamento participativo em gestões municipais petistas ocorreram no final dos anos 1980 nas cidades de Vila Velha (ES), Fortaleza (CE) e Diadema (SP). Em 1991 criaram o Fórum Nacional de Participação Popular. (PONTUAL; ALMEIDA SILVA, 2002. pp. 62 - 63)
} 
resolução dos conflitos inerentes à diversidade dos interesses em jogo”. (idem, p. 33)

c) A competência deliberativa: Devem "funcionar como instâncias deliberativas com competência legal para formular políticas e fiscalizar sua implementação, apontando no sentido da democratização da gestão" (ibidem, p. 33)

Os conselhos podem ser considerados também como

(...) espaços de disputas pelo poder que, por sua vez, estão inseridos em redes de produção das políticas públicas nas quais recursos simbólicos e materiais são disputados por atores mais diversos. (...) Os conselhos fazem parte dessas redes e, como tal, são profundamente afetados pelas dinâmicas políticas que nela se gestam. Os conselhos não só impactam o processo de produção das políticas em suas áreas específicas, mas tem perfil e dinâmicas afetados pelas características gerais que conformam a comunidade de política na qual estão inseridos. Além disso, é preciso considerar que os conselhos têm um papel a desempenhar na democratização da gestão pública, eles possuem também limites que lhes são inerentes, como, por exemplo, a sua natureza setorial e fragmentada, sua forte dependência dos governos e uma tendência à burocratização dos processos participativos pela própria natureza de suas funções. (TABAGIBA, 2010, p. 34)

Como vimos no capítulo histórico, data de 1938 o primeiro modelo do Conselho de Cultura em nível federal. O segundo modelo surgiu em 1968 a partir de interesses dos militares que criaram o Conselho Federal de Cultura que respondia diretamente ao presidente militar. O decreto 5520/2005 que reformula o conselho federal, o nomeando CNPC, foi o modelo encontrado para a nova proposta de política cultural do SNC.

A participação social já estava presente no processo de construção dessa nova política desde os debates na Câmara Federal sobre a PEC do PNC no ano 2000, ou até antes disso, nas reuniões de 1999. Foi a partir de discussões de agentes culturais que os processos ganharam força para acontecer no Congresso.

Todavia, a primeira grande ação de participação social em torno do período que nos interessa nas políticas culturais não se articulou em torno da construção de um conselho ou da legislação. Em 2003, aconteceu o Seminário Cultura para Todos que possibilitou a realização de vinte encontros em diversas regiões do país ${ }^{155}$ reunindo mais de 30 mil pessoas. Este pode ser tomado como o início das discussões em massa sobre as novas políticas que estavam sendo propostas em nível nacional.

Estes processos tiveram início já no primeiro ano de gestão, com a realização de 20 encontros do Seminário Cultura para Todos reunindo cerca de $30 \mathrm{mil}$ pessoas. A partir de 2004, foram instaladas as câmaras setoriais como instâncias de diálogo entre entidades governamentais e representantes dos

\footnotetext{
${ }^{155}$ Os seminários aconteceram nos estados do Rio de janeiro, São Paulo, Minas Gerais, Rio Grande do Sul, Pará e Pernambuco.
} 
segmentos artísticos para a elaboração de políticas setoriais e transversais, divididas pelos segmentos de música, dança, teatro, livro e leitura. (CANEDO, 2011, p. 177)

Um dos objetivos iniciais do Seminário Cultura para Todos era a discussão dos dois principais mecanismos de financiamento à cultura na época, a Lei Rouanet e a Lei do Audiovisual. Os quatro eixos gerais abordados no Seminário foram: 1. Os objetivos da legislação; 2. Os mecanismos da legislação; 3. A regulamentação das leis; 4. A operacionalização da legislação. ${ }^{156}$

Dentre os tópicos abordados no eixo "Operacionalização da legislação" aparece a pergunta: "Como integrar um sistema de articulação Federal/Estadual/Municipal em um processo de financiamento proporcional da cultura por estas três instâncias?" A questão demonstra que, apesar da temática do seminário girar em torno do financiamento à cultura por meio de leis já existentes, o MinC começava a inserir na discussão pública as reflexões pautadas na nova Política Nacional de Cultura e possibilidades de gerir a esfera a partir de um olhar federalista e sistemático.

Em outubro de 2004, o MinC lança as Câmaras Setoriais como fóruns permanentes de caráter consultivo vinculadas inicialmente ao MinC e posteriormente como parte do CNPC, a fim de dividir por setoriais as discussões do Conselho.

A partir do decreto 5.520 de 2005 que institui o Sistema Federal de Cultura e dispõe sobre o funcionamento e a composição do Conselho Nacional de Políticas Culturais, os conselhos de cultura começam a entrar na pauta e a compor uma rede de articuladores da sociedade civil. O primeiro processo de escolha dos membros dos colegiados do CNPC foi feito de modo que "o público alvo das ações governamentais é deslocado do artista para a população em geral" (CANEDO, 2011, p. 176) O decreto também possibilitou a realização da $1^{a}$ Conferência Nacional de Cultura que agora poderia contar com este instrumento normativo para pensar a implantação do SNC e do PNC.

A $1^{\text {a }} \mathrm{CNC}$ aconteceu no ano de 2005 e reuniu em torno de 55 mil pessoas ao todo, incluindo as etapas estaduais e municipais. Foram realizadas, além da plenária nacional em Brasília, também 19 conferências estaduais e 438 municipais e intermunicipais com mais de 1200 municípios envolvidos.

A plenária nacional realizada em Brasília contou com cerca de 1300 participantes e aprovou um grupo de propostas de diretrizes de políticas,

\footnotetext{
${ }^{156}$ Informações disponíveis em: < http://www.seminarioculturaparatodos.ufba.br/ > acesso em 01 de outubro de 2016.
} 
encaminhadas a instâncias colegiadas e administrativas do Governo Federal e ao Congresso Nacional. Em 2006, o Ministério da Cultura deu início ao processo de elaboração das Diretrizes Gerais do PNC, agregando os subsídios provindos dos encontros realizados desde 2003, com estudos produzidos por intelectuais, sugestões de gestores públicos e privados e pesquisas estatísticas. As 63 diretrizes foram publicadas no final de 2007. No segundo semestre de 2008, o MinC realizou 27 seminários estaduais e um fórum virtual para o aprimoramento das diretrizes do PNC, que também foram discutidas pelo Conselho Nacional de Políticas Cultural, visando o lançamento do segundo caderno de diretrizes do PNC. (CANEDO, 2011, p. 178)

Para a realização da 1a CNC, o órgão gestor do processo, a SAI de Marcio Meira, publicou um documento intitulado $1^{a}$ Conferência Nacional de Cultura - Estado e sociedade construindo políticas públicas de cultura. $\mathrm{O}$ documento trazia uma série de textos escritos pelos agentes que lideravam a SAI e o MinC e visava informar aos participantes da Conferência quais eram as premissas que deveriam ser discutidas.

O primeiro texto do caderno intitulado "Nossas bacias culturais", assinado pelo ministro Gilberto Gil, tratava de um breve histórico da cultura do país desde 1500 e apresentava qual era sua visão sobre o conceito de cultura e a importância do SNC nesse processo como "grande teia que vai unir" as regiões do país. Aqui Gil apresenta sua avaliação social sobre a proposta e o signo ideológico do sistema enquanto "teia que vai unir" o país.

Por intermédio do Sistema Nacional de Cultura iremos associar iniciativas de vários estados, de vários municípios, fazendo relações dos fenômenos culturais comuns às comunidades, às regiões. (...) O Sistema Nacional de Cultura é a grande teia que vai unir as Bacias Culturais do Norte, do CentroOeste, do Nordeste, Sudeste e Sul, dando-lhe personalidade e capilaridade neste país continental. (GIL, 2005b, p. 4)

Desde o título do texto, Gil marca seu lado poético mas também sua visão de cultura. As "bacias culturais" assim como a "grade teia que vai unir" não são apenas meras analogias. Devem ser pensadas como fortes signos ideológicos de sua visão de cultura permeada pelas idéias de diversidade, territorialidade e identidade. Além da reflexão de Gil, outros textos permeiam o enunciado com fins de informar antecipadamente o leitor que participaria da $1^{\mathrm{a}}$ Conferência Nacional. Textos de Marcio Meira, de deputados, textos sobre a Unesco, entre outros, buscam introduzir os agentes da esfera nesse novo processo que estava começando a ser desenvolvido. O texto de Marcio Meira buscou explicar detalhadamente qual era a intenção e a trajetória dos processos em diálogo e onde a conferência se encaixava. Ele destaca a importância da transversalidade, da participação social e da construção interativa e 
dialógica do sistema quando fala de "dar voz às entidades e movimentos que vêm se mobilizando pelo direito ao fazer cultural".

A Conferência é também um caminho aberto para destacar a transversalidade das políticas culturais, ao dar voz às entidades e movimentos que vêm se mobilizando pelo direito ao fazer cultural, à fruição e à afirmação identitária no campo da cultura e de outras políticas públicas, com ênfase no vínculo com a educação e a comunicação, em todas as regiões do país. (MEIRA, 2005, p. 11)

O documento informa como deveria funcionar a participação nas Conferências e as regras para a composição do CNPC. Descrevem que o CNPC deveria ser articulado por meio de quatro grupos principais: das artes, do patrimônio, das etnias formadoras e segmentos das culturas populares. Aqui é possível perceber que até aquele momento a visão da diversidade cultural estava começando a ser desenvolvida, ainda que dentro desta visão já estivesse elencada uma nova divisão que abordava as etnias e culturas populares. Ao colocar lado a lado as artes e a cultura popular e os povos originários, já demonstrava que era possível pensar a cultura não apenas pelas artes como faziam na gestão FHC.

$\mathrm{O}$ regulamento da $1^{\mathrm{a}} \mathrm{CNC}$ e a metodologia proposta para o desenvolvimento da Conferência foram implementados pelo MinC a partir da portaria de 31 de agosto de 2005, publicada no DOU, e destaca, entre outros pontos, que na conferência seriam abertos grupos com eixos temáticos de discussão: 1. Gestão pública da cultura; 2. Economia da cultura; 3. Patrimônio Cultural; 4. Cultura é cidadania e democracia (Cultura é direito e cidadania); 5. Comunicação é cultura.

Chama atenção que, nos eixos propostos, já conseguiam apresentar uma divisão inovadora de pensar as políticas culturais ao levar em conta: a gestão, a economia da cultura, a transversalidade, o diálogo entre cultura e comunicação e principalmente a cultura como direito, cidadania e democracia. Neste item quatro trazem como cerne a participação social prevista no sistema e como essa se daria. A construção dialógica do sistema deveria convergir para algo democrático e até certo ponto consensual. A democracia permite que vozes dissonantes dialoguem e tenham espaço na esfera, ainda que com disputa dialética e ideológica. Entretanto, a proposta salienta a cultura como democrática, isto é, todos teriam seu espaço, mas o sistema tinha uma proposta ideológica clara. Assim, ideias que fossem opostas aos centros de valores desta arquitetônica (diversidade, descentralização e ampliação de acesso) não entrariam nos enunciados como veremos a seguir.

Os artigos 16, 17 e 18 da portaria regulavam como deveria ser composta a organização dos delegados regionais representantes da sociedade civil. Dentre as recomendações da 
portaria, boa parte delas visam criar uma uniformidade de normas para orientar as conferências entre os entes federados, principalmente para a orientação aos delegados enviados pelos estados para compor a conferência em nível nacional.

Art. 16 - Serão delegados à $1^{\text {a }}$ Conferência Nacional de Cultura: I. O Plenário e os Colegiados Setoriais do Conselho Nacional de Política Cultural; II. Os eleitos nas Conferências Estaduais, conforme art. 18 deste regulamento; III. Os eleitos nos Seminários Setoriais de Cultura, conforme art. 19 deste regulamento. IV. Os eleitos nas Conferências Municipais e Intermunicipais, nos locais onde não forem realizadas as Conferências Estaduais de Cultura, conforme art. 20 deste regulamento; Parágrafo único Para cada delegado titular eleito haverá um suplente correspondente, que será credenciado na ausência do titular.

Art. 17 - A representação dos diversos segmentos na $1^{\text {a }}$ Conferência Nacional de Cultura, em todas as suas etapas, deverá possuir a seguinte composição: I. Poder público; II. Sociedade civil e movimentos artísticos.

Art. 18. As Conferências Estaduais elegerão delegados representantes da Sociedade Civil para a Plenária da $1^{\text {a }}$ Conferência Nacional de Cultura, conforme estabelece o anexo II, com o máximo de 30 (trinta) delegados, por conferência. $\S 1^{\circ}$. As Conferências Estaduais elegerão representantes dos entes governamentais, conforme estabelece o anexo II, com o máximo de 6 (seis) delegados. $\$ 2^{\circ}$. Para promover o equilíbrio entre os entes, é recomendável que seja eleito pelo menos um delegado por mesorregião em conformidade à classificação utilizada pelo IBGE. ${ }^{157}$

Dentre as prioridades apresentadas pelo MinC no eixo "Gestão Pública da Cultura" foi sugerido que o grupo de trabalho responsável considerasse as seguintes reflexões durante os processos interativos:

a) Implantar o SNC nas três esferas de governo com conselhos deliberativos, fóruns e conferências, garantindo: fundos de cultura, orçamento participativo, planos de cultura, censo de cultura e relatórios de gestão;

b) Implantação do Sistema Nacional de Cultura e do Plano Nacional de Cultura com participação deliberativa do Conselho Nacional de Política Cultural.

Ambas denotam a prioridade do SNC para o MinC naquele momento. A implantação tanto em territórios como do próprio sistema em termos federais, deveria ser incentivada já naquela primeira conferência, pois era um dos primeiros momentos em que todas as atenções poderiam estar voltadas a ele.

Aragão (2013) chama a atenção para a não obrigatoriedade da realização prévia de Conferências nos entes federados, condicionando à participação nesta primeira CNC. Deste

\footnotetext{
${ }^{157}$ Documento disponível em: < www.ipea.gov.br/.../pdfs/conferencias/Cultura/regimento_1_conferencia_cultura.doc $>$ acesso em 01 de outubro de 2016.
} 
modo, mesmo os territórios que não tiveram incentivo de órgãos regionais de cultura, puderam se organizar e mandar representantes.

Um detalhe importante na estrutura das conferências: a não realização de conferências estaduais (muitas não realizadas provavelmente por questões político-partidárias) não impedia os municípios (que realizaram conferência municipal ou participaram de intermunicipal) de participarem da plenária nacional. Isso estava expresso no seu regulamento e a sua importância se deve ao fato de garantir a participação do maior número de municípios no processo. O campo ainda estava desarticulado e não se deveria impor restrições à participação, essa é a leitura que pode ser feita. $O$ fato é que estados como São Paulo, por exemplo, não realizou conferência estadual, apesar de diversas conferências municipais e intermunicipais terem acontecido. (ARAGÃO, 2013, p. 90)

Dos resultados das sugestões e debates resultantes da $1^{\mathrm{a}} \mathrm{CNC}$ nenhum dos itens foi descartado, e isso favoreceu os processos de participação social. Todos foram levados para a análise e consideração para a criação das diretrizes do PNC e para o início da composição do SNC. Destacamos os itens 5, 6 e 13 evidenciados como prioritários no relatório resultante da $1^{\mathrm{a}} \mathrm{CNC}$ e que estão relacionadas com as sugestões elencadas pelo MinC para a discussão na Conferência.

5) Implantar o Sistema Nacional de Cultura como instrumento de articulação, gestão, informação, formação e promoção de políticas públicas de cultura com participação e controle pela sociedade, com distribuição de recursos nos moldes do PEC 150, envolvendo as três esferas do governo (federal, estadual e municipal), com conselhos de políticas culturais (compostos com, no mínimo, 50\%, pela sociedade civil), fundos de cultura, relatórios de gestão, conferências de cultura, planos de cultura e orçamento participativo da cultura. (...) 6) Implantar o SNC nas três esferas de governo com conselhos deliberativos, fóruns e conferências, garantindo: fundos de cultura, orçamento participativo, planos de cultura, censo de cultura e relatórios de gestão. (...) 13) Implantação do Sistema Nacional de Cultura e do Plano Nacional de Cultura com participação deliberativa do Conselho Nacional de Política Cultural, com investimentos nos moldes da PEC 150/2003; sendo que a definição das políticas, programas e prioridades, nos três níveis de governo, se darão através das conferências e conselhos de cultura com caráter deliberativo, normativo e fiscalizador, de composição, no mínimo, paritária da sociedade civil. (MINISTÉRIO DA CULTURA, 2005)

Nas oficinas do Sistema Nacional de Cultura realizadas a partir de 2006, o MinC buscou aprimorar os conteúdos que poderiam ser distribuídos para os mais diversos estados e principalmente municípios interessados em aderir ao SNC. Na publicação para as oficinas organizada pela pesquisadora carioca Lia Calabre, ela apresenta os objetivos desse processo:

As oficinas têm uma primeira parte dedicada à apresentação das ações e dos programas do MinC como um todo - secretarias e vinculadas. Em geral, 
quanto mais nos afastamos dos principais centros urbanos, menor é o grau de informação encontrado, esse é um dos grandes obstáculos que o MinC tem que ultrapassar. Um dos objetivos do projeto Oficinas é o de municiar os participantes com ferramentas que os permitam, sozinhos, localizar as informações que lhes sejam necessárias. Em termos práticos, isso significa que os participantes serão apresentados ao Sistema MinC através de seus principais projetos e programas acompanhados de instruções de como manter esse conhecimento sempre atualizado. (CALABRE, 2006, p. 42)

Destaque para o trecho que diz "Em geral, quanto mais nos afastamos dos principais centros urbanos, menor é o grau de informação encontrado, esse é um dos grandes obstáculos que o MinC tem que ultrapassar “ que evidencia nossa hipótese sobre uma maior dificuldade da implantação do sistema nos municípios menores e mais distantes dos grandes centros.

No início de 2009 com a publicação do caderno: Porque aprovar o Plano Nacional de Cultura, podemos perceber a maior participação dos agentes estaduais a partir dos 27 seminários realizados em 2008. O caderno traz 27 páginas sobre a participação de cada um dos 26 estados e Distrito Federal detalhando quais foram as sugestões de cada um deles para a revisão das diretrizes do PNC e para a discussão na plenária nacional que aconteceria na $2^{\text {a }} \mathrm{CNC}$ em 2010. Em cada uma das páginas, observamos quais são as prioridades e demandas de cada estado e como cada um deles se envolveu nos processos dos seminários, a quantidade de delegados enviados e qual o olhar em relação ao sistema. Na publicação, trazem o seguinte quadro informando números que tratam dos resultados da etapa de seminários.

Figura 12: Números sobre os seminários estaduais em 2008

\begin{tabular}{|l|}
\hline As etapas de $\mathbf{2 0 0 8}$ em números \\
• 80 alterações no texto do caderno de diretrizes, inseridas na revisão do CNPC \\
- Presença de cerca de 5 mil pessoas nos seminários estaduais \\
- Participação de 4,2 mil pessoas nos grupos de trabalho \\
- 5 relatórios de contribuiccões produzidos nos encontros de cada uma das \\
27 unidades da Federação - total de 135 relatórios \\
- 2750 participantes nas oficinas sobre 14 políticas do Sistema MinC \\
- Mais de 100 sugestões e comentários postados pela internet
\end{tabular}

Fonte: Publicação Porque aprovar o Plano Nacional de Cultura

A publicação informa que por conta das discussões nos seminários nos estados foram relizadas oitenta alterações no texto do caderno das diretrizes entre sua primeira e segunda edição e que estas foram inseridas na revisão feita pelos membros do CNPC. Também é 
importante percebermos o quarto item que trata dos 135 relatórios produzidos nos encontros estaduais. Em ambos os casos, há uma produção de reflexões dos agentes que deverá ser considerada. Assim, a participação social no sistema começa a fomentar a reflexão que vai além de meros debates em conferências. Com a interferência na publicação das diretrizes e a produção de relatórios locais, os agentes culturais e conselheiros de cultura tornam-se produtores dos conteúdos do sistema junto ao poder público.

No caderno, detalham as informações sobre como foi realizada essa revisão textual e como tomaram algumas decisões relativas ao enunciado das diretrizes do PNC:

O Conselho Nacional de Política Cultural aprovou em 26 de junho uma série de sugestões de aperfeiçoamento do texto da primeira edição do caderno de diretrizes gerais do PNC. O colegiado tomou sua decisão durante reunião extraordinária, promovida em Belo Horizonte, para análise do relatório técnico que continha os resultados do trabalho de revisão desenvolvido por uma comissão temática entre março e junho. Integram o CNPC representantes do poder público, da sociedade civil, das áreas artístico culturais e de empresas, fundações e institutos, além de personalidades convidadas. Entre os cerca de 80 pontos aprovados, os conselheiros modificaram, na seção de diagnósticos e desafios do caderno, o item que trata do reconhecimento e do apoio às expressões e ao patrimônio cultural afrobrasileiros. Foi reforçado o registro da presença transversal das contribuições dessa matriz em todas as áreas da cultura nacional. O CNPC também redimensionou a diretriz que trata da implantação do Sistema Nacional de Cultura, a partir da deliberação sobre o tema estabelecida na Conferência Nacional de Cultura, de 2005. Foram detalhadas, ainda, as menções à arte digital, ao turismo e ao impacto sociocultural das grandes obras de engenharia. As mudanças foram apresentadas junto com a primeira edição do caderno de diretrizes já no primeiro seminário estadual do plano, organizado na capital mineira, no final de junho. A partir do seminário do Mato Grosso do Sul (24 e 25 de setembro), passou-se a utilizar a segunda edição do caderno, com as informações atualizadas a partir da revisão do CNPC, correções de texto, atualização de dados estatísticos e nova programação visual. (MINISTÉRIO DA CULTURA, 2008b, p. 36)

Os seminários estaduais foram realizados entre os meses de junho e agosto de 2008, e lá foram produzidos 135 relatórios propondo alterações no texto das diretrizes do PNC.

Na publicação Porque aprovar o Plano Nacional de Cultura também são apresentadas detalhadamente quais foram as propostas sugeridas por participantes quando da realização dos Seminários Estaduais em 2008. Evidenciam quais foram os critérios utilizados para incorporar no texto das diretrizes as 80 sugestões enviadas a partir dos seminários:

a) Correspondência com os diagnósticos, valores e estratégias do caderno de diretrizes, considerando o acúmulo já existente de estudos e discussões para o delineamento das políticas de cultura; 
b) Abrangência temática, territorial e populacional: políticas de Estado pautadas pela amplitude e equilíbrio no atendimento às demandas dos setores culturais e grupos identitários, bem como na busca de diminuição das desigualdades socioeconômicas regionais;

c) Visão de longo prazo: orientação das diretrizes do Plano para a execução de políticas públicas ao longo de dez anos, compreendendo a realização de subprogramas de menor duração;

d) Perspectiva de integração de ações do Estado, iniciativa privada e sociedade civil: estímulo a dinâmicas colaborativas de implementação, tanto no que se refere aos diferentes poderes e esferas da administração pública, quanto no que diz respeito à relação entre Estado, iniciativa privada e sociedade civil.

Aqui é possível observar de modo mais transparente quais seriam os métodos usados pelo MinC para permitir que as vozes dos participantes da sociedade civil estivessem presentes nas diretrizes e nas metas do PNC. No primeiro item, percebemos que os diagnósticos, valores e estratégias do que já estava sendo proposto seriam levados em conta. A ideia de ampliação de abrangência e acesso, de pensar o Plano a longo prazo e de integração de ações de modo transversal, também apareciam como condicionantes.

Fica claro que os critérios informados no documento pré-determinavam propostas e evitariam outras completamente dissonantes, tanto em termos de conteúdo quando de estrutura. No caso da sugestão de conteúdos que trouxessem avaliações sociais muito diferentes sobre a maneira de gestar a cultura talvez não fossem aceitos. Ainda que alguns grupos ou mesmo sujeitos trouxessem diferentes pontos de vista, não seriam aceitas sugestões que alterassem o conteúdo da proposta e nem os centros de valor do SNC. Entretanto, é preciso observar que, cada um dos enunciados criados por meio das discussões abertas à sociedade civil passaram por processos que denotam tensões e disputas políticas entre determinados grupos dentro da esfera. A disputa política também acontecia entre os diferentes grupos da esfera artística-cultural. Estas disputas, ainda que não apareçam nos enunciados, estão presentes nas entrelinhas dos mesmos, pois foram construídos a partir de propostas anteriores e reescritos após sugestões oriundas de processos com ampla participação social, com grupos de procedências e interesses diferentes em interação. Bakhtin (2015) evidencia que:

(...) todo discurso concreto (enunciado) encontra o objeto para o qual se volta sempre, por assim dizer, já difamado, contestado, avaliado, envolvido ou por uma fumaça que o obscurece ou, ao contrário, pela luz de discursos 
alheios já externados a seu respeito. Ele está envolvido e penetrado por opiniões comuns, pontos de vista, avaliações alheias, acentos. O discurso voltado para seu objeto entra nesse meio dialogicamente agitado e tenso de discursos, avaliações e acentos alheios, entrelaça-se em suas complexas relações mútuas, funde-se com uns, afasta-se de outros, cruza-se com terceiros; e tudo isso pode formar com fundamento o discurso, ajustar-se em todas as suas camadas semânticas, tornar complexa sua expressão, influenciar toda sua feição estilística. (BAKHTIN, 2015, p. 48)

Ao analisar os momentos de participação social na esfera político-cultural, deve-se observar que existem dois grandes grupos de origens bem diferentes: a sociedade civil e o Estado. Ambos, ainda que tenham um objetivo em comum, a construção de um Plano de cultura, têm interesses diversos que estão em consonância com os interesses de cada esfera (esfera estatal e esfera artístico-cultural) e também com seu excedente de visão, visto de seu local de fala. É essencial aos dois grupos que compreendam empaticamente os interesses e os excedentes de visão de cada um dos grupos neste processo. Para isso, e para que possam chegar a um bom resultado final, ambos deveriam buscar conhecer melhor os universos do outro, como funcionam seus processos, quais são as dificuldades, como são as relações dentro de cada comunidade semiótica e seus modos de produção internos. Porém isso raramente acontece e evidencia a importância de gestores públicos que já foram trabalhadores da esfera cultural e agentes culturais que conheçam bem os desafios e dificuldades do poder público.

Os processos de democracia participativa são arenas de disputas ideológicas e de recursos, em que cada grupo busca garantir seus interesses culturais e materiais. A compreensão de que todos estão "no mesmo barco" buscando melhorias no setor não é consensual e dificulta a obtenção de resultados positivos.

Esta percepção do que é essencial para a boa realização do que se está buscando, no caso a construção de um sistema de cultura, pode ser considerada um ato não apenas empático das partes envolvidas, mas principalmente um ato ético. "A empatia e a co-avaliação simpática ainda não tem por si só um caráter estético. O conteúdo do ato de empatia é ético; é uma diretriz axiológica, pragmática ou moral (emocional e volitiva) de uma outra consciência.” (BAKHTIN, 2010, p. 39) Para que esse tipo de política tenha de fato bons resultados futuramente, um dos aprendizados a ser conquistado tanto pelo Estado quanto por membros da sociedade civil e os produtores de cultura é compreender que essa disputa de interesses de grupos nunca deve suplantar o interesse geral e o bem comum da cultura. Essa é a base da ética.

Em cada um dos 27 seminários estaduais, os participantes foram divididos em Grupos 
de Trabalho (GT) para discutir as diretrizes e as propostas que enviariam ao MinC. Os cinco GTs desenvolvidos em consonância com as diretrizes foram:

a) Fortalecer a ação do Estado no planejamento e na execução das políticas públicas culturais (Com 840 participantes);

b) Incentivar, proteger e valorizar a diversidade artística e cultural brasileira (com 1065 participantes);

c) Universalizar o acesso à fruição e à produção cultural (com 740 participantes);

d) Ampliar a inserção da cultura no desenvolvimento socioeconômico sustentável (com 900 participantes);

e) Consolidar os sistemas de participação social na gestão das políticas culturais (com 695 participantes).

A temática dos grupos foi sugerida pelo MinC por meio dos pressupostos já previstos nos conteúdos. É curioso perceber que o GT com menor número de participantes foi o de sistemas de participação social. Naquele momento ainda era desconhecido à maioria o que de fato representava isso e seus benefícios. Por outro lado, os GTs com maior número de pessoas tratavam de dois temas que naquele momento estavam gerando muito interesse no setor, provavelmente por conta do crescimento do Programa Cultura Viva que estava a pleno vapor: a diversidade cultural e a economia sustentável da cultura.

Na publicação também estão elencadas quais foram as sugestões que apareceram com maior frequência nos documentos produzidos pelos estados e refletiam a vontade de mais de um território (MINISTÉRIO DA CULTURA, 2008b, p.40). Aqui encontramos as respostas da sociedade civil às propostas temáticas dos encontros. Essa responsividade está prevista na interação e é um dos princípios da participação social. Os itens propostos foram:

Aprovação da estrutura geral e da maioria das diretrizes do caderno do Plano; Propostas de aprimoramento e de inclusão de itens, e algumas de exclusão; Demanda por capacitação de gestores e trabalhadores em geral; Diversidade regional expressa nos relatórios dos GTs: questão das fronteiras no Acre, no Mato Grosso do Sul e no Rio Grande do Sul, manifestações religiosas, relação com a floresta nos estados amazônicos; Necessidade de equilibrar o atendimento universal dos segmentos culturais com algumas especificidades de setores mencionadas no caderno; Debate em torno de conceitos, como "marginalizados" e "pessoas com deficiência"; Periodicidade das conferências municipais, estaduais e nacional - vários grupos de trabalho propuseram encontros nacionais a cada dois anos; Defesa de ampliação do orçamento, conforme percentuais da PEC 150; (MINISTÉRIO DA CULTURA, 2008b, p. 41)

Ao listar no enunciado quais foram as sugestões mais frequentes, o MinC permite 
escutarmos as vozes da sociedade civil, ainda que com um filtro discursivo, já que estas foram resumidas e sistematizadas. Entretanto, ao apresentar as respostas, sinaliza um caráter ético ao permitir que essas vozes participem de um documento oficial do Ministério criado para a leitura e aprovação da lei do PNC pelos parlamentares.

Os elementos provenientes da troca entre os interlocutores participantes desses processos de participação social poderão auxiliar no desenvolvimento de novas questões ainda não percebidas pelos gestores do MinC ou mesmo pelos parlamentares. Se o sistema busca de fato a descentralização e a democratização do acesso à cultura, deve ser dos fazedores de cultura boa parte do conteúdo inserido nos documentos que constroem essa nova arquitetônica. Todavia, para que isso aconteça, é necessário que todos os participantes conheçam antecipadamente os elementos iniciais sobre os conteúdos que estão sendo debatidos. Ao proporcionar que as vozes dos participantes dos processos interativos estejam presentes nos enunciados e nos conteúdos das ações do Ministério para essa nova política, os agentes do MinC tornam estes conteúdos ainda mais éticos.

Se o ato ético traz os valores axiológicos dos envolvidos nas interrelações da esfera buscando um bem comum, será por meio da presença destes valores que os conteúdos mostrarão a luz do valor ético.

(...) o elemento ético-cognitivo na realidade é o conteúdo (...) o conteúdo não pode ser puramente cognitivo, completamente privado do elemento ético; ademais, pode-se dizer que é ao campo ético que pertence a primazia essencial do conteúdo. (...) Tudo o que é conhecido deve ser posto em correlação com o mundo onde se realiza a ação humana, deve estar intimamente ligado à consciência do agente. (...) Só é diretamente ético o próprio acontecimento do ato (ato-pensamento, ato-ação, ato-sentimento, ato-desejo, etc) na sua realização viva vinda de dentro do próprio conhecimento do agente. (BAKHTIN, 2010, p. 39)

Durante os seminários estaduais, o MinC ofereceu aos participantes a possibilidade de participar de oficinas gratuitas complementares e que também deveriam auxiliar no desenvolvimento dos debates sobre o PNC. As oficinas desenvolvidas foram: Sistema Nacional de Cultura, Programa Cultura Viva, Programa Mais Cultura, Diversidade, Mário de Andrade, Patrimônio Imaterial, Observatório dos Editais, Programadora Brasil, Plano Nacional de Cultura, Financiamento, Indicadores Culturais, ProExt Cultura, Plano Nacional do Livro e Leitura, Circuito Brasil.

As oficinas visavam fornecer informação aos fazedores de cultura e à sociedade civil para que pudessem conhecer melhor as políticas culturais já existentes e as que estavam sendo 
propostas, para assim interagirem nos processos com maior propriedade acerca dos temas. Estas também proporcionaram um momento maior para o aprofundamento nos conteúdos mais complexos e assim desenvolver reflexões que possibilitariam o avanço das discussões. A realização das oficinas foi essencial para que os cinco mil participantes pudessem se preparar melhor para os debates sobre o PNC e estivessem empoderados do processo mesmo antes de discuti-lo. Ao conhecer melhor um tema, um indivíduo sente-se mais à vontade para dar sua opinião sobre e os processos tornam-se mais plurais.

A participação social realmente democrática demanda que os agentes tenham informação suficiente e equiparada, para tornar o debate mais igualitário. Munidos de informação, todos os participantes dos estados poderiam dialogar e debater os temas com mais igualdade e propriedade, contribuindo para o bem público. Dotar de informação visa empoderar os mais diversos grupos das mesmas ferramentas para o debate e disputas políticas. Contudo, o capital simbólico dos participantes dos processos interativos nem sempre é igual. Quanto maior conhecimento anterior, maior o capital simbólico do indivíduo e maior a facilidade para absorver novas informações, interagir e defender as propostas interessantes a cada território.

O capital simbólico é uma propriedade qualquer (de qualquer tipo de capital, físico, econômica, cultural, social), percebida pelos agentes sociais cujas categorias de percepção são tais que eles podem entendê-las (percebê-las) e reconhecê-las, atribuindo-lhes valor. (...) Mais precisamente é a forma que todo tipo de capital assume quando é percebido através de categorias de percepção. (BOURDIEU, 2011, p.107)

As teorias do sociólogo francês Pierre Bourdieu mostram uma relação com as teorias do Círculo de Bakhtin, principalmente Volóchinov, em um aspecto relevante à nossa tese. Ambos entendem a importância histórica dos fatos, com o ser inserido na história e no campo social de atuação. De acordo com Grillo (2012)

Semelhante à obra do Círculo, Bourdieu concebe que o sentido da constituição dos sujeitos caminha do social para o individual. Os sujeitos são formados pela incorporação de disposições produzidas por regularidades objetivas, situadas dentro da lógica de um campo determinado (ciência, mídia, família, classe social, etc) mas que são redimensionadas em razão da trajetória individual e da posição ocupada pelo sujeito nesse campo. A relação entre as condições sociais nas quais se constitui um habitus e as condições sociais nas quais ele é operado produz o sentido prático o qual é engendrado sem a sua representação explícita pelos sujeitos, que são pegos na urgência de agir. (...) Tanto as práticas sociais em Bordieu quanto as avaliações subentendidas de Volóchinov são produzidas pelos sujeitos sociais sob condições sócio-históricas determinadas. Esses sujeitos atribuem um sentido evidente às práticas e ás avaliações, sendo que o seu 
questionamento é sinal de que elas estão em via de alteração. (GRILLO, 2012, pp. $139-141)$

Se assim como compreendem tanto Bourdieu quanto Volóchinov, a construção dos sujeitos começa pelo social, o capital simbólico que os participantes destas atividades apresentam são reflexos das condições sociais e históricas de cada um deles. Isso deve ser também observado e não descartado, pois são construções também culturais. Grupos como mestres quilombolas, por exemplo, talvez não tenham letramento em burocracias estatais demandadas pelo sistema, mas poderão contribuir muito com importantes ensinamentos sobre as tradições, a dimensão simbólica da cultura e a diversidade, questões étnico-raciais, ou mesmo sobre democracia cultural e acesso.

Num país cheio de desigualdades e diferenças como o Brasil, o capital simbólico de uma coletividade de pessoas de procedências diversas pode variar bastante. Seja por conta de fatores educacionais, sociais, econômicos, ou mesmo de efetiva participação na esfera. Os cursos oferecidos pelo MinC durante os processos interativos dos Estados e em outras ações de participação social permitiram que essas diferenças diminuíssem relativamente, inclusive por meio das trocas entre os mais variados grupos, possibilitando que conhecessem não apenas seus pontos de vista, mas também suas práticas culturais. Assim, podem enriquecer os conteúdos e tornar ainda mais democráticos os processos como um todo.

A interação entre os participantes pressupõe que nem sempre os interlocutores terão os mesmos valores e o mesmo conhecimento de mundo, porém a oportunidade de informação para todos possibilita melhorar o debate e democratizar ainda mais os mecanismos de participação social. Com a oportunidade de informação, o processo é facilitado. A formação dos agentes da sociedade civil nos processos de participação social é tão importante quanto a formação dos gestores do poder público. Ribeiro, Salm e Menegasso (2007) afirmam que:

(...) a coprodução do bem público envolve a participação ativa e direta do cidadão nos processos de elaboração, desenho, implementação e avaliação das políticas públicas voltadas ao interesse público e, em última instância, à construção do bem comum. (RIBEIRO; SALM; MENEGASSO, 2007, p.232)

A participação da sociedade civil como colaboradora em todas as etapas dos processos de implantação do SNC é essencial para a efetividade e aceleração dos processos, principalmente na fase de diagnósticos. Para isso, foram criadas ferramentas digitais de quantificação de indicadores culturais a fim de incentivar a sociedade civil a participar mais ativamente de diversas etapas do processo de forma colaborativa. 
As plataformas digitais colaborativas visam criar mais um canal de participação social interativo, em que é possível aos fazedores de cultura contribuir inserindo informações. Espaços de interação digital, como a SNIIC e os mapas culturais estaduais e municipais, podem permitir a aceleração dos processos se forem bem planejados e fáceis de usar. O uso sistemático das plataformas poderá contribuir mais a cada ano se for corretamente usada e alimentada pelos produtores de cultura. Num país de grandeza continental como o Brasil, saber quantos festivais de música, quantos grupos de teatro, quantos pontos de cultura em atuação, etc. não é uma tarefa simples. Inserir informações nessas plataformas é uma das mais importantes formas de participação social no sistema, pois pode refletir nos resultados das metas tanto regionais quanto do PNC. Entretanto, nem sempre todos tem amplo acesso à internet ou mesmo letramento digital suficiente para utilizar estas plataformas. Esse é outro desafio que precisa ser pensado com cuidado.

De acordo com Mattia e Turnes (2013), para a criação de um Plano de cultura é necessário que os gestores e os fazedores de cultura compreendam as fases inseridas neste processo e participem colaborativamente nas etapas, desde seu diagnóstico. Será por meio dos diagnósticos que as demandas de cada território poderão ser analisadas. Seus resultados orientarão cada ente federado na criação dos seus planos. Contudo, sem a ampla participação social, fornecendo dados para o diagnóstico e para os indicadores culturais, é provável que, no primeiro processo de implantação, não seja levado em conta quais são as reais carências de cada território.

A realização do diagnóstico é necessária, pois busca compreender qual a real situação da cultura no Estado. A metodologia propõe algumas etapas tais como: um inventário da área cultura; análise da gestão pública da cultura; listagem dos instrumentos legais; análise da situação. Após estes estudos, é possível construir os seguintes produtos que compõem o diagnóstico da cultura no estado: Diagnóstico do Desenvolvimento da Cultura; Desafios e Oportunidades; Diretrizes e Objetivos. (MATTIA; TURNES, 2013, p. 11)

Esse processo de inserção de informação, principalmente no que tange aos mapas culturais pode gerar outros processos de interação na esfera como, por exemplo, conhecer quem são os produtores de cultura do seu bairro ou região. Os mapas mostram com "pins" onde estão localizados aqueles agentes que já inseriram as informações sobre projetos, eventos e equipamentos de cultura.

Ao fazermos um recorte apenas sobre os agentes do bairro de Santa Cecília na cidade de São Paulo, disponível no mapa de cultura municipal, é possível encontrar seus vizinhos produtores de cultura e estabelecer um primeiro contato virtual com os mesmos. 
Cada um dos "pins" representa um agente cultural inscrito, tanto individual quanto coletivo. Cada um deles apresenta informações pessoais ou coletivas na plataforma. Os pins com mais de um integrante no mesmo endereço representam mais de um agente que divide o mesmo endereço.

Figura 13: Mapa SP Cultura

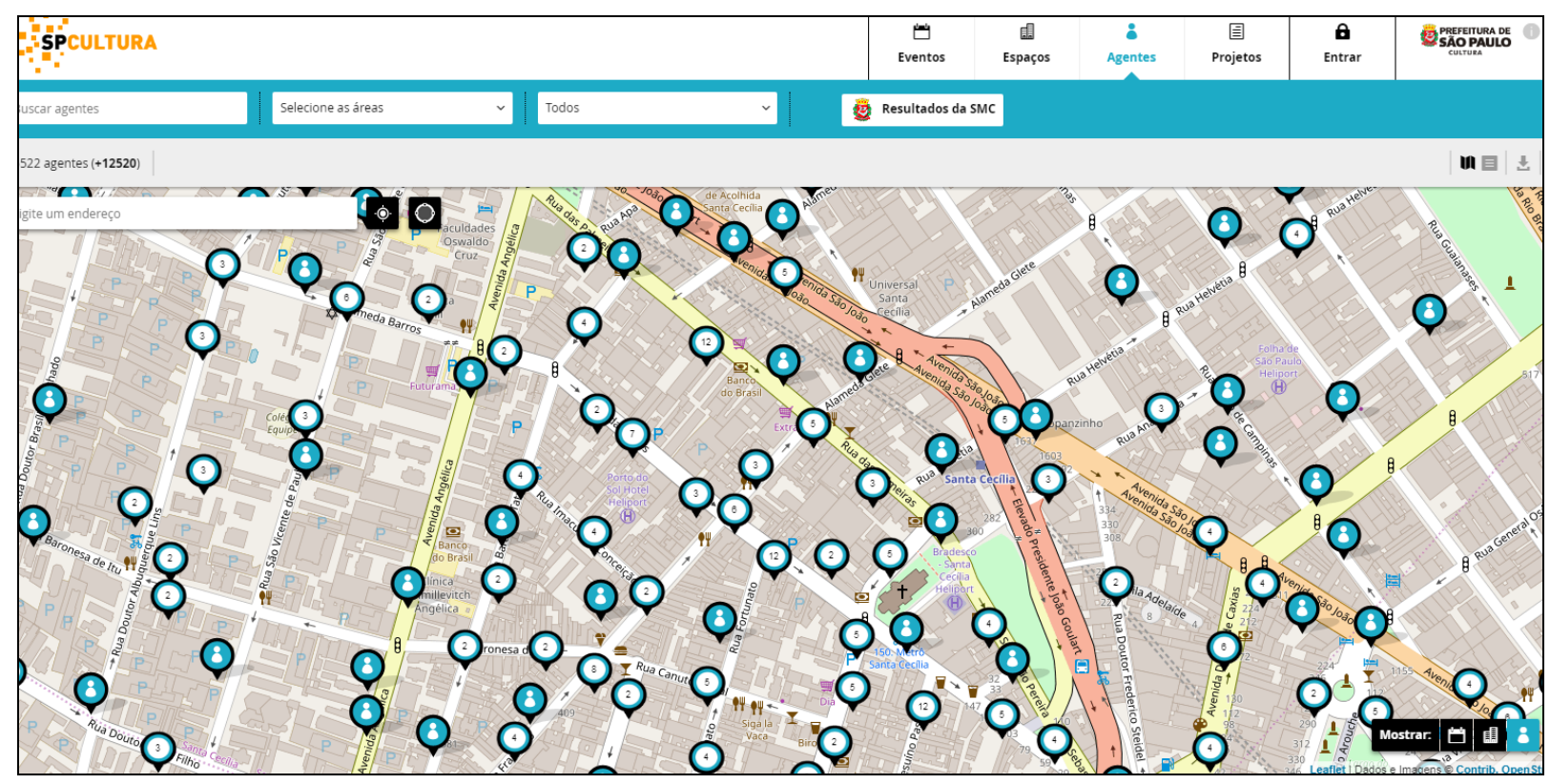

Agentes culturais do bairro de Santa Cecília em SP no Mapa da cidade: Fonte: Site SP Cultura. ${ }^{158}$.

O processo de inclusão de informação no Mapa de Cultura da cidade de SP, assim como ocorre nos de outras localidades, é feito de modo espontâneo e indica mais uma forma de participação social no sistema, já que essas informações podem ser utilizadas para mostrar: diagnósticos, demandas, potencialidades, a diversidade cultural de determinado território, recortes culturais etc.

No ano de 2010, foi realizada em Brasília a $2^{\text {a }}$ Conferência Nacional de Cultura, que contou com mais 220 mil participantes ${ }^{159}$ de todos os estados e com participantes de $57 \%$ municípios brasileiros. O contingente de pessoas e a representatividade de agentes do setor mais que triplicou se comparado à $1^{\text {a }}$ CNC realizada em 2005, que contou com aproximadamente 60 mil pessoas, de 1.190 cidades (20\%) e 17 estados. Todos os estados e 77\% dos municípios realizaram pré-conferências territoriais enviando delegados para participar da conferência federal.

\footnotetext{
${ }^{158}$ Disponível em: < http://spcultura.prefeitura.sp.gov.br > acesso em 12 de novembro de 2017.

${ }^{159}$ Este número leva em conta os participantes de todas as pré-conferências territoriais. O número de presentes na CNC em Brasília foi de aproximadamente duas mil pessoas.
} 
Esta segunda CNC foi marcada também pela maior qualificação dos presentes ali reunidos. A realização de pré-conferências territoriais possibilitou um melhor preparo dos participantes, que tiveram a oportunidade de conhecer os temas a serem tratados antecipadamente, por conta da melhor divulgação e organização do MinC e do CNPC na condução da CNC. Em boa parte dos casos, os representantes de estados e cidades chegaram à conferência com resoluções e reflexões consistentes sobre os eixos e temas a serem abordados já estabelecidos em seus âmbitos locais. A articulação da Rede Nacional dos Pontos de Cultura, ligada ao programa Cultura Viva, também possibilitou uma melhor organização das pautas e difusão das reflexões relevantes para a conferência. A presença maciça dos chamados "ponteiros ${ }^{160 "}$ ficou refletida nos resultados da CNC como poderemos ver na análise a seguir.

$\mathrm{O}$ texto base da $2^{\mathrm{a}} \mathrm{CNC}$ divulgado antecipadamente com o título "Cultura, Diversidade, Cidadania e Desenvolvimento" tinha a intenção de "ajudar a mobilização e dar subsídios aos debates que irão anteceder as Conferências". O Ministério da Cultura "divulgou o texto-base, segmentado em cinco tópicos abaixo indicados, que deverão ser lidos por todos

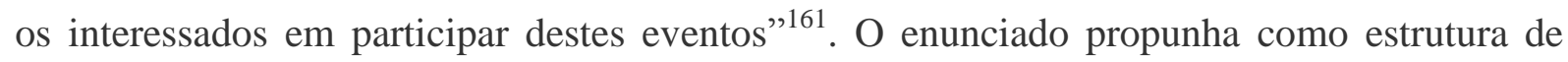
reflexão cinco eixos para discussão dos temas: Eixo I - Produção Simbólica e Diversidade Cultural; Eixo II - Cultura, Cidade e Cidadania; Eixo III - Cultura e Desenvolvimento Sustentável; Eixo IV - Cultura e Economia Criativa; Eixo V - Gestão e Institucionalidade da Cultura. Se comparado à $1^{\mathrm{a}} \mathrm{CNC}$, é possível dizer que a novidade dentre os eixos é o item I, que não constava na conferência anterior e que dá o tom para boa parte do documento base e também se reflete nos enunciados resultantes como veremos adiante. O texto-base em sua primeira página busca orientar a leitura e a compreensão dos objetivos do encontro e traz o seguinte enunciado:

Todo o poder emana do povo, que o exerce por meio de representantes eleitos ou diretamente, nos termos desta Constituição. Esse princípio, que está no parágrafo único do art. $1^{\circ}$ da Constituição da República Federativa do Brasil (CF/88), introduz no país o Estado Democrático de Direito, que combina procedimentos da democracia representativa (eleições) e da democracia participativa (direta). É com base nele que o Governo Federal, por intermédio do Ministério da Cultura (MinC), convoca a $2^{\text {a }}$ Conferência Nacional de Cultura, fórum participativo que reúne artistas, produtores, gestores, conselheiros, empresários, patrocinadores, pensadores e ativistas da cultura, e a sociedade civil em geral, com as seguintes atribuições: (i) discutir a cultura brasileira nos seus múltiplos aspectos, valorizando a diversidade das expressões e o pluralismo das opiniões; (ii) propor

\footnotetext{
${ }^{160}$ Os ponteiros são os fazedores de cultura pertencentes aos mais de cinco mil de Pontos de Cultura espalhados pelo Brasil.

${ }^{161}$ Fonte: Site do MinC. Disponível em: < cultura.gov.br > acesso 12 de março de 2017.
} 
estratégias para: fortalecer a cultura como centro dinâmico do desenvolvimento sustentável; universalizar o acesso dos brasileiros à produção e fruição da cultura; consolidar a participação e o controle social na gestão das políticas públicas de cultura; implantar e acompanhar os Sistemas Nacional, Estaduais e Municipais de Cultura e o Plano Nacional de Cultura; e (iii) avaliar os resultados obtidos a partir da $1^{\text {a }}$ Conferência Nacional de Cultura, realizada em 2005. A $2^{\text {a }}$ Conferência Nacional de Cultura, além da Plenária Nacional, terá as seguintes instâncias de discussão: (i) conferências municipais e intermunicipais; (ii) conferências estaduais e do distrito federal; (iii) pré-conferências setoriais; (iv) conferência virtual e (v) conferências livres. Além de deliberar, esses encontros visam estimular a criação e o fortalecimento de redes de agentes e instituições culturais do país, para dar prosseguimento, em caráter permanente, às discussões e articulações. (MINISTÉRIO DA CULTURA, 2005, p. 01)

Inicialmente devemos observar que, logo na primeira linha, fica evidenciado o princípio constitucional e democrático ressaltado por Marcio Meira como o tom da proposta da CNC em “Todo o poder emana do povo”. Esse princípio fala da democracia representativa, mas também da democracia participativa, e conceitua a $2^{\text {a }}$ Conferência Nacional de Cultura como um "fórum participativo que reúne artistas, produtores, gestores, conselheiros, empresários, patrocinadores, pensadores e ativistas da cultura, e a sociedade civil em geral". Aqui, o MinC reconhece a ampla gama de atuantes na esfera e de modo ético busca dar voz a todos.

O trecho também define que a conferência compreende como "instâncias de discussão" os seguintes modelos de interação: (i) conferências municipais e intermunicipais; (ii) conferências estaduais e do distrito federal; (iii) pré-conferências setoriais; (iv) conferência virtual e (v) conferências livres. Essas instâncias de discussão compõem a arquitetura do sistema e representam os espaços participativos e os momentos da arquitetônica. É nesses processos que acontecem as interações éticas e a possibilidade da troca entre sociedade civil e Estado para a construção do Sistema.

O texto coloca como norteadora a ideia de políticas culturais de abrangência e por meio disso institui a cultura em suas três dimensões: simbólica, cidadã e econômica. Estas três dimensões atuam como proposta chave para a construção dos conteúdos dessa arquitetônica ao lado dos centros arquitetônicos de diversidade e ampliação do acesso. O Eixo I "Produção simbólica e diversidade cultural" se apresenta como norteador em todo o tom do documento e traz como foco a "produção de arte e de bens simbólicos, promoção de diálogos interculturais, formação no campo da cultura e democratização da informação" (MINISTÉRIO DA CULTURA, 2005, p. 02). A compreensão da diversidade cultural em sintonia com a democratização da informação demonstra uma real preocupação naquele 
momento em que o SNC começava a se efetivar nos territórios. Isso pode ser evidenciado nos demais eixos do texto-base e no detalhamento de cada proposta de reflexão.

Podemos aferir por meio da comparação entre o texto-base da segunda CNC com o da conferência anterior três pontos relevantes:

a) Enquanto no enunciado da $1^{\text {a }} \mathrm{CNC}$ havia a predominância das vozes dos representantes do executivo e do legislativo na composição do documento, neste, há uma preocupação maior em informar as propostas de reflexão, sem nenhuma assinatura efetiva de representantes do Estado. Se levarmos em conta a forma arquitetônica do SNC, e a CNC como um dos seus elementos fundamentais para a construção de políticas públicas de cultura com ampla participação social, o apagamento das assinaturas de representantes do Estado no documento busca ressaltar o caráter mais horizontal e descentralizador adotado a partir desta segunda conferência;

b) Ainda na introdução, o tema do item 1.2 do enunciado "Convenção da diversidade e diálogos interculturais" comprova o fortalecimento da influência dos discursos da Unesco na implantação do SNC, principalmente pela citação da Convenção sobre a Proteção e a Promoção da Diversidade das Expressões Culturais de 2005. Nos itens 1.3 e 1.4 respectivamente, o enunciado aborda a relação entre cultura e educação e entre cultura e comunicação, como questões centrais para possibilitar a transversalidade da cultura;

c) A diversidade cultural ser elencada como o primeiro tema do enunciado pode comprovar que a participação social de agentes da esfera em processos anteriores trouxe uma influência no enunciado e ativou um ponto-chave do sistema.

O segundo Eixo "Cultura, cidade e cidadania" traz o foco na "cidade como espaço de produção, intervenção e trocas culturais, garantia de direitos e acesso a bens culturais" (MINISTÉRIO DA CULTURA, 2005, p. 03). O entendimento de que as cidades representam as pontas do sistema e é por meio delas que toda a política cultural deveria ser concretizada, decorre da influência da Agenda 21 da cultura. A agenda comprendia esses espaços como a potência de realização concreta das ações. Isto é, por meio das demandas das cidades é que deveriam ser construidas as diretrizes. A cidade é pensada no documento como: fenômeno social, memória, transformação social, acesso, acessibilidade e direitos culturais daqueles que aí vivem.

No que tange aos direitos culturais, podemos ressaltar a preocupação do texto em destacar quais direitos estavam ali inseridos: direito à identidade e à diversidade cultural, direito à livre participação na vida cultural, direito autoral, direito/dever de cooperação 
cultural internacional. Em todos os casos, é desenvolvida uma argumentação legitimada por documentos mundiais da ONU e Unesco, buscando assim reforçar a integração daquelas políticas propostas a uma tendência global.

No terceiro eixo, que trata da cultura como desenvolvimento sustentável, a transversalidade é posta como fator de transformação na visão de gestão pública e um todo conforme evidenciado no trecho: "Para concretizar o conceito antropológico de cultura, que se expressa na $\mathrm{CF} / 88$ como 'todos os modos de viver, fazer e criar' (art. 216), as políticas culturais têm de se articular com todas as outras políticas públicas”. Evidenciam os desafios e às dificuldades do mundo no último século (principalmente das guerras) e justificam que apenas quando a cultura for central nas políticas públicas, em relação com a educação, comunicação, segurança pública e saúde, seria possível a plena realização dos desafios propostos pelo século XXI. A transversalidade / centralidade da cultura também é colocada em relação com as áreas de turismo, meio ambiente e desenvolvimento regional.

O eixo IV intitulado "Cultura e economia criativa" apresenta uma proposta de financiamento da cultura que

(...) tem de ser pensado em função dos objetivos da política cultural. Cada objetivo pode definir uma estratégia diferente para a injeção de recursos, que podem ser provenientes de fontes diversas. O financiamento é determinado pela política e não seu determinante. (MINISTÉRIO DA CULTURA, 2010, p. 17)

Neste trecho, cabe ressaltar que há uma proposta de que a política cultural produzida na esfera determine qual tipo de financiamento à cultura deverá ser aplicado, para melhor realizar os novos objetivos propostos. Assim como tratamos anteriormente, o discurso é de tentativa de alteração da base (econômica) do financiamento a partir da superestrutura. A argumentação busca desconstruir o modelo único até então, de financiamento através dos incentivos fiscais, trazendo uma série de dados que comprovam a injustiça social e a determinação do mercado causados por estes. A partir disso, apresentam o novo modelo de financiamento do SNC e do projeto de lei Procultura que, neste momento, estava em período final de escrita antes de sua inscrição enquanto projeto de lei na Câmara dos Deputados.

Sob o império dessa concepção é que foram criadas as leis de incentivo com base na renúncia fiscal. Por meio delas o poder público abre mão de arrecadar parte de impostos dos contribuintes que se dispõem a investir nas atividades culturais. Após anos de experiências, nas diversas esferas de governo, ficaram evidentes as distorções desse modelo de financiamento. Como essas leis entregam ao mercado de patrocínio a decisão sobre o que apoiar, elas acabam provocando, como é próprio dos mercados, todo tipo de desigualdade. Desigualdade entre regiões (as que concentram mais empresas 
atraem o grosso dos patrocínios); desigualdade entre produtores (os que são mais organizados têm maior acesso às empresas e captam mais recursos); entre patrocinadores (os que têm maior faturamento podem apoiar mais projetos); entre tipos de projetos (os que, na visão das empresas, têm maior impacto de marketing obtêm mais patrocinadores); entre os artistas (as empresas preferem associar sua marca a nomes já consagrados). Os números falam por si: nos 18 anos de funcionamento da lei atual, $3 \%$ dos proponentes captaram mais de 50\% dos recursos; grande parte desses recursos (cerca de $80 \%$ ) vai para um número restrito de artistas e produtores localizados no eixo Rio-São Paulo. E o montante de recursos movimentado pela lei corresponde a nada menos do que $80 \%$ de tudo o que o Ministério da Cultura tem para aplicar em cultura. Na época em que as leis de incentivo com base na renúncia fiscal foram introduzidas na União e em vários Estados e Municípios, dizia-se que elas teriam um efeito "pedagógico" sobre as empresas. Pensava-se que os patrocinadores, com o tempo, seriam convencidos das vantagens do investimento cultural e dispensariam o incentivo público. Essa expectativa revelou-se ilusória. Quando o governo Collor extinguiu a chamada lei Sarney, as empresas imediatamente se afastaram do patrocínio cultural. $\mathrm{Na}$ atual crise financeira o mesmo fenômeno se repetiu, demonstrando que de fato é mínimo o compromisso do mercado com incentivo à cultura. Se o que se deseja é superar as desigualdades sociais, culturais e regionais, não há como abrir mão da presença ativa do Estado. Uma distorção pouco lembrada das leis de incentivo é que nelas todos os segmentos da arte e da cultura são colocados num mesmo caldeirão. Sabe-se, contudo, que a produção cultural tem características distintas conforme a natureza do produto. (...) A proposta de alteração da lei de incentivo à cultura apresentada pelo MinC vai nesse sentido, pois cria fundos específicos para setores distintos. Os editais que criam prêmios para segmentos socioculturais ou programas específicos, estão indo na mesma direção, criando o que o ex-ministro Gilberto Gil, na sua visão abrangente, chamou de "cesta" de variados mecanismos de fomento. (MINISTÉRIO DA CULTURA, 2010, pp. 17-18)

O texto evidencia ainda o caráter essencial da economia criativa da cultura para a sustentabilidade das cadeias produtivas do setor e como forma de geração de emprego e renda. A dimensão econômica da cultura busca ampliar o olhar sobre a esfera ao compreendêla não apenas como a produção simbólica e suas abstrações. Ao trazer a ideia de que a cultura pode contribuir com a economia do país de um modo mais amplo, por conta de sua potencialidade de produção e diversidade, trava uma disputa ainda maior com a visão liberal de financiamento, em que apenas alguns produtores e projetos com maior visibilidade são apoiados.

Por fim, mas não menos relevante, o eixo $\mathrm{V}$ do texto-base da $2^{\mathrm{a}} \mathrm{CNC}$ apresenta a gestão institucional da cultura com foco no "fortalecimento da ação do Estado e da participação social no campo da cultura" por meio dos sistemas e planos de cultura, federal, estaduais e municipais. Podemos aferir que, apesar deste tema ser o último abordado no 
enunciado, ele se apresenta como o objetivo principal desta segunda conferência. $\mathrm{O}$ fortalecimento do SNC neste momento é crucial para a implantação das propostas de todo o documento e das metas do PNC. Apenas com a arquitetônica prevista na proposta do SNC, seria possível iniciar uma maior democratização na distribuição das verbas de cultura, a ampliação de acesso à produção e a fruição da cultura, bem como a sustentabilidade, a transversalidade e a centralidade do setor. Ao colocar o SNC no final do documento, como uma solução estrutural aos desafios do século XXI, o MinC demonstra que sua mensagem à sociedade civil naquele enunciado era a de convencimento de que esse era o caminho a ser construído.

A $2^{\text {a }}$ CNC foi realizada nos dias 11 a 14 de março de 2010 em Brasília, onde mais de 2 mil pessoas de delegações de todos os estados brasileiros estiveram presentes. Ao todo foram analisadas e discutidas 347 propostas recebidas de todos os participantes. Destas foram escolhidas inicialmente 77, e 32 delas eleitas para compor o documento final.

No enunciado que apresentam os resultados da $2 \mathrm{a} \mathrm{CNC}$ intitulado "Prioridades da $2^{\mathrm{a}}$ CNC" são apresentadas 32 propostas e 95 estratégias setoriais prioritárias. No eixo I, da Produção Simbólica e Diversidade Cultural, percebemos uma forte presença de ações propostas para os povos tradicionais, bem como de intercâmbio e incentivo das mais diversas linguagens. O combate à discriminação, ao preconceito e à intolerância religiosa, por meio de ações socioeducativas nas diversas linguagens culturais (literatura, dança, teatro, memória e outras), também são citados. Os conteúdos presentes denotam a presença das vozes dos participantes da conferência, pois tocam em questões de forte teor ideológico social.

No sub-eixo 1.3, relativo à Cultura, Educação e Criatividade, a proposta aprovada pela maioria traz uma mescla de vozes das culturas tradicionais com a modernização das políticas públicas pela linguagem digital.

(...) elaborar e implementar conteúdos programáticos nas disciplinas curriculares e extracurriculares dedicados à cultura, à preservação do patrimônio, memória e à história afro-brasileira, indígena e de imigrantes ao desenvolvimento sustentável e ao ensino das diferentes linguagens artísticas, inclusive arte digital e línguas étnicas do território nacional, de matriz africana e indígena, e ao ensino de línguas, inserindo-os no Plano Nacional de Educação, sob a perspectiva da diversidade e pluralidade cultural, nas escolas, desde o ensino fundamental, universidades públicas e privadas com a devida capacitação dos profissionais da educação, por meio da troca de saberes com os mestres da cultura popular nos sistemas municipais, estaduais e federais, bem como (...) (26) Garantir condições financeiras e pedagógicas para a efetiva aplicação da disciplina "Língua e Cultura Local". (MINISTÉRIO DA CULTURA, 2010, p. 02) 
No eixo II - Cultura, Cidade e Cidadania chama atenção o destaque para a integração e articulação entre o plano federal, estados e municípios, ressaltando o caráter federalista do modelo do SNC. Para o fortalecimento das cidades também é destacada a importância da construção de um marco legal para o programa Cultura Viva. ${ }^{162}$

O terceiro eixo, Cultura e Desenvolvimento Sustentável, traz como prioridade o apoio aos mestres dos saberes tradicionais, o diálogo com a saúde principalmente em cidades de menor porte para o desenvolvimento de atividades artísticas e lúdicas que deveriam cooperar em tratamentos de saúde. Mais uma vez percebemos as vozes dos participantes, principalmente quando falam da relação da cultura com a saúde em cidades menores.

Já o Eixo IV - Cultura e Economia Criativa aponta como prioridade o fortalecimento do Fundo Nacional de Cultura e a aprovação da PEC 150/2003 que visa ampliar a porcentagem mínima de orçamento à cultura tanto no federal quanto nos entes federados.

Três anos depois, de 27 de novembro a 1 de dezembro de 2013, foi realizada a $3^{\mathrm{a}}$ Conferência Nacional de Cultura intitulada "Uma Política de Estado para a Cultura: Desafios do Sistema Nacional de Cultura", que contou com a participação de representantes dos 26 estados e do Distrito Federal. Ao todo, mais de 450 mil pessoas participaram dos processos: mais que o dobro de participantes da $2^{\mathrm{a}} \mathrm{CNC}$ e quase cinco vezes mais que a $1^{\mathrm{a}} \mathrm{CNC}$. Num país de mais de 200 milhões de habitantes esses números ainda não são realmente representativos, mas se considerarmos os agentes da esfera pode ser considerado um dos momentos de maior interação e troca na história do setor. O Nordeste foi a região que mais enviou representantes para o evento: $31 \%$ do total, seguida do Sudeste, com 22\%, CentroOeste, com 21\%, Sul (12\%) e Norte (9\%). Esse número maior de representantes do nordeste está ligado com o fato de que esta foi a região onde o sistema avançou mais rapidamente. No ano de 2010, o Ceará já estava com seu sistema completamente aprovado, porém os estados da Paraíba, Bahia e Pernambuco já estavam bem próximos da finalização, bem como boa parte de seus municípios. Em 2013, cinco estados estavam com seus sistemas implantados com leis aprovadas. A maioria deles do Nordeste.

A $3^{\text {a }}$ Conferência reuniu 953 delegados, 162 convidados e 391 observadores. Ao todo a conferência envolveu 1.745 pessoas presentes e $70 \%$ dos representantes estavam participando de uma CNC pela primeira vez. No que se refere ao gênero, $57 \%$ de homens e $43 \%$ de mulheres e, no quesito raça, $32 \%$ afirmaram ser brancos; $15 \%$, pardos; $14 \%$, pretos e

\footnotetext{
${ }^{162}$ A lei Cultura Viva federal foi aprovada apenas no ano de 2014, porém o programa como um todo teve corte de recursos em plano federal desde 2011, sendo apenas desenvolvido em municípios que implantaram o programa quase que de maneira autônoma como a cidade de São Paulo entre os anos de 2013 e 2016.
} 
$2 \%$, indígenas $^{163}$. O processo das pré-conferências municipais e estaduais foi iniciado em junho daquele mesmo ano, com a participação de mais de três mil municípios do país. Os participantes das pré-conferências usaram como textos-base uma publicação onde o mote remetia diretamente às 53 metas do Plano Nacional de Cultura em vigor desde 2010 e à reflexão elencadas nos 4 eixos: Implementação do Sistema Nacional de Cultura em todo o país; Produção Simbólica e Diversidade Cultural; Cidadania e Direitos Culturais; Cultura e Desenvolvimento.

No Eixo I, referente à Implementação do Sistema Nacional de Cultura, o foco foi acerca dos Impactos da Emenda Constitucional do sistema na organização da gestão cultural e na participação social nos três níveis de governo. O eixo foi subdividido nos seguintes subeixos:

1 - Marcos Legais, Participação e Controle Social e Funcionamento dos Sistemas Municipais, Estaduais/ Distrito Federal e setoriais de cultura, de acordo com os princípios constitucionais do SNC.

2 - Qualificação da Gestão Cultural: Desenvolvimento e Implementação de Planos Territoriais e Setoriais de Cultura e Formação de Gestores, Governamentais e Não Governamentais e Conselheiros de Cultura.

3 - Fortalecimento e Operacionalização dos Sistemas de Financiamento Público da Cultura: Orçamentos Públicos, Fundos de Cultura e Incentivos Fiscais.

4 - Sistemas de Informação Cultural e Governança Colaborativa.

Os sub-eixos demonstravam um caráter muito burocrático de discussão e assim demandariam dos participantes conhecimentos sobre os temas. Tanto os conhecimentos sobre trâmites legislativos quanto o financiamento público da cultura poderiam gerar em participantes iniciantes muitas dúvidas sobre os temas. Contudo, com os avanços do sistema, nesta conferência boa parte dos debatedores eram conselheiros de cultura de estados e municípios e traziam um conhecimento adquirido das etapas regionais para a discussão, contribuindo para avançar nas pautas, ampliar a troca e colocar questões de quem observa o sistema por uma perspectiva diferente do federal.

163 Dados do site do MinC. Disponível em: < http://www.cultura.gov.br/destaque-3cnc//asset_publisher/gTPxnPS4SDbT/content/encontro-reuniu-1-7-mil-participantes-sendo-a-maioriahomens/10907?redirect=http\%3A\%2F\%2Fwww.cultura.gov.br\%2Fdestaque-

3cnc\%3Fp_p_id\%3D101_INSTANCE_gTPxnPS4SDbT\%26p_p_lifecycle\%3D0\%26p_p_state\%3Dnormal\%26 p_p_mode\%3Dview\%26p_p_col_id\%3D 118 INSTANCE_bQJckHlQBK93 column$1 \% 26 p \_p \_c o l \_c o u n t \% 3 D 1>$ acesso em 16 de março de 2017. 
O Eixo 2 que tratava da Produção simbólica e da Diversidade cultural, teve como foco o fortalecimento da produção artística e de bens simbólicos e da proteção e promoção da diversidade das expressões culturais, com atenção para a diversidade étnica e racial. Os subeixos foram:

1 - Criação, Produção, preservação, intercâmbio e circulação de Bens Artísticos e Culturais.

2 - Educação e Formação Artística e Cultural.

3 - Democratização da Comunicação e Cultura Digital.

4 - Valorização do Patrimônio Cultural e Proteção aos Conhecimentos dos Povos e Comunidades Tradicionais.

Ao tratar das questões simbólica e da diversidade, o eixo dois apresenta a perspectiva da dimensão simbólica da cultura, que, deveria ser transversal aos temas, inclusive do financiamento e estrutura do sistema. O simbólico e a diversidade devem estar relacionadas com as propostas estruturantes e os representantes das mais diversas linguagens, e grupos culturais deveriam estar representados ali.

O terceiro eixo tratou da Cidadania e direitos culturais e trouxe como foco a busca pela garantia do pleno exercício dos direitos culturais e consolidação da cidadania, com atenção para a diversidade étnica e racial. Os sub-eixos:

1 - Democratização e Ampliação do Acesso à Cultura e Descentralização da Rede de Equipamentos, Serviços e Espaços Culturais, em conformidade com as convenções e acordos internacionais.

2 - Diversidade Cultural, Acessibilidade e Tecnologias Sociais.

3 - Valorização e Fomento das Iniciativas Culturais Locais e Articulação em Rede.

4 - Formação para a Diversidade, Proteção e Salvaguarda do Direito à Memória e Identidades.

E finalmente o quarto eixo mostrou a transversalidade da cultura ao tratar do desenvolvimento sustentável e com foco na economia criativa como uma estratégia de desenvolvimento. O processo também contou com uma plataforma na internet, onde era possível aos interessados da sociedade civil ter acesso aos materiais, inscrever seus municípios, entre outras ações interativas. 
Figura 14: Site da III Conferência Nacional de Cultura.

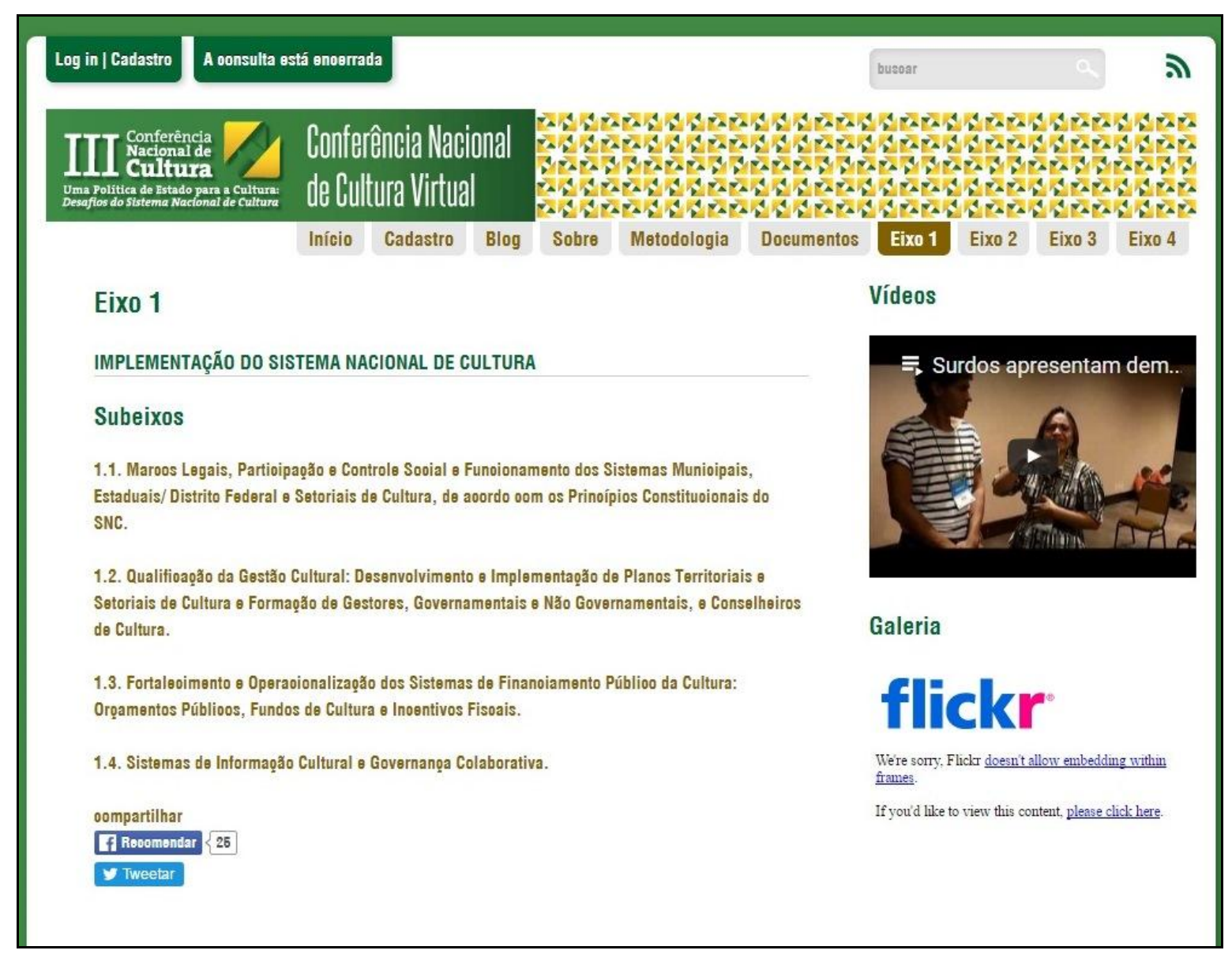

Fonte: Site http://www.cultura.gov.br/3cnc (o site foi retirado do ar em 2017)

No primeiro dia da $3^{\mathrm{a}} \mathrm{CNC}$ foram definidas 64 diretrizes para a gestão cultural, em 16 eixos iniciais, a partir das 614 propostas levadas pelos representantes das Conferências Municipais, Estaduais e Livres. Por meio de votação eletrônica, os delegados selecionaram para as quatro plenárias (4 eixos) 160 proposições consolidadas e destas escolheram as 64 diretrizes. Ao contrário de outras conferências em que foram priorizados os métodos de seminários e expositores, os grupos de trabalho se orientaram a partir dos eixos temáticos. No último dia, foi realizada uma plenária final, a fim de votar quais seriam as 20 propostas prioritárias que foram integradas como indicadores para o plano de trabalho do Ministério da Cultura. Dentre os 953 delegados, 804 deles votaram na plenária final. O evento contou ainda com apresentações culturais que buscavam evidenciar a pluralidade da cultura e foram realizadas no período da noite com apresentação dos grupos: o Surdodum, banda de percussão formada por músicos com deficiência auditiva; o grupo de rap indígena do Brasil, BRO MC'S, da aldeia Jaguapiru Bororó, do Mato Grosso do Sul; Cris Pereira, Teresa Lopes e os grupos Adora Roda e Filhos de Dona Maria representando o samba de Brasília. A realização 
de apresentações artísticas no espaço das conferências pode conferir ao evento uma característica única para o gênero conferência e ampliar o interesse de pessoas da sociedade civil não trabalhadores do setor em participar.

Os resultados da $3^{\mathrm{a}} \mathrm{CNC}$ foram publicados na Revista do MinC número 5, que pode ser baixada pela internet por meio do site do Ministério e foi amplamente divulgado no período. O documento é iniciado com o discurso da então ministra Marta Suplicy que começa o texto mostrando o tom desta conferência ao dizer "Os números mostram a grandeza desta Conferência! Toda a estrutura do Ministério da Cultura (MinC) está aqui.” Ainda que o tema da Conferência seja o SNC, Marta, em seu discurso, evidenciou o que já ressaltamos anteriormente sobre a prioridade da gestão ser o Vale-cultura.

A grande marca da gestão é o Vale-Cultura! O potencial é atingir 42 milhões de trabalhadores. Sabemos que serão anos para esta conquista mas o primeiro passo está dado e vai mudar completamente o país! Vamos fazer uma revolução porque as pessoas que ganham até cinco salários mínimos vão poder ter um cartão de crédito para gastar em cultura, desde que sua empresa faça adesão ao programa. (MINISTÉRIO DA CULTURA, 2013, p. 08)

No trecho sobre as pré-conferências, o documento evidencia que 14 dos 26 estados traziam como prioridade a aprovação da PEC 150/2003, e 12 estados priorizaram a qualificação da gestão cultural, a formação dos gestores. Outro ponto relevante para 14 estados foi a reivindicação "que cobra a implementação de políticas de acesso de pessoas com deficiência à produção, circulação e fruição de bens e serviços culturais em todos os estados do Brasil" (idem, p. 12). Neste ponto temos mais uma vez a presença concreta da voz de um grupo específico. Os representantes das comunidades dos surdos, cegos, pessoas com problemas de mobilidade etc passaram a frequentar cada vez mais essas instâncias de participação social das políticas culturais apontando o conhecimento específico de quem sabe das reais dificuldades. Esta maior participação desses grupos também foi percebida na análise de outros enunciados desenvolvidos a partir desse período.

O documento apresenta ainda um amplo descritivo das impressões de cada estado do país com fotos, prioridades de cada estado, número de delegados enviados à conferência e detalhes sobre a participação de cada um. 
Figura 15: Descritivo sobre a participação dos estados na III CNC

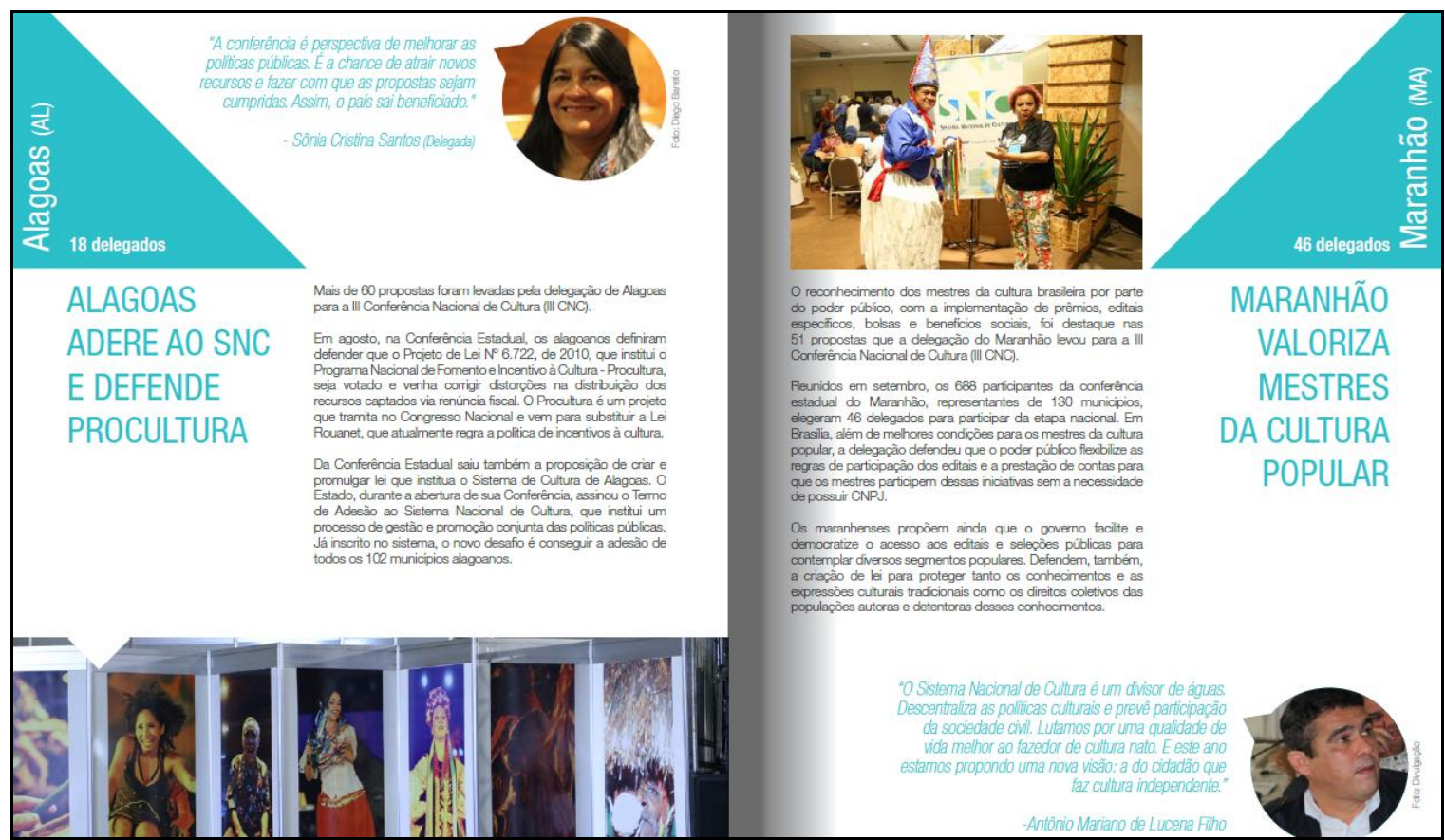

Fonte: Revista MinC N. 5.

Em nenhum momento o documento descreve quais são as reais dificuldades de cada estado ou mesmo qual é o status de implantação do sistema localmente. A apresentação de fotos dos agentes culturais representantes de cada território, indicando impressões pessoais sobre a experiência de participar da conferência, contém comentários muito positivos. Em nenhuma das páginas é percebido qualquer tom de crítica ao que estava sendo proposto, ou mesmo sugestões para a melhoria de métodos. Há claramente um consenso construído que não era o exato reflexo das disputas que ocorrem nesse tipo de processo interativo face a face, onde interesses diversos estão em jogo e tensões ocorrem a todo momento, inclusive de opositores políticos que por ventura estivessem presentes.

É essencial para o MinC e aos gestores públicos de cultura, que compreendam a riqueza de ideias provenientes da interação com os agentes culturais nesses momentos de participação social para a construção de um Sistema realmente democrático. Mesmo as vozes dos opositores políticos e os críticos ao modelo podem contribuir para a construção de algo melhor. Para Bakhtin (2015)

(...) a interpretação ativa, ao familiarizar o interpretável com o novo horizonte do interpretado estabelece uma série de interrelações complexas, consonantes e heterossonantes com o objeto de interpretação, enriquece-o com novos elementos. É exatamente essa interpretação que o falante leva em conta. Por isso sua diretriz centrada no ouvinte é uma diretriz centrada num horizonte especial, no universo especial do ouvinte, insere elementos absolutamente novos em seu discurso; porque aí ocorre uma interação de diferentes contextos, de diferentes pontos de vista, de diferentes horizontes, 
de diferentes sistemas expressivo-acentuais, de diferentes "línguas sociais". O falante procura orientar sua palavra e o horizonte do outro que a interpreta, e entra em relações dialógicas com elementos deste horizonte. $\mathrm{O}$ falante abre caminho para o horizonte alheio do ouvinte, constrói sua enunciação em território alheio, no campo aperceptivo do ouvinte. (BAKHTIN, 2015, p. 55)

A troca realizada nas conferências, entre as centenas de delegados representantes dos estados brasileiros, enriquece o repertório de todos os presentes e mostra uma "malha" de vozes que transmitem as exotopias de cada território. Estados fronteiriços falando de fronteiras, estados do nordeste falando de cultura popular e questões étnicas, estados com grande densidade populacional preocupados com o desenvolvimento do interior. Em alguns casos, os diferentes "brasis" se mostram e em outros é possível perceber que os pontos de convergência são muito mais comuns do que pensaríamos inicialmente. Todavia, não é saudável à construção do sistema que as críticas que ocorreram durante os processos não estejam presentes ou problematizadas nos documentos resultantes da conferência. Muitas dessas criticas ocorrem por desconhecimento técnico ou mesmo por diferentes pontos de vista. É importante para manter um equilíbrio democrático de vozes que apresentem esses outros olhares dissonantes e busquem corrigir erros, justificar ações questionadas e observar temas que podem de fato ser problemas a serem corrigidos. A participação social realmente democrática precisa estabelecer interações mais plurais e didáticas, em que diferentes avaliações sociais e pontos de vista acerca de uma determinado objeto possam estar dispostas e para assim tentar encontrar pontos em comum. Cabe principalmente ao MinC respeitar a diversidade de conhecimentos, vozes e ideias que foram apresentadas, mesmo as mais críticas. Se de fato o sistema se propõe como democrático, nos resultados das conferências deveriam apresentar também quais foram os pontos de tensão, os problemas encontrados (e soluções para saná-los) ou mesmo questões que foram opostas por determinados grupos.

Ao dar voz aos diferentes estados na composição da publicação da revista sobre a $3^{\mathrm{a}}$ CNC, o MinC demonstra que as identidades territoriais dos estados são um dos pontos de maior interesse na construção da arquitetônica do Sistema. Para de fato compreender no que consiste a ideia de descentralização e democratização na criação de políticas públicas de cultura deve-se compreender que para isso é necessário perceber que o país tem diferentes exotopias e demandas, e é necessário escutar um número ainda maior de agentes culturais. A responsividade aqui é percebida de diferentes maneiras. Primeiro, é relevante ressaltar a responsabilidade dos representantes de estados e cidades em estudar a fundo as reflexões do 
texto-base, com a preocupação de construir uma política cultural que possa contemplar a maior parte das demandas de todas as regiões. Entretanto esses representantes nem sempre são eleitos democraticamente. Em muitos casos, são pessoas escolhidas por secretarias a partir de favorecimento político ou com interesses de determinados grupos culturais.

Segundo, por ser uma ação voluntária, estas pessoas doam parte do seu tempo para a construção de algo comum, para o bem comum. Ao mesmo tempo, interesses políticos pessoais e a oportunidade de participar de uma experiência como essa pode gerar uma série de benefícios como contatos para futuros trabalhos, ou mesmo para a formação de grupos mais consistentes a favor de temas específicos. Os sujeitos tornam-se parte de um coletivo visando um bem comum, mas ao mesmo tempo podem ter benefícios individuais ao serem escolhidos para estarem na conferência.

Terceiro, o Estado, no caso, personificado pelos agentes responsáveis do Ministério da Cultura, deveria compreender a importância das diferentes vozes e exotopias que buscavam construir algo que beneficiaria milhares de pessoas, inclusive beneficiando quem nem conhece o que estava sendo proposto. Se a participação social era uma das partes importantes deste sistema, perceber a polifonia era tão importante quanto.

$\mathrm{Na}$ votação das propostas dos quatro eixos da $3^{\mathrm{a}} \mathrm{CNC}$ é possível perceber algumas tendências de interesse de todos, reveladas pelo grande número de votos. As quantidades na votação das prioridades refletem e refratam a vontade dos agentes da sociedade civil produtora de cultura. Ao mesmo tempo mostram a potência política e de vozes de determinados grupos. O total de votantes foi de 804 e era possível que cada eleitor votasse mais de uma vez em cada eixo.

No eixo I, chama a atenção os dois primeiros itens fazerem menção ao tema "dinheiro". A pasta da cultura é historicamente a pasta com um dos menores orçamentos, não apenas em plano federal, mas também nos entes federados.

Não adianta construir políticas culturais próximas do ideal se não há verba para o desenvolvimento das mesmas. Ao aclamar a PEC 150 por $85 \%$ dos votantes e o Fundo do Pré-sal com 66\%, é possível evidenciar a tendência de que a maior preocupação da maioria ainda era a verba. Em terceiro lugar, aparece a lei de regulamentação do SNC com $63 \%$ dos votos. No Eixo 2, a votação mais expressiva é a que faz a relação entre cultura e educação com apoio de $86 \%$ dos delegados. 
Figura 16: Resultados votação de itens prioritários da $3^{\mathrm{a}} \mathrm{CNC}$, eixos 1 e 2

\begin{tabular}{|c|c|c|c|c|c|}
\hline \multicolumn{3}{|c|}{$\begin{array}{l}\text { Todas as propostas aprovadas encontram-se na integra ao final do documento } \\
\text { EIXO } 1 \text { - IMPLEMENTAÇÃO DO SISTEMA NACIONAL DE CULTURA }\end{array}$} & \multicolumn{2}{|c|}{ EIXO 2 - PRODUÇĀO SIMBÓLICA E DIVERSIDADE CULTURAL } & 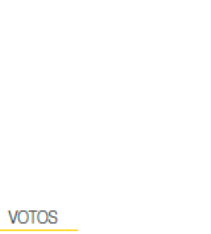 \\
\hline ORDEM & PROPOSTA & VOTOS & $1^{a}$ & 211. Educaçăa e Cultura & 610 \\
\hline $1^{\mathrm{a}}$ & 1.11: PEC 150. & 663 & $2^{\circ}$ & 2440. Sistema Nacional de Patrimônio Cultural & 492 \\
\hline$z^{2}$ & 1.26. Fundo Social do Pré-Sal & 540 & $3^{\infty}$ & 230. Comunicação e Cultura & 447 \\
\hline$x^{a}$ & 1.1: Lei do SNC & 524 & $4^{a}$ & 214. Programa Mais Cultura nas Escolas & 370 \\
\hline $\begin{array}{l}4^{a} \\
5^{a}\end{array}$ & $\begin{array}{l}\text { 1.14: Formação e Capacitaçăo em Gestão Cultural } \\
\text { 1.25. Fortalecimento do FNC: paridade com } \\
\text { renúncia fiscal e fundo-a-fundo }\end{array}$ & $\begin{array}{l}473 \\
376\end{array}$ & $g^{a}$ & $\begin{array}{l}\text { 226. Circulacăào de conteúdos/ Arte, inovaçăoe e } \\
\text { cultura digital }\end{array}$ & 299 \\
\hline & & & DEMAIS PRC & STAS APROVADAS NO EIXO 2 (por ordem nu & rica): \\
\hline DEMAIS Pr & STAS APROVADAS NO EIXO 1 (por ordem nun & rica): & $\begin{array}{l}\text { Proposta 2.1: }[ \\
\text { regionalizaçâo }\end{array}$ & $\begin{array}{l}\text { ificação, desburocratização e democratżação das in } \\
\text { ulaçâ. }\end{array}$ & de financiamento com ênfase na \\
\hline $\begin{array}{l}\text { Proposta } 1.2 \\
\text { Proposta } 1.7 \\
\text { Proposta } 1.8 \\
\text { Proposta } 1.1 \\
\text { Proposta } 1.1 \\
\text { para os servi } \\
\text { Proposta } 1.1 \\
\text { Proposta } 1.2 \\
\text { Proposta } 1.2 \\
\text { Proposta } 1.3 \\
\text { Proposta } 1.3 \\
\text { Proposta } 1.4\end{array}$ & 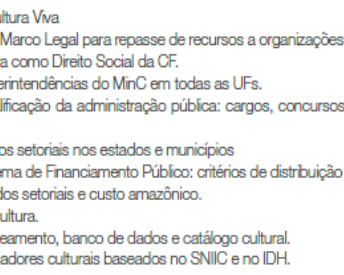 & $\begin{array}{l}\text { sociedade civil. } \\
\text { apacitaçâo, planos de carreira } \\
\text { recursos. }\end{array}$ & $\begin{array}{l}\text { Proposta 2.2. A } \\
\text { Proposta 2.3. Ir } \\
\text { Proposta 2.4. F } \\
\text { Proposta 2.5. } \\
\text { Proposta 2.8. } \\
\text { expressóes aul } \\
\text { Proposta 2.22. } \\
\text { Proposta 2.27. } \\
\text { Proposta 2.28. } \\
\text { Proposta 2.35: } \\
\text { quiombolas, pe } \\
\text { Proposta 2.43. }\end{array}$ & 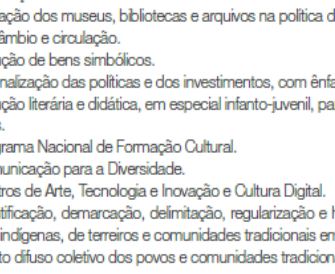 & 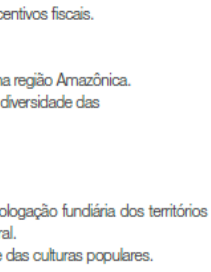 \\
\hline
\end{tabular}

Fonte: Revista do MinC, N. 5.

Aqui é reforçada a ideia de transversalidade da cultura com outros setores, e compreendida por boa parte dos participantes. Isso se reforça com a menção do turismo cultural com 322 votos, algo em torno de $40 \%$.

Figura 17: Resultados da votação de itens prioritários da $3^{\mathrm{a}} \mathrm{CNC}$, eixos 3 e 4

\begin{tabular}{|c|c|c|c|c|c|}
\hline \multicolumn{3}{|c|}{ EIXO 3 - CIDADANIA E DIREITOS CULTURAIS } & \multicolumn{3}{|c|}{ EIXO 4 - CULTURA E DESENVOLVIMENTO } \\
\hline \multicolumn{3}{|c|}{ PROPOSTAS PRIORIZADAS: } & \multicolumn{3}{|c|}{ PROPOSTAS PRIORZADAS: } \\
\hline ORDEM & PAOPOSTA & Votos & ORDEM & PAOPOSTA & VOTOS \\
\hline $1^{a}$ & 3.1. Equipamentos culturais & 653 & $1^{\mathrm{a}}$ & 4.21. Economia Criativa Local & 661 \\
\hline$z^{2}$ & 3.21. Lei Cultura Viva & 581 & $2^{2}$ & 4.31. Plano Nacional de Economia Criativa & 493 \\
\hline $3^{a}$ & $\begin{array}{l}\text { 3.39. Reconhecimento de mestres e mestras e } \\
\text { Programa Certific }\end{array}$ & 571 & $3^{\circ}$ & $\begin{array}{l}\text { 4.26. Linhas de financiamentos para } \\
\text { empreendedores culturais, pesquisa e inovaçăo } \\
\text { tecnológica }\end{array}$ & 418 \\
\hline $4^{a}$ & $\begin{array}{l}\text { 3.18. Polliticas de acesso às pessoas com } \\
\text { deficiência, incapacidade temporária ou mobililidade } \\
\text { reduzida }\end{array}$ & 480 & $4^{\mathrm{a}}$ & $\begin{array}{l}\text { 4.29. Programa Amazônia Cultural } \\
\text { 4.1. Turismo cuttural }\end{array}$ & 360 \\
\hline $5^{a}$ & 3.10. Plano Nacional do Livro e Leitura & 361 & & & \\
\hline \multicolumn{3}{|c|}{ DEMAIS PROPOSTAS APROVADAS NO EIXO 3 (por ordem numérica): } & \multicolumn{3}{|c|}{ DEMAIS PROPOSTAS APROVADAS NO EIXO 4 (por ordem numérica): } \\
\hline \multicolumn{3}{|c|}{ 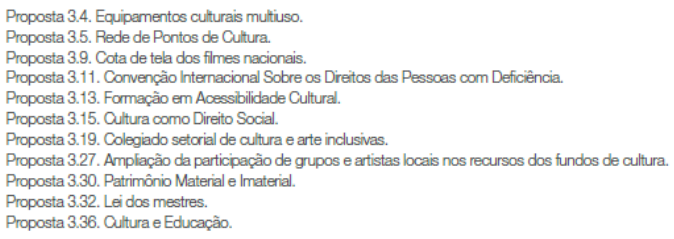 } & \multicolumn{3}{|c|}{ 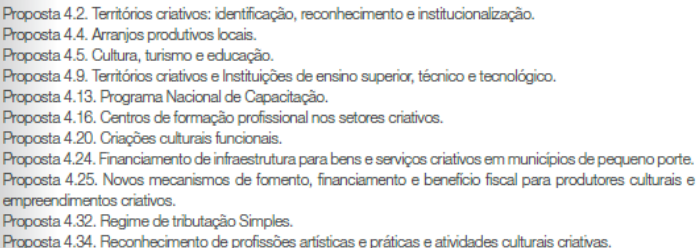 } \\
\hline
\end{tabular}

Fonte: Revista do MinC, N. 5.

No eixo 3, relativo à cidadania e direitos culturais, os equipamentos culturais 
aparecem com $84 \%$ das manifestações. Não temos a informação de quem foram os votantes neste item, porém a grande quantidade de interessados demonstra que esse ainda é um grande problema a ser resolvido, mesmo em grandes cidades.

A lei Cultura Viva também é elencada como prioridade e isso corrobora a tese de que os "ponteiros" e/ou simpatizantes do programa homônimo estavam presentes nesta conferência em grande número. $\mathrm{O}$ interesse pela cultura popular aparece com expressiva votação no item sobre o reconhecimento de mestres e mestras do programa Certific, implantado no ano seguinte e que possibilitou certificar artesãos como profissionais em seus fazeres. O Eixo 4 que trata do desenvolvimento apresentou dois itens expressivos sobre a economia criativa, acompanhando a tendência do setor que vinha crescendo desde 2011.

Ainda que os processos de construção do SNC tenham ocorrido por fatores diversos, os encontros promovidos pelo MinC, principalmente as Conferências Nacionais de Cultura são parte relevante do processo. Entretanto, o papel do Conselho Nacional de Política Cultural e dos conselhos territoriais ficou aquém do que poderia ter sido. O trabalho voluntário, a falta de recursos, a falta de apoio dos estados e municípios, a falta de diálogo entre os setores, as diferentes avaliações sociais e entendimento de cultura, o pouco uso de mídias digitais disponíveis, foram alguns dos fatores que não possibilitaram que o CNPC e os conselhos territoriais se fortalecessem ao longo dos processos. A gestão do CNPC vigente entre os anos de 2012 e 2014, por exemplo, teve apenas um encontro coletivo presencial durante o período. A função de fiscalizador do SNC foi pouco exercida por conta da distância da maioria dos membros da capital federal. O diálogo entre os titulares e suplentes de cada setorial também foi prejudicado por termos um país grande demais. O papel mais importante do CNPC deu-se nos momentos de realização das Conferências Nacionais, em que era sua função auxiliar na idealização de organização junto ao MinC. Ainda que muitos titulares e suplentes tivessem feito parte das conferências e encontros do MinC, não é justo dizer que foram os únicos responsáveis como conjunto da formulação de políticas culturais, ainda que tenham feito parte de momentos relevantes da construção efetiva do sistema. Todavia, se o CNPC for compreendido como diz o artigo 6 do decreto 5520, em toda sua gama de instâncias de construção, fica mais evidente, que o Conselho vai muito além dos agentes eleitos, titulares e suplentes.

O CNPC é a parte do todo da participação social do sistema e deve ser pensado como um conjunto que compreende toda a sociedade civil interessada em colaborar e a relação com o Estado. “Art. 6º O CNPC é integrado pelos seguintes entes: I - Plenário; II - Comitê de 
Integração de Políticas Culturais - CIPOC; III - Colegiados Setoriais; IV - Comissões Temáticas ou Grupos de Trabalho; e V - Conferência Nacional de Cultura”.

Nos territórios, estados e municípios, os conselhos de cultura locais, em boa parte em construção e adaptação à nova realidade de implantação de sistemas locais, ainda dependem da aprovação de leis locais para composição de conselhos menos centralizadores. Como bem evidenciou Tabagiba (2010), os conselhos dependem de diversos fatores para serem de fato democratizantes e nem sempre há vontade política, tanto do Estado, quanto da sociedade civil, que permita que estes atuem concretamente no interior dos órgãos de cultura. Nobre (2004) ao falar sobre o modelo de democracia participativa propõe que

\begin{abstract}
(...) as instituições representativas e o próprio governo devem ser entendidos meramente como meios de realização da vontade dos cidadãos e jamais como as instituições democráticas por excelência, o que significa, antes de mais nada, que um democrata participativo não aceita qualquer divisão rígida entre Estado e sociedade civil, mas antes, seguindo Jean Jacques Rousseau - o inspirador maior dessa vertente teórica - enfatiza a necessária identidade entre governantes e governados resultante de um único contrato social que institui um único corpo político. (NOBRE, 2004, pp. 33 - 34)
\end{abstract}

Ainda sobre a questão da participação social, é relevante ressaltar que as 53 metas do Plano Nacional de Cultura foram construídas definitivamente após a $2^{\text {a }} \mathrm{CNC}$ e aprovadas em dezembro de 2011, e publicadas no livro intitulado As metas do Plano Nacional de Cultura apenas em outubro de 2013, divulgadas amplamente dois meses antes da $3^{\text {a }}$ CNC. No momento da terceira conferência, as 53 metas ainda estavam sendo absorvidas pela maioria dos agentes culturais envolvidos nos processos. Porém, o relógio já estava correndo. O decênio do PNC estava previsto para o período de 2010 a 2020. Ainda que já tivéssemos um plano, a maioria dos agentes culturais ainda estava conhecendo os conteúdos e começava a criar seus planos territoriais, principalmente nos municípios. Em muitos casos, iniciavam o entendimento de como o processo deveria ser feito. Era uma complexa corrida contra o tempo.

\title{
4.4 - Sistema Nacional de Cultura para quem?
}

Bakhtin (2010d, p.120) acredita que apenas nos diálogos de conteúdo-sentido com o outro, ou a quem se destina o ato ético, e em relação com a realidade, a arquitetônica proposta adquire valor real. Somente assim a "luz do valor é refletida".

Se de fato esta eternidade-em-si do sentido fosse verdadeiramente válida sobre o plano do valor, o ato de sua encarnação, de seu pensamento, de sua efetiva realização por parte do pensamento operativo, seria supérfluo e inútil; 
somente em correlação com este, a eternidade do sentido adquire um valor real, torna-se significativa. O sentido eterno se torna valor que move o pensamento operativo somente como seu momento constitutivo, somente em correlação com a realidade efetiva; como eternidade do valor deste pensamento, deste livro. Mas também aqui a luz do valor é luz refletida; o que é necessariamente valioso em última instância é a eternidade real da própria realidade concreta em sua plenitude; a realidade deste ser humano, destas pessoas e de seus mundos com todos os seus momentos reais; somente assim o sentido eterno do pensamento efetivamente realizado brilha com a luz do valor (BAKHTIN, 2010d, pp. 120-121)

Os sistemas e planos de cultura devem ser reconhecidos pelos destinatários destas políticas e com suas realidades concretas (a quem se destina o sistema) para que sejam de fato valorados por esses atos pensados e projetados visando à realização futura. Com isso, propomos aqui a seguinte questão: Quem são os grupos a que se destinam as propostas nos enunciados do SNC? E quem são os grupos, até então excluídos, que deverão passar a enxergar a "luz do valor" desses enunciados na prática?

Como visto no tópico anterior, os planos de cultura são criados e escritos por diversas “mãos”. São diversas consciências com diferentes centros de valores inseridos em suas identidades. Entretanto, vimos também que nos momentos seguintes, da execução destes planos, não serão estas mesmas pessoas que estarão responsáveis pelo desenvolvimento das propostas desenvolvidas enquanto ação de política pública. Da mesma maneira, os agentes culturais a quem estas políticas se destinam podem também não ser os mesmos, afinal o tempo passa e as gerações produtoras de cultura vão se alterando. E em muitos casos nem sempre os agentes culturais participantes dos processos representam de fato a diversidade cultural, as diferentes etnias, classes e grupos sociais e as mais diversas linguagens, que se pretende alcançar.

Na obra Para uma Filosofia do Ato Responsável, Bakhtin descreve como os momentos da arquitetônica estão relacionados. O espaço e tempo e os valores contidos nas esferas, mas principalmente os agentes em relação (eu-para-mim, eu-para-o-outro, outro-para-mim) estão como centros de valor desse processo. Não apenas seus autores, mas aqueles a quem se destina o ato, o que é dito / escrito, deve ser levado em conta pois esses responderão futuramente. Os momentos da arquitetônica: eu-para-mim, o outro-para-mim, e eu-para-ooutro são essenciais para a compreensão do todo desta reflexão, pois "todos os valores da vida real e da cultura se dispõem ao redor destes pontos arquitetônicos fundamentais do mundo real do ato".

É esta arquitetônica do mundo real do ato que a filosofia moral deve 
descrever, não como um esquema abstrato, mas como o plano concreto do mundo do ato unitário singular, os momentos concretos fundamentais de sua construção e da sua disposição recíproca. Estes momentos fundamentais são: eu-para-mim, o outro-para-mim, e eu-para-o-outro; todos os valores da vida real e da cultura se dispõem ao redor destes pontos arquitetônicos fundamentais do mundo real do ato: valores científico, estéticos, políticos (incluindo também os éticos e sociais) e finalmente religiosos. (BAKHTIN, 2010d, p. 114)

As comunidades (semióticas / culturais) são consideradas quando se compõem de fatores comuns como classe, língua, território, interesses etc. As esferas e seus desdobramentos também ajudam a delimitar determinadas comunidades, por exemplo, os participantes de determinado espaço acadêmico científico, os fiéis de uma religião, os participantes do parlamento etc. No caso específico dos agentes culturais, além da comunidade mais abrangente dos fazedores de cultura como um todo, percebemos diversas matizes evidenciando a enorme diversidade de comunidades que compõe esta esfera. Os diferentes territórios, setores, linguagens artísticas, as classes sociais, os moradores dos centros urbanos e rurais e os moradores das periferias, entre outros tipos, constroem as cores desta diversidade cultural almejada. Percebemos ainda linhas mais finas desses diferentes matizes, como aqueles que produzem a arte mais erudita ou de vanguarda e os que produzem a cultura mais tradicional ou mesmo necessidades específicas da estética experimental. Toda esta diversidade deveria estar contemplada tanto na produção dos enunciados do Sistema Nacional de Cultura, quanto nos desenvolvimentos propostos pelos planos de cultura. Se de fato estes planos visam a diversidade e a ampliação do acesso, é para todos os tipos de agentes culturais e todos os públicos que estes enunciados devem falar.

Entretanto, como propõe Volóchinov (2017) na obra Marxismo e Filosofia da linguagem, os signos ideológicos nem sempre falam a todos da mesma maneira. Mesmo quando falam a mesma língua, ou quando participam e produzem em determinada esfera de atividade humana, as relações de valor para um determinado enunciado serão diferentes para os grupos.

Em cada etapa do desenvolvimento social, existe um conjunto específico e limitado de objetos que, ao chamarem a atenção da sociedade, recebem uma ênfase valorativa. Apenas esse conjunto de objetos obterá uma forma sígnica, isto é, será objeto da comunicação sígnica. O que então determina esse conjunto de objetos que são enfatizados valorativamente? Para que um objeto, independentemente do tipo da sua realidade, entre no horizonte social de um grupo e provoque uma reação ideológica sígnica, é necessário que ele esteja relacionado com as premissas socioeconômicas essenciais da existência desse grupo; é necessário que, de algum modo, ele toque, mesmo que seja parcialmente, as bases da existência material desse grupo. É claro 
que, nesse caso, o arbítrio individual não pode ter nenhuma importância. Uma vez que o signo é criado entre os indivíduos, no âmbito social, é necessário que o objeto também obtenha uma significação interindividual, pois, apenas assim ele poderá adquirir uma forma sígnica. Em outras palavras, somente aquilo que adquiriu um valor social poderá entrar no mundo da ideologia, tomar forma e nele consolidar-se. É por isso que todas as ênfases ideológicas, embora feitas por uma voz individual (por exemplo, na palavra) ou por qualquer organismo individual, são ênfases sociais que pretendem ao reconhecimento social, e apenas em prol desse reconhecimento são realizadas no exterior, no material ideológico. (VOLÓCHINOV, 2017, pp 110-111)

Para que um enunciado toque valorativamente um grupo e provoque uma "reação ideológica sígnica" é necessário que esteja relacionado com as "premissas socioeconômicas essenciais da existência desse grupo" e que dialogue com a infraestrutura que atinge esse grupo. E para nosso objeto de tese, precisa tocar as identidades culturais, mas também o financiamento das produções culturais para esses grupos.

No caso do SNC, a reflexão acima pode ajudar a compreender a importância do sistema na esfera, já que uma de suas principais funções é tentar alterar o modelo de distribuição de verbas para o setor. Aliado aos interesses de uma construção de política pública de baixo pra cima, os agentes envolvidos na construção do sistema podem vislumbrar a possibilidade de alteração na lógica de financiamento que incide na esfera político-cultural e que até então sempre privilegiou os já privilegiados. Todavia, para que isso aconteça é essencial que uma série de fatores estejam em acordo e haja vontade política (e econômica) daqueles que executarão estas políticas futuramente. Ainda que as políticas criadas sejam pensadas pelos beneficiários destas políticas, com diversidade e ampliação do acesso, ainda cabe ao Estado a decisão de aplicar ou não o que está proposto nos enunciados do sistema, mesmo que estejam previstos em marcos legais. E para que isso realmente tenha plena satisfação de todos os grupos envolvidos será necessário que de fato todos sejam contemplados nessa nova configuração da esfera pela base, isto é, pelo financiamento e o acesso aos recursos.

É relevante lembrar neste momento do texto a justificativa do projeto de lei do PNC escrito por Gilmar Machado, que logo em seu início trazia o seguinte trecho evidenciando a questão da inclusão social como um dos motivos da proposição da matéria.

A história demonstra que tem havido um processo de exclusão da maioria de nossa população. Nossas crianças e nossos jovens, embora herdeiros de um grande patrimônio cultural e criativos o suficiente para enriquecê-lo e legar às gerações que virão, não conseguem ver seu próprio rosto na grande produção cultural dominante. A política cultural tem sido privilégio de 
poucos que dividem entre si os recursos, sejam públicos ou privados, destinados à criação e produção cultural. ${ }^{164}$

Neste trecho, a questão da inclusão / exclusão é claramente evidenciada. Gilmar Machado introduz a ideia geral do texto de justificativa da lei do PNC de que os excluídos, aqueles que nunca fizeram parte das políticas culturais, a partir daquele momento precisam começar a fazer parte. No fragmento "A política cultural tem sido privilégio de poucos que dividem entre si os recursos", o autor sugere que essa nova política cultural não seria especificamente voltada à classe dominante da cultura, que sempre teve seus espaços e verbas para produção. Entretanto, a elite cultural não estaria excluída dos benefícios desta nova política, pois esta se declara democrática.

Mesmo com a proposta de democratização desta nova política cultural, a vantagem de acessar os recursos da cultura será ainda desses grupos anteriormente privilegiados, como evidenciado pelas reflexões desenvolvidas em Queiroz (2014). Aqueles que têm maior acesso aos recursos de um modo geral, ao estudo, à informação, às ferramentas digitais, ao conhecimento prévio das burocracias e dos discursos das diversas esferas que compõem a esfera das políticas culturais, têm vantagem em comparação aos demais.

$\mathrm{Na}$ análise do corpus principal desta tese, encontramos algumas evidências de quem esta nova política busca auxiliar, pelo menos em termos discursivos. No parágrafo terceiro do artigo 215 da CF, que insere o Plano Nacional de Cultura encontramos os seguintes trechos nos itens: IV - democratização do acesso aos bens de cultura; V - valorização da diversidade étnica e regional.

Como vimos em diversos momentos desta tese, a preocupação com a democratização do acesso à cultura e a diversidade aparecem como centros de valores de toda esta nova proposta de política cultural. Todavia, para que isto esteja garantido, é necessária a responsabilidade ética na distribuição dos recursos. Para que isso ocorra, deve ser prioridade do Estado o desenvolvimento de métodos para descentralizar de maneira mais justa os recursos. Essa descentralização não deve ser pensada apenas como territorial, mas como diversidade, beneficiando também às diferentes etnias, gêneros, faixas etárias etc.

Um artigo da constituição, ou mesmo uma lei regulamentar, ainda que sirvam como balizadores do modo como todo o país deve se comportar diante das leis e dos respectivos atos, nem sempre garantem sua concreta aplicação no mundo da vida.

\footnotetext{
${ }^{164}$ Texto disponível em: < http://imagem.camara.gov.br/Imagem/d/pdf/DCD19ABR2006.pdf\#page=160 > acesso em 22 de setembro de 2016 .
} 
A ideia de diversidade e ampliação de acesso como direitos culturais (e civis) aparece em diversos trechos do enunciado da lei que regulamenta o PNC aprovado em 2010 evidenciando estes dois centros de valores.

No artigo 1 que trata dos princípios do PNC (BRASIL, 2010, grifos nossos):

II - diversidade cultural; (...) III - respeito aos direitos humanos; (...) IV direito de todos à arte e à cultura; $\mathrm{V}$ - direito à informação, à comunicação e à crítica cultural; VI - direito à memória e às tradições;

No artigo 2, que trata dos objetivos do PNC:

I - reconhecer e valorizar a diversidade cultural, étnica e regional brasileira; (...) V - universalizar o acesso à arte e à cultura; (...) X - reconhecer os saberes, conhecimentos e expressões tradicionais e os direitos de seus Detentores; (...) XIII - descentralizar a implementação das políticas públicas de cultura;

No artigo 3, das atribuições do poder público:

IV - proteger e promover a diversidade cultural, a criação artística e suas manifestações e as expressões culturais, individuais ou coletivas, de todos os grupos étnicos e suas derivações sociais, reconhecendo a abrangência da noção de cultura em todo o território nacional e garantindo a multiplicidade de seus valores e formações; (...) V - promover e estimular o acesso à produção e ao empreendimento cultural; a circulação e o intercâmbio de bens, serviços e conteúdos culturais; e o contato e a fruição do público com a arte e a cultura de forma universal;

No artigo 3, podemos verificar também as ideias de abrangência geográfica e territorial, a multiplicidade de valores, o intercâmbio e a universalidade, ampliando ainda mais a questão do acesso. Dar acesso não significa apenas levar cultura para o maior número de pessoas. Ampliar o acesso significa incentivar que a produção cultural de todos tenha as mesmas chances e recursos para circulação, fruição e troca.

Entretanto, como garantir que de fato esta política cultural incentive a diversidade e o acesso amplo a todos? No texto da lei do PNC, no artigo 8, e em seu respectivo parágrafo único, vemos que cabe ao Ministério da Cultura e ao CNPC a responsabilidade de garantir que os objetivos dessa lei sejam de fato alcançados.

Art. 8o Compete ao Ministério da Cultura monitorar e avaliar periodicamente o alcance das diretrizes e eficácia das metas do Plano Nacional de Cultura com base em indicadores nacionais, regionais e locais que quantifiquem a oferta e a demanda por bens, serviços e conteúdos, os níveis de trabalho, renda e acesso da cultura, de institucionalização e gestão cultural, de desenvolvimento econômico-cultural e de implantação sustentável de equipamentos culturais. Parágrafo único. O processo de monitoramento e avaliação do PNC contará com a participação do Conselho Nacional de Política Cultural, tendo o apoio de especialistas, técnicos e 
agentes culturais, de institutos de pesquisa, de universidades, de instituições culturais, de organizações e redes socioculturais, além do apoio de outros órgãos colegiados de caráter consultivo, na forma do regulamento. (BRASIL, 2010 - grifos meus)

Todavia, é necessário pensarmos que o Ministério da Cultura nem sempre tem autonomia para suas decisões políticas e carece de recursos para desenvolver todas as ações elencadas no texto. O Estado brasileiro é regido constitucionalmente pela instância dos três poderes. Além disso, responde às decisões presidenciais e de outros ministérios com maior poder de decisão e influência na infraestrutura econômica (como o Ministério do Planejamento e da Fazenda, por exemplo). Qualquer ação relativa a uma lei ainda dialoga com o legislativo e o judiciário e requer legitimidade na sociedade civil. O fator orçamentário é ainda o mais frágil dentre os pontos do sistema. Sem um orçamento ampliado é ainda mais difícil atingir uma maior quantidade de ações, as regiões mais periféricas do país e das cidades, e aqueles que sempre estiveram excluídos das discussões. A descentralização deve ser entendida não apenas como um fator geográfico, mas como um processo de distribuição mais igualitária e justa de recursos, garantindo que de fato , a cultura é um direito de todos. No início do capítulo 1 do anexo da lei do PNC, encontramos o seguinte trecho:

O Plano Nacional de Cultura está voltado ao estabelecimento de princípios, objetivos, políticas, diretrizes e metas para gerar condições de atualização, desenvolvimento e preservação das artes e das expressões culturais, inclusive aquelas até então desconsideradas pela ação do Estado no País. O Plano reafirma uma concepção ampliada de cultura, entendida como fenômeno social e humano de múltiplos sentidos. Ela deve ser considerada em toda a sua extensão antropológica, social, produtiva, econômica, simbólica e estética. O Plano ressalta o papel regulador, indutor e fomentador do Estado, afirmando sua missão de valorizar, reconhecer, promover e preservar a diversidade cultural existente no Brasil. (BRASIL, 2010, grifos meus)

No trecho "Ela deve ser considerada em toda a sua extensão antropológica, social, produtiva, econômica, simbólica e estética", percebemos que além da ideia de inclusão temos também a ideia da cultura entendida em seu sentido mais amplo e o conceito da Unesco. Ao dizer que o PNC deveria estabelecer políticas para expressões culturais "até então desconsideradas pela ação do Estado”, o enunciado convoca esses agentes excluídos para a disputa dessas políticas (e verbas), qualificados a partir de então como responsáveis por uma considerável alteração do paradigma da sociedade brasileira.

$\mathrm{O}$ enunciado reforça, ao longo do texto, as responsabilidades que o Estado (aqui entendido principalmente como MinC) terá ao longo do processo. No anexo 1, capítulo 1, do 
que compete ao Estado, a lei propõe diversas ações de responsabilidade do MinC (grifos meus).

FORMULAR POLÍTICAS PÚBLICAS, identificando as áreas estratégicas de nosso desenvolvimento sustentável e de nossa inserção geopolítica no mundo contemporâneo, fazendo confluir vozes e respeitando os diferentes agentes culturais, atores sociais, formações humanas e grupos étnicos. • QUALIFICAR A GESTÃO CULTURAL, otimizando a alocação dos recursos públicos e (...) melhorando o atendimento das demandas sociais. • FOMENTAR A CULTURA de forma ampla, estimulando a criação, produção, circulação, promoção, difusão, acesso, consumo, documentação e memória, (...) - PROTEGER E PROMOVER A DIVERSIDADE CULTURAL, reconhecendo a complexidade e abrangência das atividades e valores culturais em todos os territórios, ambientes e contextos populacionais, buscando dissolver a hierarquização entre alta e baixa cultura, cultura erudita, popular ou de massa, primitiva e civilizada, e demais discriminações ou preconceitos. - AMPLIAR E PERMITIR O ACESSO compreendendo a cultura a partir da ótica dos direitos e liberdades do cidadão, sendo o Estado um instrumento para efetivação desses direitos e garantia de igualdade de condições, promovendo a universalização do acesso aos meios de produção e fruição cultural, fazendo equilibrar a oferta e a demanda cultural, (...) • PRESERVAR O PATRIMÔNIO MATERIAL E IMATERIAL, resguardando bens, documentos, acervos, artefatos, vestígios e sítios, assim como as atividades, técnicas, saberes, linguagens e tradições que não encontram amparo na sociedade e no mercado, permitindo a todos o cultivo da memória comum, da história e dos testemunhos do passado. • AMPLIAR A COMUNICAÇÃO E POSSIBILITAR A TROCA ENTRE OS DIVERSOS AGENTES CULTURAIS, criando espaços, dispositivos e condições (...). • DIFUNDIR OS BENS, CONTEÚDOS E VALORES oriundos das criações artísticas e das expressões culturais locais e nacionais em todo o território brasileiro e no mundo, assim como promover o intercâmbio e a interação desses com seus equivalentes estrangeiros, observando os marcos da diversidade cultural para a exportação de bens, conteúdos, produtos e serviços culturais. - ESTRUTURAR E REGULAR A ECONOMIA DA CULTURA, construindo modelos sustentáveis, estimulando a economia solidária e formalizando as cadeias produtivas, ampliando o mercado de trabalho, o emprego e a geração de renda, promovendo o equilíbrio regional, a isonomia de competição entre os agentes, principalmente em campos onde a cultura interage com o mercado, a produção e a distribuição de bens e conteúdos culturais internacionalizados. (BRASIL, 2010, grifos meus)

Neste trecho, aliado às competências do MinC, temos uma ampliação da explicação do que deveriam abarcar esses centros de valores: respeitar os diferentes agentes culturais, atores sociais, formações humanas e grupos étnicos, melhorar o atendimento das demandas sociais de forma ampla, reconhecer a complexidade e abrangência, em todos os territórios, dissolver a hierarquização entre alta e baixa cultura, cultura erudita, popular ou de massa, "primitiva" e "civilizada", e demais discriminações ou preconceitos; compreender a cultura a partir da ótica dos direitos e liberdades do cidadão, garantia de igualdade de condições, universalização do 
acesso, intercâmbio e a interação, modelos sustentáveis, ampliar o mercado de trabalho, o emprego e a geração de renda, promovendo o equilíbrio regional, a isonomia de competição entre os agentes. Entretanto em nenhum momento o documento diz como fazer com que esses processos complexos aconteçam. Caberá à construção dos Planos de Cultura, tanto o PNC quanto os territoriais, desenvolver métodos concretos para que isso um dia ocorra concretamente.

Ao dizer que é necessária a ampliação do acesso e a diversidade, o Estado propõe um tipo de visão de gestão da cultura. No trecho acima da lei do PNC estão elencadas as relações da esfera político-cultural com suas esferas de influência recíproca: econômica, política, social, educacional, do trabalho, do cotidiano, legislativa etc. Ao apontar que a cultura pode (e deve) ser um fator que gera renda, trabalho, intercâmbio social, entre outros fatores, percebe que a cultura vista pelo olhar antropológico amplia o escopo do MinC nas responsabilidades para com o Estado e a sociedade de forma mais geral. Contudo, é necessário questionar mais uma vez como ampliar essa responsabilidade social e de ação com uma verba tão pequena e sem uma real alteração no modelo de financiamento? Ou mesmo como se relacionar com outras esferas para que algumas dessas ações aconteçam de modo transversal?

No anexo da lei do PNC, o tema diversidade cultural recebe um capítulo específico para seu desenvolvimento. O primeiro parágrafo do capítulo II traz uma reflexão sobre a situação histórica da formação sociocultural brasileira:

A formação sociocultural do Brasil é marcada por encontros étnicos, sincretismos e mestiçagens. É dominante, na experiência histórica, a negociação entre suas diversas formações humanas e matrizes culturais no jogo entre identidade e alteridade, resultando no reconhecimento progressivo dos valores simbólicos presentes em nosso território. Não se pode ignorar, no entanto, as tensões, dominações e discriminações que permearam e permeiam a trajetória do País, registradas inclusive nas diferentes interpretações desses fenômenos e nos termos adotados para expressar as identidades. (BRASIL, 2010, grifos meus)

O trecho evidencia a desigualdade, a dominação das elites, o preconceito, e a diversidade étnica e racial brasileira, e as tensões resultantes dessa diversidade, como justificativa à necessidade da ampliação do acesso e da aplicação desta nova política. O capítulo sobre a diversidade elenca 68 ações de "modo a atender à Convenção da Diversidade Cultural da Unesco".

(...) a adequação da legislação e da institucionalidade da cultura brasileira de modo a atender à Convenção da Diversidade Cultural da Unesco, firmando a diversidade no centro das políticas de Estado e como elo de articulação entre segmentos populacionais e comunidades nacionais e 
internacionais. (BRASIL, 2010)

Nas 68 ações para a diversidade no PNC, destacamos trechos em que é possível observarmos diferentes grupos, comunidades, setores e linguagens contempladas nas ações:

(2.1) (...) os indígenas, os afro-brasileiros, os quilombolas, outros povos e comunidades tradicionais e moradores de zonas rurais e áreas urbanas periféricas ou degradadas; aqueles que se encontram ameaçados devido a processos migratórios, modificações do ecossistema, transformações na dinâmica social, territorial, econômica, comunicacional e tecnológica; e aqueles discriminados por questões étnicas, etárias, religiosas, de gênero, orientação sexual, deficiência física ou intelectual e pessoas em sofrimento mental; (2.1.3) (...) mestres de ofícios; (2.1.5) Capacitação - arte e cultura africana, afro-brasileira, indígena e de outras comunidades não hegemônicas; (2.1.6) (...) mapeamento, documentação e preservação das terras das comunidades quilombolas, indígenas e outras comunidades tradicionais; (2.1.7) Mapear, preservar, restaurar e difundir os acervos históricos das culturas afro-brasileira, indígenas e de outros povos e comunidades tradicionais; (2.1.10) (...) elaboração de inventários sobre a diversidade das práticas religiosas; (2.1.12) (...) políticas públicas de cultura destinadas ao segmento LGBT; (2.1.14) (...) políticas públicas de cultura voltadas aos direitos das mulheres; (2.4.1) Incentivar e promover a qualificação da produção do design, da arquitetura e do urbanismo contemporâneos; (2.4.2) (...) ações integradas de reabilitação de áreas urbanas centrais; (2.5.13) Promover e fomentar iniciativas de preservação da memória da moda, do vestuário e do design no Brasil; (2.6.2) Realizar ação integrada para a instituição de instrumentos de preservação, registro, salvaguarda e difusão de todas as línguas e falares usados no País, incluindo a Língua Brasileira de Sinais - LIBRAS; (2.6.3) (...) promoção e proteção das línguas indígenas e de outros povos e comunidades tradicionais; (2.6.4) Promover as culinárias, as gastronomias, os utensílios, as cozinhas e as festas; (2.7.1) Promover (...) seminários, à publicação de livros, revistas, jornais e outros impressos culturais, ao uso da mídia eletrônica e da internet, para a produção e a difusão da crítica artística e cultural; (2.7.2) (...) pesquisas e publicações editoriais na área de crítica, teoria e história da arte, patrimônio cultural e projetos experimentais; (2.7.4) (...) tecnologias de informação e comunicação, como as redes sociais; (2.7.6) (...) parceria com os órgãos de educação e ciência e tecnologia e pesquisa; (2.7.11) (...) mapeamento dos circuitos de arte digital; (2.7.12) (...) impacto sociocultural da programação dos meios de comunicação; (2.7.16) Capacitar educadores e agentes multiplicadores para a utilização de instrumentos voltados à formação de uma consciência histórica crítica. (BRASIL, 2010)

No Capítulo 5 do anexo da lei do PNC, que trata da participação social, além destes já detalhados, encontramos outros grupos elencados:

(5.4.2) (...) promovam a participação de jovens e idosos e representantes dos direitos da criança, das mulheres, das comunidades indígenas e de outros grupos populacionais sujeitos à discriminação e vulnerabilidade social; (BRASIL, 2010)

Neste tópico, propomos observar a quem o SNC se destina. Nos trechos acima, 
desenvolvidos para detalhar os temas diversidade cultural e participação social, é possível perceber os dezenove setores previstos no plano e no CNPC. São setores no CNPC / MinC: audiovisual, arquivos, arquitetura e urbanismo, artesanato, arte digital, artes visuais, cultura afro brasileira, cultura indígena, cultura popular, circo, dança, design, literatura, moda, música, patrimônio imaterial, patrimônio material e teatro. A ampliação de escopo também se reflete na menção a outros grupos transversais ${ }^{165}$ : mulheres, LGBT, idosos, crianças, jovens, regiões das cidades (centro, periferias, urbano e rural), tipos de equipamentos, línguas, gastronomia, festas, crítica de arte, arquitetura e urbanismo, moda, mídias em geral etc. A amplitude do escopo de grupos identitários ou mesmo de comunidades, ou de linguagens artísticas aparece como uma "lista de checagem" do sistema, em que, quando de sua escrita, buscou-se não excluir nenhum grupo cultural desse "guarda-chuva". É possível dizer que este documento, o PL do PNC, apresenta-se como primeiro de todo esse código de marcos legais do SNC, que apresentam uma maior diversidade e o olhar ampliado para a cultura.

No enunciado do artigo 216-A da Constituição relativo ao Sistema, mais especificamente, não encontramos vestígios de grupos ou comunidades culturais. $\mathrm{O}$ discurso do artigo demonstra a vocação do enunciado do Sistema para regular a gestão pública da cultura de forma mais geral, tendo como centro de valores as ações e atribuições do Sistema, como "processo de gestão e promoção conjunta de políticas públicas de cultura". (EC n.71, 2012, art. 216-A) Contudo, ainda que o trecho da constituição relativo ao SNC não traga o detalhamento de grupos que devem ser inseridos no sistema, o artigo serve como vetor dialógico e transversal entre os agentes envolvidos para seu desenvolvimento. Isso fica evidenciado nos diversos momentos do texto em que são mencionadas as ideias de interação, democratização e compartilhamento. E principalmente no princípio número 1 do $\mathrm{SNC}$, que trata da "diversidade das expressões culturais" (idem).

De nosso corpus principal, temos ainda o decreto presidencial que busca regulamentar o Sistema Federal de Cultura e instituir o CNPC (decreto 5520/2005 e seus dois decretos complementares: $n^{\circ} 6.973$, de 2009 e n 8.611, de 2015). No enunciado último, de 2015, estão elencados diversos grupos, linguagens, setores. O decreto versa sobre a composição de cadeiras do poder público no CNPC:

(...) vinte e quatro representantes do Poder Público federal, distribuídos da seguinte forma: a) dez do Ministério da Cultura; b) um da Casa Civil da Presidência da República; c) um do Ministério da Ciência e Tecnologia; d) um do Ministério das Cidades; e) um do Ministério do Desenvolvimento

\footnotetext{
${ }^{165}$ Afirmamos como grupos transversais pois podem estar em todos os setoriais.
} 
Social e Combate à Fome; f) um do Ministério da Educação; g) um do Ministério do Meio Ambiente; h) um do Ministério do Planejamento, Orçamento e Gestão; i) um do Ministério do Turismo; j) um da SecretariaGeral da Presidência da República; k) um do Ministério das Comunicações; 1) um do Ministério do Trabalho e Emprego; m) um do Ministério das Relações Exteriores; n) um da Secretaria de Comunicação Social da Presidência da República; o) um da Secretaria de Políticas de Promoção da Igualdade Racial da Presidência da República; (BRASIL, 2005)

Dos representantes da sociedade civil que comporão o CNPC:

a) artes visuais; b) música popular; c) música erudita; d) teatro; e) dança; f) circo; g) audiovisual; h) literatura, livro e leitura; i) arte digital; j) arquitetura e urbanismo; k) design; ; l) artesanato; m) moda; e ; n) cultura hip hop; VII - onze representantes da área do patrimônio cultural, indicados pelos membros da sociedade civil nos colegiados setoriais afins ou, na ausência destes, por escolha do Ministro de Estado da Cultura, a partir de lista tríplice organizada pelas associações de cada uma das seguintes áreas, de acordo com as normas definidas pelo Ministério da Cultura: a) expressões artísticas culturais afro-brasileiras; b) culturas dos povos indígenas; c) culturas populares; d) arquivos; e) museus; f) patrimônio material; g) patrimônio imaterial; h) capoeira; i) cultura alimentar; j) culturas quilombolas; k) culturas dos povos e comunidades tradicionais de matriz africana; VIII - três personalidades com comprovado notório saber na área cultural, de livre escolha do Ministro de Estado da Cultura; IX - um representante de entidades de pesquisadores na área da cultura, a ser definido, em sistema de rodízio ou sorteio, pelas associações nacionais de antropologia, ciências sociais, comunicação, filosofia, literatura comparada e história; X-um representante do Grupo de Institutos, Fundação e Empresas-GIFE; XI - um representante da Associação Nacional das Entidades de Cultura-ANEC; XII - um representante da Associação Nacional dos Dirigentes das Instituições Federais de Ensino Superior ANDIFES; XIII - um representante do Instituto Histórico e Geográfico Brasileiro - IHGB; e XIV - um representante da Sociedade Brasileira para o Progresso da Ciência - SBPC. (idem)

A presença de representantes do Estado e da sociedade civil elencados nos trechos acima evidencia mais uma vez a busca pelo contato mais próximo da cultura com outros setores. No trecho sobre as cadeiras do poder público é possível perceber a intenção dessa transversalidade e da relação com outros setores públicos. Sobre os representantes da sociedade civil, vemos que não apenas os representantes dos dezenove setores do Minc tem cadeiras garantidas no CNPC, mas também intelectuais de filosofia, história, antropologia, comunicação; empresários de institutos, fundações e empresas; dirigentes de ensino superior e da área de pesquisa acadêmica. A diversidade de grupos evidenciada nos principais enunciados do SNC pode indicar que de fato houve uma busca pela ampliação do escopo do alcance das ações do Ministério através das novas políticas propostas. Todavia, é necessário salientar que apenas a presença destes grupos nestes documentos não garante a democrática e 
igualitária destinação das verbas, nem que as ações projetadas nos planos de fato sejam realizadas a contento, ou mesmo promovam a concreta inclusão dos grupos até então excluídos. A plena realização das ações de inclusão, ampliação de acesso e diversidade cultural apenas poderão ser de fato garantidas por meio do compromisso dos governantes de forma ética em relação aos pressupostos elencados nos planos de cultura criados e escritos pelas diversas mãos e pensados pelas diversas consciências ao longo do processo. Para que isso aconteça será necessária principalmente a descentralização dos recursos.

A democracia cultural, pensada como forma de inclusão que garante não apenas o acesso à cultura, mas principalmente a garantia de um amplo e irrestrito acesso aos meios de produção cultural e às verbas, aplicados em toda diversidade de grupos e territórios, é de fato o grande desafio que esta política tem pela frente. O pesquisador brasileiro Teixeira Coelho apresenta a diferença entre democracia cultural e democratização cultural:

(...) democratização da cultura é, na essência, um processo de popularização das chamadas artes eruditas (artes plásticas, ópera música erudita, etc) $\mathrm{Na}$ base desses programas de popularização está a ideia de que diferentes segmentos de uma população gostariam de ter acesso a esses modos culturais - ou poderiam ser persuadidos a expor-se a eles - caso se recorresse aos instrumentos adequados de educação, sensibilização e facilitação dessas práticas. (...) A essa concepção opõe-se a da democracia cultural, fundada no argumento de que programas de popularização como os defendidos pela tese da democratização cultural não vão nem longe, nem fundo o suficiente e se baseiam em concepções discutíveis do que é bom ou mau em cultura, do que é ou não um valor cultural, do que deve e pode ou não deve ser consumido. Para os defensores da democracia cultural, a questão principal não reside na ampliação da população consumidora, mas na discussão sobre quem controla os mecanismos de produção cultural e na possibilitação do acesso à produção da cultura em si mesma. Políticas de democracia cultural se apoiariam não na noção de serviços culturais a serem prestados á população mas no projeto de ampliação do capital cultural de uma coletividade no sentido mais amplo dessa expressão. (COELHO, 2012, pp. 162 - 163)

A presença de outros setores nos enunciados do sistema demonstra que não cabe apenas ao MinC e à esfera político-cultural esta responsabilidade, será necessário legitimar os processos na sociedade civil como um todo. A construção do sistema parte de uma relação entre os poderes executivo e legislativo com a sociedade civil e diversos setores públicos. Ao propor a gestão da cultura como um direito social, estruturada pelo SNC, compreende a complexidade do setor que deve estar em contato com outras áreas. Entretanto, esta nova forma de enxergar a gestão cultural acaba destinando responsabilidades para agentes diversos, inclusive de outras esferas, criando uma rede que necessita de consistentes ações éticas de formação, informação e compartilhamento de reflexões e fazeres. 
Parte 3:

A ARQUITETÔNICA DO GÊNERO DISCURSIVO PLANO DE CULTURA 


\section{CAPÍTULO 5: A RESPONSABILIDADE ÉTICA E O CRONOTOPO: ATOS NO TEMPO-ESPAÇO DO SISTEMA}

Ao propormos a reflexão acerca de uma arquitetônica do Plano de Cultura, buscamos compreender elementos deste, que a partir de agora chamaremos de gênero discursivo, dada sua produtividade nos últimos anos e outros fatores que descreveremos ao longo da parte terceira da tese.

Neste quinto capítulo, faremos a reflexão e a análise de categorias essenciais para pensar a arquitetônica: o tempo e o espaço, e suas relações de sentido com os atos, agentes e objetos em construção.

Por meio das reflexões bakhtinianas sobre o cronotopo, ética e responsabilidade, analisaremos como os planos de cultura são pensados, escritos e construídos dentro das políticas públicas de cultura brasileiras. Nos tópicos seguintes, analisaremos como estes conceitos iluminam a construção do Plano Nacional de Cultura, que tem caráter mais abrangente, e no Plano Municipal de Cultura da cidade de São Paulo, que focaliza as ações concretas no tempo-espaço, nas pontas do sistema ${ }^{166}$. Assim, iniciaremos a reflexão sobre a arquitetônica do que passamos a chamar de gênero do discurso plano de cultura.

\section{1 - O cronotopo bakhtinano na esfera político-cultural brasileira e a construção do gênero Plano de Cultura}

Ao propormos a reflexão sobre a ética, o tempo e o espaço entendemos a importância destes fatores não apenas teoricamente, mas principalmente na gestão do Sistema, principalmente no que tange aos planos de cultura que são propostas decenais. No início do texto Arte e Responsabilidade, Bakhtin começa sua reflexão com o seguinte trecho:

Chama-se mecânico ao todo se alguns de seus elementos estão unidos apenas no espaço e no tempo por uma relação externa e não os penetra a unidade interna do sentido. As partes desse todo, ainda que estejam, lado a lado e se toquem, em si mesmas são estranhas umas às outras. Os três campos da cultura humana - a ciência, a arte e a vida - só adquirem unidade no indivíduo que os incorpora à sua própria unidade. (...) o que garante o nexo interno entre os elementos do indivíduo? Só a unidade da responsabilidade. (BAKHTIN, 2010b, pp. XXXIII - XXXIV)

Aqui Bakhtin aponta os elementos que nos interessam neste tópico: tempo, espaço e

\footnotetext{
${ }^{166}$ Neste momento da tese optamos por não analisar o Plano Estadual de Cultura de São Paulo por conta de sua não aprovação enquanto marco legal e diversos atrasos temporais.
} 
responsabilidade. Entretanto, deixa claro que estes elementos só possibilitam sentido numa dada esfera cultural por meio da responsabilidade do indivíduo em relação com o todo. E como toda sua teoria apresenta, este ser e o sentido só existem em relação a outros indivíduos inseridos em contextos.

Os elementos da arquitetônica de qualquer unidade de cultura são constituídos pelo tempo, espaço, agentes envolvidos, intenções e relações que a constroem. O tempo histórico existe nas relações sociais e nos atos responsáveis que envolvem os indivíduos em cada situação de comunicação, seja na vida, seja na arte, seja na ciência ou em qualquer outra esfera da atividade humana.

Ao observarmos nosso objeto de análise, percebemos inicialmente que o fator tempoespaço é crucial como ponto de partida desta reflexão. Ao compreender o sistema de cultura como uma composição de estrutura CPF, Conselhos, Planos e Fundos, a arquitetônica do SNC deve ser analisada por todos estes elementos de uma só vez, que são criados e inseridos no tempo e no espaço e em relação aos agentes do sistema. Assim, é possível dizer que o cronotopo está diretamente relacionado com a arquitetônica do sistema e este adquire sentido no contexto e nos processos históricos que buscamos aqui retratar.

As categorias de tempo e espaço nos auxiliam a compreender como é composto o cronotopo bakhtiniano e a estrutura da arquitetônica como sistema do pensamento, da razão pura, que para Bakhtin, do pensamento é transformado em ato responsável na razão prática. Bakhtin constrói a arquitetônica como uma "ponte" que vai da razão pura para a razão prática utilizando o ato ético e enunciados concretos. E esse ato é sempre único por conta de seu tempo, espaço e autor.

No ensaio "Formas de tempo e de cronotopo no romance", o cronotopo bakhtiniano pode ser entendido inicialmente como a "fusão dos indícios espaciais e temporais num todo compreensivo e concreto (...) o espaço reveste-se de sentido e é medido com o tempo" (BAKTIN, 2010e, p. 211) Ainda que a teoria do cronotopo tenha sido desenvolvida para a esfera literária, assim como Bakhtin mesmo salienta, pode ser utilizada em outras esferas.

A ciência, a arte e a literatura têm relação com os elementos semânticos que, como tais, não resistem a definições temporais e espaciais (eles são o objeto de nossa reflexão abstrata). É uma formação abstratamente conceitual, indispensável à formalização e ao estudo estritamente científico de muitos fenômenos concretos. Mas os significados existem não apenas na reflexão abstrata; (...) Ademais qualquer fenômeno, nós, de alguma forma, o interpretamos, ou seja, o incluímos não só na esfera de existência espaçotemporal, mas também na esfera semântica. Essa interpretação compreende também um elemento de apreciação. (...) para entrar na nossa experiência 
(experiência social, inclusive), esses significados, quaisquer que eles sejam, devem receber uma expressão espaço-temporal qualquer, ou seja, uma forma sígnica audível e visível por nós (um hieróglifo, uma formula matemática, uma expressão verbal e linguística, um desenho, etc). (...) sem esta expressão espaço-temporal é impossível até mesmo a reflexão mais abstrata. Consequentemente, qualquer intervenção na esfera dos significados só se realiza através da porta dos cronotopos. (BAKHTIN, 2010e, pp. 361-362)

O cronotopo é um fator essencial em nossa reflexão já que estamos lidando com enunciados que projetam atos éticos através de outros atos para o tempo futuro numa dada conjuntura em que cada qual tem autores e leitores destinatários com diferentes exotopias, em diferentes espaços-tempo. No último capítulo sobre o Cronotopo, Bakhtin traz a seguinte reflexão:

(...) de que ponto espaço-temporal observa o autor os acontecimentos por ele representados? Primeiramente, ele os observa a partir de sua contemporaneidade inacabada em toda a sua complexidade e completude, encontrando-se ele mesmo como que numa tangente de realidade representada. (...) o mundo representado, mesmo que seja realista e verídico, nunca pode ser cronotopicamente identificado com o mundo real representante, onde se encontra o autor-criador dessa imagem. (BAKHTIN, 2010e, p. 360)

Aqui Bakhtin traz a reflexão sobre a importância de compreendermos que os autores não têm a noção de realidade acabada, pois são parte de um acontecimento e com isso lhes é impossível dar um acabamento no presente. A exotopia, ou o lugar de onde observo, também deve levar em conta o tempo não apenas o espaço. Para os futuros leitores destinatários de determinado enunciado nem sempre houve a chance destes terem sido parte deste período histórico, dos processos de criação do enunciado ou mesmo do acontecimento narrado. Ao narrá-los, ou mesmo ao escreverem sobre algum fato passado ou ação futura, não terão a mesma visão exotópica deste fato que tiveram aqueles que estavam ou estarão presentes, num outro ponto do tempo-espaço. A relação entre a realidade representada num enunciado que projeta algo num tempo futuro é ainda mais abstrata, já que este ainda não aconteceu, não chegou e tudo o que for dito acerca dele é mera suposição.

Bakhtin apresenta ao longo de seu ensaio uma série de categorias cronotópicas que achamos relevante evidenciar para iniciarmos nossa reflexão. Inserimos outras categorias para ampliar a possibilidade de investigação e reflexão:

a) Tempo: pausa, momento, ruptura, evento, acontecimento, hiato, ciclo, ordem temporal, momentos que se repetem, localização histórica no tempo, tempo vazio (sem vestígios / abstrato), organização temporal, segmento temporal, curso de acontecimentos 
(normal, pragmáticos ou submetidos à causalidade), acaso, coincidência casual, concomitância, antes, depois, duração, passado, presente, futuro, ano, dia, mês, hora, ordem dos fatos, ritmo, desenvolvimento histórico, momentos composicionais e temáticos, grande tempo, pequeno tempo, efêmero, tempo biográfico, todo da existência, agora, hoje etc.

b) Espaço: cidade, campo, centro, periferia, rua, endereço, distância, proximidade, movimento, inércia, permanência, localização, extra-localização, lugar distante, lugar desconhecido, acesso ao lugar, território, obstáculos espaciais, confinamento, isolamento, movimento, possibilidade de mudança e transferência de lugar, local nomeado, caminho, ponto de encontro, espaço geográfico, fronteiras geográficas, fronteiras culturais, horizonte social, local aberto, local fechado, local público, local privado, região, estado, país, continente, ponto de vista (de onde se observa) etc.

c) Outras categorias relacionadas: costumes (de época), transformação / metamorfose, identidade, folclore, tradições, desenvolvimento, atraso, adiantamento, alternância, sucessão, processo, gerações, estações do ano, herança, destino, gênesis, devir, cotidiano, rotina, existência, cadeia produtiva, estado 1 - estado 2, imprevistos, série histórica, caminho da vida, situação, posição etc.

Bakhtin ainda elenca três tipos específicos de cronotopos observados nos enunciados literários: cronotopo de encontro, de contato, de diálogo (encontros sociais organizados). Para ele, os significados dos cronotopos dos gêneros literários podem ser: temáticos, enquanto centros organizadores dos principais acontecimentos temáticos (no caso do romance), ou figurativo, em que o tempo adquire um caráter sensivelmente concreto, os acontecimentos se concretizam, ganham corpo.

A partir dessas reflexões questionamos: Quais seriam os significados dos cronotopos específicos de uma esfera tão peculiar e complexa como a político-cultural? Estariam esses cronotopos relacionados com os atos responsáveis futuros que cada enunciado nomeia enquanto acontecimento?

Cronos em grego significa tempo e topos, lugar, espaço. Nas políticas culturais, e mais especificamente dentre os enunciados relativos ao SNC, cada ato, cada enunciado, com seus milhares de fios dialógicos, está inserido num ponto do espaço-tempo e pode projetar outra possibilidade de ato em outro ato espaço-tempo. Essa projeção de atos é uma caraterística da esfera política-cultural que se propõe a criar possibilidades futuras para o fomento à cultura. Isso nos remete à reflexão sobre o cronotopo em que Bakhtin diz "ele os observa a partir de sua contemporaneidade inacabada em toda a sua complexidade e completude, encontrando-se 
ele mesmo como que numa tangente de realidade representada" (BAKHTIN, 2010e, p. 360).

Em ambos os pontos tempo-espaciais, os centros de valores são representados pelos agentes responsáveis, que dão sentido a esses atos gerando enunciados concretos, novas unidades culturais e arquitetônicas. Ao construírem essas novas políticas culturais, por meio de enunciados de caráter oficial (legitimados na esfera estatal), os diversos agentes envolvidos nos atos (tanto individuais quanto coletivos) criam e geram sentido por meio da deliberação, da interação, da troca de ideias e de visões de mundo.

Os atos criativos previstos no SNC, principalmente a partir de ações propostas nos planos de cultura, buscam ser atos de agentes indivíduos ou coletivos, em determinado tempoespaço, feitos coletivamente, ainda que com legitimidade do Estado. Buscam projetar a possibilidade de outros atos situados em outros pontos do tempo-espaço, para que outros agentes-indivíduos (principalmente representantes do Estado) desenvolvam políticas necessárias a partir de demandas sociais.

Propomos assim um cronotopo da esfera político-cultural, como no esquema a seguir, e que busca refletir acerca da construção de um Plano de Cultura.

Figura 18: Cronotopos dos planos de cultura na esfera político-cultural

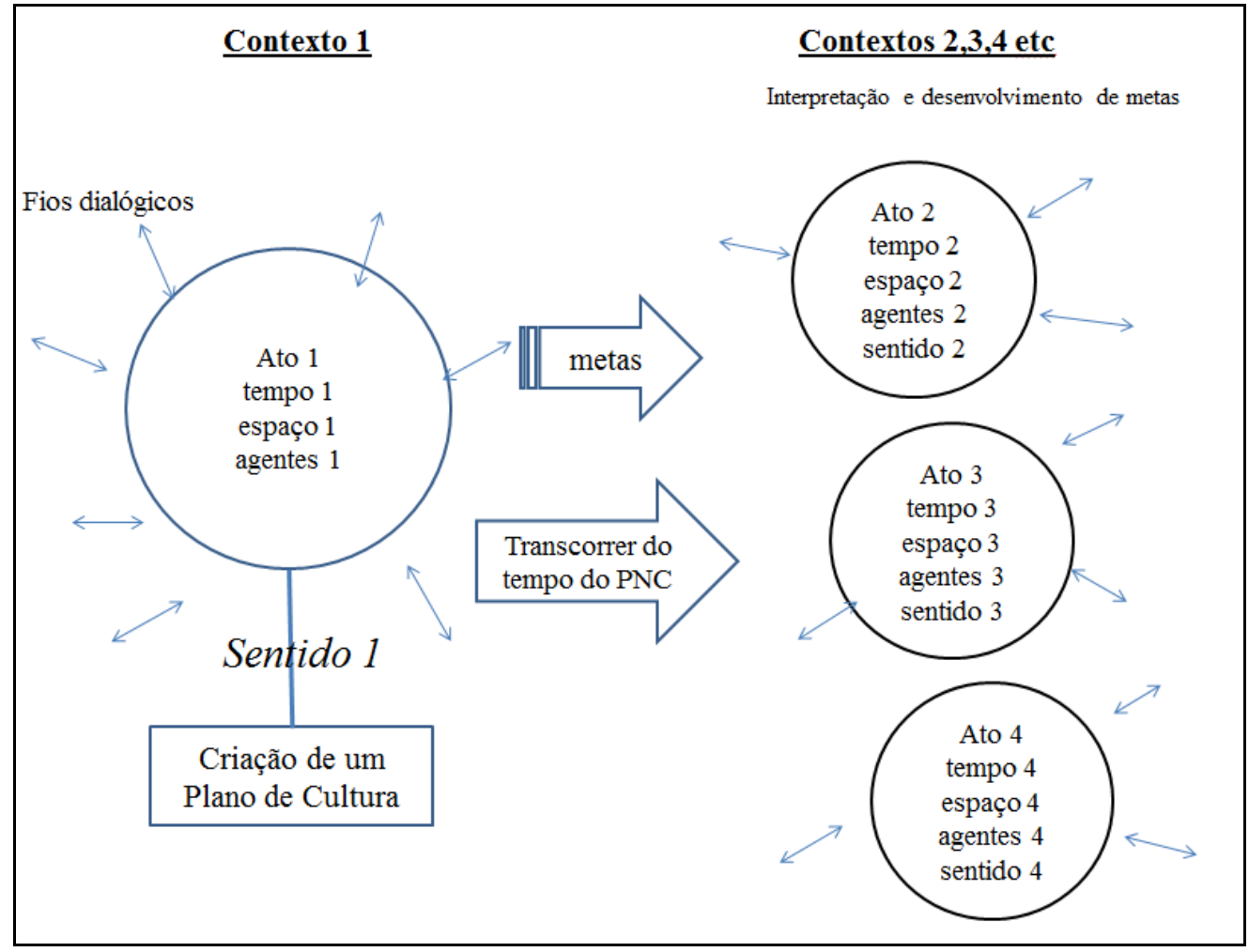

Na imagem, observamos primeiramente o contexto 1, em que temos a produção de um plano de cultura no tempo 1 . Este ato 1 está em contato com infinitos fios dialógicos que 
influenciaram sua realização (diagnósticos, adesão ao SNC, interesses políticos, etc). O tempo 1 é o enunciado de um plano de cultura aprovado, mas é pleno de pequenos tempos 1A, 1B, $1 \mathrm{C}$ etc, já que leva meses para ser criado e definitivamente publicado. O sentido é criado no ato 1 , no todo do enunciado, isto é, em sua arquitetônica, por meio da relação entre os agentes (autores), o espaço e o tempo (situação de comunicação e momento histórico) e do futuro projetado nas metas, objetivos e ações. Esse contexto 1 acontece num horizonte social mais amplo que também influencia as escolhas e questões pontuadas no próprio enunciado que está sendo criado. Nos contextos futuros 2, 3, 4 etc., temos os momentos de interpretação e desenvolvimento desse futuro projetado: as metas elencadas no plano de cultura criado e escrito no contexto 1. Nos contextos futuros teremos outros agentes, outros espaços, outros tempos, outros contextos em diálogo e por isso também outros sentidos serão criados. Outros fios dialógicos tocarão cada um dos atos futuros e a responsividade pode ser a mais variada possível. O horizonte social mais amplo também será outro e assim as oportunidades mudam. Os cronotopos encontrados nos enunciados produzidos no contexto 1 poderão auxiliar os agentes dos tempos 2,3 , 4, etc. a se orientarem melhor sobre o que estava sendo proposto e como fazer. Entretanto, ainda que estes cronotopos façam marcações de tempo-espaço, apenas o ato ético responsável dos agentes nos contextos futuros poderá garantir que sejam desenvolvidos outros atos responsáveis, o mais próximo do sugerido no enunciado produzido no contexto 1 .

Nos Planos de Cultura, podemos observar uma lista de ações a serem executadas num período de 10 anos, porém, os autores destes enunciados, na maioria das vezes, não serão os autores das ações futuras previstas nos textos. A responsabilidade das ações futuras é quase sempre do "outro" e em um tempo e espaço futuro desconhecido, ainda que estejam previstas ações decenais. Nunca se sabe quando determinada ação propoista num plano será de fato realizada, ainda que estes enunciados tragam metas com descrição de ações pontuando datas específicas. Porém acreditamos que quanto mais cronotopos estiverem presentes nesses enunciados, categorizados por signos que indiquem tempo e / ou espaço, mais serão cobradas as responsabilidades e prazos das ações dos outros nos contextos futuros.

No caso do Plano Nacional de Cultura, percebemos já no início da observação um atraso relativo em seu desenvolvimento. A PEC do PNC foi aprovada em 2005, sua lei regulamentar em 2010, ano tido como inicial em sua vigência decenal (2010-2020), porém as 53 metas do PNC foram aprovadas apenas em dezembro de 2011 e começaram a ser amplamente divulgadas em 2013 após a aprovação da PEC do SNC no final de 2012. Se a 
ideia era a implantação de metas a serem cumpridas em 10 anos, o processo sofre um relativo atraso temporal já em seu início e o cronotopo mais geral do PNC perde o "timing" de realização. Nestes primeiros anos de PNC, a maioria dos estados e municípios ainda estavam tentando se adequar à nova realidade proposta. Como vimos, apenas no ano de 2012 atingimos um número razoável de estados como parte do Sistema (85\%) e foi apenas em 2014 que passamos do patamar de mais de 50\% dos municípios inscritos no Sistema com Acordos assinados. Como é possível desenvolver um Plano Nacional de Cultura com 53 metas, em que muitas delas propõem objetivos a cumprir em até 10 anos quando nas pontas os sistemas territoriais ainda estão em fase de adaptação à mudança? Estariam os agentes envolvidos nos processos cientes de que a maior parte das metas escritas no documento seriam impossíveis de cumprir até 2020 justamente por conta da dependência de uma série de fatores externos?

Ao retornarmos às reflexões de Bakhtin observamos que os autores não têm a noção de realidade acabada, pois são parte de um acontecimento e, com isso, lhes é impossível dar um acabamento no presente. A extra-localização ou exotopia é o foco do olhar situado, do lugar de onde observo, atuo e de onde dou meu acabamento. Essa exotopia, ou extralocalização ou excedente de visão ${ }^{167}$ deve levar em conta o tempo e espaço. Apenas ao agente, do seu lugar único e singular, é possível enxergar o mundo como ele vê. Ninguém mais vê o mundo, ou algo, como ele vê.

Quando contemplo no todo um homem situado fora e diante de mim, nossos horizontes concretos efetivamente vivenciáveis não coincidem. Porque em qualquer situação ou proximidade que esse outro que contemplo possa estar em relação a mim, sempre verei e saberei algo que ele, da sua posição fora e diante de mim, não pode ver: as partes de seu corpo inacessíveis a seu próprio olhar - a cabeça, o rosto, e sua expressão - , o mundo atrás dele, toda uma série de objetos e relações que, em função dessa ou daquela relação de reciprocidade entre nós, são acessíveis a mim e inacessíveis a ele. Quando nos olhamos, dois diferentes mundos se refletem na pupila dos nossos olhos. Assumindo a devida posição, é possível reduzir ao mínimo essa diferença de horizontes, mas para eliminá-la inteiramente urge fundir-se em um todo único e tornar-se uma só pessoa. Esse excedente da minha visão, do meu conhecimento, da minha posse - excedente sempre presente em face de qualquer outro indivíduo - é condicionado pela singularidade e pela insubstituibilidade do meu lugar no mundo: porque nesse momento e nesse lugar, em que sou o único a estar situado em dado conjunto de circunstâncias, todos os outros estão fora de mim. Essa distância concreta só de mim e de todos os outros indivíduos - sem exceção - para mim, e o excedente da minha visão por ele condicionado em relação a cada um deles (...) são superados pelo conhecimento, que constrói um universo único e de

\footnotetext{
${ }^{167}$ Nas diferentes traduções brasileiras das obras de Bakhtin feitas pelo pesquisador Paulo Bezerra, os três termos são utilizados para o conceito. Segundo o tradutor, o termo russo é vnenakhodímost que significa literalmente "situado fora" .
} 
significado geral, em todos os sentidos totalmente independente daquela posição única e concreta ocupada por esse ou aquele indivíduo (...) Porém esse mundo único do conhecimento não pode ser preenchido pela diversidade da qualidade da existência, da mesma forma como percebemos uma paisagem, uma cena dramática, um edifício, etc, pois a percepção efetiva de um todo concreto pressupõe o lugar plenamente definido do contemplador, sua singularidade e possibilidade de encarnação; o mundo do conhecimento e cada um de seus elementos só podem ser supostos. (BAKHTIN, 2010b, pp. $21-22$ )

Ao pensarmos o objeto desta pesquisa fica evidente que quem escreve os Planos de Cultura não sabe ao certo quem os executará ao longo do decênio e nem quando, pois os governos são transitórios e as instabilidades políticas iminentes. Esses agentes também têm uma visão única do futuro que nem sempre é a mesma daqueles que estarão no tempo adiante. Os leitores e agentes que poderão (ou não) desenvolver as ações previstas de um determinado Plano de Cultura não necessariamente fizeram parte da criação do Plano vigente. Os agentes de execução dos Planos são os "outros" desta relação arquitetônica, poderão vir de outras cidades, outros estados. Mesmo em relação a planos territoriais como os Planos Municipais de Cultura, esses agentes não terão a mesma visão exotópica deste enunciado que tiveram aqueles que estavam presentes em sua escrita num ponto anterior do tempo-espaço.

Mesmo em curtos espaços de tempo, a realidade representada é ainda mais abstrata, já que o tempo futuro ainda não chegou, é contingente e tudo o que for dito acerca do futuro é mera suposição. As ações e os cronotopos previstos nos Planos estão sujeitos a toda e qualquer mudança de planos, que podem ocorrer por horizontes sociais impensáveis no contexto 1, por novos agentes imprevistos ou até mesmo pela substituição por propostas mais inovadoras. As ações determinadas num plano de cultura podem simplesmente não ocorrer, pois dependem de outras pessoas, de suas vontades políticas e econômicas e da conjuntura. Os enunciados projetados, os planos, são lidos e interpretados por destinatários presumidos num novo e desconhecido horizonte social.

Por esses motivos, acreditamos que a relação cronotópica com acontecimentos/atos projetados, no futuro ou no passado, deve ser tomada como um dos pontos de dificuldade e de destaque na criação de um enunciado do sistema. Neste caso, evidenciamos que os Planos de Cultura, que trazem mais cronotopos e o fator espaço-tempo como ferramenta central de sua estruturação e de gestão, terão mais chances de serem executados. Isso nos remete à questão da responsabilidade ética de seus autores, ao proporem ações para que outros realizem em um futuro contingente, e também à responsividade destes destinatários, que deverão cumprir 
metas a eles delegadas.

Aqueles que escrevem estes planos devem pensar com maior responsabilidade na possibilidade concreta de realização das propostas e nos fatores tempo-espaço em relação ao todo. As escrever enunciados que "projetam" políticas culturais no futuro devem pensar nas instabilidades da conjuntura, e na imprevisibilidade dos sujeitos que estarão à frente destas gestões. Quem escreve os planos de cultura transfere a responsabilidade de ato a outros num futuro contingente. Planos muito complexos ou mal redigidos terão chances ainda menores de serem compreendidos, aceitos e geridos pelas novas gestões.

Outro ponto essencial nas políticas públicas de cunho social é pensar no coletivo, na questão do bem comum e dos interesses de todos os cidadãos. De acordo com os enunciados do SNC, estas políticas devem ser descentralizantes e democratizantes, como o próprio artigo da constituição do sistema prevê. Há assim três fatores de imprevisibilidade futura: a conjuntura, os próximos agentes do executivo e a disponibilidade de recursos. Com a possível troca de governantes, característica das democracias, é provável que outros grupos políticos realizarão ações de políticas públicas determinadas nestes documentos escritos muitos anos antes. Num recorte decenal, temos pelo menos duas gestões e meia de governos e nem sempre serão dos mesmos partidos e de correntes político-ideológicas similares e, mesmo se forem, nem sempre apresentam agendas políticas idênticas.

Todavia, ainda que este modelo de política tenha sido proposto em uma gestão petista, conforme vimos anteriormente, os planos foram criados em interação com a sociedade civil. Independente de partidos políticos, estes agentes do setor cultural devem exigir o compromisso de atos responsáveis dos governantes futuros que realizarão concretamente as ações determinadas nestes enunciados. O que é dado e o que deve ser realizado no mundo e a coerência entre eles é ponto determinante no sucesso do que estes planos visam estabelecer. Quanto mais audacioso um plano de cultura, menor as chances dele ser realizado na íntegra, principalmente no início da implantação do sistema em que todos estão se "acostumando" com esse novo modo de fazer.

Ao falarmos de políticas públicas, é relevante destacarmos fatores do espaço e tempo. Como vimos anteriormente, no espaço temos: regiões, estados, cidades, municípios, bairros, centro, periferia, equipamentos (culturais), endereços, e pontos de localização de agentes (e suas exotopias). Nos Planos de cultura, alguns desses itens aparecem em diversos trechos dos enunciados e servem como balizadores para concretizar as projeções.

No tempo temos: o decênio dos planos de cultura, os quatro anos de vigência de 
governos eleitos (nos três âmbitos e que podem ser dobrados no caso de reeleição), os Planos Plurianuais (PPA) de vigência de quatro anos (iniciados a partir do segundo ano de gestão de cada governo eleito), os anos fiscais, a Lei Orçamentária Anual, os editais anuais de fomento às artes previstos em lei, etc.

Quando esses elementos são combinados, os cronotopos da esfera aparecem nitidamente, gerando um sentido de ação no tempo-espaço, como por exemplo numa proposição do tipo: "Construir uma biblioteca infantil no bairro de Ermelino Matarazzo até o ano de 2021."

Além do recorte quadrienal dos Planos Plurianuais e de governos, os cronotopos poderão aparecer nos enunciados como adjuntos adverbiais de tempo ou espaço, ou mesmo como traços cíclicos. Os autores de um plano, ao categorizar "prazo" e "local" para realizar determinada ação, determinam um importante fator de projeção de responsabilidade. Surge assim um cronotopo da esfera.

\subsection{O cronotopo e os desafios no Plano Nacional de Cultura}

Nas metas do Plano Nacional de Cultura (2010 - 2020), apresentadas em detalhamento e análise no site (pnc.culturadigital.br), encontramos alguns indícios gerais de que a categoria tempo-espaço foi utilizada desde o início como eixo norteador dos indicadores. Não existe uma homogeneidade de início de diagnóstico de números, nem de tempo de método de análise. Os indicadores servem como dados para avaliar se determinada meta foi ou não desenvolvida ao longo do tempo (e no espaço dos territórios).

Conforme já observamos, a primeira tentativa de criar um sistema colaborativo de indicadores e informações ( $1^{\mathrm{a}}$ versão SNIIC) sobre a situação de cada um dos pontos elencados no PNC não funcionou por motivos diversos: pouca divulgação, complexidade de inscrição e entendimento da proposta, falta de organização, pouca adesão de órgãos de cultura territoriais etc. Ao propor o segundo formato do SNIIC, o MinC compreendeu que seria necessário que os territórios se organizassem antes, para que o sistema de informações federal pudesse ser alimentado de maneira mais sistemática. Entretanto, um diagnóstico demanda investimento local para pesquisa territorial e setorial e os órgãos de cultura das cidades e estados carecem de investimentos dos executivos locais. Com isso, tornava-se cada vez mais impossível contabilizar a situação em que a cultura do país se encontrava em 2010 para saber onde chegaríamos em 2020, em termos quantitativos e qualitativos. Mesmo com a ajuda do IBGE, IPEA e de outros indicadores oficiais na construção destes dados, em um país com a 
gigante extensão territorial do Brasil, o fator tempo-espaço vs. indicadores era um desafio quase impossível de resolver rapidamente e influenciava na contabilidade cronotópica da política cultural.

Os dados apresentados em parte das metas geralmente demonstram fontes oficiais para metrificação e em alguns casos permitiram ao MinC partir de números mais consistentes. Entretanto, dois pontos ainda deveriam ser considerados: Como metrificar e projetar no tempo-espaço o que nunca foi contabilizado efetivamente? Como medir aspectos qualitativos da cultura no tempo-espaço, que norteiam algumas das metas elencadas?

Um bom exemplo do desafio, citado na questão 2, é a tabela apresentada pela Meta 3 que traz uma cartografia da diversidade das expressões culturais realizada em todo o território brasileiro e tem a intenção de produzir um mapa das expressões culturais e linguagens artísticas de todo o Brasil. No site do PNC, a meta aparece como concluída.

Figura 19: Dados Meta 3 Cartografia da diversidade das expressões culturais.

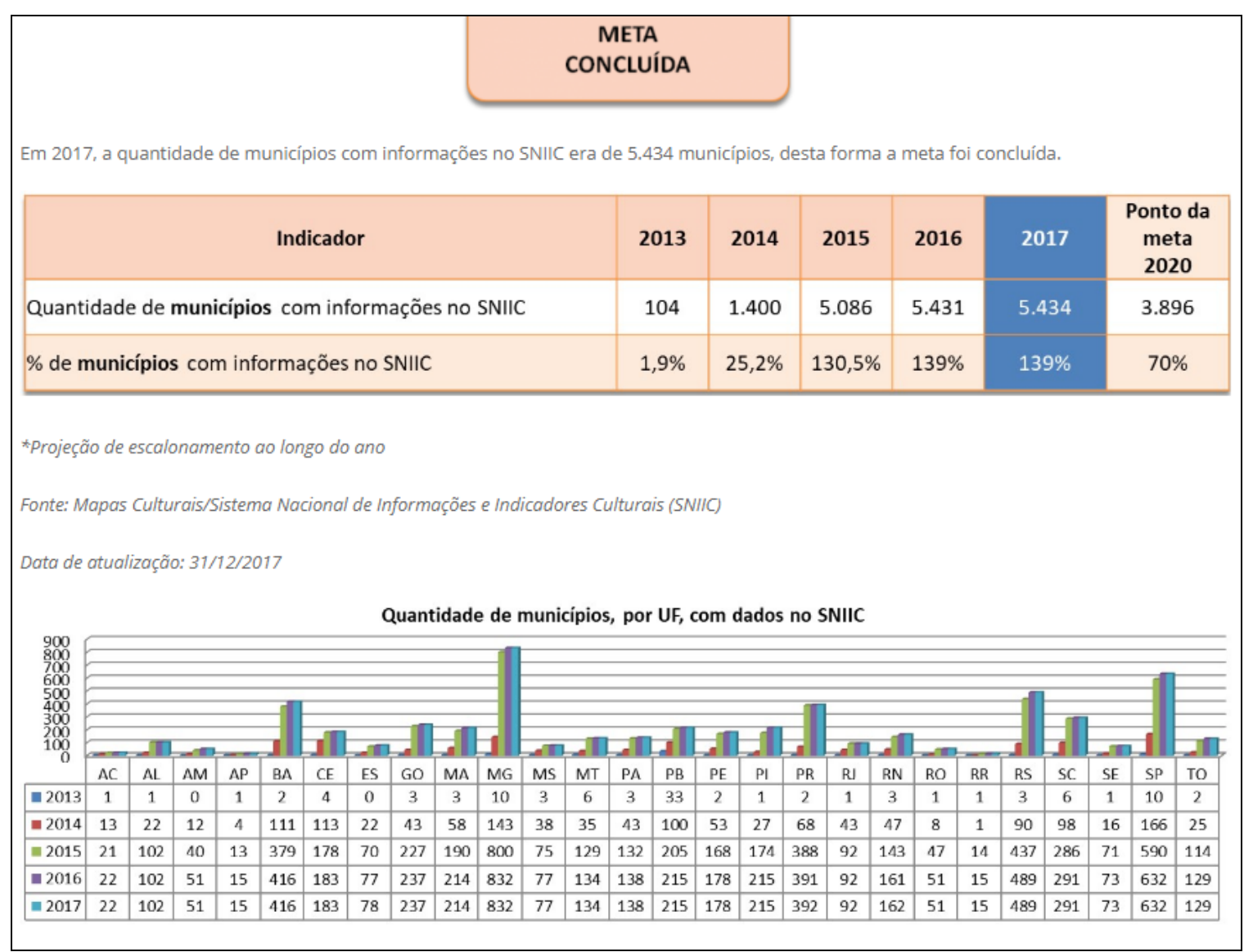

Fonte: site PNC.

Logo após a apresentação da tabela, podemos ver uma justificativa de análise da meta com o seguinte teor que evidencia que o sistema colaborativo de indicadores pode subverter a real intenção de quantificação e qualificação dos dados por ano. Os dados e a função real da 
meta se perdem no tempo e espaço e tornam-se mera abstração de análise ainda que tragam quantidades em cada um dos estados do país. A quantidade de municípios e os avanços do sistema em termos geográficos, não significa que este tenha de fato qualidade de informações que representem a diversidade cultural e a ampliação de abrangência nos territórios naquele tempo-espaço. Seria necessária a apresentação de dados reais que comprovem as realizações como, por exemplo, uma meta que prevê a criação de 100 bibliotecas em 10 anos e uma lista dessas bibliotecas a serem criadas (com determinação de prazo e local) e no futuro as que foram efetivamente construídas representando concretamente estes cronotopos da esfera.

\begin{abstract}
Apesar da meta ter sido concluída em 2015, o indicador desta meta mostrouse insuficiente para aferi-la. Pois, ao considerar as informações cadastrada no "Mapas Culturais" do SNIIC, é apresentada uma visão do que poderia ser considerado uma cartografia da diversidade cultural brasileira. É possível inferir que o aumento dos municípios se deu pelo fato de que outras bases de dados passaram a fazer parte do "Mapas Culturais", como o caso da Rede Cultura Viva e do Sistema Nacional de Bibliotecas Públicas. Ressaltamos há necessidade de se delimitar o que será considerado como "diversidade das expressões culturais" para a extração dos dados no referido sistema. Após essa definição é possível que haja uma alteração nos dados apresentados nesta meta ${ }^{168}$.
\end{abstract}

O Plano Nacional de Cultura possui um caráter mais genérico do que os planos territoriais para observar e destinar o desenvolvimento de políticas culturais. Por ser uma espécie de "guarda-chuva" de resultados e de indicadores territoriais e setoriais, o PNC fica na dependência destes dados para sua evolução. Apenas quando os territórios e os setores conseguirem implantar seus sistemas, poderemos ter uma estimativa um pouco mais organizada de números e dados qualitativos a respeito de cada um e os temas e os cronotopos poderão ser mais concretos. Os planos territoriais e setoriais devem ser escritos pensando no plano federal, porém nem sempre isso acontece. Num país diverso como o Brasil, com realidades muito distintas, nem sempre as demandas são as mesmas.

Como vimos no capítulo 3, a Meta 1, que trata da adesão e da implantação dos sistemas territoriais, foi atualizada a cada ano e teve um atraso nos avanços a partir do impeachment em 2016. Para a atualização da meta anualmente foi necessário um esforço do MinC e dos órgãos de cultura territoriais neste processo. A meta 7, que trata do mapeamento de cadeias de economia criativa, depende da organização setorial e territorial. Um exemplo disso foi a cartografia do setor da dança, que dependeu da divulgação via páginas de Facebook para sua realização.

\footnotetext{
${ }^{168}$ Meta 3 do PNC. Disponível em: < http://pnc.culturadigital.br/metas/cartografia-da-diversidade-dasexpressoes-3-culturais-em-todo-o-territorio-brasileiro-realizada/ > acesso em 22 de março de 2017.
} 
Ainda que o setor tenha uma relativa organização nos grandes centros, como atingir cidades e regiões mais distantes ao longo do tempo? Como atingir realidades tão distintas? O site do PNC informa que foram mapeadas cinco cadeias produtivas até o final de 2015 por meio de pesquisas realizadas de forma independente ao MinC. Cada um desses mapeamentos podem ser pensados como cronotopos pois geram sentidos ao fazer um recorte da esfera no tempo-espaço.

Cadeias produtivas mapeadas: "Cadeia Produtiva da Economia da Música" (Antonio Carlos Alkmim et al, 2005); "Cadeia Produtiva da Economia do Carnaval" (Prestes Filho, 2009); "Mapeamento da Indústria Brasileira e Global de Jogos Digitais" (USP, 2014); "Mapeamento estratégico para a inserção do design nos grandes eventos esportivos no Brasil - Copa do Mundo 2014 e Olimpíadas 2016 (Competitiveness, 2012)" e "Museus e a dimensão econômica - da cadeia produtiva à gestão sustentável" (Ibram, $2014)^{169}$.

Parte das metas do PNC apresentam a quantidade zero em todos seus quesitos em 2010 e continuaram com a quantidade zero no ano de 2015 quando do início da revisão do PNC, e assim permaneceram até hoje, como mostra, por exemplo, a tabela na meta 8 sobre o reconhecimento de 110 territórios criativos.

Figura 20: Desenvolvimento da Meta 8 do PNC ao longo do tempo.

\begin{tabular}{|c|c|c|c|c|c|c|c|c|c|}
\hline Indicador & 2010 & 2011 & 2012 & 2013 & 2014 & 2015 & 2016 & 2017 & $\begin{array}{c}\text { Ponto da } \\
\text { meta } \\
2020\end{array}$ \\
\hline Número total de territórios criativos reconhecidos & 0 & 0 & 0 & 0 & 0 & 0 & 0 & 0 & 110 \\
\hline $\begin{array}{l}\text { \% de alcance em relação ao planejado para o ano de } \\
2017\end{array}$ & & & & & & & & - & \\
\hline
\end{tabular}

Fonte: Site PNC. ${ }^{170}$

Não é possível dizer por meio do detalhamento da meta se não foram desenvolvidas, ou se não foram avaliadas por nenhuma entidade de pesquisa, ou mesmo se não houve uma metodologia criada pelo Ministério da Cultura durante os primeiros cinco anos de PNC. Ao buscamos maiores informações sobre os territórios criativos na internet encontramos diversos links relativos ao desenvolvimento em países da Europa, principalmente em Portugal, Espanha e França. Entretanto, sobre o desenvolvimento no Brasil, há disponível um site com o início de uma pesquisa relativa aos territórios indígenas ${ }^{171}$ que possivelmente foi declinada por conta do início da crise política em 2015. No descritivo da meta, ao contrário da tabela

\footnotetext{
${ }^{169}$ Meta 7 PNC. Disponível em: < http://pnc.culturadigital.br/metas/100-dos-segmentos-culturais-com-cadeiasprodutivas-da-economia-criativa-mapeadas-2/ > acesso em 22 de março de 2017.

${ }_{170}$ Disponível em: $<$ http://pnc.cultura.gov.br/category/metas/8/> acesso em 02 de janeiro de 2018.

${ }^{171}$ Disponível em: < http://www.territorioscriativosmt.com.br/o-projeto.html > acesso em 23 de março de 2017.
} 
que indica zero territórios criativos existentes, há a menção a quatro territórios: Madureira, Paraty, Quissamã e Cariri ${ }^{172}$. Os indícios temporais e geográficos na descrição da meta e de seu desenvolvimento denotam que ela está acontecendo de alguma forma, porém os dados na tabela dizem o contrário. Estas informações foram coletadas do site em nossa análise no ano de 2016. No ano de 2018, estas informações foram apagadas do site, o pode denotar a extinção do programa.

Se ao longo dos anos não foi possível fazer com que a meta evoluísse oficialmente e no momento desta investigação não existe nenhum rastro sobre algum território criativo delimitado por documento oficial, é cabível questionar por que esta meta 8 ainda faz parte do PNC mesmo após sua primeira revisão em 2015? A presença do programa "Territórios Criativos" no PNC decorre de uma tendência mundial inspirada pela UNESCO por conta das Redes Criativas em que cidades seriam tratadas como espaços de interesse especial. Esta meta foi inserida no enunciado por uma vontade inicial de envolvidos no processo, pois essa era uma tendência mundial e o Brasil deveria estar atualizado nesse tema.

A falta de estrutura, de verbas ou até de vontade política, fez com que metas inovadoras não conseguissem ativar novas ações na esfera. Entretanto, muitas delas não estão sendo quantificadas ou nem mesmo atualizadas. A observação de desenvolvimento de metas nem sempre é realizado. A responsabilidade por isso caberia ao Ministério da Cultura e seus agentes que inseriam esta meta no Plano? Ou aos funcionários da SADI responsáveis por alimentar o site com atualizações? Ou seria a dificuldade de quantificar questões simbólicas de uma esfera tão complexa e diversa como a cultura que impede de tratarmos tudo isso apenas com números em tabelas? Como vimos acima, a quantidade de municípios quantificados numa dada meta não consegue demonstrar a real situação, pois em termos qualitativos e espaço-temporais não apresentam nenhum sentido para a esfera.

O PNC indica assim um certo "formalismo" que não leva em conta a realidade prática da implantação das metas no país, nem seu lado simbólico. As pesquisadoras Rosimeri Carvalho da Silva e Eloise Dellagnelo (2015) falam sobre o processo de construção do PNC e a escrita de planos estaduais.

O processo de mobilização foi então incentivado e na maioria dos estados uma participação significativa foi alcançada. Os diferentes segmentos, e, sobretudo, os segmentos organizados, traziam para as reuniões um conjunto de demandas, grande parte delas bastante corporativa. Essas demandas foram incorporadas sem passar por nenhuma avaliação que implicasse um processo de aglutinação. Isso redundou em planos que indicavam ações de aberturas

\footnotetext{
${ }^{172}$ Disponível em: < http://www.territorioscriativosuff.com.br/ > acesso em 12 de novembro de 2017.
} 
de editais para cada um dos segmentos, e, caso a ação de abertura do edital para um segmento fosse retirada, seus representantes se viam prejudicados, o que impediu os técnicos de agrupar ações semelhantes em uma só. Assim o aspecto formalista dos planos parece refletir uma estratégia de absorção de conflitos que certamente surgiriam caso se colocassem discussão prioridades e agrupamento de ações. Percebemos, em alguns processos, acentuada dificuldade em discutir a prioridade das proposições a serem incluídas, e mesmo, a necessidade de agrupamentos e cortes nas proposições apresentadas. Para os representantes dos segmentos era fundamental ver cada uma de suas demandas incorporadas no documento final, ainda que isso o tornasse inviável. Apesar disso, isso pode ter sido uma estratégia importante, já que evita o esvaziamento do processo e pode, por meio do controle social na implementação do plano, levar a área a um amadurecimento que permita, no próximo plano, uma discussão mais aprofundada de suas necessidades. (CARVALHO DA SILVA; DELLAGNELO, 2015, p. 88)

Se este formalismo de fato atingiu boa parte dos planos de cultura e em especial a construção do Plano Nacional de Cultura que procurou atender as demandas dos participantes nos processos de participação social, haveria uma consciência geral de que o que estava sendo escrito como proposta de desenvolvimento da esfera seria impossível de realizar futuramente? Como bem evidenciou o trecho acima, a preocupação dos participantes era ter suas demandas presentes nos documentos, mesmo que algumas necessidades encontrassem obstáculos para serem realizadas.

É evidente que as políticas públicas de qualquer setor deveriam atender às demandas populares e ouvir quais são as reais necessidades dos trabalhadores do setor. Entretanto, o desconhecimento dos processos burocráticos e orçamentários da gestão pública, bem como a falta de consciência de que no futuro estas metas não fossem tão interessantes aos gestores de governos seguintes parecem não ter incomodado os participantes que auxiliaram a escrita dos planos de cultura. O caráter formalista do enunciado pode ser evidenciado nas metas inovadoras que visam implantar programas novos sem apoio concreto da gestão vigente no ato de escrita do documento.

$\mathrm{Na}$ análise que tentamos fazer sobre o formalismo no processo de elaboração dos planos estaduais de cultura, o aspecto mais evidente, no sentido da estratégia de construção nacional, é a construção do SNC. Considerando a necessidade da construção do sistema, alguns estados passarão provavelmente por processos de formação de seus conselhos, criação de suas políticas e elaboração de seus planos. (...) essa seria uma etapa necessária para que posteriormente a sociedade se aproprie desses elementos e os molde segundo suas especificidades. Assim, o processo de elaboração dos planos contribuiu, em muitos estados, para estruturar o campo ou para, ao menos, começar certa organização. Mobilizando as linguagens e os segmentos para organizar seus setoriais, articulando atores, criando vínculos e relações e estabelecendo uma agenda durante um ano de trabalho, no mínimo, foi 
possível evidenciar problemáticas comuns, mas também agrupar informações antes isoladas. Dessa maneira, além de efetivamente criar as instituições para a organização do sistema, o processo auxiliou na organização dos grupos interessados e na institucionalização do campo. (CARVALHO DA SILVA; DELLAGNELO, 2015, pp. 90-91)

A construção do PNC no primeiro decênio, com um SNC ainda sem regulamentação, demonstra uma experiência inovadora de participação social, interação e aprendizado em conjunto, tanto da sociedade civil quanto do estado. Como o PNC depende dos resultados quantitativos e qualitativos ao longo do tempo (e espaço) dos territórios e setoriais, em seu primeiro decênio, sua estruturação concreta não poderia trazer resultados consolidados para todas as metas, pois o país ainda estava se adaptando à nova proposta e dependia da vontade política de milhares de pessoas em todo país. É possível dizer que a melhoria dos métodos e resultados para a construção do sistema por meio de planos de cultura depende inicialmente de dois fatores: construção de categorias concretas de tempo e espaço. Mesmo para um tipo de plano mais genérico como o nacional, a determinação de categorias indicando prazos e locais, isto é, cronotopos, pode gerar indicadores de propostas que demandam responsabilidades já planejadas. Além disso a própria arquitetônica do sistema com um todo depende dessas categorias. De tempo, pois ainda necessita maturação de processo e do que vem no futuro, e espaço, pois num país de caráter continental como o Brasil, havia duas grandes dificuldades: abranger o máximo de municípios e reunir pessoas das mais diferentes identidades e necessidades. Este também era um desafio difícil de ser superado, mesmo em tempos de revolução digital.

Aliada à vontade política, tanto da sociedade civil que estava aprendendo a se organizar, quanto do Estado que estava aprendendo a escutar, está a questão ética dos participantes dos dois lados da interação e o entendimento da construção do Sistema no tempo-espaço.

Ao prever numa meta o mapeamento de $100 \%$ das atividades culturais de determinado setor (meta 7), ou mesmo, 100 mil escolas com atividade permanente de cultura e arte (meta 14), percebemos uma projeção do que seria o ideal, mas não o realmente possível na conjuntura do período e no tempo de vigência do Plano. Ao trasferir a responsabilidade de realizar uma determinada meta, deve-se pensar nos fatores que podem permitir ou não que esta seja possível. O ato ético é aquele que leva em conta o outro, o devir, a questão coletiva, o bem viver de todos, o tempo, o espaço, os agentes e os valores ali inseridos. Seria de fato ético pensar que todas as crianças deste país deveriam ter boas escolas, e de preferência que 
proporcionassem atividades permanentes de cultura e arte em suas atividades. Todavia, é ainda assim um ato ético projetar uma meta aparentemente impossível de ser construída em dez anos, de caráter genérico, sem planejamento algum, sem indicações de qual o melhor caminho para conseguir atingi-la no tempo-espaço?

O desconhecimento da burocracia brasileira e de estratégia de gestão pode ser tomado como um desafio à sociedade civil para qualificar a participação social na construção de políticas culturais. Se de fato, esta primeira tentativa de escrever um plano de cultura é uma etapa necessária para a apropriação de informações e melhorar os métodos para a criação de planos melhores no futuro, será que esse modelo resistirá aos equívocos iniciais e às constantes mudanças de governo?

\subsection{Cronotopo e descentralização no Plano Municipal de Cultura da cidade de São Paulo}

A experiência da construção do Plano Municipal de Cultura na cidade de São Paulo apresenta elementos mais concretos à nossa observação, pois ao contrário do PNC, trata-se de um plano que atinge uma cidade específica na ponta do sistema. A publicação Como fazer um plano de cultura evidencia a importância das cidades no sistema como o espaço onde "a cultura se materializa". Ao contrário do Plano nacional, o plano municipal deverá ser aquele que pode apresentar mais concretamente os cronotopos do sistema.

As cidades e áreas urbanas estão no centro do SNC. É nelas que a cultura se materializa, pois são as pessoas que nelas vivem que criam e reproduzem cultura, participando e desfrutando de atividades culturais. Ao mesmo tempo, as decisões políticas que podem interferir nesse processo vivo que acontece nos municípios dependem dos estados e do Governo Federal. (MINISTÉRIO DA CULTURA, 2013b, p.14)

A $3^{\mathrm{a}}$ Conferência Municipal de Cultura de São Paulo ( $\left.3^{\mathrm{a}} \mathrm{CMC}-\mathrm{SP}\right)$ foi desenvolvida com vistas a construir o primeiro Plano Municipal de Cultura da cidade no ano seguinte. Aconteceu nos dias 2 a 4 de agosto de 2013 e teve como tema: "Uma política de Estado para a Cultura: desafios do Sistema Municipal de Cultura". O título desta conferência municipal era quase o mesmo da $3^{\mathrm{a}} \mathrm{CNC}$ e esta era também uma preparação dos delegados municipais para os encontros estaduais de São Paulo e o nacional que ocorreram no final do mesmo ano.

Para melhor desenvolver as propostas, foram realizadas cinco pré-conferências regionais no mês de julho de 2013 nas macrorregiões da cidade: norte, sul, leste, oeste e centro. "Idealizadas como etapas preparatórias para o encontro municipal, as pré-conferências tiveram caráter mobilizador e propositivo, bem como garantiram a representatividade de 
grupos e demandas territoriais locais". (SECRETARIA MUNICIPAL DE CULTURA DE SÃO PAULO, 2014, p. 13) As pré-conferências são cronotopos da esfera político-cultural brasileira pois são acontecimentos no tempo-espaço que geram sentido na arquitetônica do sistema.

A publicação informa que as pré-conferências foram realizadas nos seguintes bairros: Santo Amaro (Sul), Guaianazes (leste), Vila Nova Cachoerinha (Norte), Lapa (Oeste) e Centro. Cada uma das pré-conferências geram diferentes sentidos cronotópicos na construção do Sistema Municipal de Cultura e consequentemente no SNC. A pré-conferência da Zona Leste, que ocorreu no bairro de Guaianazes, traz significados distintintos de outras como da Zona Sul, por exemplo. Porém ambas, em conjunto, são partes da construção desse sistema não apenas pela localização (espaço) que representam mas também pelo tempo (histórico) e de seus agentes locais responsáveis. Deste modo, a realização desta etapa da construção do Sistema Municipal de Cultura de São Paulo mostra a preocupação responsável dos agentes participantes nos processos. Tanto os agentes culturais locais, que se engajaram para participar das audiências, quanto os agentes do poder público, são responsáveis pelos resultados e sentidos gerados nestas pré-conferências com datas e locais distintos de realização. A distribuição espaço-temporal das pré-conferências contribui para a concretização dos centros da arquitetônica do sistema: diversidade, descentralização e ampliação do acesso.

A $3^{\text {a }}$ CMC - SP foi realizada no Memorial da América Latina e foi dividida em 4 eixos e sub-eixos similares aos propostos pelos textos-base para a $3^{\text {a }} \mathrm{CNC}$ : eixo 1 - Sistema Municipal de Cultura, eixo 2 - Produção simbólica e diversidade cultural, eixo 3 - cidadania e direitos culturais, eixo 4 - cultura e desenvolvimento.

Ao organizar os documentos resultantes das pré-conferências houve uma preocupação dos participantes das ações e da Secretaria Municipal de Cultura de São Paulo em respeitar os territórios da cidade e reconhecer que havia diferentes demandas numa cidade tão grande, tão plural e com tantas desigualdades. Ao designarem territórios e encontros distintos, oferecem a oportunidade de participação de agentes com demandas específicas, e assim são criados novos cronotopos.

Houve também a preocupação de escolher delegados que buscassem contemplar a diversidade de pessoas da cidade em todos os aspectos garantindo a paridade de gênero, geracional, "raça", tipo de cultura popular. Ao criarem estes parâmetros, determinam critérios para respeitar quantidades iguais de representantes para homens e mulheres, a 
proporcionalidade geracional e a diversidade.

A publicação também apresenta os inscritos na $3^{\mathrm{a}} \mathrm{CMC}$ SP por meio do aspecto geográfico da cidade em gráficos e mapas. O gráfico apresenta uma relativa quantidade superior de presentes da zona leste, que fica ainda mais evidenciada em comparação com os presentes da região central da cidade.

Figura 21: Inscritos na $3^{\mathrm{a}} \mathrm{CMC}-\mathrm{SP}$ por região da cidade.

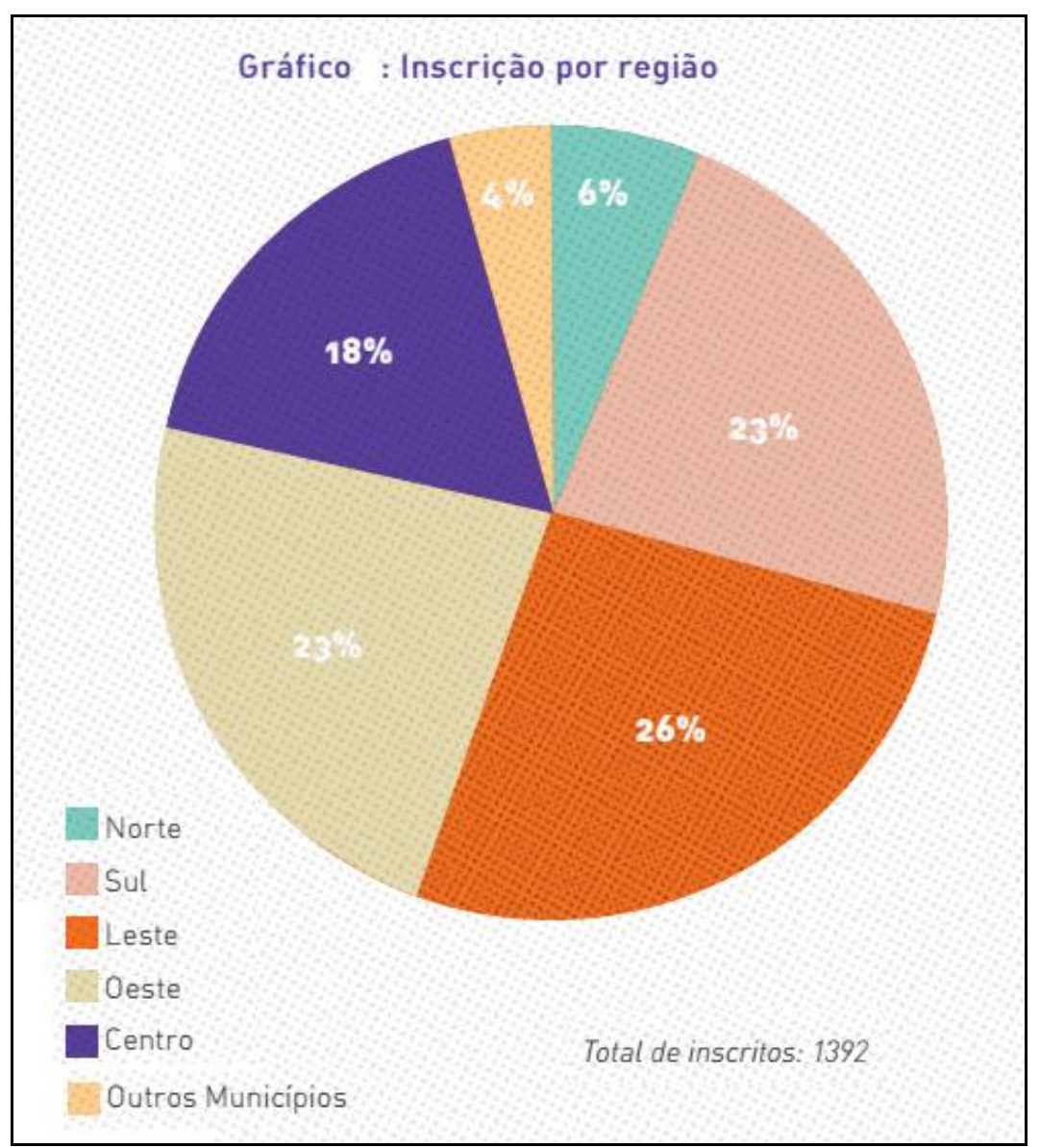

Fonte: SECRETARIA MUNICIPAL DE CULTURA DE SÃO PAULO, 2014, p.44.

Os mapas e gráficos nestes enunciados podem ser pensados como cronotopos da esfera pois geram dados relevantes ao processo, gerando sentidos por meio de categorias de tempo-espaço na construção do sistema.

No mapa a seguir, é possível perceber que a maior parte dos inscritos na conferência, mais de $10 \%$, eram oriundos da subprefeitura da Sé, região onde se encontra a Secretaria Municipal de Cultura de São Paulo.

Ainda que no mapa abaixo a subprefeitura da Sé tenha o maior número de inscritos na conferência, são as diversas periferias da cidade somadas que apresentaram maior participação. A temática transversal a todos os eixos foi a inclusão da periferia da cidade nas 
políticas culturais de maneira menos desigual. A forte presença da questão periférica nos temas abordados permeiam não apenas os mapas e gráficos, mas também os textos da publicação.

Figura 22: Distribuição de inscritos na $3^{\mathrm{a}} \mathrm{CMC}$ por subprefeitura da cidade de SP

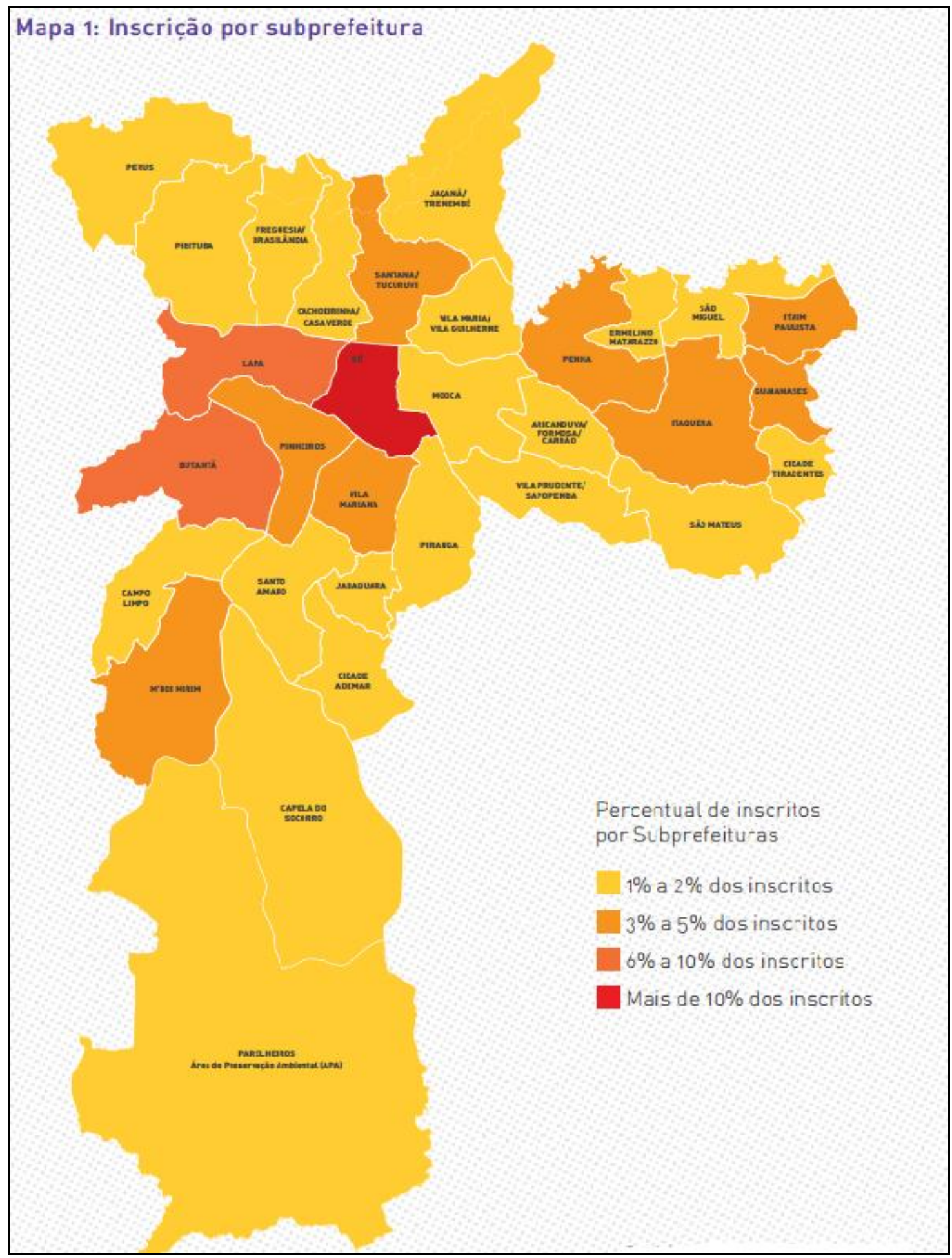

Fonte: SECRETARIA MUNICIPAL DE CULTURA DE SÃO PAULO, 2014, p.45. 
Na parte final da publicação é possível ver algumas evidências de que a periferia estava no centro das discussões. Primeiramente no trecho intitulado "Pontos de vista de grupos participantes" se destaca um texto escrito pelo Fórum de Cultura da Zona Leste intitulado "A periferia foi cobrar... e agora?" onde exigem a ampliação da participação de artistas periféricos em políticas culturais já existentes e a criação de uma lei de fomento à cultura das periferias. Logo em seguida, no anexo 3, dentre as nove moções aprovadas por consenso todas são relativas a questões periféricas e de culturas populares tradicionais. E por fim, a publicação apresenta uma moção escrita à mão com 32 assinaturas pedindo a liberação imediata de orçamento para o Prêmio Funarte de Arte Negra, que contemplou diversos grupos artísticos periféricos da cidade e que se encontrava com pagamento em atraso. Em todos os documentos relativos à periferia os argumentos não são apenas geográficos, mas também justificativas históricas, principalmente de que os gestores da cidade ainda não encontraram o caminho da periferia. A forte presença do conceito de periferia no documento como um fator transversal e representativo pode evidenciar que este é um cronotopo desse processo do Plano de Cultura de SP, enquanto fator espacial e histórico, e se relaciona diretamente com os centros da arquitetônica do sistema: a diversidade e a descentralização / ampliação do acesso. Pode ser considerado espacial, pois determina a relevância de determinados espaços da cidade e temporal pois apresenta um recorte histórico dessas periferias.

Nas duas publicações seguintes, relativas à construção do Plano Municipal de Cultura, a Secretaria Municipal de Cultura teve o mesmo cuidado de apresentar o desenvolvimento a partir de questões territoriais e temporais da cidade. Preocupou-se em construir uma estrutura inovadora para o Plano que também levaria em conta principalmente no diagnóstico os fatores geográfico e histórico na construção de políticas públicas.

A publicação da primeira etapa da construção do Plano Municipal de Cultura tratou da consulta pública da proposta sugerida por um grupo de consultores da Fundação São Paulo contratada especialmente para a ocasião. O livro, recheado de figuras, gráficos e mapas, traz em sua primeira parte um diagnóstico detalhado da situação da cultura no município até o ano de 2014. Todavia, é na construção das 50 metas propostas que percebemos que além da questão territorial, a SMC teve uma preocupação em dividir as ações do Plano dentro de uma lógica temporal.

O primeiro plano de cultura da cidade de São Paulo apresentava a novidade de dividir os dez anos em planos plurianuais criando prazos para cumprir as ações que estavam detalhadas no enunciado. A relação com a estrutura de gestão da cidade, que distribui ações de 
todos os setores através de um plano plurianual aprovado sempre no primeiro ano de gestão de um prefeito, seria a forma mais coerente e responsável de projetar políticas culturais para cada futuro governo. Isto é, nas metas já viria desenhado o que cada gestão deveria fazer num determinado espaço-tempo e de forma descentralizada, buscando assim atingir os pontos mais distantes das periferias da cidade.

Ao dividir as ações em determinados espaços da cidade em situação atual, curto prazo, médio prazo e longo prazo, os agentes que escreveram o enunciado demonstram que estavam preocupados em pensar o Plano conforme o estabelecimento de Planos Plurianuais futuros e de acordo com cada um dos próximos governos que serão eleitos na cidade e assim criaram um modelo de cronotopo para esse gênero discursivo.

Figura 23: Meta 50 da Consulta Pública do Plano Municipal de Cultura de SP

META 50: Cem ações de promoção e apoio a modelos colaborativos promovidas.

A economia colaborativa se estabelece a partir da cultura de abertura de informações e produção articulada entre profissionais de diversas áreas. Essa abordagem inova os processos produtivos nas empresas, associações, grupos e entre pessoas, abrindo possibilidades como o financiamento colaborativo (crowdfunding) e a colaboração para criar conteúdos, ideias e serviços (crowdsourcing). Mapear e permitir a troca dessas experiências é o objetivo dessa meta.

AÇÕES: Promover e apoiar modelos colaborativos no desenvolvimento das atividades no campo da cultura.

\begin{tabular}{|c|c|c|c|}
\hline Situação Atual & Curto prazo & Médio prazo & Longo prazo \\
\hline 2015 & 2017 & 2021 & 2025 \\
\hline $\begin{array}{l}\text { Ações pontuais } \\
\text { de promoção } \\
\text { de modelos } \\
\text { colaborativos. }\end{array}$ & $\begin{array}{l}\text { Ações de promoção } \\
\text { e apoio a modelos } \\
\text { colaborativos } \\
\text { elaboradas. }\end{array}$ & $\begin{array}{l}\text { Ações de promoção } \\
\text { e apoio a modelos } \\
\text { colaborativos } \\
\text { promovidas } \\
\text { e apoiadas. }\end{array}$ & \\
\hline \multicolumn{4}{|c|}{$\begin{array}{l}\text { Indicadores: Número de ações de promoção e apoio a de modelos colaborativos } \\
\text { promovidas e apoiadas. } \\
\text { Fonte: Secretaria Municipal de Cultura }\end{array}$} \\
\hline
\end{tabular}

Fonte: SECRETARIA MUNICIPAL DE CULTURA, 2016b, p. 235

As ações em curto prazo projetam o ano seguinte à publicação do Plano. As ações de médio prazo, o que deveria ser realizado pelo próximo prefeito, e a longo prazo pelo prefeito 
seguinte. Este modelo de Plano que divide as ações em Plano Plurianual traz um caráter inovador ao método de escrita de planos territoriais e nos remete ao texto inicial da PEC do PNC que trata dos Planos como realizações plurianuais, como vimos anteriormente.

Após a consulta pública do PMC, a Secretaria Municipal de Cultura passou três meses reorganizando as mais de mil sugestões de alterações propostas pela sociedade civil para compor a publicação final do processo. Além da consulta pública presencial, realizada em todas as regiões da cidade, foi disponibilizado um site em que era possível enviar sugestões para cada uma das metas propostas. A consulta pública online permaneceu disponível para interações entre 25 de fevereiro e 5 de abril de 2016 e possibilitava a todos os interessados participarem enviando sugestões para as 53 metas e votando se concordavam ou não com o que determinada meta estava propondo incialmente. Com isso, mesmo aqueles que moram nos extremos da cidade poderiam participar da consulta pública e enviar sugestões. As metas apareciam no site de modo integral, assim como foram disponibilizadas na publicação impressa distribuída durante a consulta pública presencial. Para participar, os interessados deveriam inicialmente preencher um formulário com seus dados básicos que incluíam nome, data de nascimento, região da cidade onde moravam, autodeclararão de raça, gênero e renda. Em dezembro de 2016, foi lançada, no Centro Cultural São Paulo, a publicação final com os resultados e a versão final do Plano Municipal de Cultura de São Paulo numa tiragem de cinco mil exemplares e com uma nova estruturação das metas. Na própria publicação, é possível ver que a SMC se preocupou em explicar essa nova estrutura do PMC que traz o fator espaço-temporal como transversal.

O Plano Municipal de Cultura de São Paulo está estruturado em cinco eixos temáticos contendo quatro metas cada um, totalizando vinte metas a serem cumpridas nos próximos dez anos. Cada uma das metas se efetiva por meio de diversas ações, a serem executadas no curto, médio e longo prazo - que correspondem, por sua vez, aos períodos de elaboração dos Planos Plurianuais (PPAs). (SECRETARIA MUNICIPAL DE CULTURA DE SP, 2016, p. 52)

A publicação trouxe o mesmo formato de proposta de metas, com a divisão temporal de ações em Planos Plurianuais, porém, ao contrário da proposta anterior, esta trazia apenas 20 metas, estruturadas por meio da reorganização das metas, geraram 96 ações. As temáticas de caráter mais geral, possibilitam que as ações sejam desenvolvidas de forma pontual, o que pode favorecer a atualização do plano futuramente. 
Figura 24: Estrutura do PMC SP

\begin{tabular}{|c|c|c|c|c|c|}
\hline & EIXO & META & TEMA & \multicolumn{2}{|c|}{ AÇÕES } \\
\hline \multirow{4}{*}{ I } & \multirow{4}{*}{$\begin{array}{l}\text { Do Estado e da } \\
\text { Participação } \\
\text { Social }\end{array}$} & 1 & Financiamento & 4 & \multirow{4}{*}{19} \\
\hline & & 2 & Reestruturação e regionalização & 5 & \\
\hline & & 3 & Gestão participativa & 4 & \\
\hline & & 4 & Informações e indicadores & 6 & \\
\hline \multirow{4}{*}{ II } & \multirow{4}{*}{$\begin{array}{l}\text { Do Espaço } \\
\text { Urbano e da } \\
\text { Infraestrutura } \\
\text { Cultural }\end{array}$} & 5 & $\begin{array}{l}\text { Requalificação de equipamentos } \\
\text { culturais }\end{array}$ & 5 & \multirow{4}{*}{20} \\
\hline & & 6 & $\begin{array}{l}\text { Rede municipal de equipamentos } \\
\text { culturais }\end{array}$ & 6 & \\
\hline & & 7 & $\begin{array}{l}\text { Gestão colaborativa e espaços } \\
\text { independentes }\end{array}$ & 5 & \\
\hline & & 8 & Ocupação de espaços públicos & 4 & \\
\hline \multirow{4}{*}{ III } & \multirow{4}{*}{$\begin{array}{l}\text { Do Patrimônio } \\
\text { Cultural e da } \\
\text { Memória }\end{array}$} & 9 & Preservação do patrimônio & 4 & \multirow{4}{*}{19} \\
\hline & & 10 & Educação patrimonial & 3 & \\
\hline & & 11 & Museus e memória & 5 & \\
\hline & & 12 & Gestão de acervos & 7 & \\
\hline \multirow{4}{*}{ IV } & \multirow{4}{*}{$\begin{array}{l}\text { Da Formação } \\
\text { e da Difusão } \\
\text { Cultural }\end{array}$} & 13 & Iniciação artística e cultural & 5 & \multirow{4}{*}{17} \\
\hline & & 14 & Formação técnica e profissionalizante & 3 & \\
\hline & & 15 & $\begin{array}{l}\text { Mediação cultural e formação de } \\
\text { público }\end{array}$ & 3 & \\
\hline & & 16 & Programação cultural & 6 & \\
\hline \multirow{4}{*}{ V } & \multirow{4}{*}{$\begin{array}{l}\text { Do Fomento e } \\
\text { da Economia } \\
\text { da Cultura }\end{array}$} & 17 & Cidadania cultural & 6 & \multirow{4}{*}{21} \\
\hline & & 18 & Fomento às linguagens artísticas & 5 & \\
\hline & & 19 & Sustentabilidade e colaboração & 5 & \\
\hline & & 20 & Cadeias produtivas & 5 & \\
\hline & & & & TOTAL & 96 \\
\hline
\end{tabular}

Fonte: SECRETARIA MUNICIPAL DE CULTURA, 2016b ${ }^{173}$

No que tange às questões de espaço-tempo nas responsabilidades elencadas no plano, é possível perceber em diversas metas e submetas, o caráter cronotópico das ações, e também os agentes desta arquitetônica, como, por exemplo, na meta 2, ação 2.4 que trata da articulação territorial da SMC.

Estas ações previstas em termos de tempo e espaço geram sentidos no decorrer de sua sugestão ao longo da divisão temporal e espacial proposta. Em algumas ações inclusive, é possível ver a descrição de equipamentos, nomes de bairros e regiões da cidade e a previsão de quando as ações deverão ser realizadas em cada um deles.

\footnotetext{
${ }^{173}$ Estrutura do Plano Municipal de Cultura de São Paulo. Disponível em: < http://www.planomunicipaldecultura.prefeitura.sp.gov.br/pmc-sp/ > acesso 12 abril 2017.
} 
Figura 25: Ação 2.4 na Meta 2 PMC SP.

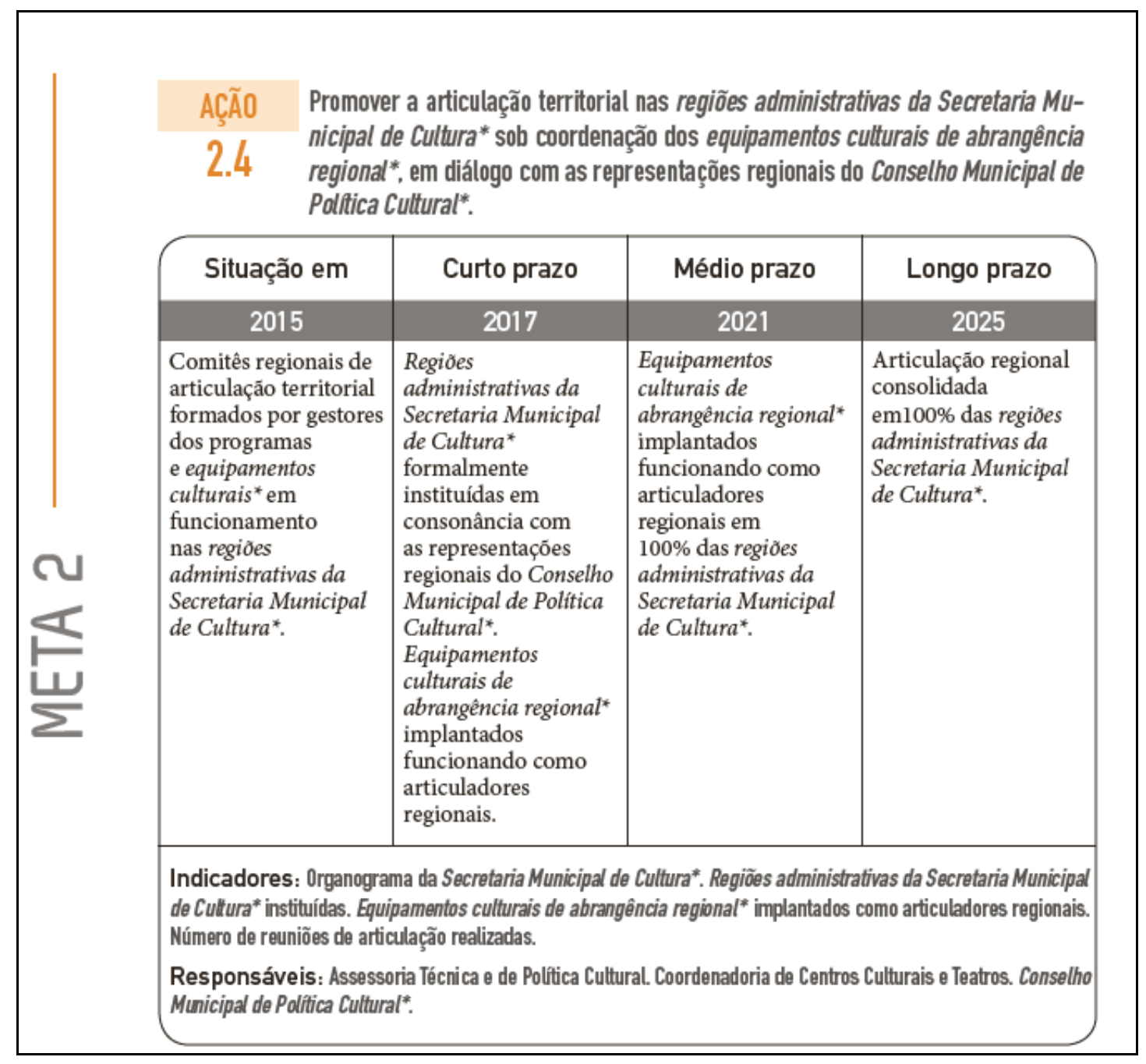

Fonte: SECRETARIA MUNICIPAL DE CULTURA, 2016b ${ }^{174}$.

Na imagem acima é possível observarmos:

a) Diversas categorias de espaço: território, regiões, Secretaria Municipal de Cultura, equipamentos culturais, comitês regionais, representações regionais do $\mathrm{CMC}$, regiões administrativas;

b) Diversas categorias de tempo: anos 2015, 2017, 2021, 2025, curto prazo, médio prazo e longo prazo;

c) A quem cabe a responsabilidade pela escrita da ação (no tempo 1): Assessoria técnica e de Política Cultural, Coordenadoria de Centros Culturais e Teatros, Conselho Municipal de Política Cultural;

d) A quem cabe a responsabilidade pela realização da ação (no tempo futuro): Comitês Regionais de Articulação Territorial, Secretaria Municipal de Cultura e Conselho Municipal

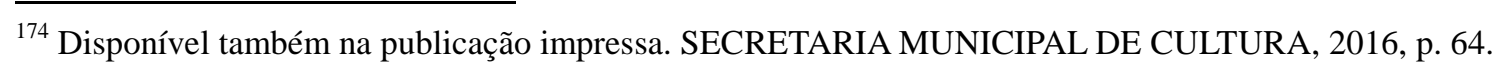


de Cultura.

No cruzamento das categorias cronotópicas com os agentes responsáveis no tempo 1 e nos tempos 2, 3, 4 é possível perceber os atos elencados e a função de cada um dos cronotopos desta ação, prevista na meta 2. Entretanto, é importante ressaltar aqui que estes Comitês Regionais de Articulação Territorial ainda precisam ser criados e a lei do Conselho Municipal de Cultura de São Paulo (CMC - SP) encontra-se ainda em tramitação na Câmara Municipal de SP pelo projeto de lei 248/2015. Esta ação demanda outras ações externas que deverão ser articuladas pela Secretaria Municipal de Cultura e depende também de outros enunciados. Primeiro é necessário que a sociedade civil organizada exija da secretaria a realização da meta / ação, criando os Comitês Regionais de Articulação Territorial. Segundo, será necessário pressionar os vereadores da Câmara Municipal de SP a aprovar o projeto de lei que cria o CMC de SP. E terceiro, é necessário ao novo prefeito e à SMC vontade política para promover a articulação prevista na Meta. Para que a responsabilidade ética projetada no tempo-espaço do sistema seja realizada, cabe principalmente aos destinatários presumidos destes enunciados a ética de assumir o compromisso pautado nesses documentos oficiais, que estabelecem atos práticos no devir.

Os agentes participantes da construção do Sistema Nacional de Cultura, tanto autores de enunciados legislativos, quanto seus coautores, e a participação social são fatores essenciais para compreender os momentos arquitetônicos do SNC. Como evidenciou Bakhtin, os autores / agentes são os principais centros de valor da arquitetônica. No preâmbulo da publicação do Plano Municipal, encontramos como conceitos eleitos para a estruturação: "noções de diversidade, cidadania cultural, territorialidade e direito a cidade", repetindo o discurso presente nos enunciados do PNC e do SNC. Também chama atenção a compreensão da responsabilidade da SMC de garantir as propostas e em "articular, para além de suas políticas, outros entes responsáveis por ações complementares”.

O que se pretende é que o PMC-SP possa se tornar um instrumento precursor ao aportar subsídios para ações afirmativas e para o reconhecimento dos direitos humanos, incorporando a cultura como ferramenta indispensável de afirmação o que se pretende e que o PMC-SP possa se tornar um instrumento precursor ao aportar subsídios para ações afirmativas e para o reconhecimento dos direitos da dignidade, da reversão de desigualdades historicamente constituídas e da garantia de direitos. Como previsto na Constituição Federal de 1988, a todo cidadão devem ser garantidos os direitos culturais, definidos como acesso a produção, a fruição e a participação cultural. Entendida como objeto fundamental das políticas culturais, a cidadania cultural está no cerne dos objetivos do PMC-SP. A cidadania cultural como prática social de democracia cultural alia o direito à cultura com a experimentação da cultura democrática. No âmbito deste 
plano, trata-se de promover o direito de fruir e produzir cultura, participar da vida cultural da cidade de São Paulo e ter livre acesso à informação e à comunicação. Essas ações ao mesmo tempo democratizam o acesso à cultura e fortalecem a cultura de cidadania. Essa garantia é de responsabilidade do estado e cabe à Secretaria Municipal de Cultura (SMC) articular, para além de suas políticas, outros entes responsáveis por ações complementares nos campos da educação, direitos humanos, defesa da igualdade de gênero e sexual, combate ao racismo, mobilidade urbana, tecnologia e serviços, comunicação, turismo, verde e meio ambiente, esporte, assistência social, saúde, trabalho e empreendedorismo e relações internacionais e federativas, entre outros, ampliando as iniciativas intersetoriais para garantia dos direitos culturais. (SECRETARIA MUNICIPAL DE CULTURA DE SP, 2016, pp. 48-49 - grifos do autor)

Ao tomar para si a responsabilidade, quando diz que "Essa garantia é de responsabilidade do estado e cabe à Secretaria Municipal de Cultura (SMC) articular, para além de suas políticas, outros entes responsáveis por ações complementares" a SMC compreende que é do poder executivo a responsabilidade pela execução das ações prevista no enunciado, ainda que ele tivesse sido escrito por milhares de consciências. Entretanto, o PMC de SP foi publicado no último mês da gestão do prefeito Fernando Haddad, consolidado por um decreto junto ao Sistema Municipal de Cultura de São Paulo, mas que juridicamente pouco garante sua execução em termos legais. O fato do sistema e o plano não estarem garantidos em uma lei faz com que, apesar do esforço dos agentes da secretaria e da sociedade civil em construir um plano bem planejado, foram prejudicados pela demora da prefeitura em enviar a proposta à Câmara e assim preferiu aprovar como um decreto, com frágil legitimidade jurídica. Como vimos no capítulo histórico, não houve um esforço da gestão seguinte para desenvolver o que estava previsto no enunciado.

Ainda que um plano de cultura esteja bem desenhado e planejado em seus mínimos detalhes como o PMC de São Paulo, nem sempre é possível que este se realize como foi escrito. A postura dissonante da gestão de João Dória na prefeitura de São Paulo, que decidiu não executar o Plano por divergência política com a gestão anterior e por não ter interesse algum em apoiar o setor cultural, prejudicou e atrasou o processo. A garantia da responsabilidade ética dos gestores destinatários de um plano de cultura é um ponto que esta nova política cultural ainda precisa resolver.

Neste capítulo, analisamos os cronotopos dos enunciados e a questão ética dos agentes participantes do sistema. Propomos inicialmente um esquema onde pudemos observar que os planos de cultura apresentam cronotopos por meio de seus tempos, atos, agentes, que ocorrem em dois momentos: primeiro na criação do enunciado e o segundo na execução do futuro 
planejado. No momento 1 há a projeção de ações futuras e no momento 2 a realização dessas ações. Porém, em nossa reflexão compreendemos que será necessário compromisso e responsabilidade dos agentes envolvidos nos dois momentos para que este futuro projetado saia do papel e se torne realidade concreta em termos de ações de gestão pública de cultura.

Por meio da análise dos planos nacional e municipal aferimos que os enunciados criados na construção do sistema apresentam cronotopos que podem ser representados por mapas, gráficos, concretude de propostas com indicação de local e prazo de realização.

O plano de cultura é um gênero do discurso que ainda busca por sua relativa estabilidade e estes cronotopos indicaram nesta análise, que podem ser um fator que gera sentidos e também responsabilidades futuras aos agentes. Ao criarem um marco espaçotemporal projetado ao futuro num desses enunciados, geram uma proposta de realização de ação de algo concretamente. Entretanto, cabe aos agentes designados nestes enunciados e seus destinatários presumidos se engajarem de maneira responsável para que de fato realizem as ações projetadas conforme previsto. 


\section{CAPÍTULO 6: AS ESPECIFICIDADES DO GÊNERO PLANO DE CULTURA}

O gênero plano de cultura é o principal mecanismo para a construção da arquitetônica proposta pelo Sistema Nacional de Cultura em seus três centros de valor: diversidade, descentralização e ampliação do acesso. É por meio destes enunciados que será possível criar políticas culturais de baixo para cima, descentralizar recursos e trazer demandas diversificadas para a realização futura.

Para afirmarmos que existe de fato um novo gênero discursivo Plano de Cultura, como observamos desde o início desta tese, será necessário comprovarmos sua existência não apenas por sua produtividade na esfera das políticas culturais, mas também analisando suas especificidades conforme trata Bakhtin em seu texto sobre os gêneros discursivos. Acreditamos que, ao analisar as propriedades do gênero, possamos colaborar para que estes enunciados sejam futuramente melhor elaborados em cada uma das situações de comunicação no tempo e espaço.

Iniciaremos o sexto e último capítulo desta tese com a reflexão acerca dos processos de escrita desses planos. Na sequência, partiremos para a análise de suas especificidades e das materialidades linguísticas dos enunciados, conforme orienta Bakhtin na obra Os gêneros do discurso.

O emprego da língua efetua-se em forma de enunciados (orais e escritos) concretos e únicos, proferidos pelos integrantes desse ou daquele campo da atividade humana. Esses enunciados refletem as condições específicas e as finalidades de cada referido campo não só por seu conteúdo (temático) e pelo estilo da linguagem, ou seja, pela seleção dos recursos lexicais, fraseológicos e gramaticais da língua, mas, acima de tudo, por sua construção composicional. Todos esses três elementos - o conteúdo temático, o estilo, a construção composicional - estão indissoluvelmente ligados no conjunto do enunciado e são igualmente determinados pela especificidade de um campo da comunicação. Evidentemente, cada enunciado particular é individual, mas cada campo de utilização da língua elabora seus tipos relativamente estáveis de enunciados, os quais denominamos gêneros do discurso. (BAKHTIN, 2016, p.11 - 12)

Utilizaremos como corpus de análise os planos de cultura nacional, estadual e municipal de São Paulo. Observaremos nestes enunciados as especificidades do que passamos a chamar a partir desta tese de gênero discursivo plano de cultura: construção composicional, conteúdo temático e estilo. De modo a auxiliar a análise, observaremos também outros enunciados do corpus desta tese, bem como outros planos de cultura estaduais e municipais e os materiais didáticos da capacitação para escrita de planos municipais proposta pelo MinC em conjunto com a UFBA. Buscaremos evidenciar assim a relativa estabilidade do gênero, 
como este tem sido construído e como tem contribuído para a construção da nova arquitetônica da esfera político-cultural brasileira.

\section{1 - A escrita do gênero plano de cultura}

A publicação Como fazer um Plano de Cultura de novembro de 2013 informa em suas primeiras linhas que a mesma "integra um conjunto de ações que o Ministério da Cultura vem fazendo para difundir o Plano Nacional de Cultura e auxiliar estados e municípios e setores culturais na elaboração de seus planos” (MINISTÉRIO DA CULTURA, 2013, p. 6). Este documento é um dos primeiros a serem criados com o fim de orientar na construção dos planos. Depois dele outros materiais foram propostos bem como um curso de capacitação EAD mediado pela UFBA.

Para compor o Sistema Nacional de Cultura em seu pacto federativo é obrigatório aos entes federados que fizerem adesão ao sistema a escrita de planos de cultura decenais, tanto territoriais quanto setoriais. A "cartilha" Como fazer um Plano de Cultura busca orientar de forma introdutória a escrita desses enunciados. Ela explica como ocorrem os processos de implantação, a metodologia, o foco nos municípios e as diferenças entre os setoriais e territoriais. A metodologia proposta na cartilha deve ser relacionada com uma série de enunciados que compõem o vasto corpus principal e auxiliar desta pesquisa, construindo, assim, um "como fazer" para implantar os sistemas de cultura em cada estado ou município. Em diversos momentos das 95 páginas desta cartilha, são apresentadas definições diferentes do que é um plano de cultura, que, apesar de distintas, se complementam:

- “(...) um documento de planejamento para o período de 10 anos” (idem, p. 8)

- "O plano de cultura é um documento preparado a muitas mãos em muitas etapas" (idem, p.13)

- "O plano de cultura é um documento formal que representa a política de gestão cultural de uma cidade. Nesse documento estão as ações culturais que se pretende desenvolver da cidade por um período de dez anos. O plano deve promover a igualdade de oportunidades e a valorização da diversidade das expressões e manifestações culturais." (idem, p. 23)

Na síntese das definições, o Plano de Cultura é um documento que representa a política cultural de determinado território para o período de dez anos e é escrito por muitas mãos em muitas etapas, isto é, vários autores e processos. Na mesma publicação, encontramos uma breve reflexão sobre a escrita dos planos de cultura, com as seguintes perguntas e respostas:

Mas como escrever o plano de cultura? Que formato ele deve seguir? 
Existem muitas formas de escrevê-lo. Uma boa opção é conhecer planos que já foram feitos em outras cidades brasileiras. E a partir daí escolher o formato que o grupo considerar melhor. Alguns planos usam as mesmas seções que apresentamos aqui: diagnóstico, diretrizes e prioridades, objetivos, estratégias, metas e ações. Outros têm um formato típico de projeto de lei, com divisão em capítulos. Há ainda os que misturam os dois formatos, criando capítulos que tratam de diretrizes metas e ações. (MINISTÉRIO DA CULTURA, 2013, p.60)

Ao afirmar que existem muitas formas de escrever um plano de cultura, o MinC possibilita uma maior autonomia e flexibilidade aos estados e municípios para a escrita dos seus planos, ainda que obrigatoriamente estes devam ser escritos em versão final em um enunciado legislativo e virar uma lei ${ }^{175}$. Entretanto, ainda que afirmem que não há uma maneira de escrever um plano, alguns de seus itens já estão pré-determinados pelo MinC nesse mesmo documento. Os itens que deverão compor a forma do enunciado a ser escrito já estão relativamente definidos e deverão ser usados na construção composicional do enunciado, como veremos no tópico a seguir.

De acordo com o manual, a escrita de um plano de cultura também deverá apresentar uma relação dialógica de concordância, responsiva e responsável, com o Plano Nacional de Cultura (tanto a emenda constitucional quanto o projeto de lei e as metas projetadas para o decênio). Deverá estar relacionado com os conteúdos de suas metas, diretrizes e princípios. Os planos de cultura, ao comporem o pacto federativo, deverão contribuir para a composição do sistema em nível nacional e estar em diálogo consensual com as diretrizes e metas mais gerais do PNC.

Deste modo, será mais difícil fazer um plano de cultura que não traga em seus conteúdos a visão de cultura ampliada abordada pelo MinC no período, e que não leve em conta as dimensões cidadã, econômica e simbólica, os três pilares essenciais do SNC. Além disso, ao pressupor esse diálogo, também será difícil escrever um plano que não seja pautado pela diversidade cultural, pela descentralização e pela ampliação do acesso, que são os centros da arquitetônica do sistema, como vimos ao longo da tese. Esse contato com os enunciados anteriores influenciará diretamente tanto na forma quanto no conteúdo dos novos planos e sistemas, reforçando a nova arquitetônica da esfera político-cultural brasileira. Este é o percurso que buscaremos tratar nas próximas páginas.

Na apostila disponibilizada pelo MinC no final do ano de 2017, feita em conjunto com pesquisadores da UFBA, observamos alguns avanços em relação aos métodos de escrita dos

\footnotetext{
${ }^{175}$ Na cidade de São Paulo, o PMC, bem como o Sistema, foram instituídos por meio de um decreto municipal, ao contrário das orientações do MinC.
} 
planos dos enunciados anteriores. Há maior foco no método de escrita e dicas de como proceder em cada etapa do processo, como por exemplo, quando orientam:

Independente da opção, o processo deve assegurar: Que cada objetivo possua, pelo menos, uma meta, mesmo não exclusiva; (b) Que cada meta possua, pelo menos, uma ação; (c) Que sejam perfeitamente identificadas relações entre objetivos e metas e entre metas e ações. (MINISTÉRIO DA CULTURA, 2017g, p. 08)

O material de 2017 aborda um nível mais detalhado de processos que inclui imagens ilustrativas para melhor explicar o método e como fazer os planos. Esses avanços nos métodos deverão facilitar os processos e trazer mais subsídios aos planos escritos daí por diante.

Figura 26: Estrutura dos planos de cultura

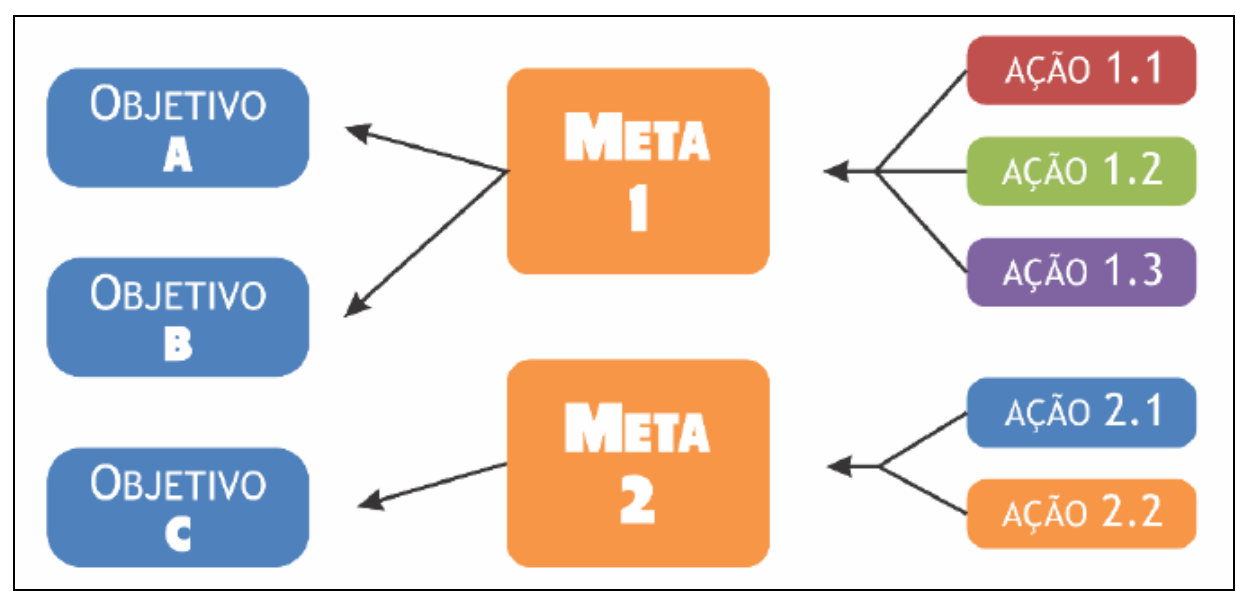

Sugerida na apostila de 2017, Elaboração dos planos - operacionalização do futuro desejado. ${ }^{176}$

O processo de escrita dos planos de cultura deverá ser precedido de uma série de outras ações, que incluem a leitura e escrita de outros enunciados que auxiliam em sua composição e conteúdos. Os primeiros enunciados que compõem essa relação são os textos do Sistema em âmbito federal. Tanto os marcos legais, quanto os manuais produzidos, e a própria Constituição Federal, influenciam diretamente esse processo dialógico que incide na forma e no conteúdo dos planos nas cidades e estados. Esses documentos foram escritos visando como destinatários presumidos aos agentes culturais e outros participantes ativos da esfera.

A assinatura de um ente federado no documento Acordo de Cooperação Federativa é o primeiro passo oficial deste processo, pois institui o início da implantação do sistema em determinado território, cria uma relação de co-responsabilidade ética entre as partes, estabelece que deverá ser criada a estrutura CPF (Conselho, Plano e Fundo de Cultura) e

\footnotetext{
${ }^{176}$ Disponível em: < http://portalsnc.cultura.gov.br/capacitacao/ > acesso em 22/10/2018.
} 
determina que um plano de cultura deverá ser escrito para compor o respectivo sistema. Para auxiliar nesse processo o MinC criou uma apostila tutorial mostrando todas as etapas para inscrição no site do SNC.

O segundo momento da implantação do sistema territorial, e que precede a construção do respectivo Plano de cultura, pressupõe a escrita de leis para a regulamentação do sistema de financiamento à cultura e do conselho de políticas culturais local. Na maior parte dos casos, a criação destes enunciados iniciais parte de secretarias de cultura ${ }^{177}$ ou secretarias equivalentes e, em pequenas cidades ainda sem este órgão, da própria prefeitura. Contudo, é inerente à adesão ao sistema que um município que ainda não tenha um órgão específico para o setor cultural, considere isso como prioridade para a construção de seu sistema territorial.

Dentre as atividades anteriores aos planos, ainda encontramos a produção de outros enunciados de diversos tipos como ofícios, e-mails, chamadas públicas etc., alguns inclusive caraterísticos da esfera político-cultural, extremamente burocrática e normatizadora por conta de seu viés principalmente estatal.

O manual Como fazer um plano de cultura ${ }^{178}$ orienta a escrita dos planos por meio de diversas perguntas que deverão auxiliar na reflexão para a composição e criação dos conteúdos em cada etapa do processo. As perguntas elencadas no documento orientam de maneira didática a construção dos novos enunciados que deverão se relacionar com os documentos anteriores do sistema, incluindo a participação social, a troca entre os mais diferentes grupos do setor. As perguntas deverão ser respondidas pensando nas características mais específicas de cada território resultantes do diagnóstico que deverá preceder a escrita do Plano. Cada enunciado de plano de cultura deverá estabelecer elos não apenas com outros enunciados anteriores, mas principalmente com as condições e a situação social de um território num determinado momento histórico. “A situação social mais próxima e o ambiente social mais amplo determinam completamente e, por assim dizer, de dentro, a estrutura do enunciado." (VOLÓCHINOV, 2017, p. 206 )

A primeira pergunta orientadora para a escrita dos planos é "Como estamos?". Esta deverá ajudar a estruturar o diagnóstico atual, principalmente do setor cultural, do ente federado que está iniciando a implantação do sistema. Para a criação do primeiro enunciado

\footnotetext{
${ }^{177}$ Como vimos anteriormente, a existência de secretarias específicas para a cultura ainda é uma raridade no país. A implantação do SNC tem sido responsável pela criação de boa parte destes novos órgãos de cultura nas pequenas cidades.

${ }^{178}$ Apesar da existência de outros materiais guias posteriores a este, achamos pertinente ao recorte de nossa pesquisa, analisarmos esta publicação prioritariamente, pois durante muitos anos serviu como base para a criação de planos de cultura nos municípios.
} 
norteador para a futura escrita do plano, que poderá ser chamado "A cultura em nossa cidade" (conforme sugere o próprio manual), cada município deverá criar inicialmente um texto base com dados históricos e geográficos, informações demográficas e avaliações (críticas) sobre a situação da cultura na cidade naquele momento. Este diagnóstico deverá mostrar quais são as demandas principais e os caminhos para a criação de cada plano. $\mathrm{O}$ diagnóstico deverá mostrar um "retrato" de cada cidade, e posteriormente ser refletido e refratado no enunciado do Plano de Cultura buscando suprir demandas, necessidades e prioridades.

A segunda pergunta orientadora é “Onde queremos chegar?" e busca auxiliar a população e os agentes culturais a refletir acerca dos avanços e mudanças pretendidas e que deverão ser obtidas concretamente por meio do plano de cultura a ser escrito. É o que o MinC passa a chamar de "futuro projetado". O manual diz que, por meio da observação dos resultados do diagnóstico feito na etapa anterior, será possível debater com a sociedade e com os agentes de cultura acerca das principais demandas e quais caminhos o plano a ser escrito deverá trilhar. Neste momento, poderão surgir as diretrizes e os eixos que servirão como "guarda-chuva" para a escrita das metas, objetivos e ações do enunciado de um plano de cultura. Ao perguntar no plural aonde se busca chegar, o texto inclui no diálogo não apenas as pessoas diretamente participantes do processo de escrita, mas também toda a sociedade de uma comunidade. $\mathrm{O}$ método sugere quase que de maneira obrigatória a participação social, que pode ser feita por meio de uma consulta pública. No entanto, para que haja um consenso acerca dos pontos realmente interessantes para toda a comunidade de determinada cidade, é importante que haja esforços para a inclusão de uma grande quantidade e diversidade de produtores de cultura atuando em interação.

A terceira pergunta que auxiliará na orientação para a escrita do plano de cultura é “Como fazer e quando chegaremos lá?”. Neste momento, a equipe designada para sistematizar as informações das duas etapas anteriores deverá conduzir o desenvolvimento do plano em diálogo com a sociedade, criando uma metodologia específica para isso. Cada tipo de cidade deverá criar um método de trabalho para que o resultado final da escrita do plano seja o mais satisfatório possível. Nesta terceira etapa, deverão ser estabelecidas as propostas iniciais de escrita para as metas, estratégias, objetivos e ações do plano de cultura de uma cidade ou estado, isto é, neste momento, teremos uma primeira versão do enunciado de um plano de cultura territorial. Esta etapa pode ser dividida em mais duas outras complementares: a consulta pública presencial e on line. Com isso a população poderá discutir e sugerir alterações no primeiro texto proposto, e assim contribuir para o enunciado chamado de 
"devolutiva" do texto final.

As três primeiras etapas de escrita do plano de cultura pressupõem uma construção textual complexa de um enunciado que nasce a partir de um texto diagnóstico, influenciador de uma proposição de metas e objetivos a serem realizados. Em diversos momentos desse processo, a participação da sociedade poderá influenciar diretamente e indiretamente no resultado final do enunciado plano de cultura com validade de dez anos. A influência dos discursos da população na versão final do documento pode variar de acordo com a disposição e a abertura da equipe e da gestão que escreverá a versão final deste documento, bem como de seu método e da sua habilidade para organizar uma grande quantidade de sugestões populares com teor diversificado. Quanto maior for a habilidade para selecionar e inserir sugestões da população e dos agentes culturais nos planos de cultura, maior será a possibilidade de termos um enunciado com diversidade de ideias e propostas e que de fato consiga refletir e refratar as demandas socioculturais. Nesses processos de participação social, o diálogo deve permear as relações de escrita, pois não há apenas um autor interessado, mas muitos autores sugerindo diferentes demandas. A relação entre interlocutores diversos, com diferentes consciências, pode ser apontada como uma característica deste tipo de enunciado. O Plano de cultura é um tipo de enunciado em que a interação verbal aparece como característica importante em sua construção.

Essa diversidade de ideias deverá ser diretamente proporcional aos grupos presentes e participantes nas consultas públicas. Grupos com maior organização, maior força política e maior conhecimento dos processos de escrita dos enunciados poderão ter maior influência discursiva nos conteúdos e no resultado final. Todavia, para que o enunciado faça sentido e possa ser executado, será necessário construir um texto final que traga equilíbrio e dissenso entre os diferentes grupos, tenha coerência em termos de gestão de políticas públicas de cultura, pense no bem comum e que possa refletir e refratar a vontade da maioria acerca de temas mais polêmicos.

A última pergunta do processo de construção de um plano de cultura abordada no manual é "Como gerir os avanços?" e refere-se a uma etapa posterior à escrita e aprovação do plano de cultura. Trata do planejamento da gestão do plano no período decenal, de sua validade e desenvolvimento em termos concretos de políticas públicas, do monitoramento dos dados e principalmente dos resultados obtidos desse processo. Este momento de gestão dos avanços acontecerá ao longo dos dez anos de vigência do Plano e busca também fiscalizar a aplicação das ações previstas no enunciado, que enfrentará todas as dificuldades de uma 
política pública estatal, como a falta de orçamentos e de vontade política de gestores, e até a obstrução de determinadas ações por incompatibilidade ideológica sobre o que é cultura e como ela deve ser gerida. O ideal é que um plano de cultura, depois de sua construção e aprovação legal, seja a base para a criação da peça orçamentária de uma dada secretaria de cultura ou mesmo influenciar no método de gestão de cultura em determinado território. Assim, será mais fácil observar os resultados das metas, bem como executar o que está previsto nos enunciados.

Uma comissão técnica dará o tom final ao documento, que seguirá para a sanção do prefeito ou governador, e a redação final será sempre deste grupo pré-determinado pela esfera estatal. Estes grupos poderão moldar a avaliação social do enunciado e determinar, como diz Volóchinov, "a escolha e a ordem de todos os principais elementos significantes do enunciado".

A avaliação social tem uma enorme importância, mesmo em um enunciado com um sentido mais amplo e apoiado em um vasto auditório social. Apesar de essa avaliação não ser expressa adequadamente por meio de uma entonação, ela determinará a escolha e a ordem de todos os principais elementos significantes do enunciado. Não existe um enunciado sem avaliação. Todo enunciado é antes de tudo uma orientação avaliativa. Por isso, em um enunciado vivo, cada elemento não só significa mas também avalia. Apenas um elemento abstrato, percebido no sistema da língua e não na estrutura do enunciado, aparece privado de avaliação. (VOLÓCHINOV, 2017, p. 236)

Ao estabelecer o grupo que fará esta redação final, a prefeitura ou secretaria de cultura antecipa, de certo modo, o tipo de avaliação social e da entonação dos enunciados. Se este grupo for composto por uma comissão democrática e diversificada, com maior variação de tipos de pessoas e procedências, isso estará refletido no enunciado. Se for o contrário, um documento escrito por um restrito número de pessoas, pertencentes a um determinado grupo social, artístico ou político, o resultado final do enunciado, ainda que este tenha passado por uma ampla consulta pública, pode ser alterado conforme "o gosto" de seu redator final.

Neste ponto é essencial pensarmos se há de fato um equilíbrio nesta metodologia. Se, por um lado, temos essa "quase" que obrigatoriedade de seguir forma e conteúdo em relação dialógica de consenso com o PNC, por outro, os grupos que participam da escrita dos planos territoriais influenciam diretamente em seu teor por meio da avaliação social. Este vínculo com a proposta do MinC faz com que os redatores finais de um plano territorial de determinado município não consigam alterá-lo radicalmente, conforme sua vontade e avaliação social. Tanto sua forma quanto seu conteúdo, ou mesmo seu estilo, já estão 
relativamente pré-determinados pelas orientações do sistema federal e passarão pelo "crivo" da sociedade que dará legitimidade (ou não) ao documento e à sua aplicação ao longo dos próximos dez anos. Cabe ao grupo redator final do plano e à população participante dos processos conceberem metas e objetivos que sejam interessantes à cidade seguindo as orientações previamente dadas, pois é a população da cidade que de fato dará sustentação para que um plano seja legítimo ou não. "O centro organizador de toda enunciação, de toda expressão, não é interior, mas exterior: está situado no meio social que circunda o indivíduo" (VOLOCHINOV, 2017, p. 216)

A autonomia da redação de um plano de cultura pode ser percebida principalmente nas escolhas das ações. Essas são motivadas inicialmente pelos dados obtidos no diagnóstico e no que a cidade ou estado já oferece ou não e direcionadas para as metas e objetivos a serem realizados. Entretanto, nem todas as demandas percebidas na etapa do diagnóstico farão parte da redação final do plano de cultura com a mesma importância, pois a presença ou não de uma meta ou objetivo dependerá principalmente:

a) da percepção e organização de dados e resultados do diagnóstico;

b) das prioridades da gestão - quase sempre diretamente relacionados ao fator ideológico e/ou proposta no período eleitoral;

c) da avaliação social do grupo técnico que escreverá a primeira e a última versão do plano;

d) da pressão da organização política de determinados grupos de agentes culturais durante a consulta pública para inclusão de metas com interesses mais específicos.

As escolhas do que será prioridade no plano de cultura estão diretamente relacionadas com a avaliação social dos grupos envolvidos nos processos, tanto os grupos de origem estatal quando da sociedade civil. Essas escolhas deverão estar refletidas no enunciado a ser produzido. Entretanto, há uma hierarquia em termos de quem de fato dá a palavra final ao texto. A sociedade civil, ainda que determine a legitimidade social do enunciado, é a que menos tem poder de escolha na redação final desses planos. O comando do que será escrito está nas mãos do grupo técnico, que depende do aval dos parlamentares do legislativo local (que podem cortar ou remendar trechos) e do prefeito ou governador, que poderá vetar o que achar necessário, ou mesmo vetar o documento como um todo. Esta relação hierárquica na escrita dos planos até sua versão final demonstra que, apesar de o SNC tratar da descentralização das decisões das políticas culturais, a estruturação real do sistema político brasileiro impede que a sociedade civil tenha sua voz e sua avaliação social plenamente 
refletidas nesses enunciados. A ideia de que os processos democratizam as relações de construção de políticas públicas de cultura deve ser pensada como relativa, já que os enunciados não são escritos e finalizados em conjunto com a sociedade civil. Há um filtro de avaliação social feito pelos agentes políticos representados pelo grupo de redação final, e que pode estar refletido em sua materialidade.

As ações são a força motriz das metas de cada plano, pois traduzem as intenções em atos, ou seja, devem indicar precisamente e em termos concretos como cada meta / objetivo poderá ser desenvolvido em programas, atividades e afins. Assim, ainda que na escrita os agentes culturais nos entes federados tenham que seguir princípios e diretrizes do plano federal, eles podem ter maior autonomia na construção das metas e principalmente nas ações. No entanto, para que a real democratização cultural ocorra, é necessário que esse "filltro" dos agentes políticos aceite e inclua no texto os discursos e as demandas da sociedade civil.

$\mathrm{Na}$ criação das chamadas metas estruturantes (do sistema), a ligação com o sistema federal é mais perceptível por ser quase que obrigatória. As metas chamadas estruturantes são relativas à construção concreta do sistema em nível nacional e se reportam à criação, consolidação e gestão dos itens que o compõem: plano, fundo, secretaria, conselho, equipamentos e sistemas de informação. A autonomia em relação às metas estruturantes de cada território é menor do que em outros temas, pois esses deverão refletir diretamente as premissas do SNC presentes na legislação federal.

Partindo dessas reflexões, entendemos que não podemos analisar os planos de cultura sem observar em conjunto os enunciados anteriores a que estes se reportam. Esses enunciados - tantos os manuais, quanto o código de legislação que compõe o SNC - constroem junto aos planos que estão sendo escritos os elos na corrente de comunicação e a nova arquitetônica da esfera político-cultural brasileira que aos poucos apresenta novos gêneros discursivos necessários à sua construção. Como evidencia Bakhtin, um novo gênero do discurso nasce a partir da necessidade de desenvolvimento de uma determinada esfera / campo.

A riqueza e a diversidade dos gêneros do discurso são infinitas porque são inesgotáveis as possibilidades da multifacetada atividade humana e porque em cada campo dessa atividade vem sendo elaborado todo um repertório de gêneros do discurso, que cresce e se diferencia à medida que tal campo se desenvolve e ganha complexidade. (BAKHTIN, 2016, p. 12)

Para compreender o gênero plano de cultura, partimos do pressuposto de que há uma relação entre os enunciados da legislação analisada no capítulo quarto desta tese (emendas constitucionais, decretos, lei de regulamentação do PNC) e os planos de cultura. Por conta da 
metodologia proposta pelo MinC, qualquer plano de cultura terá uma construção composicional relativamente similar, já que seus itens são previamente sugeridos.

Além dos planos de São Paulo inscritos em nosso corpus, foram observados também planos de diversas cidades e estados. Em todos os enunciados observados, as características principais eram similares: apresentaram itens de construção iguais ou parecidos, reportaramse ao SNC e seus princípios, faziam uma projeção de ações e metas decenais e estruturantes. Essa constatação aliada ao crescimento da produtividade deste tipo de enunciado nos permite aferir que o plano de cultura é um novo gênero do discurso, isto é, um tipo "relativamente estável de enunciado" que "refletem as condições específicas e as finalidades de cada referido campo" (BAKHTIN, 2016, pp. 11-12). Por ser um gênero novo de uma esfera da atividade humana muito específica e nova, ainda é desconhecido por grande parte da população. $\mathrm{O}$ gênero ainda encontra-se numa fase inicial de sua construção social. A cada novo enunciado produzido, o gênero Plano de Cultura fortalece sua forma relativamente estável, suas características e especificidades. E é por meio desta constatação que desenvolvemos este capítulo final da tese.

As relações produtivas e o regime sociopolítico condicionado diretamente por elas determinam todos os possíveis contatos verbais entre as pessoas, todas as formas e os meios da comunicação verbal entre elas: no trabalho, na vida política, na criação ideológica. Já as condições, as formas e os tipos de comunicação discursiva, por sua vez, determinam tanto as formas quanto os temas dos discursos verbais. (VOLÓCHINOV, 2017, p. 107).

Nas publicações Guia de orientações para os estados (2011) e Guia de orientações para municípios (2012), encontramos um formato muito similar de sugestão de escrita de plano, pautados pela metodologia de perguntas e respostas. Nas duas publicações, encontramos as seguintes perguntas:

a) O que é e o que deve conter o Plano Estadual (Municipal) de Cultura?

b) Como se faz um Plano Estadual (Municipal) de Cultura?

c) O que é e como se faz um Plano Setorial Estadual (municipal) de Cultura?

d) O Plano é de longo prazo, mas como a realidade é dinâmica pode ser que haja necessidade de adequá-lo a novas conjunturas. Isso é possível?

No desenvolvimento de cada item trazem um resumo dos mesmos conteúdos presentes na publicação Como fazer um plano de cultura em apenas duas páginas. As duas primeiras questões estão relacionadas com a construção composicional dos enunciados e não apenas com seus conteúdos. Ao questionar como fazer, a mensagem deve ser entendida também 
como uma afirmação de como deve ser feito, ainda que apresentem poucas informações detalhadas sobre como escrever um plano de cultura. Ao informar o que um plano deve ter, reforçam suas etapas de criação e construção, e principalmente sua estrutura composicional do gênero, como no trecho abaixo:

O Plano deve conter: I diagnóstico do desenvolvimento da cultura; II diretrizes e prioridades; III objetivos gerais e específicos; IV estratégias, metas e ações; V prazos de execução; VI resultados e impactos esperados; VII recursos materiais, humanos e financeiros disponíveis e necessários; VIII mecanismos e fontes de financiamento; e IX indicadores de monitoramento e avaliação. Para fazer um Plano é necessário responder às seguintes perguntas: Como estamos? Onde queremos chegar? Como fazer e quando chegaremos lá? (MINISTÉRIO DA CULTURA, 2012, p. 44)

Após esta breve introdução, iniciaremos a análise das especificidades dos planos de cultura em si. Buscaremos comprovar a construção da relativa estabilidade do gênero plano de cultura e dessa nova arquitetônica da esfera político-cultural brasileira.

\section{2 - A construção composicional dos Planos de Cultura}

Os diversos itens elencados para a escrita de um plano de cultura buscam guiar o grupo ou os redatores técnicos escolhidos para que construam este enunciado dentro dos padrões almejados pelo MinC e pelos respectivos órgãos de cultura territoriais. Ao terem que considerar a legislação, os manuais, a lei de regulamentação do PNC e as metas do PNC, comprovam o "elo na corrente de comunicação" evidenciado por Bakhtin (2016, p. 60) e possibilitam a observação do plano de cultura como um enunciado não apenas criado por meio de uma ideia, ou baseado em referências anteriores de outros planos de cultura, mas como um enunciado concreto que se constitui em resposta àqueles produzidos anteriormente, numa determinada esfera da atividade humana e que receberá respostas posteriores em relação a seus conteúdos.

Sua forma ou construção composicional, é o primeiro passo para o desenvolvimento de sua escrita, pois está diretamente relacionado a como o texto se organiza em termos de sua materialidade em resposta aos enunciados anteriores, no caso os manuais do MinC. A forma (composicional) realiza a forma arquitetônica em termos materiais "a unificação e a organização dos valores cognitivos e éticos" (BAKHIN, 2010, p. 57) O autor russo diz que "a forma é a expressão da relação axiológica ativa do autor criador e do indivíduo que percebe (co-criador) com o conteúdo" (Idem, p. 59) 
Ao estabelecer nos manuais do SNC que os planos de cultura deverão ter metas, objetivos, diretrizes, estratégias e ações, o MinC começa a sugerir uma forma para o gênero discursivo plano de cultura que deverá ser seguida de maneira relativamente estável pelos diversos tipos de autores que escreverão estes novos enunciados na esfera político-cultural. A forma de um plano de cultura está relacionada com seu conteúdo, pois a proposta de composição desta forma dialoga com a proposta ideológica de política cultural que este novo olhar para a gestão da cultura almeja e com a avaliação social dos agentes autores envolvidos nos processos.

A unidade de todos os momentos composicionais que realizam a forma e sobretudo a unidade do conjunto verbal da obra, unidade no seu aspecto formal, é baseada não naquilo que se fala ou de que se fala, mas na maneira como se fala, no sentimento de uma atividade de elocução significante, que deve ser sentida continuamente como uma atividade única, independentemente da unidade objetal e semântica do seu conteúdo. (...) Todas as articulações composicionais de um conjunto verbal - capítulos, parágrafos, estrofes, linhas, palavras - exprimem a forma apenas enquanto articulações; as etapas da atividade verbal geradora são os períodos de uma tensão única, são os momentos que atingem um certo grau de acabamento, não do conteúdo em si, como momentos determinados a partir do interior, mas momentos de uma atividade que engloba o conteúdo a partir do exterior, determinados pela atividade do autor, orientada sobre o conteúdo, ainda que, é claro, penetrem no conteúdo, dando-lhe uma forma esteticamente adequada, mas sem coação. (BAKHTIN, 2010, pp. 63 - 64)

É na relação entre a forma e o conteúdo que o plano de cultura ganha sentido enquanto ferramenta social que sugere o ato ético (ou não) numa ação de política cultural. Ao prever as diretrizes, e estas desenvolvidas em metas, objetivos e ações, desenha a estrutura da nova arquitetônica do gênero por meio de delimitações éticas que deverão reger a esfera políticocultural brasileira naquele período. Os planos de cultura são os enunciados que deverão servir de base para exprimir as necessidades da sociedade civil para o setor. Devemos considerar que, assim como evidenciado por Bakhtin, a forma composicional destes enunciados é determinada pela forma arquitetônica.

As formas composicionais que organizam o material têm um caráter teleológico, utilitário, como que inquieto e estão sujeitas a uma avaliação puramente técnica, para determinar quão adequadamente elas realizam a tarefa arquitetônica. A forma arquitetônica determina a escolha da forma composicional. (BAKHTIN, 2010, p. 25)

É necessário aos agentes que participarão dos processos saberem o que significam estes itens que compõem a forma dos enunciados e como escrever seus conteúdos, considerando os resultados do diagnóstico e dos debates sobre as reais demandas realizados 
com a sociedade e os agentes culturais. $\mathrm{O}$ conhecimento das especificidades de um gênero discursivo pode proporcionar autonomia e amplia o poder de influência dos participantes dos processos para sugerir conteúdos de acordo com os interesses do grupo a que este representa. Quanto maior o conhecimento do gênero maior a possibilidade de conceber um projeto de discurso para os enunciados em questão.

Quanto mais dominamos os gêneros, maior é a desenvoltura com que os empregamos e mais plano e nitidamente descobrimos neles a nossa individualidade (onde isso é possível e necessário), refletimos de modo mais flexível e sutil a situação singular da comunicação - em suma, tanto mais plena é a forma com que realizamos o nosso livre projeto de discurso. (BAKHTIN, 2016, p. 41)

Nos processos de capacitação promovidos pela UFBA, os participantes utilizam um template via plataforma moodle para simular um plano municipal de cultura. Em certos casos, alguns gestores aproveitam o exercício para escreverem planos de cultura de seus municípios. Porém, os planos de cultura depende da observação de diversos documentos anteriores e também da participação da sociedade civil em sua criação. O uso do template deve ser pensado apenas como um treinamento e não como um momento de criação de um plano.

O guia Como fazer um plano de cultura traz uma extensa reflexão sobre o que o MinC considera ser cada um dos itens da construção composicional e sua relação com os conteúdos de um plano de cultura. Propomos aqui um resumo dessas informações:

- Diretrizes e prioridades: “(...) são ideias princípios e compromissos que orientam a tomada de decisões. As diretrizes ajudam a planejar o caminho a percorrer, ou seja, elas mostram a direção. (...) são definidas a partir das informações do diagnóstico (...) orientam o planejamento dos objetivos, metas e ações" (MINISTÉRIO DA CULTURA, 2013, p. 49)

- Objetivos: "são os resultados que se pretende alcançar no futuro desejado. (...) decidir o que precisa mudar." (idem, p. 50)

- Estratégias: "são ações políticas e técnicas que ajudam a alcançar os objetivos e as metas. (...) tentam garantir que todos os recursos sejam utilizados da melhor maneira (...) pensar em mudanças e aproveitar oportunidades, colocando em prática novos procedimentos e parcerias". (idem, p. 50)

- Metas: "são os resultados que se deseja alcançar (...) em termos quantitativos. (...) um resultado objetivo que pode ser medido em um período de tempo. (...) o futuro que se deseja construir." (ibidem, p.52)

- Ações: "são projetos e atividades para cumprir as metas" (idem, p. 52)

Aqui percebemos algumas relações lógicas entre os itens e que podem trazer dificuldade aos agentes na hora da escrita dos planos. Entretanto, apesar das semelhanças, há diferenças que podem auxiliar nossa reflexão, como por exemplo na comparação dos itens metas, objetivos e ações: 
- Objetivos: "são os resultados que se pretende alcançar no futuro desejado (...)o que precisa mudar"

- Metas: "são os resultados que se deseja alcançar (...) em termos quantitativos."

- Ações: "são projetos e atividades para cumprir as metas"

Apesar da semelhança entre as definições de objetivos e metas, fica claro que o primeiro traz um caráter mais amplo e abstrato e as metas pedem quantidades concretas. Já as ações pedem uma maior concretude de propostas, representadas por projetos e atividades a serem desenvolvidas. Na definição das metas encontramos também o trecho "um resultado objetivo que pode ser medido em um período de tempo". A meta é um desdobramento do objetivo mais amplo, proposto de maneira concreta, pois solicita uma quantidade de resultados pré-estabelecidos num determinado período de tempo.

No manual Proposta metodológica para elaboração de Planos Estaduais de Cultura produzido pelos professores da UFSC, encontramos as seguintes definições para os mesmos itens:

- Diretrizes e objetivos: "As diretrizes constituem os principais eixos escolhidos para o desenvolvimento da cultura no estado. São referências gerais que definem a direção dos objetivos e os limites das estratégias e ações a serem adotadas. Os objetivos podem ser definidos como a situação na qual se pretende que a área da cultura esteja no futuro, de acordo com o alcance temporal do plano. Para definir os objetivos é necessário pensar onde se quer chegar, que situação se pretende alcançar na área da cultura considerando a análise situacional realizada, ou seja, considerando onde se está no momento. “(DELLAGNELO ET AL, 2014, p.37)

- Meta: "A meta é um marco, um limite, um desafio, algo que se pode realizar, um estado a ser atingido com uma ou mais ações, no seu todo ou em parte". (idem, p.47).

- Estratégia: “(...) estratégia pode ser compreendida como uma forma, uma posição, ou caminho que escolhemos e nos orienta com relação aos procedimentos que devemos iniciar hoje para obter no futuro a situação desejada". (ibidem, p.45)

- Ações: "Podemos entender as ações como projetos ou atividades, pois elas têm a finalidade de distribuir responsabilidades e de melhor controlar os resultados esperados. Serão distribuídas ao longo do tempo, de acordo com prioridades de resultados esperados e dos recursos disponíveis. Para as ações, devem ser estabelecidos indicadores de desempenho e, no seu conjunto, elas devem ser relativamente priorizadas." (ibidem, 2014, p.47)

Ao propor uma meta num período de tempo, o objetivo pode ser quantificado e dividido pelo tempo (e neste caso por ser uma política pública também divido em termos de orçamento). Por meio da quantificação prevista na meta também é possível prever ações determinadas e dividi-las ao longo do tempo com prazos definindo cronotopos. Por exemplo, 
se a meta é construir cinco bibliotecas em dez anos, as ações que a seguem deverão prever como e quando serão desenvolvidas para que se atinja essa meta dentro do período de dez anos.

Essas ações deverão ser incluídas na gestão de um órgão de cultura e serem previstas nos orçamentos de cada um dos dez anos que se seguem. A escolha de uma meta, objetivo ou ação deverá ser organizada de acordo com a percepção não apenas do diagnóstico territorial, mas em relação direta com as estratégias políticas e as avaliações sociais dos destinatários dos planos que surgirão no futuro.

\subsection{1 - A construção composicional no Plano Nacional de Cultura (PNC)}

As diretrizes e estratégias do PNC são apresentadas nas publicações Plano Nacional de Cultura Diretrizes gerais (edições 2007 e 2008), que, como vimos anteriormente, da primeira para a segunda edição tiveram muitas alterações de conteúdo após os seminários nos estados da união. As diretrizes são apresentadas na primeira publicação, num capítulo chamado "Valores e conceitos", listadas em sete itens seguidos de sua respectiva justificativa.

As estratégias são divididas em cinco e cada uma delas detalhadas em tópicos temáticos e estes detalhados em ações. Não há uma lógica para ordem das diretrizes e estratégias. É possível supor que as primeiras serão tratadas como prioritárias tanto pelos agentes em plano federal quanto pelos agentes territoriais que deverão levar o PNC em conta ao escreverem seus planos.

Na publicação As metas do Plano Nacional de Cultura, o único item nomeado é o da própria meta. Outros itens estão representados por perguntas.

$\mathrm{Na}$ imagem a seguir, relativa à meta número 1, observamos a construção composicional proposta, que utiliza recursos verbo-visuais para uma melhor compreensão do leitor, com cores diferenciadas, imagens e tabelas.

O título referente à meta apresenta inicialmente números de cada meta e um texto escrito em vermelho. Logo abaixo traz uma rápida justificativa escrita em amarelo também relativo à meta. Em seguida, é desenvolvido um texto explicativo similar a uma ementa, sobre a temática principal da meta (no caso o SNC). 
Figura 27: Meta 1 na publicação das metas do PNC.

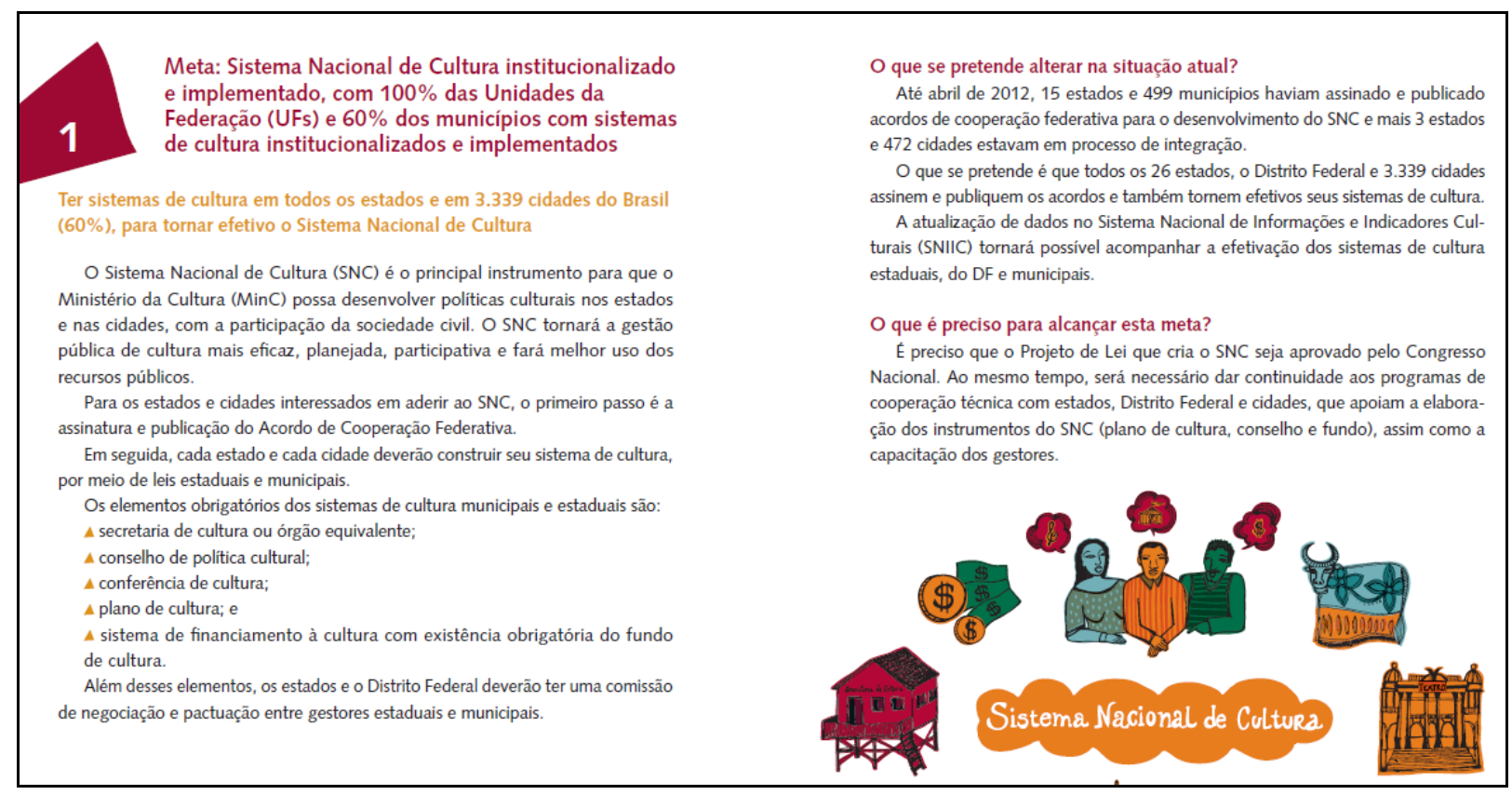

Fonte: As metas do Plano Nacional de Cultura ${ }^{179}$

O item "objetivos" pode ser considerado por meio da pergunta "O que se pretende alterar na situação atual?" também escrita em fonte vermelha, igual à da meta. Este procedimento também acontece com as "ações" que do mesmo modo não são nomeadas e substituídas pela pergunta “O que é preciso para alcançar esta meta?”. Ao não nomear os itens objetivos e ações, o PNC não contribui para estabelecer uma forma definitiva ao gênero plano de cultura. Isso pode tornar o gênero mais flexível. Contudo, ao utilizar perguntas, os autores do enunciado facilitam a compreensão dos leitores sobre o que deve ser feito. Este mesmo método é desenvolvido nas demais 52 metas do enunciado.

O caráter geográfico mais abrangente do enunciado do PNC como um plano federal traz características discursivas únicas ao texto, pois, afinal, ele é o único do tipo por enquanto. Ao contrário de um plano municipal, que deve traduzir as demandas percebidas nas pontas do sistema, o texto do PNC federal é um "guarda-chuva" que deve refletir as demandas e as vontades de milhares de cidades e estados em conjunto e influencia diretamente a escrita dos enunciados nos entes federados. Entretanto, a primeira versão desse enunciado, de 2010, apenas reflete suposições sobre esse "futuro projetado" já que no período de sua criação, os dados do SNIIC ainda eram iniciais, e as pesquisas de diagnóstico estavam baseadas apenas em informações disponíveis do MinC e do IBGE.

\footnotetext{
${ }^{179}$ Disponível em: < www.cultura.gov.br/documents/10883/11294/METAS_PNC_final.pdf/ > acesso em 25 de outubro de 2017.
} 
De acordo com Peixe (2016, pp. 225 - 226), o primeiro sistema consolidado foi o do estado do Ceará, que em 2003 já apresentava um Plano de Cultura aprovado ainda que quadrienal (2003 - 2006). Na sequência, o município de Rio Branco no Acre foi a primeira cidade com o projeto de lei de sistema datada de dezembro de 2007. O Plano Estadual de Cultura do estado do Ceará é a referência na escrita de planos territoriais, não apenas por ter sido o primeiro e anterior ao próprio $\mathrm{PNC}$, mas por ter sido o primeiro a efetuar o desenvolvimento concreto de diretrizes, metas, ações do texto apresentado no remoto ano de 2003, na gestão da secretária de cultura Claudia Leitão, e no mesmo período em que a política nacional ainda estava sendo criada no MinC. Não é possível dizer o quanto este plano influenciou os demais por falta de dados resultantes disso, ou mesmo o quanto influenciou a construção do SNC como um todo, mas, ao observar as políticas culturais cearenses atuais, constatamos que o sistema e o plano estadual são mencionados e aplicados em todas as ações culturais no estado. O primeiro plano estadual cearense de 2003 apresenta em suas articulações composicionais: eixos, estratégias, diretrizes, desafios, objetivos e princípios.

No site do Plano Nacional de Cultura, uma pequena parte das metas são atualizadas pelo MinC ao menos a cada seis meses ou de acordo com o avanço concreto observado nos resultados. Boa parte delas permanece até hoje com os dados e informações iniciais, e, depois da mudança do site no final de 2017, algumas delas não trazem nenhuma informação. Ao contrário do descritivo das metas na publicação do PNC, no site são apresentados dados iniciais e perspectivas de desenvolvimento das mesmas.

O site do PNC traz informações complementares: "Como esta meta está sendo medida" e "Situação da meta" e é possível que a população interaja com comentários sobre cada meta. Em todas as 53 metas analisadas no site encontramos o mesmo formato descritivo: número da meta, título da meta e sua justificativa, ementa descritiva.

Ao não nomear os itens no PNC, e apenas sugeri-los nos manuais, o MinC auxilia na flexibilização da forma desse tipo de enunciado. Esta flexibilidade poder ser refletida e refratada nos planos territoriais escritos nos estados e cidades, incidindo diretamente em variações de ordem de itens ou mesmo na não inclusão de alguns itens nos planos.

A supressão de itens num plano de cultura faz parte das escolhas dos grupos envolvidos nos processos de escrita. Entretanto, é preciso salientar que nem sempre são utilizados os mesmos métodos, com tempo disponível para o pleno desenvolvimento dos conteúdos, ou mesmo há um consenso em relação à forma que um plano de cultura deverá ter. 
Figura 28: Como está sendo medida e situação da Meta 1 no site do PNC.

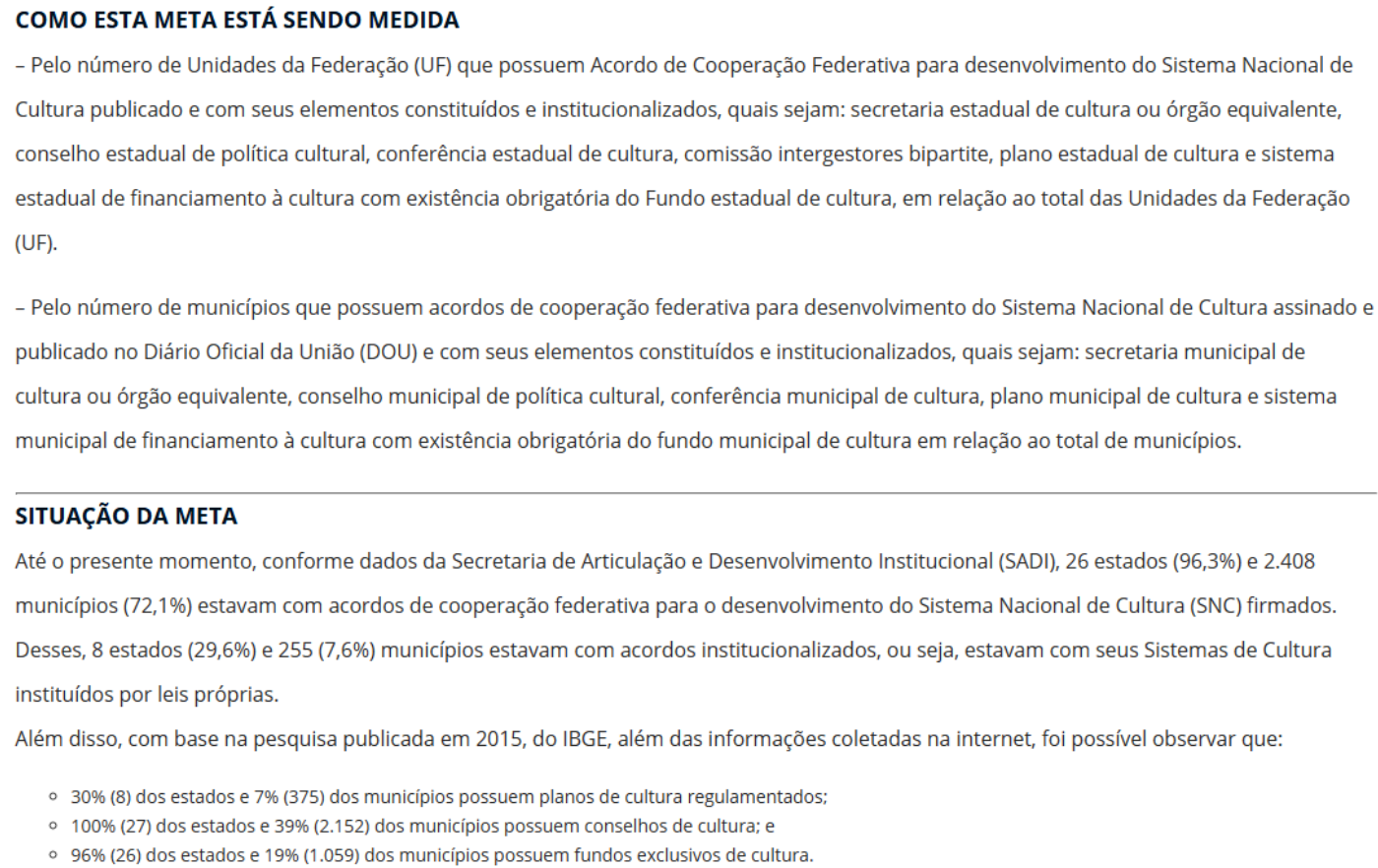

- Pelo número de Unidades da Federação (UF) que possuem Acordo de Cooperação Federativa para desenvolvimento do Sistema Nacional de Cultura publicado e com seus elementos constituídos e institucionalizados, quais sejam: secretaria estadual de cultura ou órgão equivalente, conselho estadual de política cultural, conferência estadual de cultura, comissão intergestores bipartite, plano estadual de cultura e sistema estadual de financiamento à cultura com existência obrigatória do Fundo estadual de cultura, em relação ao total das Unidades da Federação (UF).

- Pelo número de municípios que possuem acordos de cooperação federativa para desenvolvimento do Sistema Nacional de Cultura assinado e publicado no Diário Oficial da União (DOU) e com seus elementos constituídos e institucionalizados, quais sejam: secretaria municipal de cultura ou órgão equivalente, conselho municipal de política cultural, conferência municipal de cultura, plano municipal de cultura e sistema municipal de financiamento à cultura com existência obrigatória do fundo municipal de cultura em relação ao total de municípios.

SITUAÇÃO DA META

Até o presente momento, conforme dados da Secretaria de Articulação e Desenvolvimento Institucional (SADI), 26 estados (96,3\%) e 2.408 municípios (72,1\%) estavam com acordos de cooperação federativa para o desenvolvimento do Sistema Nacional de Cultura (SNC) firmados. Desses, 8 estados (29,6\%) e 255 (7,6\%) municípios estavam com acordos institucionalizados, ou seja, estavam com seus Sistemas de Cultura instituídos por leis próprias.

Além disso, com base na pesquisa publicada em 2015, do IBGE, além das informações coletadas na internet, foi possível observar que:

- $30 \%$ (8) dos estados e $7 \%$ (375) dos municípios possuem planos de cultura regulamentados:

- $100 \%$ (27) dos estados e $39 \%$ (2.152) dos municípios possuem conselhos de cultura: e

- $96 \%$ (26) dos estados e $19 \%$ (1.059) dos municípios possuem fundos exclusivos de cultura.

Fonte: Site PNC. ${ }^{180}$.

A inversão da ordem ou supressão de itens foi observada em outros 35 planos de cultura municipais já aprovados que foram analisados ao longo da pesquisa ${ }^{181}$.

Nos enunciados listados na tabela a seguir, podemos perceber que, na maioria dos casos, alguns enunciados apresentam, além dos itens descritos, introdução, histórico da meta, ementa da meta, atribuições ao poder público, descritivo do diagnóstico, ações detalhadas para as diversas linguagens artístico-culturais, financiamento / orçamento / gestão, nomes de programas e projetos já existentes.

Todavia, devemos salientar que a presença dos itens diretrizes, metas, ações, objetivos, estratégias na maior parte dos enunciados comprova nossa tese de que, apesar de ainda ser um gênero jovem de uma esfera complexa em início de construção, o plano de cultura já apresenta características comuns e nos permite afirmar que há uma relativa estabilidade na construção composicional.

\footnotetext{
${ }^{180}$ Disponível em: < http://pnc.cultura.gov.br/category/metas/1/ > acesso em 25 de outubro de 2017.

${ }^{181}$ Documentos oficiais digitalizados disponíveis para consulta no site do SNC. Até a última data de acesso, 202 municípios estavam listados no site, mas apenas 35 deles apresentavam o enunciado do PMC. Disponível em: < http://snc.cultura.gov.br/adesao/consultar/?municipio=\&page=2\&plano=on $>$ acesso em 20 de fevereiro 2018.
} 
Tabela 1: Distribuição de itens dos planos municipais analisados

\begin{tabular}{|c|c|c|c|c|c|c|c|c|c|}
\hline $\begin{array}{c}\text { Municípios } \\
\text { (Planos aprovados } \\
\text { em leis) }\end{array}$ & Formato do Plano de Cultura & 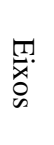 & $\stackrel{\text { : }}{\stackrel{0}{\mathrm{O}}}$ & : & $\underset{2}{\frac{3}{2}}$ & 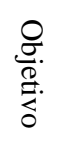 & 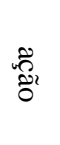 & 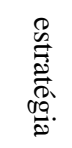 & 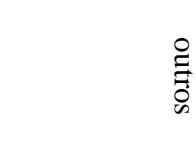 \\
\hline $\begin{array}{l}\text { Antônio Almeida } \\
(\mathrm{PI})\end{array}$ & Diretrizes $>$ Estratégias > Ações & & 1 & & & & 1 & 1 & \\
\hline $\begin{array}{l}\text { Belo Horizonte } \\
\text { (MG) }\end{array}$ & $\begin{array}{l}\text { Desafios }>\text { Diretrizes }>\text { Objetivos gerais }> \\
\text { Objetivos específicos }>\text { Ações }> \\
\text { Estratégias }\end{array}$ & & 1 & & & 1 & 1 & 1 & desafios \\
\hline Casa Branca (SP) & $\begin{array}{l}\text { Desafios > Diretrizes > Estratégias > } \\
\text { Objetivos e Metas> Metas e ações }\end{array}$ & & 1 & & 1 & 1 & 1 & 1 & desafios \\
\hline $\begin{array}{l}\text { Casimiro de Abreu } \\
\text { (RJ) }\end{array}$ & $\begin{array}{l}\text { Objetivos > Diretrizes gerais e prioridades } \\
>\text { Metas }>\text { Propostas }>\text { ações }\end{array}$ & & 1 & & 1 & 1 & 1 & & $\begin{array}{l}\text { propostas, } \\
\text { resultados e } \\
\text { impactos } \\
\text { esperados }\end{array}$ \\
\hline Catarina (CE) & $\begin{array}{l}\text { Princípios > Objetivos > estratégias > } \\
\text { metas > ações }\end{array}$ & & & 1 & 1 & 1 & 1 & 1 & \\
\hline $\begin{array}{l}\text { Caxambu do Sul } \\
\text { (SC) }\end{array}$ & $\begin{array}{l}\text { Desafios e oportunidades > propostas > } \\
\text { ações }\end{array}$ & & & & & & 1 & & $\begin{array}{l}\text { desafios e } \\
\text { oportunidades, } \\
\text { propostas }\end{array}$ \\
\hline $\begin{array}{l}\text { Conceição da Feira } \\
\text { (BA) }\end{array}$ & $\begin{array}{l}\text { Diretrizes > Ações estratégicas > } \\
\text { objetivos > ações }\end{array}$ & & 1 & & & 1 & 1 & 1 & \\
\hline Cordeiro (RJ) & $\begin{array}{l}\text { Objetivos gerais > Objetivos específicos }> \\
\text { Eixos }>\text { Diretrizes }>\text { Ações }\end{array}$ & 1 & 1 & & & 1 & 1 & & \\
\hline $\begin{array}{l}\text { Coronel Murta } \\
\text { (MG) }\end{array}$ & Diretrizes $>$ Propostas & & 1 & & & & & & propostas \\
\hline Criciúma (SC) & $\begin{array}{l}\text { Capítulos > Diretrizes > Estratégias > } \\
\text { ações }\end{array}$ & & 1 & & & & 1 & 1 & capítulos \\
\hline $\begin{array}{l}\text { Cruzeiro do Sul } \\
\text { (AC) }\end{array}$ & $\begin{array}{l}\text { Desafios e oportunidades }>\text { Diretrizes }> \\
\text { Eixos }>\text { Propostas }>\text { objetivos }>\text { Metas }> \\
\text { Ações }>\text { Prazo de execução }\end{array}$ & 1 & 1 & & 1 & 1 & 1 & & $\begin{array}{l}\text { Desafios e } \\
\text { oportunidades, } \\
\text { propostas, } \\
\text { prazo }\end{array}$ \\
\hline $\begin{array}{l}\text { Duque de Caxias } \\
\qquad(\mathrm{RJ})\end{array}$ & $\begin{array}{l}\text { Capítulos }>\text { Diretrizes }>\text { Objetivos }> \\
\text { Parcerias }>\text { Medidas }\end{array}$ & & 1 & & & 1 & & & $\begin{array}{l}\text { Capítulos, } \\
\text { Parcerias, } \\
\text { Medidas }\end{array}$ \\
\hline Felisburgo (MG) & Diretrizes > estratégias > ações & & 1 & & & & 1 & 1 & \\
\hline Fortaleza (CE) & Diretrizes $>$ Objetivos $>$ Metas $>$ Ações & & 1 & & 1 & 1 & 1 & & \\
\hline Gravataí (RS) & $\begin{array}{l}\text { Princípios }>\text { Objetivos }>\text { Diretrizes }> \\
\text { Estratégias }>\text { Ações }\end{array}$ & & 1 & 1 & & 1 & 1 & 1 & \\
\hline Guararema (SP) & $\begin{array}{l}\text { Diretrizes > Objetivos e competências > } \\
\text { Estratégias e ações }\end{array}$ & & 1 & & & 1 & 1 & 1 & competências \\
\hline Hortolândia (SP) & Princípios > objetivos & & & 1 & & 1 & & & \\
\hline Ilhéus (BA) & Princípios > Objetivos & & & 1 & & 1 & & & \\
\hline Ipaporanga (CE) & $\begin{array}{l}\text { Capítulos > Princípios > Objetivos > } \\
\text { Estrutura > diretrizes }\end{array}$ & & 1 & 1 & & 1 & & & estrutura \\
\hline
\end{tabular}




\begin{tabular}{|c|c|c|c|c|c|c|c|c|c|}
\hline Itajaí (SC) & $\begin{array}{l}\text { Princípios > objetivos }>\text { eixos }>\text { Metas > } \\
\text { ações }\end{array}$ & 1 & & 1 & 1 & 1 & 1 & & \\
\hline Itanhaém (SP) & Objetivos $>$ metas $>$ ações & & & & 1 & 1 & 1 & & \\
\hline Itu (SP) & $\begin{array}{l}\text { Programas estratégicos }>\text { diretrizes }> \\
\text { Objetivos }>\text { programas e projetos }>\text { ações } \\
\text { específicas }\end{array}$ & & & & & 1 & 1 & & $\begin{array}{l}\text { programas } \\
\text { estratégicos, } \\
\text { programas e } \\
\text { projetos }\end{array}$ \\
\hline Jaguaruana (CE) & Objetivos > metas > ações & & & & 1 & 1 & 1 & & \\
\hline Janduís (RN) & Princípios $>$ Objetivos $>$ Metas & & & 1 & 1 & 1 & & & \\
\hline $\begin{array}{l}\text { Lago do Junco } \\
\text { (MA) }\end{array}$ & $\begin{array}{l}\text { Princípios diretrizes e prioridades }> \\
\text { Objetivos gerais }>\text { Objetivos específicos }> \\
\text { Estratégias }>\text { Metas }>\text { Ações }\end{array}$ & & 1 & 1 & 1 & 1 & 1 & 1 & prioridades \\
\hline Mairiporã (SP) & $\begin{array}{l}\text { Diretrizes gerais > Objetivos estratégicos } \\
>\text { Propostas e desafios }\end{array}$ & & 1 & & & 1 & & & $\begin{array}{l}\text { propostas e } \\
\text { desafios }\end{array}$ \\
\hline Maués (AM) & $\begin{array}{l}\text { Desafios e oportunidades }>\text { Diretrizes e } \\
\text { prioridades }>\text { Estratégias }>\text { Eixos }> \\
\text { Objetivos gerais }>\text { Objetivos específicos }> \\
\text { Metas }>\text { Ações }\end{array}$ & 1 & 1 & & 1 & 1 & & 1 & $\begin{array}{l}\text { desafios e } \\
\text { oportunidades, } \\
\text { prioridades }\end{array}$ \\
\hline $\begin{array}{l}\text { Nova esperança } \\
\text { (PR) }\end{array}$ & Diretrizes $>$ Metas $>$ Estratégias $>$ Ações & & 1 & & 1 & & 1 & 1 & \\
\hline $\begin{array}{l}\text { Porto Nacional } \\
\quad \text { (TO) }\end{array}$ & $\begin{array}{l}\text { Objetivos estratégicos > Diretrizes }> \\
\text { Programas, projetos e ações }\end{array}$ & & 1 & & & & 1 & & $\begin{array}{l}\text { objetivos } \\
\text { estratégicos, } \\
\text { programas e } \\
\text { projetos }\end{array}$ \\
\hline $\begin{array}{c}\text { S. Felix do } \\
\text { Araguaia (MT) }\end{array}$ & $\begin{array}{l}\text { Princípios }>\text { Objetivos }>\text { Financiamento }> \\
\text { Diretrizes }>\text { estratégias }>\text { Ações e } \\
\text { diversidade cultural }\end{array}$ & & 1 & 1 & & 1 & 1 & 1 & \\
\hline Santa Teresa (ES) & $\begin{array}{l}\text { Diretrizes > Objetivos > Plano de } \\
\text { implementação (ações divididas por } \\
\text { setoriais ) }\end{array}$ & & 1 & & & 1 & 1 & & \\
\hline São Paulo (SP) & Meta > ação & 1 & 1 & & 1 & & 1 & & \\
\hline Silvânia (GO) & Diretrizes > estratégias > ações & & 1 & & & & 1 & 1 & \\
\hline Sorocaba (SP) & $\begin{array}{l}\text { Eixos> Objetivos específicos > Metas > } \\
\text { Ações (prazo curto, médio, longo) }\end{array}$ & 1 & & & 1 & 1 & 1 & & \\
\hline $\begin{array}{l}\text { TOTAL } \\
\text { municípios }\end{array}$ & & 7 & 25 & 9 & 15 & 25 & 27 & 15 & \\
\hline
\end{tabular}

A sugestão de itens específicos nos manuais do MinC para a escrita dos planos territoriais pode justificar o porquê de alguns itens serem encontrados com maior recorrência. A similaridade entre o que de fato significam cada um desses itens também está refletida na presença nos enunciados, pois em alguns casos pode ter ocorrido a escolha por apenas um

\footnotetext{
${ }^{182}$ No 2o semestre de 2018, esses documentos foram retirados do site do SNC e transferidos para a plataforma VER SNC que primitia a consulta pública sobre a situação de cada município e os documentos oficiais relativos aos processos locais, porém no fechamento desta tese não estavam mais disponíveis para consulta.
} 
deles, a fim de facilitar a escrita e a compreensão dos futuros leitores. Os planos escritos, aprovados e publicados inicialmente influenciaram os demais.

Dos 35 Planos Municipais de Cultura analisados, a tabela comprova a presença recorrente dos itens em escalas diferentes:

a) Com maior frequência: diretrizes (69\%); objetivos (69\%); ações (70\%);

b) Com frequência média: metas (41\%); estratégias (41\%);

c) Com baixa frequência: eixos (18\%); princípios (21\%).

É provável que a maior incidência dos itens Diretrizes e Objetivos esteja diretamente relacionada com o fato de serem itens de caráter mais geral para guiar o desenvolvimento dos planos, como a definição já diz. O item "ações" apresentou quase o dobro de citações dos itens "metas" e "estratégias" provavelmente por conta da similaridade entre a definição dos itens. Essa escolha por utilizar apenas o item "ação" para detalhar 'o que fazer' parece demonstrar uma simplificação do gênero. Em poucos casos, os itens metas e ações foram substituídos por novas nomenclaturas de itens como: propostas, medidas e prioridades.

O caso específico da cidade de Catarina no estado do Ceará chama atenção por se tratar de um plano de cultura trienal (e não decenal) e do enunciado estar composto de diversos itens diferentes para um plano de cultura, como: apresentação, histórico, plano estratégico de gestão cultural, descrição dos cargos da nova estrutura, infraestrutura cultural, calendário de festividades, etc. Esta diversificação de itens foi encontrada em alguns planos, porém com menor nível de detalhamento, conforme é possível perceber na coluna “outros” da tabela anterior.

Outra questão a ser salientada é que nem sempre é de fato reservado um espaço suficiente para o desenvolvimento das ideias e propostas para o futuro de forma equilibrada. Isto acontece em pelo menos metade dos planos analisados. Um bom exemplo é o plano do município Coronel Murta (MG), que apresentou um enunciado com 33 páginas, mas apenas duas delas com o detalhamento de diretrizes e propostas. O restante das outras 31 páginas são compostas por apresentação, diagnóstico histórico- geográfico da cidade e um relatório detalhado de seis páginas descrevendo pratos da gastronomia típica da região, inclusive com resumos de receitas culinárias.

Alguns planos de cultura apresentam itens introdutórios. Os mais recorrentes são: dados geográficos e históricos, um breve diagnóstico da situação da cultura naquele momento e uma lista com o código de leis de cultura já existentes. Entretanto, desses itens introdutórios, o único estritamente recomendado pelos manuais do SNC é o diagnóstico, que de certa 
maneira pode incluir todos os demais citados, ainda que com nomes similares, visando compreender as demandas para a escrita do plano. Encontramos diagnósticos com outros nomes, como por exemplo "análise situacional do município", "Situação atual”, "Como é hoje". A grande maioria dos planos de cultura territoriais presentes no site do SNC não apresentaram diagnóstico detalhado sobre a situação da cultura, introdução ou nenhum outro item equivalente a estes.

A análise demonstrou que as orientações e sugestões presentes nos manuais do MinC contribuem para que esta construção composicional se apresente similar na maioria dos casos, ainda que tenha alteração da ordem ou supressão dos itens. Na análise dos 35 planos municipais de cultura os itens não apresentam uma ordem estável, conforme demonstra a tabela. Ainda que estejam presentes na maior parte dos planos, nem sempre seguem a mesma lógica ou ordem, ou representam a mesma intenção de organização textual e discursiva.

É impossível observarmos todos os planos escritos até o presente momento, principalmente porque boa parte deles ainda não se encontram oficializados em algum tipo de marco legal, ou não estão disponíveis para consulta pública. Por este motivo, buscamos analisar parte daqueles já chancelados pelo próprio ministério e presentes no site do SNC. A disposição destes enunciados no site, com suas variações de formato e propostas, pode contribuir para que outros municípios ainda em início de processo de escrita, escolham o melhor modelo para cada caso e o utilizem como referência para compor o seu.

Em 10 de outubro de 2017, o site do SNC apresentava 74 documentos relativos a planos de cultura aprovados, inseridos no site pelos próprios municípios, tanto de leis quanto de planos decenais. A atualização no site do PNC indica que, no final de julho de 2017, 255 municípios já haviam completado a implantação de seus sistemas, isto é, pelo menos 255 municípios já estavam com seus Planos escritos e aprovados nos legislativos locais. Já em fevereiro de 2018, o site do SNC apresentou um número menor, apenas 35 planos de cultura decenais com textos completos estavam disponíveis e 202 municípios estavam inscritos. Conforme informado por funcionários da SADI no período, esta diminuição de municípios listados pode estar relacionada a uma avaliação mais detalhada da situação de cada município ou mesmo de sua relação atual com o SNC através do Acordo de Cooperação Federativa. Após dezembro de 2018 não verificamos mais nenhuma atualização na situação no site do SNC.

Ao considerarmos que, no gênero plano de cultura, a maior parte dos itens estão diretamente relacionados aos demais, formando uma construção com lógica específica para o 
gênero, achamos relevante analisarmos atentamente um dos trechos do PEC SP para melhor observarmos como se desenvolve essa inversão de ordem dos itens e se de fato em termos de significado do item e sua relação com o conteúdo estão de acordo com o proposto pelo MinC para a escrita de um plano de cultura.

\subsection{2 - A construção composicional no Plano Estadual de Cultura de São Paulo}

No site do Plano Estadual de Cultura de São Paulo ${ }^{183}$ (PEC SP), encontramos sua primeira versão (ainda em processo de aprovação e parado na procuradoria Geral do Estado desde 2016). O documento completo ${ }^{184}$ do PEC SP traz inicialmente quatro páginas com o histórico da composição da comissão que escreveu o plano com o nome e cidade de origem de cada um dos 42 membros titulares, sendo dez membros de cada uma das linguagens e quinze membros de órgãos e entidades que representaram o Estado. Em seguida, o relatório apresenta um detalhamento das oito reuniões realizadas para a escrita do enunciado.

Mais adiante, traz um texto de nove páginas com reflexões sobre o diagnóstico da cultura no estado de São Paulo, que, apesar do tema, raramente são demonstrados números e dados concretos, ao contrário do que orienta o MinC. O diagnóstico se apresenta como um descritivo histórico de ações de políticas culturais estaduais, mas não reflete dados da situação da cultura no estado. A seguir o documento apresenta o conteúdo das diretrizes, objetivos, ações e metas do Plano Estadual de Cultura desenvolvidos aos poucos e com muitos trechos semelhantes. O enunciado apresenta datas desatualizadas e traz ao leitor uma percepção do processo de reflexão e escrita desenvolvido pelo grupo. Todavia, devemos considerar que o conjunto de itens apresentado no final compõe a proposta de Plano de Cultura de modo mais coerente e deverá orientar sua versão final após a aprovação.

As vinte diretrizes do Plano Estadual de Cultura de São Paulo são expostas em números e tópicos e com parágrafos de em média três linhas e com algumas palavras-chave em negrito como vemos na imagem a seguir.

\footnotetext{
${ }^{183}$ Importante reiterar que o Plano Estadual de Cultura de São Paulo, até a finalização desta tese, ainda não havia sido aprovado enquanto documento legal na Assembléia Legislativa.

${ }^{184}$ Disponível em: < http://www.planoestadualdecultura.sp.gov.br/?page id=466> acesso em 25 de outubro de 2017.
} 
Figura 29: Diretrizes do Plano Estadual de Cultura de SP.

As diretrizes do PEC/SP são as seguintes:
1. Garantir e fortalecer a dimensão simbólica da cultura promovendo-a e protegendo-a, com suas infinitas
possibilidades de criação simbólica expressas em modos de vida, artes, crenças, valores, práticas, rituais e
identidades. [Compreende os bens de natureza material e imaterial que constituem o patrimônio cultural do Estado
de São Paulo, abrangendo todos os modos de viver, fazer e criar dos diferentes grupos formadores da sociedade
paulista, conforme o Art. 216 da Constituição Federal].
2. Realizar e manter atualizado o mapeamento, no âmbito do Estado e municípios, das expressões, dos patrimônios,
das linguagens e manifestações artísticas, das culturas populares, indigenas, afro-brasileiras, ciganas, quilombolas,
hip hop e tradicionais, de forma integrada ao Sistema Nacional de Informações e Indicadores Culturais (SNIIC),
levando-se em consideração as particularidades de cada "povo" e "comunidade" para subsidiar o planejamento e a
tomada de decisões referentes às politicas públicas.
3. Criar e manter atualizado um banco de dados relativo a investimentos em políticas culturais, programas, projetos
e ações dos órgãos públicos estaduais e municipais, bem como às despesas de gestão, e promover sua
acessibilidade.
4. Fortalecer a transmissão do conhecimento, dos saberes e práticas das "mestras(es)", "povos" e "comunidades"
tradicionais entre as diferentes gerações.

Fonte: Site Plano Estadual de Cultura de SP. ${ }^{185}$.

Logo após a apresentação das diretrizes, o documento traz os objetivos, os quais, como ele mesmo descreve, são "elaborados a partir das diretrizes". Neste trecho do documento, depreendemos que a relação entre diretrizes, objetivos, ações e metas é construída ao longo do enunciado, provavelmente na ordem em que foram escritas. Essa construção composicional feita gradualmente divide os itens e pode causar estranhamento ao leitor que só consegue ter acesso às informações completas no trecho final do documento.

O Plano Estadual de Cultura de São Paulo traz o item "metas" no final da construção composicional do enunciado, após as ações. A ordem dos itens no plano federal PNC, ainda que compostos por perguntas retóricas, se apresenta como: DIRETRIZES > METAS > OBJETIVOS > AÇÕES. No PEC SP, a ordem dos itens é alterada para: DIRETRIZES > OBJETIVOS > AÇÕES > METAS. Enquanto as metas no PNC estão no início da reflexão, no PEC SP estão no final.

\footnotetext{
${ }^{185}$ Disponível em: < http://www.planoestadualdecultura.sp.gov.br/?page id=466 > acesso em 25 de outubro de 2017.
} 
Figuras 30, 31 e 32: Objetivos , ações e metas do PEC SP

\section{Objetivos, elaborados a partir das diretrizes}

1.1 Planejar, criar e implantar políticas, programas, projetos e ações voltadas para o fortalecimento e promoção das expressões, dos patrimônios, das linguagens e manifestações artísticas, das culturas populares, indígenas, afrobrasileiras, ciganas, quilombolas, hip hop e tradicionais para os próximos 10 anos.

2.1 Implantar o Sistema Estadual de Informações e Indicadores Culturais como instrumento de acompanhamento, avaliação e aprimoramento da gestão e das políticas públicas de cultura.

2.2 Realizar mapeamentos das expressões, dos patrimônios, das linguagens e manifestações artísticas, das culturas populares, indígenas, afro-brasileiras, ciganas, quilombolas, hip hop e tradicionais, visando produzir informações para subsidiar ações de proteção da diversidade cultural paulista, e difundir informações sistematizadas a esse respeito.

3.1 Possibilitar acesso pleno às informações e dados gerenciais e de execução orçamentária dos órgãos públicos estaduais e municipais de cultura.

\section{Ações, elaboradas a partir dos objetivos}

1.1 Planejar, criar e implantar políticas, programas, projetos e ações voltadas para o fortalecimento e promoção das expressões, dos patrimônios, das linguagens e manifestações artísticas, das culturas populares, indígenas, afrobrasileiras, ciganas, quilombolas, hip hop e tradicionais para os próximos 10 anos.

Ação 1 - Desenvolver e ampliar programas, projetos e ações para fomentar as iniciativas permanentes das expressões, dos patrimônios, das linguagens e manifestações artísticas, das culturas populares, indígenas, afro-brasileiras, ciganas, quilombolas, hip hop, tradicionais, LGBTT e pessoas com deficiências.

Ação 2 - Garantir que o conceito de "dimensão simbólica" no seu sentido amplo seja contemplado nas diretrizes, programa, projetos e ações do Sistema Estadual de Cultura e da Secretaria de Estado da Cultura.

Ação 3 - Garantir e fortalecer o conceito de Povos e Comunidades Tradicionais de Matriz Africana como mecanismo para o diálogo com o Estado em busca do fortalecimento, reconhecimento e construção de politicas para a cultura afro-brasileira e seus detentores.

\section{Metas, elaboradas a partir das ações}

1.1 Planejar, criar e implantar políticas, programas, projetos e ações voltadas para o fortalecimento e promoção das expressões, dos patrimônios, das linguagens e manifestações artísticas, das culturas populares, indígenas, afrobrasileiras, ciganas, quilombolas, hip hop e tradicionais para os próximos 10 anos.

Ação 1 - Desenvolver e ampliar programas, projetos e ações para fomentar as iniciativas permanentes das expressões, dos patrimônios, das linguagens e manifestações artísticas, das culturas populares, indigenas, afro-brasileiras, ciganas, quilombolas, hip hop, tradicionais, LGBTT e pessoas com deficiências,

Meta 1 - Equiparar em R\$ 2 milhões até 2017, os recursos dos editais ProAC para Culturas Populares e Tradicionais, Culturas Indígenas, Cultura afro-brasileiras, Hip Hop, LGBTT e circo, garantindo pelo menos $50 \%$ dos recursos para o interior.

Meta 2 - Inserir na Virada Cultural Paulista, a partir de 2016, 500 expressões culturais dos povos indígenas, culturas afro-brasileiras, circo, hip hop, tradicional, LGBTT e pessoas com deficiências.

Meta 3 - Criar na Unidade de Formação Cultural (UFC) um programa para as expressões, os patrimônios, as linguagens e manifestações artísticas, as culturas populares, indígenas, afro-brasileiras, ciganas, quilombolas, hip hop, tradicionais, LGBTT e pessoas com deficiênciaspara atuação em todos os projetos da unidade. Garantir que este programa contemple, entre outras, as seguintes dimensões: a) Instituir ações de incentivo à transmissão de valores, saberes e práticas tradicionais.

Fonte: Site Plano Estadual de Cultura de SP, PEC SP, pp. 38 - 46. 
Muitas ações do PEC SP não apresentam meta alguma, principalmente as últimas do enunciado. Em alguns pontos do enunciado, a falta do item "meta" (ou ações) torna a proposta consideravelmente abstrata e sem projeção, impossibilitando quantificar resultados posteriores. Isso pode ser percebido em trechos como no objetivo 10.2:

(Diretriz) 10. Difundir e ampliar a visibilidade das expressões, dos patrimônios, das linguagens e manifestações artísticas, das culturas populares, indígenas, afro-brasileiras, ciganas, quilombolas, hip hop e tradicionais, na sociedade em geral como instrumento para a proteção e valorização da diversidade cultural dentro e fora do Estado e do País. (...)

(Objetivo) 10.2 - Valorizar e fortalecer o sentimento de pertença das linguagens artísticas e expressões culturais locais. (...) Ação 1 - Estimular, reconhecer e valorizar a diversidade cultural, os saberes, conhecimentos e expressões tradicionais e os direitos de seus detentores. (...) Ação 2 Valorizar, difundir de forma ampliada as linguagens artísticas, os patrimônios e as manifestações e expressões culturais. (...) Ação 3 - Garantir a transversalidade entre todas as expressões afirmando os valores, a identidade a diversidade e pluralismo cultural.

No trecho acima, podemos pensar que os autores do plano não compreenderam de fato no que consiste o item "ações", pois o conteúdo apresenta um caráter abstrato e não traz nenhum projeto, programa ou atividade para a realização concreta das diretrizes e objetivos. Ou mesmo por falta de tempo, não quiseram desenvolver essas ações naquele momento. A falta de metas relacionadas às ações torna o trecho ainda mais abstrato. Entretanto, devemos pensar em três fatores.

a) os planos devem considerar a dimensão simbólica da cultura. Em alguns casos nem sempre é possível quantificar ações;

b) alguns pontos do plano poderão ser construídos ao longo do decênio a partir do avanço de outras metas relacionadas, e incluídas na revisão que poderá acontecer por volta do quinto ano após a aprovação;

c) a compreensão de uma ação e sua relação com atos concretos exigem o desenvolvimento de propostas de projetos futuros e um diálogo mais amplo com o setor.

Em outros trechos do documento, essa abstração não ocorre. Principalmente nas metas relativas à dimensão econômica da cultura, são mencionadas instituições existentes ou programas já discutidos por determinados grupos em ocasiões anteriores.

(Objetivo) 9.2 Qualificar as instituições públicas e da sociedade civil para garantia de participação e acesso às políticas públicas. (...) Ação 1 Promover a indissociação do Patrimônio Material e Imaterial das culturas indígenas, afro-brasileira, popular e tradicional. (...) Meta 1 - Em parceria como a Secretaria de Estado da Cultura, em especial entre a Unidade de 
Preservação do Patrimônio (UPPH) e CONDEPHAAT, introduzir a gestão compartilhada do patrimônio cultural indígena, afro-brasileiro, popular, tradicional e do circo em seus aspectos materiais e imateriais. (...) Meta 2 Anualmente a partir de 2016, criar edital específico para a produção de inventários e subsídio de registro de patrimônios culturais indígenas, afrobrasileiros, ciganos, popular, tradicional, do circo e LGBTT. (...) Meta 3 Registar, Inventariar e construir o Plano de Salvaguarda do Samba Rural Paulista ou Samba de Bumbo. (...) Meta 4 - Registar, Inventariar e construir o Plano de Salvaguarda de 50 comunidades tradicionais de matriz africana, em todo o Estado até 2018. (...) Meta 5 - Registrar, inventariar e construir planos de salvaguarda de 50 comunidades indígenas existentes no Estado de São Paulo até 2018.

Em muitos momentos do Plano Estadual de Cultura de São Paulo, o item "ações" tem quase a mesma função do item “objetivos” na organização dos conteúdos, pois apresenta um caráter mais amplo ao desenvolvimento de uma determinada diretriz.

Ainda que descrevam ao longo do enunciado propostas de ações relativas às metas, nem sempre são desenvolvidas sugestões de iniciativas concretas a serem realizadas e nem informam de quem será a responsabilidade pela realização, isto é, seus destinatários específicos. Em alguns pontos, a descrição entre a função dos itens ações e metas não está devidamente colocada, pois não há uma projeção concreta quantitativa de cada programa nas metas sugeridas. A organização dos tópicos é feita por meio de números em sequência lógica como se representassem a seguinte numeração seqüencial: 1. Diretriz; 1.1 Objetivo; 1.1.1. Ação; 1.1.1.1 Meta.

$\mathrm{Na}$ tabela a seguir relativa à diretriz 1 , o descritivo no item ação 1.1.1 tem maior relação com o que o MinC determina para conceito do item objetivos.

Os projetos são mencionados apenas ao longo das metas seguintes, como por exemplo, quando tratam do Proac e da Virada Cultural Paulista ou mesmo da criação de um programa específico para as culturas populares na Unidade de formação cultural. Isso demonstra que, na construção do enunciado, o que deveria ser entendido como ação foi desenvolvido enquanto meta.

Em muitos pontos da tabela é possível também perceber a semelhança entre os trechos. Não houve preocupação do grupo em tecer um enunciado objetivo e com economia de informações. 
Tabela 2: Desenvolvimento da diretriz 1 do PEC SP e seus objetivos, metas e ações.

\begin{tabular}{|c|c|c|}
\hline ITEM & DESCRITO NO PEC SP & QUALIDADE DO ITEM DE ACORDO COM MINC \\
\hline DIRETRIZ 1 & $\begin{array}{l}\text { DIRETRIZ 1: Garantir e fortalecer a dimensão simbólica da } \\
\text { cultura promovendo-a e protegendo-a, com suas infinitas } \\
\text { possibilidades de criação simbólica expressas em modos de } \\
\text { vida, artes, crenças, valores, práticas, rituais e } \\
\text { identidades. [Compreende os bens de natureza material e } \\
\text { imaterial que constituem o patrimônio cultural do Estado } \\
\text { de São Paulo, abrangendo todos os modos de viver, fazer e } \\
\text { criar dos diferentes grupos formadores da sociedade } \\
\text { paulista, conforme o Art. } 216 \text { da Constituição Federal]. }\end{array}$ & $\begin{array}{l}\text { Diretrizes: “(...) são ideias princípios e } \\
\text { compromissos que orientam a tomada de } \\
\text { decisões. As diretrizes ajudam a planejar o } \\
\text { caminho a percorrer, ou seja, elas mostram a } \\
\text { direção. (...) são definidas a partir das } \\
\text { informações do diagnóstico (...) orientam o } \\
\text { planejamento dos objetivos, metas e ações” } \\
\text { (MINISTÉRIO DA CULTURA, 2013, p. 49) }\end{array}$ \\
\hline Objetivo 1.1 & $\begin{array}{l}\text { 1.1 Planejar, criar e implantar políticas, programas, projetos e } \\
\text { ações voltadas para o fortalecimento e promoção das } \\
\text { expressões, dos patrimônios, das linguagens e manifestações } \\
\text { artísticas, das culturas populares, indígenas, afrobrasileiras, } \\
\text { ciganas, quilombolas, hip hop e tradicionais para os próximos } \\
10 \text { anos. }\end{array}$ & $\begin{array}{l}\text { Objetivos: "são os resultados que se pretende } \\
\text { alcançar no futuro desejado. (...) decidir o que } \\
\text { precisa mudar." (idem, p. 50) }\end{array}$ \\
\hline Ação 1.1.1 & $\begin{array}{l}\text { Ação } 1 \text { - Desenvolver e ampliar programas, projetos e ações } \\
\text { para fomentar as iniciativas permanentes das } \\
\text { expressões, dos patrimônios, das linguagens e manifestações } \\
\text { artísticas, das culturas populares, indígenas, } \\
\text { afro-brasileiras, ciganas, quilombolas, hip hop, tradicionais, } \\
\text { LGBTT e pessoas com deficiências }\end{array}$ & $\begin{array}{l}\text { Ações: "são projetos e atividades para cumprir } \\
\text { as metas" (idem, p. 52) São as realizações } \\
\text { concretas na cidade / estado, nas pontas do } \\
\text { sistema, e passiveis de serem quantificadas }\end{array}$ \\
\hline Meta 1.1.1.1 & $\begin{array}{l}\text { Meta } 1 \text { - Equiparar em R\$ } 2 \text { milhões até 2017, os recursos } \\
\text { dos editais ProAC para Culturas Populares e }\end{array}$ & \\
\hline Meta 1.1.1.2 & $\begin{array}{l}\text { Meta } 2 \text { - Inserir na Virada Cultural Paulista, a partir de 2016, } \\
500 \text { expressões culturais dos povos }\end{array}$ & \\
\hline Meta 1.1.1.3 & $\begin{array}{l}\text { Meta } 3 \text { - Criar na Unidade de Formação Cultural um } \\
\text { programa para as expressões, os patrimônios, } \\
\text { as linguagens e manifestações artísticas, as culturas } \\
\text { populares, indígenas, afro-brasileiras, ciganas, } \\
\text { quilombolas, hip hop, tradicionais, LGBTT e pessoas com } \\
\text { deficiênciaspara atuação em todos os projetos } \\
\text { da unidade. Garantir que este programa contemple, entre } \\
\text { outras, as seguintes dimensões: a) Instituir ações de } \\
\text { incentivo à transmissão de valores, saberes e práticas } \\
\text { tradicionais. b) Fomentar pesquisas participativas, } \\
\text { operacionais e mapeamentos comunitários realizados pelas } \\
\text { próprias comunidades. c) Implantar pontos de cultura com } \\
\text { desenhos apropriados aos povos indígenas, culturas } \\
\text { populares, afrobrasileiras, } \\
\text { ciganas quilombolas, e tradicionais. d) Fomentar a criação de } \\
\text { espaços de memória propostos pelas comunidades } \\
\text { vinculadas aos povos } \\
\text { indígenas, culturas populares, afro-brasileiras, ciganas, } \\
\text { quilombolas e tradicionais, voltados para o } \\
\text { registro, documentação, transmissão sociocultural, e } \\
\text { valorização das tradições locais. }\end{array}$ & $\begin{array}{l}\text { Metas: "são os resultados que se deseja } \\
\text { alcançar (...) em termos quantitativos. (...) um } \\
\text { resultado objetivo que pode ser medido em um } \\
\text { período de tempo. (...) o futuro que se deseja } \\
\text { construir." (MINISTÉRIO DA CULTURA, } \\
\text { 2013, p.52) }\end{array}$ \\
\hline
\end{tabular}

O caráter mais abstrato do Plano Estadual de Cultura de São Paulo poderia ser justificado talvez por sua posição enquanto plano estadual atuando como um guarda-chuva de "Futuro projetado" dos municípios. Entretanto, os estados devem prever programas e atividades e distribuí-las pelos municípios, pois de acordo com o pacto federativo, a estes também cabe desenvolver ações de políticas públicas. 
Conforme sugerido na publicação Como fazer um plano de cultura, são os municípios, isto é, as "pontas" do sistema que deverão apresentar o caráter mais concreto e ser pensado de forma mais territorial. Isso ficará mais evidente no tópico a seguir sobre o plano municipal de cultura de São Paulo.

\subsection{3 - A construção composicional no Plano Municipal de Cultura de São Paulo}

Ao analisarmos o "Plano Municipal de Cultura de São Paulo", assim como já pontuado em capítulos anteriores, percebemos que a organização foi feita em duas etapas. Inicialmente, foi apresentada uma primeira versão aberta para a consulta pública e meses mais tarde, a versão final, com alterações estruturais de metas e eixos. Na consulta pública do PMC SP, a lógica de todo o documento se apresenta da seguinte forma: EIXOS> DIRETRIZES > METAS > AÇÕES (dividida numa tabela em espaços temporais).

Figura 33: Meta 1 PMC SP na consulta pública

\begin{tabular}{|c|c|c|c|c|}
\hline & \multicolumn{4}{|c|}{$\begin{array}{l}\text { DIREIRIZ } 1 \text { (metas 1, } 2 \text { e 3): Reestruturar a Secretaria Municipal de Cultura para } \\
\text { que sua capacidade administrativa corresponda às demandas culturais } \\
\text { da cidade, com ampliação de seu quadro de funcionários, coordenação } \\
\text { regionalizada e formaça continuada dos gestores e servidores munici- } \\
\text { pais de cultura. }\end{array}$} \\
\hline 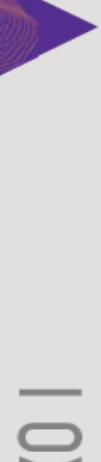 & \multicolumn{4}{|c|}{$\begin{array}{l}\text { META 1: Secretaria Municipal de Cultura reestruturada com planos de car- } \\
\text { reira implementados e concursos realizados. } \\
\text { A Secretaria Municipal de Cultura de São Paulo precisa reforçar sua estrutura } \\
\text { administrativa para atender as necessidades, demandas e desafios propostos } \\
\text { pelo Plano Municipal de Cultura. Para isso, deverá rever seu modelo organi- } \\
\text { zacional, criar planos de carreira e realizar concursos públicos para comple- } \\
\text { mentar o seu quadro de servidores. } \\
\text { AÇõES: Aprovar a reforma administrativa da Secretaria Municipal de Cultura } \\
\text { para viabilizar a implementação do Plano Municipal de Cultura, implantar } \\
\text { plano de carreira dos servidores e realizar concursos públicos. }\end{array}$} \\
\hline & Situação Atual & Curto prazo & Médio prazo & Longo prazo \\
\hline & 2015 & 2017 & 2021 & 2025 \\
\hline & $\begin{array}{l}\text { Reforma } \\
\text { administrativa } \\
\text { elaborada. } 1.457 \\
\text { servidores. }\end{array}$ & $\begin{array}{l}\text { Reforma } \\
\text { administrativa } \\
\text { da Secretaria } \\
\text { Municipal de } \\
\text { Cultura aprovada e } \\
\text { implementada. }\end{array}$ & $\begin{array}{l}\text { Carreiras e planos } \\
\text { de carreiras } \\
\text { criados e concursos } \\
\text { realizados. }\end{array}$ & \\
\hline & \multicolumn{4}{|c|}{$\begin{array}{l}\text { Indicadores: Organograma da Secretaria Municipal de Cultura. Número de cargos e } \\
\text { servidores concursados. } \\
\text { Fonle: Secretaria de Gestão e Secretaria Municipal de Cultura }\end{array}$} \\
\hline
\end{tabular}

Fonte: SECRETARIA MUNICIPAL DE CULTURA, 2016. ${ }^{186}$.

\footnotetext{
${ }^{186}$ Disponível: < http://www.planomunicipaldecultura.prefeitura.sp.gov.br/> acesso em 17 novembro 2017.
} 
Na publicação do PMC relativa à consulta pública, a diretriz, em texto na cor roxa, aparece já incluindo quais seriam as metas relacionadas, seguida de um texto que não apenas sugere a diretriz, mas também justifica sua necessidade. As metas, escritas na cor preta, buscam evidenciar como a diretriz será desenvolvida. As ações, expostas na tabela, são divididas em quatro momentos temporais: Situação atual, curto prazo, médio prazo e longo prazo. Aqui percebemos que nesta versão as metas eram consideradas em conjunto dentro de uma diretriz e as ações desenvolvidas em cada metas.

Já na construção estabelecida na versão final do PMC SP, após a consulta pública, a equipe técnica responsável pelo enunciado decidiu alterar radicalmente a estrutura do PMC, incidindo diretamente em sua construção composicional apresenta a seguinte estrutura mais simplificada: Meta (Ementa da meta) > Ação (dividida em momentos de tempo). Sendo que cada um dos seis eixos estabelecem metas > temas e assim são divididos em diversas ações.

Na publicação final do PMC SP, as metas têm a seguinte organização: o título do item destacado em roxo dentro de um retângulo (Meta 1: Financiamento), um texto de justificativa em cor preta logo abaixo e a seguir a "ementa da meta" que argumenta sua importância e necessidade. Os temas das metas apresentam um caráter mais geral que pode incluir uma dezena de ações que poderão ser alteradas sem que se altere o tema da meta.

Ao contrário do que foi feito na publicação anterior da consulta pública, as diretrizes só aparecem nos textos introdutórios sobre o plano, sem numeração. No enunciado final, os cinco eixos são apresentados numa tabela que organiza as 20 metas e 96 ações. As ações descritas nas metas ganharam uma numeração sequencial na versão final: Meta $1>$ Ação 1.1.

A meta 1 na versão final do plano apresenta ementa e é dividida em quatro ações numeradas como: 1.1, 1.2, 1,3 e 1.4. Essa mesma organização é seguida ao longo de todo o enunciado.

$\mathrm{Na}$ imagem a seguir vemos como estão estruturadas. A ementa parece buscar justificar tanto a meta quanto as ações elencadas dentro da meta. 
Figura 34: Meta 1 na versão final do PMC SP.

META 1: FINANCIAMENTO
Instituição do Sistema Municipal de Financiamento à Cultura*, com
ampliação e diversificação das fontes de recursos e implantação do Fundo
Municipal de Cultura*.
EMENTA
A implementação do Plano Municipal de Cultura pressupõe a existência de re-
cursos financeiros que viabilizem o cumprimento de suas metas e ações.
Um dos componentes do Sistema Municipal de Cultura*, o Sistema Municipal de
Financiamento à Cultura*, reúne o conjunto dos instrumentos de financiamento das
políticas culturais, incluindo: o Orçamento Municipal; os fundos - Fundo Municipal
de Cultura (FMC)*, Fundo Especial de Promoção das Atividades Culturais (FEPAC)*,
Fundo de Proteção do Patrimônio Cultural e Ambiental Paulistano (FUNCAP)*, Fun-
do Municipal de Preservação do Patrimônio Histórico e Cultural da Área do Projeto
Luz (FUNPATRI)* e Fundo de Desenvolvimento Urbano (FUNDURB)*; incentivos
fiscais*, via Programa Municipal de Apoio a Projetos Culturais (Pro-Mac)* e outros
instrumentos de renúncia de impostos para a cultura; recolhimento de preços pú-
blicos* da cessão de espaços e serviços prestados pelas unidades da Prefeitura do
Município de São Paulo; arrecadaços de bilheteria; receitas próprias das autarquias*
e empresas públicas* municipais; recursos oriundos do Sistema Nacional de Cultura*

e Sistema Estadual de Cultura*; emendas parlamentares* de origem federal, estadual e/ou municipal; patrocínios*; parcerias público-privadas*; empréstimos; entre outras fontes de recursos captados junto à iniciativa privada e organismos nacionais e internacionais.

Os Planos Plurianuais (PPAs)*, as Leis de Diretrizes Orçamentárias (LDOs)* e as Leis Orçamentárias Anuais (LOAs)* devem dispor sobre os recursos a serem destinados à execução das ações e metas do PMC e sua elaboração deve buscar a ampliação do orçamento municipal para a cultura.

A ampliação e diversificação das fontes de recurso é outra estratégia fundamental para garantia de implementação do Plano Municipal de Cultura, contemplando a desconcentração e distribuição dos recursos financeiros objetivando a redução das desigualdades socioterritoriais.

A regulamentação e implantação do Fundo Municipal de Cultura (FMC)*, destinado a apoiar e suportar financeiramente projetos culturais, deve contemplar a diversidade de linguagens, segmentos e territórios da cidade, priorizando iniciativas não atendidas pelos programas de fomento à cultura. O FMC deve ter mecanismos de transparência pública e o acompanhamento de um Conselho Gestor* com representantes da sociedade civil (eleitos pelo Conselho Municipal de Política Cultural $^{*}$ ) e do poder público.

AÇÃO Realizar projeção orçamentária para viabilizar as metas e ações previstas no Plano 1.1 Municipal de Cultura e ampliar o orçamento para sua implementação.

\begin{tabular}{|l|c|c|c|}
\hline \multicolumn{1}{|c|}{ Situação em } & \multicolumn{1}{|c|}{ Curto prazo } & \multicolumn{1}{|c|}{ Médio prazo } & \multicolumn{1}{|c|}{ Longo prazo } \\
\hline 2015 & 2017 & \multicolumn{1}{|c|}{2021} & 2025 \\
\hline $\begin{array}{l}\text { Orçamento total de } \\
\text { cerca de R\$484 milhōes } \\
\text { empenhado na função } \\
\text { cultura. }\end{array}$ & $\begin{array}{l}\text { Projeção orçamentária } \\
\text { realizada e 2\% do } \\
\text { orçamento municipal } \\
\text { destinado à cultura. }\end{array}$ & $\begin{array}{l}2 \% \text { do orçamento } \\
\text { municipal destinado à } \\
\text { cultura. }\end{array}$ & $\begin{array}{l}2 \% \text { do orçamento } \\
\text { municipal destinado à } \\
\text { cultura. }\end{array}$ \\
\hline $\begin{array}{l}\text { Indicadores: Percentual do orçamento municipal destinado à cultura. } \\
\text { Responsáveis: Assessoria Técnica e de Polittica Cultural. Coordenadoria de Administração e Finanças. } \\
\text { Secretaria Municipal de Finanças. Câmara Municipal de São Paulo. }\end{array}$ \\
\hline
\end{tabular}

Fonte: SECRETARIA MUNICIPAL DE CULTURA, $2016 \mathrm{~b}$. 
A mesma estrutura simplificada é verificada no decreto equivalente ao da publicação do Sistema Municipal de Cultura que traz o PMC SP, publicado no Diário Oficial da Cidade de São Paulo no mesmo período. O enunciado, ainda que traga o mesmo teor, não pode ser considerado o mesmo, pois é apresentado com forma, contexto, plataforma e data diferentes e a simplificação de forma apresentada denota a preocupação com um enunciado compreensível aos interlocutores.

Figura 35: Meta 1 PMC SP no decreto publicado no Diário Oficial

\begin{tabular}{|c|c|c|c|c|c|c|}
\hline \multicolumn{7}{|c|}{ 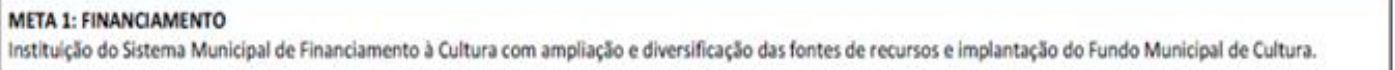 } \\
\hline \multicolumn{7}{|c|}{ 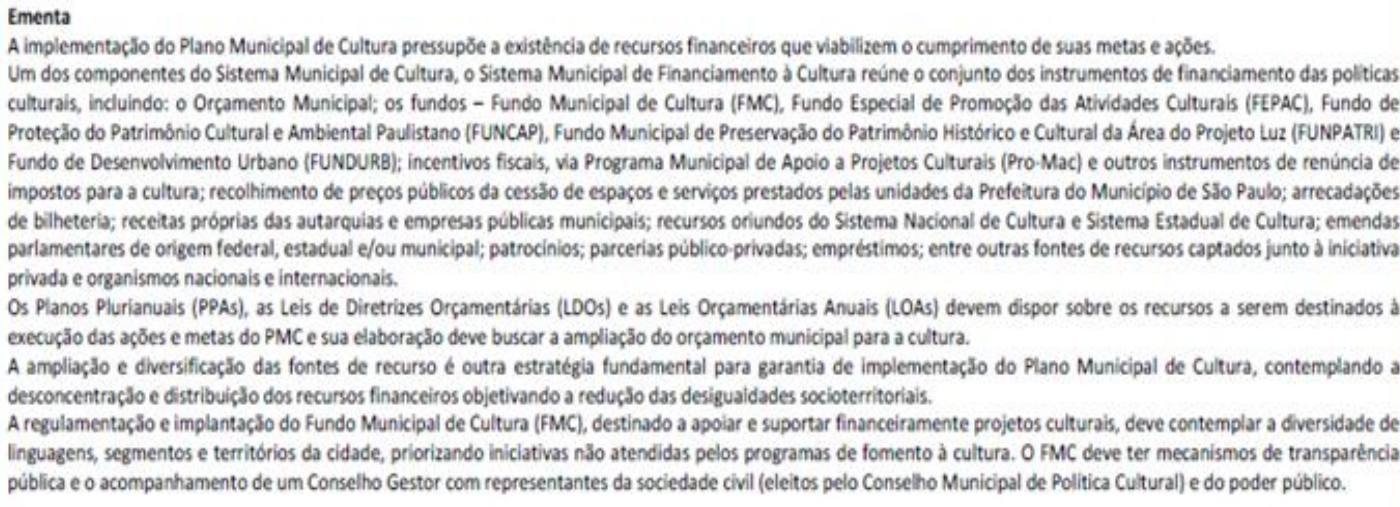 } \\
\hline AÇŌES & Situaşão em 2015 & Curto Prazo (2017) & Médio Prazo (2021) & Longo Prazo (2025) & Indicadores & Responsáveis \\
\hline $\begin{array}{l}1.1 \text { Realizar projeç̄o } \\
\text { orçamentária para viabälizar as } \\
\text { metas e aç̋̄es previstas no Plano } \\
\text { Municipal de Cultura e ampliar o } \\
\text { orçamento para sua } \\
\text { implementaç̧o. }\end{array}$ & 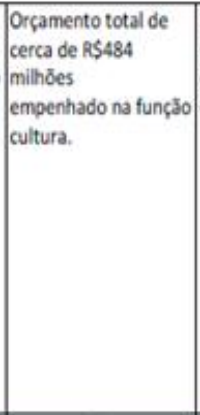 & \begin{tabular}{|l|} 
Projeção orçamentária \\
realizada e $2 \%$ do \\
orçamento municipal \\
destinado à cultura.
\end{tabular} & $\begin{array}{l}2 \% \text { do orcamento } \\
\text { municipal destinado à } \\
\text { cultura. }\end{array}$ & $\begin{array}{l}2 \% \text { do orçamento } \\
\text { municipal destinado a } \\
\text { cultura. }\end{array}$ & \begin{tabular}{|l|} 
Percentual do \\
orçamento municipal \\
destinado à cultura.
\end{tabular} & \begin{tabular}{|l} 
Assessoria \\
Técnica e de \\
Politica \\
Cultural. \\
Coordenadoria \\
de \\
Administraçăo \\
e finanças. \\
Secretaria \\
Municipal de \\
Finansas. \\
CSmara \\
Municipal de \\
Săo Paulo. \\
\end{tabular} \\
\hline
\end{tabular}

Fonte: Diário Oficial da cidade de SP. ${ }^{187}$.

O espaço de comunicação diferente, no caso da publicação do PMC no diário oficial da cidade, imprime uma nova forma ao documento. Há a supressão das cores, não há imagens ilustrativas e os textos introdutórios aparecem resumidos. Entretanto, ainda que o conteúdo seja o mesmo, a organização sem cores ou figuras gera uma economia visual ao enunciado.

Ao compararmos a organização do enunciado dos dois planos de São Paulo, estadual e municipal, concluímos que são diferentes em relação à construção composicional. Enquanto o

\footnotetext{
${ }^{187}$ Disponível em: < http://www.planomunicipaldecultura.prefeitura.sp.gov.br/> acesso 17 novembro 2017.
} 
Plano estadual apresenta uma estrutura basicamente composta por itens e tópicos, o municipal se organiza principalmente por textos descritivos (ementas) e tabelas que dividem tempo e funções.

$\mathrm{Na}$ maior parte dos casos observados em outros planos municipais, a estrutura em tópicos é recorrente e pode ser utilizada com a intenção de organizar cada tema e relacioná-lo a uma meta ou diretriz. Os tópicos organizam e destacam um assunto dos demais sem perder a relação com o todo do enunciado e cada um deles estão relacionados a ações específicas.

Em alguns planos foram utilizadas tabelas para melhor organizar a informação, como é o caso do Plano da cidade de São Paulo e do estado da Bahia. No PMC SP, as tabelas auxiliam a visualização das informações de ações a serem realizadas num determinado período de tempo. Essa projeção temporal com divisões escalonadas, orienta e auxilia a fiscalização das atividades pelos destinatários diretos do plano. Ao serem destacadas em tabelas, as atividades ganham um destaque ainda maior do que se estivessem elencadas em tópicos e permitem ao leitor o acompanhamento ao longo das gestões, já que estão divididas em planos plurianuais (PPA). O plano da cidade de São Paulo demonstrou que as tabelas podem ser pensadas como uma linha do tempo de desenvolvimento de cada meta.

É relevante dizer que no PMC, em boa parte dos casos, os tópicos apresentam em média dois períodos e são iniciados com verbos no infinitivo com sentido de realizar alguma ação: desenvolver, incentivar, criar, desenvolver, inserir, garantir, implantar etc. Essa característica também foi encontrada na maioria dos planos analisados. Ao iniciar cada tópico com um verbo no infinitivo, os autores dos planos criaram uma nova caraterística ao gênero, relacionada não apenas com sua forma, mas também com seu conteúdo e estilo. Discutiremos mais sobre o uso dos verbos nos enunciados quando tratarmos do estilo do gênero.

$$
* * *
$$

Ao analisarmos os planos de cultura do ponto de vista da forma ou construção composicional algumas características puderam ser destacadas.

Os enunciados são organizados por itens: diretrizes, princípios, metas, estratégias, objetivos e ações. Não há uma regularidade e nem uma ordem estabelecida de apresentação dos mesmos. Entretanto, os manuais do MinC sugerem a ordem: diretrizes, metas, objetivos e ações. Os planos se organizam em textos correntes em formas de ementas, tópicos e / ou tabelas. Alguns planos utilizam recursos como tempo e espaço para organizar os conteúdos e propostas. 
Além desses pontos principais, a economia de informação é outro ponto que merece ser abordado neste momento, pois mostrou-se bem variada. Boa parte dos enunciados analisados apresentaram uma variação nos tamanhos dos textos descritivos e no número de metas / ações (de 10 a 50). Ainda que o Plano Nacional de Cultura traga 53 metas, nenhum dos planos territoriais de estados e municípios apresentou mais do que 50 metas /ações. A grande maioria dos planos tem em média de 20 a 30 metas ou objetivos.

No Plano Estadual de São Paulo não são utilizadas tabelas para descrever as metas do plano, a organização é feita exclusivamente em tópicos e construída passo a passo. Nos outros 35 planos observados nesta pesquisa, o uso de tabelas ocorreu em apenas dois planos e apenas um deles apresentou a projeção de tempo escalonado em PPAs. A incidência de tópicos para a organização de ações ou metas foi encontrada em todos enunciados, demonstrando que esta é uma característica relativamente estável do gênero. Como o PMC de SP é um enunciado recente, é possível que a construção composicional com o uso de tabelas para a projeção temporal influencie outro planos, pois além de ser uma importante cidade da união, é uma forma de organização do enunciado que proporciona uma compreensão mais rápida dos leitores com reflexos no desenvolvimento concreto das ações.

Após a análise dos planos, é possível confirmar que, por meio das publicações oferecidas pelo MinC, a forma sugerida a consolidar a construção composicional do gênero, cria uma relativa estabilidade do gênero. Os documentos de orientação oferecidos pelo Ministério sugerem da mesma forma os itens a serem elencados nos enunciados e quais as perguntas que devem guiar a escrita dos conteúdos. Estes itens foram constatados nos 35 enunciados de planos observados, ainda que com algumas diferenças. Nos enunciados de São Paulo, a presença dos itens de organização dos enunciados também foi constatada, ainda que tragam diferenças de compreensão de como construir seus conteúdos.

A forma composicional dos planos de cultura analisados revela que este tipo de enunciado tem como função o planejamento de ações principalmente. Porém para isso será necessário apontar os princípios norteadores, as diretrizes para esse desenvolvimento, as metas a serem atingidas, e os objetivos pretendidos. Estes serão condicionados por meio dos conteúdos temáticos que veremos a seguir.

\section{3 - O conteúdo temático dos Planos de Cultura}

O conteúdo temático de um enunciado é um dos três elementos do gênero discursivo como reflete Bakhtin em seu texto Os gêneros do discurso. O nome do conceito revela que 
está de algum modo relacionado ao conteúdo e ao tema. Para melhor compreendermos o conceito de conteúdo temático, traremos novamente as reflexões de Bakhtin e de outros pensadores do Círculo.

O objetivo deste tópico da tese é analisar como o conteúdo temático opera dos planos de cultura: federal, estadual e municipal. Iniciaremos com a reflexão acerca do complexo conceito nas obras dos pensadores do chamado Círculo de Bakhtin. Em seguida faremos a análise dos planos, observando as temáticas operadas e as estratégias acerca dos conteúdos em cada situação, percebendo não apenas as características de cada um deles, mas a relação com o horizonte social mais amplo, com a esfera e com os agentes envolvidos nos processos.

\subsection{1 - O conceito de conteúdo temático}

Nossa abordagem do conceito de conteúdo temático partirá das reflexões do Círculo nos anos 1920 até chegar aos escritos sobre o gênero feitos por Bakhtin numa fase mais madura de suas reflexões no ensaio Os gêneros do discurso.

Os escritos de Mikhail Bakhtin sobre o conteúdo temático feitos no ensaio do início dos anos 1920 O problema do conteúdo, do material e da forma na atividade estética, principalmente quando ele trata do ato criativo, nos dão pistas sobre o início da construção do conceito nas obras do Círculo. Logo na primeira página do ensaio sobre o problema do conteúdo, Bakhtin traz a seguinte reflexão:

Com efeito, nenhum ato cultural criador tem relação com uma matéria indiferente a valores, totalmente casual e desordenada - a matéria e o caos são geralmente noções relativas; mas ele se relaciona com algo já apreciado e de certa forma ordenado, perante o qual agora ele deve ocupar, com conhecimento de causa, sua posição axiológica. Assim o ato cognitivo encontra uma realidade já elaborada nos conceitos do pensamento précientífico, mas o que é primordial, o pensamento já vem apreciado e regulamentado pelo procedimento ético, prático e cotidiano, social e político. (BAKHTIN, 2010, pp. $29-30$ )

Ao falar de valores num ato cultural, logo no início do seu ensaio O problema do conteúdo, depreendemos que este seria o primeiro indício a ser observado para a compreensão do conceito. Esses valores, como ele mesmo diz, já estão previamente apreciados socialmente por meio de procedimentos éticos, práticos, cotidianos e sociopolíticos. Ao observar que estes valores dependem de posicionamentos ou como ele mesmo diz de um "posicionamento axiológico" nos remete à questão do conteúdo não apenas como um preenchimento da forma, mas como um momento do enunciado em que um autor (ou autores) apresenta um projeto de 
discurso considerando sua visão de mundo e fazendo escolhas éticas em relação ao que está sendo dito. O conteúdo de uma unidade cultural apresenta fortemente a compreensão ética do mundo de um ser criativo em ato.

Neste ensaio, Bakhtin trata mais precisamente da criação na esfera da arte, porém salienta em mais de uma passagem que o conteúdo se revela principalmente no ato ético. "O ato ético refere-se de forma um pouco diferente à realidade preexistente do conhecimento e da visão estética. Esta relação é habitualmente expressa como a relação do dever para com a realidade" (BAKHTIN, 2010, p. 32) Para ele, o conteúdo da obra de arte "representa o momento constitutivo indispensável do objeto estético, ao qual é correlativa a forma estética que, fora dessa relação, em geral, não tem nenhum significado" (BAKHTIN, 2010, p. 35) e complementa dizendo

(...) o conteúdo e a forma se interpenetram, são inseparáveis, porém, também são indissolúveis para a análise estética, ou seja, são grandezas de ordem diferente; para que a forma tenha um significado puramente estético, o conteúdo que a envolve deve ter um sentido ético e cognitivo possível, a forma precisa do peso extra-estético do conteúdo, sem o qual ela não pode realizar-se enquanto forma. (BAKHTIN, 2010, p. 37)

Essa interpenetração da forma e do conteúdo gera na unidade cultural uma relação organizativa arquitetônica e ética. A forma condensa o conteúdo que revela os valores axiológicos entranhados na expressão do que está sendo criado. $\mathrm{O}$ conteúdo revela a ética. Ainda que neste ensaio Bakhtin trate basicamente da questão do conteúdo na obra de arte, podemos dizer que o ato ético é o que proporciona a contemplação valorada do conteúdo desta obra. Os valores éticos axiológicos constituem o conteúdo de uma unidade cultural artística e também do enunciado de outras esferas da atividade humana. É com o conteúdo destes enunciados que os leitores, contempladores, interlocutores dialogam e irão concordar, discordar, achar bom ou ruim. É o conteúdo que cria um diálogo de consenso ou dissenso com o outro, pois expõe seus valores éticos e visões de mundo.

Mais adiante nos anos 1920, Valentín Volóchinov trata do conceito de tema na obra Marxismo e filosofia da linguagem, em seu capítulo quarto, intitulado: Tema e Significação. $O$ problema da percepção ativa. Avaliação e significação. A dialética da significação.

Uma significação única e determinada, isto é, um sentido único pertence a qualquer enunciado como uma totalidade. O sentido da totalidade do enunciado será chamado de seu tema. O tema deve ser único, caso contrário não teremos nenhum fundamento para falar sobre um enunciado. Em sua essência, o tema deste é individual e irrepetível como o próprio enunciado. Ele expressa a situação histórica concreta que gerou o enunciado. (...) $\mathrm{O}$ tema do enunciado é tão concreto quanto o momento histórico ao qual ele 
pertence. $\mathrm{O}$ enunciado só possui um tema ao ser considerado um fenômeno histórico em toda a sua plenitude concreta. É isso que constitui o tema do enunciado. (VOLÓCHINOV, 2017, pp. 227-228)

O conceito de tema ao tratar da "totalidade de sentido do enunciado" se aproxima do conceito de conteúdo temático ainda que não seja o mesmo. Ao pensar o tema de um enunciado como único, irrepetível, é possível dizer que este tema, para ser construído, depende de certo modo das temáticas abordadas no enunciado e de sua função social. Assim o tema se relaciona com o conteúdo temático de um enunciado no sentido de que este tema único condensa o(s) conteúdo(s) e seus valores num momento único histórico, numa dada esfera e criado por um dado autor. O tema reúne e revela as intenções axiológicas desses conteúdos e temáticas e torna um determinado enunciado único e irrepetível.

O pensador Pavel Medviédev, também nos anos 1920, ao abordar os gêneros do discurso em sua obra $O$ método formal nos estudos literários, afirma que apenas nos enunciados artísticos é possível um "acabamento temático". Nos enunciados de outras esferas, o acabamento temático é impossível dada a inexauribilidade do objeto. Este enunciado não artístico sempre será uma resposta a outro enunciado anterior e será respondido posteriormente por outros, e seus conteúdos temáticos estão relacionados a partir dos seus valores e visões de mundo.

É suficiente dizer que, com exceção da arte, nenhum campo da criação ideológica conhece o acabamento no sentido próprio da palavra. Fora da arte, todo acabamento, todo final é convencional e superficial e antes de tudo, determinado por causas externas, e não pelo acabamento interno exaurido do próprio objeto. (...) em todos os campos da criação ideológica é possível somente um acabamento composicional do enunciado, porém, não é possível um acabamento temático autêntico dele. (MEDVIÉDEV, 2012, p. 194)

O acabamento temático está diretamente relacionado com o conteúdo temático de um enunciado visto que este é, como já dissemos, o ponto de diálogo com o outro da relação enunciativa. O conteúdo temático de um enunciado não artístico está sempre em diálogo com o conteúdo de outros enunciados anteriores e posteriores. É partir do conteúdo temático que de fato os discursos estão dialogicamente em relação. Essa impossibilidade de acabamento do enunciado também é abordada por Bakhtin, em sua reflexão no ensaio sobre os gêneros do discurso desenvolvido nos anos 1950.

Todo enunciado concreto é um elo na cadeia da comunicação discursiva de um determinado campo. Os próprios limites do enunciado são determinados pela alternância dos sujeitos do discurso. Os enunciados não são indiferentes entre si nem se bastam cada um a si mesmos; uns conhecem os outros e se refletem mutuamente uns nos outros. Esses reflexos mútuos lhes determinam 
o caráter. Todo enunciado é pleno de ecos e ressonâncias de outros enunciados com os quais está ligado pela identidade da esfera de comunicação discursiva. Todo enunciado deve ser visto antes de tudo como uma resposta aos enunciados precedentes de um determinado campo (aqui concebemos a palavra "resposta" no sentido mais amplo): ela os rejeita, confirma, completa, baseia-se neles, subentende-os como conhecidos, de certo modo os leva em conta. Porque o enunciado ocupa uma posição definida em uma dada esfera de comunicação, em uma dada questão, em um dado assunto, etc. É impossível alguém definir sua posição sem correlacioná-la com outras posições. Por isso todo enunciado é repleto de variadas atitudes responsivas a outros enunciados de um dado campo de comunicação discursiva. (...) A expressão do enunciado nunca pode ser entendida e explicada até o fim levando-se em conta apenas seu conteúdo centrado no objeto e no sentido. A expressão do enunciado, em maior ou menor grau, responde, isto é, exprime a relação do falante com os enunciados do outro, e não só a relação com os objetos do seu enunciado. (BAKHTIN, 2016, pp. $57-58$ )

Para ele, "É impossível alguém definir sua posição sem correlacioná-la com outras posições" (idem, p. 57) e isso está relacionado com o conceito de conteúdo temático no enunciado em que os valores axiológicos criam as relações de consenso e dissenso ideológico sobre o que está sendo dito. Estes enunciados estão plenos de discursos já legitimados anteriormente ou mesmo trazem novas visões de mundo a serem instituídas. Entretanto, há sempre o dialogismo com enunciados anteriores e abrem precedente à resposta de outros enunciados posteriores.

Como afirmou Medviédev, apenas nos enunciados da esfera artística há a possibilidade de um acabamento. Esta, porém, não determina que estes não tragam respostas a enunciados anteriores e que não recebam respostas posteriores. Nos demais tipos de enunciados, o acabamento não é possível nele mesmo, mas há sempre possibilidade de resposta e estas virão por meio de seus conteúdos temáticos recheados de valores e avaliações sociais.

Em síntese, o conteúdo temático contém os valores axiológicos, e estes nos levam aos elos dialógicos do discurso, a suas relações dialógicas, aos pontos de vista em diálogo, às posições perante o mundo, às relações com outros textos e sujeitos e aos contrastes nas posições axiológicas e avaliações sociais. Ele permeia o projeto de discurso de cada enunciado ao mesmo tempo que estabelece vínculos dialógicos tanto de consenso quanto de desacordo com outros discursos anteriores e posteriores. Este projeto de discurso num enunciado é carregado de vozes, discursos, avaliações sociais e posições ideológicas e sempre tem a intenção de uma ação concreta no mundo social.

As reflexões de Volochinov acerca do conceito de avaliação social estão ligados ao 
sentido e à escolha de elementos significantes do enunciado e deste modo se relacionam ao conteúdo:

A avaliação social tem uma enorme importância, mesmo em um enunciado com um sentido mais amplo e apoiado em um vasto auditório social. Apesar de essa avaliação não ser expressa adequadamente por meio de uma entonação, ela determinará a escolha e a ordem de todos os principais elementos significantes do enunciado. Não existe um enunciado sem avaliação. Todo enunciado é antes de tudo uma orientação avaliativa. Por isso, em um enunciado vivo, cada elemento não só significa mas também avalia. Apenas um elemento abstrato, percebido no sistema da língua e não na estrutura do enunciado, aparece privado de avaliação. (VOLÓCHINOV, 2017, P. 236)

Para analisarmos os conteúdos temáticos dos planos de cultura, devemos considerar os fatores apontados pelos pensadores do Círculo relacionados aos processos históricos e sociais que observamos nos capítulos anteriores. O conteúdo temático se relaciona com processos e discursos de enunciados anteriores, ao contexto, ao horizonte social mais amplo e à situação imediata de comunicação e seus participantes. Está ligado à forma, porém lhe confere o teor ético e axiológico, e essa relação constroi a forma arquitetônica do enunciado, pois esta depende da forma composicional e sua relação com o conteúdo. O conteúdo deve ser pensado por sua função social e a relação direta do gênero com determinada esfera da atividade humana. Os enunciados e interlocutores envolvidos revelam posicionamentos, avaliações sociais e propósitos discursivos (o projeto de discurso dos autores).

No caso do corpus desta tese, as relações dialógicas, entre os enunciados e discursos, são mantidas por meio de fios dialógicos semelhantes desde a proposta de política cultural construída nos textos da UNESCO nos anos 1980. Contudo, as posições axiológicas e avaliações sociais destes documentos respondem a processos históricos anteriores, como vimos no capítulo 3 desta pesquisa a respeito das influências das gestões de Mario de Andrade ou mesmo de Marilena Chauí.

$\mathrm{Na}$ análise dos documentos nos capítulos anteriores aferimos que os signos ideológicos: "diversidade", “acesso" e "descentralização" aparecem nos enunciados como centros de valores da arquitetônica do sistema. Acreditamos que estes centros de valores possam ser uma das chaves para observamos como foram construídos os conteúdos temáticos dos enunciados dos planos de cultura presentes em nosso corpus. 


\subsection{2 - O conteúdo temático no Plano Nacional de Cultura}

No caso dos planos de cultura, o conteúdo temático nos conduz aos projetos de discurso. Os discursos base e as intenções ideológicas estabelecidos nos pressupostos do PNC podem ser encontrados principalmente em seus princípios e diretrizes já presentes no trecho inserido na emenda 48/2005 da Constituição Federal:

A lei estabelecerá o Plano Nacional de Cultura, de duração plurianual, visando ao desenvolvimento cultural do País e à integração das ações do poder público que conduzem à: I - defesa e valorização do patrimônio cultural brasileiro; II - produção, promoção e difusão de bens culturais; III formação de pessoal qualificado para a gestão da cultura em suas múltiplas dimensões; IV - democratização do acesso aos bens de cultura; V valorização da diversidade étnica e regional. (BRASIL, 2005)

As diretrizes e os princípios do PNC carregam em suas linhas os conteúdos semânticos objetais da proposta de política cultural do todo do sistema e que posteriormente foi desenvolvido em dezenas de textos, leis e manuais. Também estão refletidos e refratados nos enunciados dos planos territoriais que utilizam as mesmas expressões e valores. Os conceitos de: desenvolvimento, integração, valorização do patrimônio, promoção, difusão, formação, democratização, acesso e diversidade, demonstram a avaliação social e o projeto do plano e permeiam boa parte dos enunciados que foram construídos para a formação do sistema. Estes conceitos estão carregados de valores axiológicos que se contrapõem às três tradições que, de acordo com Rubim (2010), permeavam as políticas culturais antes desse período: ausência, autoritarismo e instabilidade.

O teor axiológico das diretrizes e princípios do PNC também está refletido no desenvolvimento das metas e ações ao longo de todo o documento. As principais ideias presentes na emenda constitucional com forte teor ideológico e que deverão nortear os documentos posteriores são: Defesa e valorização do patrimônio cultural brasileiro; Democratização do acesso aos bens de cultura; Valorização da diversidade étnica e regional

No texto da lei de regulamentação do PNC em seu artigo 1, temos os seguintes princípios:

Art. $1^{\circ}$ Fica aprovado o Plano Nacional de Cultura, em conformidade com o $\S 3^{\circ}$ do art. 215 da Constituição Federal, constante do Anexo, com duração de 10 (dez) anos e regido pelos seguintes princípios: I - liberdade de expressão, criação e fruição; II - diversidade cultural; III - respeito aos direitos humanos; IV - direito de todos à arte e à cultura; V - direito à informação, à comunicação e à crítica cultural; VI - direito à memória e às tradições; VII - responsabilidade socioambiental; VIII - valorização da cultura como vetor do desenvolvimento sustentável; IX - democratização das instâncias de formulação das políticas culturais; X - responsabilidade dos 
agentes públicos pela implementação das políticas culturais; XI colaboração entre agentes públicos e privados para o desenvolvimento da economia da cultura; XII - participação e controle social na formulação e acompanhamento das políticas culturais. (BRASIL, 2010)

Aqui podemos perceber a presença de signos ideológicos que em conjunto apresentam a avaliação social e os valores axiológicos da proposta: liberdade de expressão, criação e fruição; diversidade cultural; direitos humanos; direito de todos à cultura; direito à memória; responsabilidade socioambiental; cultura como vetor de desenvolvimento; democratização; responsabilidade dos agentes públicos; colaboração entre agentes; participação, controle e acompanhamento.

Volóchinov trata da questão dos signos ideológicos em sua obra Marxismo e filosofia da linguagem.

Qualquer produto ideológico é não apenas uma parte da realidade natural e social - seja ele um corpo físico, um instrumento de produção ou um produto de consumo - mas também, ao contrário desses fenômenos, reflete e refrata outra realidade que se encontra fora dos seus limites. Tudo o que é ideológico possui uma significação: ele representa e substitui algo encontrado fora dele, ou seja, ele é um signo. Onde não há signo também não há ideologia. (VOLÓCHINOV, 2017, p. 91)

Estes signos ideológicos refletem e refratam os projetos sociopolíticos do modelo de política de cultura proposta nos enunciados e trazem os centros de valor da arquitetônica observados na análise dos manuais e demais marcos legais do SNC. A presença destes signos reforçam o projeto ideológico buscado por meio da implantação deste na esfera política mais ampla e se relaciona com o horizonte social que estava sendo desenhado no início do século XXI.

Os conceitos / signos podem ser compreendidos em relação com às três tradições citadas por Rubim, ainda que tragam uma nova forma de tratar cada um dos pontos:

a) Ausência $X$ responsabilidade, participação, colaboração, acompanhamento;

b) Autoritarismo X direitos (humanos, à cultura, à memória), liberdade de expressão, criação e fruição, democratização;

c) Instabilidade $\mathrm{X}$ desenvolvimento, controle.

A relação dialógica com as três tradições de Rubim reflete e refrata as necessidades da esfera. Entretanto, as tradições apontadas por Rubim em sua análise atentam para fatos consumados ocorridos ao longo dos anos na política cultural brasileira, enquanto que as propostas responsivas do SNC / PNC ainda se inscrevem como medidas ideais para reverter a 
precariedade apontada historicamente, propondo uma alternativa político-ideológica ao que se mostrou tradição no setor.

Ao longo das mais de 200 diretrizes e ações do PNC, presentes na publicação de 2007, podemos identificar a forte influência dos signos ideológicos elencados acima. Esta relevância também é vista na ordem em que os assuntos são abordados. Logo nos primeiros parágrafos dos textos introdutórios, temos:

O PNC não recebe esse nome por outro motivo senão o de buscar abranger as demandas culturais dos brasileiros e brasileiras de todas as situações econômicas, localizações geográficas, origens étnicas, faixas etárias e demais situações identitárias. Lidar com tal diversidade faz parte de nossa história. (BRASIL, 2007, p.11, grifos meus)

Considerando que a diversidade cultural é o maior patrimônio da população brasileira, no âmbito do PNC busca-se transcender as linguagens artísticas, sem contudo minimizar sua importância. Uma perspectiva ampliada, que articula as diversas dimensões da cultura, ganhou corpo e espaço na estrutura de financiamento público nos últimos anos e é um dos pilares do Plano Nacional de Cultura. (idem, p.12)

Para desfazer relações assimétricas e tecer uma complexa rede que estimule a diversidade, o PNC prevê a presença do poder público nos diferentes ambientes e dimensões em que a cultura brasileira se manifesta. As políticas culturais devem reconhecer e valorizar esse capital simbólico, através do fomento à sua expressão múltipla, gerando qualidade de vida, auto-estima e laços de identidade entre os brasileiros. (Ibidem, 2007, p. 12)

O acesso universal à cultura é uma meta do Plano que se traduz por meio do estímulo à criação artística, democratização das condições de produção, oferta de formação, expansão dos meios de difusão, ampliação das possibilidades de fruição, intensificação das capacidades de preservação do patrimônio e estabelecimento da livre circulação de valores culturais. (ibidem, p.12)

Ao considerar que a "diversidade cultural" é o "maior patrimônio da população brasileira" $\log$ no texto introdutório, os autores continuam fortalecendo a ideia da diversidade como um dos centros da arquitetônica do Sistema e um dos eixos do conteúdo temático da proposta. E reiteram isso quando dizem que é necessário "tecer uma rede que estimule a diversidade" ou mesmo ao "fomento à sua expressão múltipla". Contudo, para que de fato essa rede possa ser articulada e essa diversidade possa acontecer por meio dessas políticas, será necessário que essa diversidade cultural apareça nas linhas e entrelinhas do plano e mais ainda nos atos éticos dos agentes responsáveis pelo desenvolvimento do que está escrito nos enunciados.

O conteúdo temático também se relaciona com determinadas escolhas lexicais que 
preenchem de sentido o todo dos enunciados e dão um tom específico ao tema. As escolhas lexicais atuam nos conteúdos como signos ideológicos, ainda que estejam também relacionadas ao estilo, construindo uma "malha" de sentidos e significações ao enunciado. $\mathrm{O}$ conteúdo temático fornece a semântica para a avaliação social e um projeto de discurso pretendido pelos autores em determinadas situações. Estes signos constroem o projeto discursivo que marca fortemente uma posição axiológica / ideológica de proposta política nos enunciados. "O campo ideológico coincide com o campo dos signos. Eles podem ser igualados. Onde há signo há também ideologia. Tudo o que é ideológico possui significação sígnica." (VOLÓCHINOV, 2017, p. 93)

A diversificação de temáticas em diferentes metas e ações nos planos territoriais devese ao fato de terem sido enunciados produzidos por autores diferentes e em situações imediatas de comunicação e horizontes sociais amplos diferentes. Ainda que o PNC seja uma espécie de guia que influencia diretamente os temas nos planos territoriais, as demandas e os agentes locais são responsáveis pela inserção de outras temáticas absorvidas dos diagnósticos realizados, das demandas mais latentes e das consultas públicas realizadas entre a população. Estes signos ideológicos presentes nos enunciados guias, proporcionam uma cadeia de discursos, em que seus conteúdos tendem a convergir para uma mesma visão de mundo e posicionamentos axiológicos relativamente consensuais. A criação de planos de cultura de modo interativo possibilita uma espécie de "contágio" ideológico de ideias coletivas que reverberam, se multiplicam, e preenchem os vácuos das consciências individuais.

Essa cadeia ideológica se estende entre consciências individuais, unindo-as, pois o signo surge apenas no processo de interação entre consciências individuais. E a própria consciência individual está repleta de signos. Uma consciência só passa a existir como tal na medida em que é preenchida pelo conteúdo ideológico, isto é, pelos signos, portanto apenas no processo de interação social. (VOLÓCHINOV, 2017, p. 95)

O conteúdo temático do enunciado deve ser considerado arquitetonicamente em relação ao todo significativo não apenas do enunciado, mas da proposta arquitetônica de política cultural, no caso do SNC. Isto é, a produção de sentido do(s) enunciado(s) a partir de seus signos ideológicos deve ser pensada em relação ao todo da proposta do SNC envolvendo sua forma e conteúdo (organização e visão ética / axiológica) e sua relação com o tema e seus conteúdos temáticos.

De certo modo, os planos territoriais devem estar em relação com o PNC pelos focos pretendidos para o desenvolvimento as metas, afinal são nas pontas, nas cidades, onde a 
produção de cultura acontece de fato. Todavia, essa relação também deve acontecer em termos axiológicos, levando em conta os centros da arquitetônica do sistema e a visão de mundo sugerida nos enunciados iniciais do sistema. Na publicação Como fazer um plano de cultura é sugerido: "Os planos nacional, estadual e municipal devem ter correspondência entre si. Isso quer dizer que o desenvolvimento cultural da cidade deve ser planejado considerando as metas estabelecidas nos planos estadual e federal" (MINISTÉRIO DA CULTURA, 2013b, p.23)

A criação de ações consistentes nos planos territoriais, como programas e atividades detalhadas, pode contribuir para que o Sistema consiga atingir seus objetivos iniciais mais rapidamente. As temáticas abordadas nos planejamentos dos municípios, ainda que tenham metas específicas que tratem de assuntos locais, deverão se constituir em relação com os conteúdos propostos pelo PNC e pelo Plano Estadual de Cultura daquele território.

Estes conteúdos temáticos poderão ser relacionados por meios de grandes assuntos geralmente abordados pelos eixos e diretrizes, ou mesmo por metas e ações que tratem dos mais específicos. Em diversas passagens da publicação Como fazer um plano de cultura, há referências ao diálogo quase que obrigatório com o PNC para o desenvolvimento dos objetivos na construção de um Plano Municipal. Todavia, não basta apenas tratar de temas como as bibliotecas, por exemplo. As ações relacionadas às bibliotecas devem convergir axiologicamente com os signos ideológicos que estão no centro dessa arquitetônica: diversidade, acesso e descentralização. Um projeto para as bibliotecas que consiga ser pensado no âmbito da diversidade, do acesso e da descentralização é o que deverá ser priorizado na construção destes conteúdos temáticos dos planos para assim atingir o projeto discursivo previsto nas diretrizes do SNC. E assim proceder em cada uma das metas / temas a serem tratados.

Na época da criação do Plano Nacional de Cultura, não houve a preocupação inicial de dividir as 53 metas em temáticas de abrangência mais geral. Os conteúdos de cada meta foram desenvolvidos de acordo com os resultados dos seminários, encontros e principalmente conferências de cultura realizados desde o ano de 2003, conforme visto nos capítulos anteriores.

Dos documentos analisados em nosso corpus auxiliar, achamos pertinente apontar os conteúdos apresentados em um dos materiais utilizados na preparação dos delegados para a $3^{\mathrm{a}}$ Conferência Nacional de Cultura. O documento de novembro de 2013 relaciona os quatro eixos temáticos principais que deverão ser discutidos na conferência e estão diretamente 
ligados às 53 metas do PNC divididas em 16 subeixos (quatro por eixo). Alguns assuntos aparecem repetidos em eixos diferentes, justamente por apresentarem temáticas diversas:

EIXO 1: IMPLEMENTAÇÃO DO SISTEMA NACIONAL DE CULTURA 1.1 Marcos Legais, Participação e Controle Social e Funcionamento dos Sistemas - Metas: 1,2, 5, 37, 48, 49. Qualificação da Gestão Cultural: Desenvolvimento e Implementação de Planos Territoriais e Setoriais Metas: $1,18,35,36,46,47 ; 1.2)$ Fortalecimento e Operacionalização dos Sistemas de Financiamento Público da Cultura - Metas : 1, 24,50, 51, 52.

1.1 Sistemas de Informação Cultural e Governança Colaborativa - Metas: $2,3,48$.

EIXO 2: PRODUÇÃO SIMBÓLICA E DIVERSIDADE CULTURAL

2.1. Criação, produção, preservação, intercâmbio e circulação de Bens culturais - Metas: 6, 21, 22, 24,25,28,42, 43; 2.2. Educação e Formação Artística e Cultural - Metas 12 a 19; 2.3. Democratização da Comunicação e Cultura Digital. - Metas: 2, 40, 41, 42, 43, 44, 45,48; 2.4. Valorização do Patrimônio Cultural e Proteção aos Conhecimentos dos Povos e Comunidades Tradicionais. Metas: 3,4,5, 6, 12, 17,18, 45.

EIXO 3: CIDADANIA E DIREITOS CULTURAL

3.1. Democratização e Ampliação do Acesso à Cultura e Descentralização da Rede de Equipamentos, Serviços e Espaços Culturais. Metas: 20, 25,26, 27 , 28, 29, 30, 31, 32, 33, 34, 43; 3.2. Diversidade Cultural, Acessibilidade e Tecnologias Sociais. Metas: 3, 6, 29, 34, 43, 45, 47; 3.3. Valorização e Fomento das Iniciativas Culturais Locais e Articulação em Rede. Meta: 23.

3.4. Formação para a Diversidade, Proteção e Salvaguarda do Direito à Memória e Identidades. Metas: 4, 6,12, 13, 14,16,17;

EIXO 4: CULTURA E DESENVOLVIMENTO

4.1. Institucionalização de Territórios Criativos e Valorização do Patrimônio Cultural em Destinos Turísticos Brasileiros para o Desenvolvimento Local e Regional. Metas 8 e 10; 4.2. Qualificação em Gestão, Fomento Financeiro e Promoção de Bens e Serviços Criativos Nacionais no Brasil e no Exterior. Metas: 11,15, e 19; 4.3. Fomento à Criação/Produção, Difusão/Distribuição/Comercialização e Consumo/Fruição de Bens e Serviços Criativos, tendo como base as Dimensões (Econômica, Social, Ambiental e Cultural) da Sustentabilidade. Metas: 7, 9, 11, 53; 4.4. Direitos Autorais e Conexos, Aperfeiçoamento dos Marcos Legais Existentes e Criação de Arcabouço Legal para a Dinamização da Economia Criativa Brasileira. Metas: 38, 39, $42 .{ }^{188}$

Neste documento de 2013, encontramos diversos signos ideológicos com forte teor axiológico que achamos pertinente destacar:

a) Eixo 1 - Implementação do SNC: participação, controle social, qualificação da gestão, desenvolvimento, fortalecimento do sistema de financiamento;

b) Eixo 2 - Diversidade cultural: Criação, produção, preservação, intercâmbio e circulação; educação, formação, democratização; cultura digital; valorização do patrimônio e dos povos tradicionais;

\footnotetext{
${ }^{188}$ Disponível em: < http://cnc.cultura.gov.br/ > acesso em 27 de janeiro de 2018.
} 
c) Eixo 3 - Cidadania e direito cultural: democratização, ampliação do acesso, descentralização, diversidade, acessibilidade, tecnologias sociais, articulação em rede, direito à memória e à identidade;

d) Eixo 4 - Cultura e desenvolvimento: territórios criativos, valorização do patrimônio, qualificação fomento, promoção, distribuição, difusão, comercialização, consumo, fruição, sustentabilidade.

Nestes eixos, observamos a presença das três dimensões da cultura: cidadã (eixo3), econômica (eixo 4) e simbólica (eixo 2). Em todos os eixos estão elencados signos que revelam de forma otimista a intenção de uma política cultural que busca a democracia cultural e atinja a todos os produtores culturais bem como toda a cadeia produtiva com o reforço do trinômio: diversidade cultural, direito à cultura e desenvolvimento.

No final do ano de 2017, mais especificamente na gestão do Ministro Sergio de Sá Leitão, o MinC lançou uma nova proposta de site para o Plano Nacional de Cultura com vistas a acompanhar as metas do PNC. Neste período, o novo site passou a apresentar notícias de atividades atuais do Ministério vinculadas a uma dada meta relacionada e também uma tabela temática para dividir as metas do PNC.

Figura 36: Organização por eixos temáticos metas do PNC de 2017.

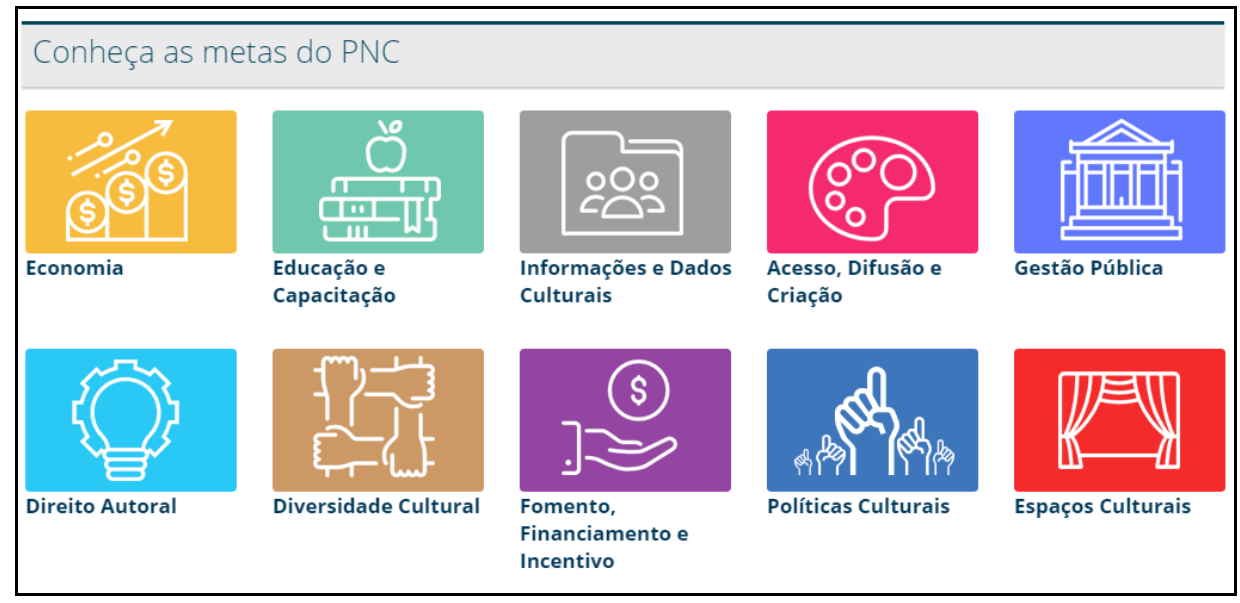

Fonte: site PNC.

Ao separar as 53 metas do PNC em dez blocos temáticos diferentes, a nova gestão do MinC demonstra um novo projeto de discurso e um direcionamento dos conteúdos temáticos conforme sua avaliação social e visão de cultura. Esta nova modelagem influenciou inclusive na organização das metas no site oficial do PNC. Em algumas das metas já existentes, os assuntos nem sempre podem ser especificados como um só. Em alguns casos, é possível dizer que a divisão de temáticas de metas estabelecida pelo MinC atualmente pode também ser lida a partir de outro ponto de vista e com outros subtemas. 
Para nos auxiliar na análise de metas, sugerimos uma tabela temática em comparação com a divisão desenvolvida pelo MinC em 2017 e estão destacados em itálico no final de cada uma das metas. As temáticas propostas se conectam diretamente com os conteúdos elencados na lei do PNC, na emenda constitucional do SNC e nas atividades desenvolvidas pelo Ministério ao longo dos últimos anos, como a $3^{\text {a }} \mathrm{CNC}$, por exemplo.

Ao considerarmos os princípios do $\mathrm{PNC}$, do $\mathrm{SNC}$ e as temáticas propostas na $3^{\text {a }} \mathrm{CNC}$, propomos abaixo uma lista de assuntos com um léxico mais próximo do projeto inicial ou mesmo complementares, como no caso de formação e educação, que aparece na proposta da nova gestão como capacitação. Utilizaremos a tabela abaixo também para a análise dos conteúdos dos planos de cultura do estado e da cidade de São Paulo como veremos a seguir.

Tabela 3: Assuntos presentes nos planos de cultura

\begin{tabular}{|c|}
\hline Sistema \\
\hline Economia criativa \\
\hline Patrimônio, memória e acervos \\
\hline Livros e bibliotecas \\
\hline Formação e educação \\
\hline Difusão cultural e formação de público \\
\hline Participação social \\
\hline Emprego e renda \\
\hline Audiovisual e Mídias \\
\hline Acessibilidade e acesso \\
\hline Espaços culturais \\
\hline Direitos autorais \\
\hline Tecnologia e cultura digital \\
\hline Descentralização de recursos e infraestrutura \\
\hline
\end{tabular}

Analisaremos algumas metas em que observamos assuntos relevantes à proposta do SNC que devem ser levadas em conta neste estudo ainda que estejam em diálogo com a divisão temática proposta pelo MinC de 2017. Devido ao extenso tamanho do documento do PNC, seria impossível analisar cada uma das 53 metas nesta tese e optamos por analisar o conteúdo temático de metas que revelaram alguma relação com os centros de valores da arquitetônica do sistema ou mesmo com a nova orientação que o MinC passa a ter nas gestões posteriores ao impeachment em 2016.

Como vimos nos capítulos anteriores, para que a arquitetônica da esfera possa estar refletida no Sistema Nacional de Cultura, é essencial que os planos de cultura possam de fato refletir e refratar os conteúdos e os signos ideológicos, para suprir as necessidades do setor 
para descentralizar, ampliar o acesso e a diversidade. As temáticas elencadas na tabela acima dialogam diretamente com as três dimensões da cultura: simbólica, cidadã e econômica e também com os princípios e conteúdos dos marcos legais do sistema que estão no corpus principal desta tese.

Utilizando a proposta de divisão temática das metas do MinC desenvolvida no ano de 2017, destacamos as metas indicadas em cada tema e analisaremos aquelas que trazem de certo modo as relações com conteúdos de outros enunciados do sistema.

- Economia: Metas 8, 9, 10, 11, 27 e 53

Meta 8) 110 territórios criativos reconhecidos (Descentralização de recursos e infraestrutura)

Meta 11) Aumento em 95\% no emprego formal do setor cultural (emprego e renda)

A temática da economia proposta pela gestão do MinC de 2017 apresenta uma abrangência ampliada da dimensão econômica da cultura. Na meta 8, por exemplo, temos não apenas a ideia de economia criativa, destacada pelo adjetivo "criativos", mas também de descentralização proposta na expansão geográfica em "110 territórios". Tanto o conceito de economia criativa quanto de territórios foram desenvolvidos ao longo do processo de criação do PNC em diálogo com os documentos da UNESCO. Ambos atuam como signos ideológicos construídos por meios dos discursos oriundos dos enunciados anteriores da Unesco sobre as políticas culturais. Contudo, como vimos no capítulo histórico desta tese, "Territórios criativos" é um programa similar a outro realizado principalmente na Espanha e que o MinC não conseguiu implantar efetivamente por conta das mudanças de prioridades dos diversos ministros que passaram pela pasta ao longo dos anos. Até o final de 2017 (data da última atualização), a meta em questão não apresenta dados de desenvolvimento efetivo na tabela histórica de territórios reconhecidos, nem mesmo perspectivas de como pretendem medir os resultados posteriores. Todavia, o descritivo da meta apresentou justificativa datada de 2016 de ações desenvolvidas para o início de um possível avanço em relação à proposta e que possibilitam perceber os desafios que as políticas públicas de cultura têm junto a essas comunidades mais tradicionais.

Em parceria com a UFF, a SEC lançou o portal www.territorioscriativosuff.com.br. O projeto propõe encontros e trocas de saberes de quatro territórios: Madureira, Paraty, Quissamã e Cariri visando potencializar a sinergia criativa dos agentes locais, resultando em trocas de saberes e em parcerias a curto, médio e longo prazo. O Portal é também um espaço de difusão dos tesouros artísticos dos Territórios. Ressalta-se que o projeto resultou na entrega dos seguintes produtos: a) Publicação descritiva 
intitulada "Territórios Criativos" contendo as prospecções e ações alcançadas nos territórios; b) Publicação "Flores da Senzala" versando sobre a tradição oral e contações de história; c) Boletim informativo "Machadinha em Foco" do Território Criativo; d) Quilombo Machadinha/Junho 2016; e) Relatório Museológico do Centro de Cultura Popular Mestre Noza e Lira Nordestina, Território Cariri; f) Projeto Museográfico para o Centro de Cultura Popular Mestre Noza, Território Cariri; e g) Dossiê de contextualização da situação de Mestres e Grupos de Tradição do Cariri. Juazeiro do Norte, Crato e Barbalha. Além disso, a SEC realizou uma série de encontros de saberes sobre territórios criativos durante o ano, sendo eles: a) Ciclo de Encontros e Partilha de Saberes de Mestres da Tradição; b) II Encontro de Saberes do projeto Territórios Criativos Cariri; c) II Encontro de Saberes do projeto Territórios Criativos Paraty; d) II Encontro de Saberes do projeto Territórios Criativos Machadinha. Ainda mais, o projeto "Prospecção e Capacitação em Territórios Criativos", em parceria com a UFF, foram trabalhados 4 territórios criativos, sendo eles: Territórios Criativos Cariri/CE; Territórios Criativos Madureira/RJ; Territórios Criativos Quilombo Machadinha/RJ, Territórios Criativos Paraty/RJ. (Meta 8, Site PNC)

No trecho acima, observamos que estão destacados alguns "territórios criativos": “Territórios Criativos Cariri/CE; Territórios Criativos Madureira/RJ; Territórios Criativos Quilombo Machadinha/RJ, Territórios Criativos Paraty/RJ". Contudo, na tabela de territórios criativos reconhecidos pelo MinC, a última estimativa apresentada do mesmo ano de 2016 é de zero territórios. Não há em parte alguma da meta ou mesmo no site

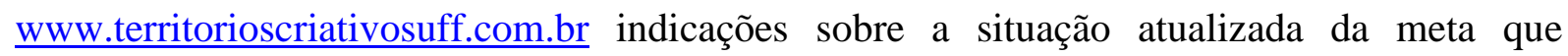
confirme o reconhecimento desses territórios.

Ainda que muitas atividades relacionadas tenham sido realizadas conjuntamente às comunidades, é possível dizer que, ao nomear uma determinada comunidade de "Território criativo", e ao fazê-lo sob a instituição de um programa de um órgão estatal, no caso o Ministério da Cultura, a dimensão simbólica (no caso das culturas populares tradicionais principalmente no Quilombo da Machadinha e no Cariri) e a normatização estatal entram numa relação dialógica nem sempre de convergência. A utilização do signo "Território Criativo", pensado aqui como de forma composta e diretamente relacionado ao programa citado acima, traz a relação dialógica de consenso com as ideias contidas nos documentos da Unesco. Os diversos encontros presenciais relatados no descritivo da meta acima permitem que nossa análise do conteúdo temático da meta reflita acerca de outros enunciados e discursos relacionados a ela.

O diálogo entre Estado e agentes culturais (no caso mais específico ao patrimônio imaterial e material e às culturas tradicionais) pode ser compreendido como feito por dois 
pontos de vista distintos. Primeiramente, o ponto de vista dos agentes culturais das comunidades, que precisam do apoio principalmente financeiro do Estado, mas podem desconfiar da intervenção estatal por meio do discurso da Economia Criativa (algo inovador e desconhecido) principalmente por serem regidos pela dimensão simbólica pautada pela tradição e manutenção dos costumes. Em segundo lugar, o olhar do Estado, que se propõe a nomear/ reconhecer aquele território / comunidade como um "Território criativo", termo relacionado à Economia Criativa, que traz junto a ideia de sustentabilidade e da produção de recursos desenvolvida na própria comunidade. Isto é, ao mesmo tempo que as comunidades estão interessadas no diálogo por conta das verbas e da estrutura que pode ser viabilizada pelo Estado (até então ausente de muitos desses polos culturais tradicionais), o Estado oferece um modelo que se pretende como inovador e de produção autossustentável a uma comunidade pautada na manutenção de seus costumes e tradições e que sofre por escassez de recursos e de infraestrutura básica de sobrevivência. Um paradoxo complexo de ser resolvido e que mostra que aqui temos uma iminente tensão de diferentes avaliações sociais. A interlocução entre as duas partes envolvidas nesta meta demonstra que as distintas visões de mundo, no caso diferentes avaliações sociais, podem também apresentar diferentes visões sobre o desenvolvimento da meta em si e inclusive impedir que esta se desenvolva plenamente. Os valores axiológicos empregados no descritivo da meta representam principalmente o discurso do Estado, mesmo que estejam pautados pelas ideias de economia autossustentável e reorganização de territórios que se constituem principalmente pela dimensão simbólica da cultura. Ao propor que estes territórios sejam pautados pela dimensão econômica da cultura, o MinC apresenta um projeto de dizer que nas entrelinhas busca alterar a lógica de produção nessas comunidades até então pautadas pelo principalmente simbólico, pelo coletivo e pelas tradições.

A lista de 110 territórios criativos prospectados pelo MinC constantes do site do programa apresenta uma grande maioria de territórios compostos por comunidades principalmente indígenas e quilombolas e que prioritariamente têm a cultura oral como base social. Em muitas dessas comunidades, a autossustentabilidade já existe desde sua origem, porém sem relação com a ideia global de Economia Criativa, que, como vimos anteriormente, foi pautada por ideais liberais na Inglaterra e Austrália. Há aqui um paradoxo a ser resolvido, pois, se, por um lado, o Estado busca trazer tecnologias sociais e econômicas inovadoras da Economia Criativa para promover um novo tipo de autossustentabilidade à essas comunidades, por outro, entram numa relação dialógica de dissenso com os valores 
axiológicos que mantêm essas comunidades reunidas: uma organização social estabelecida pelo simbólico e pela tradição. Talvez por isso a meta não tenha apresentado resultados concretos ainda que muitas atividades tenham sido realizadas nos territórios.

A meta de número onze propõe "Aumento em 95\% no emprego formal do setor cultural". Com isso, prevê a quase duplicação do emprego formal no setor em seu título, não trata das especificidades e qualificação desse trabalho. O signo "emprego formal" ainda que nos remeta à importante questão do trabalhador da cultura e as demandas de formalização do setor, não está necessariamente refletida e refratada no desenvolvimento do conteúdo temático da meta. Ao longo do texto, não apresentam algum tipo de indicativo numérico ou texto explicativo para orientar a leitura dos dados apresentados. O que mais chama atenção no título da meta é a questão do emprego formal, tema essencial aos objetivos do Sistema Nacional de Cultura relativo à descentralização de recursos e ao acesso, pois a maior parte dos agentes culturais atua na esfera informalmente e sofre pela instabilidade de vagas. A meta descreve a utilização de dados do IBGE e da Relação Anual de Informações Sociais (RAIS), porém apenas apresenta a justificativa da alteração do índice de CNAE de empresas em seu conteúdo, não especificando funções de trabalho, nem informações sobre a distribuição das vagas no país.

(...) cabe esclarecer que houve uma redefinição das atividades econômicas consideradas para a aferição da meta, pois, a partir de 2013, o Sistema de Informações e Indicadores Culturais do Instituto Brasileiro de Geografia e Estatística (IBGE) passou a definir as atividades econômicas do setor cultural com referência no CNAE 2.0 (Cadastro Nacional de Atividades Econômicas). Anteriormente, a meta era aferida por meio do CNAE $95^{189}$. (Meta 11, site PNC)

Ao longo da descrição da meta, a amostragem de dados e o texto descritivo não permitem refletir acerca da qualificação do trabalho formal do setor. Apenas é considerada a quantidade de empresas que atuam na cultura e oferecem contratos de trabalho, ou mesmo carteira assinada e não as vagas efetivas de emprego no setor. Isto é, enquanto o título da meta traz o forte signo ideológico "emprego formal", o conteúdo temático pouco reflete que os trabalhadores da esfera esperariam do tema. Ao contrário disso, trazem no conteúdo a visão do Estado e dos empregadores, em que estes agentes do setor representam apenas números. Ao tratar da ampliação de vagas, a meta 11 do Plano Nacional de Cultura se relaciona com os discursos da Lei do PNC, como nesse trecho abaixo, no anexo da lei no capítulo 1:

189 CNAE 95 - REPARAÇÃO E MANUTENÇÃO DE EQUIPAMENTOS DE INFORMÁTICA E COMUNICAÇÃO E DE OBJETOS PESSOAIS E DOMÉSTICOS. 
ESTRUTURAR E REGULAR A ECONOMIA DA CULTURA, construindo modelos sustentáveis, estimulando a economia solidária e formalizando as cadeias produtivas, ampliando o mercado de trabalho, o emprego e a geração de renda, promovendo o equilíbrio regional, a isonomia de competição entre os agentes, principalmente em campos onde a cultura interage com o mercado, a produção e a distribuição de bens e conteúdos culturais internacionalizados. (BRASIL, 2010)

Ao propor a ampliação das vagas de emprego formal no PNC, sem mencionar a qualificação destas vagas ou mesmo quais são essas funções, o MinC demonstra que, ao criar o foco da meta, apenas se preocupou em criar números positivos para o emprego. Não houve uma preocupação em trazer resultados para sanar os problemas dos trabalhadores da cultura, que em grande maioria atuam no setor informalmente. A avaliação social apresentada pela meta representa a visão estatal do trabalho, onde números positivos de empregos em um determinado setor são mais importantes que a qualidade destes trabalhos e suas respectivas rendas e condições. A temática do emprego e da renda é um ponto de preocupação dos trabalhadores da cultura, que sofrem pela instabilidade, informalidade e verbas escassas da esfera. Quando um projeto cultural acaba, termina também o contrato com estes trabalhadores. As empresas de cultura nem sempre podem absorver estas pesssoas em seus quadros fixos de trabalho formal justamente por conta do modelo de financiamento ainda pautado pelas leis de incentivo fiscal, em que um projeto tem começo, meio e fim e nem sempre conseguem uma continuidade. De certo modo, é possível dizer que as vozes e discursos dos trabalhadores da cultura não são efetivamente representados no descritivo desta meta e em seus resultados. Os valores axiológicos do que significam os signos ideológicos: trabalho, emprego formal e renda representam a visão estatal e empresarial, que pensa o trabalho em forma de números e não de qualificação de trabalho ou renda.

- Informações e dados culturais: Metas 2, 3, 7, 41 e 48.

Meta 2) $100 \%$ das Unidades da Federação (UF) e $60 \%$ dos municípios atualizando o Sistema Nacional de Informações e Indicadores Culturais (SNIIC) (Sistema)

Meta 3) Cartografia da diversidade das expressões culturais em todo o território brasileiro realizada (Expressões culturais e diversidade)

Meta 7) $100 \%$ dos segmentos culturais com cadeias produtivas da economia criativa mapeadas (Expressões culturais e diversidade)

Meta 41) $100 \%$ de bibliotecas públicas e $70 \%$ de museus e arquivos disponibilizando informações sobre seu acervo no SNIIC (Patrimônio, memória e acervos)

Meta 48) Plataforma de governança colaborativa implementada como instrumento de participação social com 100 mil usuários cadastrados, observada a distribuição da população nas macrorregiões do país. 
(Participação social)

As metas relacionadas a temáticas de Informações e dados culturais também apresentaram tanto em seus títulos quanto em seus conteúdos outros signos pertinentes ao desenvolvimento do sistema e que estão em relação dialógica com os conteúdos de outros documentos de nosso corpus.

Na meta 2, a temática principal é o desenvolvimento dos indicadores pelo SNIIC que deverão aferir os diagnósticos e resultados obtidos ao longo do desenvolvimento dos planos de cultura, tanto os territoriais quanto setoriais. Entretanto, por ser o principal mecanismo de aferição de dados do sistema, tem como tema geral sua relação direta com os resultados proporcionados pelo sistema. O SNIIC é um componente previsto no item VI do sistema no artigo 216 A da Constituição Federal e rege os artigos 9 e 10 da lei de regulamentação do PNC que trata do monitoramento e avaliação do sistema e do plano. Isto é, o SNIIC não trata apenas de dados, ele é parte fundamental do sistema, pois deverá refletir e refratar os resultados mais concretos da política cultural proposta. Este sistema de informações deve ser construído em colaboração com os agentes culturais que deverão interagir com a plataforma, inserindo dados e mantendo atualizado os processos e as atividades realizadas. O SNIIC também trata das temáticas de descentralização e ampliação do acesso que, como vimos anteriormente, são centros da arquitetônica do sistema como um todo.

No desenvolvimento desta meta no site do PNC é possível perceber que tanto nas imagens quanto nos textos descritivos, a questão espacial e temporal é fator relevante para descrever os resultados. Duas tabelas são apresentadas: uma que quantifica o número de municípios que já estão inscritos no SNIIC e também os que estão efetivamente fazendo uso da plataforma. Outra tabela mais abaixo traz a quantidade de municípios divididos por região do país e por tempo. Complementar a isso, oferecem um gráfico colorido em 3D, demonstrando o avanço das metas entre as regiões nos anos de 2014 a 2016. A preocupação com os dados reflete a importância da meta para o desenvolvimento do sistema como um todo. Contudo, não há informações mais detalhadas que possam orientar os leitores sobre como o SNIIC de fato alimenta os dados do próprio site do Plano Nacional de Cultura, pois a plataforma ainda atua como coletor de dados em fase de implantação. A SNIIC está diretamente relacionada com as três dimensões da cultura:

a) Com a dimensão cidadã, ao permitir que os agentes culturais interajam e participem ativamente do processo e tenham a responsabilidade ética de fornecer informações para alimentar o sistema; 
b) Com a dimensão econômica, ao aferir dados sobre a produção refletida em termos de investimento vs. resultados;

c) Com a dimensão simbólica, ao mapear a produção cultural do país.

A plataforma pode representar um dos poucos canais abertos para que os agentes culturais possam interagir com o Sistema efetivamente enquanto autores responsáveis por essas informações. No entanto, esta interação ainda se mostra muito frágil, já que a plataforma tem sido pouco divulgada, e assim poucos dados estão computados, e o acesso a eles não está organizado. Há pouca informação sobre a importância de utilizar o SNIIC mesmo nos enunciados relativos ao sistema. Para que ele possa de fato refletir e refratar a arquitetônica da esfera em algum momento, precisará ampliar o diálogo com os agentes culturais e incentivar a utilização e atualização constante de informações. Só com a plena inserção de dados será possível ter a diversidade de consciências em diálogo num mesmo processo construtivo. Isso pode ser considerado um desafio ainda maior quando pensarmos nas diversas comunidades dos povos tradicionais que ainda não foram incluídas digitalmente e se pautam principalmente pela cultura oral.

Ao estabelecer a responsabilidade para abastecimento de dados do sistema em uma plataforma digital e complexa de utilização aos agentes culturais dos mais diferentes tipos, o Estado abre a possibilidade de maior participação social, mas também tira de si a responsabilidade para contabilizar os avanços do sistema. O SNIIC pretende ser futuramente o espaço em que as vozes da esfera estarão em diálogo e onde a cultura do país poderá brilhar de forma organizada. Todavia, para que isso aconteça, será necessário que todos consigam interagir com a plataforma digital de forma igual. Para isso, o MinC deverá pensar futuramente em outra formas de interação para a ampliação do acesso ao SNIIC, seja por uma divulgação maior, ou mesmo por um modelo mais simples de acesso, via registro de voz (no caso de comunidades de cultura oral) ou por aplicativos em redes móveis como os celulares. Essa vocação ética ainda não está explicita no conteúdo temático da meta.

A Meta 3 do PNC trata da Cartografia da diversidade das expressões culturais realizada em todo o território brasileiro e se conecta com os três centros da arquitetônica do sistema: diversidade, acesso e descentralização. Ao falar de cartografia, dá a ideia de um tipo de mapeamento amplo, principalmente na expressão "em todo o território brasileiro" e possibilita observar demandas de falta de acesso à cultura, ou mesmo em que locais há uma predominância de determinadas manifestações culturais. $\mathrm{O}$ tema da diversidade elencado no título da meta permite que esse mapeamento seja desenvolvido com a compreensão ampliada 
de cultura, e não apenas uma cartografia das artes por exemplo. Na apresentação da meta no site do PNC, encontramos o seguinte período: "O levantamento cartográfico será constantemente atualizado no Sistema Nacional de Informações e Indicadores Culturais (SNIIC)". A relação direta com a meta anterior permite aferir que essa meta também está diretamente relacionada com a construção do sistema, pois busca mapear e trazer um diagnóstico constante da cultura como um todo. Entretanto, como vimos, a responsabilidade ética pela construção desta cartografia não é apenas do MinC, mas também dos agentes culturais que deverão interagir com a plataforma SNIC a alimentando de informações sempre atualizadas.

A "cartografia das expressões culturais em toda a sua diversidade" se propõe como um retrato da esfera, mostrando as manifestações culturais e os reflexos das políticas culturais de cada região ou a falta das mesmas. Ao analisarmos os outros enunciados do sistema, percebemos que, de fato, a meta 3 é um dos pilares da arquitetônica do SNC. De acordo com o artigo 1 da lei de regulamentação do PNC, a diversidade cultural é elencada como o segundo princípio do plano. Isto é, a diversidade é um dos signos ideológicos mais fortes no sistema e na meta 3. No artigo segundo da lei, que trata dos objetivos do PNC, o primeiro item diz que este deve "reconhecer e valorizar a diversidade cultural, étnica e regional brasileira". Para que esta diversidade seja de fato estabelecida, percebida, contabilizada e ampliada concretamente, é relevante ao sistema seu diálogo com a meta anterior e mesmo com as demais metas do PNC. Ambas são parte estruturante e de extrema relevância enquanto conteúdo temático do sistema, já que a diversidade é um forte signo ideológico da proposta político-cultural e um dos centros da arquitetônica do SNC.

Ambas as metas ( 2 e 3 ) alimentam a construção / forma e o conteúdo do sistema nos seus preceitos de descentralização, ampliação de acesso e diversidade. Uma das principais justificativas para a implantação deste novo modelo de política cultural vem justamente da concentração de recursos no eixo Rio - SP e nas linguagens artísticas hegemônicas como a música, o patrimônio, o teatro e o audiovisual. Ao propor como temática de uma meta uma cartografia das expressões culturais em todo o território e diversidade, e vinculada ao SNIIC, a meta se apresenta como uma possibilidade de observação organizada de como a esfera político-cultural pode ser alterada ideologicamente pelo SNC visando a descentralização e a diversidade. Entretanto, como salientamos anteriormente, a plataforma SNIIC não é um canal de interação que pode atingir a todos, e as cartografias dependem também destes dados. Ambas as metas estão condicionadas à responsabilidade ética de agentes culturais que em 
parte dos casos têm práticas de comunicação prioritariamente orais ou não dominam a língua portuguesa ou mesmo não tem garantido sinal de internet disponível em seus territórios para esta interação.

Algo semelhante acontece com a meta 7 que propõe mapear 100\% dos segmentos culturais com cadeias produtivas da economia criativa. Nesta meta, ao mapear as cadeias produtivas, o sistema poderá apresentar diagnósticos e resultados no desenvolvimento dos setoriais.

Cada segmento cultural tem uma ou mais cadeias produtivas, isto é, sequências de etapas de produção até que o produto esteja pronto e colocado à venda. As etapas podem ser realizadas por diferentes agentes econômicos, sempre relacionados uns com os outros como elos de uma corrente. Quando se observam a economia e as cadeias produtivas, podem-se destacar as potencialidades dos segmentos culturais para ganhos econômicos e sociais (Meta 7, PNC)

Este mapeamento por cadeias produtivas pode ser pensando a partir da dimensão econômica do sistema, pois, assim como descrito na meta 7 no site do PNC, as cadeias produtivas são os elementos das etapas de produção. Os signos ideológicos "economia criativa" e "cadeias produtivas" nos remetem diretamente a um tipo de modelo econômico. Estas cadeias produtivas movem economicamente o setor da cultura direto e setores indiretos como: hotéis, restaurantes, redes de TV, etc. Deste modo, podemos aferir que esta meta trata da mesma forma da dimensão econômica da cultura, e não apenas de informações e dados, como sugeriu a divisão temática do MinC em 2017. Ao tratar da questão econômica propõe o debate sobre o financiamento à cultura, pois possibilita perceber como as cadeias se organizam para produzir, para a venda de produtos culturais e sustentabilidade, suas regras de mercado, tipos de trabalho, estruturas produtiva e hierárquica. Os discursos acerca da cadeia produtiva ampliam o escopo da cultura e criam possibilidades de relação entre as três dimensões da cultura. Isso fica mais evidente no trecho da meta 7 que diz:

A economia criativa é um setor estratégico e dinâmico, tanto do ponto de vista econômico como social. Suas atividades geram trabalho, emprego, renda e inclusão social. A economia criativa é composta das atividades econômicas ligadas aos segmentos - de acordo com definição da Unesco como patrimônio natural e cultural, espetáculos e celebrações, artes visuais e artesanato, livros e periódicos, audiovisual e mídias interativas e design e serviços criativos. (meta 7, PNC)

Já tratamos aqui da ideia de Economia Criativa como uma nova tendência de influência liberal que, principalmente desde 2012, com a entrada da Ministra Ana de Hollanda na gestão Dilma Rousseff, passa a ter mais força no MinC. É relevante relembrar que foi neste 
mesmo período que o orçamento público para o setor começou a decair. Ao trazerem o signo ideológico da Economia Criativa como nova força de construção do MinC, pautam uma visão axiológica do novo modelo econômico proposto, com uma cultura autossustentável mas pelo viés liberal. Assim esta meta pode ser relacionada com o crescimento da ausência de verbas públicas e também a ausência do Estado, que passa a responsabilidade de gerar renda aos produtores de cultura. Ao fomentar a visão axiológica por meio da ideia de Economia Criativa, o Estado diminui a responsabilidade ética de fornecer recursos diretos e infraestrutura aos produtores de cultura, típica do Estado de Bem Estar Social e adere ao novo modelo de tendência liberal, em que o Estado delega a responsabilidade de (auto)sustento aos produtores culturais. Esta meta demonstra que a mudança no modelo de financiamento à cultura do MinC não está totalmente permeada pelo fortalecimento do Fundo Nacional de Cultura. Ao propor em algumas metas que o modelo de Economia Criativa seja utilizado em determinados programas, comunidade e setoriais, o MinC estabelece sua visão axiológica de financiamento à cultura como também pautada por um novo tipo de economia da cultura de modelo liberal. Ao mesmo tempo em que busca diminuir a influência dos incentivos fiscais na esfera, traz um novo modelo de tendência liberal para a pauta. Deste modo assumem um posicionamento ideológico em relação ao modelo de infraestrutura pretendido, que não é apenas dentro dos moldes do Estado de Bem Estar Social.

- Acesso, difusão e criação: Metas 20, 21, 25, 26, 28, 29, 30, 40, 43, 44, 45

Meta 20) Média de quatro livros lidos fora do aprendizado formal por ano, por cada brasileiro (Livros e bibliotecas)

Meta 21) 150 filmes brasileiros de longa-metragem lançados ao ano em salas de cinema (Audiovisual e mídias)

Meta 25) Aumentar o intercâmbio nacional e internacional de atividades que divulguem as manifestações culturais e brasileiras (Audiovisual e mídias).

Meta 30) 37\% dos municípios brasileiros com cineclube (Audiovisual e mídias)

Meta 40) Disponibilização na internet de conteúdos, que estejam em domínio público ou licenciados (Tecnologia e cultura digital)

Meta 43) 100\% das Unidades da Federação (UF) com um núcleo de produção digital audiovisual e um núcleo de arte tecnológica e inovação (Tecnologia $e$ cultura digital)

Meta 44) Participação da produção audiovisual independente brasileira na programação dos canais de televisão, na seguinte proporção: $25 \%$ nos canais da TV aberta; $20 \%$ nos canais da TV por assinatura (Audiovisual e mídias)

Meta 45) 450 grupos, comunidades ou coletivos beneficiados com ações de Comunicação para a Cultura (Audiovisual e mídias)

Das onze metas elencadas no grupo temático relativo ao acesso (um dos centros da arquitetônica do sistema) oito delas tratam da difusão. Entretanto, a difusão aqui é tratada pela 
gestão do MinC $^{190}$ no ano de 2017 principalmente na linguagem do audiovisual e mídias, tecnologia e cultura digital. É relevante questionar neste momento qual é a visão axiológica e a avaliação social do MinC em relação ao conceito de difusão, um substantivo que vem da ideia de difundir, ou em seu sinônimo, divulgar.

Na lei do PNC (BRASIL, 2010), podemos destacar a temática da difusão nos seguintes trechos:

VIII - dinamizar as políticas de intercâmbio e a difusão da cultura brasileira no exterior, promovendo bens culturais e criações artísticas brasileiras no ambiente internacional; dar suporte à presença desses produtos nos mercados de interesse econômico e geopolítico do País; (artigo 3- das atribuições do poder púbico) (...) 1.8.2 Instituir instrumentos tributários diferenciados para beneficiar a produção, difusão, circulação e comercialização de bens, produtos e serviços culturais. (Anexo - estratégias e ações - marcos regulatórios) (...) 1.9.5 Criar marcos legais de proteção e difusão dos conhecimentos e expressões culturais tradicionais e dos direitos coletivos das populações detentoras desses conhecimentos e autoras dessas manifestações, garantindo a participação efetiva dessas comunidades nessa ação. (Anexo estratégias e ações - gestão pública dos direitos autorais) (...) 1.10 .3 Estabelecer um sistema articulado de ações entre as diversas instâncias de governo e os meios de comunicação públicos, de modo a garantir a transversalidade de efeitos dos recursos aplicados no fomento à difusão cultural. (Anexo - estratégias e ações - articulações com outros setores) (...) 1.10.9 Realizar programas em parceria com os órgãos de educação para que as escolas atuem também como centros de produção e difusão cultural da comunidade. (Anexo - estratégias e ações - articulações com outros setores) (...) 1.10.10 Incentivar pesquisas e elaboração de materiais didáticos e de difusão referentes a conteúdos multiculturais, étnicos e de educação patrimonial. (Anexo - estratégias e ações - articulações com outros setores)

Nos trechos acima, presentes no capítulo 1 dos anexos da lei, observamos que o signo ideológico difusão pode ser empregado em temáticas que vão muito além da relação deste com os meios de comunicação e audiovisual. As possibilidades de difusão elencadas tratam da:

a) Difusão da cultura brasileira no exterior (item VIII);

b) Criação de marcos legais de proteção e difusão dos conhecimentos e expressões culturais tradicionais (Item 1.9.5);

c) Articulação com os demais setores públicos (item 1.10.3);

d) Parcerias com órgão de educação para que estes atuem como difusores da cultura (Item 1.10.9);

e) Elaborar materiais didáticos com conteúdos multiculturais, éticos e de educação patrimonial. (1.10.10).

\footnotetext{
${ }^{190}$ Importante relembrar a conhecida e forte ligação do então Ministro Sérgio Sá Leitão com o setor de audiovisual e mídias por ter sido presidente da Riofilme, entidade da prefeitura do Rio de Janeiro.
} 
Estes são apenas alguns dos exemplos de tipos distintos de possibilidades de difusão encontrados ao longo do extenso anexo da lei do PNC. Ao apontar em grande maioria os temas relativos às mídias e ao audiovisual como relacionados ao acesso e difusão, o MinC apresenta seu projeto de discurso e avaliação social de qual seria a melhor forma de difundir e também ampliar o acesso à cultura. Mesmo na meta 25, que busca "Aumentar o intercâmbio nacional e internacional de atividades que divulguem as manifestações culturais e brasileiras" o conteúdo no descritivo da meta volta-se para o desenvolvimento do setor audiovisual e não para o intercâmbio concreto dos artistas brasileiros em outras partes do mundo como acontecia no programa de intercâmbio do MinC que foi desenvolvido entre 2010 e 2016, em que, por meio de um edital, os agentes culturais pleiteavam recursos para viagens principalmente ao exterior para realizar espetáculos e divulgar suas produções.

A ideia de interlocução do setor da educação pautadas nos itens 1.10 .9 e 1.10 .10 da lei do PNC demonstra o interesse em ativar o diálogo e a transversalidade da cultura. Os itens propõem que o signo "educação" seja pensado como um difusor da cultura nacional em toda sua diversidade e que os conteúdos culturais em contrapartida auxiliem na formação dos estudantes de ensino básico. Contudo, esses itens não foram considerados em nenhuma das metas do PNC.

Por conta dos signos ideológicos que se apresentam como centros da arquitetônica do sistema estarem pautados principalmente nos temas de descentralização, diversidade e acesso, achamos relevante fazer uma análise de temáticas mais apurada por meio da observação dos grupos e setoriais citados no enunciado. Na observação ao longo do enunciado das 53 metas do PNC (e também em seus objetivos e ações) encontramos o seguinte panorama de grupos e setoriais citados:

- Biblioteca: 40 citações;

- Patrimônio (histórico e imaterial): 36 citações;

- Museu: 30 citações;

- Audiovisual: 26 citações;

- Teatro: 22 citações (com referência a teatros como equipamentos públicos e a linguagem teatral);

- Música: 21 citações ;

- Linguagens artísticas: 16 citações;

- Dança: 16 citações;

- Circo: 12 citações;

- Artes visuais: 12 citações;

- Indígenas: 9 citações;

- Literatura: 4 citações; 
- Cigano / a: 4 citações;

- Quilombolas: 3 citações;

- LGBT: 2 citações;

- Sarau: 1 citações;

- Hip Hop: 0 citações;

- Afrobrasileira/o: 0 citações;

- Artes Cênicas: 0 citações.

A presença de um maior número de citações para as bibliotecas, patrimônio e museus, reflete a herança das políticas culturais desenvolvidas na esfera principalmente a partir do século XIX em que estas instituições eram prioridade no desenvolvimento da cultura. A menção majoritária a estes setores em contraposição à minoria de citações a grupos como: afrobrasileiro, quilombolas, ciganos, indígenas, hip hop, etc, demonstra que apesar de um dos centros da arquitetônica do sistema ser a diversidade, o Plano ainda foi fortemente pautado por ideias conservadoras da gestão das políticas culturais, pois priorizou, ao longo do enunciado e em seu conteúdo temático, uma maior presença de temáticas institucionais como prioridades. Se de fato a intenção e os valores axiológicos que pautam os conteúdos temáticos do enunciado buscassem priorizar a ampliação do acesso e a diversidade cultural, por que estes grupos minoritários continuam com menor espaço ao longo do enunciado e temas como museus e patrimônio estão no topo da lista de citações?

Como vimos ao longo da análise dos conteúdos temáticos dos enunciados do PNC, a diversidade e o acesso estão presentes nas diretrizes e na lei. Entretanto, na análise de algumas metas do Plano estão refletidas e refratadas as tendências das políticas culturais anteriores a essa política de viés liberal ou mesmo de tradições institucionais. Isso fica ainda mais evidente com a presença da economia criativa no enunciado do plano e também nas diferenças de número de citações aos setoriais e grupos culturais no enunciado. Se de fato a vontade política daqueles que fizeram a versão final do PNC e também sua última revisão fosse priorizar a diversidade cultural e o acesso, por que buscariam fortalecer um modelo de financiamento como a economia criativa que reduz a ação do estado e sua responsabilidade de incentivar diretamente a produção de cultura? E por que os grupos minoritários pouco aparecem ao longo de um documento que traz o planejamento das políticas por dez anos? São questões que ainda não podemos responder por conta dos atrasos na implantação do sistema, mas achamos pertinente questionar, já que contradizem os centros da arquitetônica do mesmo. 


\subsection{3 - O conteúdo temático do Plano Estadual de Cultura de São Paulo}

Ao analisarmos o conteúdo temático na minuta do Plano Estadual de Cultura de São Paulo, ainda em trâmite de aprovação, é possível perceber que não foi proposta em nenhum momento uma divisão de blocos temáticos. Por conta de sua construção composicional "inversa", em que as metas aparecem por último depois das ações, analisaremos os 40 objetivos propostos. Em alguns casos, foi necessário analisarmos também os conteúdos das ações dentro dos objetivos para compreender melhor qual era a proposição. Para o desenvolvimento de nosso trabalho, e compreender qual era o foco principal desse plano, dividimos os objetivos do PEC em temáticas de acordo com a tabela proposta no tópico anterior.

$\mathrm{Na}$ análise dos conteúdos dos quarenta itens relativos aos objetivos e suas respectivas ações (e uma diretriz - 14) do Plano Estadual de Cultura, os objetivos encontrados foram os seguintes:

- Expressões culturais e diversidade - Objetivos: $1.1 ; 2.2 ; 4.1 ; 5.2 ; 8.1 ; 9.1 ; 9.2 ; 10.1$; 10.2; 11.1; 11.2; diretriz 14; 20.1. (13 itens)

1.1 Planejar, criar e implantar políticas, programas, projetos e ações voltadas para o fortalecimento e promoção das expressões, dos patrimônios, das linguagens e manifestações artísticas, das culturas populares, indígenas, afrobrasileiras, ciganas, quilombolas, hip hop e tradicionais para os próximos 10 anos. (...) 2.2 Realizar mapeamentos das expressões, dos patrimônios, das linguagens e manifestações artísticas, das culturas populares, indígenas, afro-brasileiras, ciganas, quilombolas, hip hop e tradicionais, visando produzir informações para subsidiar ações de proteção da diversidade cultural paulista, e difundir informações sistematizadas a esse respeito. (...) 4.1 Incentivar os processos de transmissão de conhecimentos dos saberes e práticas das "mestras(es)", "povos" e "comunidades" tradicionais entre as diferentes gerações. (...) 5.2 Disseminar o conhecimento e ampliação da apropriação social do patrimônio cultural material e imaterial. (...) 8.1 Promover a comunicação, difusão e produção de valores culturais, por meio do rádio, tv, internet, revistas e jornais que circulem com valores que simbolizam a cultura regional de seu povo. (...) 9.1 Desenvolver políticas públicas apropriadas para os praticantes das expressões, dos patrimônios, das linguagens e manifestações artísticas, das culturas populares, indígenas, afro-brasileiras, ciganas, quilombolas, hip hop e tradicionais. (...) 9.2 Qualificar as instituições públicas e da sociedade civil para garantia de participação e acesso as políticas públicas. (...) 10.1 Ampliar a circulação da produção da diversidade cultural e dinamizar as políticas de intercâmbio e difusão das culturas do Estado de São Paulo. (...) 10.2 Valorizar e fortalecer o sentimento de pertença das linguagens artísticas e expressões culturais locais. (...) 11.1 Promover a articulação das políticas públicas de cultura com as de outras áreas governamentais e não governamentais. (...) 11.2 Articular ações integradas com as demais Secretarias Estaduais de Governo e instâncias internas da Secretaria de Estado da Cultura. (...) Diretriz 14 Garantir o reconhecimento, a valorização, 
a proteção e a promoção das expressões, dos patrimônios e das linguagens e manifestações artísticas e culturais em toda sua diversidade. (...) 20.1 Manter constantes mecanismos de diálogos sociais para o debate de como a discriminação, intolerância e preconceito se estabelecem nos pensamentos e atitudes dos cidadãos. ${ }^{191}$

Ao dividir e quantificar os assuntos principais do Plano Estadual de Cultura de São Paulo (PEC), chama atenção a grande quantidade de itens relativos à diversidade cultural e economia. Ainda que nos objetivos (e diretriz) listados acima não citem especificamente questões ligadas à diversidade, verificamos uma forte presença da temática no desenvolvimento de suas metas e ações. O mesmo ocorre em relação ao tema financiamento. Tanto a diversidade quanto o financiamento representa pelo menos $30 \%$ dos assuntos tratados no PEC, enquanto outras temáticas têm espaço em apenas um dos objetivos listados como acesso, emprego e difusão.

Essa grande diferença nas quantidades de assuntos no PEC SP revela qual era a intenção e o projeto de dizer dos autores que construíram o enunciado e também sua visão axiológica de cultura. Ao priorizarem as temáticas de diversidade e financiamento, trazem o foco também para duas dimensões da cultura: simbólica e econômica. Entretanto, como veremos ao longo da análise, alguns importantes setoriais ficaram de fora do desenvolvimento e em boa parte dos objetivos que não se encaixam nos temas diversidade e economia não são desenvolvidas nem ações nem metas.

Por conta da grande quantidade de objetivos (e metas) que tratam da diversidade, assim como fizemos na análise do PNC, buscaremos destacar os grupos e setores citados no enunciado do PEC SP:

- Indígenas: 54 citações;

- Patrimônio (histórico e imaterial): 40 citações;

- Cigano / a: 29 citações;

- Hip Hop: 26 citações;

- Quilombolas: 26 citações;

- LGBTT: 18 citações;

- Afrobrasileira/o: 7 citações;

- Circo: 6 citações;

- Linguagens artísticas: 6 citações;

- Teatro: 2 citações (com referência a teatros como equipamentos públicos);

- Música: 1 citação (com referência ao ensino da música nas escolas);

- Audiovisual, Biblioteca, Museu: 1 citação cada;

- Dança, Literatura, Artes visuais, Sarau e Artes Cênicas: Zero citações cada.

${ }^{191}$ Disponível em: < http://www.planoestadualdecultura.sp.gov.br/ > acesso em 10 de julho de 2018. 
A presença de uma considerável quantidade de agentes culturais ${ }^{192}$ ligados às culturas tradicionais e à diversidade cultural na comissão composta para a escrita do PEC pode justificar o grande número de objetivos que abordam signos ideológicos relacionados à diversidade cultural, pautados principalmente pela menção aos grupos: povos tradicionais, culturas populares, afro-brasileiras, indígenas, quilombolas, ciganos e Hip Hop. Em nenhum ponto do enunciado do PEC são mencionadas algumas linguagens artísticas separadamente (teatro, literatura, artes visuais e dança), nem mesmo no desenvolvimento das ações e metas. Ao contrário disso, os grupos minoritários são destacados em diversos pontos do enunciado repetidamente, inclusive nas ações e metas.

O projeto de discurso para o enunciado em questão demonstra os valores axiológicos dos autores responsáveis pela construção do plano que buscou pautar a presença em destaque desses grupos minoritários e historicamente excluídos da sociedade, que como vimos ao tratar das atualizações do decreto do CNPC, só foram incluídos efetivamente no sistema em 2009. É na interação da construção do plano estadual de SP que surgem fortemente estes signos vinculados à diversidade. A representatividade destes grupos como autores agentes refletem e refratam o projeto de dizer com forte intenção axiológica. Os signos ideológicos relativos às comunidades tradicionais são repetidos à exaustão ao longo do enunciado, com a intenção de demonstrar para quem era a prioridade de incentivo. Ao citarem os grupos minoritários não estão apenas usando as palavras relativas a eles estão criando uma visão estratégica de dizer.

Nenhum signo cultural permanece isolado se for compreendido e ponderado, pois ele passa a fazer parte da unidade da consciência verbalmente formalizada. A consciência sempre saberá encontrar alguma aproximação verbal com o signo cultural. Por isso, em torno de todo signo ideológico se formam como que círculos crescentes de respostas e ressonâncias verbais. Qualquer refração ideológica da existência em formação, em qualquer material significante que seja, é acompanhada pela refração ideológica na palavra como um fenômeno obrigatório concomitante. A palavra está presente em todo o ato de compreensão e em todo ato de interpretação. (VOLÓCHINOV, 2017, p. 101)

Ao evidenciar uma maior quantidade de objetivos relacionados à diversidade $\mathrm{e}$ consequentemente aos grupos minoritários em quantidade similar aos itens de financiamento à cultura, é possível dizer que os autores tiveram a intenção discursiva de pensar num plano para o estado de São Paulo que teria como foco principal a diversidade e o incentivo a estes grupos. Aliado a isso, depreendemos que grande quantidade de objetivos voltados para a

\footnotetext{
${ }^{192}$ A distribuição de agentes na comissão foi feita por macroregião do estado e não por setoriais.
} 
economia da cultura visa principalmente a ampliação e reorganização do financiamento também para estas comunidades.

Ao concentrar estes objetivos em apenas dois tipos de temáticas, os autores do enunciado demonstram sua avaliação social e valores axiológicos que buscam distribuir os recursos e criar novos programas prioritariamente àqueles até então pouco atendidos pelo estado. A grande incidência dos signos indígenas, quilombolas e ciganos reflete e refrata a avaliação social e as vontades dos participantes na comissão. Essas comunidades de povos tradicionais estão espalhadas por todo Estado de São Paulo ${ }^{193}$ principalmente nas regiões mais carentes de recursos do Estado. É importante ressaltar que a Secretaria de Cultura do Estado de São Paulo foi pioneira na criação de editais específicos para estes grupos a partir de 2006 por meio do Proac Editais.

Figura 37: Distribuição de recursos por linguagem no Proac Editais.

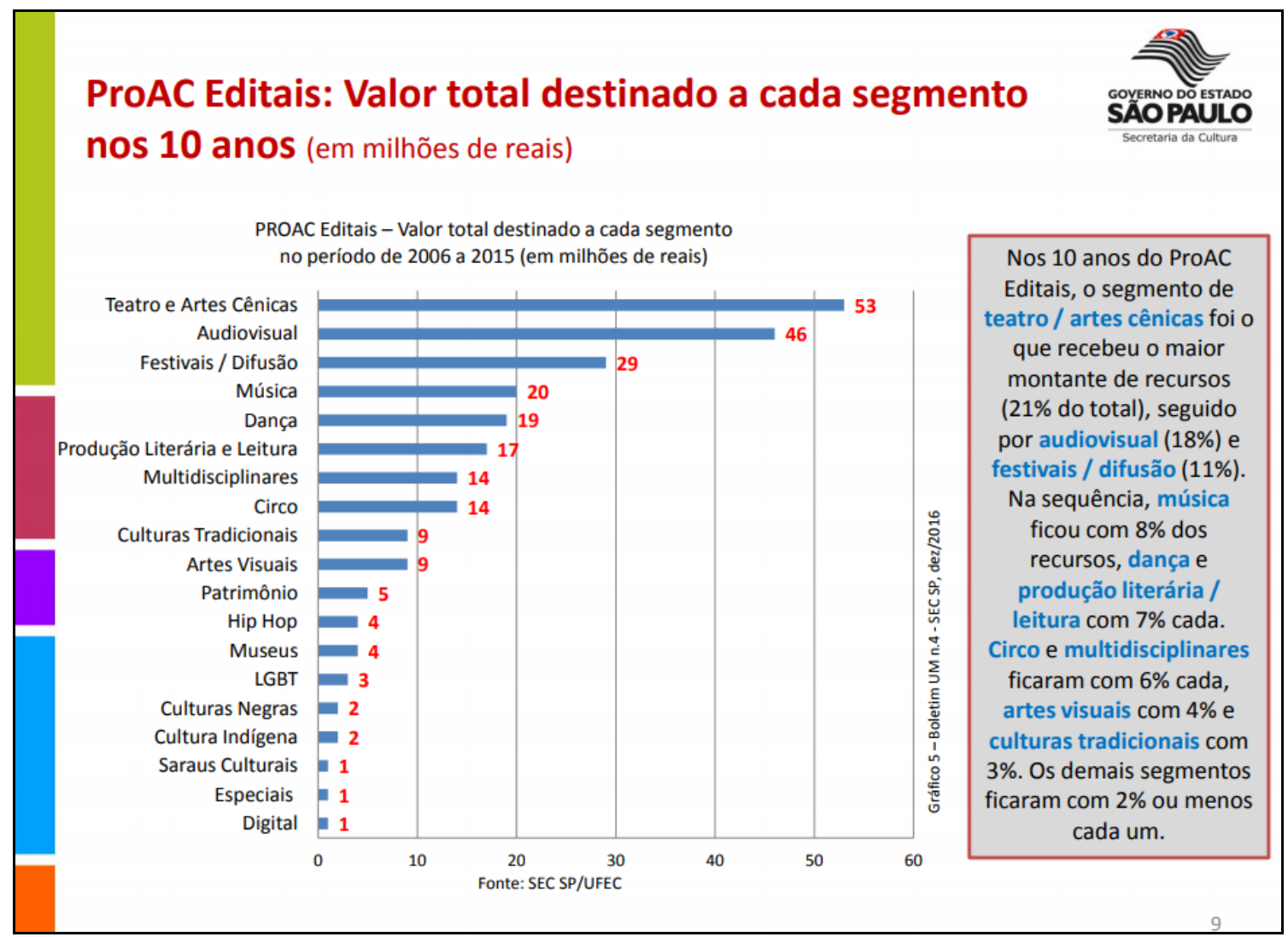

Fonte: Site SEC Transparência Cultura ${ }^{194}$.

193 No estado de São Paulo, as comunidades quilombolas estão principalmente no Vale do Ribeira. Já foram oficialmente reconhecidos 35 quilombos, mas a quantidade efetiva deve ser muito maior, dada a natureza da origem das comunidades. A população indígena está em todo o estado, com concentrações regionais de etnias e costumes. Hoje há no estado 30 territórios indígenas, sendo 14 destes já reconhecidos pela FUNAI e uma população de mais de 7 mil pessoas.

${ }^{194}$ Disponível em: http://www.transparenciacultura.sp.gov.br/secretaria-da-cultura-dados-e-numeros/ acesso 13 junho 2018. 
Através do quadro acima, percebemos que a destinação de recursos para estes grupos minoritários sempre esteve num patamar muito reduzido quando comparado às linguagens artísticas e ao audiovisual. O quadro demonstra que as políticas culturais até então desenvolvidas no estado não priorizavam estes grupos minoritários, e ao contrário disso, apontavam fortemente para as artes e o audiovisual, confirmando a tendência a reforçar os investimentos nas culturas hegemônicas.

No entanto, a destinação de recursos do Proac, mesmo para as linguagens artísticas sempre se mostrou muito aquém do que a demanda do grande estado de São Paulo com seus 645 municípios representa, já que nunca conseguiu atingir um patamar maior do que a pequena porcentagem de $0,5 \%$ do orçamento total.

- Economia criativa e financiamento da cultura: objetivos $3.1 ; 6.1 ; 13.1 ; 13.2 ; 13.3$; $16.1 ; 16.2 ; 17.1 ; 18.1 ; 18.2 ; 18.3 ; 18.4$ (12 itens)

3.1 Possibilitar acesso pleno às informações e dados gerenciais e de execução orçamentária dos órgãos públicos estaduais e municipais de cultura. (...) 6.1 Fortalecer a regulação social sobre os modelos de gestão das políticas culturais. (...) 13.1 Diversificar as modalidades de financiamento à cultura, visando atender de modo adequado e satisfatório as singularidades e complexidade do campo cultural. (...) 13.2 Ampliar o percentual da participação do orçamento da Secretaria de Estado da Cultura no orçamento global do Estado. (...) 13.3 Garantir a descentralização e distribuição dos recursos financeiros no Estado de São Paulo. (Não tem ações e nem metas) (...) 16.1 Incentivar formas de desenvolvimento sustentável e solidário que reduzam a desigualdade regional e respeitem a diversidade cultural. (Não tem ações e nem metas) (...) 16.2 Estabelecer a cultura como protagonista nas ações de desenvolvimento sustentável nas suas dimensões econômica, cidadã e simbólica. (Não tem ações e nem metas) (...) 17.1 Propiciar condições favoráveis ao surgimento de iniciativas e empreendimentos culturais sustentáveis. (Não tem metas) (...) 18.1 Consolidar o Fundo Estadual de Cultura como principal mecanismo de fomento.(Não tem metas) (...) 18.2 Garantir recursos para o financiamento adequado e satisfatório das singularidades e complexidades do campo cultural. (Não tem ações e nem metas) (...) 18.3 Garantir a descentralização e a distribuição dos investimentos. (Não tem ações e nem metas) (...) 18.4 Adequar os mecanismos de incentivo fiscal. (Não tem ações e nem metas)

Ao determinar que $30 \%$ dos objetivos do Plano Estadual de Cultura de São Paulo focassem na temática do financiamento da cultura, os autores do enunciado mostraram a preocupação com as verbas e os modelos de financiamento disponíveis para o setor. Nos objetivos, a temática está explicita em seu título e não depende da análise de suas ações e metas. Ao contrário do PNC, nos objetivos, ações e metas do PEC em nenhum momento mencionam o signo "economia criativa" no texto e como modelo de financiamento. Em 
apenas um ponto do documento, no objetivo 11.2, tratam da "economia sustentável e solidária ${ }^{195}$ " uma ideia muito diferente em termos teóricos e econômicos do que se propõe a economia criativa. O objetivo 11.2, no entanto, não foi elencado como na temática de economia, pois a maior parte do teor de suas ações e metas tratam da diversidade cultural.

Ao optarem pelo modelo de economia solidária ao invés do modelo de economia criativa proposto pelo MinC, os agentes culturais de São Paulo demonstram valores axiológicos diferentes e uma avaliação social que permeia a ideia de produção autossustentável não pautada pela tecnologia de ordem liberal que se preocupa principalmente com o produto final e com o lucro, mas sim com a um modelo de produção criado por estes grupos, que visa a subsistência dos mesmos mantendo suas tradições, costumes e formas de fazer.

No objetivo 18.1, tratam da consolidação do Fundo Estadual de Cultura (FEC) e com a garantia de recursos para o setor. A preocupação com o FEC demonstra que os discursos presentes no enunciado buscam fortalecer a importância do orçamento e dos incentivos diretos vindos do Estado. Essa visão de modelo de financiamento está no conceito central do SNC e reflete o projeto de dizer e proposta axiológica ética do Estado como fomentador de políticas públicas. O fortalecimento dos fundos de cultura é essencial para que o sistema possa funcionar conforme pautado por seus planos de cultura, fornecendo recursos necessários para o desenvolvimento das ações e metas, e para a descentralização de recursos para o setor.

O foco prioritário no financiamento reflete a preocupação com os dados do escasso orçamento do estado de São Paulo nos últimos anos que nunca ultrapassou o patamar de $0,5 \%$ e desde 2014 vem decaindo progressivamente. Ao tratar do financiamento como pauta prioritária, juntamente com a grande quantidade de objetivos sobre a diversidade cultura, os autores do plano estabelecem uma avaliação social em relação à falta de financiamento público e principalmente à participação, à democratização e à descentralização dos recursos por todo o estado. Isso está evidenciado nas passagens do enunciado em que o discurso pauta a necessidade de uma melhor distribuição regional dos recursos e a garantia destes compatíveis com a demanda estadual. É importante lembrar que, dos participantes da

\footnotetext{
195 O modelo de economia solidária foi proposto na metade dos anos 1990 pelo economista e professor da USP Paul Singer, quando era Secretario de Planejamento na prefeitura de São Paulo na Gestão de Luiza Erundina. Foi inspirado em ações já existentes nas comunidades tradicionais e também nas ações do MST e foi integrada às ideias iniciais da construção do partido dos trabalhadores. Atualmente o modelo é utilizado também em outros países do mundo. Este modelo inspirou principalmente o modelo de produção da agricultura familiar.
} 
comissão do Plano Estadual de Cultura de São Paulo, 36 deles eram representantes de outras cidades do estado além da capital. Isso reflete que, ao contrário do que se vê na cidade de São Paulo, em outras regiões do estado, a distribuição de recursos é escassa ou praticamente inexistente, pois depende dos modelos atuais de financiamento no estado de São Paulo, o Proac e as Organizações Sociais de Cultura (OS).

Achamos importante frisar que boa parte dos objetivos relativos ao financiamento trata de temáticas semelhantes e poderiam ter sido reunidos num só objetivo. Mais curioso ainda é o fato de que metade dos objetivos sobre financiamento não apresentaram desenvolvimento de conteúdos temáticos nem de metas e nem de ações ao longo do enunciado, e outros dois objetivos não trazem metas, o que pode denotar diversos fatores como: falta de tempo para desenvolver propostas mais complexas e concretas, a falta de conhecimento técnico acerca do assunto pelos agentes culturais participantes, falta de modelos de financiamento e economia da cultura para inspirar novas propostas.

As demais temáticas e objetivos elencados ao longo do Plano aparecem em quantidades muito menores, demonstrando pouca relevância efetiva nas prioridades. A maior parte destes objetivos não apresentou nem ações e nem metas desenvolvidas o que dificulta nossa análise sobre o conteúdo temático das mesmas.

- Implantação do sistema: objetivos $2.1 ; 7.1 ; 7.2 ; 7.3 ;$ (4 itens)

2.1 Implantar o Sistema Estadual de Informações e Indicadores Culturais como instrumento de acompanhamento, avaliação e aprimoramento da gestão e das políticas públicas de cultura. (...) 7.1 Consolidar as conferências, fóruns, conselhos, colegiados e sistemas setoriais e seminários que envolvam a formulação e o debate sobre as políticas culturais. (...) 7.2 Garantir instâncias de governança participativa nos processos decisórios da gestão cultural. (Não tem ações e nem metas) (...) 7.3 Promover e apoiar a instituição dos Sistemas Municipais de Cultura. (não tem ações)

- Formação e educação: objetivos $5.1 ; 5.3 ; 5.4$; (3 itens)

5.1 Promover por meio de políticas de formação continuada, pesquisa e difusão, estímulo à produção e circulação. (...) 5.3 Fortalecer e preservar a autonomia do campo de reflexão sobre a cultura. (...) 5.4 Formar gestores em políticas públicas culturais na sua dimensão econômica e financeira.

- Participação social: objetivos $12.2 ; 12.3 ;$ ( 2 itens)

12.2 Democratizar a gestão das políticas públicas de cultura. (Não tem ações e nem metas) (...) 12.3 Ampliar os mecanismos de participação e protagonismo social no processo de elaboração, implementação, monitoramento e avaliação das políticas públicas de cultura. (Não tem ações e nem metas)

- Equipamentos públicos: objetivos 15.1; 15.2; (2 itens)

15.1 Desenvolver e ampliar os espaços culturais existentes no Estado de São 
Paulo, inclusive os da Secretaria de Estado da Cultura, garantindo a ocupação cultural continuada e o contato das pessoas às culturas. (...) 15.2 Estabelecer redes de equipamentos culturais.

- Patrimônio, memória e acervos: objetivos 12.1; (1 item)

12.1 Fortalecer a articulação das esferas dos poderes públicos (Ação 1 Convergir as restrições e diretrizes para intervenções no patrimônio cultural tombado por diferentes esferas de governo, resguardadas as singularidades e competências de cada Órgão licenciador)

- Acessibilidade e acesso: objetivo 15.3 (1 item)

15.3 Promover a apropriação social das tecnologias da informação e da comunicação para ampliar o acesso à cultura e suas possibilidades de produção, difusão e fruição.

- Emprego e renda: objetivo 19.1 (1 item)

19.1 Ampliar as atividades culturais, por meio da expansão, diversificação e qualificação de sua capacidade produtiva e ampla ocupação, estimulando a geração de trabalho, emprego, renda, promovendo a profissionalização do setor e o fortalecimento da economia. (Não tem metas)

- Difusão e formação de público: objetivo 19.2 (1 item)

19.2 Promover a difusão, fruição e comercialização dos produtos e serviços culturais, respeitando o meio ambiente e garantindo a acessibilidade, a inclusão e a sustentabilidade etnobiológica. (Não tem metas) ${ }^{196}$

Nos objetivos elencados acima, e que não tratam de financiamento e diversidade, encontramos alguns de extrema importância para o SNC: implantação do Sistema, acessibilidade e acesso, difusão e formação, patrimônio, equipamentos, participação social etc. Todavia, podemos ressaltar que estas temáticas também foram abordadas nos objetivos elencados na diversidade e voltados prioritariamente para esses grupos. Deste modo, é possível aferir que o Plano Estadual de Cultura de São Paulo, trouxe a diversidade e o financiamento quase que como temas transversais e deste modo se conectam com os centros da arquitetônica do sistema.

O PEC SP, ao contrário do enunciado nacional, teve a preocupação em fortalecer e incentivar os grupos até então excluídos dessas políticas, consolidando, assim, a diversidade como conteúdo temático principal e consequentemente o acesso. A citação reiterada em diversas passagens do enunciado, ao contrário do que ocorreu no enunciado federal, fortalecem estes grupos enquanto signos ideológicos representativos do enunciado e do projeto de dizer de seus autores. Isto nos relembra a justificativa presente na primeira versão da lei do PNC em que a intenção principal dessa política era possibilitar a inclusão dos então

\footnotetext{
${ }^{196}$ Disponível em: < http://www.planoestadualdecultura.sp.gov.br/ > acesso em 10 de julho do 2018.
} 
excluídos na distribuição dos programas e recursos. Ao utilizarem a diversidade e o financiamento como temas transversais (pois estão em pelo menos $60 \%$ dos objetivos), os autores do PEC estabelecem seu projeto de discurso em torno de outros centros da arquitetônica do sistema (acesso, democratização e descentralização). O PEC demonstra que só com a efetiva preocupação pelo financiamento da diversidade cultural na aplicação dessas políticas públicas de cultura será possível desenvolver estes outros centros da arquitetônica efetivamente e vice-versa. Num primeiro momento, o financiamento da diversidade poderá gerar um relativo equilíbrio do acesso e a descentralização almejados pela proposta política do SNC.

\subsection{4 - O conteúdo temático do Plano Municipal de Cultura de São Paulo}

O Plano Municipal de Cultura da cidade de São Paulo, ao contrário do estadual, apresentou em suas duas versões (consulta pública e final) diferentes eixos para orientar a leitura do enunciado. Analisaremos a divisão proposta na versão final, aprovada por meio de um decreto junto ao Sistema Municipal de Cultura em dezembro de 2016.

Esta última (e definitiva) versão traz uma proposta distinta daquela da consulta pública e mostrou-se ao longo da análise com conteúdos temáticos mais próximos dos presentes no Plano Nacional de Cultura, mas também podem ser relacionadas com o histórico das políticas culturais desenvolvidas anteriormente na cidade.

Na publicação do PMC encontramos a tabela com a estrutura do plano (ver página 274) onde chama atenção o item "tema", que se mostra como uma subdivisão temática das metas. A organização se preocupou em dividir as metas e temas de maneira equilibrada. $\mathrm{O}$ PMC tem 5 eixos, quatro metas por eixo, quatro temas por meta e três a sete ações por tema, totalizando 96 ações ao todo.

Nos eixos, é possível observar a escolha de temas prioritários do plano que demonstram as escolhas axiológicas dos assuntos que devem ser incentivados ao longo dos dez anos de desenvolvimento do mesmo. É relevante relembrar que, durante o período de consulta pública do PMC, foram recebidas mais de mil sugestões de inclusão de temas, metas e ações. A versão inicial do plano, que foi apresentada na consulta pública, sugeria 55 metas. $\mathrm{Na}$ versão final, boa parte delas foram transformadas e outras foram inseridas, totalizando 96 ações. Isso nos leva a crer que pelo menos 41 novas ações foram incluídas na versão final. Entretanto, algumas das ações elencadas na versão final fizeram a junção de sugestões e de 
metas inicialmente pensadas ${ }^{197}$.

Em alguns pontos do PMC são sugeridos temas que podem ser relacionados ao tipo de ente federado, no caso uma cidade, isto é, a ponta do sistema, como por exemplo: "Do espaço urbano" (Eixo I), "Rede municipal de equipamentos culturais" (Meta 6) ou mesmo "Programação cultural” (Meta 16).

O acúmulo histórico das políticas culturais da cidade também pode ser observado nos conteúdos ao longo das metas:

- Meta 7 - Gestão colaborativa de espaços independentes - se relaciona às Casas de Cultura e às ocupações culturais que há décadas se desenvolvem na cidade.

- Meta 8 - Iniciação artística e cultural - relacionada aos programas de formação artística, principalmente a EMIA (Escola Municipal de Iniciação Artística que existe desde 1980) e o Programa PIÁ (que realiza a formação artística em vários equipamentos públicos da cidade desde 2008 para menores de até 13 anos de idade).

- Meta 17 - Cidadania cultural - Relembra a vocação dos programas de cultura implantados na cidade desde a gestão da secretaria Marilena Chauí e que foram sendo desenvolvidos e ganharam força principalmente a partir do programa VAI.

- Meta 18 - Fomento às linguagens artísticas - Desde 2002, a cidade é beneficiada pelos programas de Fomento. Atualmente conta com leis e editais de diversas linguagens: Teatro, dança, circo, música, reggae e cultura da periferia.

Ao contrário do plano estadual, a presença desta relação com as políticas culturais já existentes nos temas do Plano Municipal de Cultura de São Paulo demonstra a responsabilidade dos autores finais do enunciado em organizar e buscar desenvolver e avançar os acúmulos já existentes na cidade. A presença dessas políticas no plano também reflete o fato destas terem sido criadas em conjunto com os agentes culturais em momento passados e com forte participação popular em todos eles.

As metas destacadas estão relacionadas com leis há muito existentes como, por exemplo, Fomento ao Teatro (desde 2002) ou mesmo a programas que nasceram dentro de atividades plenamente populares, como o programa Vocacional, originado do projeto cultural Teatro Vocacional. O mesmo aconteceu com a Lei de Fomento à Cultura das Periferias que surgiu da demanda popular de agentes das periferias da cidade. Este projeto de lei foi de

\footnotetext{
197 Informações sobre como foi desenvolvida a versão final do PMC coletadas com participantes do grupo técnico responsável pelo enunciado.
} 
iniciativa popular e não proposto por um vereador da cidade. Deste modo é possível dizer que o PMC SP reflete e refrata diversos processos de criação de políticas culturais criadas de baixo para cima, com ampla participação popular e assim traz vozes e discursos de atos, agentes e enunciados anteriores. Assim, o PMC se origina não só por seu processo de criação, mas principalmente de acúmulos de processos históricos de conscientização pela necessidade social da busca por mais leis que apoiem a cultura e principalmente pela luta na ampliação do orçamento para o setor. A presença de determinadas temáticas demonstra o projeto de dizer dos envolvidos que também trouxe os discursos e as vozes dos agentes culturais participantes dos atos anteriores. Isso se confirma ao pensarmos que na comparação dos enunciados "consulta pública" e "versão final" muitas metas e temáticas novas foram inseridas, dentre elas algumas com signos ideológicos com fortes indícios do "popular" como, por exemplo, a "gestão compartilhada de equipamentos".

O elo com as políticas culturais criadas anteriormente fortalece os processos de interação e participação social, e principalmente de democracia cultural. Estes refletem a avaliação social dos grupos envolvidos na construção dos enunciados, a importância dada aos processos históricos ocorridos no passado na esfera político-cultural na cidade e o horizonte valorativo dos agentes da esfera.

A consideração da avaliação social é necessária justamente para compreender a formação histórica do tema e das significações que o realizam. A formação do sentido na língua está sempre relacionada com a formação do horizonte valorativo do grupo social, e, por sua vez, essa formação, compreendida como um conjunto de tudo que possui significado ou importância para o grupo, é determinada inteiramente pela ampliação da base econômica. Em decorrência da ampliação da base, amplia-se significativamente o horizonte da existência acessível, compreensível e essencial para o homem. (VOLÓCHINOV, 2017, pp. 237-238)

Ao apresentarem propostas relacionadas com programas e leis de origem popular, o Plano Municipal de Cultura reforça o caráter social do enunciado e fortalece o vínculo com os destinatários dessas políticas, dando mais força à proposta e a legitimando na sociedade. Como Volóchinov menciona no trecho acima, ao apresentarem as escolhas dos elementos presentes no enunciado do PMC, os autores demonstram a formação do horizonte avaliativo do(s) grupo(s) permeado pelo elo com a leis de fomento e consequentemente na ideia da ampliação da participação nos recursos, isto é, na base econômica. Apenas com essa ampliação, representada também pelos conceitos de descentralização, democratização, acesso e diversidade, é possível ampliar o horizonte de existência dos grupos envolvidos. 
Em todas as metas do PMC são apresentados os enunciados anteriores que deram origem à cada uma das ações previstas. Na imagem abaixo, do descritivo presente na meta 6 , observamos as leis de referência, as metas do PNC e as propostas da $3^{\mathrm{a}} \mathrm{CMC}$.

Figura 38: Enunciados de referência na Meta 6 PMC SP

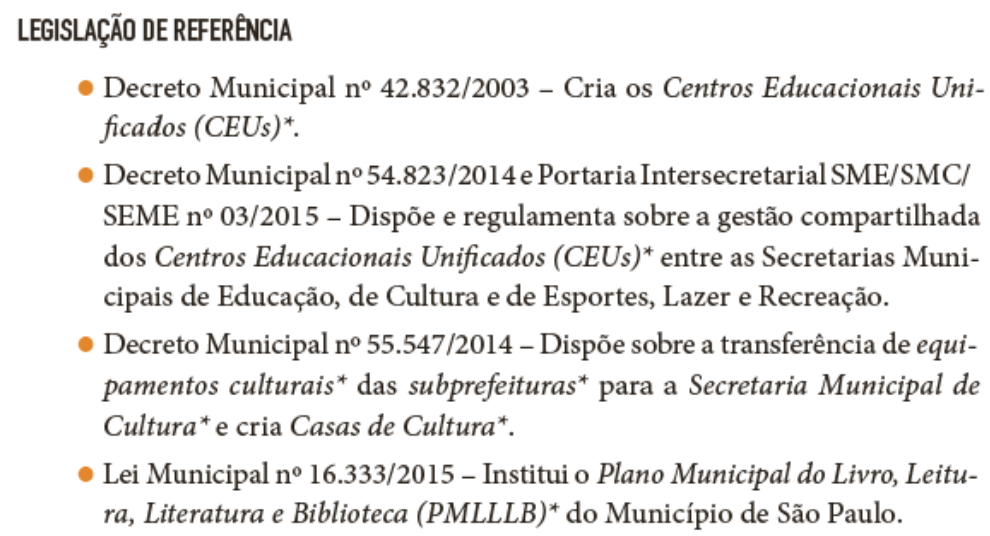

- Decreto Municipal no 42.832/2003 - Cria os Centros Educacionais Unificados $(C E U s)^{*}$.

- Decreto Municipal n 54.823/2014 e Portaria Intersecretarial SME/SMC/ SEME $n^{\circ} 03 / 2015$ - Dispõe e regulamenta sobre a gestão compartilhada dos Centros Educacionais Unificados (CEUs)* entre as Secretarias Municipais de Educação, de Cultura e de Esportes, Lazer e Recreação.

- Decreto Municipal no 55.547/2014 - Dispõe sobre a transferência de equipamentos culturais ${ }^{*}$ das subprefeituras ${ }^{*}$ para a Secretaria Municipal de Cultura* e cria Casas de Cultura*.

- Lei Municipal n 16.333/2015 - Institui o Plano Municipal do Livro, Leitura, Literatura e Biblioteca (PMLLLB)* do Município de São Paulo.

\section{PLANO NACIONAL DE CULTURA}

META 31: Municípios brasileiros com algum tipo de instituição ou equipamento cultural $^{*}$, entre museu $^{*}$, teatro ou sala de espetáculo, arquivo público ou centro de documentação, cinema e centro cultural* .

META 32: $100 \%$ dos municípios brasileiros com ao menos uma biblioteca pública em funcionamento.

\section{CONFERENCIA MUNICIPAL DECULTURA}

PROPOSTA 5: Retomar as Casas de Cultura ${ }^{*}$ para a SMC*. Assim como transformar o decreto por subprefeitura* de regulamentação das mesmas em lei e com orçamento próprio, tendo como meta a destinação de uma Casa de Cultura* e uma biblioteca pública por distrito*.

PROPOSTA 11: Políticas Públicas voltadas para o hip hop com efetivação da Semana Municipal do Hip Hop, conforme determina a lei (referência legal) e com autonomia do Movimento Hip Hop na organização; reconhecimento do Fórum Municipal das Mulheres do Hip Hop

Fonte: PMC SP

Ao relacionar os conteúdos das metas com enunciados anteriores da esfera, o PMC confirma o que Bakhtin afirma no ensaio sobre os gêneros do discurso sobre "os elos na corrente de comunicação discursiva". Ou mesmo pode estar relacionado com a falta de acabamento de um enunciado não artístico como salienta Medviédev na obra sobre o Método Formal.

A descrição de leis já existentes, metas do PNC e propostas da $3^{\mathrm{a}} \mathrm{CMC}$ de SP permitem também fortalecer o discurso e os valores axiológicos no presente enunciado, já que, ao citar estes outros enunciados assume que está pleno de vozes e discursos originários de acontecimentos e enunciados passados que já foram legitimados socialmente em outros pontos de tempo-espaço. Deste modo, os elos de comunicação aparentes reforçam a construção da arquitetônica do sistema não apenas em termos gerais mas também como uma 
arquitetônica local.

A citação a estes documentos também permite uma observação da arquitetônica do sistema, que se compõe pela construção de sentidos do todo nas relações dialógicas de seus enunciados.

A presença de extensas ementas no início de cada uma das metas pode ser considerada como uma justificativa pois reforça a argumentação para o desenvolvimento de cada uma de suas ações. Essas ementas são recheadas de avaliações sociais e valores axiológicos acerca das temáticas tratadas. Atuam como uma introdução para a justificativa da presença de determinadas temáticas no plano da cidade de São Paulo e assim demonstram o projeto de dizer e a visão de cultura daqueles que formularam o enunciado.

Figura 39: Ementa da Meta 18 PMC SP

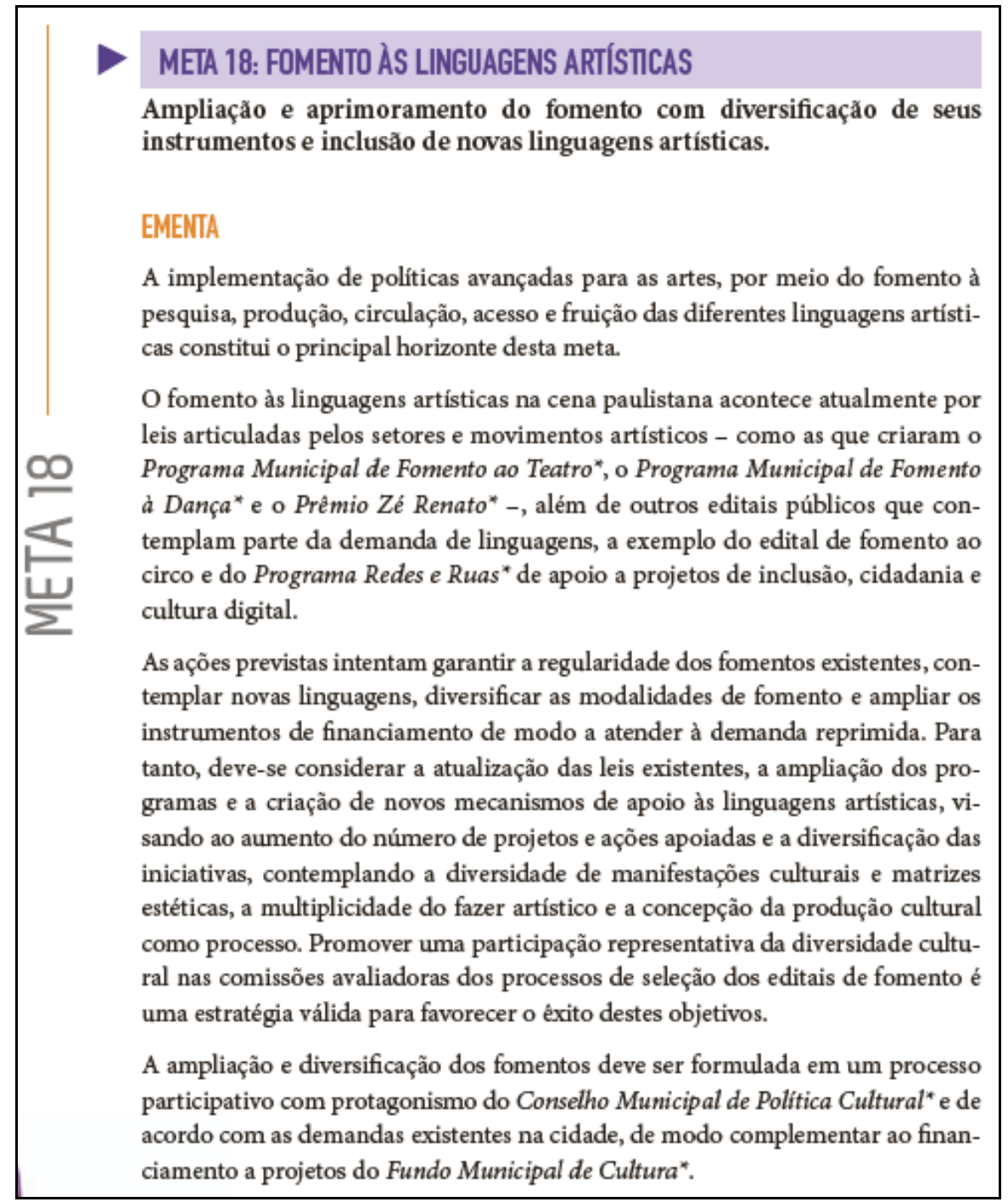

Fonte: PMC SP. ${ }^{198}$

198 SECRETARIA MUNICIPAL DE CULTURA DE SÃO PAULO, 2016, p. 168. 
O texto da ementa da meta 18, por exemplo, traz formulações que demonstram o projeto ideológico pretendido no enunciado como: "A ampliação e diversificação dos fomentos deve ser formulada em um processo participativo com protagonismo do Conselho Municipal de Política Cultural e de acordo com as demandas existentes na cidade”. Este tipo de processo de explanação sobre o tema da meta acontece em todas as ementas presentes no enunciado.

Aqui devemos considerar principalmente a ideia de "processo participativo com protagonismo" no caso do conselho (a representatividade dos agentes culturais) e as demandas da cidade. Essa formulação, com forte teor axiológico, destina a responsabilidade de criação dessas políticas à base da esfera e aos processos de construção de baixo para cima como já formulado nos preceitos iniciais do SNC. Nesta ementa relativa à meta 18, sobre o fomento às linguagens artísticas, é possível observar a menção às leis de fomento e programas culturais já realizados pela Secretaria Municipal de Cultura como os Fomentos ao Teatro e à Dança. A "ampliação e diversificação" destes decorrem da menção, por exemplo, à lei "SP Cidade da Música", citada na ação 18.2 e que no momento de construção do PMC estava em fase de aprovação do PL 376/2016 na Câmara Municipal da Cidade, e contou com um processo de ampla participação popular. Neste caso, o PMC responde a outro enunciado e a uma demanda que estava ocorrendo naquele mesmo momento na esfera: a necessidade de um fomento à música. A relação dialógica do PMC com outros enunciados da corrente de comunicação discursiva acontece também com documentos e atos posteriores a ele.

Dentro do previsto em cada uma das ações, o quadro acima sugere quais deverão ser desenvolvidas ao longo de cada plano plurianual, prevê as quantidades dos avanços por período temporal, descreve os indicadores que nortearam as informações descritivas da ação, propõe a quem esta ação está endereçada e também nomeia os órgãos responsáveis pelas ações.

Ao prever no descritivo da ação quem serão os responsáveis no futuro e quanto cada uma delas deverá avançar, o enunciado nomeia destinatários, pede o comprometimento de outros agentes responsáveis e especifica os resultados esperados de seus atos éticos. 
Figura 40: Ação 16.4 na Meta 16 PMC SP

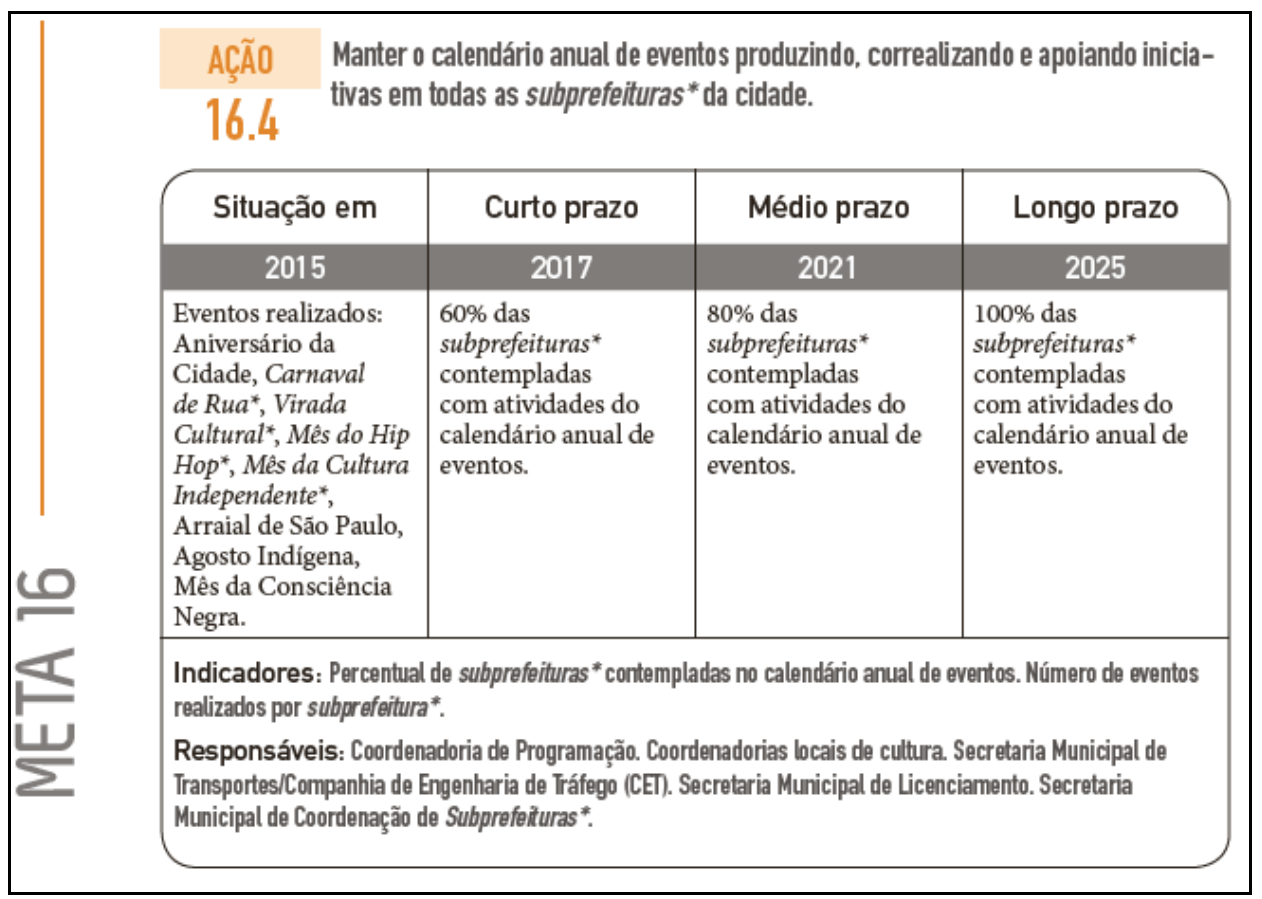

Fonte: PMC SP SECRETARIA MUNICIPAL DE CULTURA DE SÃO PAULO, 2016, p. 152

O diálogo com os destinatários acontece por meio dos conteúdos temáticos do enunciado. Ao nomear estes órgãos responsáveis no quadro, o PMC cria um elo de responsabilidade ética, pois designa um destinatário para realizar o que está ali proposto.

Assim como nas análises do PNC e do Plano Estadual de Cultura, apresentamos abaixo a quantidade de menções aos setoriais e grupos culturais. As citações serão quantificadas a partir dos resultados observados nos itens metas, ementas e ações.

- Biblioteca: 56 citações;

- Patrimônio (histórico e imaterial): 35 citações;

- Audiovisual: 27 citações;

- Música: 20 citações;

- Museu: 19 citações;

- Teatro: 19 citações (com referência a teatros como equipamentos públicos e a linguagem teatral);

- Linguagens artísticas: 19 citações;

- Dança: 14 citações;

- Indígenas: 14 citações;

- Hip Hop: 9 citações;

- Circo: 8 citações;

- Literatura: 8 citações;

- Artes visuais: 6 citações; 
- Sarau: 4 citações;

- Artes Cênicas: 2 citações;

- LGBTTQ: 1 citação;

- Afrobrasileira/o: 0 citações;

- Cigano / a: 0 citações;

- Quilombolas: 0 citações.

A predominância de citações para bibliotecas, patrimônio e audiovisual pode indicar a grande quantidade de equipamentos relativos a estes setoriais na cidade do país que mais conta com esses espaços. Ao mesmo tempo, pode ser relacionado com o resultado de tipos de citações do Plano Nacional, em que essa tendência nos sugere o histórico das políticas culturais que sempre priorizou estes setores, como por exemplo, o audiovisual que foi amplamente incentivado a partir do governo Vargas. Entretanto, a maior presença do setor audiovisual no enunciado pode ser justificada também pela motivação de dois fatores: a criação da agência SP Cine no início da gestão Haddad e o crescimento do setor em todo país nos últimos anos, principalmente em São Paulo. A maior presença de incidências das artes (teatro, música, dança, literatura, circo) pode refletir a forte atuação de trabalhadores dessas linguagens nos processos de construção do Plano (desde as conferências municipais) mas também a existência de leis e editais de fomento que pedem que essa participação se mantenha sempre atualizada.

As baixas (ou nenhuma) incidências de alguns grupos minoritários como os quilombolas e ciganos, por exemplo, podem demonstrar que esses grupos não encontram-se tão presentes no contexto urbano como nos territórios espalhados pelo estado de São Paulo. Todavia, a maior incidência de “indígenas" dentre as citações dos grupos de povos tradicionais deve-se aos seguintes fatores: a) São Paulo é uma cidade de origem indígena; b) Em seu espaço geográfico existem pelo menos 10 aldeias prioritariamente da etnia Guarani Mbya; c) Agentes dessas comunidades indígenas são muito ativos nos processos de construção de políticas cultura ${ }^{199}$.

Por outro lado, a inexistência dos termos quilombo ou quilombola, pode indicar a ausência de quilombos reconhecidos no perímetro da cidade ou a pequena participação destes grupos organizados nos processos de construção do Plano Municipal de SP.

De modo geral, há uma maior proximidade entre os dados de citações do Plano

\footnotetext{
${ }^{199}$ Isso está refletido inclusive na existência de um programa exclusivo para as políticas indígenas, o Aldeias, que foi transformado em projeto lei para as políticas indígenas no ano de 2017 (ainda em trâmite), por meio grande participação de agentes das aldeias da cidade e está relacionado a outras secretarias além da de cultura.
} 
nacional e municipal. Ambos priorizam as artes, bibliotecas e o audiovisual, ao contrário do plano estadual que apresentam números muito baixos ou inexistentes em relação a esses assuntos. Na comparação das citações aos grupos e setoriais em cada um dos planos analisados (federal, estadual e municipal) podemos ver a seguinte tabela:

Tabela 4: Incidência de citações a grupos setoriais nos planos

\begin{tabular}{|l|c|c|c|}
\hline Setores / grupos & PNC & PEC & PMC \\
\hline Afrobrasileira(o) & 0 & 7 & 0 \\
\hline Artes Cênicas & 0 & 0 & 2 \\
\hline Artes Visuais & 12 & 0 & 6 \\
\hline Audiovisual & 26 & 1 & 27 \\
\hline Biblioteca & 40 & 1 & 56 \\
\hline Cigano(a) (s) & 4 & 29 & 0 \\
\hline Circo & 12 & 6 & 8 \\
\hline Dança & 16 & 0 & 14 \\
\hline Hip Hop & 0 & 26 & 9 \\
\hline Indígenas & 9 & 54 & 14 \\
\hline LGBT(TQ) & 2 & 18 & 1 \\
\hline Linguagens artísticas & 16 & 6 & 19 \\
\hline Literatura & 4 & 0 & 8 \\
\hline Museu & 30 & 1 & 19 \\
\hline Música & 21 & 1 & 20 \\
\hline Patrimônio & 36 & 40 & 35 \\
\hline Quilombola & 3 & 26 & 0 \\
\hline Saraus & 1 & 0 & 4 \\
\hline Teatro & 22 & 2 & 19 \\
\hline
\end{tabular}

A grande incidência de citações para patrimônio nos três planos analisados pode demonstrar que trazemos ainda uma forte herança do passado e de suas políticas culturais que privilegiaram essa visão institucional durante muitas décadas no setor. Os valores axiológicos dos projetos de dizer ainda estão muito próximos da visão de cultura mais tradicional e hegemônica nos casos dos planos federal e municipal de São Paulo. Isso pode ser justificado por dois fatores de relevância na esfera: a) O primeiro órgão federal de cultura a ser criado ter sido do SPHAN, gerido por Mario de Andrade, o primeiro gestor de cultura do país e criador do primeiro Departamento de Cultura na cidade de São Paulo; b) O SPHAN mais tarde foi transformado no IPHAN e em boa parte das capitais do país é o único órgão que representa o MinC no estado.

A incidência do Hip Hop no Plano Municipal e sua inexistência no Nacional pode estar relacionado aos seguintes fatores: a) o Hip Hop ainda não havia sido reconhecido pelo MinC enquanto cultura no momento da escrita do PNC; b) a grande relevância da cena Hip Hop na cidade de São Paulo em comparação com a existência de grupos dessa linguagem por 
todo país; c) O Hip Hop é originalmente uma linguagem cultural urbana, ligada às cidades.

Como vimos anteriormente, o Plano Estadual de Cultura de SP teve maior preocupação em marcar a presença dos grupos culturais minoritários por conta da forte presença de representantes da cultura popular na comissão que escreveu o enunciado. $\mathrm{Na}$ comparação com os planos municipal e nacional, estas prioridades ficam ainda mais evidenciadas. Entretanto ficam também marcados os desequilíbrios pela ausência total de citações a importantes linguagens como audiovisual, dança, literatura e artes visuais. Deste modo cada um dos planos demonstrou o projeto de dizer recheado com os valores axiológicos de seus autores e comunidades semióticas participantes. Ainda que o Plano Nacional de Cultura trouxesse uma avaliação social e uma proposta de dizer fomentada nos preceitos dos centros de valor diversidade, acesso e descentralização, em nossa análise demonstrou que ainda carece do fortalecimento de signos ideológico propícios para isso e também de formulações políticas (e econômicas) para de fato refletir e refratar a proposta da arquitetônica projetada pelas diretrizes do SNC. Quem mais se aproximou destes valores axiológicos ligados à diversidade e acesso foi o PEC SP que priorizou o financiamento dos grupos minoritários como tônica do enunciado.

$$
* * *
$$

A partir dessa análise do conteúdo temático dos planos de cultura, identificamos três características comuns do gênero e suas relativas estabilidades:

a) Todos apresentaram a busca pelo planejamento das políticas culturais regionais: o PNC de todo o país, o PEC do Estado de São Paulo e o PMC da cidade. No caso do gênero Plano de Cultura, o que o torna único é o território (ou setorial) a que se destina, o ponto histórico (tempo-espaço) e o horizonte social em que foi construído (conjuntura) e os autores participantes de sua criação;

b) Outra característica do conteúdo temático do gênero é a presença dos centros da arquitetônica representados pelos conceitos de diversidade cultural, acesso e descentralização e que influenciaram na criação de metas, objetivos e ações. Em outros termos, os centros da arquitetônica do sistema influenciaram na forma arquitetônica dos planos. Nos três planos analisados, estes conceitos foram encontrados em seus descritivos, no desenvolvimento e na organização das metas e em maior ou menor grau exemplificados em seus conteúdos como na comparação entre os planos municipal e federal, que trataram menos dos grupos minoritários, em comparação com o estadual, que os trouxe como prioridade; 
c) A menção aos setoriais e grupos minoritários também foi depreendida como uma característica dos conteúdos temáticos no gênero. Nos planos analisados, encontramos essas citações em maior ou menor quantidade. Este ponto deve pensado principalmente pelo fato de que este tipo de enunciado é construído muitas mãos, e deste modo reflete e refrata os discursos, necessidades e demandas dos respectivos grupos participantes.

\section{4 - O estilo nos planos de cultura}

O conceito de estilo foi construído ao longo das obras do chamado Círculo de Bakhtin. Para nossa reflexão inicial sobre o estilo no gênero plano de cultura é necessário compreendermos que este opera de modo a construir / produzir sentidos no discurso por meio das escolhas na composição dos enunciados.

O estilo está na dimensão discursiva dos enunciados, sempre ancorado em um determinado tempo e espaço, historicamente situado. Para os pensadores do Círculo, sua construção nunca é apenas individual. Ao contrário disso, é sempre dialógica, direcionada ao outro ou a um grupo social.

No caso dos planos de cultura, a produção destes enunciados depende diretamente dos fatores: tempo, espaço, grupos sociais interessados e participantes dos processos. Ao escreverem e publicarem um plano de cultura, o delimitam temporal e espacialmente, com a menção à cidade, estado e seus anos de vigência, e, como vimos em capítulos anteriores, também com indícios espaço-temporais ao longo de todo o texto criando cronotopos.

O estilo está sempre impregnado de atitude avaliativa em seu conteúdo temático, o que nos leva ao tecido ideológico do enunciado que ganha nuances estilísticas discursivas, por meio da escolhas de palavras, expressões, construções sintáticas, modos de expressão, que atuam como base na estrutura argumentativa. Essas escolhas aparecem como signos ideológicos, e também nas construções sintáticas, semânticas e lexicais. Em cada um dos objetivos e metas dos planos de cultura, as avaliações sociais são desenhadas para argumentar demandas e ações.

Nestes últimos tópicos da tese relativos ao estilo do gênero, observamos de maneira ainda mais detalhada como estes pressupostos são construídos ao longo dos enunciados dos planos nacional, estadual e municipal de São Paulo. Para esta análise do estilo na materialidade linguística, buscaremos demonstrar suas principais características comparando trechos dos três enunciados. 
A situação de comunicação e seus participantes determinam a forma, conteúdo e o estilo de um enunciado, assim como a esfera auxilia na escolha do gênero discursivo empregado na situação de comunicação. É o estilo que evidencia a relação do locutor / autor com os destinatários / interlocutores do enunciado. O plano de cultura é um gênero discursivo novo, e ainda busca por uma relativa estabilidade, como vimos ao tratar da construção composicional e do conteúdo temático. No caso do estilo deste gênero, acreditamos que não seria diferente. Esta relativa estabilidade ainda está em construção.

Ao longo desta tese, foi possível perceber que, por conta da juventude deste gênero, ainda buscamos compreender quais métodos seriam mais eficazes para melhorar e facilitar a construção de sentidos nos enunciados por meio dos diálogos travados nos encontros de conselhos de cultura ou mesmo nas consultas públicas dos planos.

Nem todos os gêneros discursivos são propícios à influência de estilos de autores individuais e o gênero plano de cultura, ao se propor enquanto um gênero da esfera estatal, se configura enquanto um gênero que realça um forte estilo do gênero, de caráter normativo e impessoal como demanda a esfera estatal.

O estilo opera palavras da língua em relação aos componentes do mundo, seus valores e formas de viver. Deste modo, ao pensarmos o estilo na construção de um plano de cultura, é necessário perceber a relação de influência recíproca de esferas diferentes e discursos de comunidades semióticas diferentes. Ao mesmo tempo em que temos participantes oriundos do poder público representando a esfera estatal, com seus discursos regulados por regras normativas e leis, por outro temos diversos grupos culturais que vão desde o olhar mais popular e oral, até os mais eruditos, acadêmicos e hegemônicos, das belas artes. Estas diferentes visões de mundo, e consequentemente diferentes discursos, deverão estar presentes no enunciado de um plano de cultura que pretende de fato contemplar todo o universo que o criou.

A arquitetônica de um plano de cultura é construída por meio das tensões dialógicas entre as diferenças destes discursos e avaliações sociais. O estilo do gênero, ainda que normatizado e influenciado pelas esferas legislativa e estatal (responsável pela escrita final do texto que se tornará uma lei) deverá refletir e refratar as necessidades apontadas nos diálogos com a sociedade civil.

No tópico a seguir, traremos as reflexões dos pensadores do Círculo de Bakhtin sobre o conceito de estilo. Assim, poderemos compreender como o conceito poderá nos auxiliar na análise do estilo do gênero plano de cultura e como este se relaciona com a arquitetônica do 
Sistema Nacional de Cultura e da esfera político-cultural brasileira nos últimos anos.

\subsection{1 - O conceito de estilo no Círculo de Bakhtin}

Iniciamos esta reflexão a partir de um trecho encontrado no ensaio $O$ problema do conteúdo do material e da forma na criação literária [1923 / 1924], quando Bakhtin trata do material e de sua relação com a arquitetônica do enunciado.

O processo de realização do objeto estético, ou melhor, da tarefa artística na sua essência, é um processo de transformação sistemática de um conjunto verbal, compreendido linguística e composicionalmente, no todo arquitetônico de um evento esteticamente acabado; linguística e composicional transformam-se em relações arquitetônicas extraverbais. (BAKHTIN, 2010, p.51)

Ao tratar do material na criação de um objeto estético, Bakhtin compreende que há uma relação entre a composição deste material (linguístico), seu processo de criação e sua arquitetônica. O processo de criação é uma etapa essencial da produção de sentido que é gerada na transformação deste material em um todo arquitetônico. Ainda que Bakhtin esteja tratando mais especificamente neste texto da estética de obras literárias, para compreendermos o estilo e a produção de sentido de um enunciado por meio de seu material, não podemos esquecer o processo de criação / transformação e sua relação com a arquitetônica, pois este "conjunto verbal" deve ser compreendido "linguisticamente" no todo arquitetônico. Se pensarmos que o estilo está relacionado com a produção de sentidos na materialidade linguística de um enunciado, é assim um dos fatores essenciais em sua arquitetônica. Este processo é transformador na construção dos sentidos, pois ao compor um determinado material (linguístico) produz determinadas expressões que são refletidas na arquitetônica dos enunciados.

As primeiras citações do conceito de estilo aparecem no ensaio $O$ autor $e$ a personagem na atividade estética [1924 /1927]. No último tópico do último capítulo deste ensaio, Bakhtin inicia sua reflexão com o seguinte trecho:

Chamamos de estilo à unidade de procedimentos de enformação e acabamento da personagem e do seu mundo e dos procedimentos, por estes determinados, de elaboração e adaptação (superação imanente) do material. Em que relação se encontram o estilo e o autor enquanto individualidade? Como o estilo se relaciona com o conteúdo, isto é, com o mundo dos outros, suscetível de acabamento? Que importância tem a tradição no contexto axiológico do autor contemplador? A unidade segura do estilo (grande e vigoroso) só é possível onde existe unidade de tensão ético-cognitiva da vida, indiscutibilidade do antedado guiado por ela: esta é a primeira 
condição. A segunda são a indiscutibilidade e a convicção da posição de distância (em suma, como veremos a confiança religiosa no fato de que a vida não é solitária, é tensa e se move a partir de si mesmo não em um vazio axiológico), o lugar sólido e inquestionável da arte no conjunto da cultura. A posição casual da distância não pode ser segura em si mesma; o estilo não pode ser casual. Essas duas condições estão intimamente ligadas entre si e se intercondicionam. $\mathrm{O}$ grande estilo abarca todos os campos da arte ou não existe, pois ele é, acima de tudo, o estilo da própria visão de mundo e só depois é o estilo da elaboração do material. (BAKHTIN, 2010b, pp. 186187)

Aqui, Bakhtin propõe a continuação da reflexão com avanços teóricos sobre o conceito, principalmente em relação à esfera literária e ao objeto estético. O estilo corresponde a: processo, enformação, elaboração, procedimentos que estão recheados de tensão, visões de mundo do autor, relação com os interlocutores. O estilo não é apenas a elaboração do material, antes disso reflete a própria visão de mundo do seu autor por meio das escolhas e assim se relaciona com o conteúdo da obra e com sua arquitetônica. A visão de mundo é um componente do estilo, mas também do conteúdo temático de um enunciado.

Na obra Problemas da poética de Dostoiévski [1963], Bakhtin trata do estilo e da estilística em diversas passagens. Chama atenção o trecho sobre os tipos de discurso, das tarefas de estilística:

A estilística deve basear-se não apenas e nem tanto na linguística quanto na metalinguística, que estuda a palavra não no sistema da língua e nem num "texto" tirado da comunicação dialógica, mas precisamente no campo propriamente dito da comunicação dialógica, ou seja, no campo da vida autêntica da palavra. A palavra não é um objeto, mas um meio constantemente ativo, constantemente mutável de comunicação dialógica. Ela nunca basta a uma consciência, a uma voz. Sua vida está na passagem de boca em boca, de um contexto para outro, de um grupo social para outro, de uma geração para outra. Nesse processo ela não perde o seu caminho nem pode libertar-se até o fim do poder daqueles contextos concretos que integrou. (BAKHTIN, 2010c, pp. 231 - 232)

Neste trecho, Bakhtin evidencia que a estilística, ou o estudo do estilo, deve basear-se não apenas na linguística e na metalinguística, mas na vida, no processo dialógico de comunicação. O estilo de um enunciado aparece na vida de um enunciado, no diálogo, na relação entre os enunciados e entre grupos sociais. Está no linguístico mas também no extralingüístico, isto é, nos processos comunicativos e sociais do mundo da vida.

No fim dos anos 1920, Valentin Volóchinov trata do estilo na parte terceira da obra Marxismo e filosofia da linguagem [1929] quando aborda as formas do enunciado nas construções da língua e o discurso alheio sobre o estilo pictórico e estilo linear. De acordo com Brait (2010) ao longo desta terceira parte ele discorre: 
A partir de duas grandes categorias estilísticas para transmissão do discurso de outrem, estilo linear e estilo pictórico, o que se vê, em lugar de concepções genéricas, é um estudo minucioso sobre o discurso direto, o discurso indireto e suas variantes, propiciando uma visão enunciativa e discursiva das formas de citação, uma vez que a história destas formas é localizada no tempo e no espaço. (BRAIT, 2010, p. 83)

A definição dos conceitos de estilo linear e pictórico nos dá pistas sobre diferentes tipos de estilo encontrados por Volóchinov. Em resumo, o estilo linear que traz o discurso alheio como ele é, e o pictórico fere a integridade do discurso alheio.

Essa primeira orientação da dinâmica da orientação discursiva mútua entre o discurso autoral e o alheio poderia ser chamada, recorrendo ao termo de Wölfflin usado na crítica da arte, de estilo linear (der lineare Stil) de transmissão do discurso alheio. A sua tendência é a criação de contornos claros e exteriores do discurso alheio diante da fraqueza da sua individualização interior. À vista da homogeneidade total e estilística de todo o contexto (o autor e os seus protagonistas se expressam do mesmo), o discurso alheio alcança, do ponto de vista gramatical e composicional, um isolamento máximo e uma solidez escultural. Na segunda tendência da dinâmica da mútua orientação entre o discurso autoral e o alheio, percebemos processos de caráter diametralmente opostos. A língua elabora os meios de introdução mais sutil e flexível da resposta e do comentário autoral no discurso alheio. O contexto autoral tende a decompor a integridade e o fechamento do discurso alheio, à sua dissolução e ao apagamento das suas fronteiras. Podemos chamar esse estilo de transmissão do discurso alheio de pictórico. Ele tende a apagar os contornos nítidos e exteriores da palavra alheia. Nesse caso, o próprio discurso é muito mais individualizado e a percepção dos diferentes aspectos do enunciado alheio pode ser extremamente aguçada. Percebe-se não apenas o seu sentido objetual, a afirmação nele contida, mas também todas as particularidades linguísticas da sua encarnação verbal. (VOLÓCHINOV, 2017, pp. 257-258)

Já no ensaio Discurso na vida, discurso na arte (1992 [1926]), Volóchinov trata o estilo por seu viés dialógico e social e apresenta reflexões importantes. O ensaio, ao tratar das relações do autor, com o herói e o leitor, traz o estilo como uma espécie de "ponte" dialógica entre essas três extremidades do enunciado.

O autor, herói e ouvinte de que estamos falando todo esse tempo devem ser compreendidos não como entidades fora da própria percepção de uma obra artística, entidades que são fatores constitutivos essenciais da obra. Eles são a força viva que determina a forma e o estilo e são distintamente detectáveis por qualquer contemplador competente. (VOLÓCHINOV, 1992 [1926]), p.13)

"O estilo é o homem", dizem; mas poderíamos dizer: o estilo é pelo menos duas pessoas ou, mais precisamente, uma pessoa mais seu grupo social na forma do seu representante autorizado, o ouvinte - o participante constante na fala interior e exterior de uma pessoa. (idem, p.16) 
Nestes trechos, assim como ao longo de todo o texto, Volóchinov apresenta sua visão acerca do conceito. Para ele, o autor, o herói e o ouvinte são as forças vivas que determinam o estilo de um enunciado. Não há estilo sem a influência direta dos envolvidos na comunicação. Ao dizer que o "estilo é pelo menos duas pessoas" evidencia a teoria dialógica do discurso do Círculo e o caráter vivenciado e social do estilo.

Na obra Questões de estilísticas no ensino da língua, Bakhtin traz uma nova maneira de compreender a estilística, operando sua análise no ensino da língua russa em sala de aula e através principalmente dos estudos da sintaxe. O ensaio começa com a seguinte passagem:

As formas gramaticais não podem ser estudadas sem que se leve sempre em conta seu significado estilístico. Quando isolada dos aspectos semânticos e estilísticos da língua, a gramática inevitavelmente degenera em escolaticismo. (...) Toda forma gramatical é, ao mesmo tempo, um meio de representação. Por isso, todas essas formas podem e devem ser analisadas do ponto de vista das suas possibilidades de representação e de expressão, isto é, esclarecidas e avaliadas de uma perspectiva estilística. (BAKHTIN, 2013[1945], pp. 23-25)

O significado estilístico da materialidade linguística de um enunciado e seus aspectos semânticos, de produção de sentido, apresentam "possibilidades de representação e de expressão". As escolhas linguísticas e discursivas de um determinado autor (ou autores) num enunciado devem sempre ser pensadas por um projeto de dizer e para a construção de sentidos. $\mathrm{O}$ autor tem intenção discursiva e esta se expressa na materialidade lingüística.

No ensaio Os gêneros do discurso [1952 - 53], Bakhtin, já no início do texto, apresenta o que ele entende por estilo da linguagem quanto diz que: "Esses enunciados refletem as condições específicas e as finalidades de cada referido campo não só por seu conteúdo temático e pelo estilo da linguagem, ou seja, pela seleção dos recursos lexicais, fraseológicos e gramaticais da língua." (BAKHTIN, 2016 [1952-53], p.11-12) E continua a reflexão acerca de um novo modo de pensar a estilística:

Tratemos em primeiro lugar da estilística. Todo estilo está indissoluvelmente ligado ao enunciado e às formas típicas de enunciados, ou seja, aos gêneros do discurso. Todo enunciado - oral e escrito, primário e secundário e também qualquer campo da comunicação discursiva (rietchevóie obschênie) - é individual e por isso pode refletir a individualidade do falante (ou de quem escreve), isto é, pode ter estilo individual. Entretanto, nem todos os gêneros são igualmente propícios a tal reflexo da individualidade do falante na linguagem do enunciado, ou seja, ao estilo individual. Os mais favoráveis são os gêneros da literatura de ficção (...) As condições menos propícias para o reflexo da individualidade na linguagem estão presentes naqueles gêneros do discurso que requerem uma forma padronizada, por exemplo, em muitas 
modalidades de documentos oficiais, de ordens militares, nos sinais verbalizados da produção, etc. aqui só podem refletir-se os aspectos mais superficiais, quase biológicos da individualidade. (...) Na imensa maioria dos gêneros discursivos (exceto nos artísticos-literários), o estilo individual não faz parte do plano do enunciado, não serve como um objetivo seu, mas é, por assim dizer, um epifenômeno do enunciado, seu produto complementar. (...) A relação orgânica e indissolúvel do estilo com o gênero se revela nitidamente também na questão dos estilos de linguagem ou funcionais. No fundo, os estilos de linguagem ou funcionais não são outra coisa se não estilos de gênero de determinadas esferas da atividade humana e da comunicação. (...) O estilo é indissociável de determinadas unidades temáticas e - o que é de especial importância - de determinadas unidades composicionais: de determinados tipos de construção do conjunto, de tipos do seu acabamento, de tipos da relação do falante com outros participantes da comunicação discursiva - com os ouvintes, os leitores, os parceiros, o discurso do outro. (BAKHTIN, 2016, pp.17 - 18)

Ainda que alguns tipos de enunciados, como os literários, por exemplo, apresentem o estilo do autor / falante, outros, como é o caso do gênero plano de cultura, apresentam o estilo do gênero. Isto acontece por conta de seu caráter oficial/ estatal orientado por regras padronizadas de expressão. Bakhtin evidencia que o estilo é indissociável de outras características da constituição do gênero: "determinados tipos de construção do conjunto, de tipos do seu acabamento, de tipos da relação do falante com outros participantes da comunicação discursiva".

Pode-se dizer que a gramática e a estilística convergem e divergem em qualquer fenômeno concreto de linguagem: se examinamos apenas no sistema da língua estamos diante de um fenômeno gramatical, mas se os examinamos no conjunto de um enunciado individual ou do gênero discursivo já estamos diante de um fenômeno estilístico. Porque a própria escolha de uma determinada forma gramatical pelo falante é um ato estilístico. (BAKHTIN, 2016, p.22)

Essa relação do estilo com os participantes da comunicação comprova que o autor / falante, ao escolher determinadas formas gramaticais e compô-las num conjunto discursivo, cria não apenas um novo enunciado, mas se relacionam com o conteúdo temático e com a forma deste enunciado, isto é, com seu gênero.

Após observarmos as reflexões dos pensadores do Círculo sobre o conceito de estilo (e sobre a estilística), podemos afirmar que o estilo trata das escolhas lexicais, fraseológicas e gramaticais no âmbito de um determinado enunciado e seu gênero. Relaciona-se com o tempo e espaço do mesmo, ou seja, é historicamente situado. O estilo não é apenas individual, pois pressupõe ao menos duas pessoas em diálogo, ou se intercomunica com determinados grupos 
sociais. A situação de comunicação e os participantes determinam o gênero e o estilo do enunciado. A escolha das palavras também acontece em relação aos componentes do mundo, seus valores e à vida e seus processos interativos.

Muitos gêneros do discurso não são propícios à expressão da individualidade do autor / falante como, por exemplo, os gêneros burocráticos e oficiais. Já nos gêneros literários a individualidade e a subjetividade ganham mais força.

O estilo revela as ênfases valorativas, pois trata das escolhas linguísticas e estas têm intenção discursiva e são condicionadas ideologicamente. O estilo pode expor o viés ideológico da linguagem, seja de indivíduos, ou mesmos de grupos sociais, pois ao escolher determinados elementos linguísticos do enunciado, os autores revelam seus posicionamentos e assim se relacionam à arquitetônica do enunciado e do gênero.

\subsection{2 - A análise do estilo do gênero plano de cultura}

Para analisarmos o estilo de um plano de cultura, devemos observar inicialmente que este tipo de enunciado é quase sempre escrito por dezenas de mãos e consciências sociais diversas. O plano de cultura é um tipo de enunciado oficial estatal, em que, como evidenciou Bakhtin "As condições menos propícias para o reflexo da individualidade na linguagem estão presentes naqueles gêneros do discurso que requerem uma forma padronizada" (BAKHTIN, 2016, p.17)

As escolhas linguísticas dos planos de cultura podem ser descritas como da ordem do estilo do gênero e são realizadas a partir de posições ideológicas dos sujeitos-autores políticos e auxiliar na compreensão dos enunciados por seus dois tipos principais de interlocutores, no caso, o poder público e cidadãos interessados. Contudo, é preciso considerar que a escrita destes enunciados é feita por pessoas e estas podem influenciar nas escolhas linguísticas discursivas, no estilo do gênero.

Por mais normativo que um gênero possa se apresentar, sua estabilidade estilística é sempre relativa e acontece por diversos fatores. Um deles é a influência dos diferentes agentes presentes no processo de construção de determinado enunciado. Em um gênero da esfera estatal, as marcas subjetivas são quase imperceptíveis, pois é característico destes gêneros o destaque do estilo do gênero e as formas impessoais. Entretanto, tanto os indivíduos quanto os grupos sociais estarão lá e poderão influenciar nas escolhas linguístico-discursivas.

Os guias e manuais do MinC, como por exemplo a publicação Como fazer um plano de cultura?, pouco falam sobre detalhes linguístico-discursivos para escrever um plano de 
cultura. Entretanto, nos cursos ministrados pelas universidades via sistema moodle, oferecidos a gestores e conselheiros de cultura de cidades e estados, a metodologia de composição dos planos, balizou pontos relativos às estratégias discursivas para auxiliar na construção destes enunciados. Isto de certo modo pode ser tomado como um indício de padronização da escrita dos mesmos. De acordo com Costa (2017):

A metodologia definiu o papel das diretrizes como "Linhas de orientação que servem como elementos balizadores para o alcance dos objetivos, metas e execução de ações" e ofereceu cinco recomendações a serem cumpridas quando da sua formulação: a) deveriam ser voltadas para o futuro, norteando a formulação dos objetivos, assim como o caminho a percorrer para que fossem alcançados; b) balizariam decisões e comportamentos dos gestores e técnicos em relação ao PMC; c) não seriam hierarquizáveis, mas aplicadas para todo o Plano; d) deveriam ser poucas, mas claras e elementares; e, e) seria preciso estar atento para a sua elaboração, utilizando verbos que não denotassem execução, colocando sempre no infinitivo. (COSTA, 2017, p. 108)

Como vimos ao longo da tese, para Bakhtin, os autores-criadores de um enunciado têm projeto de dizer e intenção criativa de produção de determinados sentidos. Bakhtin trata das escolhas linguísticas dizendo que "a escolha dos recursos linguísticos e do gênero do discurso é determinada principalmente pelos problemas de execução que o sentido implica para o autor." (BAKHTIN, 2003, p. 308). Geraldo Tadeu de Souza, pesquisador brasileiro da obra de Bakhtin, aponta que:

Essa escolha dos recursos linguísticos e do gênero do discurso, aliada à necessidade de expressividade do autor ante o objeto de seu enunciado, compõe as particularidades que determinam o estilo e a composição do enunciado, ao mesmo tempo que explicita a relação do enunciado com seu autor. (SOUZA, 2002. p.96)

Nestes dois últimos tópicos finais de nossa tese, analisaremos em conjunto os enunciados: Plano Nacional de Cultura, Plano Estadual de Cultura e Plano Municipal de Cultura de São Paulo. Deste modo, poderemos comprovar a hipótese de que há um gênero plano de cultura e que este apresenta relativa estabilidade na especificidade do estilo.

Iniciamos esta análise do estilo do gênero plano de cultura tratando da questão verbal em suas aplicações morfológicas, semânticas, sintáticas e pragmáticas como um ponto relevante ao nosso estudo. Essas escolhas linguísticas e gramaticais são parte da construção do sentido do enunciado e nos auxiliarão na compreensão da arquitetônica do Sistema e também da esfera.

A primeira característica que chama atenção é que em diversas partes de cada um dos 
planos de cultura observamos diversos verbos no infinitivo. Essa característica também foi encontrada no estilo do gênero projeto cultural em Queiroz (2014). Assim como evidenciou Costa (2017) nos cursos ministrados sobre a construção dos planos, a principal orientação é que os verbos não denotassem execução e para isso seria necessária a utilização de verbos no infinitivo. A maioria dos verbos encontrados aparece no início de cada item dos objetivos, metas e ações e auxiliam na organização textual:

No PNC (grifos meus):

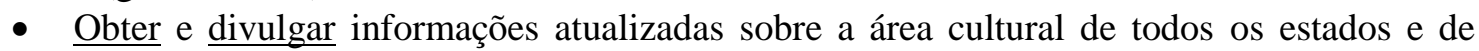
3.339 cidades do Brasil (60\%) (PNC, Objetivo, meta 2)

- Reunir e divulgar informações da área cultural serão objetivos do Sistema Nacional de Informações e Indicadores de Cultura (SNIIC). (PNC, Ação, meta 2)

- Produzir um mapa das expressões culturais e linguagens artísticas de todo o Brasil (PNC, Objetivo, meta 3)

- $\quad \underline{T e r}$ leis que valorizem e protejam as culturas populares e tradicionais (PNC, objetivo, meta 4)

- Proteger tanto os conhecimentos e as expressões culturais tradicionais como os direitos coletivos das populações autoras e detentoras desses conhecimentos (ação, meta 4)

No PEC - SP:

- Implantar o Sistema Estadual de Informações e Indicadores Culturais como instrumento de acompanhamento, avaliação e aprimoramento da gestão e das políticas públicas de cultura. (PEC, Objetivo, diretriz 2)

- $\quad$ Criar o Sistema Estadual de Informações e Indicadores Culturais. (PEC, ação, objetivo 2.1)

- Construir um teatro multiuso, com estrutura para atividades circenses, em cada cidade com mais de 50 mil habitantes. (PEC, meta 1, objetivo 15.1)

No PMC - SP:

- Promover a ocupação dos espaços públicos com atividades artísticas e culturais, assegurando o direito à cidade e a transformação da cultura urbana. (PMC, Diretriz 5)

- Regulamentar e implantar o Fundo Municipal de cultura destinado a apoiar financeiramente projetos culturais como instrumento complementar de financiamento articulado às políticas de fomento. (PMC, meta 1, ação 1.3)

- Vincular as supervisões de cultura à Secretaria Municipal de cultura e implantar coordenadorias locais de cultura em cada território correspondente às subprefeituras. (PMC, meta 2, ação 2.5)

O pesquisador brasileiro, Ataliba Castilho, na obra A pequena gramática do português brasileiro propõe que "O verbo se destaca dentre outras classes de palavras por ter a propriedade de organizar a sentença" (CASTILHO, 2012, p. 134). Os linguistas Rodolfo Ilari e Renato Basso afirmam que o verbo tem como função ser "molde ou matriz para a construção de sentenças" (ILARI; BASSO, 2008, p. 164) Como vimos, os verbos no infinitivo são utilizados principalmente no início de cada trecho dos planos e, com isso, organizam o enunciado. 
O uso dos verbos no infinitivo, sem flexão de tempo e pessoa, traz também ideias impessoalidade e da falta de projeção temporal. Entretanto, ao não apresentar um tempo verbal, pode se condicionar a um tempo vindouro do fazer. Temos assim uma proposição, um fazer proposto. Se ali está escrito um fazer, alguém deverá assumir a responsabilidade deste fazer.

$\mathrm{O}(\mathrm{s})$ outro(s) dessa relação / ato, isto é, seus destinatários diretos (e presumidos pois geralmente a maioria deles só serão conhecidos após a próxima eleição) deverão assumir (ou não) a responsabilidade ética destes fazeres elencados nos planos. Assumir a responsabilidade deste fazer é uma questão de escolha ética e incide diretamente na arquitetônica do projeto de poder (e fazer político) destes destinatários e seus resultados. O semanticista italiano Genaro Chierchia aborda as escolhas lexicais verbais e a relação com os princípios éticos da proposição no enunciado.

No fundo, quando avaliamos alguma coisa como possível ou necessário, é sempre em virtude de alguma coisa: possível/necessário devido ao nosso modo de ser, possível/necessário em razão do que sabemos, possível/necessário com base em nossos princípios éticos. (...) a necessidade de uma proposição é sua verdade em todas as circunstâncias relevantes. (CHIERCHIA, 2003, p.471)

A maior parte dos verbos no infinitivo encontrados no texto são verbos de ação, isto é, são verbos de fazer e demonstram uma projeção de ação positiva, uma proposição. Todos indicam o que é necessário fazer algo para atingir / cumprir demandas. Em termos sintáticos, os verbos no infinitivo seguidos de objetos (na maior parte dos casos objetos diretos) apresentam uma carga de significado positivo e assim planejam o futuro que será desenvolvido pelo poder público. A forma 'verbo no infinitivo (fazer)' + 'objeto (o que)' se torna uma proposição / proposta de fazer na esfera político-cultural.

Verbo de ação
no infinitivo

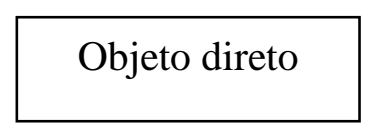

Em alguns casos são usados dois ou três verbos na sequência, com a conjução "e" relativos ao mesmo objeto.

No PNC:

- Ter sistemas de cultura em todos os estados (PNC, objetivo meta 1)

- Criar mais de 1,5 milhão de empregos formais no setor cultural (PNC, Objetivo, meta 11)

- Triplicar as vagas e as bolsas de estudos de graduação e pós-graduação nas áreas de arte e cultura (PNC, objetivo, meta 16) 
No PEC-SP:

- Recuperar os espaços culturais existentes que estejam degradados. (PEC, meta 3, objetivo 15.1)

- Propiciar condições favoráveis ao surgimento de iniciativas e empreendimentos culturais sustentáveis. (PEC, objetivo 17.1)

- Identificar e fortalecer os territórios e cadeias produtivas na área cultural. (PEC, ação 2, objetivo 17.1)

\section{No PMC-SP:}

- $\quad$ Promover, realizar e apoiar ações de formação para a sustentabilidade voltadas às cadeias produtivas e arranjos produtivos locais. (PMC, ação 19.1, meta 19)

- Investir na produção de projetos audiovisuais de curta duração com foco na inovação, experimentação e desenvolvimento de linguagem. PMC, ação 18.4, meta 18)

- Mapear, valorizar e fortalecer as culturas indígenas. (PMC, ação 17.5, meta 17)

Destacamos ainda a frequente repetição de alguns verbos, que foram encontrados também em outros planos observados ao longo da tese. Para isso, criamos uma tabela e quantificamos a presença destes nos três enunciados (nacional, estadual e municipal de São Paulo).

Tabela 5: Verbos nos planos de cultura

\begin{tabular}{|l|r|r|r|r|}
\hline VERBO & PNC & PEC & PMC & total \\
\hline Ampliar & 50 & 14 & 31 & 95 \\
\hline Apoiar & 16 & 3 & 8 & 27 \\
\hline Aprimorar & 12 & 0 & 3 & 15 \\
\hline Articular & 13 & 3 & 6 & 22 \\
\hline Assegurar & 4 & 3 & 3 & 10 \\
\hline Atender & 7 & 1 & 10 & 18 \\
\hline Aumentar & 52 & 0 & 1 & 53 \\
\hline Consolidar & 9 & 3 & 16 & 28 \\
\hline Construir & 8 & 9 & 3 & 20 \\
\hline Contemplar & 1 & 1 & 13 & 15 \\
\hline Contribuir & 19 & 0 & 0 & 19 \\
\hline Criar & 37 & 15 & 15 & 67 \\
\hline Desenvolver & 26 & 6 & 9 & 41 \\
\hline Difundir & 11 & 3 & 5 & 19 \\
\hline Disponibilizar & 4 & 1 & 5 & 10 \\
\hline Diversificar & 3 & 1 & 9 & 13 \\
\hline Divulgar & 10 & 1 & 0 & 11 \\
\hline Elaborar & 11 & 2 & 3 & 16 \\
\hline Estabelecer & 34 & 8 & 7 & 49 \\
\hline Estimular & 73 & 5 & 7 & 85 \\
\hline Fomentar & 45 & 15 & 7 & 67 \\
\hline Formar & 9 & 2 & 2 & 13 \\
\hline Fortalecer & 24 & 18 & 8 & 50 \\
\hline Garantir & 27 & 18 & 17 & 62 \\
\hline Identificar & 8 & 3 & 3 & 14 \\
\hline
\end{tabular}




\begin{tabular}{|l|r|r|r|r|} 
Implantar & 3 & 12 & 20 & 35 \\
\hline Implementar & 5 & 2 & 6 & 13 \\
\hline Incentivar & 26 & 6 & 1 & 33 \\
\hline Instituir & 13 & 9 & 8 & 30 \\
\hline Integrar & 9 & 0 & 5 & 14 \\
\hline Manter & 1 & 5 & 8 & 14 \\
\hline Mapear & 9 & 7 & 7 & 23 \\
\hline Oferecer & 15 & 0 & 1 & 16 \\
\hline Promover & 70 & 19 & 41 & 130 \\
\hline Qualificar & 10 & 2 & 5 & 17 \\
\hline Realizar & 23 & 4 & 16 & 43 \\
\hline Reconhecer & 12 & 2 & 8 & 22 \\
\hline regulamentar & 2 & 2 & 7 & 11 \\
\hline Valorizar & 11 & 5 & 5 & 21 \\
\hline
\end{tabular}

Os verbos encontrados com maior frequência demonstram afinidade também com os conteúdos temáticos dos planos, pois apresentam proposições de melhoria ou ampliação de uma situação no futuro. Na tabela priorizamos os verbos com maior incidência nos enunciados (acima de 10 incidências). Em nossa lista inicial foram encontrados 110 verbos diferentes no infinitivo posicionados no início de tópicos. Dentre os 41 verbos elencados na tabela acima, destacamos aqueles que apareceram com uma frequência acima de 50 incidências: ampliar, aumentar, criar, estimular, fomentar, fortalecer, garantir, promover. Muitos deles apresentam significados e semânticas similares e com proposição de melhoria ou ampliação de algo, no caso de seus objetos.

Dentre os verbos com maior incidência, percebemos que, além de semânticas positivas, há uma semelhança de serem verbos que indicam ação-processo e com sujeitos (indeterminados) causativos. E seus complementos também dialogam com os conteúdos dos enunciados. De acordo com o dicionário de verbos de Borba (1990), os verbos significam:

Ampliar - I. Indica ação-processo, com sujeito agente/ causativo. 1. Com complemento expresso por nome concreto não-animado significa tornar amplo ou maior, alargar, aumentar. (...) 2. Com complemento expresso por nome abstrato, significa estender, desenvolver, intensificar. (BORBA, 1990, p. 102)

Fomentar - I. Indica ação-processo com sujeito agente/causativo e com complemento expresso por nome abstrato. Significa estimular, promover. (idem, p. 770)

Promover - I. Indica ação-processo. (...) 2. Com sujeito causativo e com complemento expresso por nome abstrato significa causar, gerar, originar. (ibidem, p. 1061) 
A escolha de itens lexicais nos enunciados, possibilita percebermos o estilo. Neste caso, é possível depreender que uma das características desse tipo de enunciado é o uso de verbos no infinitivo, com valor positivo, mas verbos relacionados aos conteúdos temáticos dos enunciados e seus objetivos e não qualquer tipo de verbo.

Os verbos com maior incidência estão diretamente relacionados com a proposta central do Sistema Nacional de Cultura e com a projeção da arquitetônica da esfera políticocultural naquele momento, como por exemplo: Ampliar (o orçamento), aumentar (o acesso), criar (novos meios), estimular (a produção), fomentar (culturas), fortalecer (programas), garantir (direitos), promover (a descentralização). A construção de sentido por meio do uso exclusivo de verbos com carga positiva e a escolha de determinados verbos relacionados com os conteúdos temáticos dos enunciados, evidenciam a proposta de fazer do sistema como um todo. Se ao contrário disso, tivessem sido utilizados verbos com carga semântica negativa como, por exemplo: cortar, reduzir, destruir, suprimir etc., a proposta seria o oposto do que foi apresentada no Sistema e traria um projeto ideológico completamente diferente em termos políticos.

O uso dos verbos no infinitivo nos remete ao tipo de linguagem impessoal, sem a exposição de sujeitos e subjetividades nos enunciados e se relaciona ao "Princípio da Impessoalidade" comum no direito administrativo público que tem como premissa, defender os interesses coletivos. O "Princípio da Impessoalidade" está presente no caput do artigo $5^{\circ}$ da Constituição Cidadã de 1988, quando se refere que "todos são iguais perante as leis" e direciona ao princípio da igualdade, base ideológica defendida pela Constituição como um todo. O tom impessoal nos enunciados analisados nesta pesquisa confirma uma característica comum a todos os documentos da esfera estatal. Ainda que na esfera político-cultural, a variedade de gêneros possa apresentar alguma incidência de subjetividade, como no caso dos projetos culturais evidenciados em Queiroz (2014), os planos de cultura, se pensados como enunciados escritos por diversas mãos (inclusive da sociedade civil), mas diretamente relacionados a marcos legais, absorveram o estilo impessoal de gêneros da administração pública e da esfera jurídico-legislativa.

O verbo modal "dever" (modalidade deôntica) aparece principalmente nos trechos argumentativos dos Planos de Cultura. O modal "dever", ainda que flexionado em tempo e pessoa, influencia de forma flexível e modalizadora não só os objetivos a serem cumpridos, mas a possibilidade ou não da realização de uma determinada meta.

A forma "dever + verbo" foi encontrada nos enunciados e possibilitou a observação 
dessa alteração de sentido que remonta a uma flexibilidade circunstacial. Ao mesmo tempo, esta forma traz a carga semântica de uma obrigação do "dever fazer". O verbo auxiliar modal “dever", na situação de “deve acontecer X”, dá também a entender que existe a opção de não acontecer tal ação. Encontramos os seguintes exemplos:

No PNC:

- Aumentar para 4 a média de livros que os brasileiros lêem por ano, fora da escola, deve contribuir para ampliar a capacidade intelectual e de interação do indivíduo. Deve ajudá-lo a desenvolver habilidades e formar opiniões acerca de novos conceitos. (PNC, ementa Meta 20)

- Para ampliar o número de Pontos de Cultura, deve-se aumentar, também, a participação dos estados e das cidades em sua gestão e execução. (PNC, justificativa Meta 23)

- Para que a biblioteca possa realizar esse papel de principal centro de informações de uma cidade, seu acervo deve ser periodicamente renovado com publicações e obras de diversas linguagens artísticas e culturais (PNC, ementa meta 32)

- essa instituição deverá ser responsável pelo registro de obras intelectuais (musicais, literárias, visuais, entre outras) e pela promoção e supervisão da gestão coletiva de direitos. (PNC, ementa meta 38)

\section{No PEC-SP:}

- Instituir, até 2018, a carreira de "Especialista em Patrimônio Cultural", cujo provimento dos cargos deverá contemplar a multidisciplinaridade característica do campo patrimonial, incluindo áreas como arquitetura, história, geografia, antropologia, sociologia, biologia, engenharias, entre outras (PEC, meta 2, objetivo 5.3)

- O documento dizia que a Comissão deveria ser formada por 42 (quarenta e dois) membros titulares e seus respectivos suplentes de acordo com parâmetros abaixo (Introdução do Plano)

- as tentativas de identificação de tipologias das modalidades de políticas culturais devem levar em conta seu desenvolvimento histórico, os objetivos dessas políticas, os conceitos de cultura que lhes são subjacentes e seus instrumentos de intervenção (Introdução do plano)

\section{No PMC:}

- A ampliação da oferta de exposições deve vir acompanhada da ampliação de público nestes espaços, por meio da criação de estratégias quanto à realização de visitas monitoradas, palestras e oficinas. (PMC, ementa meta 11)

- Com relação aos acervos bibliográficos do Sistema Municipal de Bibliotecas, deve haver a renovação constante de títulos a partir de uma política de desenvolvimento de coleções, que leve em consideração a diversificação dos acervos (PMC, ementa meta 1)

- A oferta de atividades formativas deve ser interdisciplinar e descentralizada, respeitando o princípio da territorialização e contemplando a diversidade etária, de públicos e níveis de escolaridade. (PMC, ementa meta 14)

- A programação deve contemplar a diversidade de linguagens e expressões culturais (PMC, ementa meta 16)

De acordo com a semioticista brasileira Diana Barros, os verbos modais "modalizam ou modificam a relação do sujeito com os valores e os fazeres" (BARROS, 2005, p.21), isto é, flexibilizam o discurso alterando o sentido de forma sutil. Sua aplicação gera um efeito de sentido modalizador, pois modifica sutilmente a relação de certeza do enunciado com o fazer 
proposto. No caso dos planos de cultura, um gênero que planeja algo que deverá ser feito no tempo futuro, a modalização possibilita a escolha de um fazer (ou não) e pode ao mesmo tempo desobrigar certos fazeres.

O frequente uso de substantivos com os sufixos / morfemas [-ção] e [- mento] nos enunciados analisados também chama atenção em termos morfológicos e semânticos. Estes substantivos auxiliam na organização tópica do enunciado e evidenciam os referentes conforme pontuado por Neves (2009).

(...) No processo discursivo se criam os referentes, e que se essa organização referencial se mantém em ligação com a organização tópica, que dirige o fluxo de informação. Insisto em que há escolhas do falante que dirigem a criação e a identificação de referentes nos enunciados, escolhas que não são apenas das manifestações textuais, mas ainda da própria condição referencial - ou não - dos indivíduos que povoam o texto, as quais se operam a partir do que sugere o universo de discurso negociado na interação. Nessas escolhas, o que o falante busca é garantir os dados necessários à identificação dos objetos-de-discurso na textualização (...) Essa qualidade referencial nominal implica definitude a qual em certas condições, se resolve mais concretamente no contexto, e em outras condições, se resolve por via de avaliação congnitiva mais independente do contexto. (NEVES, 2009, p. 26)

No caso, a organização tópica deste tipo de enunciado acontece frequentemente com: uma com um verbo no infinitivo mais um referente ou com um substantivo nuclear ao predicado mais um referente no papel de objeto.

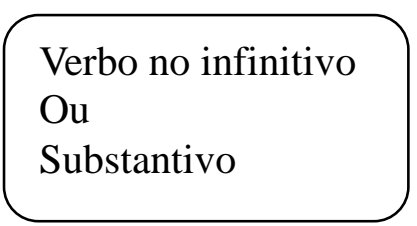

Vamos aos exemplos:

\section{Referente textual (Substantivo concreto ou abstrato)}

No PNC:

- Aumento em $200 \%$ de vagas de graduação e pós-graduação nas áreas do conhecimento relacionadas às linguagens artísticas, patrimônio cultural e demais áreas da cultura, com aumento proporcional do número de bolsas (PNC, meta 16)

- Política nacional de proteção e valorização dos conhecimentos e expressões das culturas populares e tradicionais implantada. (PNC, meta 4)

- Participação da produção audiovisual independente brasileira na programação dos canais de televisão (PNC, Meta 44)

\section{No PEC-SP:}

- Garantir a descentralização e a distribuição dos investimentos. (PEC, objetivo 18.3)

- Implantar o Sistema Estadual de Informações e Indicadores Culturais como instrumento de acompanhamento, avaliação e aprimoramento da gestão e das políticas públicas de cultura. (PEC, objetivo 2.1) 
- Constituir o Sistema Estadual de Informações e Indicadores Culturais como ferramenta pública de execução, acompanhamento e avaliação do Plano Estadual de Cultura. (PEC, ação 2, objetivo 2.1)

- Disseminar o conhecimento e ampliação da apropriação social do patrimônio cultural material e imaterial. (PEC, objetivo 5.2)

- Promover a comunicação, difusão e produção de valores culturais, por meio do rádio, tv, internet, revistas e jornais que circulem com valores que simbolizam a cultura regional de seu povo. (PEC, objetivo 8.1)

\section{No PMC-SP:}

- Fomento às linguagens artísticas: Ampliação e aprimoramento do fomento com diversificação de seus instrumentos e inclusão de novas linguagens artísticas. (PMC, Meta 18)

- Programação cultural: Consolidação do Circuito Municipal de Cultura* para oferta de programação cultural de maneira integrada e participativa. (PMC, Meta 16)

- Iniciação artística e cultural: Ampliação, aprimoramento e consolidação dos programas, oficinas e cursos de iniciação artística e cultural. (PMC, Meta 13)

Em boa parte dos casos, os substantivos encontrados apresentam os sufixos [-ção] e [mento] e estes encontram no todo do enunciado verbos no infinitivo com raiz idêntica. Contudo, em nenhum dos casos estão dispostos no mesmo período. Isso acontece de acordo com Bechara, pois o infinitivo atua como forma nominal do verbo "Assim se chamam o infinitivo, o particípio e o gerúndio, porque ao lado do seu valor verbal, podem desempenhar função de nomes. O infinitivo pode ter função de substantivo (Recordar é viver - recordação é vida)". (BECHARA, 2011, p. 224)

Estes substantivos são gerados na língua portuguesa por derivação que "Consiste na formação de novas palavras por meio de afixos adicionados à palavra-base". (LAROCA, 2003, p. 72) Isso evidencia que as escolhas lexicais da esfera levam ao uso de substantivos e verbos similares típicos da esfera para a realizar as ações necessárias contidas nas propostas. Já no âmbito da língua, por exemplo, uma oração como "Ampliar a ampliação" não será encontrada por gerar uma redundância e um estranhamento discursivo. Entretanto, é possível observar muitos casos como "Ampliar o fomento" e logo na meta seguinte "Fomentar a ampliação de (algo)", pois são lexemas comuns à esfera. Esse tipo de construção nos remete à derivação na morfologia. Sobre isso, Monteiro (2002) afirma que:

Na língua portuguesa existe um padrão lexical geral segundo o qual, para qualquer verbo, deverá existir uma contraparte nominal. Isto explica a ocorrência de uma proporção muito maior de nomes deverbais do que de nomes morfologicamente básicos associados a verbos. (MONTEIRO, 2002, p. 145)

A reflexão de Monteiro aponta que a alta incidência dos sufixos [-ção] e [-mento] são características da morfologia e do léxico da língua portuguesa. No entanto, podemos afirmar 
que o estilo impessoal do gênero e a falta de sujeitos-pessoas cooperam para a grande quantidade de substantivos do tipo neste gênero discursivo, pois o foco do enunciado é sempre em objetos e processos e nunca em pessoas. De acordo com Basílio (2002), estes tipos de sufixos ocorrem por derivação nominal de verbos.

(...) o caso dos sufixos -ção e -mento, aparentemente em competição na formação de substantivos a partir de verbos em português. Nas bases para os quais não temos restrições determinadas, tanto pode ocorrer um sufixo como o outro e, muitas vezes, ambos ocorrem. (BASÍLIO, 2002, pp. 368 - 369)

O pesquisador português Mário Vilela analisa que:

Estes derivados são substantivos verbais autênticos: assumem os traços do verbo, a sua valência etc, (...) os substantivos derivados de verbos transitivos com auxílio dos afixos [ - agem], [ -ção], [-mento] podem assumir também o valor resultativo, o que faz com que possam ocorrer no singular e no plural.(...) Isso acontece porque os deverbais abstratos possuem a propriedade de designar objetos concretos que se encontram numa determinada relação com a ação, o processo implicado no significado do verbo, designar objetos concretos resultantes da ação de $\mathrm{V}$, sobretudo com lexemas verbais cujo conteúdo aponta para uma atividade criadora e em que os produtos são nomeados por essa nome deverbal, como composição, construção, criação, instituição, plantação, publicação, etc. (VILELA, 1994, pp. $68-69)$

Os planos de cultura apresentam alta incidência de substantivos próprios e topônimos que aparecem como nomes de cidades, estados, instituições públicas, marcos legais, programas estatais e equipamentos culturais, geralmente como objetos diretos e indiretos nos períodos. Curiosamente, foi possível verificar uma maior incidência de nomes de equipamentos culturais e programas no Plano Municipal de Cultura da cidade de São Paulo. Podemos afirmar que isso acontece por conta da vocação da cidade, como ponta do sistema, em dar maior foco a detalhes locais e pontos específicos do que a generalidades como no Plano federal, por exemplo.

No PNC (grifos meus):

- Também será necessário estabelecer parcerias com outras instituições, como o Serviço Brasileiro de Apoio às Micro e Pequenas Empresas (Sebrae), o Banco Nacional de Desenvolvimento Econômico e Social (BNDES), o Instituto Brasileiro de Geografia e Estatística (IBGE), o Instituto de Pesquisa Econômica Aplicada (Ipea), entre outros. (PNC, ação meta 9)

- O Ministério do Turismo estabeleceu um Índice de Competitividade para avaliar os 65 principais destinos turísticos do Brasil. (PNC, Justificativa, meta10)

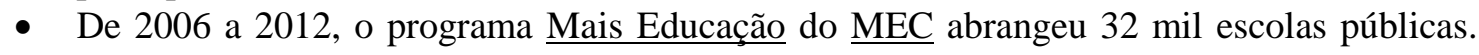
(PNC, objetivo, meta 14)

\section{No PEC-SP:}


- Em parceria com a Secretaria de Estado da Cultura, Unidade de Fomento e Difusão da Produção Cultural (UFDPC), Sistema Minc, Secretaria da Cidadania e Diversidade Cultural (SCDC), implantar ao menos 01 Pontão de Culturas Indígenas, 01 Pontão de Cultura LGBTT, 01 Pontão de Cultura Cigana e 01 Pontão de Cultura Negra no Estado, com a finalidade de promover a articulação, mobilização e formação em Rede. (PEC, Meta 4 , objetivo 8.1)

- Construir uma plataforma digital para divulgação de todos os projetos aprovados no ProAC Edital e ICMS para que a sociedade possa acompanhar as realizações selecionadas. (PEC, meta 1, objetivo 15.2)

- Assegurar a implantação da Lei Cultura Viva Estadual. (PEC, ação 1, objetivo 13.2)

No PMC-SP:

- Biblioteca Braile e Biblioteca de Culturas Surdas no Centro Cultural São Paulo. (PMC, ação 12.6, meta 12)

- Sistemas variados implantados para gestão, consulta e disponibilização das diversas tipologias de acervos*: Sistema Alexandria (Sistema Municipal de Bibliotecas); Cadastro de Imóveis Tombados (Departamento do Patrimônio Histórico); relíquias virtuais (Arquivo Histórico Municipal); Portal de Acervos Artísticos e Culturais da Prefeitura de São Paulo. (PMC, ação 12.3, meta 12)

- $\quad$ Ruas Abertas implantadas em 29 subprefeituras. 120 Praças Wi-Fi Livre SP em operação. (PMC, ação 8.1, meta 8)

- 13 Bosques de Leitura em gestão compartilhada com a Secretaria Municipal do Verde e Meio Ambiente. (PMC, ação 6.6, meta 6)

A menção a nomes próprios de equipamentos culturais e topônimos auxilia na concretude semântica dos enunciados, já que estes lugares existem, tem características e endereços únicos. De certo modo, também cooperam no referenciamento e no endereçamento do enunciado, ainda que não sejam mencionadas pessoas. Ao citar a Biblioteca de Culturas Surdas no Centro Cultural São Paulo, por exemplo, o texto busca um referente existente e não uma biblioteca qualquer. $\mathrm{O}$ ato de determinar um topônimo específico no enunciado possibilita a seus leitores e destinatários receberem a mensagem de que, no caso da ação 12.6 que trata da "implantação de tecnologias assistivas" e da garantia da acessibilidade a acervos", aquela biblioteca é um local em que esse fazer é prioridade. Tanto a comunidade surda que frequenta o local, quanto os funcionários da biblioteca em questão, são destinatários diretos desta ação e os maiores interessados na proposição. O mesmo acontece com a menção à Secretaria Municipal do Verde e Meio Ambiente, no caso citada como destinatária da ação 6.6 da meta seis. Ao ser mencionada, essa secretaria torna-se destinatária direta dessa proposição política, pois deverá se responsabilizar pela gestão compartilhada dos Bosques de Leitura junto à Secretaria Municipal de Cultura.

Um traço essencial (constitutivo) do enunciado é o seu direcionamento a alguém, o seu endereçamento. À diferença das unidades significativas da 
língua - palavras e orações - que são impessoais, de ninguém e a ninguém estão endereçadas, o enunciado tem autor (e, respectivamente, expressão, do que já falamos) e destinatário. Esse destinatário pode ser um participanteinterlocutor direto do diálogo cotidiano, pode ser uma coletividade diferenciada de especialistas de algum campo especial da comunicação cultural, pode ser um público mais ou menos diferenciado, um povo, os contemporâneos, os correligionários, os adversários e inimigos, o subordinado, o chefe, um inferior, um superior, uma pessoa íntima, um estranho, etc.; ele também pode ser um outro totalmente indefinido, não concretizado. (BAKHTIN, 2003, p. 301)

Bakhtin vê o destinatário presumido ou interlocutor não como um participante passivo do discurso, mas alguém que atua numa posição ativa-responsiva. De acordo com Bakhtin (2003, p. 271), o destinatário “ao perceber, compreender o significado (linguístico) do discurso, ocupa simultaneamente em relação a ele, uma ativa posição responsiva, concorda ou discorda dele (total ou parcialmente), completa-o, aplica-o, prepara-se para usá-lo, etc.” Esta responsividade será formada ao longo do processo de comunicação, desde o primeiro contato entre os interlocutores, mesmo que isto ocorra por meio de enunciados complexos, como os de nosso corpus. No caso dos planos de cultura, para que a Secretaria do Verde ou mesmo a Biblioteca dos Surdos seja mencionada, é possível afirmar que ocorreu alguma interação anterior com pessoas destas instituições para que fossem citadas ali. O interesse destes destinatários nas propostas poderá auxiliar na concretização das mesmas, porém, como vimos anteriormente, por questões políticas e orçamentárias, nem sempre as decisões sobre a concretização do que está ali determinado cabe aos maiores interessados, isto é, aos agentes culturais ou trabalhadores desses órgãos. Todavia, ao citarem estas instituições e programas, seus participantes diretos tornam-se destinatários dos enunciados e poderão responder a estes com ações e outros enunciados futuros, ainda que sejam enunciados para, por exemplo, reivindicar as propostas elencadas nos planos. Essa possibilidade de resposta gerada por um determinado enunciado dá ainda mais vida às vozes inseridas nos mesmos, cria os limites dos enunciados e os fios dialógicos nas esferas da atividade humana.

Essa alternância dos sujeitos do discurso, que cria limites precisos do enunciado nos diversos campos da atividade humana e da vida, dependendo das diversas funções da linguagem e das diferentes condições e situações de comunicação, é de natureza diferente e assume formas várias. (BAKHTIN, 2003, p. 275)

Em relação ao referenciamento, estes nomes próprios auxiliam aos leitores e destinatários a saber exatamente a o que o enunciado se refere. Há nessas escolhas lexicais um direcionamento direto a algo existente no mundo e com isso cria uma relação de açãoprocesso a um determinado sítio ou programa. “Os nomes próprios são considerados as 
expressões referenciais por excelência pois geralmente, a cada nome, buscamos uma referência única no mundo". (CANÇADO, 2012, p. 89) Esta referência cria uma imagem quase que real e uma ligação com algo único e assim determina um sentido único no mundo e nas ações propostas nos planos.

A referência é a identidade apontada por uma expressão linguística em determinado contexto de uso. O sentido é o modo no qual a referência é apresentada, ou seja, o modo como uma expressão linguística nos apresenta a entidade que ela nomeia. (...) O sentido é único, imutável e é o que nos capacita a efetivar a comunicação com o outro. Já a imagem na retina é subjetiva e varia de observador para observador. (CANÇADO, 2012, pp. 94 $-95)$

Essas referências dadas por nomes próprios e indícios do mundo dependem do contexto para que se tornem determinantes não apenas no discurso, mas na realização das propostas. Ainda que sejam referentes reais, é o contexto que possibilita que se tornem reais efetivamente. Nos planos de cultura, esse contexto é dado por toda arquitetônica do sistema e da esfera e determinado pela designação do território e pelo tempo em que tal plano é criado e implantado.

(...) a indicialidade da linguagem e do discurso quebra a ilusão de dar uma descrição única e estável do mundo e sublinha sua necessária dependência contextual. No lugar de ser atribuível a uma falta de eficácia do sistema linguístico e cognitivo, esta dimensão manifesta sua capacidade de tratar a variabilidade das situações através de uma categorização adaptativa. $\mathrm{O}$ fato de que as descrições do mundo são necessariamente incompletas e de que a categorização evolui de modo flexível torna sua produção indissociável do trabalho de interpretação pelo qual o interlocutor as completa e as ajusta ao contexto. (MONDADA; DUBOIS, 2003, p. 40)

Os adjetivos presentes nos enunciados dos planos de cultura, na maior parte dos casos, foram encontrados nos textos de justificativas e ementas dos planos, como vemos nos exemplos a seguir:

No PNC:

- O benefício dará a essas pessoas melhores condições para a produção e transmissão de seus saberes e fazeres. Também será uma forma eficiente de proteção a esses notórios detentores de saberes tradicionais significativos da diversidade cultural brasileira e da identidade nacional. (PNC, justificativa, meta 4)

- A economia criativa é um setor estratégico e dinâmico, tanto do ponto de vista econômico como social. (PNC, ementa meta 7)

- O objetivo dessa política é fazer da escola o grande espaço para circulação da cultura brasileira, acesso aos bens culturais e respeito à sua diversidade. (PNC, justificativa, meta 12)

No PEC-SP:

- Fortalecer a participação da cultura no desenvolvimento sustentável do Estado de São 
Paulo (PEC, diretriz 16)

- Promover por meio de políticas de formação continuada, pesquisa e difusão, estímulo à produção e circulação (PEC, Objetivo 5.1)

- Desenvolver políticas públicas apropriadas para os praticantes das expressões, dos patrimônios, das linguagens e manifestações artísticas, das culturas populares, indígenas, afro-brasileiras, ciganas, quilombolas, hip hop e tradicionais. (PEC, objetivo 9.1)

No PMC:

- Licitação aberta para compra de equipamentos de exibição cinematográfica e prestação de serviços de instalação e manutenção de 19 salas de cinema nos equipamentos culturais municipais (PMC, ação 6.3)

- Ampliação deve ser feita a partir de carreiras existentes, da criação de novas carreiras e da realização de concursos públicos, contemplando as leis de cotas raciais e para pessoas com deficiência (PMC, Ementa meta 2)

- O Conselho Municipal de Política Cultural e a principal ferramenta de representação e participação da sociedade civil na estrutura do Sistema Municipal de Cultura (PMC, ementa meta 3)

- Construídos em diferentes períodos, a estrutura física e as condições de funcionamento de cada um desses espaços são bastante variáveis, havendo necessidade de reformas e requalificação para atendimento as normas de segurança, acessibilidade, conectividade e integração com o entorno, além de manutenção permanente. (PMC, ementa meta 5) (Grifos meus)

Ainda que a incidência de adjetivos seja inferior à presença de substantivos e verbos ao longo de metas e objetivos, eles estão presentes principalmente nos textos de ementas e justificativas, isto é, em momentos em que há a necessidade de fortalecer a argumentação do enunciado, qualificando substantivos para defender uma ideia. Nos trechos acima, analisamos que os adjetivos auxiliaram na defesa de pontos e na construção de valores acerca dos temas tratados. Nos períodos abaixo, a defesa de um argumento ganha forma com os adjetivos:

"O benefício dará a essas pessoas melhores condições para a produção e transmissão de seus saberes e fazeres."

"A economia criativa é um setor estratégico e dinâmico"

O uso de terminologias específicas também é um ponto relevante à nossa observação. As terminologias encontradas nos enunciados nos remetem à esfera políticocultural que, assim como tratado em Queiroz (2014), é uma esfera que sofre influência de outras esferas da atividade humana.

A esfera das políticas culturais no Brasil é uma clara mescla de discursos de esferas socialmente constituídas, que não apenas influenciam nos processos de sua constituição, mas também deixam marcas concretas nos enunciados produzidos nessa esfera. É possível notar, com base na circulação desses projetos culturais por outras esferas, a influência direta das esferas cultural, política e econômica, que organizam as bases para a existência e para os processos da esfera político-cultural. Observando no nível da superestrutura, 
temos outras seis esferas: a legislativa, a midiática, a publicitária, a corporativa, a estatal e a artística. (QUEIROZ, 2014, p.85)

O gênero plano de cultura pertence à esfera político-cultural, mas também é parte integrante da esfera estatal e sofre influência de outras esferas. Deste modo, a presença de terminologias destas esferas se misturam e apresentam formas diversas, tanto para atender ao leitor da sociedade civil, quanto ao destinatário mais técnico da esfera estatal. Será necessário aos leitores destes enunciados o conhecimento de terminologias destas esferas para a satisfatória compreensão dos enunciados. Ainda que os autores dos enunciados buscassem a simplificação dos termos, alguns destes já são habituais na esfera. Entretanto, para aqueles leitores não habituados, alguns termos complexos podem causar certo estranhamento, principalmente ao cidadão comum e não iniciado nessa participação popular ou na leitura dos enunciados do campo. Alguns exemplos encontrados:

a) No PNC: acervos iconográficos, planos setoriais, Griô, Rede Certific, Libras, Braile, audiodescrição, vídeoarte, vídeodança, inventário, inventariados, cabodifusão, Reizado, Umbigada, Coco de Umbigada, Carimbó, colegiados, Conta Satélite da Cultura etc;

b) No PEC-SP: democracia cultural, difusão, patrimônio material, patrimônio imaterial, intersetorialidade, fomento, sentimento de pertença, fruição, sustentabilidade etnobiológica, transversalidade, pluralismo, economia sustentável e solidária, notório saber, salvaguarda, cadeia produtiva, consórcios culturais, Revelando SP, sigilo fiscal, Samba de Bumbo, Samba Rural Paulista, Software Livre etc;

c) No PMC-SP: audiovisual expandido, Jongo, Governo Aberto, Crowdsourcing ${ }^{200}$, Crowdfunding ${ }^{201}$, Coworking ${ }^{202}$, Bibliodiversidade, autarquia pública, acessibilidade comunicacional, conselho gestor, Geosampa, gestão colaborativa, licenças livres, mediação cultural, orçamento participativo, bem imaterial, startups, tombamento etc.

A maior parte destes termos são característicos do meio cultural e apenas quem atua nesta esfera, ou mais especifcamente em determinadas linguagens culturais, os compreende sem o auxílio de um dicionário terminológico e sabe qual é a real função de cada uma delas no processo de produção cultural. $\mathrm{O}$ autor dos enunciados deve pensar que nem todos têm

\footnotetext{
200 Processo de obtenção de serviços, ideias ou conteúdo mediante a solicitação de contribuições de um grande grupo de pessoas e, especialmente, de uma comunidade online.

${ }^{201}$ Modalidade de financiamento baseada na obtenção de capital para iniciativas de interesse coletivo através da agregação de múltiplas fontes de financiamento, em geral pessoas físicas interessadas na iniciativa, normalmente por meio da internet.

${ }^{202}$ Modelo de trabalho que se baseia no compartilhamento de espaço e recursos de escritório, reunindo pessoas que trabalham não necessariamente para a mesma empresa ou na mesma área de atuação.
} 
familiaridade com os termos técnicos utilizados na esfera. Algumas pessoas terão maior dificuldade que outras dependendo da bagagem anterior que trazem sobre os temas. Todavia, alguns destes termos traduzem de forma específica formas de produção muito específicas e dificilmente poderiam ser "traduzidos" em termos mais simples. O Plano Municipal de Cultura de São Paulo traz no final do enunciado um glossário terminológico apresentando definições de termos complexos e dos programas citados no enunciado. Esse tipo de glossário auxilia o leitor em sua leitura e pesquisa e provê o melhor entendimento dos conteúdos.

A escolha desses itens terminológicos está ligada diretamente à "capacidade do discurso de produzir imagens" (BAKHTIN, 2013, p. 33) e, aliada ao uso correto do léxico da esfera, auxilia na economicidade discursiva. Os maiores interessados nas proposições dos planos de cultura em grande parte são especialistas de cada respectiva área cultural. Nos temas relativos às áreas de arte, são artistas, agentes culturais ou produtores de determinado setorial a que cada meta do plano se refere. No caso particular do restauro de patrimônio histórico, por exemplo, são trabalhadores do setor ou mesmo arquitetos especialistas em restauro de edificações históricas. A utilização de terminologias específicas gera identificação por meio de palavras ou expressões de certa área cultural nos enunciados. Este é um recurso que auxilia a harmonia dialógica entre os interlocutores e destinatários diretos. Estes termos podem ser pensados como pertencentes a um mesmo campo semântico ou a uma comunidade semiótica mais específica.

Ullmann define o campo semântico como "certas nomenclaturas solidamente organizadas" (ULLMANN, 1973, p.133). Para ele "A importância deste papel dependerá, em larga medida, da natureza do próprio campo, conforme ele seja concreto ou abstrato, contínuo ou formado por elementos distintos”. (idem, p. 513) Nas terminologias específicas encontradas nos três enunciados dos planos analisados, é possível verificar a associação entre os itens por meio de seu campo semântico associativo. Boa parte dos termos encontrados apresentam concretude, refletindo semanticamente a concretude da esfera e da produção cultural.

A utilização de algarismos numéricos, ao se referir a quantidades ou mesmo na parte referente às projeções das metas e objetivos, pode ser afirmada como uma característica do estilo do gênero plano de cultura. A necessidade de projetar uma quantificação a partir da situação atual da meta e do que se pretende atingir possibilita o foco nos números pretendidos. Os algarismos aparecem ao longo das metas principalmente, mas também são vistos ao longo de toda a argumentação. Exemplos: 


\section{No PNC:}

- $\quad \underline{100}$ mil escolas públicas de Educação Básica desenvolvendo permanentemente atividades de arte e cultura (PNC, meta 14)

- $\underline{110}$ territórios criativos reconhecidos (PNC, meta 8)

- Sistema Nacional de Patrimônio Cultural implantado, com $100 \%$ das Unidades da Federação (UFs) e $\underline{60 \%}$ dos municípios com legislação e política de patrimônio aprovadas (PNC, meta 5)

- 300 projetos de apoio à sustentabilidade econômica da produção cultural local (PNC, meta 9)

\section{No PEC-SP:}

- Distinguir $\underline{2}$ mil trabalhadores da cultura com saberes reconhecidos e certificados pelo Ministério da Educação (MEC). (PEC, meta 3, objetivo 4.1)

- Cadastrar $100 \%$ da arte e expressões artísticas e culturais (municípios) até dois anos (PEC, Meta 2, objetivo 2.1)

- Aumento em $\underline{100 \%}$ no total de pessoas qualificadas anualmente em cursos, oficinas, fóruns e seminários com conteúdo de gestão cultural, linguagens artísticas, patrimônio cultural e demais áreas da cultura. (PEC, meta 1, objetivo 5.3)

- Fomentar com recursos públicos estaduais 30\% dos municípios de cada região do Estado com produção e circulação de espetáculos e atividades artísticas e culturais (PEC, meta 2, objetivo 6.1)

\section{No PMC:}

- 1.457 servidores em atuação. 104 vagas de estagio oferecidas. (PMC, ação 2.2, meta 2)

- Formações específicas oferecidas a $75 \%$ dos servidores da cultura e formação continuada oferecida a $\underline{50 \%}$ dos servidores da cultura (PMC, ação 2.3, meta 2)

- $100 \%$ dos equipamentos culturais* com canais de participação social* implantados. (PMC, ação 3.3, meta 3)

- Licitação aberta para compra de equipamentos de exibição cinematográfica e prestação de serviços de instalação e manutenção de $\underline{19}$ salas de cinema nos equipamentos culturais* municipais (incluindo uma biblioteca, dois centros culturais* e 16 CEUs*), abrangendo $\underline{20 \%}$ dos distritos*. (PMC, ação 6.3, meta 6)

- Quatro casas de cultura do hip hop* criadas nas regiões leste, sul, centro e noroeste. (PMC, ação 6.4, meta 6) (Grifos meus)

Podemos afirmar que os autores preferiram utilizar algarismos numéricos não só por conta da economia da linguagem, da objetividade gerada pelos algarismos, mas também pela facilidade de compreensão, ou mesmo para gerar um maior impacto, que a menção do número por extenso poderia proporcionar aos leitores dos enunciados e seus destinatarios diretos. Em alguns casos, encontramos o número por extenso quando este apresenta quantidades menores. $\mathrm{O}$ uso frequente de números percentuais também se mostra como uma característica comum a todos os enunciados e pode ser tomada como fator intencional para gerar uma flexibilidade de resultados satisfatórios, já que o percentual é uma projeção não exata.

Os números também são vistos na apresentação constante de datas nos enunciados, principalmente anos e prazos para realização das metas. Ao apresentarem ao longo de todo 
enunciado prazos de anos, ou mesmo palavras que remetem à questão temporal, auxiliam no comprometimento da realização das propostas ao longo do tempo. A menção a datas e a fatores temporais são encontrados tanto referentes ao passado, quando exemplificam os diagnósticos da situação atual, quanto a projeções futuras, dos prazos em que a meta precisa alcançar. Essa característica nos remete diretamente aos cronotopos dos planos, pois relaciona ações no plano territorial à ações num determinado período de tempo. As datas e palavras que remetem ao sentido temporal são encontrados em diversos pontos dos enunciados. Exemplos:

No PNC:

- Até abril de 2012, 15 estados e 499 municípios haviam assinado e publicado acordos de cooperação federativa para o desenvolvimento do SNC e mais 3 estados e 472 cidades estavam em processo de integração. (PNC, diagnóstico Meta 1)

- É preciso que até o final de 2012 sejam implantadas no SNIIC as soluções tecnológicas de coleta de informação e disponibilização de dados. (PNC, ações meta 2)

- Até maio de 2012, o Brasil e outros 121 países já haviam ratificado a Convenção sobre a Proteção e a Promoção da Diversidade das Expressões Culturais da Unesco. (PNC, ementa meta 4)

- Existem hoje no Brasil aproximadamente 4,5 milhões de famílias que pertencem a 26 povos e comunidades tradicionais. (PNC, ementa meta 6 )

- O objetivo é que até $\underline{2020}$ mais de 1,5 milhão de trabalhadores do setor cultural tenham conquistado empregos formais. (PNC, objetivos meta 11)

- Até o momento, somente os trabalhadores da área de música podem receber reconhecimento e certificação profissional por meio da Rede Certific, do MEC. (PNC, diagnóstico meta 17)

\section{No PEC-SP:}

- Inserir na Virada Cultural Paulista, a partir de 2016, 500 expressões culturais dos povos indígenas, culturas afro-brasileiras, circo, hip hop, tradicional, LGBTT e pessoas com deficiências. (PEC, meta 2, objetivo 1.1)

- Transformar a Assessoria para Gêneros e Etnias (ACGE) da Secretaria de Estado da Cultura em Unidade da Cidadania e Diversidade Cultural até 2017 (PEC, Meta 1, ação 2, objetivo 1.1)

- Reunir as informações dos programas já existentes no interior paulista, Mapa Cultural, Circuito Cultural, Revelando SP, Oficinas Culturais dos últimos 10 anos como embasamento inicial da produção cultural paulista. (PEC, meta 4, objetivo 2.2)

- Desenvolver, até 2018, ações para veiculação e comercialização dos produtos de culturas indígenas, ampliando a circulação dos bens culturais indígenas. (PEC, meta 3, objetivo 5.1) (Grifos meus)

O estilo de linguagem utilizado nos planos de cultura é formado por terminologias específicas do setor, o que pode trazer dificuldades aos leitores não habituados com este tipo de léxico. Não são utilizadas gírias e em nenhum momento há indícios de linguagem informal. Ainda que o gênero esteja situado na esfera político-cultural e na estatal, verificamos baixa incidência de termos jurídicos complexos. Entretanto, não podemos nos 
esquecer de que estes planos de cultura só existem por conta do Sistema Nacional de Cultura e respondem imediatamente a esses marcos legais na esfera legislativa.

A relação com enunciados legislativos traz aos planos de cultura uma influência da normatividade do setor e que de acordo com Maciel (2004) apresenta na maior parte dos enunciados "Atos de fala". Um bom exemplo disso é visível ao observarmos o decreto que institui o Sistema e o Plano Municipal de Cultura de cidade de São Paulo.

Artigo $1^{\circ}$ Fica instituído o Sistema Municipal de Cultura da Cidade de São Paulo, conjunto articulado e integrado de instituições, instâncias, mecanismos e instrumentos de planejamento, participação social, financiamento e informação, que tem por finalidade a gestão democrática e permanente das políticas públicas de cultura no Município, bem como o Plano Municipal de Cultura de São Paulo constante do anexo deste decreto. (SECRETARIA MUNICIPAL DE CULTURA, 2016, p. 190)

Aqui verificamos um ato de fala, em que um enunciado não apenas fala algo, mas faz algo. Deste modo, o ato de fala inscrito em um marco legal, institui uma norma a ser seguida. No trecho "Fica instituído o Sistema Municipal de Cultura" há uma sentença performativa, em que, como diz Levinson existe "um procedimento convencional que tenha um efeito convencional" (LEVINSON, 2007, p. 291) no caso da institução de um decreto municipal. De acordo com Maciel (2004):

O propósito imediato da norma jurídica é disciplinar o comportamento dos governantes, entidades e cidadãos. Como um mandamento, não se constitui em um juízo de valor, mas em um imperativo, posto que é uma manifestção de comando, antes que expressão de conhecimento. Seu objetivo, portanto, não é informar, mas instituir princípios e prescrever modos de agir. (MACIEL, 2004, p. 240)

O Plano de Cultura é um anexo do texto da lei de regulamentação do PNC e traz consigo uma força ilocucionária do marco legal que institui uma norma no universo do direito e na esfera estatal. Levinson (2007) diz que um ato ilocucionário é "o ato de fazer uma declaração, oferta, promessa etc. Ao anunciar uma sentença, em virtude da força convencional associada a ela (ou à sua paráfrase performativa explícita)" (LEVINSON, 2007, p. 300)

Este tipo de enunciado tem sua existência oficial condicionada aos marcos legais do Sistema e consequentemente à Constituição Federal de 1988 que dará poderes como forma máxima do direito brasileiro como o ato de fala jurídico principal.

A macroestrutura do texto da Constituição segue um padrão que parece comum aos sistemas de governo inspirados no Direito Romano. Compreende o preâmbulo, o corpo do texto e a conclusão. O preâmbulo, como ato de fala primordial, é a parte mais importante. Torna legítima a autoridade do destinador, "representantes do povo brasileiro, reunidos em Assembleia 
Nacional Constituinte" e explicita seu propósito "instituir um Estado Democrático". Desse modo, prepara a enunciação fundadora do ato de fala jurídico por excelência: a promulgação. Assim a fórmula "progulgamos" cria o conjunto de normas primeiras das quais derivarão todas as outras a serem posteriormente emitidas. (MACIEL, 2004, p. 242)

Com esta reflexão de Maciel (2004) é possível aferir que o plano de cultura, sofre influência do estilo normativo da esfera legislativa, por responder ao código legal do Sistema, mas traz de forma não implícita a força ilocucionária dos atos de fala. Este é um tipo de enunciado que por meio dessa influência, apresenta-se como uma forma performativa implícita, mas pode ser considerado como um ato de fala pois traz o que Austin (1975) chamou de "como fazer coisas com palavras"203.

Maciel (2004) fala das especificidades das normas constitucionais, que são de três tipos: "Programáticas fundamentais, normas de organização e de normas de atribuição de poder e competência." (idem, p. 246). No caso dos planos de cultura são normas programáticas de ação. Estas, de acordo com Maciel:

(...) traçam planos que visam à projeção de ações que se realizarão posteriormente. Implicam, portanto, uma visão dinâmica do universo em desenvolvimento. Expressas por predicados de ação-processo, estabelecem uma meta que deverá ser alcançada e indicam uma trasformação a ser operada. Sua realização exige um sujeito causativo capaz de desencadear um processo que resultará em transformação da situação atual. (MACIEL, 2004, p. 249)

O Plano de Cultura, ao apresentar uma lista de verbos no infinitivo somados a determinados programas, instituições etc; institui também procedimentos / fazeres relacionados a metas a serem cumpridas no âmbito do poder público. Estas podem ser configuradas como normas programáticas de ação. Assim como evidenciou Maciel (2004), estas são "expressas por predicados de ação-processo" e "estabelecem uma meta que deverá ser alcançada", mas para isso será necessário um "sujeito causativo" capaz de realizar essa ação instituída por meio do ato de fala previsto no marco legal que legitima o plano de cultura em termos oficiais e legais. Como vimos ao analisar os verbos mais utilizados nos planos, estes são verbos de ação-processo e que necessitam de sujeitos causativos.

As leis de regulamentação de um plano de cultura apresentam em um dos seus artigos uma norma de atribuição de poder e competência, isto é, da designação de poderes de realização da norma programática por um sujeito-outro (que pode ser tanto de pessoas quanto

${ }^{203}$ AUSTIN, J. L. "How to do things with words" (1975). 
instituições oficiais). Tanto na lei do Plano Nacional de Cultura quanto no Decreto Municipal 57.484/2016 do Sistema e Plano Municipal de Cultura, depreendemos estas normas de atribuição de poder, que evidenciam o endereçamento direto do fazer que este tipo de enunciado propõe. Assim, estes legitimam um fazer e designam o poder fazer à instituição competente para isso, isto é, a convoca a realizar um ato ético responsável futuro.

No Plano Municipal Cultura:

Art. $8^{\circ}$ São Atribuições da Secretaria Municipal de Cultura, no âmbito do Sistema Municipal de Cultura: I. Implementar o Sistema Municipal de Cultura, integrado aos Sistemas Nacional e Estadual de Cultura, articulando os atores públicos e privados no âmbito do município, bem como os órgãos e entidades da Administração Municipal Direta e Indireta, visando a transversalidade das ações culturais; II. Planejar, instituir, regulamentar, manter e aperfeiçoar as políticas culturais, garantindo ampla participação social e transparência na formulação, gestão e acompanhamento; (SECRETARIA MUNICIPAL DE CULTURA, 2016, p. 192)

Estas normas de atribuição de poder demonstram com maior clareza o endereçamento do enunciado e a quem se destina a responsabilidade dos fazeres elencados nos documentos. No Plano Municipal de Cultura, além das atribuições feitas à Secretaria de Cultura, que deverá ser a principal responsável pela implantação do Plano, temos a indicação da atribuição de poderes e responsabilidades elencadas em cada uma das ações.

\subsubsection{1 - Análise do estilo na dimensão verbo-visual dos planos de cultura}

Outro ponto que chama atenção na análise dos enunciados é a verbo-visualidade dos planos. Inicialmente é possível dizer que estes recursos são utilizados para organizar melhor os temas, e assim auxiliar os leitores a compreender melhor os conteúdos, mas também para tornar a leitura mais leve e menos densa não iniciados nos discursos da esfera estatal.

Os recursos verbo-visuais de um enunciado devem ser entendidos como parte do discurso de um determinado gênero, são signos e representam ideologias.

Qualquer produto ideológico é não apenas uma parte da realidade natural e social - seja ele um corpo físico, um instrumento de produção ou um produto de consumo - mas também, ao contrário dos fenômenos acima enumerados, reflete e refrata outra realidade que se encontra fora dos seus limites. Tudo o que é ideológico possui um significado: ele representa e substitui algo encontrado fora dele, ou seja, ele é um signo. (VOLÓCHINOV, 2017[1929], p. 91)

No conjunto dos mais de 30 planos de cultura observados ao longo da pesquisa, não é frequente o uso de imagens nos enunciados, mas estes recursos são utilizados nos enunciados 
com desenvolvimento mais avançado. Nos três planos de nosso corpus foram encontrados recursos verbo-visuais.

É característico de todo o material produzido pelo Ministério da Cultura o uso de imagens, tanto fotografias quanto ilustrações, nos enunciados relacionados ao Sistema Nacional de Cultura. Esses recursos estão presentes em todos os manuais e guias, mas também na publicação das metas do PNC. Em muitos deles é possível observar que os tons utilizados tanto para fundo de página quanto para os caracteres utilizam as cores da bandeira do Brasil.

Em quase todas as páginas da publicação As Metas do Plano Nacional de Cultura (2012) são encontradas ilustrações e recursos gráficos coloridos. As ilustrações nos remetem às temáticas tratadas em cada uma das metas ou inerentes à cultura brasileira.

Figura 41: Verbo-visualidade no PNC

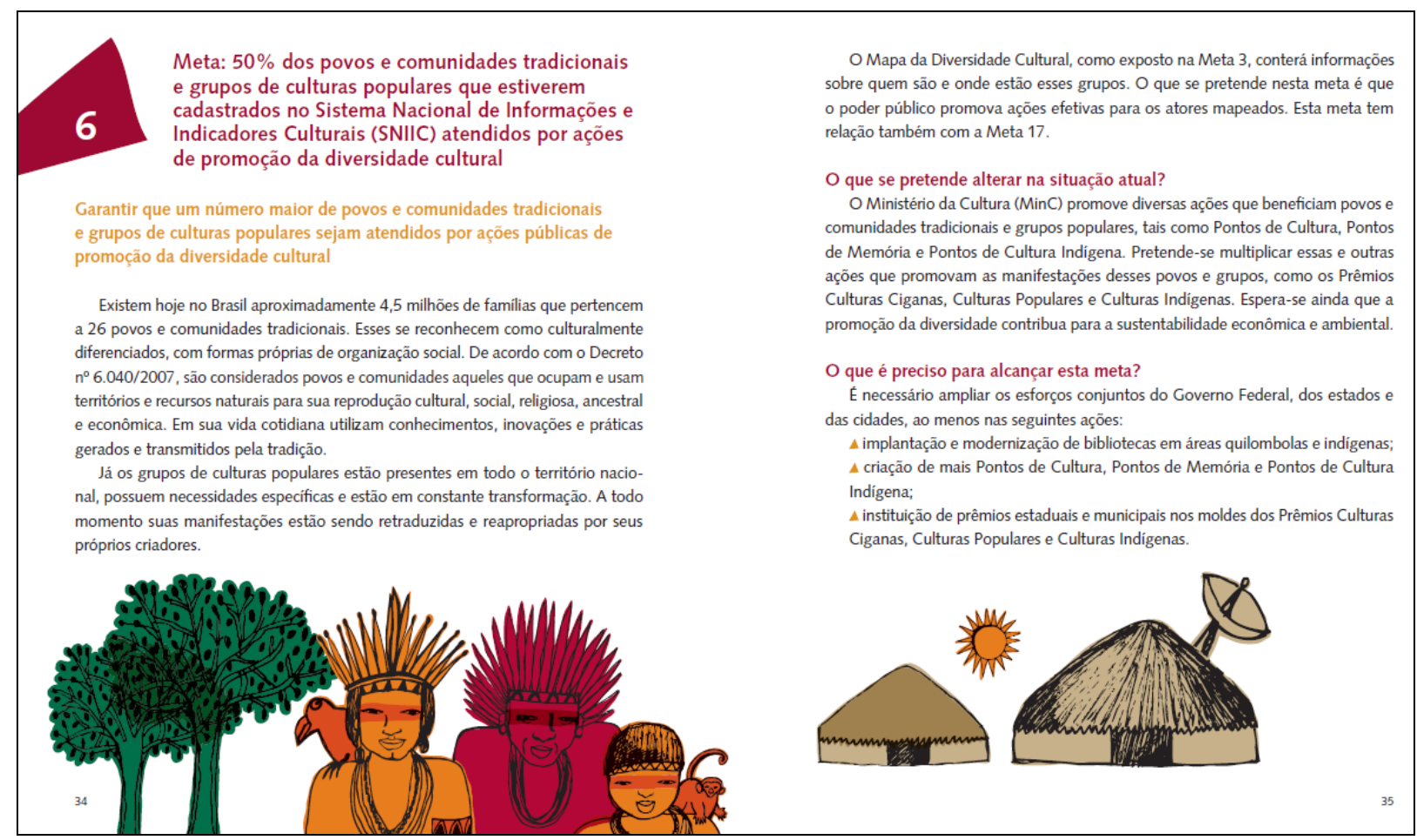

Fonte: Publicação As Metas do Plano Nacional de Cultura (2012)

Os desenhos assinados pela ilustradora Joana Lira, trazem um estilo naive ${ }^{204} \mathrm{em}$ termos estéticos. Em alguns momentos lembra inclusive o estilo das ilustrações do cordel $^{205}$. O estilo chamado de naive é comum nas artes visuais do país, principalmente de artistas mais

\footnotetext{
${ }^{204}$ Naif, naive - designação de origem francesa - literalmente, arte ingênua - para pinturas e esculturas de técnica autodidata, livre, espontânea, rude e frequentemente popular. O termo foi cunhado pela crítica cultural dos finais do século XIX, tornando-se por base o estilo do pintor Henri Rousseau. (CUNHA, 2003, p.461)

205 Literatura de cordel também conhecida no Brasil como folheto, literatura popular em verso, ou simplesmente cordel, é um gênero literário popular escrito frequentemente na forma rimada, originado em relatos orais e depois impresso em folhetos.
} 
ligados à cultura popular e ao artesanato.

Ao apresentar no enunciado ilustrações nesse estilo mais "popular", o Ministério da Cultura se filia à cultura mais tradicional e a um dos centros arquitetônicos do próprio $\mathrm{SNC}$, de ampliação de acesso à cultura e de descentralização. A presença de ilustrações no estilo naive, ao contrário, por exemplo, das artes mais eruditas, demonstra o foco das políticas culturais e dá importância a um tipo de estética tratada erroneamente como inferior em círculos mais eruditos. O estilo indica a estética mais "popular" como prioritária, e pode ser relacionada com os conteúdos temáticos dos enunciados que priorizam a ampliação do acesso e a diversidade cultural.

Ao contrário das demais publicações do MinC no período, as cores utilizadas aqui são o vermelho, o laranja e o verde escuro.

No Plano Municipal de Cultura de São Paulo e nas publicações relativas aos processos de implantação do sistema municipal, também são encontrados fotografias e elementos gráficos coloridos. Toda a comunicação visual das três publicações do Sistema Municipal de Cultura (Participação e cidadania - $3^{a}$ Conferência, Caderno de Consulta Pública e PMC final) apresenta recursos gráficos semelhantes em tons de laranja e roxo.

No Plano municipal, os aspectos de tempo foram organizados dentro de uma tabela cronológica desenvolvida pensando na relação com os planos plurianuais (PPAs), como vimos em capítulos anteriores.

Essa tabela que sugere uma forma diferente de organização temporal das ações proposta pelo PMC-SP não foi encontrada em nenhum dos 35 planos de cultura observados ao longo da pesquisa. Todavia, a forma sugerida pelo PMC poderá influenciar outros enunciados do tipo no futuro, não apenas por ser uma solução interessante ao gênero, já que indica os PPAs dos próximos prefeitos, mas pela relevância da cidade de São Paulo no contexto nacional. 
Figura 42: Verbo-visualidade no PMC SP

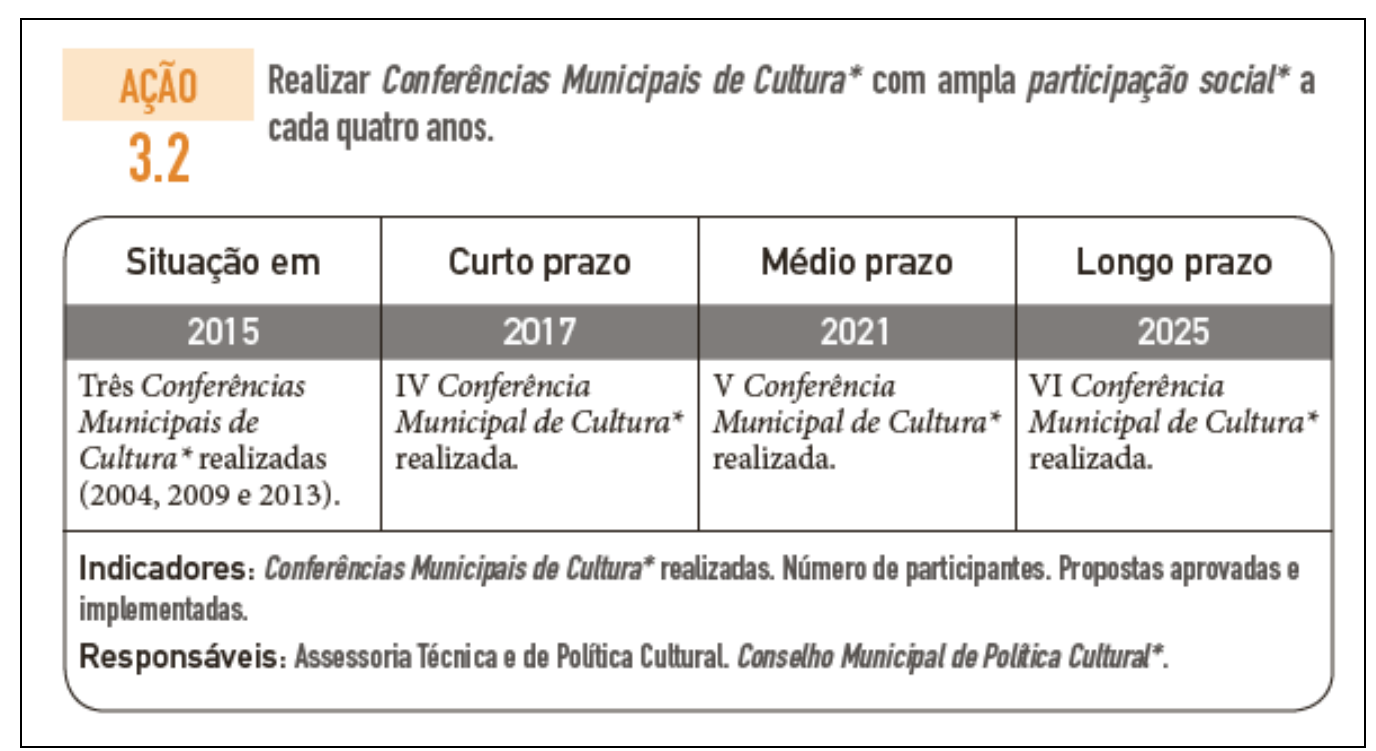

Fonte: SECRETARIA MUNICIPAL DE CULTURA, 2016b, p. 69.

Essa nova forma de trabalhar a questão temporal no enunciado demonstra que o gênero plano de cultura ainda está em busca de melhores alternativas discursivas. Sua juventude enquanto gênero discursivo justifica estas "subversões" em sua forma e estilo bem como mostra que este tipo de enunciado ainda está "fase de testes". O uso da tabela como linha cronológica é uma escolha discursiva que utiliza recursos verbo-visuais para compor um enunciado a fim de organizá-lo melhor. No quadro acima, por exemplo, condicionam a realização das Conferências Municipais de Cultura a cada um dos períodos / gestões futuras.

No enunciado do PMC final, grandes fotos de página inteira dos participantes dos encontros das consultas públicas para a escrita do plano abrem cada um dos capítulos da publicação. No início de cada um dos eixos, fotos com detalhes mais aproximados, se relacionam tematicamente ao que cada eixo trata.

A utilização de diferentes imagens das conferências e consultas públicas, evidenciando principalmente a participação popular, busca trazer o foco para a sociedade civil e legitimar essa participação como prioritária e assim busca mostrar a quem esse plano se destina de fato. Desde a capa da publicação é possível ver a busca pelo foco na participação social nas imagens.

Nas fotos é possível ver a sociedade civil como observadora, como auditório das atividades, mas principalmente como agentes interessados, em posições que evidenciam a participação: estão quase sempre lendo a publicação da consulta pública. As imagens buscam mostrar estas pessoas como agentes do processo e interagindo com as informações transmitidas ao longo das reuniões. 
Figuras 43, 44, 45, 46: Fotos da publicação final PMC - SP
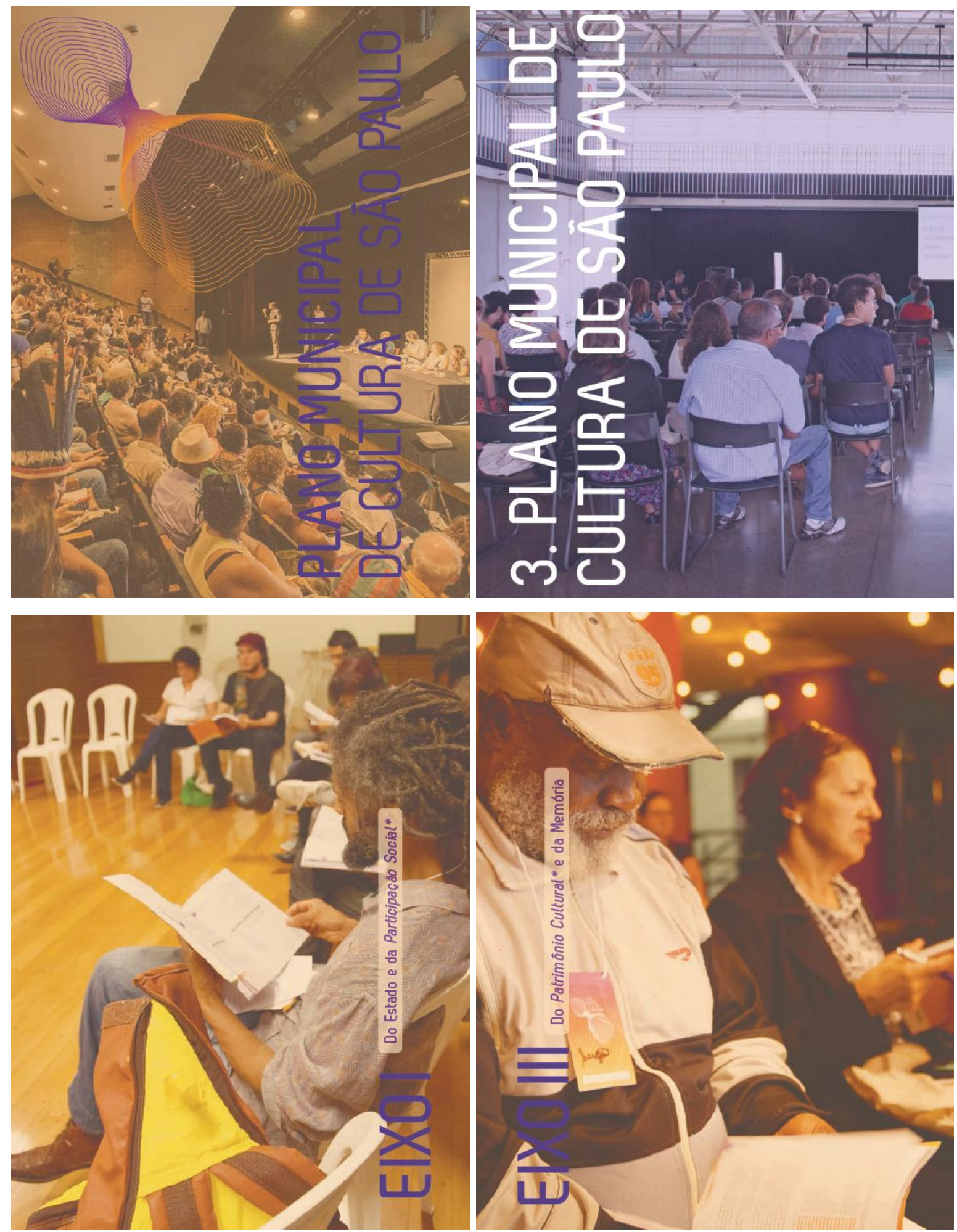

Fonte: Publicação PMC - SP (SECRETARIA MUNICIPAL DE CULTURA DE SP, 2016)

No descritivo do plano, cada eixo do PMC-SP apresenta inicialmente um texto introdutório com letras altas no tom roxo e cada meta traz uma régua gráfica no tom roxo 
mais claro e o nome da meta com letras em roxo escuro, seguida na lateral de um destaque para o número da meta em tom cinza. A utilização de cores diferentes no enunciado busca auxiliar e didatizar a leitura.

Figura 47: Verbo-visualidade no Eixo 2 do PMC-SP

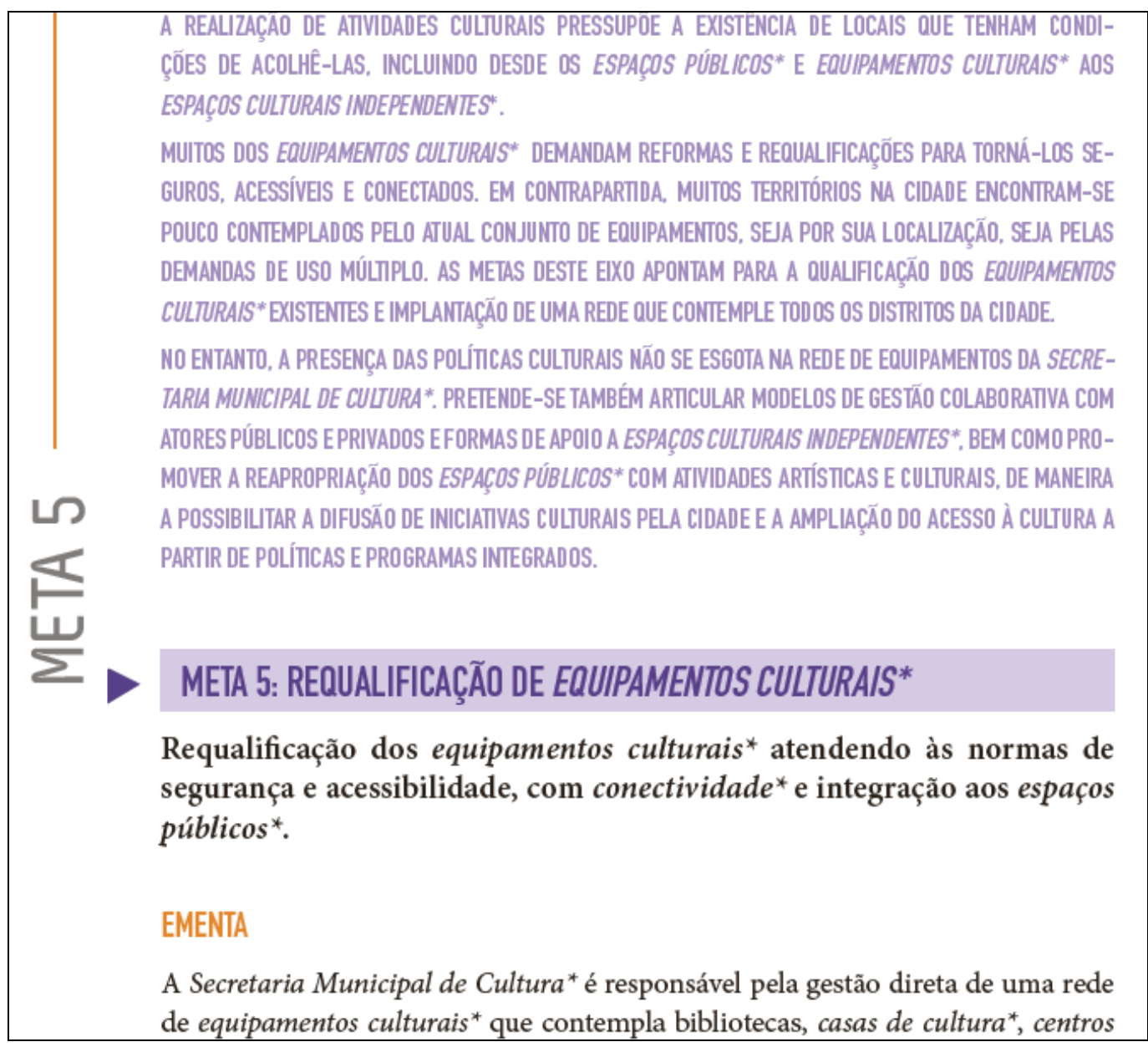

Fonte: SECRETARIA MUNICIPAL DE CULTURA. 2016b, p.82.

Cada meta é dividida em ações e cada ação tem seu número apresentado com um recurso gráfico em tom laranja, destacando o número de uma nova ação no enunciado e facilitando a visualização dos leitores. Em todas as 96 ações do PMC são apresentadas as tabelas cronológicas que dividem os 10 anos do plano em 4 tempos: 2015 (início), 2017, 2021, 2025 (fim). Estas cores e formas são padronizadas ao longo de todo o enunciado no plano e facilitam ao leitor perceber a diferença entre cada trecho do plano: eixos, metas, ações e prazos. A utilização destes recursos gráficos organiza o enunciado principalmente pensando no leitor presumido, pois torna mais rápida a percepção do enunciado e colabora para sua 
compreemsão.

No enunciado do Plano Estadual de Cultura de São Paulo, não há a presença de fotos. O único tipo de ilustração presente no enunciado é a logomarca do Plano destacada na parte superior de cada página do enunciado.

Figura 48: Verbo-visualidade no Plano Estadual de Cultura de SP.

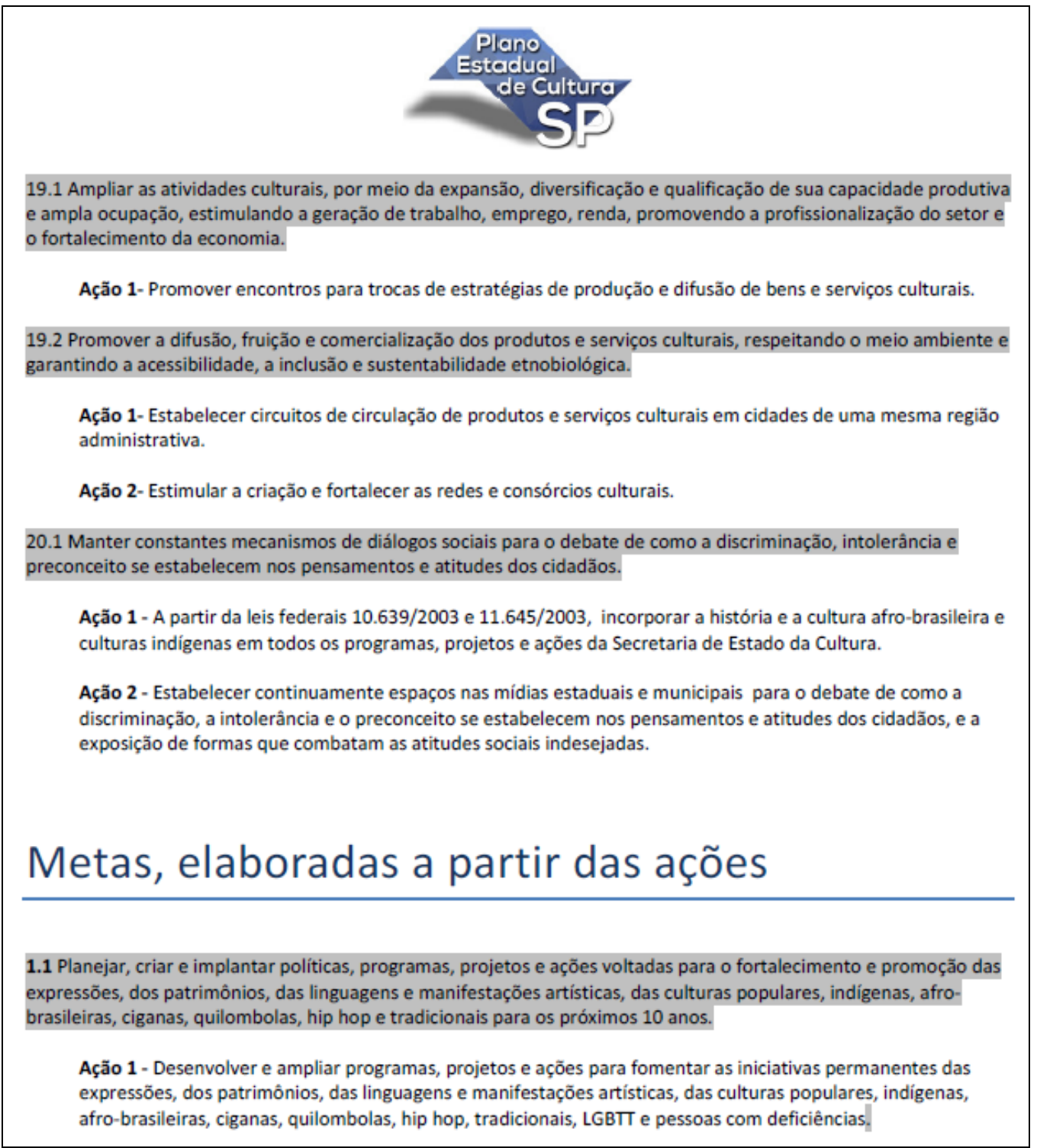

Fonte: Site PEC SP.

Os recursos gráficos em cor azul ou cinza são utilizados para organizar o texto, orientar o leitor e tirar um pouco do caráter "sisudo" de um simples documento da esfera estatal. Cada capítulo do plano é iniciado com letras em fontes maiores em azul e os objetivos do plano destacados em cinza. Desta forma, o leitor poderá encontra maior facilidade na leitura, já que o formato do plano estadual não segue a estrutura clássica em que as metas aparecem antes dos objetivos e ações. 
O estilo do gênero Plano de Cultura apresentou características semelhantes nos três enunciados analisados. Estas semelhanças também foram observadas nos demais planos do nosso corpus auxiliar.

A grande maioria dos verbos encontrados nos enunciados estavam no infinitivo, isto é, sem flexão alguma de tempo e pessoa e estavam posicionados no início de cada tópico. Isso reforça o caráter impessoal do enunciado e demonstra que é parte da esfera estatal, que preza pelo "Princípio da impessoalidade" . O sujeito / agente é sempre indeterminado, mas as ações-processo se destinam a um sujeito-agente causativo que deverá realizar uma mudança no estado das coisas.

Dos verbos no infinitivo encontrados, alguns deles apareceram com maior frequência em todos os enunciados analisados: ampliar, aumentar, criar, estimular, fomentar, fortalecer, garantir, promover. A incidência recorrente desses verbos evidencia uma proposição positiva em relação ao que se pretende realizar por meio desses enunciados. O verbo modal dever foi encontrado na forma [Dever] + [Fazer] e pode indicar a necessidade de flexibilização de alguns fazeres.

Nos enunciados, verificamos uma grande quantidade de substantivos com os sufixos [mento] e [-ção]. A maior parte destes substantivos derivam dos verbos encontrados com maior frequência no enunciado, configurando assim que são parte do léxico da específico da esfera e ao mesmo tempo reforçam o estilo impessoal do gênero.

É possível afirmar que outra característica do gênero Plano de Cultura é a menção constante de substantivos próprios ou topônimos: de localidades, de instituições públicas, marcos legais, programas estatais e equipamentos culturais. Ao fazer a nomeação de instituições, programas e equipamentos, o plano de cultura direciona fazeres a outros responsáveis e acaba endereçando responsabilidades futuras. Esse direcionamento é ainda maior quando, nos enunciados, são proferidas as atribuições de poder e competência. Isso demonstra que o endereçamento dos enunciados é parte do estilo dos mesmos.

$\mathrm{O}$ uso mais frequente de adjetivos foi encontrado nos trechos relativos a justificativas e argumentações necessárias à defesa da importância de cada uma das metas. Estes atuam como qualificadores e auxiliam na argumentação.

As terminologias específicas da esfera são utilizadas ao longo do documento e podem causar estranhamento em leitores não habituados com léxico da esfera. Contudo, essas 
terminologias auxiliam na compreensão mais técnica de áreas específicas, tanto de trabalhadores do setor quanto do poder público.

O uso recorrente de algarismos numéricos e datas pode refletir o caráter técnico deste tipo de enunciado. Os números são utilizados principalmente para propor avanços nas propostas de maneira quantitativa. As datas devem refletir os prazos ideais para a realização das ações previstas e sua relação com os cronotopos típicos do gênero.

Os planos de cultura, como enunciados parte de um compêndio de marcos legais, respondem a estes enunciados diretamente e assim recebem influência direta em termos de estilo tanto em sua forma quanto em seu conteúdo. Os enunciados legais devem ser tomados enquanto atos de fala e influenciam com essa normatividade e força ilocucionária os planos de cultura. Assim, os planos são uma ação, agem como uma norma programática de ação, um dever-fazer que projeta metas ao futuro.

Os manuais dos planos de cultura sugerem que, para escrever novos enunciados do tipo, sejam consultados outros já aprovados anteriormente e assim auxiliar na escrita dos mesmos. Essa prática pode colaborar para que enunciados deste gênero no futuro sejam não apenas similares, mas que carreguem de certo modo construção composicional, conteúdos temáticos e estilos semelhantes. Entretanto, como vimos ao longo da tese, todo enunciado é único no tempo e no espaço e responde ao outros enunciados anteriores. Por conta de sua crescente produtividade e das semelhanças encontradas em suas especificidades, o plano de cultura pode ser tomado a partir dessa tese como um importante gênero discursivo da esfera político-cultural no início do século XXI. Este tipo de enunciado reflete e refrata as demandas e projeções das políticas culturais em termos territoriais e setoriais e com isso relaciona-se com a arquitetônica da esfera. Ainda que seja um gênero jovem, que está construindo suas especificidades, é sem dúvida uma peça chave na construção do Sistema. Mesmo com as recentes rupturas e com os atrasos ocorridos na implantação do SNC, os planos de cultura devem ser observados como um gênero relevante para a construção do futuro das políticas culturais no Brasil e como base de sua arquitetônica. 


\section{Considerações finais}

Como vimos ao longo dos capítulos, e principalmente no primeiro capítulo, o conceito de arquitetônica nos estudos bakhtinianos pode ser entendido de duas formas: como sistematizador, que engloba todas as categorias filosóficas bakhtinianas de compreensão de mundo e também como um todo englobante de sentido que é realizado num ato responsável.

A arquitetônica da esfera político-cultural brasileira neste início do século XXI, está refletida e refratada nos enunciados e nos processos de construção do sistema, na sistematização dos sentidos organizados num todo englobante. Seja pelas visões de mundo de seus autores, seja pelos cronotopos dos enunciados, ou mesmo pelas especificidades do gênero plano de cultura, a arquitetônica foi sendo construída a cada ato responsável, pontuada por seus centros de valor: diversidade, descentralização e ampliação de acesso.

Nesta tese, nossa metodologia e nosso percurso de análise foram inspirados na reflexão filosófica bakhtiniana a respeito da arquitetônica do mundo real do ato ético e foi fundamentada para o estudo dos enunciados do Sistema Nacional de Cultura. Para a análise, utilizamos também as reflexões do Método Sociológico de Valentim Volóchinov e a Metalinguística bakhtiniana.

Por meio do desenvolvimento da hipótese proposta inicialmente, foi possível aferir que a implantação do SNC no Brasil é fruto de um processo histórico de acúmulo de discussões, ações, rupturas, avanços, disputas políticas, militâncias e articulações das mais diversas. O surgimento da proposta na virada para o século XXI, logo após um longo período de tradicionais "instabilidades, ausências e autoritarismos", como diria o pesquisador Albino Rubim, demonstrou que esse acúmulo contribuiu para a possibilidade de mudança por meio de um caráter democratizante e descentralizante. Entretanto, a complexidade do sistema e as rupturas políticas recentes indicaram que ainda não foi possível resolver essas três "tristes" tradições da esfera. A construção de uma nova proposta de arquitetônica para a esfera político-cultural deve ser compreendida na somatória dos fatores que geram sentidos e atuam como forças centrífugas sociopolíticas. Contudo, até o momento a implantação do Sistema ainda não alcançou um dos seus mais importantes e desafiantes objetivos: a alteração concreta do modelo de financiamento à cultura.

Decorridos quatro anos de pesquisa, com diversas reflexões, conversas, leituras, coleta de dados e acontecimentos inesperados, podemos aferir que a proposta de visão de cultura ampliada e de um sistema federativo de cultura foi um importante fator para uma relativa 
alteração no campo cultural. Chegamos ao ano de 2019 com muitos atrasos e rupturas no SNC, porém a esfera e seus agentes não são mais os mesmos que eram em 1999 e isso devese também aos processos de implantação do Sistema. A participação social promovida pelo MinC e por outros órgãos de cultura, como por exemplo na cidade de São Paulo, alteraram consideravelmente a visão de cultura e o engajamento de agentes culturais, alterando assim outros processos da esfera e a cultura política dos agentes.

A influência de Gilberto Gil deve-se ser tomada como fator positivo, não apenas por seu protagonismo no MinC no início da implantação do Sistema, ou por ser uma celebridade da cultura conhecida mundialmente, mas por trazer um "brilho" maior à pasta da cultura, gerando assim mais agentes interessados em participar. Seu discurso de posse traduziu bem as tendências mundiais para as políticas culturais no período, principalmente aquelas balizadas pela Unesco e representava uma demanda do setor cultural que buscava ampliar sua voz e principalmente sua representatividade. Deste modo, Gil aproximou os trabalhadores da cultura do ministério e de suas ações, e assim contribuiu para a reflexão coletiva sobre o complexo conceito de cultura.

A análise do histórico, da autoria e da participação social demonstrou que, de fato, a construção do SNC e suas partes vêm de uma ação / construção compartilhada por diversas consciências. Por meio dessa análise aferimos que os centros de valor da arquitetônica apontaram para alguns agentes principais: Gilberto Gil, Gilmar Machado, Marcio Meira, Fátima Bezerra, Paulo Pimenta, José Roberto Peixe, Marta Suplicy, o presidente Luis Inácio Lula da Silva e agentes da sociedade civil (conselheiros de cultura, artistas, grupos organizados etc). Nosso estudo evidenciou também, por meio da análise dos enunciados e dos processos interativos, que os principais signos ideológicos que balizam essa nova arquitetônica são: democracia cultural, ampliação de acesso, descentralização e diversidade cultural. Ao longo dos anos, a construção do Sistema decorreu de um compartilhamento de valores, ativismos e vontades.

A pesquisa também observou os cronotopos da esfera propostos nos enunciados, em que os planos de cultura projetam futuros desejados, assim como orientado nos manuais de criação de planos. Porém, o gênero plano de cultura conta com um fator desafiador, pois nem sempre temos os mesmos agentes e conjunturas nesse futuro. Essa alteração de agentes, conjunturas e vontades pode trazer dificuldades imprevisíveis na implantação do Sistema. Isso foi comprovado principalmente na observação dos acontecimentos na cidade e estado de São Paulo. 
A análise das especificidades do gênero plano de cultura permitiu afirmarmos este enquanto um novo gênero da esfera político-cultural, pois, ainda que seja um tipo de enunciado recente, apresentou caraterísticas similares de: construção composicional (itens recorrentes em sua organização), conteúdo temático (temáticas recorrentes e em diálogo com os enunciados principais do sistema), e estilo (tom impessoal, verbos no infinitivo, uso recorrente de substantivos, topônimos, adjetivos, algarismos numéricos e terminologias do setor cultural, ilustrações e verbovisualidade orientada a didatizar a leitura dos enunciados).

A escrita e aprovação de pouco mais de 200 planos de cultura no país ainda se apresenta como um número muito abaixo das expectativas iniciais (que previam a escrita de pelo menos 2000 planos até 2020). Ainda assim pudemos analisar esse tipo de enunciado e comprovar suas especificidades e caraterísticas mais recorrentes, o configurando como um novo gênero dessa arquitetônica.

Por conta da ruptura governamental ocorrida em 2016, com o Impeachment da Presidenta Dilma Rousseff, e os atrasos e instabilidades gerados, e a recente eleição do Presidente Jair Bolsonaro, é impossível afirmar qual será o futuro do Sistema nos próximos anos.

Concluímos a análise com a observação da esfera até o final de 2018, a fim de evidenciar que mesmo com as diversas rupturas na implantação do Sistema, esta nova forma de pensar as políticas públicas de cultura criou algumas raízes e novas perspectivas, e principalmente, trouxe avanços significativos, muitos deles irreversíveis, como necessidade da participação social nesses processos. O SNC ao propor um novo modelo de política cultural influi na esfera de modo a ativar, principalmente nos agentes, novas perspectivas, possibilidades e esperanças de que existe uma maneira concreta de distribuir melhor os recursos. Como Marcio Meira disse na entrevista a Paula Reis, um Sistema não se constrói por decreto. Acreditamos que um Sistema também não se destrói por decreto. Os processos de participação social ocorridos durante a construção do PNC e SNC e demais planos de cultura territoriais, trouxeram aos agentes culturais uma nova visão sobre as políticas culturais. Os processos demonstraram que é possível construir conjuntamente com o Estado e de forma mais democrática, as políticas que queremos. Entretanto, como vimos, apenas com a alteração concreta no modelo de financiamento, essa alteração de paradigma poderá acontecer de forma satisfatória. Sem a ampliação do orçamento da cultura e sem fortalecimento do FNC com um mecanismo que reverta os recursos para o sistema como o Procultura, por exemplo, ele será apenas um novo modelo de política cultural, com menores possibilidades de distribuição 
democrática dos recursos.

A gestão instituída no MinC após o impeachment de Dilma em 2016, trouxe um caráter mais conservador e demonstrou direcionamentos não tão democráticos para a gestão pública de cultura. Ainda assim, a proposta do Sistema continuou acontecendo com uma redução na velocidade dos atos e sem a distribuição de recursos. Nos últimos dois anos, novas cidades passaram a ter marcos legais de sistema e planos de cultura. Secretarias de cultura e conselhos foram criados, ao mesmo tempo que outros foram fechados. Isto pode significar que o Sistema por enquanto persiste e resiste, colaborando para a mudança na cultura política de diversos grupos e territórios.

Por conta da contemporaneidade dos fatos e dos enunciados, algumas questões não se revelaram por completo, como por exemplo, quais mecanismos poderiam gerar compromissos dos futuros governantes de cada ente federado para continuar os processos previstos nos planos? Ou mesmo, qual é a melhor forma de sensibilizar a população para participar mais ativamente dos processos de escrita dos planos nos municípios?

Só o tempo dirá se o SNC realmente causou uma alteração definitiva na esfera político-cultural brasileira, e que seja forte o suficiente para suportar novas rupturas e ser considerada uma política de Estado e não apenas um projeto ou sonho de um grupo de agentes do setor. 


\section{REFERÊNCIAS}

AARÃO REIS FILHO, Daniel. As revoluções russas e o socialismo soviético. São Paulo: UNESP, 2003.

ABBAGNANO, Nicola. Dicionário de filosofia. $1^{\text {a }}$ Ed. Coord. Alfredo Bosi. Tradução Ivone Castilho Benedetti. São Paulo: Martins Fontes, 2015.

ACKRILL, J.L. Sobre a eudaimonia em Aristóteles. In: ZINGANO, Marco. Sobre a Ética Nicomaqueia de Aristóteles. Textos selecionados. São Paulo: Odysseus, 2010. p. 103 -125.

ALCANTARA, Taiane F. S. Carta ao leitor. In: ROCHA, Sofia. Planos de Cultura. Coleção Política e Gestão Culturais. Salvador: P55 edições, 2013. p. 05.

AMORIM, Ana Maria. Legislações culturais. Salvador: P55 edições, 2013.

AQUINO, Tomás de. Comentário a la Ética a Nicómaco de Aristoteles. 3. ed. Trad. Ana Mallea. Navarra: Ed. Universidad de Navarra (Espanha), 2010.

ARAGÃO, Ana Lúcia. As conferências nacionais de Cultura no Brasil como instâncias de escuta e de exercício do direito de participação na vida cultural. In: Revista Pensamento e Realidade. Ano XVIv. $28 \quad \mathrm{n}^{\circ} \quad 4, \quad 2013 . \quad$ p. $85 \quad-\quad 105 . \quad$ Disponível em: < http://revistas.pucsp.br/index.php/pensamentorealidade/article/viewFile/17984/13350 > acesso em 05 de outubro de 2016.

ARAUJO, Rodrigo A. Ampliação da imagem arquitetônica como sistema na historia da filosofia. In: Revista Kinesis, vol III. No 6, 2011. p. 93-106. Disponível em: < www.marilia.unesp.br/revistas/index.php/kinesis/article/view/4426/3242 > acesso em 03 de agosto de 2015.

ARETCHE, Marta. Estado federativo e políticas sociais: determinantes da descentralização. São Paulo: Fapesp, Rio de Janeiro: Revam, 2000.

ARISTÓTELES. Ética a Nicômaco. Tradução, notas e introdução Mario da Gama Kury. Brasília: Ed, UnB, 1985.

Ética a Nicomaco; Poética. Seleção de textos de José Américo Motta Pessanha. 4. ed. São Paulo: Nova Cultural, 1991 (Os Pensadores; v.2)

A política. Trad. Roberto L. Ferreira. 2a Ed. São Paulo: Martins Fontes, 1998.

. Ética a Nicômaco. Trad. Edson Bini 2. ed.Bauru: Edipro, 2007.

ARISTOTELES. Etica a Nicómaco. Trad, Maria Araujo y Julian Marias. Madrid: editora Centro de estúdios Constitucionales, 2002.

. Etica nicomaquea. 1. ed. Buenos Aires, Ar: Losada, 2007.

ARISTOTELES. Éthique à Nicomaque. Traduction de J. Barthelemy Saint-Hilaire. Le livre de poche, Librairie Generale Française, 1992.

ARISTOTLE. Nicomachean ethics. Translated by H. Rackham. London UK. Cambridge UK, Cambridge University Press, 1961. 
Publishing Company, 1985

Press, 2002.

Nicomachean ethics. Translated by Christopher Rowe. Oxford UK. Oxford University

Nicomachean ethics. Translated by Roger Crisp. Cambridge UK, Cambridge University Press, 2005.

AUSTIN, John L. How to do things with words. 2 ed. Cambridge, Mass.: Harvard University Press, 1975.

BAJTIN, M. Hacia uma filosofia del acto ético. De los boradores y otros escritos. Trad. Taiana Bubnova. Puerto Rico: Anthropos, 1997.

BAKHTIN, Mikhail. M. Gêneros do discurso. In: Estética da criação verbal. Trad. Paulo Bezerra. 4. ed. São Paulo: Martins Fontes, 2003[1952-53]. p. 261-308.

A cultura popular na idade média e no renascimento: o contexto de François Rabelais. Trad. de Yara Frateschi Vieira. 6. ed. São Paulo: Hucitec, 2008.

O freudismo: um esboço crítico. Trad. Paulo Bezerra. São Paulo: Perspectiva, 2009.

O problema do conteúdo, do material e da forma na criação literária. In: Questões de literatura e de estética. A teoria do romance. São Paulo: Hucitec, 2010. p. 13 - 70.

Estética da criação verbal. Trad. Paulo Bezerra. São Paulo: Martins Fontes, 2010b.

Problemas da poética de Dostoiévski. Trad. Paulo Bezerra. 5. ed. Rio de Janeiro: Forense Universitária, 2010c [1963].

Para uma filosofia do ato responsável. Trad. Valdemir Miotello e Carlos Faraco. São Carlos: Pedro \& João Editores, 2010d [1920-24].

Formas de tempo e de cronotopo no romance (ensaios de poética histórica). In:

Questões de literatura e de estética. A teoria do romance. São Paulo: Hucitec, 2010e.

Questões de estilística no ensino da língua. Tradução, pósfácio e notas de Sheila Grillo e Ekaterina Volkova Américo; Apresentação Beth Brait; organização e notas da edição russa de Serguei Botcharov e Liudmila Gogotichvili, - São Paulo: Editora 34, 2013.

Teoria do romance I: A estilística. Trad. Paulo Bezerra. Org. Serguei Bocharov e Vadim Kojinov. São Paulo: Editora 34, 2015.

Os gêneros do discurso. Organização, tradução, posfacio e notas de Paulo Bezerra; notas e edição russa de Serguei Botcharov, - São Paulo: Editora 34, 2016.

BARBALHO, Alexandre. "Por um conceito de política cultural". IN: Textos nômades: política, cultura e mídia. Fortaleza: Banco do Nordeste do Brasil, 2008.

O Sistema Nacional de Cultura no governo Dilma: continuidades e avanços. In: Revista Lusófona de Estudos Culturais. Lusophone Journal of Cultural Studies Vol. 2, n.2, p. 188-207, 2014. Disponível em: < http://estudosculturais.com/revistalusofona/index.php/rlec/article/viewFile/87/114 > 
acesso em 13 de novembro de 2017.

BARBALHO, Alexandre; BARROS, José M.; CALABRE, Lia. Federalismo e políticas culturais no Brasil. Salvador: Edufba, 2013.

BARROS, Diana Pessoa de. Teoria semiótica do texto. São Paulo: Parma, 2005.

BASÍLIO, Margarida et all. Derivação, composição e flexão no português falado: condições de produção. In: CASTILHO, Ataliba T.. Gramática do português falado. V. III. Campinas, SP: Ed. UNICAMP, 2002. p. $363-432$.

BECHARA, Evanildo. Moderna gramática portuguesa. 37 ed. Rio de Janeiro: Lucena, 2001.

BEMONG, Nele (org). Bakhtin e o cronotopo: reflexões, aplicações, perspectivas. Trad. Oziris Borges. $1^{\text {a } E d . ~ S a ̂ o ~ P a u l o: ~ P a r a ́ b o l a, ~} 2015$.

BINI, Edson. Notas. In: ARISTÓTELES. Ética a Nicômaco. Trad. Edson Bini, 2. ed. Bauru, SP: Edipro, 2007.

BOBBIO. Norberto. Teoria do ordenamento jurídico. Trad. Ma celeste Santos. Brasília: Ed. UNB, 1997.

Mandarim, 2000.

Direito e Estado no pensamento de Emanuel Kant. Trad. Alfredo Fait. São Paulo:

BOBBIO, Norberto; BOVERO, Michelangelo. Sociedade e estado na filosofia política moderna. Trad. Carlos Nelson Coutinho. $3^{\text {a }}$ Ed. São Paulo: Brasiliense, 1991.

BOLZANI FILHO, Roberto. Seis filósofos na sala de aula. São Paulo: Berlendis \& Vertecchia, 2006.

BORBA, Francisco da Silva et all. Dicionário gramatical de verbos do português contemporâneo do Brasil. São Paulo: Ed. Unesp, 1990.

BOTELHO, Isaura. Dimensões da cultura e políticas públicas. IN: São Paulo em Perspectiva. v. 15, n. $1,2000$.

Para uma discussão sobre política e gestão cultural. In: CALABRE, Lia (org.) Oficinas do Sistema Nacional de Cultura. Brasília: Ministério da Cultura, 2006. p. 45 - 60. Disponível em: < http://hugoribeiro.com.br/biblioteca-digital/MinC-2006-Oficinas_do_sistema_nacional_de_cultura.pdf $>$ acesso em 10 de novembro de 2017.

2016.

Dimensões da cultura: políticas culturais e seus desafios. São Paulo: Ed. SESC SP,

BOURDIEU, Pierre. A Economia das Trocas Simbólicas. São Paulo: Perspectiva, 1974.

O poder simbólico. Rio de janeiro: Bertrand Brasil, 1989.

Papirus, 2011

Razões práticas: sobre a teoria da ação. Trad. Mariza Correa, $11^{\mathrm{a}}$ Ed. Campinas:

BRAIT, Beth. Bakhtin: outros conceitos-chave. São Paulo: Contexto, 2006.

Problemas da poética de Dostoiévski e estudos da linguagem. In: (org) Bakhtin, 
dialogismo e polifonia. São Paulo: Contexto, 2009. p. 45 - 72.

Bakhtin conceitos chave. São Paulo: Contexto, 2010.

BRASIL. Lei No 7.505, de 2 julho 1986. LEI SARNEY. Dispõe sobre benefícios fiscais na área do imposto de renda a operações de caráter cultural ou artístico. Brasília. 1986. Disponível em: <http://www.planalto.gov.br/ccivil_03/Leis/L7505.htm > acesso em 27 de fevereiro de 2012.

Lei 8.313/91 de 23 dezembro 1991. LEI ROUANET. Restabelece princípios da Lei ${ }^{\circ}$ 7.505, de 2 de julho de 1986, institui o Programa Nacional de Apoio à Cultura (Pronac) e dá outras providências, 1991. Disponível em Planalto Federal, Presidência da Republica Federativa do Brasil. Brasília. 2011. < http://www.planalto.gov.br/ccivil_03/leis/L8313cons.htm> acesso em 27 de fevereiro de 2012.

Decreto 591, de 6 de julho de 1992. Atos Internacionais. Pacto Internacional sobre Direitos Econômicos, Sociais e Culturais (ONU). Promulgação, 1992. [1966] Disponível em: < http://www.planalto.gov.br/ccivil_03/decreto/1990-1994/d0591.htm > acesso em 20 de abril de 2016.

PEC 306/2000. SNC. Acrescenta $\S 3^{\circ}$ ao art. 215 da Constituição Federal, instituindo o

Plano Nacional de Cultura, 2000. Disponível em: <
https://www.camara.leg.br/proposicoesWeb/fichadetramitacao?idProposicao=14692 > acesso em $10 \mathrm{de}$ maio de 2013.

PEC 34/2012. SNC. Acrescenta o art. 216-A à Constituição Federal para instituir o Sistema Nacional de Cultura. 2005. Disponível em: < https://www12.senado.leg.br/ecidadania/visualizacaomateria?id=106347> acesso em 10 de maio de 2013.

Emenda Constitucional $\mathbf{n}^{\mathbf{0}} \mathbf{4 8}$, de 10 de agosto de 2005. Acrescenta o $\S 3^{\circ}$ ao art. 215 da Constituição Federal, instituindo o Plano Nacional de Cultura. Disponível em: < http://www.planalto.gov.br/ccivil_03/Constituicao/Emendas/Emc/emc48.htm> acesso em 21 de janeiro de 2016.

PEC 416/2005. Institui o Sistema Nacional de Cultura. 2005. Disponível em: < http://blogs.cultura.gov.br/snc/ > acesso em 10 de maio de 2013.

Decreto n'5.520, de 24 agosto de 2005. Institui o Sistema Federal de Cultura - SFC e dispõe sobre a composição e o funcionamento do Conselho Nacional de Política Cultural - CNPC do Ministério da Cultura e dá outras providências. 2005b.

Ministério da Cultura. Programa Cultural para o Desenvolvimento do Brasil. Brasília, DF, nov. 2006.

Decreto $\mathbf{n}^{\mathbf{0} 6.973}$, de 07 de outubro de 2009. Altera o decreto $\mathbf{n}^{\mathbf{0} 5.520}$, de 24 agosto de 2005 que institui o Sistema Federal de Cultura - SFC e dispõe sobre a composição e o funcionamento do Conselho Nacional de Política Cultural - CNPC do Ministério da Cultura e dá outras providências, 2009.

Lei $\mathbf{n}^{\mathbf{0}}$ 12.343, de 2 dezembro 2010. Institui o Plano Nacional de Cultura - PNC, cria o Sistema Nacional de informações e Indicadores Culturais - SNIIC e dá outras providências, 2010.

Emenda Constitucional $\mathbf{n}^{\mathbf{0}}$ 71, de 29 novembro 2012. Acrescenta o art. 216-A à Constituição para instituir o Sistema Nacional de Cultura. 2012.

Decreto $\mathbf{n}^{\mathbf{0} 8.611}$, de 21 de dezembro de 2015. Altera o decreto $\mathbf{n}^{\mathbf{0}} \mathbf{5 . 5 2 0}$, de 24 agosto de 
2005 que institui o Sistema Federal de Cultura - SFC e dispõe sobre a composição e o funcionamento do Conselho Nacional de Política Cultural - CNPC do Ministério da Cultura e dá outras providências, 2015.

BRESSER PEREIRA, Luiz Carlos. Reforma do Estado para a cidadania. A reforma gerencial brasileira na perspectiva internacional. São Paulo: Ed. 34, Brasília: ENAP, 1998.

BRITTO, Neusa H.. Planos Municipais de Cultura: guia de elaboração. Salvador: UFBA, 2017.

BUARQUE, Cristovam. A missão do PT e de seus governos. In: MAGALHÃES, Inês; BARRETO, Luiz; TREVAS, Vicente (orgs). Governo e cidadania. Balanços e reflexões sobre o modo petista de governar. $1^{\text {a }}$ reimpressão. São Paulo: Fund. Perseu Bramo, 2002. p. 46 - 50.

BUBNOVA, Tatiana G. O princípio ético como fundamento do dialogismo em Mikhail Bakhtin. In: Revista Conexão Letras. V. 8. N. 10, Porto Alegre, 2013.

CALABRE, Lia. Política cultural no Brasil: um histórico. IN: publicação do I ENECULT - Encontro de Estudos Multidisciplinares em Cultura. Ed. UFBA: Salvador, 2005. Anais eletrônico do Encontro de Estudos Multidisciplinares em Cultura. Disponível em: < http://www.cult.ufba.br/enecul2005/LiaCalabre.pdf > acesso em 12 março de 2015.

CALABRE, Lia (org.) Oficinas do Sistema Nacional de Cultura. Brasília: Ministério da Cultura, 2006. Disponível em: < $\underline{\text { http://hugoribeiro.com.br/biblioteca-digital/MinC-2006- }}$ Oficinas_do_sistema_nacional_de_cultura.pdf

$>$ acesso em 10 de novembro de 2017.

2009.

Políticas culturais no Brasil: dos anos 1930 ao século XXI. Rio de janeiro: Ed. FGV,

CALIL, Carlos A. O prazer de mandarzinho. In: Me esqueci completamente de mim, sou um departamento de cultura (textos e entrevistas de Mario de Andrade, Fabio Prado, Oneyda Alvarenga et all...) São Paulo: Imprensa oficial, 2015. p. 13 - 17.

CAMACHO, Roberto G.. O Substantivo. In: CASTILHO, Ataliba T.. Gramática do português falado no Brasil. Campinas, SP: Ed. Unicamp, 2008. p. 29 - 39.

CANÇADO, Márcia. Manual de semântica: noções básicas e exercícios. São Paulo: Contexto, 2012.

CANEDO, Daniele. A mobilização da sociedade para a participação na elaboração de políticas públicas de cultura. In: Barbalho ET AL. Cultura e desenvolvimento: perspectivas políticas e econômicas. Salvador: EDUFBA, 2011. p. 175 - 202.

CARVALHO DA SILVA, Rosimeri de F; DELLAGNELO, E. H. L. . Formalismo como estratégia na construção dos planos estaduais de cultura. In: CALABRE, Lia. (Org.). Políticas culturais: olhares e contextos. 1ed. Rio de Janeiro: Fundação Casa de Rui Barbosa, 2015, v. , p. 84 - 92

CASSIRER, Ernest. Ensaio sobre o homem: introdução a uma filosofia da cultura humana. Trad. Tomás Bueno. São Paulo: Martins Fontes, 1994.

2009.

Linguagem e mito. Trad. J. Guinsburg e Miriam Schnaiderman. São Paulo: Perspectiva,

CASTILHO, Ataliba T. de. Pequena gramática do português brasileiro. Vanda Maria Elias. São Paulo: Contexto, 2012. 
CASTRO, Flávia; RODRIGUES, Luiz Augusto (orgs) Cultura e gestão cultural. - 1 ed. Rio de Janeiro: Lumen Juris, 2017.

CAYGILL, Howard. Dicionário Kant. Trad. Alvaro Cabral. Revisão Valerio Rohden. Rio de janeiro: Jorge Zahar, 2000.

CHAUÍ, Marilena. Cultura e democracia. O discurso competente e outras falas. $8^{\text {a }}$ Ed. Sâo Paulo: Cortez, 2000.

$2000 \mathrm{~b}$

Brasil: mito fundador e sociedade autoritária. São Paulo: Fund. Perseu Abramo, Convite à Filosofia. São Paulo: Ática, 2006.

Abramo, 2006b.

Cidadania cultural: o direito à cultura. São Paulo: Editora Fundação Perseu

CHIERCHIA, Genaro. Semântica. Trad. Luiz Arthur Pagani, Lígia Neri, Rodolfo Ilari. Campinas: Editora UNICAMP, 2003.

CLARK, Katerina; HOLQUIST, Michael. Mikhail Bakhtin. Trad. J. Guinsburg. São Paulo: Perspectiva, 2008.

COELHO, Teixeira. Dicionário crítico de política cultural. SP: Iluminuras. 2012.

COMISSÃO DE SISTEMATIZAÇÃO DE INFORMAÇÕES, ELABORAÇÃO E REDAÇÃO DO PLANO ESTADUAL DE CULTURA DO ESTADO DE SÃO PAULO. Plano Estadual de Cultura SP, 2015. Disponível em: < http://www.planoestadualdecultura.sp.gov.br/?page id=466> acesso em: 10 de maio de 2016.

CONNOR, Steven. Teoria e valor cultural. Trad. Adail Sobral e Maria Stela Gonçalves. São Paulo: Edições Loyola, 1994.

COOPER, John M. A comunidade política e o bem supremo. In: ZINGANO, Marco. Sobre a Ética Nicomaqueia de Aristóteles. Textos selecionados. São Paulo: Odysseus, 2010. p. 439 - 491.

COSTA, Cleisemery Campos da. História da cultura e gestão: do MEC ao MINC. IN: CALABRE, Lia. Políticas culturais : reflexões e ações. - São Paulo : Itaú Cultural ; Rio de Janeiro : Fundação Casa de Rui Barbosa, 2009. p. 71 - 80.

COSTA, Kátia Maria de Souza A Diversidade Cultural no Projeto de Apoio e Assistência Técnica à Elaboração de Planos Municipais de Cultura. Dissertação (Mestrado - Programa Multidisciplinar de Pós-Graduação em Cultura e Sociedade) - Universidade Federal da Bahia (IHAC/UFBA) Salvador, 2017.

COSTA, Luiz Rosalvo. A questão da ideologia no Círculo de Bakhtin: e os embates no discurso de divulgação científica da revista Ciência Hoje. Cotia, SP, 2017.

COSTA, Rodrigo Vieira; TELLES, Mário Ferreira de P.. Cultura e direitos culturais. Orgs: Flavia L. de Castro, Luiz Augusto Fernandes Rodrigues, - 1 ed. Rio de Janeiro: Lumen Juris, 2017.

COTRIM, Gilberto; FERNANDES, Mirna. Fundamentos da filosofia. Volume único. São Paulo: Saraiva, 2010. 
CUNHA, Newton. Dicionário SESC: a linguagem da cultura. São Paulo: Perspectiva, 2003.

CUNHA FILHO, Francisco H.; RIBEIRO, Sabrina F.. Federalismo brasileiro: significados para a cultura. In: BARBALHO, Alexandre; BARROS, José Marcio; CALABRE, Lia.(Orgs). Federalismo e políticas culturais no Brasil. Salvador: EDUFBA, 2013. p. 13 - 42.

DELEUZE, Gilles. A filosofia crítica de Kant. Lisboa: Ed. 70, 2000.

DELLAGNELO, Eloise Helena do Livramento (Org). Proposta metodológica para elaboração de planos estaduais de cultura. Florianópolis: UFSC, 2014.

DEMO, Pedro. Política social, educação e cidadania. 11ª Ed. São Paulo: Papirus, 1994.

DE PAULA, Luciane; STAFUZZA, Grenissa. Círculo de Bakhtin: teoria inclassificável. 1. ed. Campinas: Mercado de Letras, 2010.

DE PAULA, Luciane. Círculo de Bakhtin: diálogos in possíveis. V.2 Campinas: Mercado de letras, 2011.

DICIONÁRIO COMPLETO DA LÍNGUA PORTUGUESA. São Paulo: Publifolha, 2000.

EAGLETON, Terry. Ideologia. Uma introdução. Trad. Silvana Vieira. São Paulo: Ed.Unesp; Boitempo, 1997.

EMERSON, Caryl. Os cem primeiros anos de Mikhail Bakhtin. Trad. Pedro Jorgensen Jr. Rio de janeiro: Difel, 2003.

FARACO, Carlos Alberto. O problema do conteúdo, do material e da forma na arte verbal. In: BRAIT, Beth (org) Bakhtin, dialogismo e polifonia. São Paulo: Contexto, 2009. p. 95 - 112. Autor e autoria. In: BRAIT, Beth. Bakhtin conceitos chave. São Paulo: Contexto, 2010.

FARACO, Carlos Alberto.; TEZZA, Cristovão; CASTRO, Gilberto de. (org.) Vinte ensaios sobre Bakhtin. Petrópolis: Vozes, 2006

FARIA, Hamilton. Uma política cultural para a cidade de São Paulo. In: FARIA, Hamilton; SOUZA, Valmir de (Orgs). Cidadania cultural. Leituras de uma política pública. São Paulo: Polís, 1997. p. 1121.

FERRATER MORA, Jose. Filosofia y arquitectura. In: Cuestiones disputadas. Ensayos de filosofía, Madrid, Revista de Occidente, 1955, p. 43-59. Disponível em: < http://www.unav.es/gep/FerraterFilosofiaArquitectura.html > acesso em 07 de setembro de 2015.

Dicionário de Filosofia. Tomo 1. São Paulo: Loyola, 2000.

FERREIRA, Aurélio Buarque de Holanda. Mini-Aurélio Século XXI: O Minidicionário da língua portuguesa. 5a. edição ver. Ampliada. Rio de Janeiro: Nova Fronteira, 2001.

FERREIRA, Juca. Ministro da Cultura 2008. IN: Produção cultural no Brasil. Vol. 1 Rio de Janeiro: Beco do Azougue, 2010. p. $17-24$.

Discurso de Posse no Ministério da Cultura em 2015. Disponível em: < http://www.cultura.gov.br/banner2/-/asset_publisher/B8a2Gazsrvex/content/discurso-de-posse-dejuca-ferreira/10883 > acesso em 15 de janeiro de 2015. 
FINZETO, Yves C.. Difusão da cultura brasileira no exterior: a Divisão de Operações de Difusão Cultural do Itamaraty no Governo Lula. (Dissertação de mestrado em Filosofia). EACH - USP, São Paulo, 2017.

FRANCO, Renato. Censura e modernização cultural a época da ditadura. S. Paulo: Perspectivas, 1997.

GARCÍA CANCLINI, Nestor. Culturas hibridas: estratégias para entrar e sair da modernidade. Trad. Heloisa Cintrão e Ana Regina Lessa - São Paulo: Edusp, 1997.

. El consumo cultural: una propuesta teórica. In: SUNKEL, G. El consumo cultural en América Latina. Bogotá: Convenio Andrés Bello, 2006.

GIL, Gilberto. Discursos do Ministro da Cultura. Brasília, Ministério da Cultura, 2003 - 2005. Disponível em: http://www.cultura.gov.br > Acesso em 05 de maio de 2015.

Nossas bacias culturais. In: $\mathbf{1}^{\mathbf{a}}$ Conferência Nacional de Cultura - Caderno de Propostas. Estado e sociedade construindo políticas públicas de cultura. Brasília: MinC, 2005b.

GONH, Maria da Glória. Conselhos gestores e participação sociopolítica. 2.ed. São Paulo: Cortez, 2003.

GRILLO, Sheila V. C.. Esfera e campo. In: BRAIT, Beth (org). Bakhtin: Outros conceitos-chave. 2.ed. São Paulo: Contexto, 2012.

Marxismo e filosofia da linguagem: uma resposta à ciência da linguagem do séc. XIX e início do XX. In: VOLÓCHINOV, Valentin. Marxismo e filosofia da linguagem: problemas fundamentais do método sociológico na ciência da linguagem. Tradução, notas e glossário Sheila Grillo e Ekaterina Volkova Américo; ensaio introdutório de Sheila Grillo - São Paulo: Editora 34, 2017.

GRILLO, Sheila V. C.; AMÈRICO, Ekaterina Volkova. Bakhtin, Vinográdov e estilística. In: Questões de estilística no ensino da língua. Tradução, pósfácio e notas de Sheila Grillo e Ekaterina Volkova Américo; Apresentação Beth Brait; organização e notas da edição russa de Serguei Botcharov e Liudmila Gogotichvili, - São Paulo: Editora 34, 2013. p. 93 - 116.

GRUMAN, Marcelo. A UNESCO e as políticas culturais no Brasil. In: Políticas culturais em revista, 2p. 2008. p. 174-86.

GUEROULT, Martial. Lógica, arquitetônica e estruturas constitutivas dos sistemas filosóficos. In: Revista Trans/Form/Ação, São Paulo, tradução Pedro Jonas de Almeida. 30 (1), 2007, p. 235-246. Disponível em: < http:// WWW.scielo.br/pdf/trans/v30n1/v30n1a15.pdf > acesso em 15 de julho de 2015.

Grupo de Estudos dos gêneros do Discurso (GEGe). Questões de cultura e contemporaneidade: o olhar oblíquo de Bakhtin. São Carlos: Pedro \& João Editores, 2011.

HOllandA, Ana de. Discurso de Posse no Ministério da Cultura em 3 de janeiro de 2011. Disponível em: < www.cultura.gov.br > acesso em 6 de janeiro de 2015.

HOUAISS, A. (2010) Dicionário Houaiss da Língua Portuguesa [online]. Disponível em: < http://houaiss.uol.com.br >. Acesso em 5 de agosto de 2015.

ILARI, Rodolfo; BASSO, Renato. O verbo. In: CASTILHO, Ataliba T.. Gramática do português 
falado no Brasil. Campinas, SP: Ed. Unicamp, 2008. p. 161 - 169.

IMMERGUTT, Ellen M. As regras do jogo: a lógica da política de saúde na França, na Suiça e na Suécia. In: RBCB, No 30, ano 11, 1996, p. 139 - 165.

IPHAN (Instituto do Patrimônio Histórico e Artístico Nacional) Patrimônio Cultural Imaterial: para saber mais. Texto e revisão de Natália Guerra Brayner. 3. ed. Brasília, DF : Iphan, 2012

JAPIASSU, Hilton; MARCONDES, Danilo. Dicionário básico de filosofia. 3. ed. Rio de janeiro, 1996.

JORDÃO, Gisele. Panorama setorial da cultura brasileira 2011/2012. São Paulo: Alucci \& Associados, 2012.

KANT. Emmanuel. Textos pré-críticos.Trad. José Andrade e Alberto Reis. Porto (Portugal): Rêseditora, 1983.

KANT, Immanuel. Textos selecionados Trad. Tania Maria Bernkopf, Paulo Quintela, Rubens R. Torres Filho. 2ª ed. São Paulo: Abril Cultural, 1984.

Duas introduções à crítica do Juízo. São Paulo: Iluminuras, 1995.

Crítica della ragion pura. Introduzione e traduzione Constantino Esposito. Milano, It: Bompiani Il Pensiero Occidentale, 2004.

A metafísica dos costumes. Trad. e notas de Edson Bini. Bauru, SP: Edipro, $2^{\mathrm{a}}$ ed.

2008.

Fundamentação da metafísica dos costumes. Trad. Introd. Notas de Guido Antonio Almeida. São Paulo: Discurso; Barcarolla, 2009. (Edição bilingue - Coleção Philosofia)

Crítica da razão pura. Tradução e notas de Fernando C. Mattos. Petrópolis, RJ: Vozes; Bragança Paulista, SP: Ed. Universitária São Francisco, 2012. (Coleção Pensamento Humano).

KAUARK, Giuliana. O Ministério da Cultura e a Convenção sobre a Diversidade Cultural. In: Anais IV Seminário Internacional de Políticas Culturais. Casa Rui Barbosa, 2010. Disponível em < http://culturadigital.br/politicaculturalcasaderuibarbosa/files/2010/09/14-GIULIANA-KAUARK.1.pdf $>$ acesso em 25 de maio de 2016.

LAFFER, Celso. O sistema político brasileiro. São Paulo: Perspectiva, 1975.

LALANDE, André. Vocabulário técnico e crítico da filosofia. 3. ed. São Paulo: Martins Fontes, 1999.

LAROCA, Maria de Nazaré de C.. Manual de morfologia do português. 3.3ed. Campinas: Pontes, 2003.

LEIBNIZ, Princípios da Filosofia ou a Monadologia. Trad. Fernando Barreto Gallas. 2007. Disponível em < http://www.leibnizbrasil.pro.br > acesso em 10 de setembro de 2015.

LEVINSON, Stephen. Pragmática. Trad. Luis Carlos Borges, Aníbal mari. Revisão Ténica Rodolfo Ilari. - São Paulo: Martins Fontes, 2007.

LOPES, Marisa. O animal político: estudos sobre justiça e virtude em Aristóteles. São Paulo: Singular; Esfera Pública, 2008. 
LOPEZ, Luiz Roberto. Cultura brasileira: de 1808 ao pré-modernismo. $2^{\mathrm{a}}$ Ed. Porto Alegre: Ed. UFRGS, 1995.

MACHADO, Ralph. Lula AC - DC. Política econômica antes e depois da Carta ao povo brasileiro. Sâo Paulo: Annablume, 2007.

MACIEL, Anna Maria Becker. Configuração da especificidade do termo no texto legislativo. In: ISQUIERDO, Aparecida Negri; KRIEGER, Maria da Graça. As ciências do léxico: lexicologia, lexicografia, terminologia. Vol. II. Campo Grande, MS: Ed. UFMS, 2004. p. 239 - 252.

MAGALHÃES, Inês; BARRETO, Luiz; TREVAS, Vicente (orgs). Governo e cidadania. Balanços e reflexões sobre o modo petista de governar. 1 $^{a}$ reimpressão. São Paulo: Fund. Perseu Bramo, 2002.

MARCUSCHI, Luiz Antonio. A repetição na língua falada como estratégia de formulação textual. In: $\mathrm{KOCH}$, Ingedore G. Villaça (org.) Gramática do português falado. Vol. VI. Campinas, SP: Ed. UNICAMP / Fapesp, 1996. p. 95 - 130.

MATTIA, Clenia; TURNES, Valerio. A Metodologia para a elaboração dos Planos Estaduais de Cultura fomenta a coprodução do bem público? In: Anais do XXXVII Encontro da ANPAD, Rio de Janeiro, 2013. Disponível em: < http://www.anpad.org.br/admin/pdf/2013_EnANPAD_APB2264.pdf $>$ acesso em 05 de outubro de 2016.

MEDVIÉDEV, Pável Nikoláievich. O método formal nos estudos literários: introdução crítica a uma poética sociológica. Trad. Sheila. V. Grillo e Ekaterina V. Americo. São Paulo: Contexto, 2012.

MEIRA, Marcio. Novos rumos para a cultura no Brasil. In: $\mathbf{1}^{\mathbf{a}}$ Conferência Nacional de Cultura Caderno de Propostas. Estado e sociedade construindo políticas públicas de cultura. Brasília: MinC, 2005.

MEIRA, Márcio; GAZZINELLI, Gustavo (2006) "Sistema Nacional de Cultura", in CALABRE, Lia (org.) Oficinas do Sistema Nacional de Cultura. Brasília: Ministério da Cultura, p. 09-24. Disponível em: < $\quad$ http://hugoribeiro.com.br/biblioteca-digital/MinC-2006Oficinas_do_sistema_nacional_de_cultura.pdf

$>$ acesso em 10 de novembro de 2017.

MENDOZA, Celina A. L. AQUINO. Estudio preliminar. In: Tomás de. Comentário a la Ética a Nicómaco de Aristoteles. 3. ed. Trad. Ana Mallea. Navarra: Ed. Universidad de Navarra (Espanha), 2010.

MICELI, Sergio. Estado e Cultura no Brasil. São Paulo: Difel Editorial, 1984.

MONTEIRO, Antonio. As categorias de Aristóteles. Lisboa: Ed. Lisboa, 2002.

MINISTÉRIO DA CULTURA. Secretaria de Articulação Institucional - SAI. 1 $^{\text {a }}$ Conferência Nacional de Cultura 2005. Estado e sociedade construindo políticas públicas de cultura. Brasília, 2005.

Secretaria de Articulação Institucional - SAI. 1 ${ }^{\text {a }}$ Conferência Nacional de Cultura 2005. Estado e sociedade construindo políticas públicas de cultura. Brasília, 2005.

Plano Nacional de Cultura. Diretrizes gerais. 1. ed. Brasília: Ministério da Cultura, 2007.

Plano Nacional de Cultura. Diretrizes gerais. 2 ed. Brasília: Min. da Cultura, 2008. 
Porque aprovar o Plano Nacional de Cultura. Brasília: Min. da Cultura, 2009.

Secretaria de Articulação Institucional - SAI. $2^{\text {a }}$ Conferência Nacional de Cultura 2010. Texto base. Brasília, 2010. Disponível em: < http://www.cultura.pr.gov.br/pagina-500.html > acesso em 13 de fevereiro de 2019.

Conselho Nacional de Política Cultural. Secretaria de Articulação Institucional - SAI. Estruturação, Institucionalização e Implementação do Sistema Nacional de Cultura. Brasília, 2011c.

. Conselho Nacional de Política Cultural. Secretaria de Articulação Institucional - SAI. Sistema Nacional de Cultura Guia de Orientação para os Estados. Brasília, 2011b.

Conselho Nacional de Política Cultural. Secretaria de Articulação Institucional - SAI. Sistema Nacional de Cultura Guia de Orientação para os Municípios. Brasília, 2012.

. As Metas do Plano Nacional de Cultura. Brasília; Ministério da Cultura, 2012.

. Como fazer um plano de cultura. São Paulo: Instituto Via Pública / MINC, 2013.

. Secretaria de Articulação Institucional - SAI. Oficinas de Implementação de Sistemas Estaduais e Municipais de Cultura. Brasília, 2013b.

1. Brasília, 2017.

Planos Municipais de Cultura em Ambiente de Aprendizagem a Distância. Módulo

. Planos Municipais de Cultura em Ambiente de Aprendizagem a Distância. Módulo 2. Brasília, $2017 b$.

3. Brasília, 2017c.

Planos Municipais de Cultura em Ambiente de Aprendizagem a Distância. Módulo

. Planos Municipais de Cultura em Ambiente de Aprendizagem a Distância. Módulo 4. Brasília, 2017d.

. Planos Municipais de Cultura em Ambiente de Aprendizagem a Distância. Módulo 5.1. Brasília, 2017e.

. Planos Municipais de Cultura em Ambiente de Aprendizagem a Distância. Módulo 5.2. Brasília, 2017f.

Planos Municipais de Cultura em Ambiente de Aprendizagem a Distância. Módulo 5.3. Brasília, 2017g.

Planos Municipais de Cultura em Ambiente de Aprendizagem a Distância. Módulo 5.4. Brasília, 2017h.

MINISTÉRIO DA EDUCAÇÃO E CULTURA. Política Nacional de Cultura. Brasília, 1975.

MONDADA, Lorenza; DUBOIS, Danielle. Construção dos objetos de discurso e categorização: uma abordagem dos processos de referenciação. In: CAVALCANTE, Monica Magalhães et all. Referenciação. São Paulo: Contexto, 2003. p. 36 - 44. 
MONTEIRO, José Lemos. Morfologia portuguesa. $4^{\mathrm{a}}$ Ed,. Campinas: Pontes, 2002.

NAÇÕES UNIDAS. Conferência Geral. Declaração universal sobre a diversidade cultural. Brasília, DF: Organização das Nações Unidas para a Educação, a Ciência e a Cultura - Unesco, 2002. [7] p. (CLT 2002/WS/9). Disponível em: < http://unesdoc.unesco.org/images/0013/001394/139423por.pdf Acesso em: 25 de abril de 2016.

- Declaração Universal dos Direitos Humanos, 1948. Disponível em: < https://www.ohchr.org/EN/UDHR/Pages/Language.aspx?LangID=por $>$ acesso em 25 de abril de 2016.

NATALE, Edson; OLIVIEIRI, Cristiane. Guia brasileiro de produção cultural. ${ }^{\text {a }}$. Edição. São Paulo: Zé do Livro, 2003.

Guia brasileiro de produção cultural. 2a . Edição. São Paulo: Zé do Livro, 2006.

. Guia brasileiro de produção cultural. 5a . Edição. São Paulo: SESC, 2010.

NEVES, Maria Helena de Moura. Gramática de usos de português. 2aed. São Paulo: Ed. UNESP, 2011.

A construção da significação no enunciado: a gramática. In: REZENDE, Letícia Marcondes et all. Léxico e gramática: dos sentidos à construção do significado. São Paulo: Cultura Acadêmica, 2009. p. $23-37$.

NOBRE, Marcos. Participação e deliberação na teoria democrática: uma introdução. In: COELHO, Vera Shattan. Participação e deliberação: teoria democrática e experiências institucionais no Brasil contemporâneo. São Paulo: Ed. 34, 2004. p. 21 - 40.

OBSERVATÓRIO ITAÚ CULTURAL. Agenda 21 da Cultura. In: Revista Observatório do Itaú Cultural. N.1 (jan/abr.2007) São Paulo: Itaú Cultural, 2007.

OLIVIERI, Telma L. P.. Desafios para formação de gestores públicos na implantação de uma Política de Estado para a Cultura e a consolidação do Sistema Nacional de Cultura. In: La gestión cultural desde Latinoamérica: Formación e investigación. Referencias y retos del campo disciplinar. Tomo 1 / Carlos Yáñez Canal, Ursula Rucker, María del

Carmen Valenzuela Gómez, comps. 1a ed. Santiago: Ediciones Egac, 2018. p. 160 - 196.

ORTIZ, Renato. Mundialização e cultura. São Paulo: Brasiliense, 2007.

PARTIDO DOS TRABALHADORES. A imaginação a serviço do Brasil. Programa da coligação 2002 Lula presidente. Programa de Políticas Públicas de Cultura. São Paulo: Fundação Perseu Abramo, 2002.

PAIVA NETO, Carlos B. Modelo federal de financiamento e fomento à cultura. In: RUBIM, Antonio Albino; VASCONCELOS, Fernanda Pimenta. Financiamento e fomento à cultura no Brasil: estados e Distrito Federal. Salvador: EDUFBA, 2017.

PEIXE, João Roberto. Sistema Nacional de Cultura. Coleção Política e Gestão culturais. Salvador: P55 edições, 2013.

Sistema Nacional de Cultura: um novo modelo de gestão cultural para o Brasil. In: RUBIM, Antonio Albino C. (Org) Política cultural e gestão democrática no Brasil. São Paulo: Ed. Fund. Perseu Abramo, 2016.

PELLEGRIN, Pierre. Vocabulário de Aristóteles. Trad. Claudia Berliner. São Paulo: Ed. WMF 
Martins Fontes, 2010.

PENTEADO, Flávio R. Sonhar, respirar, conversar, viver Departamento. In: Me esqueci completamente de mim, sou um departamento de cultura (textos e entrevistas de mario de Andrade, Fabio Prado, Oneyda Alvarenga et alli...) São Paulo: Imprensa oficial, 2015. p. 18 - 25.

PETERSON, Paul. The price of federalism. New York: Twntieth century Fund, 1995.

PLATÃO (Platone). O político. Introduzione e traduzione Giovanni Giordini, Milano, It: Ed. Bur, 2012.

POLIS, Instituto de Estudos, Formação e Assessoria em Políticas Sociais. Juventudes e formação: trajetórias, narrativas e poéticas- São Paulo: Instituto Pólis, 2017.

PONTUAL, Pedro; ALMEIDA SILVA, Carla. Participação popular nos governos petistas: trajetórias, mecanismos e caráter. In: MAGALHÃES, Inês; BARRETO, Luiz; TREVAS, Vicente (orgs). Governo e cidadania. Balanços e reflexões sobre o modo petista de governar. $1^{\mathrm{a}}$ reimpressão. São Paulo: Fund. Perseu Bramo, 2002. p. $61-70$.

PONZIO, Augusto. A concepção bakhtiniana do ato como dar um passo. In: BAKHTIN, M. Para uma filosofia do ato responsável. Trad. Valdemir Miotello e Carlos Faraco. São Carlos: Pedro \& João Editores, 2010d [1920-24]. p. 9 - 40.

QUEIROZ, Inti Anny. Projeto cultural: as especificidades de um novo gênero do discurso. $199 f$. Dissertação Mestrado. Faculdade de Filosofia, Letras e Ciências Humanas, São Paulo, 2014.

A produção cultural responsável: uma reflexão histórica e prática. In: BARROS, José Marcio (Org) Pensar e agir com cultura. Observatório da diversidade cultural. Salvador / Belo Horizonte: EDUFBA / UEMG, 2018.

REIS, Paula Felix dos. Políticas culturais do governo Lula: análise do Sistema e do Plano Nacional de Cultura. Dissertação de mestrado. UFBA. Salvador: 2008.

Política cultural no Brasil: análise do Sistema e do Plano Nacional de Cultura. In: BARBALHO, Alexandre et all (orgs). Cultura e desenvolvimento: perspectivas políticas e econômicas. Salvador: Edufba, 2011.p. 153 - 174.

RIBEIRO, Ana Paula Goulart; SACRAMENTO, Igor. (Org.) Mikhail Bakhtin: linguagens, cultura e mídia. São Carlos: Pedro \& João, 2010.

RIBEIRO, Rebeca de M.; MENEGASSO, Maria Esther.; SALM, José Francisco. Co-produção do bem público e o desenvolvimento da cidadania: o caso do PROERD em Santa Catarina. Revista Alcance. Univali, 14 (2), 2007. p. 231- 246.

ROCHA, Sofia. Planos de Cultura. Col. Política e Gestão Culturais. Salvador: P55 ed., 2013.

RUBIM, Antonio Albino C. (Org) Políticas culturais no governo Lula. Salvador: Edufba, 2010.

2016.

. Política cultural e gestão democrática no Brasil. São Paulo: Ed. Fund. Perseu Abramo,

RUBIM, Antonio Albino C.; ROCHA, Renata. (Orgs) Políticas culturais. Salvador: EDUFBA, 2012.

RUBIM, Antonio Albino Rubim; FERNANDES, Taiane; RUBIM, Iuri. (Orgs) Políticas culturais, democracia e conselhos de cultura. Salvador: EDUFBA, 2010. 
RUBIM, Linda.(org) Organização e produção da cultura. Salvador: EDUFBA, 2005.

SADER, Emir (org). Governo Lula: decifrando o enigma. São Paulo: Viramundo, 2004.

10 anos de governos pós-liberais no Brasil: Lula e Dilma. São Paulo: Boitempo; Rio de janeiro: Flasco, 2013.

SECRETARIA MUNiCiPAl DE CUltura DE SÃO PAUlO. Plano Municipal de Cultura. São Paulo: SMC, 2016.

. Plano Municipal de Cultura: caderno de consulta pública. São Paulo: SMC, 2016b.

Org: Ana Paula do Val; Luciana Piazzon Lima; Maria Vasconcelos Oliveira; Viviane Cristina Pinto. Participação e cidadania cultural: a experiência da III conferência Municipal de Cultura de São Paulo. São Paulo: SMC, 2014.

SILVA, José Afonso da. Princípios constitucionais fundamentais. In: 20 anos da Constituição Cidadã. Rio de janeiro: Fund. Konrad Adenauer, 2008. p. 9 - 20.

SILVA, Maria Cecília Pérez de Souza; KOCH, Ingedore Grunfeld Villaça. Linguística aplicada ao português: morfologia. 15. Ed. São Paulo: Cortez, 2005.

SIMIS, Anita. Estado e cinema no Brasil. São Paulo: Annablume, 1996.

SOBRAL, Adail. Ético e estético. Na vida, na arte e na pesquisa em ciências Humanas. In: BRAIT, Beth. Bakhtin: conceitos chave. São Paulo: Contexto, 2010. p. 103 - 122.

SOBRAL, Adail. Do dialogismo ao gênero: as bases do pensamento do círculo de Bakhtin. Campinas: Mercado de Letras, 2009.

SOTO, Cecilia; CANEDO, Daniele; OLIVEIRA, Gleise; SALGADO, Julia. Políticas públicas de cultura: os mecanismos de participação social. In: RUBIM, Antonio A. C. (Orgs) Políticas culturais no governo Lula. Salvador: Edufba, 2010.

SOUZA, Geraldo. Introdução à teoria do enunciado concreto. São Paulo: Humanitas, 2002.

SOUZA, Valmir de. São Paulo: diversidade cultural e discurso oficial. In: FARIA, Hamilton; SOUZA, Valmir de (Orgs). Cidadania cultural. Leituras de uma política pública. São Paulo: Polís, 1997. p. 1121.

SUPLICY, Marta. Discurso de posse da Ministra Marta Suplicy. Disponível em: < http://www2.cultura.gov.br/site/2012/09/13/discurso-de-posse-da-ministra-da-cultura-marta-suplicy/ > acesso em 26 de setembro de 2013.

TABAGIBA, Luciana. Os conselhos e a construção da democracia no Brasil: um rápido balanço de duas décadas de participação conselhista. In: RUBIM, Albino et all. Políticas culturais, democracia e conselhos de cultura. Salvador: EDUFBA, 2010.

TEIXEIRA, Ana Claudia Chaves. Os sentidos da democracia e da participação. São Paulo: Instituto Pólis, 2004.

TERRA, Ricardo Ribeiro. Reflexão e Sistema: as duas introduções à crítica do Juízo. In: KANT, Immanuel. Duas introduções à crítica do Juízo. Org. Ricardo Ribeiro Terra. São Paulo: Iluminuras, 
1995.

A arquitetônica da filosofia prática kantiana. In: Revista Studia kantiana, V. 1, 1998. p. 291 - 305. Disponível em: < www.sociedadekant.org/studiakantiana/index.php/sk/article/.../12/87 > acesso em 05 de agosto de 2015.

TEZZA, Cristovão. Entre a prosa e a poesia: Bakhtin e o formalismo russo. Rio de Janeiro: Rocco, 2003.

UCLG. Agenda 21 da cultura. Cidades e governos unidos - comissão da cultura. Barcelona: Ajuntment de Barcelona / Institut de Cultura; United Cities and Local Governaments, 2004. Disponível em: < http://www.agenda21culture.net/index.php/pt/docman/agenda21/9-ag21 cptpdf/file> acesso em 2 de junho de 2016.

ULLMANN, Stephen. Semântica: uma introdução a ciência do significado. $3^{\text {a }}$ Ed. Lisboa: Fundação Calouste Gulbenkian, 1973.

UNESCO. Constitution of the United Nations Educational, Scientific and Cultural Organization, Londres: UNESCO. 1945.

Convenção para a Proteção do Patrimônio Mundial, Cultural e Natural. Paris: UNESCO, 1972. Disponível em: < http://whc.UNESCO.org/archive/convention-pt.pdf > acesso em 15 de junho de 2016.

Mexico City Declaration on Cultural Policies. Paris: UNESCO, 1982.

La culture: clef du développement. Paris: UNESCO, 1983.

Nuestra diversidade creativa. Informe de la Comissión Mundial de Cultura y Desarrollo. Paris, 1996. Disponível em < http://unesdoc.unesco.org/images/0010/001055/105586sb.pdf > acesso em 16 de junho de 2016.

Planejamento de médio prazo, 1977-1982. Paris: UNESCO. 1997.

UNESCO Brasil: challenges and strategies. Traslated by Daniela Stephenson; ilustrated by Edson Fogaça. Brasilia: UNESCO, 1999.

UNESCO Brasil: novos marcos de ação. Brasília: UNESCO, 2001.

. Declaração Universal sobre a Diversidade Cultural. Paris: UNESCO. 2002.

2002.

Um novo caminho para o Brasil no século XXI. Brasília: UNESCO. Instituto de Política,

L'UNESCO et la question de la diversité culturelle: bilan et stratégies, 1946-2004: étude réalisée à partir d'um choix de documents officiels. Paris: Divisão de Políticas Culturais e do Diálogo Intercultural/UNESCO, 2004.

Convenção sobre a proteção e a promoção da diversidade das expressões culturais. Brasília: UNESCO, 2006.

VARELLA, Guilherme. Plano Nacional de Cultura: direitos e políticas culturais no Brasil. Rio de Janeiro: Azougue, 2014. 
VERGNIERES, Solange. Ética e política em Aristóteles: Physis, Ethos, Nomos. São Paulo: Paulus, 1998.

VERMEREN, Patrice. La Philosophie saisie par L'UNESCO. Paris: UNESCO 2003.

VERNANT, Jean-Pierre; VIDAL-NAQUET, Pierre. Mito e tragédia na Grécia antiga. $1^{\mathrm{a}}$. ed. São Paulo: Perspectiva, 1991.

VILELA, Mário. Estudos de lexicologia do português. Coimbra: Livraria Almedina, 1994.

VOLÓCHINOV, Valentin. (BAKHTIN, Mikhail) Marxismo e filosofia da linguagem. Trad. do francês de Michel Lahud e Yara Frateschi. 13ª ed. São Paulo: Hucitec, 2009 ([1929].).

VOLÓCHINOV, Valentin. Discurso na vida e discurso na arte. Tradução de Carlos Alberto Faraco e Cristovão Tezza, para uso didático, com base na tradução inglesa de I. R. Titunik ("Discourse in life and discourse in art - concerning sociological poetics"). In: Voloshinov, V. N. Freudism, New York: Academic Press, 1992.

Marxismo e filosofia da linguagem: problemas fundamentais do método sociológico na ciência da linguagem. Tradução, notas e glossário Sheila V. Grillo e Ekaterina Volkova Américo; ensaio introdutório de Sheila Grillo - São Paulo: Editora 34, 2017.

VOSSLER. Karl. Los limites de la sociologia linguistica. In: Filosofia del language. Ensayos. Traduccion y notas Amado Alonso y Raimundo Lida. Buenos Aires, Ar: Ed. Losada, 1963.

WARNE, Christopher. Aristotle's Nicomachean Ethics. Reader`s guide. London: Continuum Books, 2006.

WEFFORT, Francisco; SOUZA, Marcio. (orgs) Um olhar sobre a cultura brasileira. Rio de Janeiro: Associação de amigos da FUNARTE, 1998.

WIGGINS, David. Deliberação e razão prática. In: ZINGANO, Marco. Sobre a Ética Nicomaqueia de Aristóteles. Textos selecionados. São Paulo: Odysseus, 2010.

WILLIAMS, Daryle. Culture wars in Brazil. The first Vargas regime 1930 - 1945. London: Duke University Press, 2001.

WILLIAMS, Raymond. Marxismo e Literatura. São Paulo:Zahar Editores. 1979.

Cultura. Rio de janeiro: Paz e Terra, 1992.

Palavras-chave: um vocabulário de cultura e sociedade. Trad. Sandra Vasconcelos. São Paulo: Boitempo, 2007.

Cultura e materialismo. Trad. André Glaser. São Paulo: Unesp, 2011.

WITKOSKI, Antonio Carlos. Diversidade intelectual e cultura política. Abordagem gramsciana da pedagogia petista. São Paulo: Annablume; Fortaleza: Secretaria da Cultura e desposto do Gov do Ceará, 2000.

WOLFF, Francis. Aristóteles e a Política. Trad. Christina F. Stummer, Lygia Watanabe. 2a . ed. São Paulo: Discurso editorial, 2001.

ZINGANO, Marco. Razão e sensação em Aristóteles: um ensaio sobre De Anima III 4 - 5. Porto Alegre: L \& PM, 1998. 
Platão e Aristóteles os caminhos do conhecimento. São Paulo: Odysseus, 2002.

Aristóteles: tratado da virtude moral; Ethiaca Nicomachea I 13 - III 8. São Paulo: Odysseus, 2008.

2010.

Sobre a Ética Nicomaqueia de Aristóteles. Textos selecionados. São Paulo: Odysseus, 